RAILWAYS AND THE TRANSFORMATION OF

\title{
THE SCOTTISH ECONOMY
}

\begin{abstract}
A thesis presented by Wray Vamplew to the University of Edinourgh in candidacy for the degree of Doctor of Philosophy.
\end{abstract} 1969

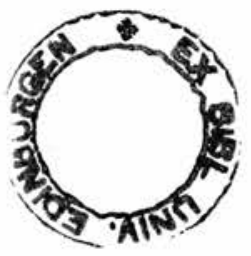


"For a study which is often classed at universities amongst the social sciences written economic history is extraordinarily unsociable. It is usually muddy in expression (if not in thought also), abstract, impersonal, and beset with qualifications: which means that it is quite disagreeăble to read."

$$
\text { Michael Robbins, "What Kind of Railway }
$$

History Do We Want?" Journal of Transport History, November 1957, p.74. 
This thesis is primarily concerned with assessing, by the use of quantitative method and economic analysis, the role that the indigenous railways played, as consumers of industrial products and as suppliers of transport, in the rise of the Scottish heavy industries during the nineteenth century. Secondary themes include the source and productivity of railwey capital; the railways as employers; the influence they had on Scottish agriculture; and their effect on other forms of transport.

An examination of the backward linkages between the Scottish railways and the native engineering, iron and steel, and coal industries suggests that rallway demand had little immediate impact upon these industries. In the third quarter of the century, however, a locomotive building industry was established on the basis of Scottish rallway demand; direct demand for coal was never important but, when indirect demand via the iron and steel industries is taken into account, the significance of coal consumption attributable to the railways increases, especially around 1870; railway demand for Scottish iron and steel increased in importance with the coming of the steel age but still remained of minor significance, though the construction of the Forth Bridge in the last two decades of the century may have had important qualitative influences on both the steel and engineering industries. More immediate was the influence 
of the railways as transportation agencies, partly in reducing the amount of relatively expensive road transport required for most journeys, but also, and perhaps initially more important, in forcing existing forms of transport to charge much nearer to marginal costs than they had previously done.

It can also be suggested that foreign aid in the form of men, money and materials was essential to the creation of the Scottish railway system, at least prior to 1850 , if not even later. Domestic capital was relatively scarce because of competing demands during the long expansionary wave throughout the economy, following the application of the hot blast to the iron industry. The ensuing desire to attract external capital was one reason for the employment of well-known English civil engineers. Another was their previous experience; a factor that also partially explains the purchase of rolling stock, especially locomotives, and rails from south of the border. Technical problems too played a part in determining the utilisation of non-Scottish rails and, for a while, coal. Finally, Irish navvies and Inglish craftsmen were active in constructing Scottish lines though the operating staff tended to be more locally recruited. 


\section{ERRATA}

.203 footnote 1. line 4. For "rate" read "return".

.210 line 2. Insert "it" after "employed".

.308 line 20. For "Morr" read "Moor".

.377 line 25. Insert "expenditure of the railways on wagon stock from 1888 made possible the great" after "increased".

.510 line 9. For "1839" read "1836".

.513 line 1. For "1839" read "1836".

.540 line 1. For "post" read "poet". 


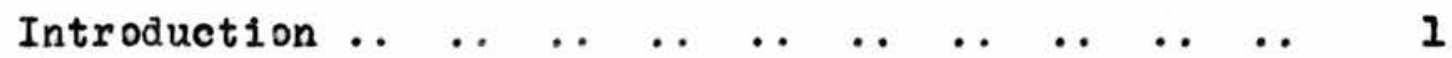

1. An Outline of Railway Development in Scotland . .. 9

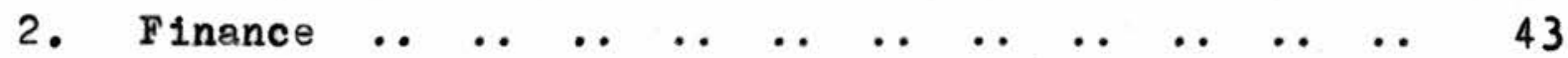

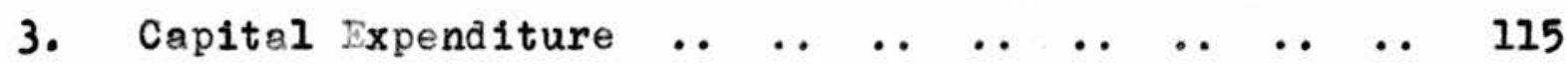

4. Railways and Engineering .

5. Railways and the Iron and Steel Industries .. . 282

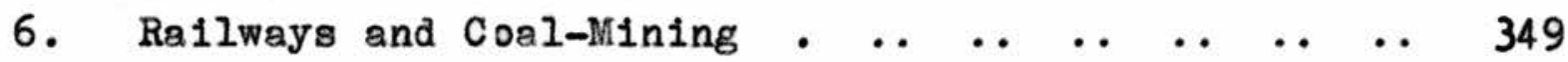

7. Aspects of Railway Employment $\quad \ldots \quad$.

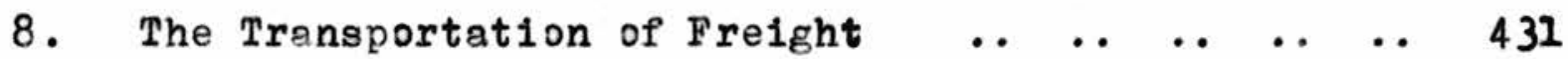

9. The Transportation of Passengers . . . . . . . 483

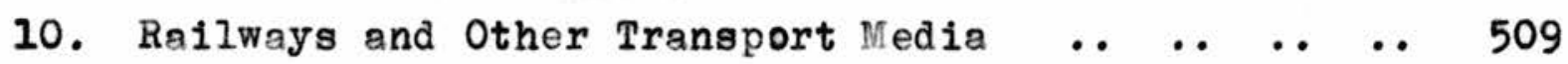

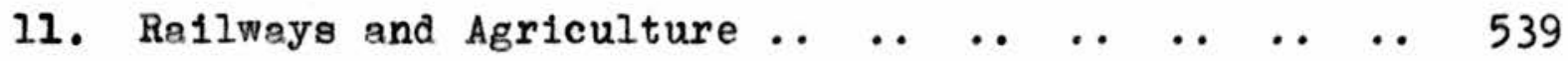

12. Conclusions Bibliograpny 


\section{ABBREVIATIONS}

Most sources will be named in full, but where frequent reference has been made to a particular source abbreviations have been used so as to avoid unnecessary repetition. B.R. Historical Records of the British Rail Board H.R.J. Herapath's Railway Journal J.W.S. Journal of the west of Scotland Iron and Steel Institute N.I.S. National Library of Scotland

R.C. Royal Commission

S.C. Select Committee

S.R.0. Scottish Record Office

T.E.S.S. Pransactions of the Engineers and Shipbuilders of Scotland Tr.if.S. Transactions of the Highland and Agricultural Society

The reference numbers given to documents are those assigned by the Scottish Record Office or the British Rail Archivist. No abbreviations will be made to railway company names apart from the dropping of the word railway from their title where appropriate. 


\section{INTRODUCTION}

Recently it was suggested that perhaps "Scottish railways have not been subjected to the research they deserve." (1) This was a rhetorical question as far as economic history was concerned for the last attempt to analyse their economic effects was in 1890. (2) Since then the writers of Scottish economic history have reiterated the views forwarded at that time, or have speculated on the basis of English experience without undertaking specific Scottish research, or have produced some combination of the two. This is not to say that there has been no original work done, for the past decade has witnessed the publication of several books on Scottish railways, but, catering for a specialised market, they have emphasised chronological development and locomotive technology to the virtual exclusion of economic analysis. The object of this thesis is to rectify the situation by using economic theory to examine the role of the railways in nineteenth century Scottish economic development.

At the beginning of the nineteenth century the Scottish economy was dominated by agriculture and textile production. By the end of the century these were still important, but heavy industry in the shape of coal-mining, iron and steel production, engineering and shipbuilding had come to the fore. (3) In addition to

1. S.B. Saul, Scottish Journal of Political Economy, vol.12, June, 1965, p.212.

2. W.M. Acworth, The Railways of Scotland. 1890

3. W.H. Harwick, Sconomic Developmentsin Victorian Scotland. 1936. Pp. 22-24. 
assessing the part played by the railways in this transformation - was their effect instantaneous, gradual or negligible? - an attempt will be made to measure the saving to the economy of such cheaper and faster transport. Other points to be covered include the degree and sources of investment, the resources in manpower and materials required for construction and operation, and the effect that the railways had on other modes of transport. The thesis is limited in that it confines itself to Scotland and to the nineteenth century. However, unless all of Britain was to be studied, some geo graphical line had to be drawn. The choice of scotland was encouraged by two factors. Firstly, even in the mid twentieth century it could be claimed by a reputable economist that "there is a sufficient degree of segregation from the rest of the economy, and a sufficient diversity within Scotland, to allow one to speak of the Scottish economy, functioning as a unit and with an independent momentum." (32) Secondly, the fact that the network of the scottish railway companies was practically confined to scotland and that no English oompany ventured north of the border greatly eases the task of regional economic analysis. The time period follows from the choice of area, for it was within the nineteenth century that the transformation of the Scottish economy occurred.

Throughout the thesis emphasis will be placed on quantification. Professor Ashton has claimed that "if the humdrum methods of the historian are less precise, they are not necessarily less

3a. A.K. Cairncross (ed.), The Scottish Bconomy. 1954, p.1. 
accurate than those of the statistician," but it can be suggested that this does not hold for every case. (4) For example, the rise of the Scottish heavy industries coincided with the development of the railways and, because of the obvious links between the two phenomena, the non-statistical historian might be tempted to accept the universality of Rostow's dictum that "the development of railways has led on to the development of modern coal, iron and engineering industries." (5) The recent work of Fogel has, however, demonstrated the naivety of making such statements without subjecting them to statistical verification. (6)

Unfortunately, although essential to any hypothesis concerning the relationships between economic factors, quantitative evidence is not always available. In the particular case of the influence of the railway on Scottish economic development, factors such as the volume and productivity of capital expenditure, the savings on the transport of goods and passengers, and the railways' consumption of the output of the heavy industries are capable of being subjected to measurement, but this is less true of matters such as the spread of knowledge and the development of managerial techniques. Even where measurement can take place, inadequate data and the assumptions involved in quantification frequently do not allow for absolute precision, and often all that can be said is that an effect was "small" or was "large." All that can be hoped for is that some order of magnitude can be established, but, as Fogel has pointed out, "more often than not, historical

4. T.S. Ashton, Fluctuations in the English Economy, 1700-1800. 1959. p.33.

5. W.W. Rostow, The Stages of Economic Growth. 1963, p.55. 6. R.W. Fogel, Railroads and American Economic Growth. 1964. 
hypotheses turn on orders of magnitudes rather than particular values." (7)

One of the factors preventing absolute precision in this thesis was the statistical sampling rendered necessary by there being over one hundred companies involved in the creation of the Scottish railway network. A more intensive study of one or two companies might have yielded more accurate results in their particular cases, but little could be said about the effect of the railways in general until other studies, using the same techniques and posing the same questions, verified that the original studies produced information of general validity. The aim of research is surely not to seek the "exceptional, unique or nonsystematic experience in historical data."

Limitations of both time and space prevent the thesis from being fully comprehensive. Little attention, for example, has been paid to personalities. This is partly because quantitative studies, by their nature, tend to take the soul out of economic history, but it is also because the writer believes that personality studies, if they are to be useful, should follow the lines of Professor Cochran's work on American railroad leaders, a task which would be a thesis in itself. (9)

Another aspect of railway development not given full coverage is that of the problems of management which were faced and overcome. Chander stresses this role of the railways in aiding

7. Fogel, og. cit., p.245.

8. A.H. Coñad \&.R. Meyer, Studies in Econometric History. 1965. p.17.

9. T.C. Cochran, Railroad Leaders, 1845-70: The Business Mind in Action. 1953. 
the expansion of American business. In being the first to meet the challenge of handling large amounts of men, money and materials efficiently within a single business unit, they set a precedent for other potential large-scale enterprises to follow. (10) However, as with the influence of personalities, the study of railway management warrants a thesis of its own.

Perhaps the most important omission is the lack of emphasis on regional, and more so local, economic effects of the coming of the railway. The prospectuses issued by railway promoters in fact were primarily concerned with the benefits that would accrue to particular places or areas when the greatness of the railway was thrust upon them. In many cases their predictions were justified and prosperity was attained, but this does not necessarily infer that scotland as a whole benefited, for while some areas prospered, others were not so lucky. Coal mines by-passed by the Ayrshire railways failed to expand their output along side the rest of the industry. The Dumfries to Portpatrick railway did little for local industry, and, by weakening the coastal trade, produced a decline in the activity of Kirkcudbright as a port. The mills at Gatehouse, also in Kirkcudbrightshire, failed to revive from the cotton slump of the 1860 s partially because they had no railway connection. In Fife the growth of the railways diverted some of the trade from the East Neuk ports. The

10. A.D. Chandler, 'The Railroads: Pioneers in Modern Corporate Management,' Business History Review, vol.39, 1965.

11. As for example T.R. Gourvish, Britigh Railway Management in the Nineteenth Century, with special reference to the career of Captain Mark Huish. Ph.D. London 1967. 
inhabitants of Greenock had hoped that the coming of the railway would help them capture back some of the cargo trade which they had lost to Glasgow, but their expectations were not fulfilled. In addition the professional classes tended to move out of the town as the railway facilitated commuter traffic. (12)

It would be a Herculean task to take every town and parish in Scotland and attempt to balance the pros and cons of railway development. Instead aggregate figures of capital expenditure and railway demands for industrial products must be resorted to if an assessment is to be made as to whether railway development was overall to the national advantage. Such an approach must inevitably neglect local, and even regional differences. The writer is well aware that the railway might have meant economic life or death to a community, but the subject of the thesis is the Scottish economy as a whole and not the rise or fall of spatial sectors within that economy.

The number of people to whom thanks are owed for encouraging, enabling and forcing me to finish this thesis is not the least of quantification problems. Specific help with certain chapters will be acknowledged in the appropriate part of the thesis, but here let me take the opportunity of giving thanks to people who have played a major role in getting this study off the ground.

12. See Chapter six, pp. 363-364.

Third Statistical Account of Kirkeudbright and Wigtownshire. 1965. p.28

Third Statistical Account of Renfrew. 1962. p.37. Third Statistical Account of Fife. 1952. p.52. 
Firstly, Don Hudson, my sixth-form teacher, who stimulated my interest in economic history and encouraged me to venture south for my university education. Next I must thank the staff of the Faculty of Social Science at Southampton, both for their teaching of the many disciplines utilised in this thesis and for their bowling which indirectly led to my doing research at Edinburgh. To my supervisors at Edinburgh, Professor S.B. Saul and Professor M. Flinn, I owe a great deal, not only for setting immature thoughts on the right path, but also for the degree of freedom which they allowed me in my approach to the subject. In fact thanks must go to the whole Department of Economic History for their suggestions, criticisms and toleration.

It has been pointed out that one danger of quantitative history is that its followers might refuse to get their hands dirty. I hope that this criticism does not apply to this thesis for I have endeavoured to use whatever evidence I could. For help in digging this out I am indebted to the staffs of the Scottish Record Office, the National Library of Scotland, and various other libraries throughout Scotland, especially the Mitchell Library, Glasgow and the Bdinburgh Central Library. My main thanks, however, must go to $\mathbb{M r}$. G.M. Hogg and his staff, especially Jim Barber, at the British Rail Board's collection of historical records, Waterloo Place, gdinburgh.

Finally, I would like to thank my parents for their financial support and my wife for making me realise that a thesis was not everything in life.

Most of chapter five has been published as 'The Railways 
and the Iron Industry: A Study of their Relationship in Scotland' in M.C. Reed (ed.), Railways in the Victorian Economy: Studies in Finance and Economic Growth. David \& Charles, Newton Abbot. 1969.

\author{
Wray Vamplew, \\ University of Edinburgh.
}


CHAPTER ONE

AN UUTLINE OF RAILWAY DEVELOPNENT IN SCOTLAND

"The first (though far from the oniy) duty of the railway historian is to establish a firm foundation for his story by means of an adequate chronology of the physical development of lines he is concerned with."

Michael Robbins, Journal of Transport History, vol.1,

\section{1.}

When Michael Robbins wrote that "the railway was invented .... in Britain, and, more specifically, in England," he was merely underlining the relatively slow development of this form of transport in scotland, a retardation as apparent to contemporaries as to those with the benefit of hindsight. (1) A letter to the Railway Times in 1840 pointed out that in Scotland "they are children as to railways" and a later correspondent was pleased that the Scots were at last "being seriously drawn to railway locomotion." (2) Scotland clearly lagged behind England in laying down her iron roads. By 1840 there were 137 route miles of railway in operation north of the border, but the rest of Britain could claim nearly 400 miles a decade previously. The lag was not due to a lack of initiative in transport innovation for scotsmen pioneered many transport improvements. One has only to recall Telford's roads and Henry Bell's "Comet," and legend has it that William Murdoch would have applied the

1. M. Robbins, The Railway Age. 1965. p.106.

2. Railway Times, 15 August, I840; 3 April, 1841. 
steam engine to railway locomotion had James Watt been less conservative. Nor can the lag be attributed to a lack of interest in railways, as there is ample evidence that railways were discussed in scottish business circles quite early in the nineteenth century and plans formulated for their construction, although in most cases these proposals proved abortive. By the early 1820s several large collieries and ironworks possessed short distance tramways, but plans for railways between Kelso and Berwick, Berwick and Glasgow, Glasgow and Edinburgh, Ardrossan and Sourkie, Dalkeith and St. Boswells, and for a line through Strathmore all turned out to be premature. (1)

If the denand for railways was to become effective copital had to be provided, and it is the difficulties of finance which suggest the most plausible answer to the question of Scotland's late development relative to that of her southern neighbour. Normally railways take time to construct and experience a long gestation period before returns are obtained on the capital invested. Scotland simply could not afford to divert capital from other sectors of her economy and tie it up in the building of railways.

The railways that were built lend support to the hypothesis of fund raising difficulties being the key factor in explaining

1. Mr.H.S., vol.6, 1824 .

W.A.P. Johnman, The Canals, Tramroads, and Railways of Roxburghshire,' Transactions of the Hawick Archeological Society. 1919. p.16. Scots Magazine, 1810. p.329; 1812. p.817. Edinourgh Magazine, 1818. vol.2, p.484; 1818. vol.3, p.282. Airlie Papers, G.D.16, section $38 / 82$, bundle 1, no.15, p.2. S.R.o. 
the slowness of rallway development in Scotland. As in England, there is a long history of rails being put down to aid in the exploitation of coal deposits - a line from Tranent to Cockenzie crossed the battlefield of Prestonpans - and in fact all but one of the Scottish railways built before 1836 were to facilitate mineral development. (1) Iheir promoters were frequently, if not generally, the proprietors of the coal and ironstone fields to be opened up, and they could afford the relatively small capital expenditure of these short lines from which they sought indirect rather than direct returns. Appropriately enough, although the first real railway in Scotland, the Kilmarnock and Troon (1810), issued shares, it was virtually the private property of the Duke of Portland whose mines and harbour it was designed to aid. (2)

Non-mineral lines and expensive projects had to wait. A railway to link Edinburgh and Glasgow was originally envisaged in 1812, was first surveyed in 1825, and was eventually brought to the public in 1832, only to be prevented from fruition by a lack of finance (and the opposition of canal and stagecoach proprietors). (3) The only line built before the mid 1830s which was not predominantly concerned with the carriage of minerals was the Dundee and Newtyle, and this underwent severe financial difficulties, - its eleven miles of single track taking over five years

1. G. Dott, Early Scottish Wagonways. 1945. pp.1-3 lists nineteen private wagonways to assist in the conveyance of coal.

2. A.S. Turberville, A History of Welbeck Abbey. 1939. vol.2,p.366.

3. G.M. Nisbett, Report to the Wonkland and Rirkintilloch Railway, 15 December, 1830. MitcheII Mibrary. Scottish Guardian, 6 March, 1832. 
to complete. (1) Even proposed mineral lines were not guaranteed the necessary support. In 1825 a railway was contemplated through Fife to connect Bilbernie colliery and the Forthar lime works with the port of Newburgh. This scheme came to naught, but was revived in 1835 on a much larger scale. However, once again nothing positive was done and the proposal languished until it was taken up once more at the end of the 1830s, but even then several years elapsed before the final plan was acted upon. (2)

It must now be asked why Scotland could not afford to build railways. The answer lies in her economic situation. Whereas not exactly undeveloped in the first decades of the nineteenth century, Scotland could certainly be ranked as underdeveloped. Her limited capital had to be utilised with care if a take-off was to be made. Obviously some would have to be used in creating social overhead capital, but when the creation of the infrastructure is dependent upon private initiative it is more likely to go hand in hand with economic development than precede it. Such was the case in Scotland. Those most likely to benefit from the establishment of sanals and railways, viz. local mineral proprietors and merchants, put money into them, but their investment was limited by the financial needs of their primary enterprises. (3) Few funds would be available for blind investment and what there were would be unlikely to be risked on railways,

1. Airlie Papers, G.D.16, section $38 / 77$, bundle 1 , passim. S.R.0.

2. T. Grainger \& J. Miller, Report Relative to a Railway Communication from Montrose to Brechin. 1839. Mitchell Iibrary.

3. The sources of finance for Scottish railways will be discussed further in the following chapter. 
as yet unproved as viable financial undertakings. Sustained economic growth most likely began with the rapid expansion of the Scottish pig iron industry on the basis of the low cost production made possible by the application of the hot blast in the late 1820s. (1) The boom conditions in this industry encouraged complementary expansion elsewhere in the economy, of which railway development was but one facet. Many of the profits made, especially in the iron industry, would be required for ploughing back and would thus be unavailable for railway investment. Presumably the expanding economy generated some surplus funds for general investment purposes, but the railways were not the sole seekers of these funds and, no matter what the liverpool and Manchester had achieved, a major Scottish line had still to demonstrate the attractiveness of railway investment as compared with, for example, government funds or overseas investrent companies. Prior to the expansion of the iron industry there was probably insufficient capital available to finance substantial railway building; after the take-off there were perhaps too many other demands for railways to expect the buik of capital to come their way, especially in view of their, as yet, undetermined financial

1. Prior to this scottish iron was priced out of most markets. Two solutions were open to the industry; it could either develop specialised finished products such as those with which the Carron Company had found success, or it could lower production costs. For a number of reasons the former proved difficult and it was on the basis of low cost production, reniered geologically feasible by the blackband ironstone and technically possible by the hot blast, that the Scottish iron industry expanded. Low mineral royalties and cheap labour also played a part. R.H. Campbell, The Growth and Fluctuations of the Scottish Pig Iron Trade, 1828-1873. Ph.D., Aberdeen. 1956. chapters 1-2. 
prospects. Scotland could not therefore establish an expensive railway system at this time without externel financial assistance, and English investors, those most likely to offer aid, were finding enough outlets at home, partly in laying the foundations of their own railwey network. (1)

Financial difficulties restricted scottish railway development before the mid 1830 s to a scattering of short, predominantly unconnected lines. Only in the mineral fields of Lanarkshire had there been any attempt to link up and, even here, less than thirty miles of railway were involved. Many contemporaries were dissatisfied with "those insulated patches of railways here and there, for particular purposes, or for the convenience of private individuals," but men such as Charles McLaren, editor of the Scotsman, who envisaged an extensive Scottish railway network were ahead of their time. (2) The railway "idea" was not sufficiently advanced for his visionary schemes to be seriously considered.

It should be noted that improvements in other forms of transport were not neglected. In 1824, for example, navigation was improved on the River Leven and Loch Lomond and the succeeding years witnessed several plans for better canal communication. (3)

1. The role of English capital in the financing of Scottish railways is discussed in section three of chapter two.

2. Memorial to the Lord Provost and Magistrates of Edinburgh respecting the Projected Railways. G.D.26, section 15/94, P.2. S.K.0.

C. Maclaren, Railways compared with Canals and Common Roads. 1825. This is a collection of articles orifinally published in the Scotsman but with additions and corrections.

3. H. Baird, Report on the Improvements. 1824. Mitchell Iibrary. 
Roads too were not omitted from improvement plans and proposals. 1829 was a 'boom' year with Grainger and Miller (later to achieve eminence as railway engineers) surveying a road from Glasgow to Ayrshire, with Stirling's road, the northern approach to Glasgow, actually being improved and with better communication between the Old and New lowns being planned in Edinburgh. (1) However, as with many railway scheres, achievements did not match up to ambitions, partly because of financial difficulties, but also because of a growing realisation thet many improvements would "ultimately be found inadequate" owing to railway development. (2)

Despite the growing popularity of the railway "idea" - as railway became the cant word for modern, Henry Ballantyne, a woollen manufacturer of Galashiels, put out a pattern designgted "railway check" - the minor British railway mania of the mid 1830s left scotland relatively unscathed. (3) Few schemes were put forward and even less materialised. The Kelso Agricultural Association revived the Berwick-Kelso project, but it again failed to get under way as did the resurrected Glasgow and Falkirk

1. T. Grainger \& J. Miller, Report on the Improvements of Stirling's Road. 1829. Mitchell Library. PIan of Communication Between the New and old Town of Bdinburgh. 1829. Mitchen Library. T. Grainger \& J. Niller, Report on the Best Road From the dity of Glasgow to Ayrshire. 1829. Mitchell jibrary.

2. Report to the committee appointed by the Town council of Kilmarnock to survey the country between Kilmarnock and Glasgow for railroad communication. 1836. p.1. Mitchell Iibrary.

3. Sales Ledger of $\mathrm{H}$. Ballantyne and Son. 1828-39. I am grateful to HI. C. Gulvin of the Portsmouth College of Technology for this reference. 
Junction, first proposed in 1830. (1) only three small lines were sanctioned, the Dundee and Arbroath, the Arbroath and Forfar, and the Edinburgh, Leith and Newhaven.

However, Scotsmen were awakening to the possibilities of railway investment especially as the fruits of the economic expansion engendered by the hot blast were becoming available. Railways south of the border had proved themselves to be worthwhile propositions so why should not those in Scotland? The result of the stimulus of available capital and English example was the construction in the late 1830 s and early 1840 s of three great inter-urban lines, the Edinburgh and Glasgow, the Glasgow, Paisley and Ayr, and the Glasgow, Paisley, Kilmarnock and Ayr. (2)

It was at this time that the idea of a Scottish railway network began to emerge. Although the Dundee and Arbroath and the Arbroath and Forfar had a 516" gauge which their engineer thought best facilitated locomotive construction and performance, the Edinburgh and Glasgow, under the same engineer, deliberately adopted a gauge of $4 \cdot 8 \frac{1}{2} "$ so as to be able to link up with the two

1. Johnman, op.cit., p.18. Glasgow and FaIkixk Junction Railway, 19 February, 1836. Witchell Library.

2. The Edinburgh and Glasgow was in fact a product of the mania whose authorisation had been delayed by parliamentary technicalities. Significantly, of the three railways the Edinburgh and Glasgow had the greatest proportion of its capital raised in England. (see chapter two pp.64-66) Evidence that the success of English lines was used to persuade scots to invest in their own lines is cited in chapter three $\mathrm{pp} \cdot 139-140$. 
other great inter-urban lines. (1) By 1850 all the railways in Scotland were on this standard gauge, unlike in England where the Great Western retained its 7 ' broad gauge until 189 ?.

No railways were authorised in Scotland between 1838 and 1843, but promotional activity was not dead. In February, 1840 the Railway Times commented on "the great interest taken by the Scotch people generally in the progress of railway undertakings in that country, as compared with the apathy which pervades the English public, in reference to similar works in the South." (2) Competitive routes were being surveyed through fife in early 1841 and another line projected to the north of Edinburgh at this time was the Falkirk, Stirling and Perth. Even further north proposals were in the air for lines around Montrose and Brechin and between Aberdeen and Inverness, and Aberdeen and the Edinburgh and Glassow railway. Over in the west railway interest showed itself in plans to link Ayr with Cumnock. (3)

Yet, as stated above, none of these schemes was authorised at the time and the reason for this must be conjectured. Scotland was basking in an atmosphere of relative economic prosperity and this perhaps stimulated the proposals. However, substantial amounts of capital were being invested in the pig

1. S.C. on Rallways. $1839 \mathrm{x}, \mathrm{q} .3406,3421$. Railway Times, 25 August, 1838.

2. Tailway Times, 8 February, 1840 .

3. Sinburgh Evening Courant, 2 January, 1841. Abercairney papers, G.D.24, section 924 , item $1, p_{0} 3,22$ February, 1841 and circular of the Scottish Central Railway, 29 February, 1844. S.n. 0. Railway Times, 3 August, 1839; 10 September, 1839; 21 September, 1839; 10 April, 1841; 23 October, 1841; 22 January, 1842. 
iron industry and in the completion of other projects, anong them the inter-urban lines previously mentioned. (1) This would limit the amount of funds potentially available for railway investment. Despite English economic horizons being cloudy English capitalists were probably not keen to invest in new Scottish railways until the fate of those already under construction became clear. The reluctance of both Scottish and English investors would be strengthened by most of these proposals being outside the central industrial belt where it was not apparent that they would be profitable concerns.

The period between the railway manias of the mid 1830s and mid 1840s was one of great interest in railways which were to link scotland with Bngland. In some instances the initiative for the schemes lay south of the border, but it is clear that the Scots were desirous of railway connections with England. In August, 1834 the Company of Merchants of Edinburgh recognised the importance to both agricultural and commercial interests of bringing Edinburgh and London "as near to each other as possible." (2) The method they envisaged was an acceleration of the mails, but it was inevitable that transborder railways would be seen as

1. R. H. Campbell, Investment in the Scottish Pig Iron Trade 1830-1843,' Scottish Journal of Political Economy, vol.1, no.3, october, 1954, pp.247-248.

2. G.D.135, Box 82, 25 August, 1834. S.R.O. 
an alternative, and probably better, solution.

The first proposal for an Anglo-Scottish line was the abortive Glasgow-Berwick project of 1810, but there was no possibility of such a length of line being built anywhere until shorter railways had proved their worth. A more realistic proposal came in 1832 when the Great Northern Junction was planned to link Newcastle with Edinburgh via Otterburn, Jedburgh and ifelrose. (1) Nothing came of this but the idea of a line to link these two centres did not languish, and the late 1830 s witnessed the proposal of three such schemes, all of which originated in England. (2)

On the west coast, however, the initiative lay with the Scots and two rival projects were promoted to link Glasgow with Carlisle and the south. (3) one scheme was to extend the

1. Johnman, o..cit., p.25.

2. J. Richardson, General Report on the Newcastle, Edinburgh and Glasgow Railway. 1837. Dunglas Papers, G.D.206, section 1/63a, item 5, 3 September. 1838 Ra1 lway Times, 25 August, 1838.

3. It is interesting to conjecture why the initiative for the routes came from where it did. Glasgow and Newcastle may have commercially dominated their prospective railway terminal of Carlisle and Edinburgh and were perhaps eager to seek potential markets. However, the east coast line to be built in fact stemned from Edinbirgh. The Newcastle party presumably gave up their scheme in the depresion years of the early 1840 s and Bdinburgh would thus have to take it up if the railway was not to be thwarted for several years at least. It is suggested in chapter three $(p .155)$ that Scotland did not suffer as badly in the depression of the early 1840 s and adinburgh's railway supporters may have felt that a delay was unnecessary. They certainly had the political influence to push forward the scheme (as the provisional committee sh ows), yet the argument is weakened by the fact that Edinburgh could not provide the capital for the railway. The railway that the Bdinburgh party first envisaged was to run only to Dunbar, but was extended to Berwick in order to make sure that snglish financiers knew that it was to be more than a local scottish line. (NBR 1/1, $19 \mathrm{Lay}, 1943, \mathrm{~B} . \mathrm{k}$.$) It is possible that the Edinburgh in-$ terests, despite their apparent lack of capital, were frightened that if the west coast line was built first the east coast line might be lost for ever. 
Glasgow, Paisley, Kilmarnock and Ayr into England via Nithsdale. This line had been planned with a gauge of $4 \cdot 8 \frac{7}{2} "$ so as to facilitate through traffic with English railways should a connection ever be established. (1) The other major proposal was to take a. Iine through Annandale and over Beattock. A driving force here was the personality of J.J. Hope-Johnstone, promoter of the line. Not content with the original surveys favouring the Nithsdale route, he persuaded Locke, the influential English engineer and original surveyor of both west coast routes, to change his opinion on the difficulties of the climb to Beattock summit. (2)

Despite the multiplicity of projects it was generally recognised that only one route could be profitable and gradually all the parties involved accepted the idea of letting the government decide. The government itself accepted the sole railway argument; Gladstone maintained that as late as 1842 "it was firmly believed to be absolutely impossible that there should ever be more than one railway into Scotland." (3) The confidence of the various promoters in risking arbitration was, however, justified in that within the decade three of the major projects were in operation. The government made it clear that they had no intention of taking over, but were only desirous that the best line should be selected. (4)

1. Railway Times, 8 Neptember, 1838. J.k.F. Gardner, Railway interprise. 1934. p.13.

2. Locke decided that the gradient was "not of that formidable character that I at first apprehended." Mss.6678(2) Caledonian, Noveraber, 1837, p.4. N.L.S.

3. Wuted in W.M. Acworth, The Railways of Scotland. 1890. p.29.

4. Railway Times, 25 January, 1841. 
The official verdict went in favour of the Annandale scheme, but an important rider was added - either antecedent to, or simultaneously with, the building of this line, another railway should be undertaken to link Carlisle with lancaster. If this did not happen and parties should be found to construct the line from Darlington to Edinburgh, then the western route ought to be abandoned for the present. (1)

In fact Hope-Johnstone's line was delayed for a different reason. Technical difficulties were pleaded, but "there can be no question that the real impediment (was) the want of support of the landed proprietors and residents of the district." (2) The retardation of this scheme focussed attention on the eastern routes, one of which, the North British, becare sanctioned, despite a last ditoh attempt by the undaunted Annandale devotees to prevent the authorisation on the grounds of the "wasteful expenditure of competing lines." (3) However, once the North British had been authorised their tune changed to "now .... (it is) felt and admitted on all hands that an east coast route is inadequate to meet the wants of the country, and that an additional line of railway to connect with the English western line at Carlisle is imperatively called for." (4)

The advocates of the western routes proclaimed the relative merits of the Annandale and Nithsdale schemes, now respectively

1. Fourth Report of the Committee Respecting Railway Communication between London, Dublin, Edinourgh and Glasgow. 1841 XXV, p.66.

2. Q.ilway Times, II Merch, 1843.

3. MSS. 6354. .60 , Captain Huish to Hope and Oliphant, 6 March, I844. N.I.S.

4. A pamphlet titled Remarks on the Caledonian Railway. N.L.S. 
titled the Caledonian and the Glasgow, Dumfries and Carlisle railways. Not to be outdone the North British proposed to link Edinburgh with Carlisle by a line through Havick. The Board of Trade was called upon to decide which, if any, should be sanctioned. There was much debate and a considerable difference of opinion between the officials concerned, but, whatever their points of view, one memoranda pointed out that "the people of Scotland generally seen to be of the opinion that they require additional railway connection with England especially a connection with Lancashire and the manufacturing districts." (1) In the end both westem routes were authorised.

All the Scottish lines were still dependent on the completion of connecting English lines to provide effective transborder linkage. In the west the Lancaster and Carlisle preceded the Scottish lines, being officially opened in early 1847, but in the east the North British, opened in June, 1846, had to wait just over a year for the Newcastle and Berwick to begin operations.

The Edjuburgh and Hawick had not had its extension approved and was to remain a cul-de-sac until the late 1850s. Although Parliament had rejected a continuation to Carlisle in 1857, both the Caledonian and the North British maintained agitation for the authorisation of such a route, the former company wanting to go via Liddesdale, the latter through Langholm. Eventually Parliament succumbed to the pressure and, after a prolonged and severe parliamentary struggle, victory went to the North British. found in the Dalhousie Papers, G.D.45, section $7 / 59$, bundle 1 . 
The final transborder link came in 1876 with the opening of the Settle to Carlisle route of the vidland railway. This had been sanctioned in 1866, but the Mialand had sought to abandon the project because of financial troubles in 1867 and 1868. However, the Lancashire and Yorkshire and the North British companies successfully opposed this policy on the grounds that it was essential for through traffic to Angland via Carlisle to have a choice of routes south of the border. (1) Until this time all Anglo-Scottish traffic on the Glasgow and South Western (formed in 1848 by the amalgamation of the Glasgow, Paisley, Kilmarnock and Ayr and the Glasgow, Dumfries and Carlisle) had been hindered by trans-shipment difficulties at Carlisle, but the opening of the Settle line encouraged an intimate relationship with the vidland and resulted in the scottish railway becoming increasingly important as a through line.

\section{3 .}

The extent to which Scotland participated in the great railway mania of $1845 / 46$ is evidenced in the fact that a newspaper was published specifically to deal with scottish railway matters. (2) Proposal after proposal was put forward. Many were eminently practicable, but others were epitomised by Punch's "John $\mathrm{O}^{\prime}$ Groat and Land's End Junction, with branches to Ben Lomond and Battersea." (3)

1. Nailway News, 6 May, 1876.

2. Scottish kailway Gazette, first issue 5 April, 1845.

3. Punch, v01. X, 1846. p.88. 
"We have railways proposed in every direction" wrote one contemporary observer. (1) How right he was, for in December, 1845 plans for one hundred and fifteen Scottish railways were deposited with the Board of Trade. (2) sven the most isolated areas were not ignored. A Northern Counties line was to run through Ross, Sutherland and Caithness, whilst Oban was to be linked with Balloch by the Scottish Western. (3) The Railway Times feared that Berwickshire might be neglected because it was "almost exclusively agricultural," but within a few weeks of their suggestion proposals were afoot for a Berwickshire and Lothians Iine and also a Berwickshire Centril Junction. (4)

There is some evidence of financial chicanery, especially by "Scotch premium hunters" who, as in the case of the General Terminus, sought to create an artificial scarcity by alloting nearly all the shares to promoters and their friends. (5) However, bubble schemes of the type lampooned by Professor Aytoun in his article, "How we got up the Glenmutchkin Railway and how we got out of it," were rare. (6) A more prevalent danger was "the amount of competition which is now organised for particular lines." (7) In one week three schemes were gut forward for

1. Airlie pavers, G.D.16, section 38/82, bunale 2, item 5,6 April, 1844. S.K.0.

2. Railway Times, 13 Decenber, 1845.

3. Seaforth papers, G.D.46, section 1/400, itern 1, october, 1845. G.D.122, volume 3, no.863c. S.R.O.

4. Railway Times, 11 october, 1845; 8 November, 1845.

5. Railway Times, 1 June, 1845. Scottish Railway Gazette, 18 october, 1845.

6. Blackwood's Edinburgh Mgazine, october, 1845 .

7. Kailway himes, 22 November, 1845. 
railways between Perth and Inverness. The route to connect with the Irish Channel traffic was also the objective of three companies, a competition "unparalleled in the annals even of railway madness." Even worse perhaps were the plans concerning Edinburgh and Leith which, although already connected by a good road, were to be linked by five different railways, three of which were to be atmospheric. (1)

Railway shares at this time tended to be purchased, not as investments, but as speculative ventures in the hope of obtaining quick capital gains. New railways were heavily over-subscribed in an effort to get shares at par as this would, in the circumstances of the time, virtually ensure a swift profit. (2) The speculation was encouraged by only a deposit on the shares (usually 10\%) having to be paid and, in many cases, shares were allocated to one person who then sold them to another at a profit without parting with any money of his own at all. The prices of scrip and shares rocketed sky high and inevitably panic set in. When it did some harsh facts had to be faced. The heady years of the mania soon gave way to a sobering aftermath as speculators found themselves comitted to undertaking investment far in excess of their financial resources. A movement for postponements and abandonments quickly gained momentum and the remaining jears of the decade witnessed freyuent reports of windings up or requests for an extension of time before the

1. Scottish Railway Gazette, 28 March, 1846; 18 October, 1945; November, 1845; 17 May, 1845.

2. Mss. 6078 (4). Letters to the shureholders of the Caledonian Kailway. N.I.S. Pitfirrane Mss: 6480 (176). N.L.S. 
commencement of construction.

However, it must be emphasised that many of the proposals made for railways during the mania period were based on sound investment criteria. Although some of them were unable to proceed because of difficulties in raising capital in the post-mania years, others went ahead, and the last half of the 1840s saw over eleven hundred miles of track brought into operation. No other quinquenium could register a comparable increase as can be seen from Table 1.1 .

TABLE 1.1

EXPANSION OF THE SCOTTISH RAILWAY SYSTEM

Period Total Route Miles Increase Total Mrack Miles Increase pre 1840 $1840 / 44$

$1845 / 49$

$1850 / 54$

$1855 / 59$

$1860 / 64$

$1865 / 69$

$1870 / 74$

$1875 / 79$

$1880 / 84$

$1885 / 89$

$1890 / 94$

$1895 / 99$

137

282

872

1,062

1,418

2,105

2,399

2,700

2,864

2,999

3,118

3,328

145

590

190

356

687

294

301

164

135

119

210

152
181

442

1,568

1,845

2,265

3,017

3,396

3,738

3,958

4,139

4,336

4,641

4,884
261

1,126

277

420

752

379

342

230

181

197

305

243

Source: Board of Trade Railway Returns, Bradshaw's Guide to Railway Shareholders and a miscellany of railway histories.

Yet it must also be pointed out that the majority of the scottish railways in operation during the immediate post-mania

1. Strictly speaking this is not obvious from the format of Table 1.2, but it is true that no five year period witnessed as auch construction as the years from 1845 to 1849 (inclusive). 
period were in financial difficulties to a greater or lesser degree. This was especially true of the two major companies, the North British and the Caledonian. Dividends and the North British shareholders remained strangers for seven years and by 1851 the concern was described as having fallen into "a hopeless atrophy." (1) The trouble in this case seems to have stemmed from the directors trying to do too much at once in the way of new construction. The Caledonian on the other hand over-reached itself by way of takeovers. It took on too many committments, guaranteeing dividends to absorbed companies which were far too high to achieve, let alone sustain. For a while, as with the Aberdeen and the Bdinburgh, Perth and Dundee railways, the very existence of the company was in the balance. (2)

Scotland appears to have been singularly affected at this time in that "nine-tenths of the railways in that country are in a worse plight than the leading English companies." (3) Why this should be is not readily apparent. Perhaps the sudden late development meant that there had been an expansion of railway communication out of all proportion to the traffic that cokid be expected to develop in the short run. The larger companies had tried to do too much too soon and the smaller ones were not sufficiently capitalised to do more than keep their heads above water. In addition there were frequent charges of capital being so extravagantly expended as to render the original estimates

1. Railway Times, 13 December, 1851.

2. H...J., 14 September, 1850. Railway Times, 29 March, 1851.

3. Railway Times, 26 April, 1851. 
works of fiction. (1)

In the early 1850 s there was a burst of enthusiasm for railways built on what was termed the "cheap principle." These were generally single line railways with few heavy works and inexpensively constructed stations. Building on the "cheap principle" may have been a reaction against the high expenditure of much post-mania construction, but a more likely explanation is that these lines were primarily to serve agricultural districts which could not produce enough traffic to guarantee reasonable dividends on heavier capital expenditure. (2)

The promoter of the Deeside in 1850 had had his attention drawn to "the means of construction and the working of railways at a far cheaper rate than has hitherto been usual." (3) Presumably this was an article in Chambers' Edinburgh Journal, 8 December, 1849 on "the new and cheaper kind of railway system." In 1852 the publicity given to the Peebles line gave an impetus to the movement for such railways. (4) The President of the Institute of Engineers and Shipbuilders of Scotland later warned that a railway built on the cheap principle "not only fails to produce any real economy, but is absolutely ruinous on working

1. E.8. H.R.J., 15 April, 1854; 11 May, 1850

Report of the committee of Inquiry to the Shareholders of the North British Railway, 1849. p.6. KAC/S) I/1A. B.K. Whether capital was extravagently expended will be discussed in section four of chapter three.

2. I have been unable to trace any lines built on the "cheap principle" outside agricultural areas.

3. R.R. Notman, A Letter to the Landed Broprietors of Deeside. 1850. p.1.

4. H.R.J., 15 May, 1852; 10 JuIy, 1852; 1 August, 1852; 9 october, 1852 . 
expenses." (1) However, this was being wise after the event and such thoughts, if they were ever contemplated at the time, did not deter the promoters and the innovation was adopted enthusiastically. By the end of 1854 an editorial in Herapath's Railway Journal on "The Costly Old and the Economical New Scottish Railways" could list over ten lines built on the new principle. (2)

However, it should be stressed that the najority of lines laid down in the 1850 s were of the conventional type although, as can be deduced from Table 1.1, many were single line. Major lines were constructed in the north-east, an area deemed relatively unprofitable in the scramble for capital following the mania. Elsewhere, attention turned to filling out the railway map with secondary and branch lines, though not to the exclusion of main line building.

It was during the 1850 s that the North British ventured into England. The first Scottish steps over the border had been the minor ones of approaching Berwick and Carlisle, but now the North British ws promoting the nominally indevendent Border Counties and Wansbeck railways. The same company later purchased the Northumberland and the Carlisle and Silloth Bay railways, and the Caledonian took over the Solway Junction. In general, however, the Scottish companies stayed their own side of the border.

The late 1850s witnessed an intense agitation for the benefits of railway communication to be extended to the hyperborean regions of scotland. These areas had not been ignored

1. 2...S.S., $1858 / 59$, p.7.

2. H.R.J., il November, 1854 . 


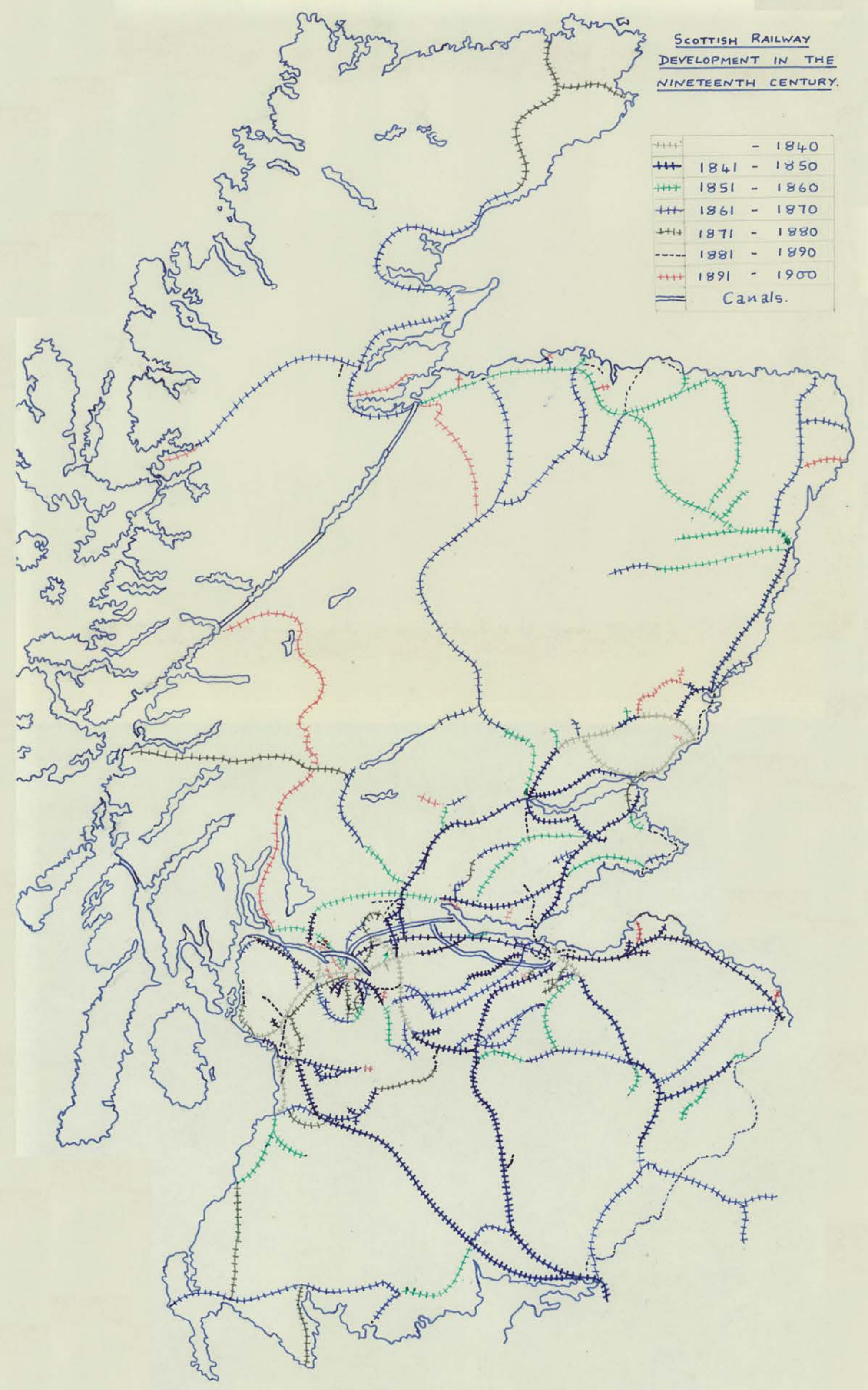


by the promoters of 1845, but, as the financial atmosphere worsened and investors opted for lines with better prospects, their lack of potential traffic meant they had to wait, and, as can be seen from the map of chronological development on page 30 as late as 1850 there was not a single mile of track north of a line drawn to connect Greenock and Aberdeen.

In the following decade the Great North of Scotland developed in the north east, but the Highlands still had to wait. Towards the end of the 1850s the Inverness Courier reported a movenent afoot "among influential landowners north of Inverness to have the railway extended, first to Dingwall, and afterwards still further north." (1) Suggestions and proposals concerning these areas increased in frequency, but only gradually, and in a piecemeal fashion, was the situation rectified, wick and Thurso not being reached until 1874. The north-west, with its mangled coast and low density of population, had no option but to remain at the back of the queue for railway communication, and not until the 1890s was the West Highland line put under construction, and Mallaig had to await the turn of the century for its place on the railway map.

It will also be apparent from the map of chronological development that railways were long in coming to the sparsely populated territory of the south-west. As in the north, the schemes of the mania period had proved too ambitious. The important project in this region came in the late $1850 \mathrm{~s}$ with the

1. woted in H.R.J., 15 November, 1858. 
plan for the Portpatrick railway, whose importance lay in providing the means of developing the short sea route between Scotland and Ireland. This was expected to be a great postal route as the government was spending large sums on improving Portpatrick harbour, but arrangements did not turn out as anticipated because the harbour silted up and was eventually all but abandoned. (1) Thereafter Stranraer became the port for steamboat commuication with Iarne in Ireland.

The progressive increase in mileage was matched by improvement in management as experience replaced pioneering enterprise. By 1857 Bradshaw could report an "appreciable increase ... in the value of railway property" and five years later Herapath's editor eulogised "a number of Scotch lines now paying good rates of dividend, and promising excellent things hereafter," attributing their success "to faithful and economical management." (2)

\section{5.}

As the railway companies increased in stature and stability the memories of 1845 faded and promotional activity increased again. Both five year periods after 1854 witnessed increases in the mileage constructed, as can be seen in Table 1.1. Bradshaw's review of 1864 commented that "the remote villages of Scotland and Wales are vying with each other in an earnest endeavour to secure for themselves advantages which the established interests are not disposed to carry out." The established

1. H.R.J., 18 April, 1868.

2. H.R.J., 3 May, 1862 . 
companies in scotland were too much involved in their own schemes to help out. Another railway mania was in the offing as a rash of ventures were proposed. However, although often referred to as a minor railway mania the proposals of $1865 / 66$ had little constructional impact in Scotland, the years 1865-74 producing less mileage than the quinquenium immediately preceding it. One reason for this was that the Caledonian, the North British, and the Glasgow and South Western proposed so many schemes that their shareholders revolted. Commonsense, and perhaps an $8 \%$ discount rate, triumphed and the companies agreed to pair off schemes, abandoning projects estimated to have cost over seven million pounds had they been proceeded with. (1) The mania of the mid 1860s was, as far as Scotland was concerned, as much concerned with amalgamations and takeovers as with construction. Its aftermath was the amergence of five large companies who, at the end of 1866, controlled 2,193 of the 2,244 route miles of railway in operation in Scotland. (2) By dint of construction and amalgamation these companies had secured the possession of certain areas. The North British controlled the eastern section of the lowlands and part of Fife;

1. H.R.J., 30 December, 1865; 15 September, 1866.

2. Their respective mileages were the North British (735), the Caledonian (673), the Great North of Scotland (289), the Glasgow and South Western (254) and the Highland (242). It is interesting to note that twenty years earlier a Board of amalgamations and working agreements in negotiation at the time would be "to hand over the whole of Scotland to about four or five companies at the most." Second Report of the S.C. on Railway and Canal Amalgamations. 1846 XIII, p. $22 \overline{6}$ 
the Caledonian centred on Glasgow but stretched north to Aberdeen and south to Carlisle; the Glasgow and South Western and the Highland covered the regions that their names imply; and the north-east was the province of the Great North of Scotland. These territories were fairly well defined, but were at times subject to demarcation disputes as companies switched from uneasy peace to outright aggression. (1)

\section{6.}

Inter-company rivalry between the North British and the Caledonian partly accounts for the shortening of the east coast routes to the north by the bridging of the Tay and Forth estuaries in the final quarter of the nineteenth century. Discussion of these projects long preceded the finance and technical knowledge necessary for their construction. Inadequate engineering experience and ability was in fact a key factor in the collapse of the first Tay Bridge in December, 1879, only six months after it was opened. (2)

The first plan to bridge the Forth was in 1817 at Alloa Ferry and the same point was chosen in 1845 and again by the Caledonian in 1865. When the North British abandoned their $\$ 800,000$ plan for a bridge in the late 1860 s on the insistence of their shareholders and substituted a more modest $\$ 55,000$ scheme, they too favoured the Alloa site. (3) However, when eventually

1. The question of inter-company rivalry will be taken up again in section two of chapter three.

2. See chapter four, p.21\%.

3. H.R.J., 16 September, 1865; 4 April, 1868. 
built the Forth Bridge crossed further down river at North and South Queensferry replacing the ferries inaugurated by the Edinburgh, Perth and Dundee in 1849. The reas on for this perhaps had something to do with the renewal of competition with the Caledonian, the route chosen being more direct than the one in the previous schemes and thus giving the North British an even greater advantage over their rival company. (I) The advantage that it did give can be seen in Tables 1.2 and 1.3 .

The bridge was authorised in 1873 but insufficient capital was fortheoming for the project. (It should be pointed out that although the bridge was the child of the North British, shareholders had insisted it be floated as a separate undertaking). In an effort to encourage investors the North British, together with three English railways, agreed to guarantee a net annual Income of $£ 35,000$, but the Tay Bridge disaster shattered the confidence of the investing public in great suspension bridges. When the scheme was revived in 1882 on the initiative of the Midland company it was for a steel cantilever bridge which necessitated increased guarantees.

The bridges over the east coast estuaries were important in shortening the journey from England into Scotland both in distance, by avoiding the detour around Stirling, and in time, by avoiding the use of ferries, but of course they gave a proportionally greater saving to travellers within Scotland. 1. H.R.J., 17 July, 1869; 13 November, 1869. 2. Acworth, op. cit., p.i20. 


\section{TABLE 1.2}

Effects of the Forth Bridge on Transborder Routes

London to Perth

via
East Coast (North British)

West Coast (Cale- 450 miles 450 miles donian)

before after

462 miles $441 \frac{1}{2}$ miles

Source: Railway Distance Books. B.R.
Iondon to Aberdeen

before after

552 miles 523 miles

540 miles 540 miles

\section{TABLE 1.3}

Comparison of Internal Routes after Forth Bridge via Caledonian via North British

Edinburgh - Aberdeen

Edinburgh - Dundee

Edinburgh - Perth
159 miles

90 miles

69 miles
130 miles

59 miles

48 miles

Source: Railway Distance Books. B.R.

It was also during the last quarter of the nineteenth century that suburban lines achieved great popularity in scotland. The North British had proposed establishing a system of suburban lines within and around Edinburgh in 1865, but the revolt of their shareholders delayed the scheme for several years. (1) The Edinburgh Southside and Suburban railway was authorised in 1880 and again, with improvements, in 1882. However, it was

1. $\operatorname{RAC}(S) 1 / 1 \mathrm{~A}, 23 \mathrm{March}, 1865$. B.R. 
not solely a suburbän line but had a second function of allowing Fife traffic to the south of Edinburgh to avoid the bottleneck of Haymarket tunnel. (1)

The Glasgow City and District, authorised in 1882, also served a purpose other than developing a large urban traffic. It was to provide a convenient access to the dooks on the north bank of the clyde. (2) More conventional suburban railways in Glasgow were the Cathcart District, sanctioned in 1880, its extension into a circle underground, authorised in 1887, and the Glasgow Central, officially blessed one year later. (3) Further north, successful suburban services were established in Aberdeen, but plans for a Dundee Suburban railway fell through despite its authorisation in 1884. (4)

\section{7.}

Some regions were still without railway communication. These were mostly rural districts, unlikely to support a viable railway enterprise if substential capital expenditure was involved. The proposed solution to their problem was a late nineteenth century extension of the 'cheap principle' in what were termed 'light railways,' single track and frequently narrow guage lines. Promotionally, though not financially, these lines gained much support in the rural areas of Scotland.

1. D.I.G. Hunter, Edinburgh's Transport. 1964. p.152.

2. Acworth, op.cit., p.70.

3. H.R.J., $2 \frac{5}{5}$ February, $1888 ; 28$ June, 1895.

4. H.R.J., 17 inarch, 1888 . 
As early as 1876 a Railway News editorial asked why Scotland was so late in following the narrow guage example of angland, America, Spain, Sweden, France, Norway and India. (1) A proposal was in fact in the air to connect Braemar with the south by such a railway, which it was estimated would cost between 35 to $45 \%$ less to construct and $20 \%$ less to operate than a more normal railway. However, the engineer of this line, Mr. Buchanan of Edinburgh, was not destined to become a second stephenson, for it was not until the stimulus of the Light Railways Act of 1896 that such lines really gripped the imagination of the scots. (2)

This Act freed light railways from certain Board of Trade regulations, a privilege which the editor of one railway journal thought tantamount to a bounty from the state. (3) The implications of the Act were not lost upon the Scots. A few proposals had preceded the Act but after its passing plans and promotions increased relatively rapidly. (4) Ten applications for authorisation, many with a plea for financial assistance, were made in December, 1896, and a further five followed in May, 1897. (5) Several of these were promoted by the established companies. The policy of the Highland was "to assist in promoting light lines where these would be of advantage as feeders" to their

1. Railway News, 27 May, 1876.

2. The only light railway built in Scotland prior to this Act was the Campbelltown and Macrihanish opened in 1881 using a 2 " gauge because of the paucity of the traffic and the improbability of connection with any other line. (R.W. Kidner, Light Railway Handbook. 1950. p.60.

3. H.R.J., 29 Warch, 1895.

4. H.R.J., 6 September, 1895; 18 october, 1895.

5. Parliamentary Papers. 1898 IXXXI. 
own line. (1) The Glasgow and South Western, however, pointed out the wisdom of adopting a more cautious attitude as "light railways were new and they did not know much about them." (2)

Unlike the burst of 'cheap principle' proposals earlier in the century, this promotional wave had few positive results for hardly any lines were built, and those that were had to await the turn of the century. Once again finance had been the trouble. The light railways which were constructed were primarily those taken up by the existing wealthy companies, whilst those attempting to be independent or failing to attract the attention of the established railways remained pipe dreams. Even then the railway companies frequently required a guarantee of Treasury or local government assistance before undertaking the projects. (3)

Traffic in a purely agricultural area could not normally provide even the interest on the capital expenditure of a railway of the conventional type. Such regions must either take up light railways or do without railway communication altogether. The contemporary argument was that to adopt the latter proposition was to ignore the overwhelming continental evidence of the extension of cheap railway communication into sparsely populated districts helping to promote agricultural prosperity. It was in the production of perishable commodities, presumably to be carried by light railways, that one contemporary economist saw

1. H.R.J., 6 November, 1896.

2. H.K.J., 20 May, 1898.

3. The question of the state providing financial aid to railway building in Scotland is discussed in section ten of the following chapter. 
"the best hope for the future" of British farming. (1) However, such railways on the continent were rarely the children of private enterprise, but the British authorities insisted that state aid be limited to one third of the estimated capital cost of any project. (2) The result of this policy, as far as Scotland was concerned, can be seen in a parliamentary inquiry after the first world war which found most rural districts that had considered having light railways just as isolated as they ever had been. (3)

The century closed with the West Highland almost at Mallaig and the first sods having been cut on the Lauder and Comrie St. Fillans light rallways. There was little activity in the industrial areas for with the existing location of industry little remained to be done. This may account for the slowing down in the rate of Scottish railway construction from the $1870 \mathrm{~s}$, the last twenty five years of the nineteenth century witnessing only 780 route miles opened as compared with 1,828 miles in the preceding twenty five years. The big five companies had consolidated their stocks and extinguished their associated companies by amalgamating them into the parental concern. The odd branch was being projected, but the Scottish railway network was virtually at its peak with nearly 3,500 route miles in operation.

It has been suggested that emphasis should be placed on the role of geography in conditioning the development of the scottish

1. W.N. Acworth, 'Light Railways,' Journal of the Royal Agricultural Society, third series, v0l.6, 1895. p.649.

2. H.L.J., I4 JuIy, 1899 .

3. S.C. on Rural Transport (Scotland). 1919 Xxx. 
railway system. (1) However, although the actual routes may have been influenced by geo-physical factors, it was undoubtedly the supply of investible funds that determined the chronology and location of rallway construction. The determinants of profitability, and hence presumably the availability of capital, may of course have been closely correllated with geographical factors in so far as natural conditions helped determine the location of the pre-railway centres of population and industry.

Even though geography influenced the routes followed it did not necessarily determine them. The principal geographical problems facing rallway builders in scotland were high relief and crossing the great estuaries, and these were problems only in that their solution was expensive. The meanderings of the Highland were to avoid steep gradients and tunnels, but the reason for this avoidance was the greater cost of constructing routes as the crow flies. The great bridges were delayed until the last quarter of the century partly because of the state of engineering knowledge, but also because the investing public adjudged other works liable to prove more profitable. As a contemporary journal remarked in a discussion on the feasibility of a bridge over the Forth, "of course, the whole matter is one of capital."

Short, inexpensively constructed lines could be financed

1. Ibid.

.C. O'Dell, 'A Geographical Examination of the Development of Scottish Railways,' Scottish Geographical Magazine, vol.

55, May, 1939. 1956.

2. Scottish Railway Gazette, 27 0ctober, 1860 
by a few individuals, but a railway network was dependent upon the whims of the money market. Promotional activity ebbed and flowed, but the funds available decided which schemes came into being. A government inquiry might have stated which transborder railway was to be built first, but the supply of capital determined otherwise. Many eminently practicable proposals for railways had to wait years for their fulfilment because capital was not avaliable. Success in the competition for funds was the key factor in the development of railways in Scotlend. 


\title{
CHAPTER TWO
}

\section{FINANCE (1)}

\begin{abstract}
"The extent to which the passion for railway gambling had penetrated the upper and middle classes is scarcely credible. In every street of every town persons were to be found who were holders of railway shares."
\end{abstract}

Tooke and Newmarch, A History of Prices. 1857. p.234.

\section{1.}

The inherent characteristics of railway investment make for problems in the formation of such social overhead capital. The financing of a railway of any length is beyond the pocket of the individual. Moreover their long gestation period may witness a change in the circumstances of their backers which renders it impossible to collect the final installments on shares. Vain demands for the payment of calls were a significant phenomenon of the post-mania period as many investors discovered that they had substantially over-committed themselves in the previous perioa of easy money. Well into 1848 arrears on scottish lines for the previous three years totalled over 2777,000 . (2) A third endemic $f \in a t u r e$ of railway capital expenditure is that the larger share of its returns might well fall as indirect benefits to the community as a whole rather than as monetary rewards to its shareholders. That money might not be forth-

1. Parts of this chapter were read as a paper at the Conference of Scottish conomic Historians, December, 1967 in the University of Glasgow and benefitted from the ensuing discussion. 2. Calculated from Parliamentary Papers. 1847/48 IXIII. 
coming for Highland railways considered as "mere pecuniary speculations" was soon recognised and emphasis placed instead on "the indirect advantages which such undertakings, whether lucrative to the promoters or not, never fail to secure." (I)

The problems can be further intensified by factors unique to the individual railway company such as the rismanagement on the Caledonian where at one stage bills, either overdue or due within a fortnight, totalled 2674,000 , whilst the treasury was "absolutely and literally empty." In addition the banks were owed $£ 168,495$, sundry debts came to 2192,293 and the engines had been seized in respect of a land claim. (2) Miscalculation of costs could also cause trouble as on the Scottish Central where final land costs soared three times above the original estimates. (3)

Finally, exogenous factors could produce financial difficulties. Those such as "the severe pressure for money in the country generally" probably had a wider impact than the lock up of funds caused by the failure of the City of Glasgow Bank, but both would have had adverse effects when companies had an "inadequacy of funds in hand to meet exigencies at the proper moment and in sufficient degree." (4)

Host of the Scottish railway companies found themselves in financial trouble at some time, but there were notable exceptions,

1. Railway Times, 10 April, 1841.

2. H.R.J., 23 March, 1850.

3. RAC(S) $1 / 35,22$ January, 1850. B.R.

4. NBR 1/4, 9 Warch, 1850. B.R. RAC(S) 1/1A, March, 1876, B.R. RAC(S) I/IA, 11 September, 1855. B.R. 
primarily the short mineral lines first laid down. The Kilmarnock and Proon showed remarkable profitability, frequently paying over 10\%, and in 1857 the Monklands (formed from three mineral lines, the Monkland and Kirkintilloch, the Ballochney and the Slamannan) was the only railway in Britain paying a bonafide dividend of $8 \%$.

\section{2 .}

The traditional method of raising capital for an original undertaking was to have a survey locally financed, followed by public meetings, and the issue of a prospectus inviting subscriptions. (1) Great play was made of railway companies having limited liability unlike most industrial concerns: the prospectus of the North British proclaimed in block capitals that "no subscriber (was) liable beyond the amount of his subscription." (2) The final allocation of shares was usually kept in the hands of the company, although they made use of agents, who might include stock-brokers, paying them a commission for the initial obtainment of subscriptions and deposits. (3) At first little use was made of the stock exchanges, but in the 1840 s provincial exchanges sprang up, dealing largely with the trading of railway shares though not usually with their flotation. Glasgow obtained

1. See H. Pollins, The Marketing of Railway Shares in the first half of the nineteenth century,' Economic History Review, second series, vol. vii, 1954 .

2. H.A. Shannon maintained that "it was the railways that won the acceptance of general limited liability." "The Coming of General Limited Liability' in E.M. Carus-wilson (ed.), Essays in Sconomic History. 1954. vol.1, p.376. Railway Times, 16 August, 1843.

3. Polijns ge.cit. p.237 ies oan be found in NBR $1 / 1$ and GNS 111 . B.R. 
a new stock exchange in 1844 and Edinburgh's was opened the following year. (1) Later the increased use of preference shares extended the role of the stock exchanges and, despite the spread of limited liability to other forms of investment, in 1872 the scotsman could report that railway business predominated on the Edinburgh Exchange. (2)

Once a company was established it tended to abandon the traditional procedure when financing a new line, and merely issue shares which would participate in the general profits of the company. It also tended to rely less on the general public and more upon the existing body of shareholders for any additions to its capital - or so it would appear. (3) However, the primary reason for first offering a new issue of shares to current shareholders was perhaps to benefit them rather than the railway. If the shares were issued at par, but stood at a premium in the market, then the original proprietors would, in reselling them, obtain a bonus from the railway "formed by their means and at their risk." (4) A premium could be artificially created by issuing the new shares at a discount as was done by the Dundee

1. E.V. Morgan and W.A. Thomas, The Stock Exchange. 1962. p.107. W. A. Marwick, Economic Developments in Victorian Scotland. 1936. p.71. Scottish Railway Gazette, 4 October, 1845.

2. Morgan and Thomas, op.cit, , p.110. Marwick, op.cit., p.53. (Quoting Scotsman of 6 February, 1872).

3. S.C. Management of Railroads. 1846 XIII, q.1026. Although this evidence of the Scottish railway engineer, John Miller, was given at the time of the railway mania, it does not appear to be atypical, as the reports and accounts of all the scottish companies suggest that throughout the century existing shareholders were given the first opportunity to purchase a new issue of shares.

4. Report of the Monkland and Kirkintilloch, 8 Januar, 1836. Witchell Library. S.C. Management of Railroads. 1846 XIII, 9.1027. 
and Newtyle. (1) Forfeited shares were also occasionally sold to existing shareholders as by the Great North of Scotland who sold \&lo shares on which $\$ 4 / 10$ s had been paid for $£ 4$ each on a pro-rata basis. (2) The traditional method of raising capital may have been abandoned, but the market was still being appealed to.

The normal industrial method of financing expansion by the ploughing back of profits was not practised by the railway companies. One reason for this was that the size and periodicity of their capital expenditure did not facilitate investment by the retention of revenue. Another reason was the attitude of the shareholders, who preferred to take their rewards in the short term rather than risk long run developments. (3) This may have had something to do with the disappointing dividends that followed the high expectations of the mania period. In any event, as preference shares and guaranteed stocks came increasingly into use, there would be less possibility of retaining profits for internal investment.

It was therefore essential to encourage the reinvestment of distributed profits and, because of the volume of expenditure planned, also attract new funds. The best way of doing this

1. Bradshaw's Guide to Railway Shareholders. 1853. pp.45-49.

2. ...J., 8 0ctober, 1853 .

On one occasion the North British elected to sell half its forfeited stock on the London market, but this was probably an expedient measure since money was urgently required to pay the approaching dividend on preference shares. (NBR $1 / 5$, p.474. B. R.).

3. The chairman of the Peebles line argued that permanent improvements to the railways should be paid for out of revenue and not by a new issue of shares, but found that railway shareholders "for the most part care nothing for the remote and contingent prosperity of the undertaking, and will not, or cannot, make a corresponding sacrifice." (w. Chambers, About Railways. 1865. p.19). 
was to raintain dividends. Fluctuations in both expenditure and revenue did not always make this easy and various expedients were adopted. One method was to establish a reserve fund which could be drawn upon when profits were low. (1) Another way was to alter the dates of the financial half years so that rates of return on capital would be reasonably uniform. (2) Sven less reputable was the extreme procedure of paying dividends out of capital. (3)

Further breaks from the traditional method of financing came with the difficulties of raising capital in the 1850 s and 1860s. These difficulties were the product of several factors. Firstly, the payment of interest on calls had been prohibited in 1847, but this was evaded by, among other methods, the interest being paid by the contractors. Of more importance was the long period between the promotion of a railway and the obtaining of returns. This, together with the belief that the more profitable routes had been built first, discouraged fresh investment, especially in a period of tight money. It also often led to the existing shareholders of a company insisting that the capital of extensions and branches should be separate from the original stock and should not at once participate in the company's general

1. H.R.J., 19 September, 1851. The setting up of a reserve fund would interfere with profits only when they were above average, and even then the contributions to the fund would reduce dividends for less than would a policy of ploughing back profits. For these reasons shareholders would not object as strongly to such a fund.

2. Railway Times, 9 September, 1843.

3. Report of the Committee of Investigation to the Shareholders of the worth British railway, 14 November, 1866.3 .1$. H.h.J., 26 February, 1881. 
profits. If this occurred then once again new investrent might be discouraged. Finally, it could be suggested that many of the dividends paid by scottish railway companies at this time were scarcely conducive to the attraction of capital. As can be seen from Table 2.1 the efforts of the companies to maintain their dividends were not always successful. (1) In fact if other lines of investment were offering increasing rates of return, then merely maintaining railway dividends might not be enough. At times better opportunities were available for investors; not so much in industry where unlimited liability still held sway, but more perhaps in overseas railways. (2) One way out of the difficulties was for the larger contractors to organise or support a new company and accept a large part of their payment in shares. The primary aim of this tendency for "the original relations between railway companies and their contractors to be reversed," however, was not to aid the railway companies, but to keep the contractor's permanent staff together and his capital equipment permanently employed. (3) The extent of such intervention into the railway capital market is unknown, but it is clear that contractors played a

1. All the methods of maintajning dividends were ultimately dependent upon the ability of the railway company to pay its way. When revenue was lagging behind costs low and negligible dividends were inevitable.

2. However, as is stated in section four of this chapter, much work remains to be done on the point of whether home and overseas investment attracted the same type of scottish capitalist.

3. Ho Pollins, Railway Contractors and the Pinance of Railway Development in Britain,' Journal of mransport History, vol.3, no.1, May, 1957. Quotation from L.H. Jenks, The Higration of British Capital. 1927. p.137. 
TABLE 2.I

DIVIDENDS OF THE MAJOR SCOTTISH RAILWAY COMPANIES 1841-1900 $(\mathcal{E} \%)$

(1) (2)..

(3)

(4)

(5)

(6)

$18412 / 10 / 0$

$18423 / 10 / 0 \quad 2 / 10 / 0^{*}$

$18432 / 10 / 0 \quad 4 / 15 / 0$

$18444 / 5 / 04 / 15 / 0$

$18455 / 10 \% 5 / 10 / 0$

$18467 \% 0 \%$

$18477 \% 0 \%$

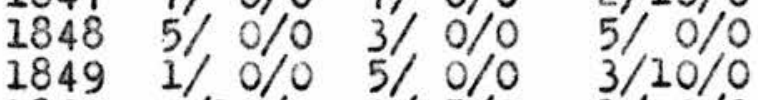

$18502 / 10 / 0$ 2/ $5 / 0 \quad 1 / 0 / 0$

$1 / 10 / 0 \quad 7 / 0 / 0$

$\begin{array}{lllllll}1851 & 2 / 2 / 6 & 3 / 0 / 0 & \text { NIL } & \text { NII } & 1 / 12 / 0 & \\ 1852 & 2 / 0 / 0 & 3 / 0 / 0 & \text { NIL } & 0 / 11 / 0 & 1 / 18 / 0 & 1 / 12 / 6 \\ 1853 & 2 / 10 / 0 & 3 / 0 / 0 & \text { NIL } & 2 / 5 / 0 & 4 / 0 / 0 & 2 / 5 / 0 \\ 1854 & 3 / 10 / 0 & 3 / 0 / 0 & 0 / 7 / 6 & 3 / 0 / 0 & 4 / 10 & 2 / 12 / 6 \\ 1855 & 3 / 10 / 0 & 3 / 0 / 0 & N I I & 3 / 0 / 0 & 5 / 0 / 0 & 3 / 5 / 0 \\ 1856 & 3 / 15 / 0 & 2 / 0 / 0 & 1 / 5 / 0 & 1 / 10 / 0 & 5 / 10 & 3 / 10 / 0 \\ 1857 & 5 / 0 / 0 & 2 / 15 / 0 & 2 / 12 / 6 & 3 / 10 / 0 & 5 / 10 / 0 & 3 / 10 / 0 \\ 1858 & 4 / 7 / 0 & 3 / 2 / 6 & 2 / 15 / 0 & 4 / 5 / 0 & 5 / 10 / 0 & 4 / 0 / 0 \\ 1859 & 4 / 15 / 0 & 3 / 1 / 0 & 2 / 17 / 6 & 3 / 17 / 6 & 5 / 12 / 6 & 4 / 0 / 0 \\ 1860 & 5 / 2 / 6 & 3 / 12 / 6 & 3 / 0 / 0 & 4 / 12 / 6 & 5 / 10 / 0 & 4 / 2 / 6\end{array}$

$1861 \quad 5 / 5 / 0 \quad 4 / 5 / 0 \quad 3 / 2 / 6 \quad 5 / 5 / 0 \quad 5 / 15 / 0 \quad 4 / 15 / 0$

$18625 / 5 / 0 \quad 3 / 12 / 6 \quad 2 / 0 / 0 \quad 5 / 5 / 0$

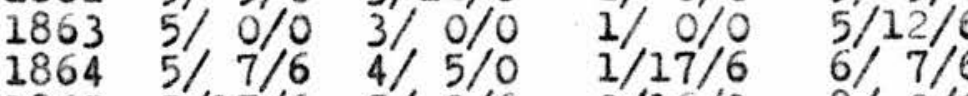

$1865 \quad 5 / 17 / 6 \quad 5 / 2 / 6 \quad 2 / 16 / 3 \quad 8 / 0 / 0$

$18667 / 0 / 02 / 5 / 0 \quad 1 / 10 / 0 \quad 7 / 7 / 6$

$5 / 15 / 0 \quad 5 / 2 / 6$

$5 / 17 / 6 \quad 4 / 15 / 0$

$6 / 12 / 6 \quad 4 / 17 / 6$

$18675 / 17 / 6$

$18684 / 15 / 0$

1869

$4 / 15 / 0$

NIL

NIL

NIL

$5 / 17 / 6$

$7 / 0 / 0$

$5 / 6 / 3$

$18705 / 10 / 0$

$0 / 14 / 6$

NIL

NIL

$2 / 12 / 6$

NII $\quad 3 / 13 / 0$

$18715 / 5 / 0$

1872

$5 / 17 / 6$

1874

$3 / 5 / 0$

$3 / 15 / 0$

$18763 / 17 / 6$

1877

$4 / 5 / 0$

1878

$3 / 15 / 0$

$18792 / 17 / 6$

$1 / 15 / 0$

$4 / 10 / 0$

NIL

$4 / 10 / 0$

1/ $7 / 6$

$4 / 10 / 0$

$1 / 12 / 6$

o/ $6 / 3$

NIL

$4 / 10 / 0$

2/15/0

$5 / 7 / 6$

$6 / 15 / 0$

$3 / 17 / 6$

$3 / 10 / 0$

$3 / 0 / 0$

$5 / 17 / 6$

2/ $7 / 6$

$1 / 12 / 6$

$6 / 15 / 0$

$6 / 12 / 6$

$0 / 10 / 0$

$5 / 5 / 0$

$3 / 7 / 6$

$18804 / 10 / 0$ 
TABLE 2.1 (cont.)

(7)

(8)

(9)

(10)

(11)

(12)

1851

1852

1853

1854

1855

1856

1857

1858

1859

1860

$1 / 5 / 0$

$1 / 5 / 0$

$1 / 15 / 0$

$3 / 15 / 0$

$4 / 12 / 6$

$1 / 10 / 0$

$1 / 5 / 0$

$6 / 0 / 0$

$6 / 15 / 0$

$0 / 10 / 0$

$4 / 10 / 0$

$8 / 0$

NII

$4 / 11 / 0$

$7 / 10 / 0$

$3 / 10 / 0$

$8 / 0 / 0$

$3 / 0 / 0$

2/, $5 / 0$

1861

$6 / 15 / 0 \quad 5 / 10 / 0$

$0 / 11 / 6$

$3 / 17 / 6$

$7 / 5 / 0 \quad 5 / 10 / 0$

$7 / 0$

$4 / 10 / 0$

1863

$5 / 0 / 0$

$5 / 0 / 0$

$1 / 7 / 6$

$0 / 15 / 0$

$4 / 5 / 0$

$4 / 12 / 6$

NII

$1 / 2 / 6$

NII

NII

NII

NII

1869

NIL

$1 / 12 / 6$

2/ $2 / 6 \quad 3 / 0^{*} \quad 2 / 5 / 0$

$1 / 0 / 0^{*}$

$2 / 10 / 0$

1866

1867

1870

NIL

NIL

NIL

1873

1874

1875

1876

1877

1878

1879
1880

$1 / 10 / 0$

$1 / 12 / 6$

$2 / 10 / 0$

2/ $2 / 6$

$0 / 15 / 0$

$0 / 10 / 0$

$0 / 10 / 0$

i) $0 / 0$

$1 / 10 / 0$

$3 / 0$

$2 / 15 / 0$

$3 / 0 / 0$

$4 / 10 / 0$

$6 / 0 / 0$

$5 / 10 / 0$

$4 / 10 / 0$

$3 / 10 / 0$

$4 / 17 / 6$

$5 / 0$

$5 \% 0 \%$

$3 / 17 / 6$

4/ $5 / 0$

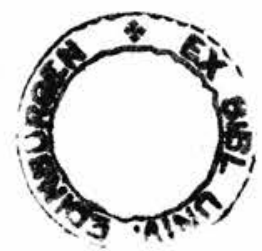


TABLE 2.1 (cont.)

(1)

1881

1882

1883

1884

1885

1886

1887

1888

1889

1890

1891

1892

1893

1894

1895

1896

1897

1898

1899

1900
(3)

$2 / 0 / 0$

$3 / 7 / 6$

4/ 5/0

$4 / 10 / 0$

$3 / 5 / 0$

$2 / 10 / 0$

$3 / 5 / 0$

4) $2 / 6$

2/ $7 / 6$

$2 / 12 / 6$

NIL

0/7/6

$0 / 10 / 0$

$0 / 12 / 6$

NII

1) $2 / 6$

1/ $2 / 6$

1) $0 / 0$

1) $5 / 0$

$0 / 15 / 0$
(4)

$3 / 7 / 0$

$4 / 10 / 0$

$4 / 10 / 0$

4/ $7 / 6$

$3 / 15 / 0$

$3 / 12 / 6$

4/ $2 / 6$

5/ $2 / 6$

$5 / 0 / 0$

$3 / 17 / 6$

4/ $5 / 0$

4/ $2 / 6$

4/ $7 / 6$

$3 / 17 / 6$

$5 / 5 / 0$

5/ $2 / 6$

$5 / 0 / 0$

$4 / 17 / 6$

$4 / 10 / 0$
(8)

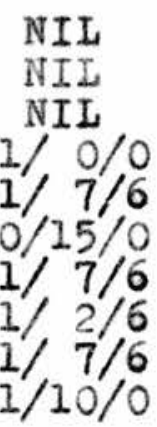

$2 / 10 / 0$

$3 / 5 / 0$

$3 / 0 / 0$

$3 / 5 / 0$

$3 / 5 / 0$

$3 / 12 / 6$

$3 / 10 / 0$

$3 / 15 / 0$

$3 / 15 / 0$

$2 / 10 / 0$
(11)(12)

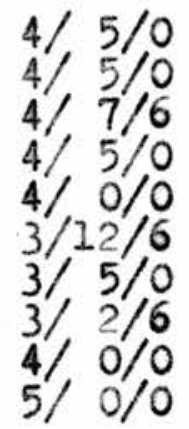

$4 / 10 / 0$
$4 / 17 / 6$
$4 / 17 / 6$
$4 / 17 / 6$
$3 / 10 / 0$
$1 / 15 / 0$
$1 / 0 / 0$
$0 / 15 / 0$
$0 / 10 / 0$
NII

Source: Bradshaw's Guide to Railway Shareholders.

Key: (1) Glasgow, Paisley, Kilmarnock, and Ayr - became Glasgow and South Western in 1848 on amalgamation with Glasgow, Dumfries and Carlisle.

(2) Edinburgh and Glasgow - taken over by North British

(3) North British

(4) Caledonian

(5) Scottish Central - taken over by the Caledonian

(6) Scottish Midland - with (10) formed Scottish North Sastern

(7) Edinburgh, Perth and Dundee - taken over by North British

(8) Great North of Scotland

(9) Monklands

(10) Aberdeen - no dividends paid before amalgamation. Separate accounts kept 1861-66

(11) Inverness and Aberdeen - with (12) (13) formed the Highland

(12) Inverness and Perth

(13) Inverness and Nairn

* half year only. 
substantial role in the financing of railway development in the period 1852-66, although the claim of one parliamentary agent, Robert Baxter, that "nine railways out of ten are made with the aid of contractors" is undoubtedly exaggerated. (1) sxamples of this type of financing in scotland were the contractors of the Selkirk railway subscribing $\& 6,000$ of the 218,000 to $\& 19,000$ needed; those of the Portpatriok contributing $\& 11,000$; and Thomas Brassey promising $£ 20,000$ to the Inverness and Aberdeen Junction. (2) Later, when money was easier to obtain, the offers of contractors to provide capital were not always as warmly received. John Waddell's offer to take all the stock of the Edinburgh, Suburban and Southside was rejected, presumably because he wanted a $5 \%$ discount for doing so. (3) A more general reason for rejecting the overtures of the contractors, when other sources of finance were available, may have been the desire of the railway direotors to avoid any risk of their authority being usurped by a domineering contractor.

It should be noted that not all the shareholdings of contractors represented bona-fide investment. Paying the contractors in shares was fairly common when a railway company was struggling through its infancy. It might even be a condition of the contract. The North Britich was quite certain that at least one-third of their capital could be raised from the

1. S.C. Standing Orders (Parliamentary Deposits). $1864 \mathrm{X}$, 9. 645 .

2. Peeblesshire Advertiser, 1 July, 1854. H.T.J.' 2 October, 1858; 28 June, 1856.

3. ESSI/i, 4 April, 1881. B.R. 
contractors "for every description of work connected with the railway." (1) The final contribution of Brassey and his partner to the Inverness and Aberdeen Junction totalled 887,000 , and another contractor, George Merrill, agreed to take $£ 40,000$ in shares as part of his contract with the Forth and clyde Junction. (2) Whether the established companies continued to work on this principle is not clear, but the West Highland, promoted in the 1890s under the auspices of the North British, successfully asked the contractors to take half their payment in cash and half in shares. (3) Companies were not always so fortunate. Mr. Matheson refused to accept the financial arrangements proposed by the Edinburgh, Perth and Dundee, and Russell and MacNee, carriage builders of Edinburgh, "absolutely declined to take any preference stock" of the same company.

It was not just the contractors for the works who were asked to accept shares, but also the suppliers of rolling stock, the engineers and frequently the landowners en route. When a railway was in serious financial difficulties even small accounts were apt to be settled in stock. The Edinburgh, Perth and Dundee, for example, paid $£ 30$ in preference shares and the balance in cash to Alex Ritchie, an engraver, and Robert Sclater, a die

1. NBR 1/1, 19 May, 1843. B.R.

2. IAJI/I, 4 June, 1855. B.R. Cunninghame - Grahame Papers, G.D.22, section 1/594, 9 April, 1855. S.R.O. Not only did the contractors often help in promoting and financing a railway, but occasionally leased it, as was originally planned on the Great North of Scotland, or maintained the line under contract, as wa done on the Caledonian for one. (Bradshaw's Guide to Railway Shareholders. 1853. j.88 \& R.K. Middlemas, The Master Builders. 1963. p.48).

3. $\mathrm{HEH} 1 / 1, \mathrm{j} .2$ B.R.

4. EPDI/3, N.i1 and 249. B.R. 
cutter, in payment of bills for $\$ 35 / 5 / 10$ and $\$ 36 / 14 / 6$ respectively. The stock later declined in value and sclater applied for, and was granted, free passes. (1)

The inevitable concomitant of the low dividends in the decade following the great railway mania was low share prices, as can be seen in Table 2.2. This also produced a change in the traditional mode of financing. Flows of funds between borrowers and lenders are facilitated if the financial assets involved can be readily realised by the lender without capital loss. However, when, as in the case of the Caledonian, stock has fallen to a discount of over $80 \%$, marketability without capital loss is impossible. This experience would make capitalists wary of buying further ordinary stock, unless it was at these very high rates of discount. However, the railway companies would be reluctant to offer this, partly for prestige reasons, but mainly because low dividends would henceforth be well nigh inevitable, which would not go down very well with the original body of shareholders who had paid full price for their stock.

The solution devised by the railway companies was to introduce the preference share. (2) There was less liklihood of a share falling in value if a dividend was either guaranteed or at least was promised first claim on the profits. In prosperous

1. Ibid, $p p .231$ and 283.

2. Although theoretically the issue of preference shares could be due to a desire of the ordinary shareholders to expand the company without impairing their own power (preference shares carried less voting rights), or to the railway conpanies taking advantage of a period of easy money to raise capital at low fixed interest rates, I have found no evidence of this taking place in practice. 


\section{TABLE 2.2}

Price of Caledonian 2100 Ordinary Stock 1845-56

$\begin{array}{lllc}\text { October } & 1845 & 22 \% & \text { premium } \\ \text { January } & 1846 & 12 \% & " \\ \text { October } & 1847 & 34 \% & \text { discount } \\ \text { October } & 1848 & 68 \% & " 1 \\ \text { December } & 1849 & 80 \% & " \\ \text { April } & 1850 & 86 \% & " \\ \text { December } & 1852 & 30 \% & " \\ \text { May } & 1853 & 29 \% & " \\ \text { September } & 1856 & 48 \% & \text { " }\end{array}$

Source: Rerapath's Railway Journal

Note: It was in July, 1848 that the Caledonian decided to create a $7 \%$ preference stock. (H.R.J., 8 July, 1848)

\section{TABLE 2.3}

The Growth of Soottish Railway Capital $(£ \cdot 000)$

Year

Shares

Ordinary Guaranteed Preference Loans

Debenture Stock Total

$1849 \quad 15,632$

$1854 \quad 15,576$

185919,028

186421,079

186921,708

187423,705

187931,747

188434,102

188941,492

189438,221

189940,330

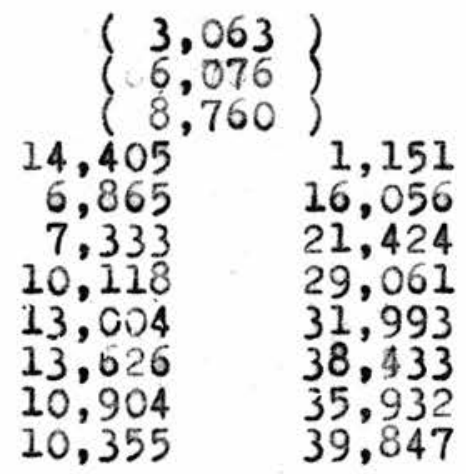

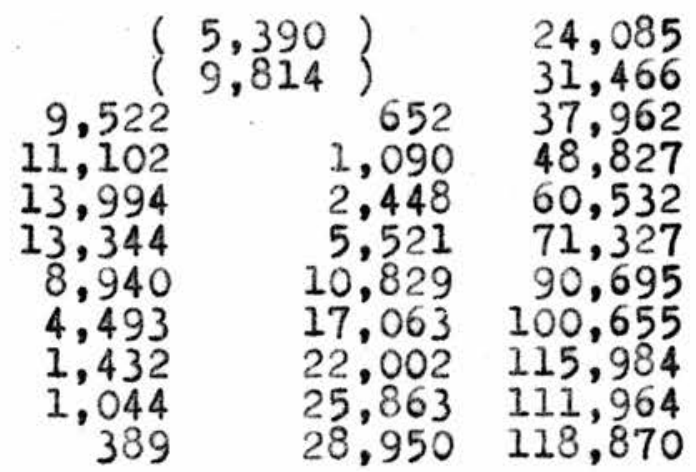

Source: Railway Returns of the Board of Trade (corrected for omissions)

Note: The totals for 1894 and 1899 have been corrected for notainal capital created by the consolidation of stocks. Totals for consolidations first appeared in 1890 and if the figures for 1889 is adjusted on the assumption that there was no consolidation in that year the read
28,609
10,903
33,931
4,493
21,951
97,887 
tines, of course, the ordinary shareholders would obtain the lion's share of the profits and would therefore, if they envisaged brighter prospects, not object strongly to the creation of this new type of share. In the event, many ordinary shareholders also purchased preference stock. In addition the preference share right well have attracted a new type of investor into the railway capital market; the seeker of a reasonably stable income who was relatively unconcerned with the marketability of his assets.

Once introduced, the preference and guaranteed share became increasingly popular with both the railway companies and the investing public, and, as can be seen in Table 2.3 , dominated the railway share market by the late 1860s. However, their popularity was not instantaneous and there was much initial debate about the morality and desirability of their use. In 1849 the North British deemed it "absolutely necessary to complete the works" and thought "no better, more economical or more equitable mode of raising the requisite funds could be devised." (1) Others were not so enthusiastic, believing such issues to be "an act of gross injustice to the original shareholders, as it was never contemplated by them," although they were forced to adinit that "there may be cases in which they cannot be done without." (2) In addition some companies feared that in certain circumstances too high a guaranteed rate of return would have to be offered to

1. Report of the Committee of Investigation, $26 \mathrm{July}, 1849$. p.6. RAC(S) I/IA. B.R.

2. H.R.J., 23 September, 1848 . 
induce the taking up of preference shares, and this would have to be borne in perpetuity.

As far as the investing public were concerned, preference shares had value only if thele was an expectation of profits on which the right of preference could be exercised. Similarly, guaranteed shares were attractive only if it was believed that the company could make $\wedge^{\text {good }}$ ts guarantee. This was not always apparent in the early days of the preference share. The chairman of the Aberdeen railway criticised his shareholders for taking up only $\$ 6,000$ of the $\$ 30,000$ issue of $5 \%$ preference stock, but he really could not expect any more, as this issue ranked behind a previous one of $6 \%$ preference stock which was still waiting for its dividend to be paid. (2) During a later period of financial distress some companies went so far as to attempt to establish pre-preference stocks, but the patience of existing shareholders was exhausted and the public's belief in guarantees too shaken for this expedient to be adopted. (3)

Although the Inverness and Aberdeen "had experienced no difficulty in disposing of their preference stock to persons other than shareholders," it is suggested that, as with the Highland's issue of 1899, the existing body of shareholders frequently took up new preference shares. (4) There is evidence of a divergence of interest between holders of ordinary and

1. See $\operatorname{RAC}(S) 1 / 36$ (Aberdeen), 1848. B.R.

2. H.R, J., 30 November, 1850.

3. H.J.J., I0 April, 1867; 8 June, 1867; 16 November, 1867.

4. H...J., 7 November, 1863; 28 April, 1899. 
preference stock within the North British company at the time of the Tay Bridge disaster. In the debate over the rebuilding of the bridge the preference shareholders argued that if the briage fell down they were expected to bear the brunt by forgoing their dividend, but if it stood then the ordinary shareholder would obtain all the benefit. (1) However, the North British was in an unusual position in that its preference shareholders swamped the holders of ordinary stock both in numbers and in value of holdings.

Some indication as to the extent of the duality of holdings of ordinary and preference stock can be obtained from two parliamentary returns of 1886 and 1902. (2) These give the numbers of holders of ordinary, preference, guaranteed and debenture stock and also the total number of stockholders for each company. The extent to which the total of all holders is exceeded by the summed total of each category of holders indicates the degree to which holdings were diversified among the different types of stock. Unfortunately the returns do not allow monetary significance to be given to this multiplicity of holdings and all that can be asserted is that a substantial minority of ordinary shareholders of Scottish railways also took up preference shares or debentures within the same company. However, it is extremely unlikely that it was debenture stock that was also

1. Scotsman, 31 March, 1880.

2. 1886 LVII, $p .935$.

1902 XC, p.889. 
taken up as the returns for companies not issuing preference shares show no tendency for ordinary shareholders to buy debentures, and, when the shareholders of the Highland were offered debentures, few were taken, although the same people were quite willing to purchase preference shares.

\section{3.}

Who had the foresight and the ability to provide the Scottish railways with their first capital is difficult to determine because of faults inherent in the source material. The Shareholders' Registers that exist are not the original ones, and the transfer of shares over time obscures the identity of the men who were prepared to take a leap in the dark. (2) In the absence of a comprehensive series of such registers the subscription contracts must be utilised. The validity of these as indicators of genuine investors was widely criticised by contemporaries, who claimed that the signatures of influential persons were fraudulently used to attract the public, that signatures were often forged or purchased in order to fill up the list so as to impress parliament, and that to sign the contract was merely a promise to purchase shares which may not have been

1. H.R.J., I May, 1896; 28 April, 1899.

2. Wuch research remains to be done on the question of whether railway shareholders were a permanent or floating body. It has been shown that at least $25 \%$ of the original signatories of the Iiverpool and Manchester subscription contract in $1825 / 26$ were still holding shares in 1848. (H. Pollins, 'The Finances of the Liverpool and Manchester Railway.' Economic History Review, second series, vol.v, 1952). However, the surviving shareholders' registers of the Scottish railway companies leave much more than a twenty year gap of knowledge to be filled. 
kept. (1) This latter criticism was especially relevant where there was a long interval between the signing of the contract and the authorisation of the railway, as was the case with the Bdinburgh and Glasgow, in which the signatory may have died, become insolvent or transferred his interest. (2) However, one reputable railway historian has argued that as it was not until 1858 that the subscription contract was abolished, on the grounds of it not being a reliable guarantee that a proposed railway had a solid body of financial support, then up to a few years of that date the contract had to be treated seriously.

Bearing in mind these potential pitfalls, what can be said about the financing of Scottish railway development? Undoubtedly the early mineral lines were partially financed by the proprietors of the resources to be developed. The shares of the Kilmarnock and Troon, generally acknowledged to be the first real railway in Scotland, were primarily held by the Duke of Portland whose coalfield and harbour the railway was designed to aid. (4) over in the east mineral owners and landed proprietors promoted the Bdinburgh and Dalkeith for the conveyance of coals from the Lothian pits to the Scottish metropolis. (5) However, the

1. See H. Siencer, 'Railway Morals and Railway Policy,' Edinburgh Review, October, 1854.

2. Railway Times, I7 February, 1838.

3. H. Pollins, Railway Contractors and the Finance of Railway Development in Britain,' Journal of Transport History, vol.3 no.1, May, 1957.

4. A.S. Turberville, The History of Welbeck Abbey. 1939 says that the Duke held 74 of the 77 shares issued, but Professor Simmons suggests a proportion of 67 out of 80 with 10 being held by the Duke's daughter. ("The Scottish Records of the British Transport Commission,' Journal of Transport History, vol.3, no.3, 1957, p.163).

5. A list of proprietors can be found in G.D.135, Box 82, January, 1834, item five. S.R.O. 
lines designed to exploit the Lanarkshire mineral fields in the 1820 s and 1830 s were less reliant on the capital of coal owners. The Monkland and Kirkintilloch was financed by local men, many of them coal merchants, and the Pollock and Govan was the property of William Dixon, a colliery owner, but the others were chiefly in the hands of Glasgow merchants and manufacturers, though not to the exclusion of the local coalmasters. (1) Presumably the reason for this was that many of the coalmasters did not have the capital to spare for railway enterprise as they were branching into coal mining from farming and other activities. (2) On the other hand, many of the merchants and manufacturers were well established and wealthy, with at least the latter group having a vested interest in seeing the mineral fields developed. Their motivation to invest was probably a combination of a desire for both direct and indirect returns. Short branches from these railways were provided by the company concerned, but only if the traders would reimburse them "within a certain space of time by tonnage dues." (3)

Short mineral lines could be locally, even individually, financed, but this was scarcely feasible once railways on a larger scale were contemplated. Admittedly the Dundee and Arbroath and the Arbroath and Forfar were locally financed by

1. G. Buchanan, Account of the Garnkirk and Glasgow Railway. 1832. Castlemilk Muniments, Ms. 5321, 14 uctober, 1825, N.L.S. Bradshaw's Guide to Railway Shareholders. 1853. See also R.H. CampbeII, The Growth and Fluctuations of the Scottish Pig Iron trade, 1828-1873,' Ph.D., Aberdeen. 1956. chapter one.

2. Information supplied by the Central Library, Hamilton - much of this seems to have been based on the Dictionary of National Biography.

3. Report of the Ballochney, 2 February, 1836. Mitchell Library. 
leading mercantile men and several landowners, but, as the concept of inter-urban services widened, and three major trunk routes were planned to radiate from Glasgow, there came a change in the locality of capital. (1) Tables $2.4,2.5$ and 2.6 show that although the Glasgow, Paisley and Greenock found its shares "warmly taken up on the spot (meaning locally)," the Glasgow, Paisley, Kilmarnock and Ayr, to a minor extent, and the Edinburgh and Glasgow, to a substantial degree, had their capital subscribed for south of the border, primarily in Lancashire. (2) In fact both these latter companies sought out English capital from the beginning. (3)

Capital was becoming blind. In August, 1836 the Circular to Bankers had maintained that "no considerable railway can be completed that depends on local money for its outlay." (4) Although this was not an axiomatic truth in respect to Scotland, it is fair to say that from that date the local character of railway finance was no longer as dominant as it had been. The evidence in Tables 2.5 and 2.6 supports Broadbridges assertion that at this time Lancashire not London was the chief reservoir of railway capital, but raises the question of why the Lancastrians did not invest in the other Scottish railways. (5) The

1. J.M. MoBain, Arbroath Past and Present. 1887. pp.198 and 205. S.E.G. Ly the, 'Barly Days of the Arbroath and Forfar Railway,' Railway Magazine, vol. XCIX, January, 1953.

2. Railwav Magaine and the Annals of Science, vol.IV, 1838, p.18.

3. G.P.K. I/1, P.100. B.R. G.G.R.III, pp.1-5 and 31. B.R.

4. Whoted in S. Broadbridge, The Barly Capital harket: the Lancashire and Yorkshire Railway, 'Sonomic History Review, second series, vol.VIII, no.2, 1955, p.211.

5. Ibid. 


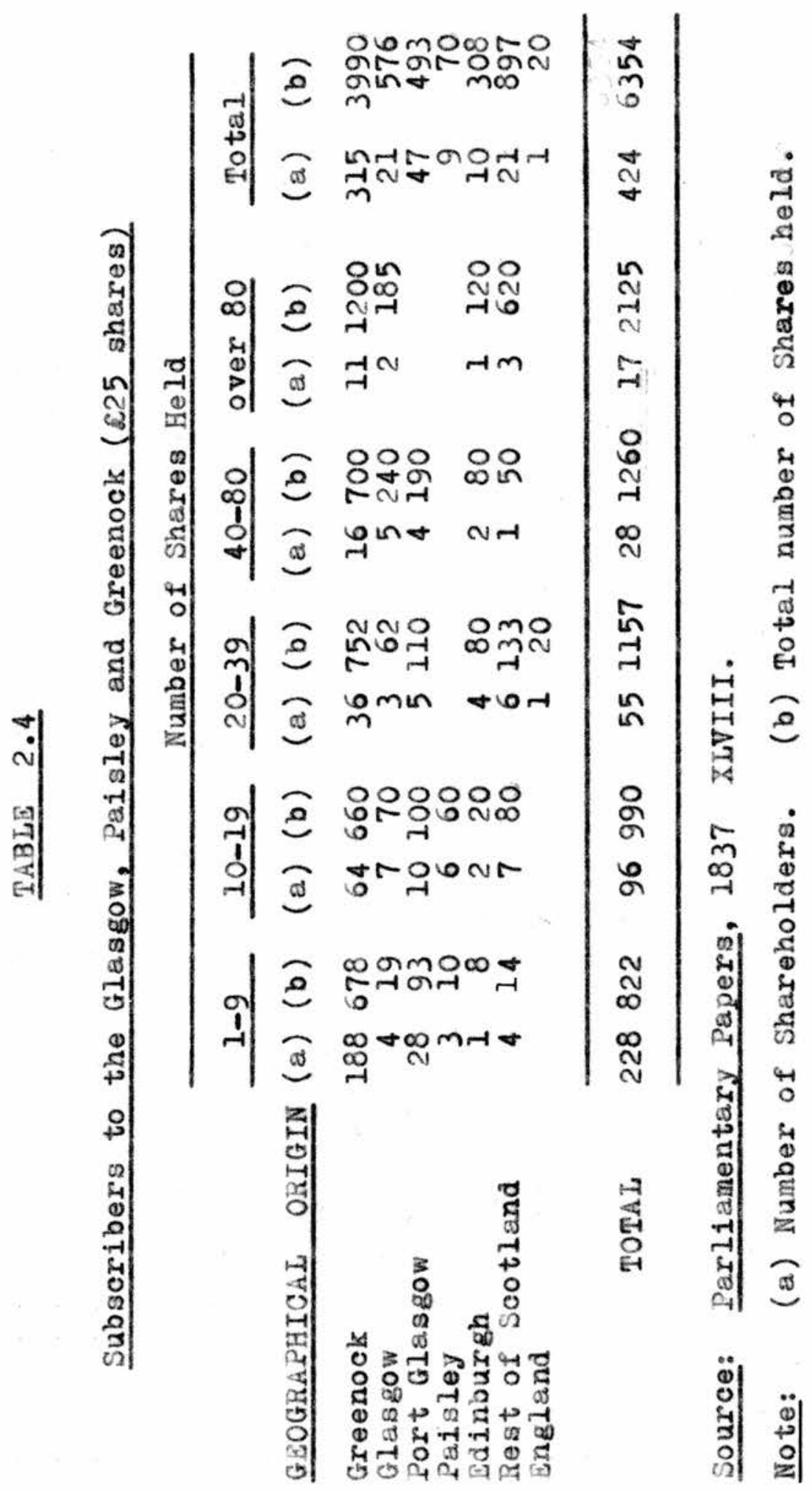




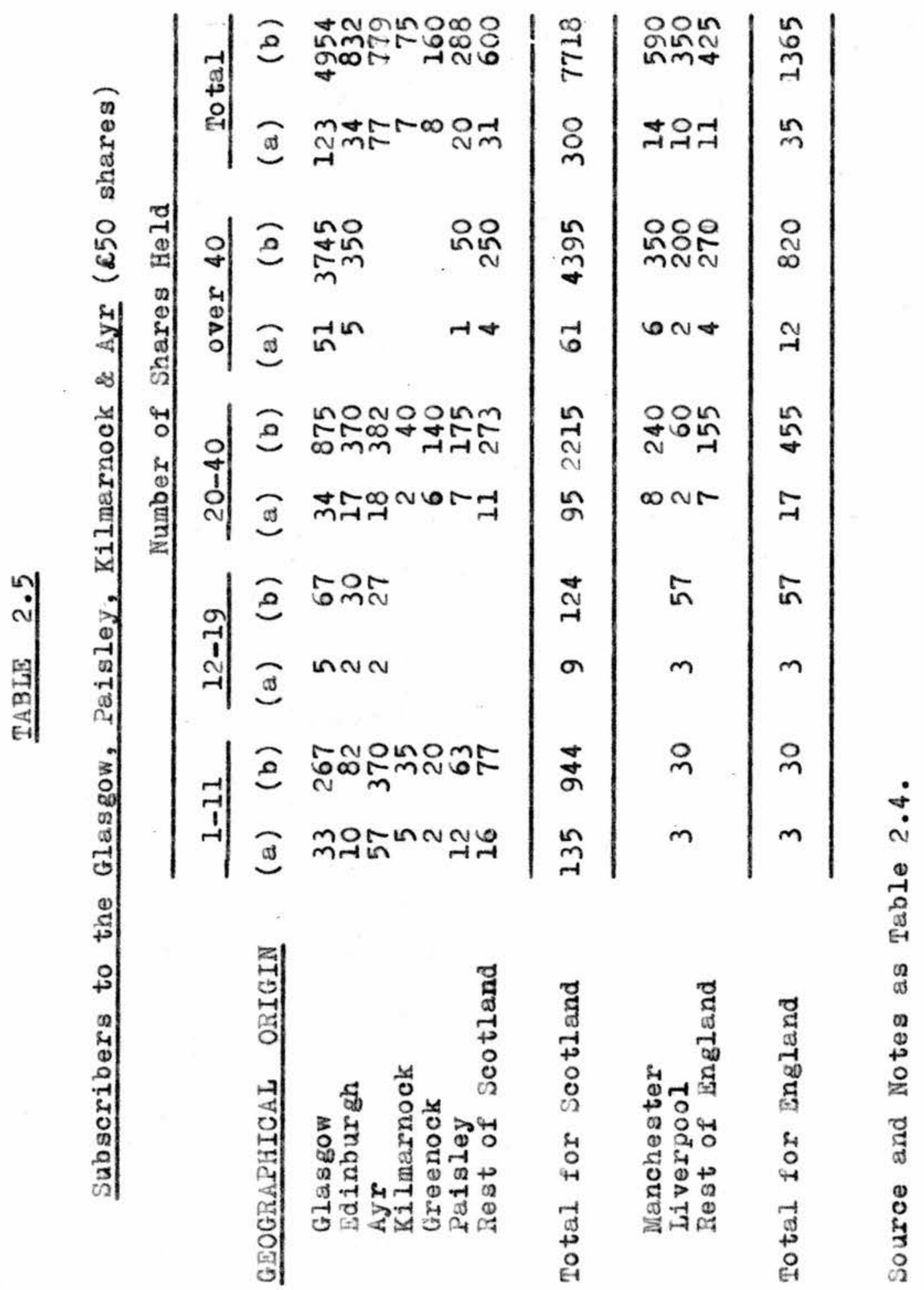




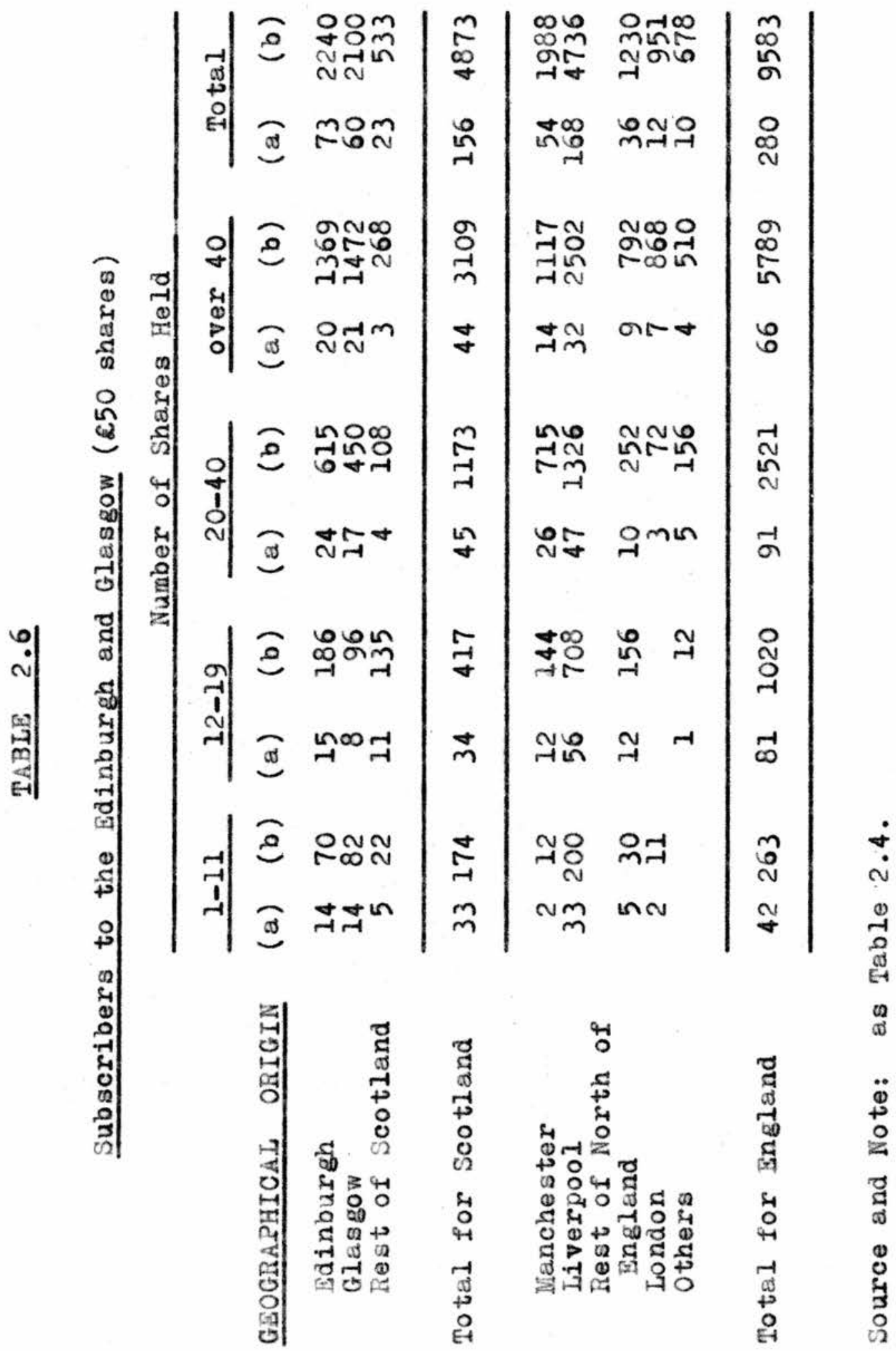


explanation that they did not know about them may seem too simple, but there is evidence to back this hypothesis. The Glasgow, Paisley and Greenock was "not so well known, nor its merits so generally appreciated, on this (English) side of the Tweed, as they deserve to be." (1) Similarly, the Arbroath and Forfar was "comparatively unknown" in England and the adjoining Dundee and Arbroath "not so well known as it ought to be beyond the particular locality where it is situated." (2) Once attention had been drawn to the Glasgow, Paisley and Greenock the English capitalists plunged in. Ten thousand of its sixteen thousand shares had changed hands by early 1841 and, three years later, a plea that a Mr. Lake should join the board was made on the grounds that he lived "in Ingland where so many of the shareholders resided." (3)

J. Reid, writing in 1841 , believed that "the days of speculation in new railways are at an end .... and if any more railways are brought forward to unite cities more closely, they must be supported by the individuals interested in the localities where they are proposed to be established." (4) However, the railways being planned in scotland at this time were the transborder routes and the Scots had no intention of building them without English financial assistance; indeed it is arguable that the expected most of the money to come from England.

1. Railway Times, 29 December, 1838.

2. Railway Times, 29 June, $1839 ; 6$ July, 1839.

3. Railway Times, 10 Aprii, 1841 ; 16 March, 1844.

4. J. Reid, Manual of Scottish Stocks. 184i. p.io. 
In the west the heroic role of the Scottish landowner, J.J. Hope-Johnstone, has often been stressed, but he did ask the English Grand Junction railway to pretend that his Annandale scheme was in fact their idea in an attempt to obtain the English public's financial backing. Unfortunately the plan came at a time when the English investors were awaiting the results of the mid 1830 s mania, and John Moss of the Grand Junction pointed out "... of the importance of a line of railway to Scotland no-one can doubt, but I question very much whether any new line would go down with the public just now; one line of 100 miles will show the public just what can be done." (1) In the event the trade depression of the early 1840s put paid to hopes of obtaining English capital for a while, and, for want of sufficient Scottish finance, the project languished until 1845.

In the east the Edinburgh and Dunbar scheme of 1836 had roughly $90 \%$ of its capital subscribed for in scotland, but not enough of that promised was actually forthcoming and the project proved abortive. (2) Presumably too many persons shared the opinion of Sir John Hall's legal advisers that an east coast railway would "certainly never pay the shareholders." (3) When the scheme was revived some years later as the North British faith was no longer put in Scottish paper promises, and the promoters resolved that after five thousand shares $h_{a} d$ been sold in Edinburgh the prospectus should be circulated, and brokers

1. Ms. 6354, letters dated 13 April, 1837 and 19 April, 1837. N.L.S.

2. Parliamentary Papers. 1837 XIVIII.

3. Dunglas Papers, G.D.206, section $1 / 63 \mathrm{~A} / 5,24$ November, 1838. S.R.O. 
appointed, in all the large English towns. However, the trade depression meant that they received a cold financial welcome on their visit to England in the surmer of 1842. They decided to wait a session in the belief that the revival of trade and the progress of the Darlington to Newcastle line would produce "a much greater likelihood" of support from Bngland. Later they also resolved to extend the line to Berwick, instead of terminating at Dunbar as originally planned, so that the railway would be less apparently a local scottish one, and thus be more likely to attract English capital. This decision was encouraged by George Hudson's assurance that he would be able to form a company to construct a line to link Berwick with the south. (1) The attempt to attract English money into these two transborder schemes proved extremely successful. In 1848 it was estimated that over $90 \%$ of the Caledonian's shares were held in England, and an investigation into the affairs of the North British in 1849 revealed that 927 scots held 23,904 shares and 3,163 Bnglishmen held 77,937 shares. (2)

Once the depression lifted, English capital was not slow in coming forward for other scottish schemes. In April, 1844 the committee of the Edinburgh and Hawick announced that "a spirited Company in London was ready to advance the whole money

1. NBR 1/1, 14 January, 1842; 15 June, 1842; 2 November, 1842; TT Hay, 1843 . B.R.

2. H.R.J., 26 August, 1848; 4 November, 1848. Report of the Committee of Investigation to the Shareholders of the North British Railway, 26 July, 1849. Appendix 12. An incomplete list of large shareholders of the Caledonian in 1852 gives some indication of the heavy investment in this line from Menchester, Liverpool and the rest of Lancashire. ( 
necessary to complete the undertaking." (1) As the mania gathered in momentum Scottish lines everywhere sought English capital. Books to receive subscriptions were opened throughout Gngland. English engineers with a reputation for railway work were deliberately employed because English capitalists would know of them. (2) The Scottish Midland Junction even went so far to make a special condition for English subscribers that there deposits would be returned in full if the Board of Trade decision went against the line. (3) So successful were these efforts that towards the close of 1846 the Scottish Railway Gazette commented that "the Scottish railways, were like the Scottish moors, becoming a hunting ground for England." (4)

Some indication of the magnitude of this success can be obtained from an examination of a volume of Parliamentary Papers containing the names, occupations and addresses of all persons subscribing at least $£ 2,000$ to any railway lodging its subscription contract in the Private Bill office during the 1846 session. (5) The assumption underlying the analysis is that these large subscribers would dominate the subscription contract. This assumption would appear reasonable when the money promised is compared with the capital actually authorised to be raised,

1. W.A. Johnman, 'The Canals, Tramroads, and Railways of Roxburghshire,' Transactions of the Hawick Archeological Society. 1919. p.27.

2. Airlie Papers, G.D.16, section 38/82, bundle 1 , items 22 and 23.5 .2 .0 .

3. Ibid., item 45.

4. Scottish Railway Gazette, 21 November, 1846.

5. Parliamentary Papers, 1846 XXXVIII. 
remembering that frequently only three-quarters of the estimated total capital was subscribed before the contract was deposited with the government officials. In some cases the large subscribers were not financially significant, but the contracts of 1837 suggest that if English finance was important in the larger holdings it also tended to be present in the smaller ones. In addition to the objections that can be made about the use of any subscription contract as an indicator of investors, these can be further challenged on the grounds that they were a product of the railway mania and may reflect speculation rather than actual sources of finance. Against this it can be argued that correspondence in the railway journals suggests that in cases of deliberate stock jobbing in Scottish lines, scrip was transferred from Scottish to English hands which would tend to produce an underestimation of the contribution of English capitalists. Two other factors might also exaggerate the Scottish share. Firstly, the companies wanted to demonstrate to the Board of Trade that their schemes had local support, but these locally subscribed shares might have been sold out soon after. Secondly, it was not uncommon for directors to "subscribe" enough to fill up a contract and hope that someone would take the shares in the future.

There is also the problem of Scots in England sending money home. This is in fact "Snglish" money, although their motive for investment might have been more patriotic than that of the

1. Railway Times, 1 June, 1844. Scottish Railway Gazette, 18 october, 1845. 
rational English investor. It is impossible to determine the statistical significance of this repatriated investment. The impression of the writer is that it was slight, but it must be emphasised that this is only an impression and could quite conceivably be proved wrong.

The problems inherent in the source material render a strict quantification invalid, but the results can perhaps be taken as heuristically reasonable in indicating trends and tendencies. Not all the Scottish lines constructed needed external finance, nor on the other hand was there some mystic percentage of English money that would guarantee construction. Yet, it remains true that if the desire to contribute can be equated with the ability to do so, then, as is shown in Table 2.7,

\section{TABLE 2.7}

Total Subscribed in Amounts of $\$ 2000$ and more to Railways in 1846

Origin of Subscriptions ande of suosoritiong

Scottish

English

\section{Scottish Railways}

(a)

(b)

Source: Calculated from P.P. 1846. XXXVIII.

Notes:

(a) railways built before 1850
(b) railways either delayed or never built
(c) $\& 1,302,000$ of this was director subscribed.

English capitalists were responsible for over £l.6 million of the $\$ 4.3$ million which was promised by large subscribers in 1846 to railways constructed in the immediate post-mania period. 
This is roughtly $38 \%$, but, since 21.3 million of the Scottish share was director subscribed, the actual percentage may well have been higher. It is important to note that a considerable proportion of the English capital went to the older railways that had previously relied on this source. About $\$ 680,000$ of English money was expended in building branches of the North British and Caledonian.

Were the majority of English subscribers to Scottish railways then merely expanding links that they already had with the established companies? A sample from the contracts makes it clear that even the Englishmen who put money into Scottish railways put much more into lines south of the border. Why then did they bother to come north? The heavy investment in the Glasgow, Dumfries and Carlisle, potentially the third transborder route, by merchants and industrialists in Lanceshire and Yorkshire - ¿305,000 and $\$ 192,000$ respectively, and their previous high investment in the Caledonian and North British suggests that such English investors might have been channelling their capital into lines likely to be of direct practical benefit to northern England and not just financially rewarding to the shareholder. Defining practical benefit lines as being those of direct importance to the transborder routes i.e. not small local feeders, but lines of some length designed to increase through traffic, though excluding lines north of the Firths of Forth and Clyde, then, as Table 2.8 shows, approximately $75 \%$ of English subscriptions to lines built, and $52 \%$ to those which were not, were promised to practical benefit lines. 
TABLE 2.8

Geographical Origin of English Subscriptions over £2000 (in £'000)

\begin{tabular}{|c|c|c|c|c|c|c|}
\hline Type of & Line & Lancashire & $\begin{array}{l}\text { Rest of North } \\
\text { of } \operatorname{singland}(\mathrm{a})\end{array}$ & Iondon & others & Total \\
\hline $\begin{array}{l}\text { Practical) } \\
\text { Benefit }\end{array}$ & $\begin{array}{l}\text { built } \\
\text { not built }\end{array}$ & $\begin{array}{l}426 \\
163\end{array}$ & $\begin{array}{r}462 \\
86\end{array}$ & $\begin{array}{l}115 \\
320\end{array}$ & $\begin{array}{l}200 \\
134\end{array}$ & $\begin{array}{r}1203 \\
703\end{array}$ \\
\hline Others & $\begin{array}{l}\text { built } \\
\text { not built }\end{array}$ & $\begin{array}{l}31 \\
80\end{array}$ & $\begin{array}{r}8 \\
90\end{array}$ & $\begin{array}{l}296(b) \\
397\end{array}$ & $\begin{array}{r}79 \\
111\end{array}$ & $\begin{array}{l}414(b) \\
678\end{array}$ \\
\hline
\end{tabular}

Source: Calculated from P.P.1846, XXXVIII

Notes: (a) Northumberland, Durham, Cumberland, Cheshire, Derbyshire, Nottinghamshire and Yorkshire.

(b) includes a $£ 240,000$ director subscription.

These figures, of course, mean very little if there was no opportunity to invest in non-practical benefit lines. In fact there was ample opportunity, for well over £ll millions was subscribed to such lines, of which only 10\% was English compared with $40 \%$ of the $\$ 4.7$ millions promised to practical benefit lines. If lines north of the Forth and Clude designed to link up with the routes to the south and Englend are excluded from the first total, the English proportion drops from $10 \%$ to $6 \%$.

The hypothesis of "utility investment" predominating over solely profit seeking investment might lose force if the origins of the English capital lay primarily in the south of that country. (1) However, despite London's reputation as a financial centre, Table 2.8 suggests that the north of England was most

1. Data of trensborder traffic flows in the 1860 s suggest that London was an important terminus but was it expected to be in the mid 1840s? (NBR 4/236; 4/237). The prospectuses of the proposed transborder railways tend to emphasise the nearer north of England destinations. 
prominent in putting money into scottish railwa,s, especially those that were built. This does not 'prove' the hypothesis as Laneashire was traditionally a source of railway capital, but there are two points which lend some support to the argument. Firstly, an examination of the North British minute books shows that south of England support for this line was much stronger in its early days, when there was little alternative opportunity for railway investment, than in 1846 when such opportunities were available almost everywhere. The second factor is that London stood highest on the list of English contributors to non-practical benefit lines and to practical benefit lines which were never built (presumably of less utility than those which were authorised).

It is not being maintained that the English investors were fundamentally philanthropic benefactors to the Scottish economy. Practical benefit must not be taken to infer a lack of financial benefit. Despite the ex-post effect of dividends and the Caledonian and North British shareholders remaining but fleeting acquaintances for several years, on an a priori analysis these trunk lines appeared worthwhile investment projects. In fact it could be argued that the practical benefit lines were perhaps expected to produce greater financial rewards than internal Scottish lines, because practical benefit lines were better integrated and likely to carry more freight and possibly more passengers. However, it should be noted that when construction on the "cheap principle" became popular in Scotland, English capital, despite the possibility of greater dividends than those 
offered by (say) the Caledonian, remained aloof from these lines designed to contribute so lely to the economic welfare of scotland. Of course this might simply be a case of once bitten twice shy.

How much English capital went into scottish railways in the first half of the nineteenth century is difficult to say. Qualitative statementsabound, especially when the English shareholders revolted against the expending capital accounts of the Scottish companies. Some of these statements included statistical claims, but no doubt these were inflated by patriotic indignation. Herapath's Railway Journal stated that a new board of the Caledonian, including directors appointed by the English shareholders, were "endeavouring to save some portion of the $22,850,000$ of English money expended in Scotland among Scottish landowners, Scottish contractors, Scottish workmen, Scottish engineers and Scottish lawyers." (1) The same paper also described the North British as "an English railway on Scottish ground." (2) The Railway Times believed that "the great majority of shareholders in the principal Scottish lines are resident on the sunnier (presumably English) side of the Tweed." (3) Herapatins too claimed that the ordinary stock of Scottish railways "is generally held almost entirely by Englishmen." (4)

1. H.R.J., 30 October, 1850.

2. H.R.J., 3 october, 1850.

3. Railway Times, 22 March, 1851.

4. H.R.J., 26 Hovember, 1853. 
How much English money continued to flow into Scotland's railways after 1850 is even more incalculable. The North British and the Caledonian were responsible for a substantial proportion of scottish railway construction in the second half of the nineteenth century, either by building it themselves or by subscribing to other railways. New shares of these two companies were generally offered to existing shareholders on a pro-rata basis, and more especially to the holders of ordinary stock who were primarily English. If they took up their option then possible English capital would remain of importance depending on whether or not the stock was resold. Occasional references in company reports suggest that the privilege was exercised. A list of large shareholders of the Caledonian in 1908 (see Table 2.9) shows some tendency for the Scots to oust the English as suppliers of railway capital, but this can partially be explained by the totals including shareholdings in companies taken over by the Caledonian.

However, it can be conjectured that with the development of railways north of the Central Lowland belt English money would be of declining importance to Scottish railway capital formation as a whole. This is because little English money appears to have gone to such lines except when they were promoted by the Caledonian or North British. One reason may have been that many of these lines were not quoted on the English markets;

1. e.g. $\operatorname{RAC}(S)$ 1/1A, 11 September, 1856; 22 March, 1860. B.R. RAC(S) $1 / 3$, 1870 s possim. B.R. 


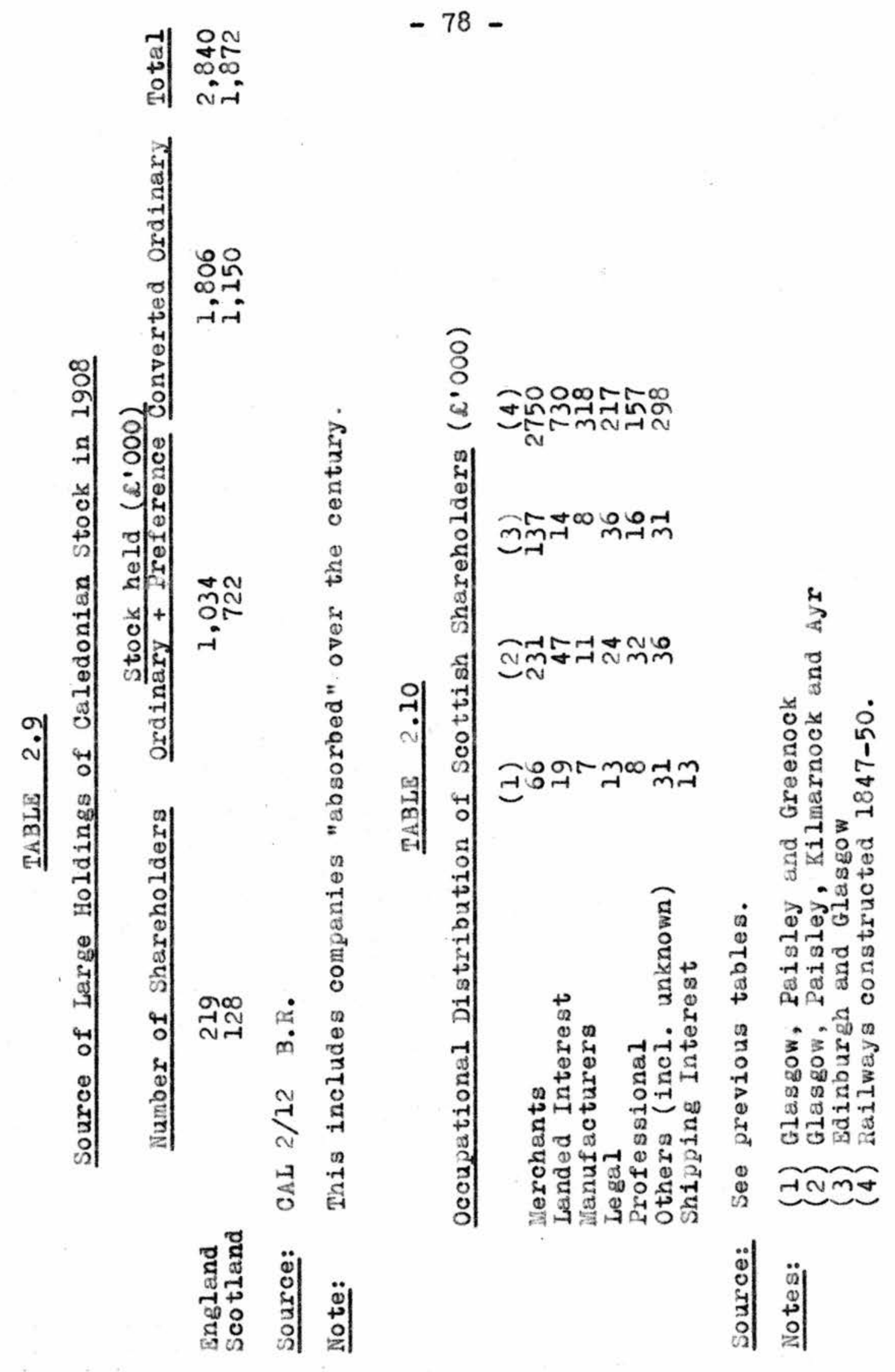


"a more general one (might) be the great ignorance that prevails as to the real resources of our northern counties," but a third possibility could be that these lines were not seen as aiding the English economy. (1)

\section{4.}

Why did the Scots not build more of their own railways? Prior to (say) 1850 it is arguable that they simply did not have the capital to spare. The evidence is fairly conclusive that the major scottish contributors to their indigenous railways before 1850 were the merchants, and especially the merchants of Glasgow. (2) As can be seen in Table 2.10 their contributions stand in contrast to those of manufacturers and industrialists. A few individual industrialists made large investments, but generally Scottish manufacturers participated only to a limited extent in railway investment unlike their English counterparts. (3) let at a later date such men were often prominent on the boards of railway companies demonstrating that they were well aware of the importance of rail transport to their business interests. (4) As being a director of a railway infers a substantial financial interest in the company concerned, it could

1. Scottish Railway Gazette, 24 May, 1845.

2. One difficult, here is the precise definition of a merchant. The Scots language was curiousl inflationary at this time "in the grandiloquous speech of scotlind, a merchant means a shopkeeper as a pound means a shilling." [R. Southey, Journal of a Tour in Scotland in 1819. 1929].

3. Information supplied by .c. Reed of Nuffield College, oxford.

4. See W.H. Marwick, op. cit., p.62. Also the Reports and Accounts of the Scottish railway companies. B.R. 
be suggested that their own needs for capital during the earlier period, especially those of the ironmasters, had prevented their earlier contributions being on a larger scale.

The investment gap left by the industrialists was partially filled by the scottish landed interest. Some of their shares would in fact be in lieu of compensation, but the abundance of qualitative evidence of landowner support and the quantitative evidence of 1846 (and later of the investment in the Highlands) tends to negate any application further north of Professor Spring's assertion that in England there was "comparatively little activity on the part of the gentry" in railway investment. (1) In fact one authority on railways went so far as to suggest that "broadly speaking, in England it was the landowners who opposed the railways, in Scotland it was the landowners who favoured the railways, while the landless were indifferent or antagonistic." (2)

This still does not explain why the scots as a whole did not invest more in their own transport system. One reason for advocating that it was because of a lack of capital lies in the fact that there was little Scottish money flowing into English railways at a time when the capital market must have been coming more perfect, judging from the flow of funds north, the development of the financial press, and the spread of books and pamphlets dealing with railways and railway investment. (3)

1. D. Spring, The English Landed Gentry in the Age of Coal and Iron: 1830-1880,' Journal of Economic History, vol.11, no.l 1951, p.7.

2. W. Gordon, our Home Railways. 1910. vol.11, p.163. Quoted in J.T. Ward, TSottish Landowners and the Railways: A PreIiminary Note,' Scottish Railways, vol.2, 1967. p.6.

3. Information supplied by l.c. Reed of Nuffield College, oxford. 
In the second half of the nineteenth century the scots did contribute more to their own railway development, although the continued dominance of English money in the two major companies may have prevented even greater involvement. Presumably as regards the industrialists there were profits surplus to internal requirements available for railway purposes now the initial burst of industrial expansion was over.(1) Evidence of an abundance of investible funds in general comes from the establishment of overseas investment trusts and a considerable outflow of capital from Scotland. Between 1873 and 1875 one million pounds were invested by the Scottish American Investment Trust, principally in mortgage bonds of American railways. (2) Blackwoods magazine for October, 1884 proclaimed that "Scotland revels in foreign investment ... three-fourths of foreign and colonial investment companies are of Scottish origin." (3) Admittedly Aberdeen, for one, had been a centre for overseas investment from the 1820s, especially investment in Australia, but these early investment companies were "essentially a

1. They may, of course, have regarded railway investment as akin to internal investment seeking indirect returns in the form of cheap transportation rather than merely financial returns in the form of dividends.

2. C.H. Walker, Unincorporated Investment Trusts in the Nineteenth Century, ' Economic History, vol.IV, $1940, \mathrm{pp} .345$ and 355.

3. Quoted in W.H. Marwick, Scotland in Modern Times. 1964. p.114. Further evidence of Scottish overseas investment in the second half of the nineteenth century can be found in: R.E. Tyson, - Scottish Investment in American Railways: The Case of the City of Glasgow Bank, 1856-81,' in P.L. Payne (ed.), Studies in Scottish Business History. 1967; W.G. Kerr, 'Scotland and the Texas Hortgage Business,' Economic History Review, second series, vol.XVI, no.l, August, 1963; A.E. Smith, George Smith's Money: A Scottish Investor in America. 1966; and D.R. Adler, British Investment in American Railways 1834-1898. Ph.D. Cambridge, 1958 . 
co-partnery of small investors, many of them working and lower middle class," which may strengthen the hypothesis of a relatively capital denuded Scotland having to rely to a significant degree on England for the provision of social overhead capital, at least to 1850. (1) In the 1820s George Stephenson argued that a shortage of capital was hindering Scottish transport developments, and it is true that many proposals for railways were put forward, few of which became effective. (2)

It ma. well be, of course, that these earlier overseas investment trusts were of more importance than is at present apparent, but without better statistics of capital outflow this is difficult to determine. If in fact the outflow was considerable then this might have been a reason for less Scottish investment in their home railways at this time. However, it could justifiably be argued that there is a lack of consistency in this hypothesis and the earlier suggestion that the outflow of funds in the later nineteenth century did not act against domestic railway investment. That substantial indigenous investment in scottish rallways in the later period occurred at the same time as funds were going overseas is easy to substantiate, but does this infer anything? There does not appear to be any

1. D.S. MacMillan, The Debtors' War. 1960. p.3. See also D.S. Miecllillan, Scottish Enterprise in Australia 1798-1879 in P.L. Payne, op.cit.; D.S. MacMillan, The Scottish Australian Company 1840-50, Scottish History Review. 1960; and J.D. Bailey, Australian Borrowing in Scotland in the Nineteenth Century,' Economic History Review, vol.XII, no.2, December, 1959.

2. Tr.H.S., vol.6, 1824 . 
easy solution to the problem. In the north east the lack of financial success of the Aberdeen Canal may well have deterred potential investors in subsequent transport developments, especially in view of the high dividends being promised in Australia, but this does not explain the investment preferences of the early investment companies in Edinburgh and Glasgow. The answer may lie in the direction of showing that home and foreign investment were courses pursued by different people and that abundance, or otherwise, of funds flowing out of the country had little significance for domestic capital formation. This is generally accepted as being true towards the end of the century, but, as far as can be ascertained, no-one has attempted to verify this for an earlier period. (1) There may also be some significance in the fact that in the earlier period ordinary railway shares would have to be purchased whereas after 1850 guaranteed stock was available.

\section{5.}

The Scottish Railway Gazette maintained that no scheme would rise above its prospectus "without the name and assistance of persons of considerable capital, and a character for sagacity," but it would also require aid from small capitalists who "individually weak" become "collectively strong." (2)

The influential name was frequently sought. The Scottish

1. A.K. Cairncross, Home and Foreign Investment. 1953.

2. Scottish Railway Gazette, 26 July, 1845. 
Central asked Najor Moray Stirling if they could list him as a supporter, "it being distinctly understood that you are not thereby to incur any pecuniary liability." (1) All that the Aberdeen company required of Lord Airlie was that he gave his countenance to the scheme - "no money and no obligations" and later they duly recognised that his publicised support "did us great good." (2) However, to lend moral and not financial support was probably not the general case.

Although the Bconomist reckoned railway investment "introduced commercial feelings to the firesides of thousands," Cainncross was undoubtedly correct in his assertion that in Victorian Britain "the typical private investor was always a man of wealth:" (3) Two returns of 1886 and 1902 give average holdings in a railway company to be $£ 1,642$ and $£ 1,622$ respectively. (4) However, these are simple arithmetical averages and all that can be said is that small investors did not provide the majority of the capital. Even in railways such as the Callander and Oban where the small unit of investment was numerically quite strong, the major portion of the finance came from a few large shareholders, as can be seen in Table 2.11.

Yet at times the companies attempted to attract the small investor. This can perhaps be seen in the reduction of the size

1. Abercairny Papers, G. .24, section 924, 24 February, 1844. S.R.0

2. Airlie papers, G.D.I6, section $38 / 82$, bundle 1 , items 5 and

3. Economist, 1845, p.310. Cairneross, op.cit., pp.84-85. Cairncross does, however, allow that the smaller man was probably more numerous in railway investment.

4. Parliamentary Papers. 1886 LVII, p.935; 1902 XC, p.889. 


\section{TABLE 2.11}

The Financing of the Callander and Oban 1865

Number

318

52

18

1

1
Description

Holding 1-10 shares

Holding 11-100 shares

Holding 100-450 shares

Duke of Argy 11

Earl of Breadalbane

Caledonian Railway
Total Holding

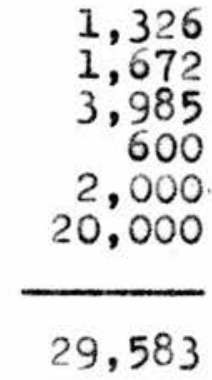

Source: $\operatorname{COB} 2 / 1$ B.R.

of shares. The most typical value of shares issued before 1840 being $£ 25$ or $£ 50$, but coming down to $£ 10$ to $£ 25$ in the 1840 s and to 210 in the following decade. The reason for looking to the small capitalist was twofold. Firstly, at particular points of time contributions in small amounts might have been deemed essential, especially in periods of considerable alternative i.e. non railway opportunity for the larger capitalist, or at times when capital in general was shy but railway spending was inevitable. Later in the century when the established companies felt more secure in their source of funds the little man may have been less welcome. The North British, for example, allocated their issue of shares in 1888 on a pro-rata basis to those already holaing at least £l,000 of stock. (1) Secondly, there was usually a desire to demongtrate to Parliament, and to the potential large investor, that a district really wanted rail

1. H.R.J., 25 August, 1888 . 
communication, and the best way to do this was to collect local subscriptions. These, however, frequently tended to be for only small amounts of shares. The Scottish Midland Junction thought local subscriptions "important in order to show the opinion and good feeling of those immediately interested," but they were well aware that notmany tenants or proprietors would want to, or would be able to, make substantial investments, and so they only asked for numbers and goodwill as "the large sums of money may, it is hoped, be got in the share market." (1) Typically the small investor was a local investor and, if the contributions of the large landowners are discounted, the converse also holds. Table 2.12 shows that the larger shareholdings tended to come from outside the area of the proposed railway, though some of this will be attributable to directors of the established companies signing the subscription contract.

If capital at a distance stood aloof then it might be essential to encourage local finance to come forward. Small share values were as much a function of locality as of time. Mr. John Bathgate, promoter of the Peebles and Innerleithen Line, maintained that such a railway was a necessity, but realised that "the time was past when they could look for strangers to invest capital in a local line of railway in a

1. Airlie Papers, G.D.16, section 38/82, 9 July, 1844. S.R.O. Sometimes this desire to show local support produced an element of blackmail, as when the menufacturers of Galashiels promised that "every exertion will be made by us to advance the interests of the North British Railway Coinpany" if they in turn guaranteed to carry coal to Galashiels at $1 \frac{1}{2} \alpha$ a ton mile; or when the town council of Inverury decided to take a more substantial interest in the Great North of Scotland if the stations were designed to their satisfaction. (Minute Book of the Galashiels Manufacturers' Corporation, December, I858, Pp.90-91; GNS I/1, p.327. B.K.) 
TABLE 2.12

Local Support for Scottish Railways in the 1850 s

Year Railway

1853 Peebles

Forth and Clyde Junction

1854 Ayr and Maybole

Selkirk and Galushiels

Inverness and Nairn

Fife and Kinross

1855 Glasgow, Dumbarton and

Helensburgh

Jedburgh

Inverury and old Meldrum

East of $\mathrm{Fife}$

Banff, MacDuff \& Turiff

1856 Alford Valley

Maybole and Girvan

Denny Junction

Inverness and Aberdeen

Junction

Perth and Almond Valley 22. 15,030

Castle Douglas \& Dumfries $490 \quad 54,100$

1857 Keith and Dufftown

Leslie

Kinross-shire

British and Irish Grand Junction

1858 Carlisle and Hawick Junction

Carlisle, Langholm and

Hawick

Aly th

Symington, Biggar and

Broughton

Devon Valley
Local Subscribers other Subscribers

No. Amount $(\Sigma)$ No. Amount $(\hat{E})$

11635,530

$18 \quad 19,450$

962,200

6217,370

$48 \quad 12,140$

18248,710

1059,680

188100,890

14115,810

$80 \quad 12,130$

$75 \quad 21,950$

? 90,350

158,900

36,200

1213,300

$31 \quad 35,060$

1683,500

410,800

$\begin{array}{ll}9 & 4,370 \\ 3 & 2,200\end{array}$

NIL

NII

$\begin{array}{ll} & ? \\ 259 & 24,920 \\ & 24,270\end{array}$

8944,240

312165,900

$51 \quad 26,940$

$14 \quad 34,930$

$8 \quad 78,000$

1815,620

? 26,350

? 39,910

750153,140

? 25,920

? 73,750

?

$57 \quad 51,730$

$5 \quad 32,300$

NII

NIL

$120 \quad 34,950$

? $\quad 378,520$

? 198,780

16614,270

$87 \quad 18,650$

28

1

7,230

17243,520

421,690

Source: Parliamentary Intelligence of the contemporary reilway journals. 
district such as this." (1) On the other hand, the Esk Valley promoters desired local support so that the company might "be as independent as possible." (2) Local support, however, was more generally involuntary independence caused by a reluctance of the established companies to provide all the necessary capital.

Usually some degree of external finance was necessary to the successful flotation of a small, local railway. Few railways outside the Highlands could match the claim of the St. Andrews line that "nearly the whole of the shareholders are directly connected with this locality." (3) Even the town council had subseribed to this "locally created undertaking - a real development of the actual wants and necessities of the district through which it runs, without the intervention of 'foreign' capitalists or speculators." (4) However, the early enthusiasm could not have been equalled by financial ability as in 1855 Herapath's could write of "forfeited shares." (5)

\section{6.}

In the initial phase of railway promotion it is the shareholders who are important, for at least half the authorised capital had to be paid up before loans could be applied for, but, once this stage has been reached, loans and mortgages achieve considerable significance, either in meeting temporary demands or, more generally, in becoming virtually permanent capital.

1. H.R.J., 6 November, 1858.

2. Scottish Rallway Gazette, 22 December, 1860.

3. Railway Times, II January, 1851.

4. Railway Tines, 19 July, 1851 .

5. H.R.J., 20 October, 1855. 
Authorised borrowing powers were frequently exceeded though this was often due to lining up one loan to replace the one about to mature. (1)

Lending money to the railways was popular with the small capitalist because security of capital and stability of income were guaranteed. Widows and spinsters especially abound in the pages of debenture books and mortgage ledgers. (2) Trustees, too, swell the loan registers as on the cathcart District where over three-quarters of the loans listed in one volume were credited to such persons. (3)

The small lender was sometimes deliberately cultivated. The North British allowed their $4 \%$ debenture stock to be taken up in installments "thus accommodating those who may desire to invest moderate sums from time to time," but this was only after they found a reluctance on the part of the public to take above \&2,900 of the stock. (4) This produces a suspicion that in general the significance of srall loans in monetary terms may be slight, and this appears to be supported by the evidence obtained from three volumes of railway company loan books selected at randon. Of 101 mortgages totalling 2488,000 granted to the North British in 1845/46 \$420,000 came from only 19 individuals or institutions. The Berwickshire's register of debentures shows

1. S.C. Borrowing Powers. 1864 XI, q.76.

2. See also S.C. Railway Aets Enactments. 1846 XIV, appendix 2. However, about two-fifths of the shareholders of the Bank of Scotland and the Commercial Bank of Scotland in the 1870s were women, and of these almost two-thirds were single. (J.J. Hobsbawm, Industry and Empire. 1968. p.97).

4. $\frac{\mathrm{CDK} 2 / 3}{\mathrm{RAC}(\mathrm{S}) \mathrm{i} / \mathrm{A}, 4} 4$ September, 1858. B.R. 
that in the period 1863-80 12 persons (15\%) contributed £34,000 $(46 \%)$ and a further $19(24 \%)$ another $\$ 21,700$ (29\%) of the money raised by such means. Similarly, the register of mortgages of the Cathcart has 24 entries for 1884 totalling $\$ 60,729$, but four members of the Baird family provided $\& 49,497$ and four other individuals provided a further $\$ 5,400$

Banks and insurance companies took a more active part in the debenture market than in that for railway shares for the same reason that appealed to the widow and spinster. In the North British mortgages previously mentioned the Edinburgh Life Assurance provided $£ 30,000$, the Scottish Widows Fund $£ 50,000$ and the Royal Bank of Scotland, the British Linen Company, and the National Bank $£ 70,000$ each. Bonds to the Colonial Life Insurance Company and the Scottish Union Insurance Company easily dominated personal loans made to the Inverness and Aberdeen Junction. (2)

Small loans may have been attractive to the railway companies because of the greater likelihood of them being renewed. At the top end of the scale the capital market for loans was fairly perfect but this may have been less true for smaller amounts of finance. Large lenders at times sought out potential borrowers and in 1847 the North British found that their decision to refuse to pay $5 \%$ on loans, a rate which other companies were prepared
1. $\mathrm{NBR} 1 / 2 . \mathrm{B} . \mathrm{R}$.
BWR 2/I. B. .
CDR 2T7. B.R.
2. IAJI/I, October, 1857. B.R. 
to pay, had lost them "several large loans." (I) when loans were paid off it was usually by the raising of a fresh loan and not from revenue, but there was in fact a significant degree of renewals as is apparent from the company records. The Monkland company, for example, records 24 bonds issued between september, 1849 and August, 1851 of which 13 were renewed and 5 extended yet again. (2) In the mid 1860 s loans were harder to renew in Scotland than in England judging from the fact that the companies allowed $\frac{1}{2} \%$ commission to solicitors bringing or renewing loans, whereas the English railways allowed only $\frac{1}{4} \%$, unless the loan was for three years or more. (3) The precarious nature of existing loans and, more specificelly the bitter experience of attempting to meet their obligations after 1866 stimulated the Scottish railway directors to substitute permanent debenture stock for terminable loans. As can be seen in table 2.3 such stock rose from being about a twelfth of non share capital in 1864 to being practically all of it by the end of the century. A further advantage to this type of loan was that if the conversion was made at a time of low interest rates the railway company would save money in the long run, not only by avoiding the costs of renewal, but also in the total interest paid.

\section{7.}

The banks were reluctant to aid fixed capital formation by

1. NBR $1 / 3,9$ June, 1847. B.R.

2. MNK 271 . B.R.

3. H...J., 12 october, 1867. 
the purchase of railway shares because of their need for possessing liyuid resources. (1) No examples have been traced of banks taking shares in a railway company before the line was opened i.e. risk capital was not forthcoming from the banks. Where the banks did purchase railway shares it would seem it was to obtain a return on their surplus funds. As these shares were in established railways they would be more marketable, especially as most of them bore guaranteed dividends and did not participate in the general fortunes of the railway company as did ordinary shares. Whether or not this flow of funds in and out of the railway share market had any direct impact on the finances of

1. I am grateful to Professor S.G. Checkland for allowing me to make use of the transcripts of the minute books of the scottish banks. I am also grateful to the directors of the banks for permission to quote from these transcripts. Where general statements based on a survey of the various minute books are made no specific references will be given.

A brief oxtline of the traditional view of Scottish banking is perhaps essential here in order to throw more light on the arguments presented in the text of this section. The general criticism of the lending policy of the established chartered and Edinburgh private banks was that inadequate funds were available to meet the growing demands of industry. The banks' cautious emphasis on stability had led to the largest part of their loanable funds being absorbed in discounting bills and in investment in government securities. Bven the Cormercial and National Banks, founded in 1810 and 1825 respectively, despite their avowed national coverage and more liberal lending policies, proved themselves to be pseudo-revolutionaries and came within the fold of the older institutions by 1830 . The reaction to this was a burst of new banking activity in the following decade, primarily in the west of Scotland. These new banks pursued an ageressive financial policy employing a large proportion of their resources in the discounting of ordinar. trade bills, but there was still a general reluctance on the part of all the scottish banks to participate in direct industrial financing. (i.H. Campbell, Scotland Since 1707 . 1965. pp.139-142). 
individual railway companies is open to question. Those railway directors who were also on the boards of banks could perhaps manipulate the banks' dealings in railway shares so s.s to influence the price of their own railway stock, but this would only be of importance to the railway at the time of floating new issues.

There is some evidence that one of the newer banks, the Clydesdale, was making share purchases throughout the 1840s, and that the Commercial was also involved in such operations before the railway mania, but, as far as can be ascertained, the general policy of most banks was to remain aloof from dealings in railway shares in the first half of the nineteenth century. (1) Until the railway mania there was no stock exchange in either Edinburgh or Glasgow on which railway shares could be marketed. This would perhaps deter the Scottish banks in dealing in such investments. It might also explain why the Commercial Bank dealt in English and not Scottish railway shares. After the railway mania when achievements failed to match up to expectations an odium fell on railway shares for several years which must have dissuaded the banks from moving into this sphere of equity investment. It dissuaded most types of investor for the railway companies found it necessary to issue preference shares when they next went to the market for capital. With the development of

1. Not until May, 1852 did the directors of the Union Bank of Scotland revise their previous opinions and accept that it might be considered "safe as well as advantageous to the Bank to employ a certain portion of their funds in such investments." (R. Rait, The History of the Union Bank of Scotland. 1930. pp. 295-296). 
the preference share and the gradual revival in the value of ordinary stock the railways eventually came to be acknowledged as stable financial units and, as railway stock grew in status, it entered more into the investment portfolios of the commercial banks.

It has just been stated that the Scottish banks played only a minor role in the direct formation of fixed railway capital before 1850, but in fact they did aid capital formation indirectly by giving loans which is tantamount to providing long term capital if the loans were constantly renewed. Railways were entitled to borrow appoximately a quarter of their authorised capital, and a great proportion of the loans came from the banks, both from the newer, less conservative ones and from the older, established institutions. A reading of the minute books of the railway companies and of the banks makes it clear that loans from the banks to the railway companies were forthcoming throughout the century. The banks did this for several reasons. First and foremost it was profitaole. Secondly, it encouraged the circulation of their banknotes. Finally, it was a way of attracting railway company accounts which gave the bank use of the parliamentary deposit while the railway company's bill was being discussed. (1) In fact in order to obtain accounts or safeguard those they already had, it seems to have been general policy to offer differential rates of interest on loans given

1. It should be stressed that the banks did not make a general practice of lending to a railway company which had not begun operations. However, lending to established companies which were constructing branches was not unknown. 
to those railways which banked with the bank giving the loen and those which banked elsewhere. (1)

Did this lending to the railways clash with the avowed policy of high liquidity advocated by some of the banks? It may be that the total amounts involved were slight in relation to other advances or deposits. It is virtually impossible to ascertain how much the banks were in fact lending to the various sectors of the economy, but considering the extent to which the railway companies were involved in bank loans the impression gained is that railway loans were not an insignificant proportion of total bank advances. It may be that the capital market was so saturated with demands that the banks allowed the railway companies to use them as a last resort, but there is no evidence of an ebb and flow in the railways' reliance on bank loans which might be expected from such a policy. It may be of course that the banks were never so reluctant to aid industry and commerce as has been made out by some authorities. (2) Walter Scott, writing in 1826, had no doubt that economic development "had been produced by the fecilities of procuring credit, which the Scottish banks held forth, both by discounting bills, and by granting cash accounts. (3)

1. Minute Book of the Royal Bank of Scotland, 21 January, 1846 ; and Hinute Book of the Commercial Bank of Scotland, 17 october, 1844 make it clear that railway companies bargained with the banks over such differential rates.

2. This is impossible to say without a detailed survey of the banks' minute books, but the impression gained from a random sample is that few long term loans were forthcoming for business enterprises. It has not proved possible to verify how many of the shorter term loans were renewed, but where a check could be made it seems that there was little renewing. However, the results of the check were biased by not knowing how many renewals were sought or how many of the businesses tried other banks.

3. kuoted in Reid, op. cit., p.25. 
Unfortunately he did not 60 into details.

However, the main reason why the banks were willing to loan money to the railway companies (and to other enterprises) was that it was virtually risk-free lending. The newer banks, shut out of certain lines of business by the established institutions, might have been more willing to expand in other directions and thus follow a less cautious leading policy than the older banks, but it is clear that neither were prepared to advance much, if any, risk capital. In fact they went to some lengths to minimise the risks involved in railway loans. Quite of ten loans were made only if stipulated conditions were followed as when the Great North of Scotland obtained $£ 30,000$ for six months from the North of Scotland Bank on the proviso that the remaining calls on preference shares were made within that six months. (1) The Wishaw and Coltness had to promise to bring actions against defaulting shareholders before the Royal Bank of Scotland would Lend them $\$ 20,000$. (2) The Arbroath and Forfar, in debt to the British Linen Company, had to ask the pernission of that bank when they wanted to pay a dividend. (3) Such interference with the financial policy of the railway companies was not uncommon, but the general method of ensuring relatively risk-free lending was to bind the railways' directors personally responsible as individuals for the repayment. Railway property was not a very marketable asset, and as such was an imperfect security with

1. GNS 1/1, 26 March, 1854. 3.R.

2. Report of the Wishaw and Coltness, 30 June, 1835. Mitchell ilorary.

3. Minute Book of the British Linen Company, I June, 1840. 
which to obtain a loan, but where the directors were willing to pledge themselves responsible for paying it back, a loan was much more likely. However, the directors usually made sure that they were relieved of their liabilities by the shareholders. The banks were well aware that this occurred, but, as they had the directors' signatures on the loan contract, they knew that their money was secure. (1)

Even when the directors were willing to bind themselves a loan was not automatically forthcoming; the banks had to be sure that the railway concerned was a worthwhile project. Generally loans were made only to railways which were in operation. One exception to this was when the Royal Bank lent $£ 20,000$ to the slammanan while it was still being built, but as nearly $\$ 70,000$ had already been spent on the line it was thought that every effort would be made to get the line completed, especially in view of the respectability of the shareholders. (2) As demands from the railway companies for loans increased in the 1840s, the Comaercial Bank set up a committee specifically to deal with the question of such lending. The outcome of this was the laying down of certain general principles, which, al though never explicitly expounded by the other banks, seem to have been generally followed by them. Loans were to be granted only to trunk line companies which were completed and in remunerative operation; the borrowings of these companies should be within

1. NBR 1/5, p.391. B.R. See also S.C. Boxrowing Powers. 1864 XI, q.97-98. 2. Minute Book of the hoval Bank of Scotland, 6 Narch, 1839. 
their legal limitation; and the duration of the loan should not extend to any very lengthened period. (I)

This final regulation, if gut into practice, would appear to conflict with the previously mentioned idea of continued loans being used to finance long term fixed capital projects. In fact it would seem that the renewal of a bank loan was by no means certain, but it would also seem that alternative loans, usually from other banks, were found without much difficulty. (2) This was not really a case of a second bank putting its capital at a distinct risk which a first bank had decided was too great, but more the conventions of banking at work. The banks simply did not regard themselves as providers of long term loans and limited the renewals of their short and medium term loans accordingly.

The banks were understandably cautious in their dealings with railway companies. They were even more careful when individuals attempted to borrow money using railway shares as securities. The Clydesdale Bank had advanced up to 50\% of the value of such shares in 1839 , but, as the railway mania developed in the mid 1840 and speculators in railway shares sought advances on the security of their stocks, the banks became more and more reluctant to give them accommodation. (3) Generally they were given only to established and valued clients and only then when it was deemed "necessary to keep the customers attached to the

1. Minute Book of the Commercial Bank of Scotland, 17 October, 1844 .

2. e.g. EPD 1/3, P..11, 109, 386. B.R.

$$
\text { GNS I/I, } \mathrm{pp} .430,441 \text {. B.R. }
$$

3. Minute Book of the Clydesdale Bank, 22 February, 1839. 
Bank." (I) Even then strict precautions were made as to the maintenance of a wide (at least $25 \%$ ) margin between the value of the shares and the amount of the loan. (2)

A direct consequence of the failure of the banks to meet the extensive demands for personal loans during the railway mania was the rise of an institution peculiar to Scotland, the Exchange Company. The first, the Glasgow Commercial Exchange Company, came in way, 1845 and by early 1846 there were six more in that city alone. Edinburgh had only one, the Exchange Bank of Scotland, although another was projected in late 1846. Further north several companies developed around Dundee and Aberdeen. (3) The plan of these companies was to lend up to three-quarters of the market value of the stock taken as security. Funds were to be obtained partly from paid up capital and partly from attracting deposits by offering high rates of interest. (4)

There was tremendous criticism of these companies by the normal commercial banks. Charles Boase of the Dundee Banking Company judged them "a sort of society got up for promoting the mania of the day." (5) They were ably defended by George Kinnear, manager of the Glasgow Commercial Exchange Company, who maintained that not only was the theory on which they were based sound, but that the commercial banks recognised this and were attempting to take away some of the Exchanges' business by forming the British

1. Minute Book of the Commercial Bank of Scotland, 1 April, 1845.

2. Ioid.; also 16 December, 1846.

3. A.W. Kerr, History of Banking in Scotland. 1926. p.215.

4. G. Kinnear, Banks and Exchange Companies. 1847.

5. vuoted in W.H. Narwick, o.cit., p.77. 
Trust Company to perform a similar function. (1) There was substance in his allegations for such a company was being promoted by the Royal Bank, the British Linen Company, and the Bank of Scotland "for the purpose of correcting the evils which have arisen to the banking interests of scotland out of the operations of the existing Exchange Companies." (2)

The banks were far better equipped to manage such business both in terms of financial reserves and commercial expertise. It was not they, but the Bxchange Companies, that went bankrupt in the financial aftermath of the railway mania. The Exchange Companies had stated that if the value of the shares they held as security fell by over $10 \%$ the difference had to be repaid by the borrower or the stock was liable to be sold. However, when times changed and there was a general depression of railway property, they did not, or could not, take advantage of their declared policy. They had also taken the precaution of transferring many of the shares into their own names (a policy which the banks wisely refused to follow) in order to have full control over their disposal should the occasion arise. (3) This, however, proved to be their downfall as the. were forced to pay the calls on the shares, it being impossible to sell them on the market because of the capital loss involved. In addition some of the companies appear to have actively participated in the speculation, though, if the Northern Investment and Exchange

1. Kinnear, 10c.cit.

2. Minute Book of the Royal Bank of Scotland, 17 February, 1847.

3. NBR 1/5, P.86. B.R. 
Company is any guide, only to a limited extent. (1) Shareholders in this company received a divident of 5\% in 1846 and 1847 but then nothing until March, 1849 when they obtained 25\% of their capital back prior to the winding up of the company in 1851. (2) The West of Scotland Exchange Investment Company was wound up in September, 1846; three other companies disappeared in 1848; but one of the Glasgow enterprises survived until 1853 and the little known North British Bank lasted even longer. (3)

\section{8.}

Into the mainstream of fund raising - shares, loans and mortgages - flowed many tributaries of financial expedients, their depth and speed of flow regulated by the financial circumstances of the companies. One of the most common was to apply capital to revenue jurposes and vice versa. The Caledonian and Dumbartonshire 'losned' 212,995 from its revenue account and the North British also advanced money for its capital expenditure from its current receipts. (4) However, a few years later the North British was paying dividends out of capital to attract potential investors or lenders by showing a favourable financial position. (5)

1. Tooke and Newmarch, op.cit., p.366. Account Book of the Northern Investment and Exchange Company. B.R.

2. Ibid.

3. Railway Times, 3 September, 1846. H.K.J., 6 April, 1850 ; 21 April, 1849. Kerr, op.cit., p.216. Tooke and Newmarch, op.eit., pp.365-367.

4. Bradshaw's Guide to hailway Shareholders. 1853. pp.24-25. RAC(S) I/IA, 18 March, 1856. B.R.

5. Report of the Committee of Investigation to the North British Railway Shareholders, 14 November, 1866. B.K. 
Dividends on guaranteed stocks were liable to be deferred and, to add insult to injury, occasionally converted into preference shares bearing a further guaranteed return. (1) Ordinary dividends too were apt to be forsaken if circumstances were pressing. The Edinburgh and Glasgow explained that their decision not to divide the profits was "not a proposition to increase the capital account, or to increase the expenditure. It was merely a loan from the shareholders to the Company instead of borrowing from the banks or private individuals."

When money was tight creditors were frequently asked to take promissary notes for twelve months or even longer. Others were induced to allow their bills to be settled over time - the early minute books of Edinburgh, Perth and Dundee suggest a tendency to pay creditors (say) $£ 50$ every time a request for settlement was made.

Contracts for the purchase of rolling stock and other expensive capital equipment were also subject to hire purchase agreements, and at times the giving of favourable terms seems to have been more important in securing a contract than the efficiency of the stock concerned. (3)

1. RAC(S) 1/1A, September, 1868; March, 1888. B.R. RAC(S) 1/36, Narch and September, 1849. B.R.

2. H.R.J., I April, 1848.

3. e.g. GNS 1/1, P.435. B.R.

Report of the Committee of Investigation to the North British Railway Shareholders, 14 November, 1866. B.R. H.R.J.' 19 September, 1857. SPDI $/ 3, P .381$. B.R. 
9.

There was little independent promotion of railways in the late nineteenth century. By far the commonest method of financing a railway after (say) 1870 was to rely on the established companies which were, by this time, reasonably stable financial units. With substantial financial and physical assets as security they were perhaps more likely to attract new investment than a small independent line, especially in view of the fact that the major company would not be issuing shares for the specific purpose of building the line, but would merely allocate funds from its general capital account. This would mean that the investor would not be gambling on the profitability of a single line, but would be sharing in the profits of the parent concern, or would be receiving a guaranteed rate of return from that company. Some of the lines built were nominally in the hands of independent parties, but these persons had no intention of undertaking construction except under the auspices of a parent company who would subiscribe for the vast majority of the shares. Subscriptions to other companies were not peculiar to the late nineteenth century. In the mania of the 1840 s some of the major companies, fearing isolation or the threat of competition, subscribed to adjoining railways, often without their shareholders' knowledge or consent. The Edinburgh and Glasgow illegally took shares totalling $\$ 877,800$ in four other companies, and the North British also purchased shares in several other railways without legal sanction. When the directors of the latter company 
abandoned their attempt to obtain a commanding interest in the Edinburgh, Perth and Dundee, nearly $\$ 85,000$ was lost on realising the shares. (1) Once the discovered what was happening the shareholders did not stand idly by. The North British directors were forced to take some of the losses on their own account, and the shareholders of the caledonian obtained an interdict forbidding that company to apply its funds to the purchase of shares in other lines. (2) The latter's share dealings had led one shareholder to wonder "what was meant by a subscription to the Caledonian Railway ... if to the buying up of the Scottish Midland Railway, why not of Peruvian mines?" (3)

Once into the 1850 s subscriptions to other companies grew apace. Many railways adopted the policy of the Great North of Scotland which "did not make branches themselves but subscribed a certain sum ... to help the parties locally interested to bring the scheme to maturity." (4) They were not prepared to do everything and wished their "shareholders to be relieved of a fair share of the burden," as when they expected local supporters of the Formartine and Buchan to provide a quarter of the $\$ 400,000$ capital needed. (5) Other companies were not always prepared to go so far. The North British would provide only half the

1. Railway Times, 22 May, 1850.

Report of the Comittee of Investigation to the North British Railway Shareholders, 14 November, 1866.

2. Ibid. Railway Chronicle, 1 December, 1849.

3. M.6578(4), May, 1847 . N.L.S.

4. H.R.J., November, 1855.

5. H,R.J., 20 vovember, 1858. 
Berwickshire's $£ 100,000$, although on the other hand their interest in the Galashiels to Peebles line was so preponderant as to compel them to take over that company. (1) The Glasgow and South Western refused to take up any of the stock it was entitled to in the Portpatrick, but this was because of a dispute over the working of the line. (2) Even the Great North of Scotland believed it "a judicious condition" to insist that half the shares of the Keith and Dufftown should be subscribed for by parties "locally interested." (3)

Yet on occasions the financial pendulum swung the other way. The Caledonian at first declared that they would not give money to the Symington, Biggar and Broughton, but eventually subscribed ¿7,500 when "the proprietors found it impossible to raise the whole money." (4) From the inception of the Hawick to Carlisle scheme, however, the North British was prepared to make up "any deficiency in the capital required." (5) Perhaps if a line was considered essential or of definite financial importance to a major company then its capital would be ensured, but, if its contribution to their coffers was open to doubt, the involvement of the major railways might be limited. The latter course of action could have been encouraged by the knowledge that the use of their name frequently stimulated subscriptions, as it did on the abortive Brampton and Longtown, where several important

1. H.R.J., 19 April, 1862; 11 May, 1861.

2. H.R.J., 6 March, 1861.

3. Scottish Railway Gazette, 24 March, 1860.

4. H.R.J., 8 May, 1858 .

5. 1.K.J., 22 August, 1857. 
contributors refused to pay for their shares on the grounds that they had been induced to take them up on the false representation that the North British and the Glasgow and South Western were to subscribe $\$ 30,000$ each. (1) Presumably such inducement was the reason for the North British having to give less than $\$ 6,000$ to the Kelvin Valley although a $\$ 30,000$ contribution had been authorised by their shareholders. (2)

After the mania of the mid 1860s subscriptions to other companies in fact declined in total, but only because the established companies were constructing so much themselves. However, there was no decline in the importance of inter-company investment for most works of significance employed other companies' capital to some extent. The city of Glasgow Union was dorinated by the holdings of the North British and the Glasgow and South Western; a great deal of local money went into the Cathcart District line, but the Caledonian took over half the shares; the same company also poured capital into the Callander and Oban. The Glasgow Subway was "manifestly under Glasgow and South Western auspices" and the North British contributed $£ 200,000$ to the West Highland line. The two bridges across the eastern estuaries were perhaps the greatest projects of the late nineteenth century, if not of the whole of scottish railway development. Of these the Tay Bridge capital account was heavily weighted by North British money and the Forth Bridge was in effect

1. H.R.J., 8 December, 1866.

2. H...J., 27 September, 1879. 
a joint concern of the Midland, the Great Northern, the North Bastern, and the North British companies. (1)

10.

When the Edinburgh and Glasgow promised a $15 \%$ return, the Glasgow, Paisley and Greenock 12 $\frac{1}{2} \%$, the Glasgow and Ayrshire 12\% and the North British $8 \%$ there was little reason for capital to consider venturing into the relatively isolated northern regions. (2) The solution to the problem of financing advanced by those who wanted railway communication in the Highlands was government aid; a plea which provoked a scornful editorial from the Railway Times - "These hill people have been too long accustomed to draw on the public treasury for the expenses of all their local improvements ... it is now high time they should cease praying to Hercules, and put their own shoulder to the wheel." (3)

There was sufficient precedent in Scotland as a whole, as well as in the Highlands, to justify the request for state assistance. It is generally known that the Caledonian and Crinan canals had to resort to the public purse in order to reach completion, but perhaps not so well appreciated that the Edinburgh and Glasgow Union canal borrowed $\$ 50,000$ from the government in 1820 and a similar amount three years later. Military and parliamentary roads had also been constructed in the Highlands

1. $\operatorname{CDR} 2 / 9,2 / 10,2 / 11$. B.R. Railway News, 27 November, 1886. W. Moworth, The Railways of Scotland. 1890. passim.

2. Railway Magaziñe and the Annals of Solence, vol.3, 1837, p.241. Railway Times, 2 September, 1843.

3. Railway Times, 10 April, 1841. 
with the aid of state grants. In addition loans totalling over $£ 100,000$ were made between 1817 and 1839 to help with road improvements in Scotland. Significantly those with the debt still outstanding in 1846 tended to be in the northern regions. Towns and cities also had received loans to help in improvements viz., £2,000 to Dunfermline in 1821, £50,000 to Glasgow in 1826/ 27, and $£ 95,000$ to Edinburgh in 1833. (1) However, when it came to Scottish railways, parliament appears to have developed a blind spot. Walter scott had proposed borrowing the sum necessary for constructing a line up Gala Water from the government in 1820, but nothing came of this, and, al though a total of $\$ 490,000$ was loaned to eleven railway companies between 1817 and 1842, none of them were in Scotland. (2) In the post mania depression representatives of many of the leading Scottish railway companies petitioned the Government for assistance in the form of loans, to enable them to keep their construction going, and hence prevent mass unemployment, but the government, despite admitting the importance of the object in view, refused their request. (3)

Why the government should be prepared to give money to assist railway development in Ireland but refuse similar aid, or even loans, to Scotland is not eassy to answer. It may have been that once the railway age was past adolescence they feared that the giving of even one grant would have encouraged a wait

1. Parliamentary Papers. 1846 XXV.

2. Ibidille Papers. Ms.642(99), 24 February, 1820. N.L.S. 3. H.R.J., 3 June, 1848. 
and see policy on the part of private investors to the detriment of railway development, whereas in Ireland they might have considered that private capital would never be forthcoming without some form of government sponsorship. The government did maintain that Ireland had "considerations quite peculiar to itself," but these may have been political rather than economic. (1)

It was not until the 1890s, when the Highlands perhaps became politically more like Ireland, that the government finally decided to assist Highland railway construction. (2) In 1891 they agreed to give grants or guarantees for lines in the north west which were recommended by a commission they had set up. (3) The first recommendation was for a 66,000 per annum annuity for the Garve and Ullapool, but only on condition that the line was built and worked for six months first. They "would be under no liability whatever to contribute anything if the line was not completed and worked." However, the project fell through because the sponsoring company, the Highland, demanded a twenty-five year guarantee from the government without themselves promising to complete the line. (4) In August, 1894 the prospect was broached of extending the West Highland railway, being constructed under

1. Railway Times, 24 April, 1841.

2. Petitions to parliament at this time constantly reiterated the differential treatment received by Scotland and Ireland in the matter of railway communications. (See papers in D.D.8/2. S.R.O.) The only financial assistance given by the state to any Scottish railway before the 1890s came in the form of compensation to the Portpatrick for the loss of potential Irish traffic in consequence of the government withdrawing their plans for the improvement of Portpatrick harbour. (Stair Papers, G.D.135, box 116, p.35. S.R.0.)

3. H.R.J., 26 September, I891.

4. Dothian Papers, Ms.5801, pp.31-32. N.L.S. 
the auspices of the North British, to Mallaig with the aid of a Treasury guarantee of $3 \%$ for thirty years on five-eighths of the estimated capital. (1) It was maintained that the extension would pay $2 \frac{1}{2} \%$ thus creating only a small liability on the Mreasury. However, once again the Highland proved troublesome, defeating this proposal by their parliamentary opposition, and causing the scheme to be set aside for several years until official financial assistance was allowed to be given. (2) The only other successful proposal in the 1890s for government aid to a Highland line was the $£ 45,000$ given to help in the construction of a line from Strome-ferry to Kyle of Lochalsh. (3)

In 1895 the government announced that it had no intention of granting subsidies, or otherwise assisting in the raising of capital for extending the benefits of railway communication to agricultural districts. However, they were persuaded that generally lines through agricultural areas did not pay the shareholders, and would therefore have little chance of attracting capital on a commercial basis. This led them to pass the Light Railways Act of 1896 which allowed for local and central government assistance. (4) Unfortunately the Act proved ineffective in its application to the Highland counties. Very few grants awarded exceeded one-third of the estimated capital cost and the interested districts failed to raise the rest, leaving a position in July, 1899 where not one of the dozen authorised schemes had

1. H.R.J., 10 August, 1894 .

2. H.R.J.', 7 June, 1895; 6 September, 1895.

3. H.K.J., 17 December, 1892 .

4. 
reached the stage of negotiating for land. (1) A few lines were constructed before the first world war, but the great majority of proposals never bore fruit. The difficulties of local finance were not the only problems to be overcome. One other obstacle was the Treasury's insistence that if an existing railway company saw fit to promote one of these light railways then it had to bind itself to construct the line and work it for ninety nine years, a period thought too long by the interested companies. (2)

In the virtual absence of government assistance who did build the railways in the Highlands; lines described by the editor of the Railway News as being "made on what might be termed patriotic grounds and (which) do not represent the same interest to the investor as those constructed as commercial undertakings, and looking to a fair return from the work done for the capital invested." (3) The answer supplied by Captain Tyler of the Board of Mrade was that Highland railway construction was the "enlightened action of a few wealthy individuals and large landed proprietors." (4)

As early as 1841 a Railway Mimes correspondent maintained that the Highlands had no chance of railways "if left to private enterprise alone." (5) Fortunately Scottish lairds had a tradition of undertaking long term investment for the general benefit of their estates and this extended into the field of

1. H.R.J., 14 July, 1899.

2. D.D. $8 / 2,22$ July, 1899. S.R.O.

3. Railway News, 31 October, 1874.

4. S.C. Railway Companies Amalgamations, 1872 XIII, p.823.

5. hailway Mimes, 24 April, 1841. 
transport. In the 1820s, for example, Sir John Stewart, Sir Neil Menzies and Sir John Patrick Murray had "felt themselves individually called upon to undertake extensive obligations" as to roads in Perthshire. (1) As regards railways, it is true that some of the Scottish landed interest were violently antagonistic towards such enterprises, but, as has been pointed out, it is also true that others were fully prepared to contribute to the provision of railway communication. This was especially true in the north. 240,000 was raised for the Dingwall and Skye by the owners of the land which it traversed. (2) The Earl of Caithness attempted to promote a Caithness railway, but less than three-fifths of the necessary capital was promised. However, on receipt of two pounds for each share held he magnaminously relieved the shareholders of any further liability. (3) The stock issued by the Highland, the company responsible for most of the building in the remoter northern counties, was "held for the most part by the great landed proprietors in the north of Scotland." (4) Total contributions to this railway included $£ 20,000$ from Lord Tweedmouth, $£ 30,000$ from B.W. Mackintosh of Raigmore, a similar amount from the Barl of Fife, 273,000 each from the Earl of Seafield and Sir Alex Mathieson, $£ 80,000$ from Lords Albert and Ronald Leverson-Gower, 285,000 from Mr. Merry of Belladrum, but overshadowing all these was the $\$ 355,000$

1. Murthly Castle Papers, G.D.121, Box 82. S.R.0.

2. H.K.J., 30 Ju1y, 1864 .

3. Mey Papers, G.D.96, section 661, 27 July, 1872. S.R.0.

4. H.K.J., 3 February, 1872 . 
invested by the Duke of Sutherland. (1) The Duke had even continued the Sutherland line from Golspie to Helnsdale at his own expenge. (2)

When built the Highland lines gave an "important lesson" that "railways honestly and economically constructed, and cheaply worked, can be made to prosper even in countries (where) they could not have been expected to bear even the cost of working and maintenance." (3) However, prior to their construction the anticipated dividends were lower than those thought obtainable elsewhere, which gave the "outside public ... no inducement to sink capital in such enterprises." (4) Is it then to be inferred that philanthropy was the motive of the Duke of Sutherland and the other landowners? It is arguable that the rise in rents and saving in transport costs consequent upon the coming of the railway might have more than covered their contributions in the not too distant future. (5) At the same time as encouraging railway development the Duke of Sutherland was carrying out extensive land reclamations, establishing lime works and promoting the Brora industries. (6) It may be that the real answer is improving but not merely philanthropic.

The reason for the slow coming of the railway to the Highlands has still to be conjectured. In the mania period it seemed that capital would be forthcoming and so presumably the lairds

1. Stephenson Locomotive Society, The Highland Railway. 1957. p.11.

2. H.R.J., 6 November, 1859.

3. S.C. Railway Companies Amalgamations, 1872 XIII, p.823.

4. Railway News, I August, 1874 .

5. The evidence cited in chapter eleven, section ten suggests that railways had a favourable effect on land values in the northern counties.

6. J. MacDonald, 'On the Agriculture of the County of Sutherland,' Tr.H.S. 1880. 
were content to let investment take its course. When these plans failed to flower a delay was inevitable, for no one was going to promote Highland railways in the tightening financial conditions of the late 1840s, not even the lairds for many of them were becoming near bankrupt in giving poor relief during a widespread Highland famine. The mounting capital costs of the railways constructed in the post mania period were scarcely conducive to rallway enterprise, especially in the north where it was not apparent what railways could do for Highland economy, lacking industrial and passenger traffic as it did. A dilatory policy was therefore adopted, producing piecemeal construction which eventually stretched up both Highland coasts, but took over half a century to do so. 


\section{CHAPIER THREE}

\section{CAPITAL EXPENDITURE (1)}

$"$ "... if when made it (a railway) fails to render public service by carrying traffic, the money is as absolutely wasted as though it had been spent on prospecting for gold where no gold existed."

$$
\text { W.M. Acworth, The Elements of Railway Economics. }
$$

"No doubt it is possible to expend capital unproductively even in railroads; but we may venture to assert that no line can be laid down in this country, even across the most barren moor, without conferring benefit of some kind upon the district."

$$
\text { Scottish Railway Gazette, } 12 \text { April, } 1845 .
$$

\section{1.}

In estimating the capital expenditure of the scottish railways it is more useful to look at the original company accounts rather than those printed in the contemporary railway journals, for the simple reason that the potential pitfalls inherent in the use of the original documents are substantial enough without adding to them by resorting to second hand information. (2) Well into the nineteenth century accountancy was an unformalised science both in doctrine and technique, and the railways' accountants were no

1. I am indebted to Dr. B.R. Mitchell for supplying me with a draft concerning the methodology he employed in computing estimates of the capital formation of British railways. For his estimates see 'The Coming of the Railway and United Kingdom Econonic Growth,' Journal of Economic History, vol.XXIV, no.3, 1964 .

2. A fairly complete (at least after 1840) collection of accounts is retained in the Historical Archives of the British Rail Board, Edinburgh. 
exception to the general rule. (1) Although the keeping of accounts was obligatory, personal judgement of ten decided the format of the accounts with the result that there was little uniformity between one company and another, or even over time within the same company. There is evidence of the companies seeking the best method of presentation, but they were doing so as individuals without attempting to secure universal standardisation. As late as 1867 a Royal Commission could state that "each company is at liberty to adopt the form it considers most convenient, and to vary that form from time to time." (2) Following this report accounts became standardised by Act of Parliament and their interpretation is much easier. (3). Accountants' experiments are not the sole bete-noirs of the user of railway company statistics. Fraud occasionally reared its head. The prime example of this in scotland being on the

1. S. Pollard, 'Capital Accounting in the Industrial Revolution,' Yorkshire Bulletin of Economic and Social Research, vol.15, no.2, 1963 . H. Pollins, 'Aspects of Railway Accounting before 1868' in A.C. Littleton and B.S. Yamey, Studies in the History of Accounting. 1956. C.H. Newton, Railway Accounts. 1930.

2. R.C. Railways. 1867 XXXVIII, p.xxiii.

3. Before this date, however, it is essential to go through the original accounts and sort them out in the light of modern accounting technique. The necessity of doing this is perhaps illustrated by contemporary statements about the two leading Scottish companies. In 1850 the Times reckoned that the Caledonian's accounts were in "just such a tangle as one might dream of after supping on lobster salad and champagne" and later in the century a lesser chronicle clained, with the benefit of hindsight, that the "North British accounts are intelligible only back to 1866. Before that it was the deluge pure and simple;" (Times, 30 September, 1850; The Rialto, 30 March, 1889). 
North British where an inquiry subsequent to the discovery of fraud yielded the following example of company morality:

Wuestion: "Have the annual accounts as laid before the shareholders been systematically cooked, so as to mislead them as to the true position of the revenue and expenditure of the company, and simply to exhibit an ability to pay the particular dividend desired by Mr. Hodgson (the Chairman), regardless of the free revenue of the company being adequate for the purpose?"

Answer (from Mr. Lythgoe, the Company Accountant): "Yes, that has been the plan." (1)

The unhealthy financial position of the company was consequently hidden from the shareholders by "a careful and most ingenious fabrication of imaginary accounts." (2) However, reference to the auditors' reports in such instances of known fraud enables the accounts to be adjusted, although the extent of undetected malfeasance is open to conjecture. The element of personal discretion in the early accounts would undoubtedly hamper the annual auditors and presumably some deception would escape unnoticed.

The greatest advantage in using the original accounts is that the genuine items of capital expenditure can be distinguished. Well could the Times exclaim that "the besetting evil of Railway Finance has arisen from the confusion of two things - Capital and Revenue." (3) Examples of the abuse and misuse of these two accounts abound, and the situation is not helped by the traditional

1. Report of the Committee of Investigation to the Shareholders of the North British Railway, 14 November, 1866. pp.20-21.

2. Ibia., p.II. Another example of deception practised on the shareholders was on the Caledonian where a profit of less than $£ 4000$ was represented as nearly $\$ 32,000$ in the published accounts. (H.R.J., 24 January, 1852).

3. Times, 29 Notober, 1867. 
dichotomy between what the accountant terms capital expenditure and what the economist would accept as such. Thus in order to obtain a reliable estimate of railway capital formation both capital and revenue accounts have to be examined. Firstly, certain entries have to be deducted from the capital accounts. These include purchases of existing assets, expenditure placed in the account as a result of amalgamations, subscriptions to other companies for whorn separate accounts exist, interest paid on loans or calls subsequent to the opening of a line, capitalisation of arrears of interest or dividends on guaranteed stock together with all nominal additions to capital made on the conversion or consolidation of stocks, capitalisation of revenue account deficits and the repayment of loans. Secondly, the revenue accounts must be scoured for items of expenditure which economists would normally class as capital expenditure.

This includes replacement of rolling stock and, more

1. In estimating the extent of capital expenditure in the revenue accounts Dr. Mitchell opts for the data on repairs and renewals given in the Railway Returns (for track and buildings from 1854 and for carriages and wagons from 1860) in preference to the more time-consuming method of searching the actual accounts. However, his assumptions as to the proportions of these amounts that can be taken as representing capital expenditure leads to substantial error if used on the Scottish data. This is due, I believe, to a confusion between "net" and "gross" expenditure. The difficulties of digtinguishing the two in the capital account proper invalidates any generalisations from the official repairs and renewals statistics, and it is more realistic to concentrate on measuring gross expenditure than to attempt to assess what proportion of maintenance is "betterment."

George Graham of the Caledonian tried to convince his directors that "improvement" of the permanent way could be justified as capital expenditure, and the North British did, at one point, class "the improved value on rebuilt wagons" separately in the capital account, but such instances were rare. (Ms.6356,

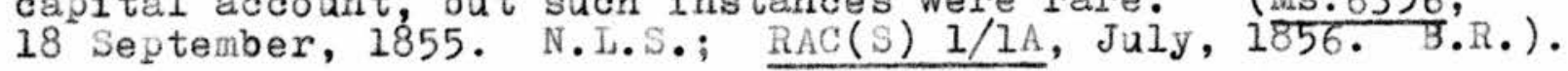


controversially, spending on repairs and renewals. The inclusion of the latter is justified by there being essentially no real difference between totally replacing a worn out asset at a specific point of time and gradually replacing it over a period of time.

Not all companies, however, possessed comprehensive records in their early days and others appear to have died intestate. Much of the relatively small deficiency in information after 1845 can be made up from the summarised accounts published in the railway journals. These do not allow all the incorrect entries to be sorted out, but it is possible to exclude two major sources of potential trouble, namely subscriptions to other companies and the purchase of existing assets. However, this still leaves several blanks in our knowledge of pre-mania capital formation. Fortunately a parliamentary return exists giving the amounts of money spent by individual railway companies in each triennial period ending the 1 January, 1841, 1844 and 1847. (1) A few companies misinterpreted the instructions and gave all expenditure before 1841, but this can be allowed for by reference to the existing accounts and the appendices to the Report of the Select Committee on Railway Acts Enactments. (2) Figures for capital expenditure in the periods $1838 / 40,1841 / 43$ and $1844 / 46$ can therefore be obtained. A total for the period 1831/37 was also derived from these sources together with the appendix to the Select Committee on Railways of 1839. (3).

1. Parliamentary Papers. 1847 LXIII.

2. Perliamentary Papers. 1846 XIV.

3. Parliamentary Papers. $1839 \mathrm{x}$. 
The problem then arises of how to produce annual estimates of capital formation from these statistics relating to periods of years. The known expenditure could be distributed in proportion to the capital authorised each year on the grounds that the money authorised would eventually be raised and spent, and that usually this would take place in the years immediately following the authorisation. Allowance has to be made for abortive projects, but a more important problem is that of what lags to adopt between authorisation and spending. Huch depends on whether a new company was being set up or whether the authorisation was for an established company determined on expansion. Mitchell suggests that the pattern of expenditure in the first case would be

$$
\begin{aligned}
& 10-15 \% \text { in the year of authorisation } \\
& 25-30 \% \text { in the second year } \\
& 30-35 \% \text { in the third year } \\
& 25-30 \% \text { in the fourth year }
\end{aligned}
$$

whereas additions to the authorised capital of existing companies would be spent much quicker, perhaps 10-20\% in the year of authorisation and most of the remainder the following year. Matthews adas weight to this argument by maintaining that the established companies did not usually issue new securities unless they needed the money at that time. (1)

Little evidence exists to confirm or invalidate the application of Mitchell's assumptions to Scotland. Table 3.1 summarises the

1. R.C.0. Matthews, A Study in Trade Cycle History. 1954. p.121. It should be noted that in the mid 1850 s the GIasgow and South Western stated, in reference to their authorised capital, that they did not "anticipate requiring all this money for many years." (H.R.J., 9 June, 1855). However, this policy is outwith the period under discussion here. 
data taken from the surviving accounts of companies authorised prior to 1840 and would suggest that the employment of his figures would not lead to substantial error, especially when it is born in mind that over $70 \%$ of the capital expenditure before 1843 , and nearly $80 \%$ before 1846, is directly traceable anyhow. Most of the companies for which accounts are not available were relatively small and thus may have had a different pattern of expenditure from the two inter-urban lines cited in the table. However, the significant lag between their sanctioning and opening might suggest that their spending was more akin to Mitchell's model than to the actuality of the Edinburgh and Glasgow and the Glasgow, Paisley, Kilmarnock and Ayr.

TABLE 3.1

SPENDING OF AUTHORISED CAPITAL

Company $\quad$ Year of Act $\frac{\text { 2nd }}{\text { year }} \quad \underline{\text { year }} \quad \underline{\text { yeth }}$

Glasgow, Paisley, Kilmarnock $12 \% \quad 36 \% \quad 36 \% \quad 16 \%$ and Ayr

$\begin{array}{lllll}\text { Edinburgh and Glasgow } & 12 \% & 28 \% & 40 \% & 20 \%\end{array}$

Source: $\operatorname{RAC}(S) 1 / 9 ; 1 / 35 . \quad B . R$.

From 1843 the Railway Returns of the Board of Trade give statistics of paid up capital which can be used in conjunction with the surviving accounts to complete the estimate of capital expenditure. This was done by assuming that the companies for which accounts exist were representative, and then working on the basis that the ratio of their capital expenditure to their paid 
up capital would hold for Scottish railways as a whole. (1) In all yearg the known capital expenditure group accounted for well over $90 \%$ of the total paid up capital which makes the degree of error emanating from these assumptions small. Total paid up capital and expenditure were taken in preference to marginal figures (i.e. annual increases) because of the lesser danger of error due to lags. Finally it should be noted that, although paid up capital figures are available from 1843, the method outlined immediately above was not employed until 1847, preference being given to the earlier mode of computation because of the total expenditure for the sub-period $1844 / 45$ being known.

The estimates of Scottish railway capital expenditure derived from these sets of calculations are shown in Tables 3.2 (a) and 3.2(b). They include the cost of land, railway investment outside Scotland and parliamentary costs and legal expenses incurred in obtaining sanction to construct. The significance of these items will be discussed later in the chapter. Estimate (1) gives the expenditure in current prices, as does estimate (2) which includes repairs and renewals, but estimate (3) is an attempt to assess the expenditure in real terms by deflating estimate (2) by Miaiwald's index of building costs. (2) This is far from satisfactory as the index refers to the United Kingdom as a whole

1. Double cointing in the form of subscriptions to other companies and nominal additions to paid up capital must, of course, be eliminated from the paid up capital statistics of both the sample and the total before any proportionality is established.

2. K. Maiwald, 'An Index of Building Costs in the United Kingdom, 1845-1938,' Economic History Review, second series, vol.VII, no.2, 1954, p.193. 
and is more related to construction in the building sense, but it does include "basic materials" and wages, both of which were of high importance in railway expenditure, and, in the absence of anything more suitable, it has to be used. Ideally separate price deflators should be used for each aspect of railway capital expenditure, but these simply are unobtainable. It is possible to construct one for rolling stock, but, in addition to the faults inherent in its construction, there are numerous obstacles to its

$$
\text { TABLE } 3.2(\mathrm{a})
$$

SCOTTISH RAILWAY CAPITAL EXPENDITURE 1831-1846. (Emillion)

Year $\frac{\text { Expenditure of }}{\text { Sample }} \frac{\text { Expenditure of }}{\text { Estimated Total Expenditure }}$

1831

1832

1833

1834

1835

1836

1837

1838

1839

1840

1841

1842

1843

1844

1845

1846

Source: see text.

0.04
0.07

0.03

0.02

$(0.48)$

0.01

0.05

0.15

0.20

0.39

$(0.51)$

0.88

1.07

$(0.26)$

0.99

0.60

0.30

0.61

0.32

$0.46 \quad 0.48$

$\begin{array}{lll}1.48 & 1.52 & 1.75\end{array}$

$3.85 \quad 3.90$ 
TABLE $3.2(b)$

SCOTIISH RAILWAY CAPITAL EXPENDITURE 1847-1900 (Emiliion)

Year $\frac{\text { Expenditure of }}{\text { (cumulative) }} \frac{\% \text { total paid up }}{\frac{\text { sapital covered }}{\text { oy sample }}}$

$\begin{array}{ll}1847 & 16.97 \\ 1848 & 20.72 \\ 1849 & 23.67 \\ 1850 & 25.12 \\ 1851 & 26.59 \\ 1852 & 27.13 \\ 1853 & 27.80 \\ 1854 & 28.78 \\ 1855 & 29.76\end{array}$

$1856 \quad 30.66$

$1857 \quad 31.63$

$1858 \quad 32.56$

$1859 \quad 33.68$

$1860 \quad 35.10$

$1861 \quad 36.69$

$1862 \quad 38.29$

186340.42

$1864 \quad 42.64$

$1865 \quad 44.90$

$1866 \quad 47.72$

$1867 \quad 49.49$

$1868 \quad 50.85$

$1869 \quad 52.31$

$1870 \quad 53.62$

$1871 \quad 54.99$

$1872 \quad 56.50$

$1873 \quad 58.79$

$1874 \quad 61.61$

$1875 \quad 63.85$

$1876 \quad 66.34$

$1877 \quad 68.87$

$1878 \quad 70.99$

$1879 \quad 72.51$

$1880 \quad 74.42$

98.25

97.82

97.80

97.09

96.97

96.76

96.48

96.35

95.85

94.95

94.18

94.21

94.12

93.58

93.54

93.68

94.03

94.06

94.25

94.55

94.79

94.99

95.15

95.25

95.38

95.57

95.71

95.85

95.91

96.04

96.04

96.15

96.14

96.22
Estimated Total Expenditure

(1)

(2)

(3) (ii)

$\begin{array}{lll}6.40 & 6.46 & 7.10 \\ 3.81 & 3.88 & 4.43 \\ 3.03 & 3.16 & 3.91 \\ 1.66 & 1.80 & 2.36\end{array}$

$\begin{array}{lll}1.54 & 1.71 & 2.29\end{array}$

$\begin{array}{lll}0.52 & 0.73 & 0.71\end{array}$

$\begin{array}{lll}0.77 & 1.02 & 1.17\end{array}$

$\begin{array}{lll}1.06 \quad 1.35 & 1.56\end{array}$

$\begin{array}{lll}1.29 & 1.61 & 1.92\end{array}$

$1.14 \quad 1.46 \quad 1.79$

$\begin{array}{lll}1.29 & 1.61 & 1.97\end{array}$

$0.98 \quad 1.32 \quad 1.68$

$\begin{array}{lll}1.18 & 1.53 & 1.94\end{array}$

$\begin{array}{lll}1.77 & 2.13 & 2.67\end{array}$

$\begin{array}{lll}1.72 & 2.18 & 2.78\end{array}$

$\begin{array}{lll}1.65 & 2.18 & 2.82\end{array}$

$2.12 \quad 2.62 \quad 3.31$

$\begin{array}{lll}2.35 & 2.84 & 3.46\end{array}$

$\begin{array}{lll}2.31 & 2.79 & 3.44\end{array}$

$\begin{array}{lll}2.83 & 3.47 & 4.17\end{array}$

$1.74 \quad 2.52 \quad 3.11$

$\begin{array}{lll}1.32 & 2.16 \quad 2.66\end{array}$

$\begin{array}{lll}1.45 & 2.36 & 2.85\end{array}$

$\begin{array}{lll}1.38 & 2.36 & 2.80\end{array}$

$\begin{array}{lll}1.31 & 2.40 \quad 2.80\end{array}$

$\begin{array}{lll}1.46 & 2.61 & 2.73\end{array}$

$\begin{array}{lll}2.31 & 3.57 & 3.32\end{array}$

$2.84 \quad 4.19 \quad 4.05$

$2.30 \quad 3.68 \quad 3.95$

$\begin{array}{lll}2.51 & 3.89 & 4.28\end{array}$

$2.63 \quad 4.01 \quad 4.48$

$2.12 \quad 3.48 \quad 4.03$

$\begin{array}{lll}1.59 & 2.95 & 3.57\end{array}$

$\begin{array}{lll}1.93 & 3.27 & 3.70\end{array}$ 
TABLE $3.2(b)$ (cont.)

Year $\frac{\text { Expenditure of }}{\text { (cumplative) }} \frac{\% \text { total pald up }}{\frac{\text { capital covered }}{\text { by sample }}}$

$\begin{array}{ll}1881 & 75.72 \\ 1882 & 76.75 \\ 1883 & 78.36 \\ 1884 & 80.46 \\ 1885 & 82.48\end{array}$

95.16
96.00
96.04
95.80
95.50

$1886 \quad 84.42$

$1887 \quad 86.15$

$1888 \quad 88.21$

188999.64

1890

92.95

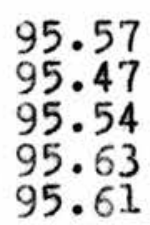

1891

1892

95.39

1893

98.11

1894

100.77

1895

103.14

105.63

1896

108.30

1897

110.36

1898

113.15

1899

116.11

$1900 \quad 118.94$

95.67

95.66

95.10

94.81

94.71

94.78

94.80

94.83

94.70

94.70
Estimated Total Expenditure

(1)

(2)

(3) (ii)

$1.40 \quad 2.77 \quad 3.26$

$\begin{array}{lll}1.21 & 2.59 & 2.99\end{array}$

$\begin{array}{lll}1.64 & 3.08 \quad 3.63\end{array}$

$\begin{array}{lll}2.40 & 3.75 \quad 4.56\end{array}$

$2.38 \quad 3.74 \quad 4.62$

$\begin{array}{lll}1.96 & 3.32 & 4.23 \\ 1.91 & 3.26 & 4.18\end{array}$

$2.08 \quad 3.46 \quad 4.42$

$2.45,3.86 \quad 4.67$

2.56 (i) $3.99 \quad 4.60$

$\begin{array}{lll}2.49 & 3.95 & 4.72\end{array}$

$2.85 \quad 4.34 \quad 5.23$

$\begin{array}{lll}3.40 & 4.91 & 6.05\end{array}$

$2.83 \quad 4.37 \quad 5.42$

$2.74 \quad 4.30 \quad 5.39$

$2.64 \quad 4.25 \quad 5.21$

$2.15 \quad 3.82 \quad 4.60$

$2.90 \quad 4.64 \quad 5.32$

$3.30 \quad 5.10 \quad 5.53$

Source: see text.

Notes: (i) The estimate for 1890 may have an upward bias and those for the $1880 \mathrm{~s}$ a downward one because of the difficulties in this period of determining when nominal. additions to capital took place.

(ii) Maiwald's index was re-structured to express estimates in 1900 prices. 
application to the estimates e.g., not knowing the proportions of capital expenditure that went on rolling stock for each company, and, in the early accounts, not being able to distinguish spending on locomotives from that on carriages and wagons. (1)

It must be emphasised that all the estimates relate to the periods when expenditure was recorded in the company accounts and these may not correspond to the periods when the work was actually undertaken. On the North British two contractors were not paid until 1853 although their work was finished several years before, but this may have been an isolated example due to arguments about, and adjustments of, their accounts. (2) Mitchell reckons the lag to be of importance only in the immediate post mania period of the late 1840s. By the use of construction wage data and estimates of the cost of iron, he suggests that figures will be exaggerated in the years 1848 - 1851 inclusive and correspondingly understated in 1845 and 1846 . The respective degrees of error he estimates at $+6 \%,+16 \%,+16 \%,+10 \%,-16 \%$ and $-23 \%$. The amplitude of the cycle will of course be affected by this, but it is difficult to determine how to apply Mitchell's findings to Scotland, since little data exist on the costs of construction in Scotland. It has been estimated that Irish wage costs were less than half those on English railway construction, but no-one seems to know to which pole the Scottish costs orientated. (3) Mitchell's argument is in any case based on the assumption that the cost of

1. See chapter four, p.

2. NBR 1/2, 18 March, 1853. B.R.

3. J. Lee, The Construction Costs of Irish Railways 1830-53," Business History, vol.IX, no.2, 1967, p.103. 
men and materials would not exhibit marked variations in their share of total construction costs. This may be true, but the response of landlords, labourers and entrepreneurs to price stimuli are implicitly assumed as being equal, which is highly debatable. In the absence of sufficient Scottish data on these points, the estimates are left unadjusted and must therefore be used carefully, bearing this potential source of error in mind. Heving derived estimates of Scottish railway capital expenditure what can be said about them? One point is that spending on repairs and renewals, despite a slight fall in the early 1860s and a period of relative stagnation from 1875 to 1877 , generally exhibited an upward trend as the erowing stock of lines and equipment demanded more and more maintenance (in absolute terms rather than per unit, though the adoption of heavier equipment and permanent way would probably increase unit costs as well). The effect of this, as can be seen from the rising secular trend to the troughs in figure 3.1, was to set a floor to the cycles in railway ceipital expenditure produced by new construction.

It must be stressed that the estimates give only some indication of the order of magnitude of capital spending and no claims are made as to the strict accuracy of the figures in the absolute sense. Host confidence can be placed in the undeflated estimates (because of the scope of Naiwald's index) and the discussion will therefore centre around this computation. Figure 3.1 does suggest that the use of Maiwald's index has more effect on the amplitude of the cycles than on their periodicity, though, of course, a more comprehensive and relevant price index might have 
Figure 3.1

SCOTTISH RAILWAY CAPITAL EXPENDITURE

A oomparison of real and monetary measures

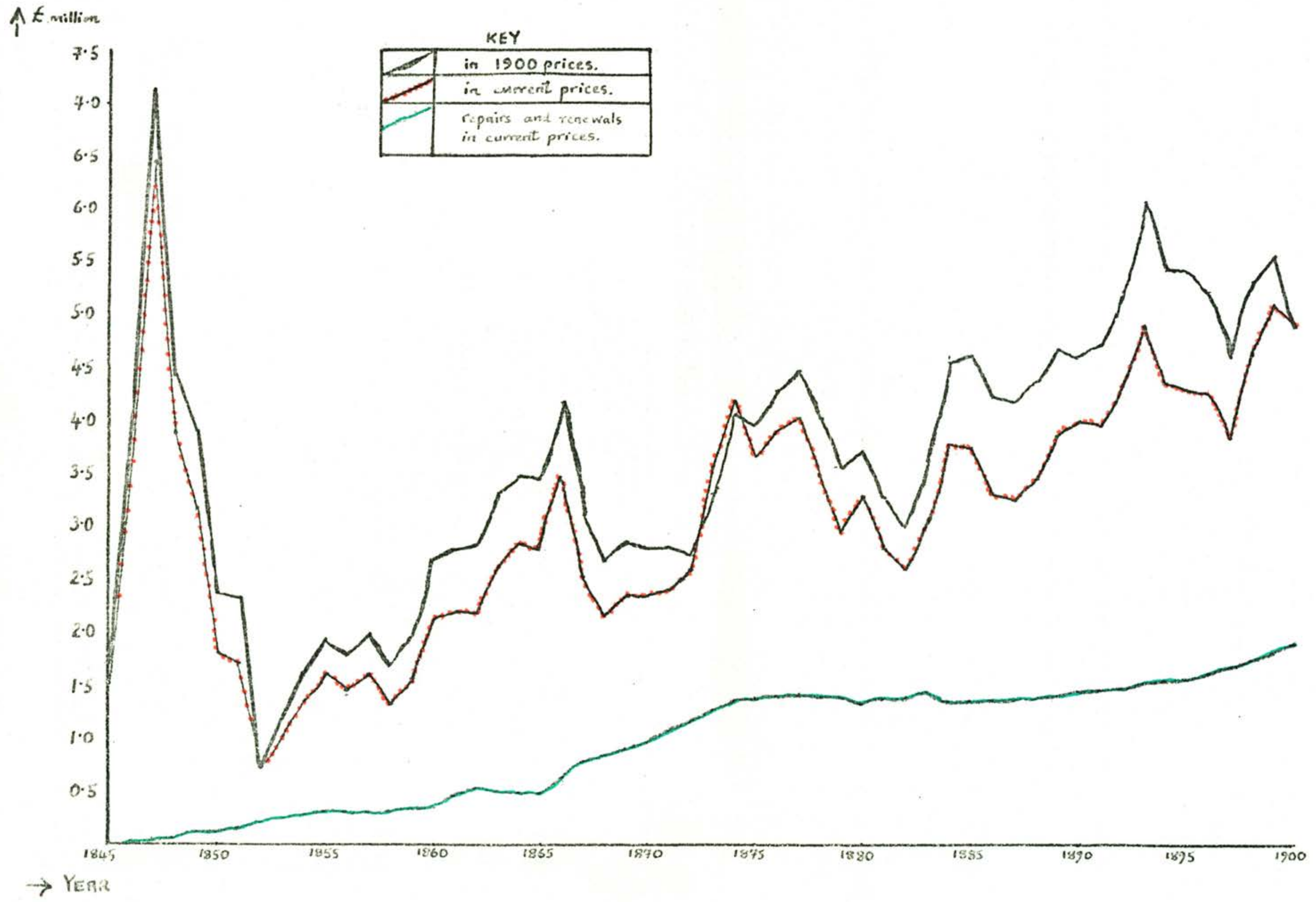


yielded a different result. The relationship between the series of deflated and undeflated expenditure only changes substantially in the early $1870 \mathrm{~s}$ and the greater part of this is perhaps explicable in terms of the coming of the steel rail. (1)

Figure 3.1 also makes it clear that there were such things as capital expenditure cycles. That an individual company should have a cycle is understandable in the light of the time lag between proposing to construct and actually bringing a line into operation, but why this should produce cycles in the aggregate is less obvious unless some nationwide force was influencing the investment decisions of all, or the majority, of companies. (2) That there was some such force is suggested by the evidence in Table 3.3, which shows that the timing of peaks and troughs in Scotland coincided fairly well with those of the United Kingdom as a whole, especially when the turning points are considered as indicating years around which changes occurred rather marking definite and decisive breaks. Slight variations in periodicity can be explained as the products of the employment of different models and perhaps also as the result of comparing an aggregate with a component of that aggregate. That there were also specific factors affecting railway development in Scotland is brought out in the early 1890s when the peak of outlay in Scotland coincides with a trough of expenditure for Britain as a whole.

1. See chapter five, $p p .291-293$.

2. Or, of course, unless one or two decisions at any point of time were important enough to significantly influence the pattern of total spending. 
TABLE 3.3

GROSS RAILWAY CAPITAL EXPENDITURE CYCLES 1830-1900

\begin{tabular}{|c|c|c|c|c|c|c|c|}
\hline \multicolumn{2}{|c|}{ Scotland } & \multicolumn{2}{|c|}{ U.K. } & \multicolumn{2}{|c|}{ U.K. } & \multicolumn{2}{|c|}{ U.K. } \\
\hline Peak & Trough & Peak & Trough & Peak & Trough & Peak & Trough \\
\hline 1840 & 1843 & 1839 & 1843 & 1840 & 1843 & & \\
\hline 1847 & $\begin{array}{l}18530 \mathrm{r}(\mathrm{a}) \\
1856\end{array}$ & 1847 & $\begin{array}{l}18520 r(b) \\
1856\end{array}$ & 1847 & $\begin{array}{l}18520 r(c) \\
1856\end{array}$ & & \\
\hline 1866 & 1868 & 1865 & 1869 & 1866 & 1869 & & \\
\hline 1874 & 1882 & 1874 & 1880 & $1875 ?$ & & 1875 & 1879 \\
\hline 1885 & 1887 & 1884 & 1888 & & & 1883 & 1887 \\
\hline 1893 & 1897 & 1891 & 1893 & & & 1891 & 1894 \\
\hline 1899 & & 1900 & & & & 1900 & \\
\hline
\end{tabular}

Source: (1) Table 3.2 .

(2) B.R. Mitchell, The Coming of the Railway and United Kingdom Economic Growth,' Journal of Economic History, vol.XXIV, no.3, 1964.

(3) A.G. Kenwood, 'Railway Investment in Britain 1825-75,' Economica, vol.XXXII, no.127, 1965.

(4) A.K. Cairncross, Home and Foreign Investment. 1953. p. 137 .

Notes: (a) The figures for Scotland show a dip in 1856 but not to the low level of 1853 .

(b) Mitchell's figures show a dip in 1852 but find their lowest point in 1856 .

(c) Although $1852^{\circ}$ is his low point Kenwood opts for 1856 as the trough.

(d) Series ends on an upward trend. 
This is partially explicable in terms of the construction of expensive underground railways in Glasgow. (1)

\section{2 .}

What was the motivation behind all this capital outlay? Presumably most, if not all, of the lines constructed had some economic or social justification or else they would not have been sanctioned, but were there more general feotors operating on either the demend or supply side which determined, or at least influenced, the timing and extent of the investment decision?

Throughout the chapter charting the development of the scottish railway system emphasis was laid on the availability of capital as the determining factor in the construction of a railway. However, the role of the cost of capital must also be examined, partly because it is allied to the question of availability, but mainly because it is often thought that the rate of interest has an influence on the formation of capital assets with long lives and gestation periods, as is the case with railways.

Two indicators of the cost of money were considered, the bank rate and the yield on consols. The former is probably the more sensitive indicator of financial stringency judging by the greater number of alterations in its level. In fact such was the volatility of these changes that they have to be smoothed in order to make the graph in Pigure 3.2 comprehensible. The bank rate

1. Mitchell specifically excluded the London underground railways from his estimates on the grounds of them being atypical Fresumably their inclusion might alter the degree of correlation between Gcottish and British railway building cycles. 
probably has most influence on the cost of the shortterm loans, but the jield on consols most likely exerted its conditioning influence on the rate that the railway companies would have to promise to those purchasing preference shares and guaranteed stock. The influence of this return on government stock would parhaps increase over time as the railways helped develop a national financial market, and as they themselves resorted more and more to offering pre-determined rates of return in order to attract investors.

Changes in these two indicators of the cost of capital were graphed against annual levels of capital authorisation and capital spending as can be seen in figure 3.2. For consols the average annual yield was taken which raises no problems, but where the bank rate is concerned, the changes, despite being smoothed, are much more discrete than the series for authorisations and expanditure, and care must be taken if any correllations are to be suggested. The estimates of capital expenditure taken were those in current prices on the grounds that the yield on consols and the bank rate would, to some extent, reflect the current value of money. As can be seen from Figure 3.2 the annual increases in the capital authorised exhibit wider fluctuations than does the graph of capital spent. This is primarily because the timeconsuming nature of railway construction renders the series for expenditure a distributed lag of the series for authorisation, or at least part of it.

The relationship between the decision to invest and the cost of money would be better seen if a series were constructed for 
Figure 3.2

CAPITAL EXPENDITURE AND THE COST OF CAPITAL

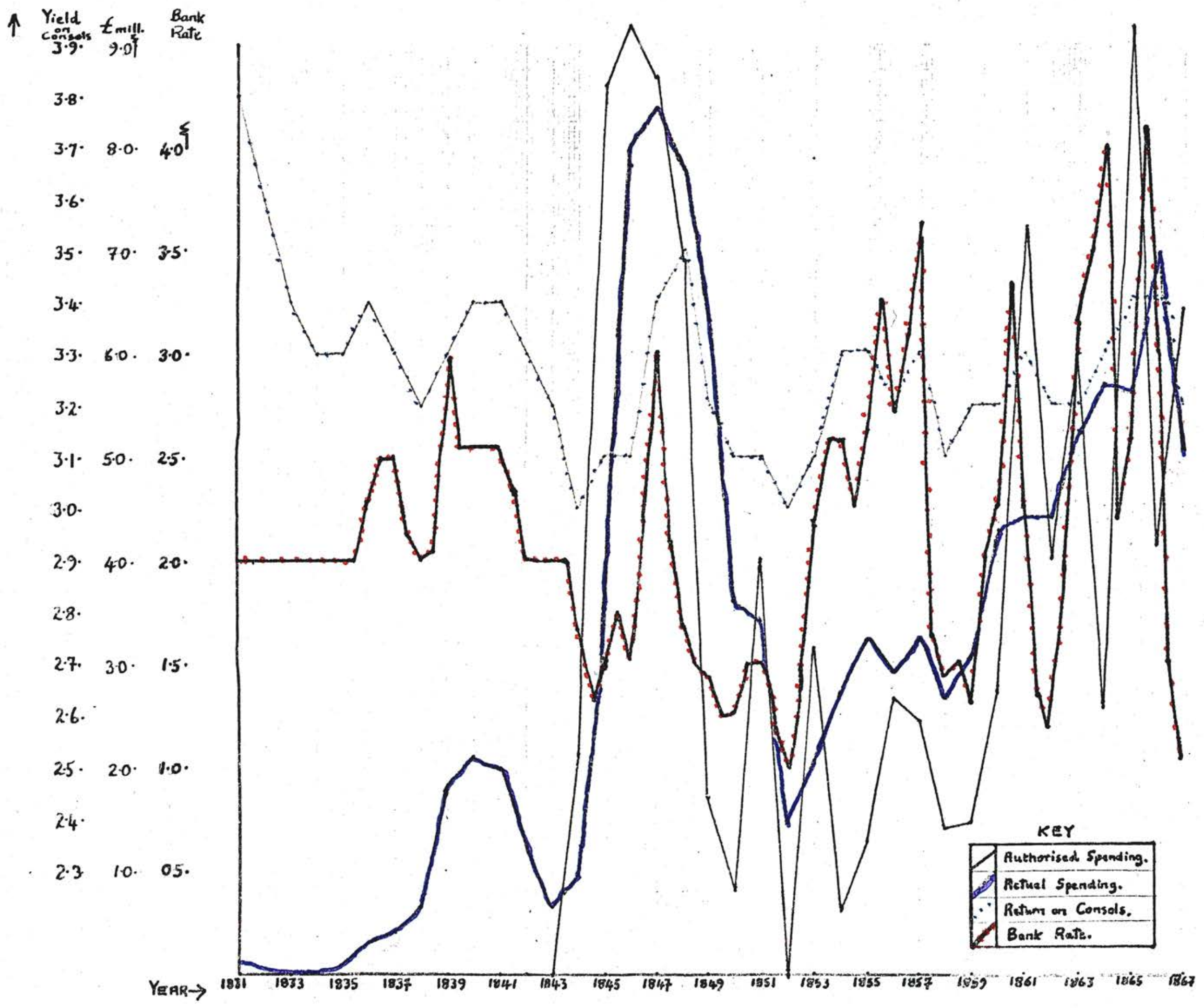


Figure 3.2 (cont.)

CAPITAL EXPENDITURE AND THE COST OF CAPITAL

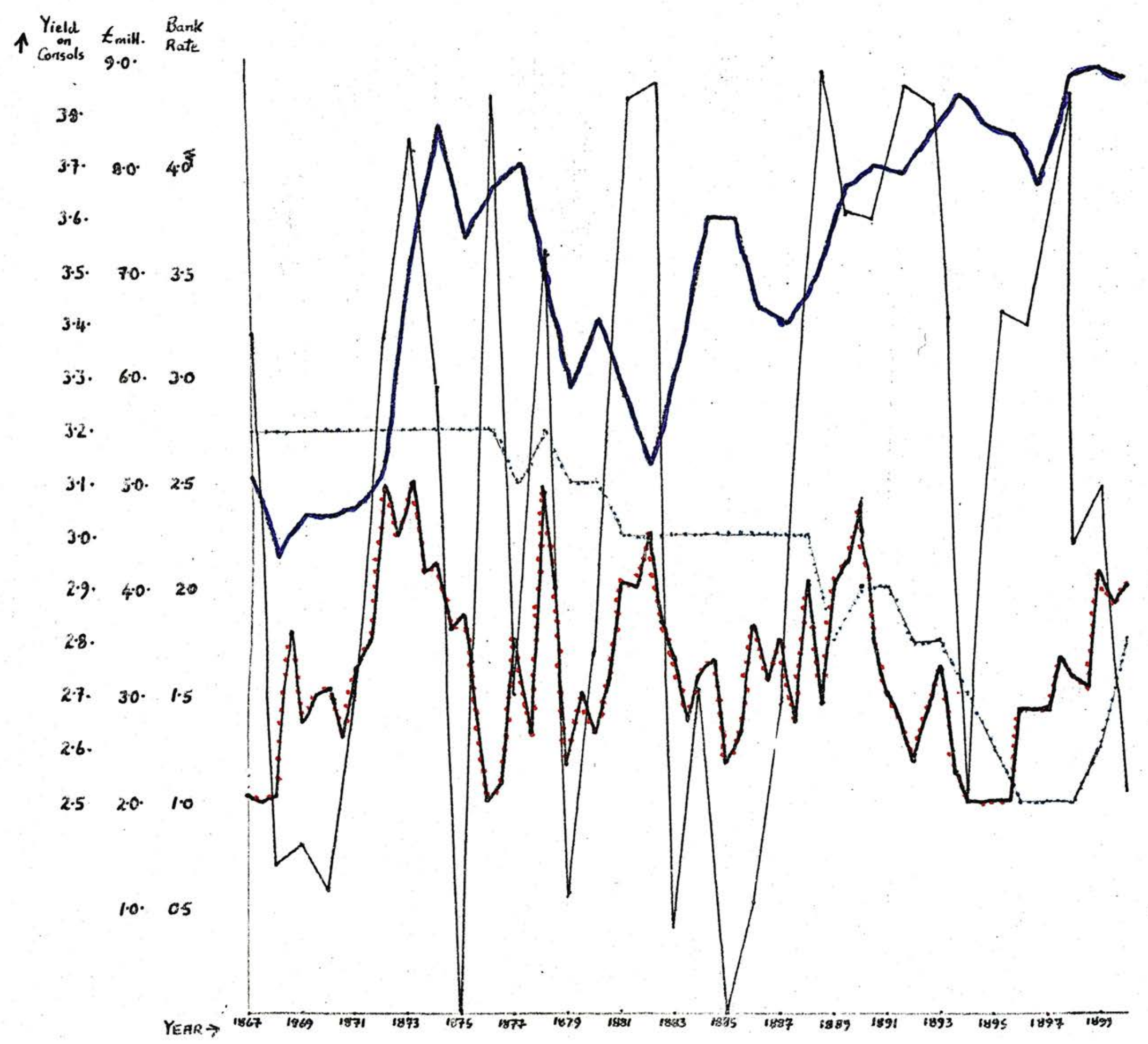


applications to parliament rather than using the final authorisations, but the statistics of the latter are much more easy to come by. The authorisations series should in fact be a dampened version of an applications one, especially in years of competing and unrealistic schemes. In any case there is little reason to believe that the periodicity of the two series would markedly differ. Did the cost of money play any part in determining the investment decision? It is clear from figure 3.2 that, where allowance is made for the time lag between first promotion and parliamentary authorisation, periods of relatively low bank rate correllated reasonably well with upsurges in the volume of capital suthorised to be spent in the early 1840s, perhaps in the very early 1850s, in the very early 1860s, in the mid 1860s, perhaps in the very early 1870s, in the mid 1870s, in the late 1870s, in the mid 1880s and in the mid 1890s. However, a closer study of the early 1840s could suggest that the low bank rates were of as much relevance as indicators of the availability of money rather than of its cost. Witing in February, 1844 a supporter of the Scottish Central reckoned that the time was ripe for starting the line ".. in consequence of ... the present very favourable state of the money market." (1) Later in the year the Morning Chronicle commented that "capital clamours for profitable investment, confidence has become eager, and may shortly become blind; railroads present the first tangible form of investment." (2) Yet another comment

1. Abercairney Papers. G.D.24, section 924, no.3, 24 February,

2. Morning Chronicle, 12 October, 1844 . 
suggesting that capital was easily available came from the promoterg of the North British who thought early 1845 a "very fit time" for raising funds, as judging "from the great abundance of funds in the country," they believed they would "have little difficulty in procuring such sums as they may want, at a very reasonable rate of interest." (1) When dividends in the order of $10 \%$ and more were confidently expected the cost of capital was probably not a limiting factor. The mania was most likely the product of easy rather than cheap money. However, low interest rates may have had more influence in later periods when widespread past failures dampened expectations as to the probable level of financial returns. Yet cheap money, as reflected in the bank rate, did not guarantee an upsurge in authorisations. It can be seen in Figure 3.2 that there was little response to relatively low bank rates in the early 1850 s and early 1890s though it is fair to say that in general low rates did stimulate an upward movement in the volume of capital sanctioned to be spent by the railways.

Whatever the effect of cheap money in initiating investment, once the decision to invest began to be implemented it was difficult to halt even if financial conditions tightened. Admittedly in the post mania period the postponement and abandonment of schemes was not infrequent, but few of these projects had begun to be constructed. Companies like the Aberdeen which were obliged to suspend a portion of their works "in consequence of the intense pressure in the money market" were in the minority. (2) 
In many, if not most, cases where construction was underway it would be deemed imperative to get funds at all costs in order to render the previous spending productive as soon as possible. The North British, for one, issued preference shares in the post mania period on the grounds that "it was absolutely necessary to complete the works which had been so far advanced." (1)

That spending did not completely cease in periods of dear money is therefore attributable to the desire of the companies to get partly constructed lines into operation. Perhaps there was a threshold value to the rate of interest beyond which the companies would not go, but generally it would seem that once building had started then work would proceed regardless of the cost of money. In fact it could be argued that once the investment decision had been taken, the cost of money would have little relevance to a project since the capital had already been promised. Only if calls fell into arrears or borrowing powers had to be re-exercised would the cost of money enter into the calculations of the directors. Why then did any scheme fail to materialise? The answer would appear to be linked with the availability of capital. In the mania of the 1840 s many shareholders substantially overcommitted themselves, producing a situation where the short term demand of the railway companies for capital vastly exceeded the supply of loanable funds. Inevitably the more marginal projects would be abandoned. A similar situation arose in the mid 1860s when the proposals for the Fochabers and Germaills and the Dingwall and Skye lines, potentially not the most profitable 
of railways, had to be put aside. However, at this time the North British also ran into trouble, having to partially suspend its works as it had engeged "in expenditure before ways and means were provided by the previous issue of shares and bonds." (1)

Dear money did, however, influence railway capital expenditure in the sense of choking off applications for new investment. It can be seen in Figure 3.2 that this occurred in the imrediate post-mania period, in the mid 1850s, the early 1860s, the mid 1860s, the early 1870s, the late 1870s and the early 1880s. (It should be noted that dear money is taken as relative to the period previously rather then in absolute terms).

As regards the availability of capital from normal channels, the major determinant is probably the rate of return expected on the capital invested or loaned. The ability of the directors to "sell" a project might well have determined whether or not the necessary capital was forthcoming. Schumpeter saw successful entrepreneurial performance as having two main roles. Firstly, as possessing the ability to perceive new opportunities that cannot be proved at the moment at which action has to be taken, and, secondly, in having the willpower to break down the resistance which the social environment offers to change. (2) Measured by his criteria the Scottish railway promoters were scarcely dynamic. Undoubtedly the proprietors of the early

1. H.R.J., 10 November, 1866; 1 December, 1866 . Economist, 9 March, 1867.

2. WA. Schumpeter, 'The Creative Response in Economic History,' Journal of Economic History, vol.VII, no.2, November, 1947. 
lines played an important part as innovators, but little opposition had to be overcome as they were looking after their own interests in developing the mineral fields. As for the later, more large-scale, development, it is best described as imitation rather than innovation.

The success of lines in England was used to break down the barriers of financial resistance in Scotland, by it being pointed out that railways of a similar nature (or even railways at all) were making profits elsewhere, so why not north of the border. It is significant that no major lines were constructed in Scotland until the lines in Fingland and the minor railways in Scotland had demonstrated their financial practicability. With few funds available for social overhead the Scots were determined not to waste them. The promoters of the Edinburgh, Leith and Glasgow in 1831 pushed "the brilliant success which has attended the Liverpool and Lanchester Railway, infinitely exceeding the expectations even of the most sanguine, has proved, beyond doubt, not only the utility of that undertaking in a national point of view, but has shown the immense advantage which the towns in connection with it, have derived from the superiority of the conveyance which it has established between them." (1) However, as far as the potential Scottish investors were concerned one swallow did not make a summer, and not until the late 1830 s did the idea of a railway to link Edinburgh and Glasgow have tangible results. This time the prospectus could claim that "the success of many of the railroads

1. Prospectus, 28 December, 1831. Mitchell Library. 
which have been established in England and Scotland, and the gradual adoption of that description of inland communication in almost every populous district of the country, has of late recalled public attention to the importance of establishing a line of railway which shall afford the mans of more rapid travelling between Edinburgh and Glasgow and between the east and west coasts." (I) Since at this time scotland possessed less than 70 miles of railway, most comparisons would have to be drawn with England's experience. The favourable results of English lines were also used to whip up the mania enthusiasm e.g., proposals for an Aberdeen, Dundee and Perth railway were centred around "the success which has generally attended the formation of railways in Englend and the incalculable benefits thence resulting." (2)

By the time the larger schemes came to be considered in Scotland, railways had become accepted, and the only resistance to be overcome was that of recalcitrant landowners whose opposition frequently proved susceptible to financial persuasion. In many cases it was not a question of resistance to be overcome, but of towns actively wanting to be on the railway map. The inhabitants of Crieff and the surrounding district approached the directors of the Scottish Central in an attempt to obtain a line through Upper Strathearn, and the populace of Inverness insisted on having a direct route to the south instead of that through

1. $P X B(S) 1 / 7, P .14$. B.R. On this point of following the example set by the English see F. Wishaw, The Railways of Great Britain and Ireland. 1840. p.102, and J. Richardson, General Report on the Newcastle, Einburgh and Glasgow Railway. 1837.

2. Airlie Papers. G.D.16, Section 38/82, bundle 1, 19 March, 1844 . N.K. 
Aberdeen which was proposed by the Great North of Scotland. (1) Not all towns were similarly disposed. The inhabitants of Haddington objected to not being on the main line of the North British, although when questioned it turned out that they were against the idea of being on any railway, but if they were to have a line then they preferred the main line to a branch of it: (2) Presumably this was a matter of prestige, but most towns demanded railway communication because of a realisation that to keep in the van of economic progress links were needed with the outside world. Perhaps this is best summarised by Kilmarnock town council who appointed a committee to consider the question of constructing a railway to Glasgow "in order that the se manufacturing towns may keep pace with the rapid improvements of the age, and have similar advantages with places of far less importance in points of manufactures where railway communications are in progress or contemplation." (3)

After the railway mania construction the dividends of the railway companies, in England as well as in Scotland, clearly failed to match up to expectations. (Was this perhaps the reason why expenditure never again touched the heights of the immediate post mania spending?) No matter what benefits the railways brought to anyone else the railway shareholder did not see him self as essentially altruistic, and the railway companies accordingly found it difficult to raise money on ordinary stock.

1. Abercairney Papers. G.D.24, section 924, item 20, 3 July, 1844. S.R.0.

C.H. Ellis, The North British Railway. 1959. p.244.

2. NBR 1/3, p. 171-175. B.R.

3. Report, 16 June, 1836. Mitchell Library. 
Their answer to this was to issue preference and guaranteed shares. (1) As can be seen in Figure 3.2, government stock was low in the early 1850 s and this alternative channel for fixed interest investment was thus attractive. After this period better management (or, in the case of the North British, deliberate mismanagement) restored the fortunes of ordinary stock. In the later 1860s, however, they once again slumped and from this time onwards preference and guaranteed stock came to play a dominant role in the capital accounts of the rallway companies, and from the early 1870s this is perhaps reflected in the increasing inverse relationship between the yield on consols and the capital expenditure of the railway companies as can be seen in Figure 3.2.

To seek a monocausal solution to the question of the determinants of the investment decision is to ignore the work of countless economists. The state of the money market may well have been the major influence on the capital spending of the railway companies, especially since the companies did not plough back profits, but it was by no means the sole factor operating.

A proportion of capital expenditure was unavoidable if the railway was to continue its operations. The major part of this was that concerned with repairs and renewals and this expenditure is depicted in Figure 3.3. It would seem that Mitchell's estimates are not in accordance with those of Kenwood and dairncross and the following discussion will therefore not concern itself 
with his figures. (1) The estimates for both Scotland, and the United Kingdom do not show any marked indications of cyclical influence. This is probably because of the great differences in the longevity of the various capital assets. There are, however, several points that can be made on the trends exhibited. In the early 1860 s the series for scotland dips markedly and then shows a much more rapid upward movement than the United Kingdom graph. This might be explicable as repairs and renewals being put off as long as possible whilst new capital expenditure was on an upward climb, and then lost ground being made up. Yet it is not apparent that this would apply only to Scotland. The answer probably lies in the emergence of the big five companies in Scotland following a period of widespread amalgamation in the 1860s. The major companies would need as much money as they could spare to finance their takeovers and the objects of their attentions would not deem it worthwhile to replace equipment with a takeover in the offing. (2) The consequent catching up may have been exaggerated by the construction done on the "cheap principle" in the 1850 s requiring attention at a stage in advance of more normal railways. The periods of fairly rapid acceleration of the trend in the late 1860s - early 1870s and in the last decade of the century are probably due to the adoption of the relatively expensive steel rail and the first bout of renewals of that type of

1. Mitchell's figures probably differ because of the assumptions he makes about the proportions of the Railway Return statistics. See the footnote on p.118.

2. Some of the comments of the locomotive superintendents in the late 1860 s suggest that the rolling stock of the taken over companies had not been kept up to standard. 


\section{Figure 3.3}

\section{RERAIRS AND RENEWALS EXPENDITURE}

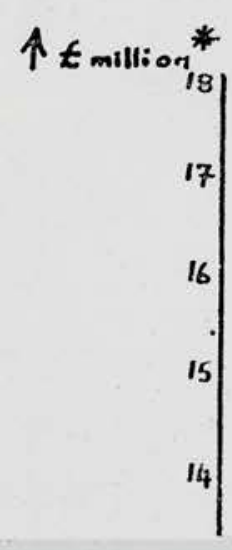

$\backslash$

I I ${ }_{3}^{8}$

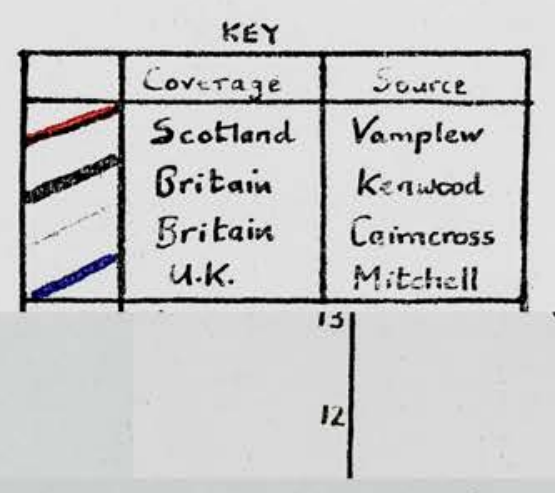

II

1

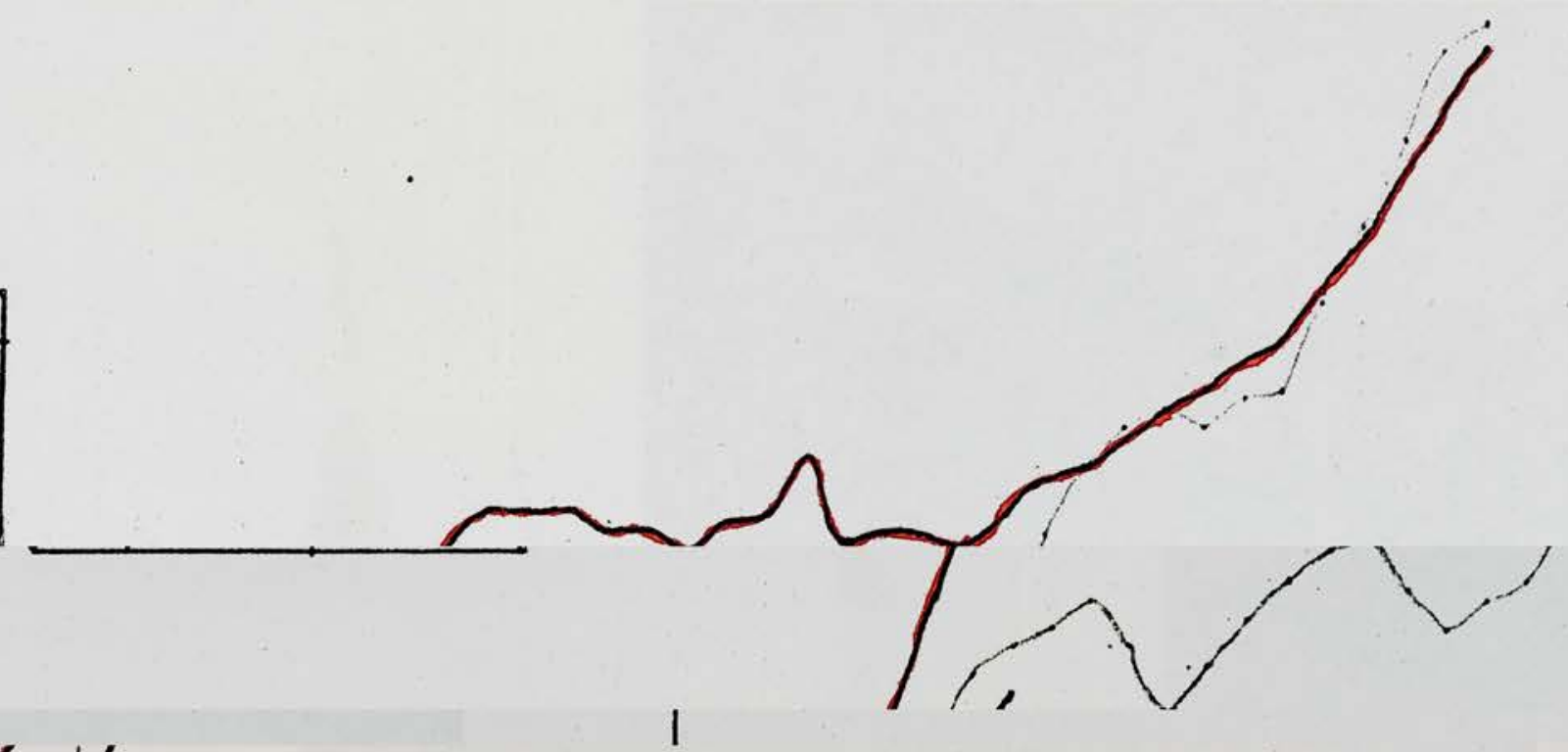

d

10

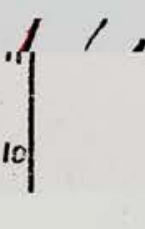

$+1$

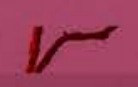

s

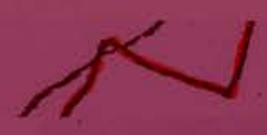

3)

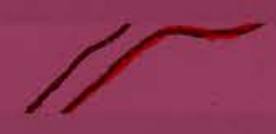

$\rightarrow Y_{E A R}{ }^{1845}$

1850

1855

1860

1865

1870

1875

1880 
rail. That the trends of repairs and renewals for Scotland and Britain exhibit different patterns in the early 1890 s may have something to do with the two areas also having different capital expenditure cycles in this period.

However, overall it can be suggested that repairs and renewals could not be left to the whim of the capital market as safety regulations would surely put a threshold on any discretionary powers as to how long they could be left. It is scarcely feasible that the companies would risk accidents (and the compensation involved) by long delaying them when due. It was admitted on the Caledonian that repairs might well have to be done "when perhaps the markets and other circumstances were not very

favourable." (1) Some spending was compulsory because of government regulations, e.8. the early 1890s witnessed the statutory completion of block telegraphs, interlocking points and signals, and continuous brakes on certain classes of rolling stock. (2) This would also accentuate the upward trend primarily due to the renewal of the steel rail. Renewals could of course be advanced but no evidence has come to light of this being general policy. Pressure on existing facilities also created quasi-compulsory expenditure. If the railway was not to come to a standstill then the bottlenecks had to be removed. Judging from the statements made to shareholders this was the prime reason for the reconstruction and enlarging of many of the major stations and also the

1. T.S.S.S., 1890/91. p.58.

2. H.R.J., 30 September, 1893. 
building of several new ones. (1)

A substantial proportion of Scottish railway capital investment can be explained by a nineteenth century economist's dictum that "the keynote to the Scottish railway system" was to be found "in universal and ubiquitous competition." (2) The theme of inter-company rivalry reiterates time and again through the history of Scottish railway construction. Undoubtedly, many of the lines would have been built anyway because of economic justification, but their timing may well have been determined by a desire to get in first. The promoters of the Scottish Central decided that "... It is of the utmost importance that the Central railway should occupy the country about Falkirk and Carron so as to command the traffic there and prevent the introduction of hostile lines." (3) Two decades later the North British chairman summed up the general attitude of the railway companies when he commented "if we do not make the lines where asked this is a temptation for other companies to step in," though it should be noted that the initiative was often that of the rallway company exogenous to any local request.

1. See also J.R. Kellett, 'Glasgow's Railways, 1830-80; A Study in Natural Growth,' Economic History Review, second series, vol.XVII, no.2, December, 1964. W. Ashworth, An Bconomic History of ingland, 1870-1939. 1960. pp.120-121 argues that in the later nineteenth century the rallways of Britain could not carry the extra traffic which brought higher turnover unless they increased their capital. The spare capacity in existence for several years after initial building had been used up, and "in the last quarter of the nineteenth centur on one main route after another, the point was reached at which extra traffic involved heavy expenditure on the enlargement and improvement of fixed capital."

2. W.M. Acworth, The Railways of Scotland. 1890. p.3.

3. Abercairney Papers. G.D.24, section 925, item 5, 25 September, 1845. S.R.O. 
(1) In fact it can be suggested that, as the major companies came to do more and more of the building and independent promotion faded away, railway construction became less a response to demand and more a desire to aggrandise the power of the railway directors.

The usual justification for such preclusive building was based on the divine right to exclusively occupy certain territories. This concept was not slow to emerge, for before Scotland had attained a century of railway mileage the Ballochney was staking its claim to certain mineral fields "which naturally belonged to the company." (2) As the scottish railway network was being mapped out in the 1840 s the North British thought it "desirable that a general system of railway communication should be established in Scotland by the country being divided into districts and the railways in each district amalgamated and put under one management." (3) In 1860 the editor of the Scottish Railway Gazette was advocating that established companies alone should have the privilege of constructing local lines within the areas that they served. (4) A few years later, at the height of another railway mania, the North British reiterated its earlier

1. RAC(S) 1/1A, 23 March, 1866. B.R. Building did not always take place immediately an Act was obtained. The Caledonian complained that the purpose of the North British in securing legislation for their Stobcross extension in Glasgow was "merely strategical" in serving to keep the Caledonian out of the area, construction being delayed several years. (J.R. Kellett, 'Urban Transport History from Legal Records,' Journal of Transport History. vol.VI, no.4, 1963, p.237).

2. Report, 7 February, 1837. Mitchell Library.

3. NBR 172,16 December, 1845. B.R.

4. Scottish Railway Gazette, 24 November, 1860. 
proposal, but in a modified form - "it appeared to the directors that boundary lines might be drawn, enclosing districts which might properly be said to belong to the North British, Caledonian, Glasgow and South western respectively and that within these districts none but the owning company should, without its consent, project railways or enter into agreements with other companies for amalgamation or otherwise." (1)

This proposal, however, had no more success than the previous schemes and the reason is not difficult to find. It is simply that the companiea could not agree in whom the divine right had been invested. A tremendous demarcation dispute broke out between the North British and the Caledonian as to who should build the line from Hawick to Carlisle, the former company maintaining that this was a logical extension of their Edinburgh to Hawick line, and the latter reckoning that any railway into Carlisle from that direction was automatically their prerogative as their station in Carlisle provided a link with the south. (2) Another struggle between these two companies over the right to construct the Peebles to Galashiels line provoked the comment that "it is the old battle of the Hawick and Carlisle extension over again, but on a different field." (3) Such feelings of deja-vu must have been common.

1. RAC(S) 1/1A, 23 March, 1866. B.R.

2. Speeches from the respective chairmen illustrate the belief they each had as to their rights. One company claimed it was "a battle between the North British Railway Company and the public on one side and the Caledonian Railway Company on the other," whereas the other company maintained "the question is one between the Caledonian and the public on one hand and the North British on the other." (H.R.J., 11 September, 1858; 18 September, 1858 ).

3. Scottish Railway Gazette, 21 July, 1860. 
The places and the companies might change but the cause of the argument remained the same. The Caledonian and the Scottish Central fought in parliament over the Denny railway, and so intense was the rivalry between the City of Glasgow Union and the Caledonian that the railway contractor, John Fowler, was led to comment that he never remembed"an occasion in which the Union Company have been in parliament on which the Caledonian have not been opposite." (I)

This empire building frequently hit the profits of the companies in the short run but generally the directors were able to proceed with their plans without a shareholders' revolt. At times, however, when dividends disappeared or threatened to do so because too much construction was being attempted, the shareholders were roused from their lethargy. In the post mania hangover most of the major Scottish companies were subjected to a shareholders' inquiry, usually instigated by the English stockholders, and in some instances the boards were overthrown. (2) Again the late 1860s witnessed the shareholders of the Glasgow, and South Western, the Caledonian and the North British uniting to successfully demand a reduction in the proposed capital expenditure of these companies, which they feared would reduce the chences of a dividend on the ordinary stock. Many of them were shareholders in all three companies which would stimulate their efforts to reduce competitive spending even more. (3) Still,

1. Kellett, op. cit., (1964), p.367.

2. $\operatorname{RAC}(S) 1 / \sqrt{1 \mathrm{~A}}, \overline{1 / 3}$. B.R. H.R.J., 9 March, 1850; 11 May, 1850; 18 May, 1850.

3. H.R.J., 8 February, 1868; 10 July, 1870. 
considering the nineteenth century as a whole, Michael Robbins could truthfully assert that "through most of the railway age, the shareholder was very much the sleeping partner." (1) In an impersonal. share market the diversification of ownership may have hindered opposition to the directors policies. In most cases anyhow the directors were able to raise sufficient proxies to have their way, probably because although not maximising profits in the short run, it could be argued that this was not true of the longer period, either because traffic would develop, or more likely because building to exclude other companies, whilst not significantly enlarging profits, definitely served to conserve them.

Towards the close of the nineteenth century, however, the major companies appear to have reorientated their thinking away from the concept of attack being the best form of defence and towards the idea of restricting competitive building. Perhaps this was because there was little left to construct, but it is also possible that the shareholders exerted some influence, for the Economist maintained that "it is the knowledge that they have each come well nigh to the end of their tether in respect of raising money that has had much to do with the conciliatory attitude the boards have now taken up towards each other." (2)

Yet overall as regards the policy of railway directors it could be written about the North British and Caledonian companies, but with general application to Scottish railway development, that "the practice in extension hitherto has been for one company to

1. M. Robbins, the Railway Age. 1965. p.88.

2. Economist, 24 October, 1891 . 
pursue the other wherever it went." (1) The net result of this was that at the turn of the century only Oban and Ayr of the Scottish towns of any importance were served by a single railway company.

It could perhaps be suggested that mitigating this hypothesis of power complex construction was the building of several lines for altruistic reasons. The promoters of the Wishaw and Coltness railway thought that their line should be constructed as soon as possible in the late 1820 s as "it will afford the means of providing immediate and, at least temporary relief to a considerable portion of the manufacturing population of Lanarkshire, now utterly destitute of eaployment and the means of subsistence." (2) That their lines would provide work for the unemployed was also an argument proffered by railway directors in an attempt to obtain state assistance in the post mania period. (3) The timing of some construction may well have been influenced by a consideration of the level of unemployment, but no lines were ever projected with this in mind because of the unavoidable lags between conceiving a scheme, obtaining parliamentary approval and setting to work. It has been argued that much of the Highland system owes its existence to philanthropic benefactors, but this idea has been challenged in the previous chapter and the hypothesis proposed that if any enlightened development policy was being pursued, it was geared predominately to the development of the benefactors' estates rather than the Highlands as a whole.

1. conomist, 3 December, 1903.

2. WIC $4 / 3$. 1829. B.R.

3. H.R.J., 3 June, 1848.

4. See chapter two, section ten. 
In attempting to assess the motivation behind the capital expenditure of the Scottish railway companies notice must be taken of Cairncross's warning that "averages for the whole industry are not a reliable guide to the complex of incentives to investment." (1) Aggregations can be seriously influenced by a dominant component and, before any conclusions are firmly advanced, studies of individual companies ought to be undertaken. It can, however, be suggested that the major influence upon railway capital expenditure in Scotland was a management policy geared to expansion (and perhaps maximisation of long term profits) conditioned by the terms (cost and availability) on which money could be raised.

\section{3.}

Heving discussed the volume of capital expenditure made by the Scottish railway companies and the reasons for its timing and outlay, the next stage is to determine the effects of this expenditure on the scottish economy. In their operation the railways generally reflected the business cycle (except, of course, when a rail strike had an exogenous impact on the cycle), but in their construction they could significantly influence cyclical patterns. c.N. Ward-Perkins has demonstrated the cushioning effect on the British economy of railway building in the late 1840 s following the promotional mania, but any attempt to ascertain whether his general conclusions can be specifically applied to Scotland is hampered by there being no estimates for scottish national income

1. A.K. Cairncross, Home and Foreign Investment. 1953. p.141. 
or investment. (1) However, some hypotheses can be advanced especially in relation to the pre-1850 period.

In his "General Theory" Keynes criticised the classical economists for warping our way of thinking on the utility of capital investment in certain forms, a specific instance being their condemnation of the building of railways where there was no demand. (2) Acworth's viewpoint has already been cited in the heading to this chapter. Contemporaries, however, were well aware of the beneficial effects potential in railway construction irrespective of its useage as a transport agency. Way back in the formative and experinental years the $\$ 100,000$ or so spent on the Kilmarnock and Troon was praised on the grounds that "as nearly the whole of that sum is expended in work within the coumty, it must prove an immediate blessing to the poor, and a source of profit to many." (3) And at the time of the railway mania the Scottion Railway Gazette gave a useful description of a pump-primer process in action when prophesying the effects of injecting the huge axm of money into the economy.

"... and when at last the whole sums shall be wi thdrawn out from the names of the directors, to whom will they have been transferred? First to the contractors, and, through them, to their labourers in earth, stone, and iron; and through them again, to the clothier, hatter, hosier, grocer, brewer, baker, butcher, and farmer; and by them again, to the banks, almost as fast as drawn out. The money will have made a revolution most profitable to the country, and left behind it an instrument of permanent utility; subsisting in the meantime, thousands on industrious families, and encouraging all useful products for their subsistence and comfort." (4)

1. C.I. Ward-Perkins, 'The Commercial Crisis of 1847,' Oxford Economic Papers, vol.II, 1950.

2. J.M. Keynes, General Theory of Employment, Interest and Money. 1936. p.131.

3. W. Aiton, The Agriculture of Ayrshire. 1811. p.556.

4. Scottish Railway Gazette, 24 January, 1846. 
The Economist also clained that "by raising capital for railway construction a large command over resources is transferred into the hands of the railway companies. This means new demand for labour, a rise of wages, increased consumption." (1) However, it must be noted that others believed that the construction of the railways merely transferred spending power from the hands of individuals to the hands of the railway companies and consequently disrupted established spendine patterns and the industries and businesses associated with them. (2) Given the high marginal propensity to spend of the railways and the fact that the typical railway shareholder was not a small capitalist, then, assuming that Keynes' thesis of a declining marginal propensity to consume is applicable to the mid nineteenth century, it could be suggested that overall the Scottish economy would benefit from this trensfer of monetary resources.

However, it is arguable that the building of the railways may not have eased the position of the Scottish labouring population as a whole, either in the post-mania period or at any other time, because of the regional concentration of the operations and because of the origins of the construction workers. (3) A director of the Glasgow, Paisley, Kilmamock and Ayr, claimed that the building of his line in 1838 gave "employment to thousands of individuals who otherwise might have been in the depths of destitution." but most of these were Irish so the Scots working man could not have

1. Bconomist, 1847, sp.405-407.

2. e.g. D.M. Evans, the Commercial Crisis. 1849.

3. The origins of the work force are discussed in chepter seven, section two. 
benefitted, except in that downward pressure on wages in other employment may have been eased. (1) Even if the majority of the eight thousand men at work constructing the Edinburgh and Glasgow, and the three thousand on the Glasgow, Paisley and Greenock in 1840 were Scots, which is questionable, it is unlikely that many would have been unemployed without this work, for the depressi on that hit England so hard in the early 1840s lagged a little in Scotland. (2) The Inquiry into the Scottish Poor Law points to there being no great distress until 1842, a year which witnessed a drop in savings-banks' deposits and the birth of relief funds. (3) Railway construction could do little to aid at this time as there was hardly any under way, although the Committee for the Relief of Unemployed Operatives in Edinburgh did persuade two local railway companies to advance certain operations so as to provide some jobs. (4)

It is unlikely that the delay in the onset of the depression can be attributed primarily to railway building, for although a majority of the able-bodies unemployed in Edinburgh were Irish navvies, recently discharged following the completion of the Bdinburgh and Glasgow line, it must be noted that local railway construction had ended two years before severe distress struck Greenock and Paisley. (5) The Scottish economy was suffering from the downswing of a long wave economic boom, stemming from

1. Railway Mimes, 4 August, 1838; 11 August, 1838.

2. Glasgow Constitutional, 4 July, 1840.

3. Perliamentary Papers. $1844 \mathrm{X}$.

4. Ibid., q.3402; 3430 .

5. Ibid., q.2917; 3414. 
the discover. of the hot blast in 1828. This discovery, together with cheap labour inputs, made possible an expansion of the Scottish iron industry on the basis of low cost production. So great was the impact of this innovation that even falling prices and a gradual decline into depression between 1837 and 1843 did not stop investment in the industry. (1) The expansion of the corl industry with strong forward linkages with the ixon industry followed almost automatically, as did, to a lesser ex ent, those industries with backward linkages such as engineering and shipbuilding. The continued investment in the iron industry gave bouyancy to the economy and helped create an atmosphere of boom and prosperity which encouraged other investment in railways, banks and shipping companies, all of which were a feature of the Scottish economy in the mid and late 1830s. Railways were but one facet of a general expansion, and their completion but one aspect of its slowing down. (2)

It is interesting to note that on this occasion, before the transborder roites came into being, Scotland exhibited a different

1. R.H. Campbell, 'Investment in the Scottish Pig Iron Irade 18301843,' Scottish Journal of Political Economy, vol.I, October, 1954 .

2. Unlike the situation at the time of the railway mania where the atmosphere of profitable expectations engendered by the upsurge in railway investment and speculation stimulated other proposals, some of permanent utility such as the stock exchanges in Edinburgh and Glasgow, others of a more ephemeral nature such as the Edinburgh Washing and Bleaching Company, the Airdrie Cemetary Company, the Greenock Arcade and Improvement Company and the North British Deep Sea Fishing Company, all of which were wound up without making much progress. (Scottish Railway Gazette, 12 July, 1845; 19 July, 1845; Railway Times, 20 otober, 1845; 20 September, 1845; 24 January, 1846T. 
cyclical pattern frow England, but that immediately the two economies became more closely linked by the North British and the Caledonian railways their troubles became mutual. The explanation of this, however, is allied to the differential impact of the hot blast on the two economies, in the earlier period and not to the coming of the railways in the mid $1840 \mathrm{~s}$.

Unlike the earlier mania in the 1830 s whose detrimental effects were mainly felt south of the border, the railway mania of the $1840 \mathrm{~s}$ and its aftermath of financial debacle and business chaos did not leave Scotland unscathed. Protestations by the commercial classes were loud as bankruptcies, debts and the liquidation of firms multiplied. (1) It was considered by many that railway construction had eased the distress and further building was envisaged as a panacea to current troubles. (2) Since 0ctober, 1847 the railways leading into Glasgow had dismissed over fourteen thousand labourers, mainly Irish and Highlanders, who flocked into the city to eggravate the unemoloyment situation. (3) A memorial was sent to the Lord Provost pointing out that a large proportion of this surplus labour could go back to the railways "if the several companies only enjoyed the means of defraying the necessary expenditure." In consequence of this a deputation from Glasgow and its environs sought an Exchequer Bill Grant to facilitate such construction "as the best means of rendering available the capital sunk in those works, and also to give employment to the working

1. Evans, op. cit., see appendix.

S.C. Commercial Distress. $1847 / 48$ VIII. $q .3841$.

2. Ibid. 1.3846 (evidence of the Sheriff of the County of Lanark).

3. Ibid., q.3853; 3863 . 
people out of employment." (1) However, succour was not forthcoming and thus the railways did little to ease the position of the labouring populace suffering in the depressed areas.

How far the influx of labour that the cessation of works thrust into towns materially affected the resident workers would depend on the employment situation existing in those towns. Competition could hardly depress wages if there were no jobs to be competed for, but it is questionable if the level of unemployment in any trade ever fell so low. Whatever the effects of the post-manie building, the demand for construction workers after 1850 was never high enough to seriously affect the mass of the scots wage-earning classes, the highest known total being 9499 in 1860 wich was only about $1 \%$ of the occupied work force of scotland.

Some Scots did benefit directly from the railway construction. These were the shopkeepers, lodging house proprietors, and publicans en route. The armies of navvies may have terrorised the neighbourhood on paydays, but their renowned appetites for food and beer must have had important multiplier effects (damped slightly by the existence of truck) for the area. (4) This was recognised

1. Ibid., 9.3850 .

- Kailway Times, 25 March, 1848.

2. Some or the unemployed in Galashiels and Hawick found work on the construction of the Edinburgh to Hawick line. (Border Advertiser, 9 June, 1848). But the general impression gained is that construction workers were not usually of local origin.

3. The figures are from lable 7.1 It must be noted that the statistics are known only for certain years and the importance of the construction force may have been more in an unknown year, but rough calculations based on mileage opened do not suggest a wide variance.

4. The Chairman of the Peebles railway wrote that their "appetite for beef, fried ham and ale (was) immense" and added that "it has been stated on good authority that a sum equal to 21000 per mile on all railways in Great Britain has thus been wastefully squandered." (". Chambers, hbout Railways. 1865. pp.26-27). I+ was also pointed out that navvies "earned high wages and they spent them." ( $J$. Francis. A History of the English Railway.

1851. vol.2, p.70). 
in 1840 by the Kilmarnock Journal, which reported that "the lodging houses in Kilwinning, Dalry and Beith, are crowded with labourers employed on the railway, whose expenditure must be felt in a considerable degree by those villages." (1) However, it is unlikely that the producers and retailers of the agricultural commodities and products, on which the navvies spent their money, would, in meeting what was essentially a temporary and regional demand, expand their labour requirenents sufficiently to absorb or even attract the surplus labour from the depressed industrial districts.

It can also be suggested that there was unlikely to be significant secondary employment in scotland emanating from the demands of the Scottish railways for raw materials and industrial products before (say) 1860 as many of these were initially supplied outwith Scotland. Many of the contractors and engineers on the Scottish Lines in the 1840 s were English, partly because they were experienced in the trade but also to attract Bnglish capital, and they often had a say in alloting the contracts for rails, rolling stock and other equipment. Frequently they recommended English firms, but there is no evidence of this being done for nationalistic reasons. The basic fact was that scotland, for a variety of reasons, was unable to meet the requirements of her own railways. Over time, however, the si tuation was rectified and the capital expenditure of the Scottish companies became less of a transfer

1. woted in The itress, 2 May, 1840. 
payment from one set of Anglishmen to another. (I)

The railways in operation hed perhaps a rore instant inpact on the Scottish econony with their demands, though even here local coal proved unsuitable for use in the early days. (2) The minute books of the railway companies do suggest that locel firms did benerit from their multitudinous demands, but they also give the inpression that when expensive eguipment was needed the compenies searched far and wide. It may well be that the cost of transport (imputed or actual) deternined thet low velue (in relation to bulk) commodities were purchased in local markets. (3)

1. The effect of railway development on the scottish iron and engineering industries is discussed in more detail in the following two chapters. In addition to their purchases of capital equipment south of the border so me line construction was incurrea in angland under the aegis of scottish companies. Estimated expenditure on this building, exclusive of repairs and renewals, is snown below.

$1841 / 50$ unable to estimate though Caledonian was

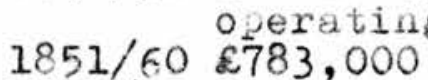

$1861 / 70 \approx 982,000$

$1871 / 80 £ 219,000$

$1881 / 1900$ unable to be estimated.

2. See chapter six, section fire.

3. examples of scottish firms producing goods for the railway narket include the Clydesdale Chemical Company, Glasgow and the North British Uil and Candle Company, both of which manufacturea railway axle grease. (H.R.J., 2 January, 1858; Railway News, 14 July, 1877). Canvas used for wagon covers añd by carriege builders was produced by Richards and Company, Aberdeen, James hacllwraith and Co., Glasgow and Wlliam L. Boase and Co., Dundee. (Railway News, 16 January, 1880). Carriage door'locks were provided oy Maxwell and Sons, Dundee and Mcilaughton and Bosweil, also of Dundee. (Railway Year Book, 1901; Scottish News, 20 hay, 1886). Springs were manufactured by sterne and Co., Glasgow, signalling equipment by Stevens and Sons, Glasgow, and rivets by the Clyde hivet Company, George Millar and Co, and Bilsland's Victoria Bolt and Rivet Work, all of Glasgow. ( $J$. Hayer, Engineering and Shipbuilding Industries of Glasgow and the clyde valley. 1870; sngineering, 28 February, 1890). However, in the aosence of evidene no claims are made as to the Scottish railway market providing the base for the existence or expansion of these firms. 
There is no doubt that becoming a railway centre added permanently to the prosperity of a town in contrast to the temporary benefits given by construction. The railway companies were well aware of their position as potential benefactors to a community. In the late 1850s the Chairman of the Glasgow and South Western was convinced that the removal of that company's workshops to Kilmarnock would "prove most beneficial to that town, in the prosperity of which we are deeply interested. Our expenditure for wages etc. wi.11 scatter more than $\& 30$, 000 per annum amongst that industrious population." (1) Towards the end of the century the Great North of Scotland found that the pressure of demand was putting the price of rolling stock out of their reach and consequently they made arrangenents to build stock at Kittybrewster "thus securing to Aberdeen the expenditure locally of a very large sum of money to the benefit of the trade of the city." (2) However, the costs of being committed to one particular centre were not too great to prevent the transfer of workshops etc., e.g. the North British decided to concentrate its building at Cowlairs to the detriment of St. lfargarets, the Caledonian reduced the volume of work done at the shops of absorbed companies, and the move of the Glasgow and South Western from Cook Street, Glasgow to Kilmarnock has already been mentioned. (3) That prosperity dependent on the siting of railway works might

1. H.R.J., 21 March, 1857.

2. KRC(S) 1/15, Warch, 1895. B.R.

3. G. Dow, he Pirst hailway Across the Border. 1946 . p.26. H.i..J.. 30 September, 1865 . 0.. Nock, The Caledonian hailway. 1962. p.87. Weekly News, 5 November, 1898. 
prove transitory was a possibility to be acknowledged in the plans of local businessmen, but whether it ever determined their actions, except in the very short run, is open to conjecture.

One aspect of the railways' capital spending that warrants further analysis is the effect that it had on the building trades. On occasions the railways south of the border had themselves demanded a substantial proportion of the brick output of England and Wales. (1) Whether the proportion was higher or lower in scotland depends on the differential use made of stone in rallway and industrial building, and evidence on this point is unavailable. In the early days bridges and stations were frequently constructed of timber and throughout its history the scottish railway system has been relatively devoid of tunnels. (2) Still their demand could be significant at times. The witness proclaimed in 1840 that "had it not been that milions of bricks were consumed at the different arches and tunnels connected with the railways, the (Glasgow) trade would have been exceedingly flat." (3)

The statistics of brick production before 1846 give the impression that the counties experiencing railway construction also had an upsurge in brick production of a greater percentage increase than in counties without railways. (4) However, whether or not this was due to investment induced by the railways, the railways' own demands, or some exogenous factor is difficult to say.

1. H.A. Shannon, Bricks: A Trade Index, 1785-1849; Economica, 1934

2. Railway Chronicle, 10 November, 1849. Railway limes, 8 January, 1859. Engineering, 16 April, 1869; 4 October, 1867.

3. The witness, 7 October, 1840.

4. Parliamentary Papers. 1846 XXV. 
Professor Spring quotes Lord Palmerston writing to his brother in 1845 that 'railways create station-houses, and station-houses begat villages, and little towns are springing up everywhere upon the lines of railways." (1) An account of such constructional evolution occurring in the Highlands is given by D. Campbell in his autobiography. (2) It has also been argued that railway development in scotland led to the creation and extension of spas, tourist resorts and the like. (3) Such induced investment was often deliberately invoked by the railway companies offering special rates to persons constructing houses along the line. Their rationale was that if people went to live somewhere then goods would have to be transported to them and the railways presumed that this traffic would inevitably come their way. (4)

In the second half of the century the development of suburban railways no doubt affected decisions on urban demolition and rebuilding. (5) A public meeting in Glasgow was opposed to the building of the City of Glasgow Union railway as it would pass "through the most densely peopled part of the city, by which thousands of inhabitants will be dispossessed of their houses and other premises, and the future improvement of the city seriously impeded." (6) This latter charge could not be levied against

1. D. Spring, 'The English Landed Estate in the Age of Coal and Iron, 1830-1880,' Journal of Economic History, vol.II, no.l, 1954, p.34.

2. D. Campbeli, Reminiscences and Reflections of an Octogenarian Highlander. 18.90. See also H.F.J., 9 hay, 1892.

3. J.B. Caird, The Making of the Scottish Rural Landscape,' Scottish Geographical Magazine, vol.80, no.2, September, 1964, pp.78-79.

4. See chapter nine pp.502-503.

5. H.R.J., 27 January, 1866 (Glasgow); 24 February, 1860 (Leith).

6. H.R.J., 25 June, 1866 . 
the Glasgow Central in the $1890 \mathrm{~s}$ as this company had to spend over $£ 300,000$ on the construction of sewerage, gas and water mains. (1) Over the century the estimates of housebuilding and the rate of demolition in Glasgow correspond fairly well to railway building in that city, but once again it was not necessarily due to the railways for the City Improvement Irust spent over 21.3 million between 1870 and 1883, displacing over 30,000 persons in the process, and must therefore have been a significant influence. (2) In fact one urban historian has suggested that the railways by clearing one area merely increased the pressure upon space in neighbouring slums, consequently raising their value to the owners and making them less likely to be redeveloped by the workings of the free market. (3)

\section{4 .}

Many contemporaries of the railway mania feared damage to other economic sectors through the railways absorbing capital which was needed elsewhere. (4) Most railway enthusiasts, however, believed "it is absurd to say that the railways will swallow up the surplus capital of the country. They will increase and develop it." (5) In his study of the aftermath of the mania Ward-Perkins

1. T.E.S.S., 1891/92, p.6. KaIIway World, August, 1894, p.270.

2. Cirnoross, op. cit., pp.26-27. Engineering, 7 A ugust, 1868.

3. C.MIIan, The Genesis of British Urban Redevelopment with special reference to Glasgow, Economic History Review, second series, vol.XVIII, no.3, December, 1965, p.600.

4. See e.g. Railway Times, 21 March, 1846.

5. Scottish Kailway Gazette, 26 July, 1845. The Great North of scotland promoters did, however, defer building on the grounds that "the sudden diversion of a large amount of capital into the channel of railway enterprise might be productive of serious embarassment in the money and labour markets." (Scottish Railway Gazette. 29 August. 1846) 
maintained that there was no solid evidence that other industries were starved of working capital, but undoubtedly a cogent factor in the crash of the Ayrshire Malleable Iron Company was its inability to raise funds because of the involvement of one proprietor, a Mr. Alison, in railway investment. (1) However, to "prove" that railway construction prevented other industries obtaining access to capital is, in the light of current knowledge, an impossible task.

Allied to the point raised above is the question of the returns on the capital invested in the railways. Capital formation in itself is not necessarily a stimulant to economic growth. What is important is the productivity of the investment. If the construction and operation of the railways did prevent other sectors from growing it is essential to know the productivity of railway investment in order to ascertain whether the capital could have been more fruitfully employed elsewhere.

Periods of low dividends were a common feature on Scottish railways as is shown in Table 2.1 , but it is arguable that dividends are not meaningful as an index of productivity. The variable policy as to the presentation of accounts meant that dividends could be maintained by omitting depreciation, by failing to make contributions to the renewal fund or by going to the extreme of paying them out of capital so that "in practice the calculation of profits was often influenced significantly by changing financial

1. Ward-Perkins, op. cit., p.85.

Details of Alison's speculations, including one where he lost \&10,000, can be found in R.H. Campbell, op. cit. (Ph.D. Thesis) p.131. 
circumstances and the dictates of management policy." (1) Thus although in theory having to attract back distributed profits could lead to efficiency, in order to maintain dividends, in practice the purpose was frequently served by financial manipulation. The growth of the preference share and the guaranteeing of a specified rate of return to companies subjected to take-over or working agreements would encourage this line of development. On the other side of the account the volume of watered capital (some $\$ 41,8$ millions of the $\$ 158.9$ millions of total capitalisation in 1898) resulting from stock conversions and amalgamations must have inevitably produced a dividend lower than the true rate of return.

A better measurement of the rate of return on capital can be obtained from the use of the estimates of capital expendi ture made in section one. A major difficulty in their utilisation comes from not knowing what rate of depreciation to employ on the capital stock. Table 3.4 shows capital/output ratios and estimated rates of profit for Scottish railway investment in the nineteenth century and how they are affected by different assumptions as to the life span of the capital assets. Recent official publications assume a life of 100 years for railway track, buildings and works. (2) If this is taken as applying to the nineteenth century then, although the figure would be reduced when rolling stock and rails are considered, the reduction would still leave a life span of

1. H. Pollins, op. cit., (Littleton and Yamey), p.351.

2. C...0., National Income and Expenditure. 1964. 0.106. 


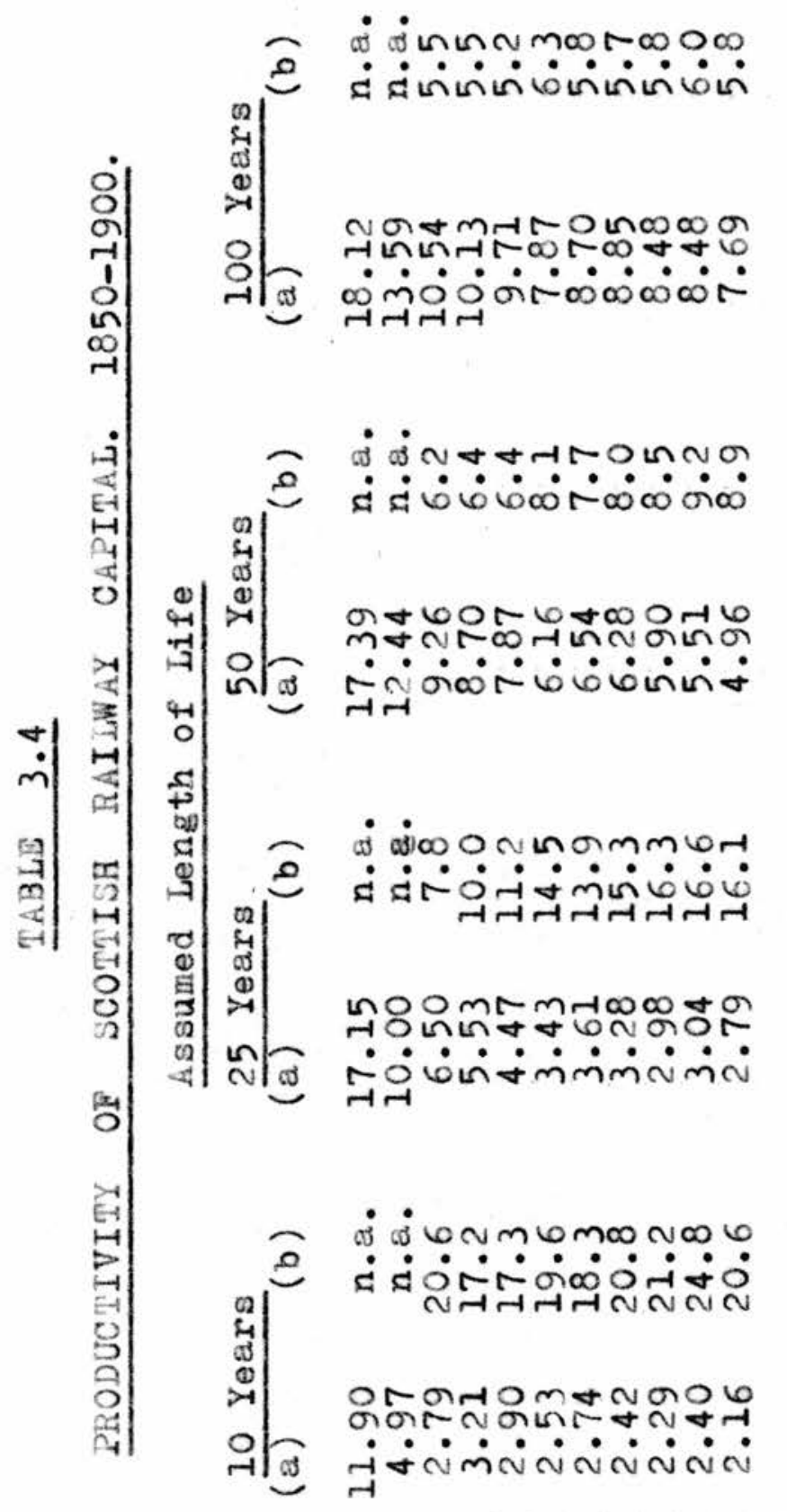

点

$+$

0
0
0
+0
0
0

웅

है

(1) $\mathrm{C}+{ }^{2}$

क्ष 0502

ॠ मु

o2 020.4

(c) 10 \&

\& :

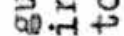

r- $\rightarrow-1$ 岳

of $-1 \cdot r$

त्र है ब

की. त्र

का 4 in

$x$ द्य 4 व

(1) त्र की

శृ

电

तो 3

(1) 더맘

040

क्ष $0+0$

4

02

की द्व

(1) $4{ }^{4-1}$

गम क्ष पू

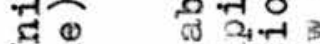

ता समत्र है

त- 3 (2)

or द्र $>$

$0 \rightarrow \quad$ is

†워

of

स 02

$+\stackrel{02}{0}+$

उद्यु न्त

a 304

3

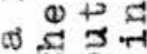

के $\mathrm{O}_{4}$

प1 0 क

(1) क् 0 का

0 iे -1 .

离

(2) (1) त्र

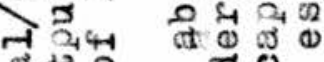

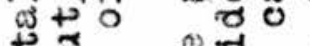

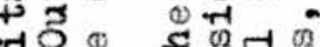

क ल

ये क 0 के

(4)

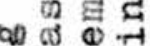

ट 3 \&

उ 10

4 Onomounounoino

(1)

เกเ

$\ddot{0}$
0
+3
0
2 


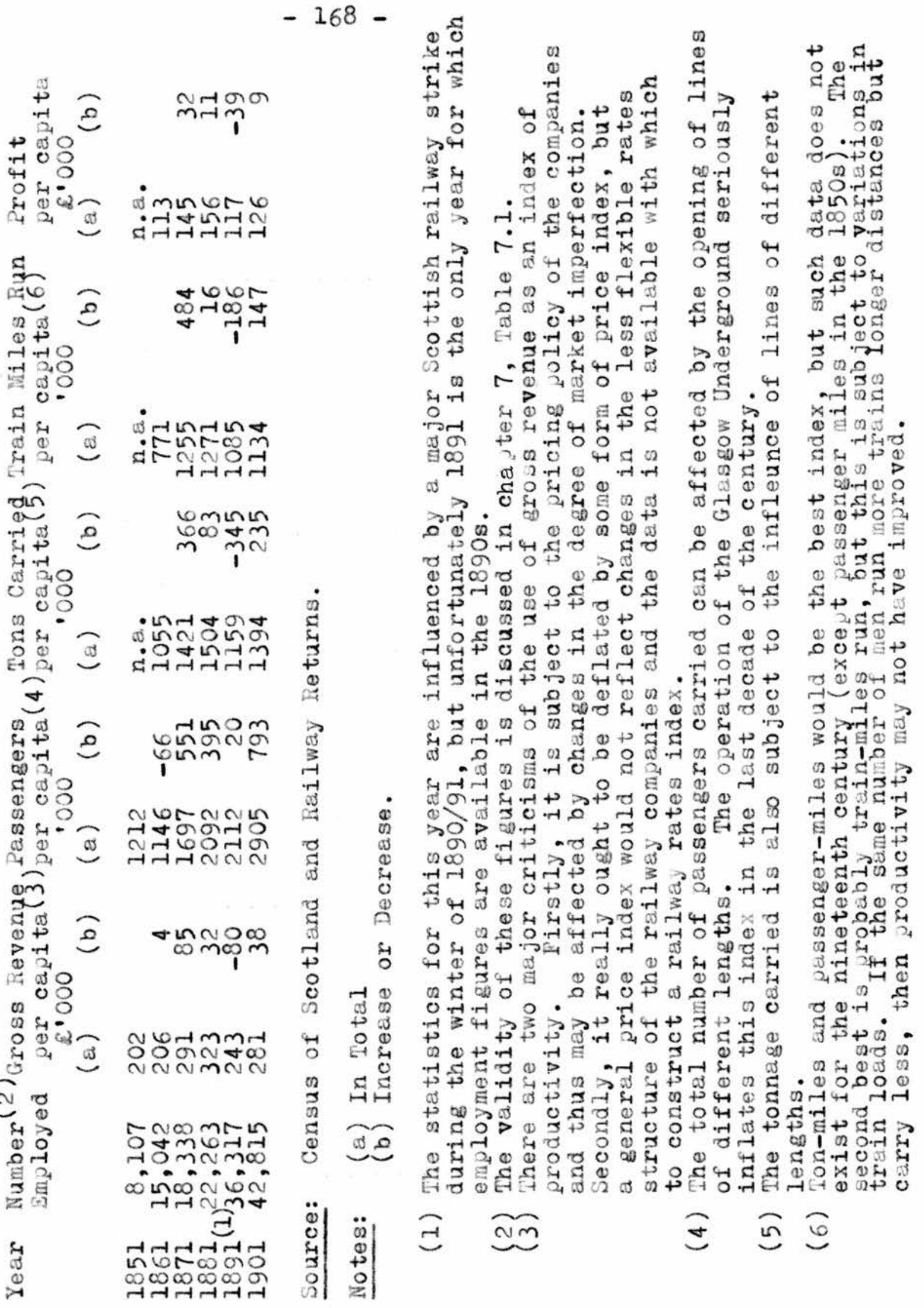


well over 25 years for assets on average, and most probably nearer 50 years. It is unfortunate that the capital expenditure estimates are incapable of being broken down so that different depreciation rates could be applied to different, assets since this leaves the interpretation of the table susceptible to error from the concentration of investment on one particular type of asset at a particular period of time.

The secular trend of productivity and profitability is upwards which may weaken Psofessor Ashworth's assertion that of the railways constructed in the late nineteenth century "probably the majority ... brought little benefit to the nation's economy." In particular he cited the lines built in the isolated areas of northern Scotland. That there was an upward trend in the productivity of railway capital in scotland as a whole does not disprove Ashworth's hypothesis and unfortunately the railway accounts do not allow for the production of statistics to verify or refute the argument. However, assuming a fifty year depreciation period, the following capital/output ratios are obtained for the Highland and Great North of Scotland systems, a substantial proportion of which was in the areas cited by Ashworth - $187324.33 ; 24.04$ and 1897 18.87; 13.26. Although showing that productivity was increasing these figures also demonstrate that the level of

1. W. Ashworth, An Economic History of England, 1870-1939. 1960. p.112. See also his article 'The Lete victorian Economy' in Economica, February, 1966. To could seem that Ashworth discredits his own hypothesis for later in his book (p.122) he reckoned that "most of it (railway capital expenditure in the late nineteenth century) went to the serving of an overwhelming national need." The key to this apparent paradox perhaps lies in the proportion of capital that went on line construction - using Mitchell's data a cost of $£ 20,000$ per mile would take $28 \%$ of total capital spending. 
productivity was absolutely lower than that pertaining to scotland as a whole. This would suggest that there is some truth in Ashworth's allegation about the northern railways, but it does not prove it, for it is theoretically feasible that the new building was exhibiting a high level of productivity which was being outweighed by a rapid decline in the productivity of the older track. Unfortunately the North British accounts do not allow data pertaining to the West Highland line to be satisfactorily sorted out. What little information that can be obtained does back up the argument of a lower level of productivity in the isolated regions, but it is essentially a subjective impression rather than a statistical truth.

Overall, however, railway capital productivity was rising. Yet it can still be suggested that the Scottish railways contributed to the declining rate of economic growth in the later nineteenth century by exhibiting a slowing down in the rate of growth of capital productivity. (1) Between 1855 and 1870 capital productivity increased by c.0.31\% per annum (assuming a fifty year depreciation period), but between 1870 and 1900 by only c.0.24\% per annum. (2)

The relationship between national economic growth and the productivity of a sector of that economy is difficult to determine

1. D.H. Aldcroft, The Bfficiency and Enterprise of British Railways 1870-1914,' Explorations in Entrepreneurial History, second series, vol.5, no.?, 1968, has suggested that British railways as a whole had declining total productivity and not merely a decreasing rate of growth, but this is perhaps because he used the paid up capital statistics in the Railway Returns without allowing for noinal capital.

2. It was considered that 1850 would bias the results too much in favour of the argument that is being made about a declining rate of productivity growth after 1870. 
at any time. In the case of a service industry like railways it is even more complicated. The capital productivity of such an industry could be low through its pricing policy (if productivity is being measured in monetary terms) rather than through any inefficiencies in working. This may produce a misallocation of economic resources, but, in an imperfect market, second best theory and a cost benefit analysis may allow that the benefits to the consumer of low prices outweighs the loss to the railways. (1) An assessment of the railways' role is made even more complex by Scottish railway capital expenditure declining as a percentage of total British gross capital formation from $3.6 \%$ in $1870 / 74$ to $3.4 \%$ in $1896 / 1900$. (2) Without specific Scottish investment statistics it is impossible to ascertain whether this decline was as true of Scottish as opposed to British capital formation.

So far capital productivity has been concentrated on, but it must be stressed, as Dr. W.E.G. Salter wisely pointed out, "we cannot divorce chnges in the productivity of one factor from the productivity of other factors, or indeed, from all the elements in an interrelated economic system." (3) Labour productivity may well rise through an expansion in the employment of capital equipment though simultaneously the labour force could become less efficient. In fact the real measure of productivity is the output per unit of input and in most cases the input is an amalgam of both labour and

1. An attempt to calculate some of these benefits is made in chapters eight and nine.

2. Based on C.H. Feinstein's figures in B.R. Mitchell and P. Deane, Abstract of British Historical Statistics. 1962. p.373.

3. T.E.G. SaIter and \%.3. Reddaway, Productivity and Technical Change. 1966 . p.3. 
capital. However, the difficulties of measuring such a combination usually make it easier to consider labour and capital productivity separately. Although each indicator is open to debate regarding its merits it would appear from Table 3.5 that labour productivity was higher at the end of the century than in 1851, but that the growth was not uniform. In fact it would seem that productivity was perhaps on a downward trend if 1891 was an atypical year as is suggested in the note to the table.

That capital productivity and labour productivity exhibit different trends raises no theoretical problems, but does render it imperative to decide which outweighs the other in order for anything to be said about total productivity, for capital or labour productivity in themselves are only measures not explanations. It can be suggested a priori that total productivity could not have been rising at an increasing rate because neither of the two sectoral productivities show such a tendency. What has to be decided is whether total productivity was actually falling or merely increasing at a decreasing rate. The only way to do this is to compute the inputs of capital and labour in monetary terms and assess various quantifiable aspects of railway output as a return on these inputs. The results, summarised in Table 3.6 , although the inputs are measured in undeflated monetary terms, suggest, but do not prove because of the assumptions involved, that different conclusions must be advanced depending on whether productivity is being assessed in physical or monetary terms. Even within the monetary measures a difference is to be noted: where gross revenue is considered a productivity peak was reached 


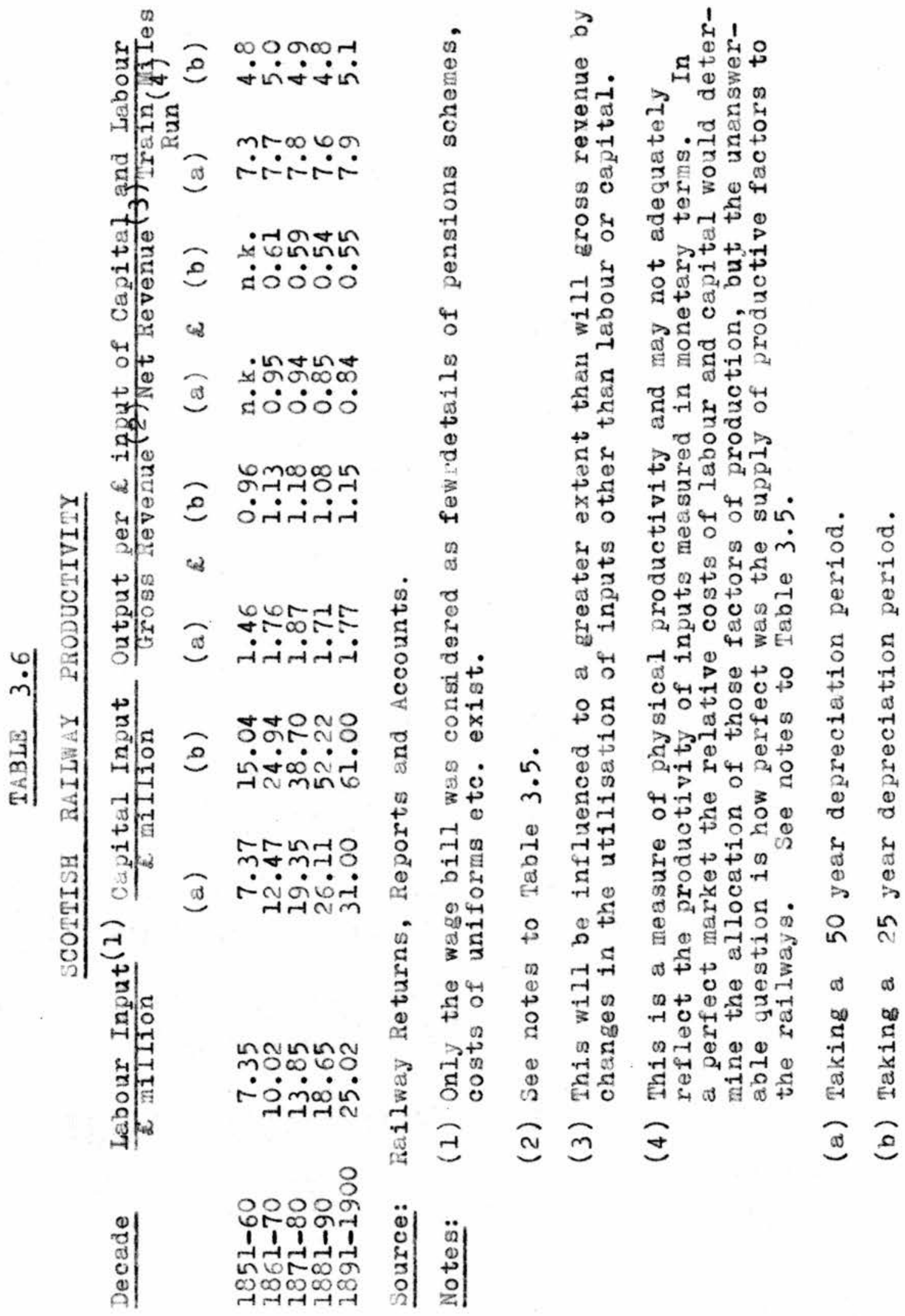


in the 1870s, and, although rising towards the end of the century, the earlier level was not reached again; where net revenue is taken then productivity would appear to have continually declined throughout the second half of the century with an accelerated decline in the $1880 \mathrm{~s}$. This would suggest that costs were tending to outpace revenues. When train miles run is the productivity measurement considered, however, it would seem that productivity was higher at the end of the century than at any previous time, although the rise during the second half of the century was not without interruption. Despite the higher absolute level of physical productivity, it can be suggested that the rate of growth was declining, since utilising the 1850 s as a base, an absolute productivity increase of 0.5 is recorded by the $1870 \mathrm{~s}$, but only a further 0.1 by the end of the century. (1) Judging from the quantities involved this cannot be predominantly assigned to a small base.

What factors were making for a declining rate of productivity growth? Which blade of the productivity scissors was most responsible - was too much capital (and labour) being wastefully expended or was revenue insufficient to yield a reasonable return on even the most frugally constructed and operated line?

Entrepreneurs usually come in for some criticism when the economy as a whole in the late nineteenth century is studied. Can the directors and managers of the Scottish railways be so

1. This is taking a 50 year depreciation period. If a 25 year period was substituted then productivity declines absolutely from the 1870 s to the 1890 s and in terms of rates of growth an absolute productivity increase of 0.2 is recorded from the 1850 s to the 1860 s and of 0.1 during the next three decades. 
arraigned? The directors proved themselves rather conservative once railways becane the property of the many and not the few. Scotland was never at the forefront of railway development, her pioneering being restricted to the Forth Bridge and loconotive design, though it should be stressed that these did come in the later part of the century. Possibly the best testimony to Scotland's relative backwardness in reilway matters is the history of electrification. An electric railway fitted up by Kay, Brown and Company of Edinburgh was demonstrated at that city's exhibition in 1886, but the idea of such railways as viable propositions was not followed up. The Glasgow Subway built in the 1890s was not converted to power by elactric notor until 1935. Admittedly at the time of construction the motors available did not have a high power/weight ratio, but the delay in conversion when these were devised was still substantial. On more nornal railways the controversy as to the relative merits of the overhead and the third rail could account for a lag in the adoption of electrification at the turn of the eantury, but in fact Scotland waited until November, 1960 for her first electric train service. (1)

Recently Dr. Aldcroft has argued that British (presumably including Scottish) railway management failed to respond sufficiently to the increasing density of trafic and fell far short of achieving the potential efficiencies that could have been attained in the handiing of this traffic. (2) How true was this and to what extent

1. Scottish News, 13 Maj, 1880 .

W.R. Bruce, The Electrification of the Glasgow District Subway,' T. ... 1935/36.

G. BIake, Glasgow Electric. 1960.

2. Alderoft, Ioc.cit. 
can management be blared?

Some inefficiency stemned from the inter-relatedness of the railways and other sectors of the economy. It was impossible for the railways to improve soine aspects of their performance without industrial entrepreneurs also making improvements. Larger capacity wagons for example could not be employed unless the owners of sidings etc. were willing to replace much of their equipment. (1) Although larger wagons would have out shunting costs and reduced operating expenses, the difficulties of persuading industrialists to write off existing capital equipment prevented more than a small percentage of twenty ton mineral wagons being introduced. (2)

The pattern of traffic tended towards short hauls and small consignments and thus did not encourage the introduction of costly capital equipment which might not be fully utilised. Two points can be made here. Firstly, although a multiplicity of stations and depots was condemned by the 1962 Beeching Report, in the circumstances of the nineteenth century when the only alternative form of transport generally feasible was relatively expensive horse haulage, transport costs were probably lower in the aggregate with the railway station network as dense as it was. (3) Secondly, that consignments were frequently less than would fill a single wagon was a decision of the traders not of the railway companies, except in the sense that the railways allowed them. That the

1. This point is discussed further in chaptex six, pp.379-380.

2. In Britain as a whole only $3 \%$ of the wagon stock were twenty tonners in 1932. (Aldcroft, op. cit., p.166).

3. The Reshaping of British Railways. 1963. p.3. 
average load of a ten ton goods wagon was less than three tons certainly gave the railways little incentive to increase wagon capacity. (1) Whether as well as producing inefficiency on the railways the acceptance of small loads also encouraged inefficiency in the general economy by encouraging the continued existence of small firms is open to conjecture.

Although recognising the role played by inter-relatedness and the traffic pattern, Dr. Aldoroft still laid the blame for much of the inefficiency of operation on the failures of managenent. In this he is perhaps justified, but he does not give enough evidence to support his allegations, and also fails to suggest why management acted as they did. He points out that few freight wagons were fitted with automatic brakes or oil axle boxes which permitted faster running, but does not attempt to assess the importance of faster running. (2) Was it feasible to introduce such devices when trains might include private wagons? Could traders be induced to follow suit? A great deal would depend on whether the railway company concerned possessed a complete monopoly of the trader's traffic and whether they sould prevent another company building to break this monopoly position. In scotland the intense intercompany rivalry may have acted against the railways attempting to force innovations on their clients. It certainly prevented them insisting on demeurrage charges. (3)

It is true that standardisation of rolling stock seems to

1. Alderoft, o. cit., p.167.

2. Ibid.,

3. Ecoñomist, 5 December, 1903. 
have been ignored. In 1918 on British railways as a whole there were no less than two hundred different types of axle boxes and over forty varieties of wagon handbrakes. An official committee in that year claimed that "in no other country has individuality been allowed so much free scope, with the result that British railways are severely handicapped, and the working of them not as economical as it might be." (1) However, if improvements were being made in such devices then a collection of stock built up over time must inevitably include different types. The important point is whether or not the same company was purchasing different types at the same time and, as far as can be ascertained, this was not the case in Scotland. That the locomotive supe rintendents of the various companies might hold different views as to the best practice is understandable, and, although this perhaps hindered inter-changes of traffic, to expect standardisation from rival companies in a private enterprise economy is to expect too much. Not until the firat world war did cooperation replace competition between companies.

It was argued above that the fragmented traffic acted as an obstacle to the introduction of larger capacity wagons, but Aldcroft suggests that this characteristic of the traffic was directly attributable to the railways paying too much attention to the needs of individual customers and encouraging a situation to develop where a client expected his requirements to be met irrespective of the cost to the company and to the economy.

1. Report on the Standardisation of Railway Equipment. 1918. P.3.H.M.S.O. 
Complaints as to the service offered by the railways do not give the impression that this was universal, and where it did occur it could be hazarded that, as in the case of private wagons and non-standardisation, the culprit may not have been management inefficiency but inter-company rivalry. Can management be fairly criticised for being competitive?

Rising operating costs may have played a part in slowing down the rate of increase of net returns on investment. Between 1870 and 1900 operating costs per train mile travelled rose from $25.84 \mathrm{~d}$ to $31.88 \mathrm{~d}$, an increase of approximately $23 \%$. (1) One reason was a rise in labour costs; the average wage per man employed rose from $\$ 58.9$ in 1871 to $\$ 68.9$ in 1901. (2) There was also \& sharp rise in the cost of coal in the 1890 s which was primarily responsible for increasing the cost of locomotive power per train mile from 6.77 d between $1886 / 1890$ to 3.49 din the period $1896 / 1900$. However, it should be pointed out that $1886 / 1890$ was a low point and the average for $1872 / 1890$ was $7.48 \mathrm{~d}$. (3)

How did scottish railways fare in this respect as compared with the rest of Britain? Bearing in mind the fact that operating costs may be meaningless as a comparison of performance, because actual performance might bear no relationship to the potential economic efficiency that could be attained, it can be suggested that overall Scottish railways were relatively more efficiently operated than their counterparts elsewhero in Britain. It can be

1. Statisties taken from the Railway Returns.

2. Calculated from wage bills in company accounts and employment figures in census of seotland.

3. Calculated from the Railway Returns. 
seen from Table 3.7 that when costs are expressed as a percentage of total revenue scotland compares very favoursbiy with the rest of Britain, but this nay have had more to do with rate structures and traffic available than relative econoric efficiency. However, as operating costs per train mile run put the Scottish companies in an even more favourable position it seems reasonable to assume that efficiency played some part.

On the revenue side the Scottish companies do not emerge in so favourable a light as can be seen in Table 3. Only Ireland fared worse and this country had needed financial assistance from the Treasury to build its network as it was expected thet the returns would not be high enough to attract private investors. Still it should be noted that over the last thirty years of the century the rate of growth of scottish receipts, either per train mile run or per nile of track in operation, was greater than for the other countries.

The relatively low figures for revenue earned by Soottish railways in the ears immediately following the mania might have been even lower for in too few schemes of the mania ere had "sufficient thought been given to the comparative national advantage to be gained." (1) Fortunately the Board of Trade was there to knock the unfit and ill-advised schemes on the head. They decided that it would be to take too narrow a view to sanction schemes "merely because at a time of unusual excitement, parties were eager 1. Dalhousie Papers. G. .45 , section 7/59, bundle 1, 13 February, 


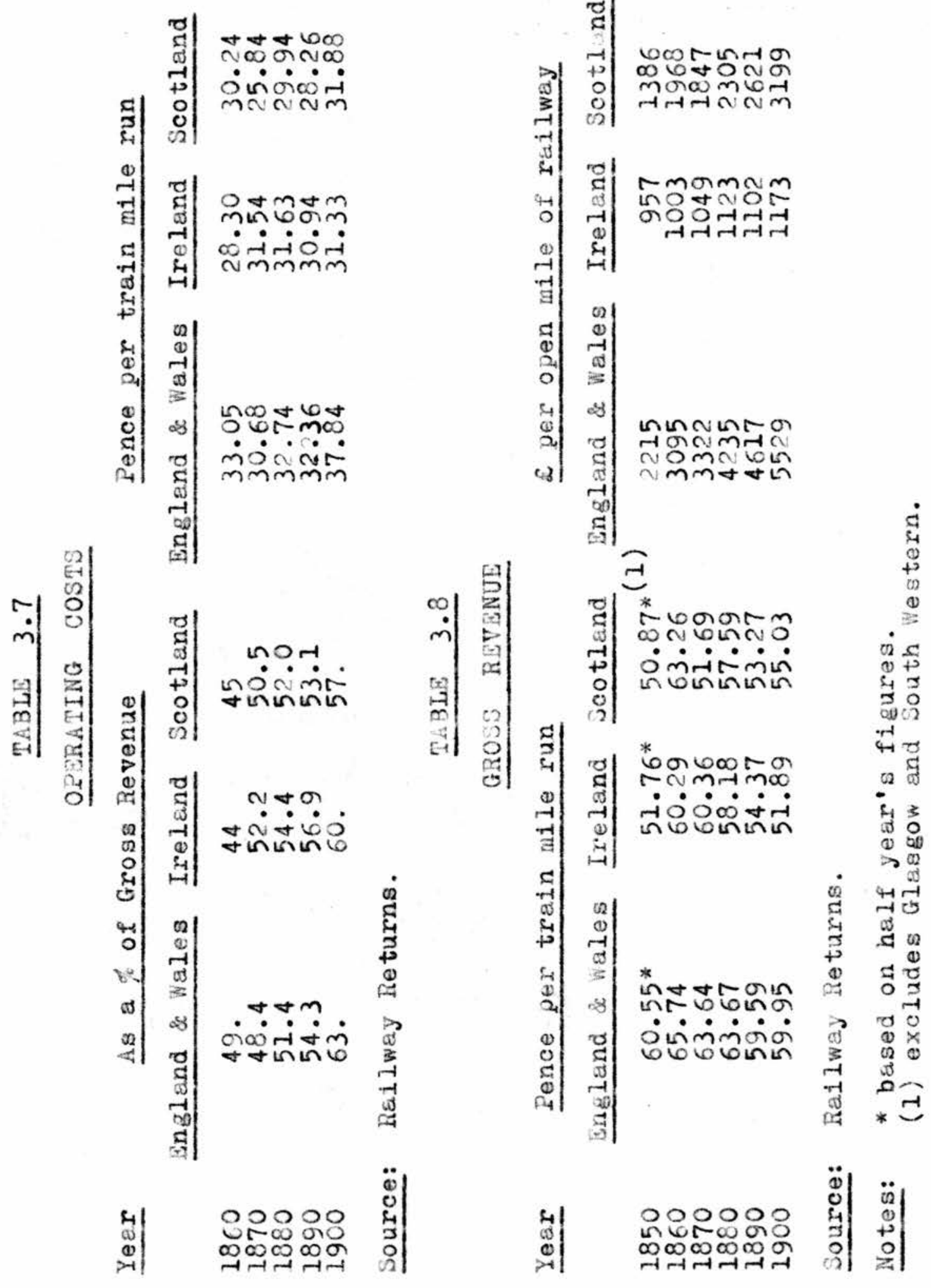


to invest money in the works." (1) Fox-Maule made it clear that the policy adopted by the Board in considering the nerits of any proposal was simply to ask whether a district required a line and whether the project was a good one for that purpose. (2) Such a policy made sure that a certain amount of rationality and system emerged from the mania. They reported that "the Soottish Central line to Perth must be Essumed as the basis of a system of railway communication for the northern portion of Scotland and "it is equally clear that the Aberdeen line is a proper and necessary part of such a system." The link between the two could have been either the Scottish Midland Junction or the Dundee and Perth, but the gaps of the latter in Dundee and Arbroath led the Board to adjudge the former "to be necessary as an integral portion of the Northern line of communication." (3) These and other decisions helped ease, but not completely ameliorate, the chaotic state that private enterprise had brought about. The fact that Scottish railway development had lagged could have made for the creation of a more rationally planned system, but the clash of the main era of proposals with the period of railway madness, coupled with the prevailing concept of the pre-eminence of the individual and freeenterprise destroyed any such hopes.

The result of the mania was to give the Scottish railway map much of its early twentieth century appearance. Wost railway towns were put on the railway network and only the Highlands and

1. Ibia.

2. Ibid., 23 Pebruary, 1845.

3. Mirlie Papers. G.D.16, section 38/82, bundle 1, 10 March, $1845.3 . \ldots .0$. 
the far south west were completely devoid of railway communication. Yet it could be argued that, in terms of the utilisation of scarce resources, the position had been achieved too expensively. The North British had a trunk line and virtually a loop line from Berwick; the Caledonian and the Glasgow and South Western both ran from Carlisle to Glasgow; the original Edinburgh and Glasgow faced competition from branches of the Caledonian; the Scottish Central was looped by the Edinburgh, Perth and Dundee and the Stirling and Dunfermline; and Arbroath could be reached from Perth by either the Scottish Midland Junction or the Forfar branch of the Aberdeen company. In time these duplicate lines may have been needed, but, as the revenue figures indicate, they were not essential when first built.

Throughout the century in fact it was argued that lines were being built that were scarcely paying their way, if indeed they reached the break even point. Ashworth's assertions have already been discussed, but contemporaries did not restrict their criticisms to the north of Scotland. Chattaway, at one time an official of the company, wrote of the North British directors promoting "several branches which it was thought would be valuable feeders to the main line. They have proved to be the very opposite, and have sucked it financially dry. The undertaking is consequently in a prostrate position, paying no dividend, and its 2100 stock now selling for \$29." (1) Later in the century the same company received the strictures of a Scottish journal which proclaimed "more than half

1. E.D. Chattaway, Railways-Their Capital and Dividends. 1855. p.26. 
of the North British is made up of branches to mouldering old towns and cross lines over hills sacred to sheep and wandering botanists." ( 1 )

Unfortunately the information to hand does not allow any decision to be made as to the relative productivity of branch lines. An analysis of station receipts on the Caledonian system in 1900 shows that $4 \%$ of the stations produced $48.9 \%$ of the goods revenue and $1.8 \%$ produced $46.7 \%$ of the passenger revenue, whereas at the other end of the scale $12.4 \%$ of the passenger revenue came from $68.7 \%$ of the stations and $17 \%$ of the goods revenue came from 79.5\% of the stations. (2) However, without details of the comparative costs of construction and operation, it is impossible to say whether the larger stations were more productive than those on branch lines. That only 166 miles of track was closed to passengers during the nineteenth century could imply that branch lines were not as unproductive as was suggested. (3) On the other hand all it may mean is that the railway directors simply did not know the relative merits of their branch lines. It may be of significance to the latter point that nearly half the closures were implemented by one company, the Glasgow and South Western. When road competition intensified in the twentieth century the Scottish railway system was rationalised a little, over 360 miles being closed to passengers between 1900 and 1939. Still in the

1. The Rialto, 30 Warch, 1889.

2. Calculated from CAL 4/88. B.R.

3. M.D. Greville andJ. Spence, A Handbook to Closed Passenger Lines of Scotland. 1963. 
1950s it could be stated by a Ministry of Transport official that "We find one of the most difficult things in the Ministry is to discover where money is actually lost - it is very difficult to get an answer to that." (1) Judging from the state of the account books this was no easier a task in the nineteenth century. The operating of branch lines with a lower intensity of traffic than elsewhere was perhaps one reason for the rate of growth of gross revenue failing to keep pace with that for operating costs. Dr. Aldcroft also suggested several other factors that were at work, not all of which can be 'proved' because of the nature of the statistics kept by the railway companies. Firstly, he argues that much of the traffic on the suburban lines was less profitable than had been anticipated since a good deal of it consisted of workmen travelling at reduced fares. In addition peak hour travelling necessitated extra outlay on rolling stock and labour. The argument is theoretically plausible, but that ex-post and ex-ante results did not coincide does not mean that the railways as a whole decreased in productivity for the level of profitability on suburban lines could still be higher than the average. However, on the evidence of the one suburban railway for which both capital and revenue statistics are obtainable, the City of Glasgow Union, it can be suggested that this was not the case. In 1895 (the last year for which figures are available) the capital output ratio was $22 . ?$ if a fifty year depreciation period was taken which compares very unfavourably with the average

1. P. Donaldson, Guide to the British Bconomy. 1966. p.101. 
for Scotland. It can also be suggested that the reason for this lay more in high capital costs, through having to purchase urban property, than in low revenue.

Secondly, he suggests that the nature of the traffic was changing towards a greater number of small consignments and shorter hauls which tends to raise the costs of handling. This was most likely true, but the statement must be conditioned by the fact that, if the character of the traffic was moving in this direction, then gross revenue would gain because of the rates structure which penalised short distance, low volume freight.

On two further points Dr. Aldcroft is on much firmer ground. Firstly, he suggests that an increasing proportion of the railways' total traffic consisted of the cheaper grades, especially coal, which was carried at a very low margin of profit. For Scotland, minerals (it is impossible to differentiate coal) in volume terms accounted for $74 \%$ of total merchandise traffic in 1861 and $80 \%$ in 1901. In revenue terms the figures were $44 \%$ and $48 \%$ respectively. (1) Both sets of statistics lend some support to his hypothesis. Even more soundly based is his second point that the railways were providing a far wider range of services, often at very little extra cost to the customer. Examples of this were the introduction of corridor trains, dining cars and sleepers, all of which increased tare weight and necessitated bigger locomotives, which in turn led to heavier and more expensive permanent way being required. (2) Price increases were limited by the sanctioning

1. Calculated from Railway Returns.

2. T.E.S.S. 1898/99, p.99. 
Act, but there appears to have been a margin to work in. However, after the Railway and Canal Traffic Act of 1894 price increases had to be justified to the Board of Trade and the deficiencies of the railways' costing techniques made this a difficult proposition. In addition the competition between companies throughout the period would act to keep prices down. Competition in fact was the reason for the introduction and extension of these extra facilities. (1) Intercompany rivalry also led to the running of duplicate trains which by misutilising resources was detrimental to productivity. One such burst of competition roused the Sconomist to coment "if the Scotch companies will give aditional accommodation to a diminishing traffic they must take the consequences." (2) It should, however, be noted that although profits may have been affected by the provision of extra facilities, this was not necessarily true of social returns.

Even if the least productive line proved to be viable this does not infer that optimum use was made of resources. It is especially argued that capital was wastefully expended in ostentatious building, in competing for scarce resources needed for construction, and in paying excessive amounts for land, compansation, and parliamentary and legal expenses.

One reason for heavy, and probably excessive, capital expenditure was that the British bore the costs of being first in the field. As pioneers they had to allow a wide margin for safety

1. See e.g. Railway Times, 5 October, 1878.

2. Economist, 27 September, 1879. 
and in addition the developments in civil and mechanical engineering that would allow sharper curves and steeper gradients to be constructed were yet to come. (1) This feature was common to all Britain but other reasons for heavy. expenditure in the years before (say) 1850 may have been more important in Scotland, as one railway journal claimed that "no country (had) been so frightfully extravagent as the Scotch in the construction of their lines."

However, a lesson must have been leamed for in 1865 it could be written, admittedly by a Scottish railway official, that "a railway engineer assures us that he cannot make lines so cheaply in England as in Scotland, because English directors insist on having fine stations, and will not generally work unless they have some special advantage in view; while in various instances, Scotch directors, from some local patriotic feeling, not only exact no remuneration, but are satisfied with stations and other equipments of a very modest description." (3) Ostentation, however, was perhaps not a major influence on the capital account even in the earlier years, for the North British specifically promised "to avoid all useless expenditure in ornamental works at stations or otherwise." (4) Such was their cheese-paring that many of their bridges collapsed when put under strain and had to be reconstructed. (5) Against this the Glasgow, Dumfries and Carlisle did admit

1. Tooke and Newmarch, History of Prices. 1857. p.381.

2. H.R.J., 15 April, 1854 .

3. W. Chambers, op. cit., pp.87-88.

4. Prospectus, August, 1843 .

5. Newcastle Journal, 24 October, 1844 . 
that "a most unnecessary outlay has been allowed in the erection of several of the stations south of Dumfries." (1)

A more important inflationary influence on the capital account was alleged to be the unregulated competition for resources. Wages of navvies rose by fifty per cent between 1843 and 1846 , and in 1845 the price of Scottish pig iron shot to $\$ 5 / 10$ s a ton from a level of about $£ 1 / 12 \mathrm{~s}$. (2) The Edinburgh, Leith and Granton railway found that between the time that estimates were first made and the opening of the line, workmen's wages had risen one to two shillings a week and the price of bricks had increased from $42 \mathrm{~s}$ a thousand to $68 / 5 \mathrm{~d}$. (3) The competition was intensified by the larger companies pushing their aspirations too high and attempting to do too much in too short a time. The shareholders of the North British were told that if the company had "completed one part for traffic before any great outlay was incurred upon the rest, instead of attempting so large an extent of milage at once, a great saving in interest of money, and probably in salaries to engineers, and prices to contractors would have been made, and earlier returns upon the expenditure secured to shaxeholders." (4) There is, however, no evidence that the pressure on resources was greater in the later part of the century. Another factor rendering the original estimate a work of fiction was that opposition to the coming of a railway might have

.2. H.R.J., 13 April, 1850.

2. I. 3rassey, Work and Wages. 1872. p.28.

I. L. Bell, The Iron Trade of the United Kingdom. 1886. p.7.

3. Report, 23 Decenber, 1847.

4. Repurt of Committee of Inquiry to Shareholders of the North British Railway. 1849. p.6. B.K. 
to be bought off. Purt of the hostility to the railways was that mistrust and suspicion of anything new, characterised perhaps by a Mrs. Hunter of Arbroath who cautioned one poor girl, "it's an awfu' thing lassie to tak your mother's corpse on the railroad." (1) Other objections might be more eccentric such as Sir John Henderson's opposition to a station at the east end of Perth as being injurious to the sanitary condition of the town by preventing the free circulation of the river breeze. (2) There may also be something in the claim of the counsel supporting the Glasgow and Paisley Joint Canal Bill in 1870 that "the Scotch always dislike what they do not like, and they consequently always oppose whatever they do not support." (3) However, the most expensive opposition (though not the most determined, for the dogmatic Sabbatarians must surely take this honour) seems to have come from those who saw in the railway a threat to the beauty and amenity of their estates. (4)

In 1817 Charles Oliphant found his railway promotion dashed by the Marquis of Abercorn's agent, Mr. Guthrie Wright, who "being fond of the picturesque, and not deeming a railway an object of beauty" would not give his aid to the project. (5) Eighty years

1. J.M. MaBain, Arbroath, Past and Present. 1887. p.210.

2. Scottish Railway Gazette, 10 May, 1845.

3. TH(S) 1/39. B.R.

4. The Sabbatarians, though not opposed to the building of railways, were violently against them being operated on Sundays. At almost every shareholders' meeting the issue of working on the Sabbath was raised. The Tay Bridge disaster was even attributed to sunday travelling. (H.R.J., 27 March, 1880). Their successes in obtaining the suspension of limitation of Sunday operations must have affected productivity but, over the century, as companies grew in size and also as mail services developed, their efforts were less successful.

5. G.D.26, section 13/882, 23 September, 1817. S.R.0. 
later the proposal for the Lochearnhead, St. Fillans and Comrie line was referred to a special committee on the grounds that it would be projected through the valley of the Earn and"seriously impair the scenic view." (1) In the intervening span of time opposition to railways on aesthetic grounds had scarcely waned. Some like Cockburn protested about "brutal inroads ... on the most sacred haunts;" others insisted on keeping the railway out of sight. The Princes Street proprietors, for example, enforced the Edinburgh and Glasgow to construct an embankment and make "a profuse use of ivy, evergreens and trees" to hide the trains from house occupants." (2) Much of this opposition was genuine, but an element smacked of hypocrisy and greed, such as Wajor James Drysdale of the Jerviston estate whose argument of loss of amenity was somewhat spoiled by him having let a public bleaching ground far nearer to his house then the railway would tres-pass. (3) Most of the opposition however proved susceptible to financial arrangements. (4) In fact it began to be argued that objections were being deliberately raised so as to procure cash from the railway companies. (5) The general thesis that opposition to the railways resulted in excessive prices being paid for land has

1. H.R.J., 23 July, 1897.

2. Tutation of Cockburn in Marwick, op. cit., (Economic Developments) 0.73 .

D. Robertson, The Princes Street Proprietors. 1935. pp.31-46.

3. WIC 4/3, objections in Parliament. 18.9. B.R.

4. Only occasionally did landlord hostility take a physical form in the obstruction or attacking of survey parties. (Scottish Railway Gazette, 22. November, 1845; 29 November, 1845).

5. This was first suggested as far as I have been able to ascertain in 1838 , at least where Scottish railways wexe concerned. (Railway Times, 7 April, 1838). 
passed into railway folklore as "the blackmails of the forties," a phrase coined by Lord Stamp when he was president of the London, Midland and Scottish Railway. (1) The terminology may well have been original but not so the concept. A contemporary railway journal hit out at the Scottish landlords of the mania era:

"The greatest difficulty railway interests have to contend with in Scotland is the unreasonable demands, - nay, the avaricious cupidity of the owners of the soil. The most sterile patch of the Ochills, the bleakest moor in Nithsdale, the craggiest acre within the shade of the Grampians, touch it but by a railway, and you will hear of land valued at $\$ 3$ an acre that never yielded as much grass as would suffice for a weeks summer keep to a shetland pony. Spoiling the view from the hall, "laying open the privacy" (a favourite phrase) of a gentieman's residence, coming too close to a rabbit warren or smoking the gude wifes washing, are but a few of the items manufactured in 'railway claims shops." (2)

Overall it was officially estimated that land had cost the railways at least one to two thousand pounds a mile in excess of its true value and unofficially that "railway companies have in the majority of cases paid from ten to a hundredfold beyond the legitimate value of the properties purchased by them." (3)

Clearly the market position was in favour of the seller as the railways needed the land as an essential prerequisite of constructing the way and the works. A narrow strip of land would have little agricultural value in its own right and thus the price paid by the rallway companies must have included a fair proportion of economic rent. The Scottish Central, for one, found that

1. W.V. Wood and J. Stamp, Railways. 1928. p.12.

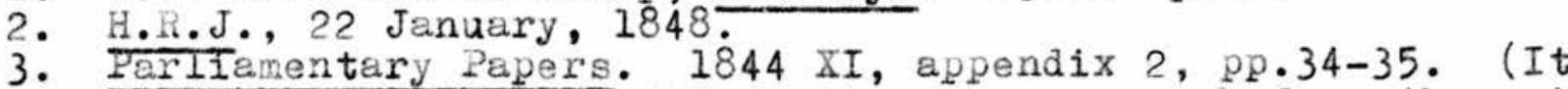
should be noted that this estimate was maue before the railway mania).

Chattaway, op. cit., p.24. 
"claims were pressed, not merely on the ground of the value of the land, or the injury it would suffer, but on the ground that the Company could not do without it." (1)

Individual landlords did well out of the railways. Sir George Douglas epitomised the accepted picture of the rapacious landlord. He was originally opposed to having any railway pass over his property (but feared to oppose any project in parliament because of the expense), but finding that both the North British and the Caledonian were promoting lines he eventually, by playing off one company against the other, concluded "one of the most favourable railway transactions ever made in Scotland" in which he obtained $£ 25,000$. This was not the end of his railway enterprise for a year later he managed to extract $₫ 700$ above the railway company's original offer of $£ 6,000$ for ground at Springwood Park though he "did give the Railway People a good bargain of the quarry (for) it is all found money and but for the railway wo uld probably never be used." Whilst freely admitting that the line would probably benefit his estate, and knowing that the railways were in financial difficulties, he still drove a hard bargain and "received more Railway Compensation than any other proprietor in Scotland." (2) Although Sir George was an extreme case, literary evidence of other landowners, more so those who had few mineral deposits on their estates, exploiting the railways is not hard to come by. On the other hand there is also abundant evidence of landowners actively supporting railway schemes and selling

1. H.R.J., 17 March, 1849.

2. Ms.8084, 14 January, 1845; $28 \mathrm{July,} 1846 ; 8$ August, 1846; 20 JuIy, 1847; October, 1848. N.L.S. 
their property for a nominal figure or at most its agricultural value. (1) Thus more than mere literary evidence is required before support can be given to the blackmails hypothesis.

Henry Pollins has attempted a quantitative study of the thesis and concluded that it ought to be cast on the scrapheap of economic history .

Although "there can be little doubt that, in general, landowners demanded, and very often received, more than the companies expected to pay," an examination of twenty seven companies showed that on average $13.9 \%$ of construction costs (excluding stations and rolling stock) went on land, which in his view was sufficiently low to allow "the conclusion that while individual landowners may have done well out of the sale of land to railway companies - and may have even 'blackmailed' the companies on occasion, the latter nevertheless spent the bulk of their money on the money on the more legitimate side of their business." In fact "British railway companies would have gained if land had been cheaper, but this would not appreciably have reduced their difficulties." (2)

As Pollins' sample included only one Scottish company it was deemed worthwhile to amplify his analysis for Scotland using the original accounts and extending the time range. The reason for this latter move was because a reading of the annual directors' reports does not give the impression of blackmails being confined to the mania period of the 1840s. Utilising as many original accounts as possible, land and compensation costs were computed

1. On this see J.T. Ward, 'Scottish Landowners and the Railways: A Preliminary Note.' Scottish Railways. No.2.

2. H. Pollins, 'A Note on Railway Construction Costs 1825-50,' Ecohomica, vol.XIX, no.70, November, 1952. 
as a percentage of the total spent on works and land (excluding rolling stock, but, unlike Pollins, including stations).

Six year periods were considered most likely to yield adequate results over time whilst reducing error caused by the expenditure on land usually preceding actual construction. Allowance was also made for land bought for purposes other than railway construction and for land bought and later sold. (2) Until the format of accounts became standardised allocation of conveyancing costs might have been classed under land or legal expenses but little can be done about this. Pollins also pointed out that many land purchases were made on the condition that "accommodation works" would be provided. Such works could legitimately be considered as compensation, but most probably they are included as construction expenditure. An estimate of such costs is impossible as contracts were usually awarded for a whole stretch of line. It can, however, be assumed that Pollins was justified in claiming that "the margin of error is unlikely to be so high as to reduce the analysis to absurdity." (3)

In the absence of a norm, any attempt to decide if land costs

1. It is impossible to completely differentiate land costs from compensation in the early accounts, and no distinction at all can be made once the standard format of accounts came in. However, this does not matter for the purposes of the investigation.

2. This was not universally possible as several companies appear to have taken the attitude of the General Terminus and Glasgow Harbour whose shareholders were told, "you will all see the necessity of our not stating at present, what profit we may have made from the sales of land which we have already affected. To do so might expose the affairs of the company too much."

(H.R.J., 10 Bpril, 1847).

3. PoIIIns, op. cit., p.402. 
were excessive is subjective, even in a quantitative analysis, but it is clear from Table 3.9 that if the Scottish railway companies were held to ransom by landed proprietors the period of blackmail was certainly not the 1840s. Even allowing for price changes, later periods witnessed greater spending on land and compensation both in proportion to total construction spending and to milage constructed. It is also apparent that Scottish railways paid a greater percentage of their construction costs to landowners than did the companies of Pollins' model, especially when it is born in mind that his total costs did not include stations. The high figures for the last thirty years of the century can probably be attributed to the building of suburban railways and to the erection and reconstruction of large terminal facilities in Edinburgh and Glasgow. (1) The railway companies of the 1840s refused to allow urban landlords to accumulate windfall profits and settled for inadequate termini which later had to be improved, extended or relocated at great cost. High prices had to be paid for land already allocated to industrial or commercial purposes. (2) The value to the seller in this instance would be much nere than that of agricultural land and in addition an amount for replacement and removal to another site, compensation for the loss of possible developmental opportunities and perhaps an element of blackmail might have added to the survejor's valuation.

1. In Glasgow $10-15 \%$ of the central property was purchased and demolished by the railway companies and by 1880 the Caledonian owned over 160 acres of such land. (J.R. Kellett, op. cit., (Glasgow's Railways), p.354)

2. S.G. Checkland, The British Industrial City as History: The Glasgow Case,' Urban Studies, vol.1, no.1, Way, 1964. 
It is, however, less easy to explain the high land costs of the 1850s. Some of the high percentage is attributable to lower total construction costs (as on the cheap principle) but this could not explain it all. Some may have been due to paying for land utilised previously but there is little evidence of this. Perhaps they are only explicable in terms of blackmail.

It is true that the railways paid more for their land than they expected to. The North British, for example, found their original estimate of 2218,812 inflated to $\$ 571,757$ because the land traversed by their lines was "not only costly for its intrinsic value but (also) on account of the number of noblemen's and gentlemen's residences which have grown upon it and were interfered with." (1) Another reason for the inflation must have been the absence of precedence to guide them in their calculations, hurriedly prepared estimates in order to beat Board of Trade deadines and, of some significance, the support given by the legislature to the principle of compensation on top of the cost of the land required.

1. Report of the Committee of Inquiry. 1849. 3.R.

2. A Select Committee of the House of Lords on Compensation for Lands taken or injured by the kai ways (1845 X) reckoned that not Iess than $50 \%$ should be added to the mariket value on the grounds of the sale being compulsory. In addition they gave the green light to those who feared loss of amenity by declaring that in many cases the land taken should be considered "not merely as a source of income, but as the object of expensive embellishrent, and subservient to the enjoyment and recreation of the proprietor... Public advantage may require all these private considerations to be sacrificed; but as it is the only ground upon which a man can justly be deprived of his property and enjoyments, so, in the case of railways, though the public may be considered ultimately the gainers, the immediate motive to their construction is the interest of the speculators, who have no right to complain of being obliged to purchase, at a somewhat high rate, the means of carrying on their speculation." 
The railway companies were not altogether blameless in the escalation of their land accounts for they frequently gave in to a demand in their anxiety to secure support, reduce opposition or avoid a parliamentary contest. The tutors of the Barl of Rothes were not untypical in threatening the Leslie railway with parliamentary opposition unless they received a good price for the land needed by the company, yet they were only following a trend established with the connivance of the railways; "the success of one rapacious claimant ... doubtless, enticed others to prefer similar unjust demands." (1) Frecedent may well have been a cogent factor in the magnification of land costs later on in the century .

In view of the actual figures why should so much emphasis have been placed on the 1840 s as the period of blackmails? The answer probably lies in the novelty of the railways. The 1840s was the era of railway development. Although there had been specific complaints of landlord exploitation before, the majority of lines previously constructed were essentially designed to develop mineral resources and accordingly received support from the landowners involved. (2). With the railway mania, however, most of the lines proposed were not primarily aimed at exploiting mineral deposits and in addition the competition between companies to obtain routes inust have bid up land prices. So, for the first time, there was a widespread experience of high land costs which

1. Railway Rines, 15 November, 1851; 7 April, 1838.

2. Railway Mimes, 29 Septe ber, 1838; 7 Septerber, 1839; 15 February, 1840 . 
gave rise to the blackmails hypothesis. Lending support would be the publicity given to the extravagent claims by the not unbiased railway journals, many of them products of the mania themselves. Land prices did not fall over time, but although the railways continued to complain that they paid more than the market price for land, the issue was dead, for the 1840 s had established this as normal procedure.

Using a Parliamentary Return (1859 XXIII) Pollins also showed that the majority of companies has preliminary expenses amounting to less than $5 \%$ of total constructional outlay and concluded that "the financial results of the difficulty of obtaining Acts were not important and may be dismissed as an annoying interlude in railway financial history." (1) However, an analysis employing the original accounts reveals a slightly different picture for Scotland as can be seen in Table 3.10. The proportion of expenditure going on preliminary expenses before 1860 is higher than that estimated in Pollins model. One reason was that the Blue Book employed by Pollins dealt only with existing companies whereas the computations involving the original accounts included lines which were authorised and later abandoned. The proportion spent directly on Parliamentary costs would be lower than the figures given in the table as "preliminary expenses" can include surveys, maps and the general costs of promotion, but still to spend over $8 \%$ of construction outlay between 1841 and 1860 on preliminary costs seems an excessive waste of capital. A North British share-

1. Pollins, op. cit., p.402. 

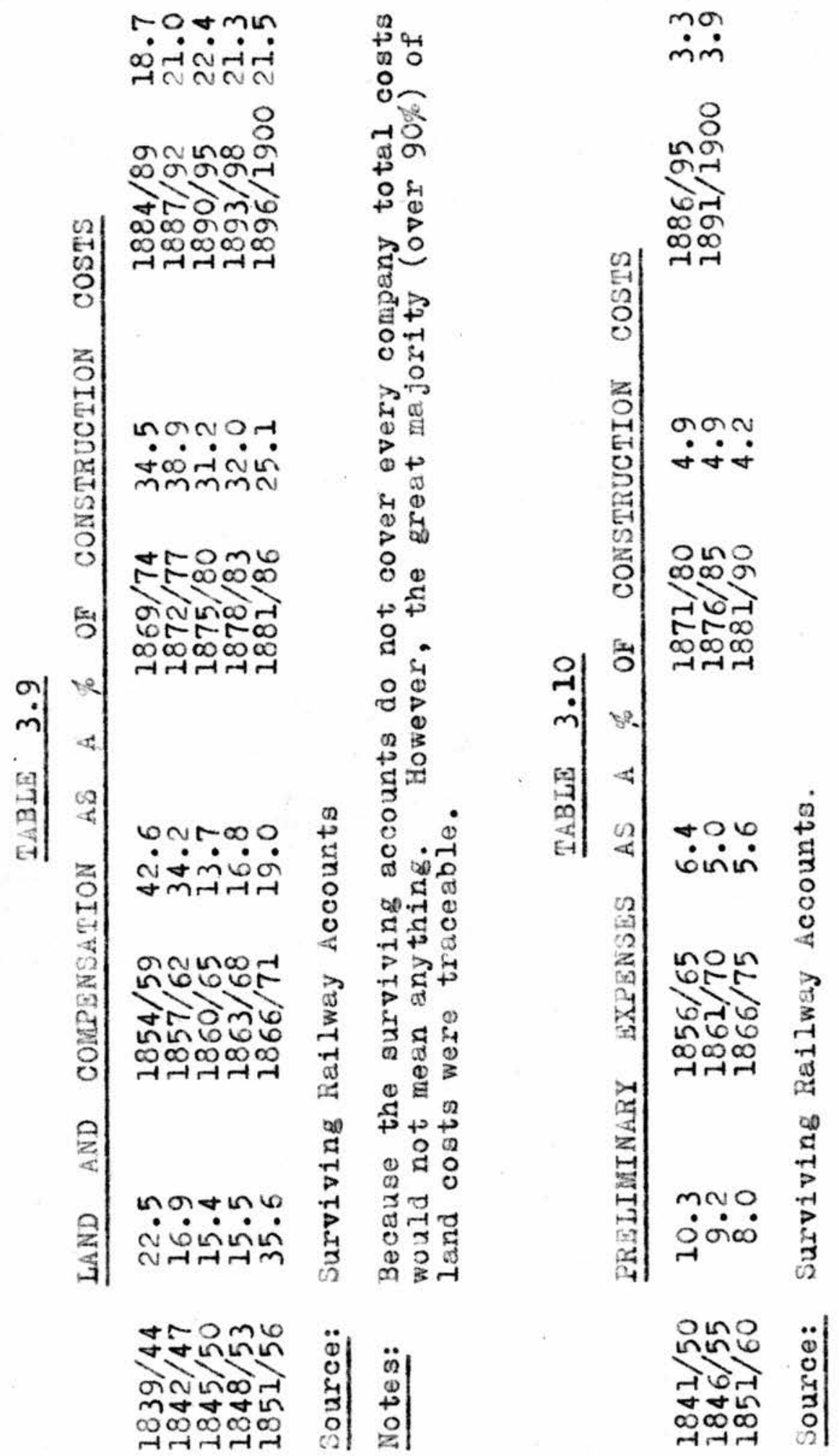
holders' investigation in the 1860 s summed up the situation with respect to that company, but their conclusion is most likely valid for other companies:
"An important item of the Company's obligations consists of Preliminary and Parliamentary Expenses incurred in consequence of the rival aggressions, undue competition, and too rapid extension, that have characterised the policy of this and other railway companies ... Part of this outlay was undoubtedly necessary, and might at the time it was entered upon have been consi dered justifiable; but the Committee are satisfied that a very large portion of it has been unnecessarily incurred, and produced no corresponding beneficial results to the Company." (1)

over time there is an apparent decline in the proportion of capital going on preliminary expenses though some of this is attributable to a change in the accounting policy of several companies who began to pay certain expenses from revenue.

Overall it can be suggested that land costs, parliamentary expenses and preliminary outlays contributed to a lowering of the productivity of railway capital. In successive decades from 1840 the percentage of construction costs channelled in their direction totalled approximately $28 \%, 42 \%, 21 \%, 38 \%, 27 \%$ and $26 \%$ of course the effect of this on the productivity of the economy would depend on what happened to the money received by the landowners, parliamentary agents, solicitors, lawyers, surveyors etc. and unfortunately no data is available on this point.

Further misdirection of capital resources might have stemmed from the ancilliary projects undertaken by the railway companies. In the period 1840 to 1900 about $2 \%$ of Scottish railway capital expeniture went on ancilliary investment. Even more went on the

1. Report of the Committee of Investigation, 15 November, 1866 . p.9. B.R. 
purchase of existing assets but this was not a misairection of capital if the financial resources released were invested productively, but, as in the case of land and preliminary expenses, this is impossible to determine. It is also impossible to determine how productive the ancilliary enterprises were in general because the railway companies were not legally required to produce accounts in respect of these undertakings. The Highland claimed that their station hotel at Inverness was "a highly remunerative investment," but the general reticence of the railway companies to produce figures leads to a suspicion that their prime contribution may have been to attract customers to the railways, rather than be directly profitable in themselves. (1)

Overall it can be suggested that there was a significant deviation from optimum use of capital. Chattaway claimed that the actual gross revenue of lines built before 1860 "in almost every case far exceeded the anticipations of the most sanguine," but he should have added that anticipated dividends were well above those actually attained because of excess capital wastage. This was partly because of high land costs and preliminary expenses, but also because the strong sense of company rivalry led to a building of non-essential lines, perhaps some unproductive ancilliary investment, and the offering of duplicate facilities.

1. H.R.J., 7 Mas, 1887; 29 September, 1888.

Further information on the question of ancilliary investment will be found in chapter ten.

2. Chattaway, op. cit., p.22. 
Why the rate of productivity growth fell off is not easy to determine. Perhaps it was inevitable since the rate of growth of traffic on existing lines was ultimately dependent upon the rate of growth of the econony, and this was slowing down. The building of lines in the north, and later the construction of suburban railways, probably played a part. Rising operating costs and the trend towards a greater proportion of minerals in totel traffic would also make a contribution. Finally, as traffic developed on the existing lines pressure would be put on capacity and the problem of inter-relatedness run up against. This would take time as the post-mania construction bequeathed Scotland a good deal of excess cepacity which could be utilised as demands on the system increased.

Whether the multiplier effects of the railway expenditure and the increased accommodation offered to the public outweighed the loss to the economy of a diversion of capital from sectors, which may have been laster growth points, is not determinable until more evidence comes to light of the relative productiveness of these sectors or potential sectors. (1) However, the investing public had not chosen these other sectors, whatever their potential productivity, but had opted for railways and, in the absence of government directive, railways it was.

1. If a fair comparison is to be made with railways then the latter's returns should include the savings they enabled others to make. An attempt to ascertain a true rate of rate on railway capital will be made in the concluding chapter of this thesis. 


\section{GHAPTER FOUR}

\section{RAILWAYS AND BNGINEERING}

"Scotch engineers ... were the soundest minded men; they were not in any great hurry, but once having taken up a thing they prosecuted it steadily."

$$
\text { I.E.S.S. } 1869 / 70 \text {. p.160. }
$$

"The railroad at the crossing of the canal will be immersed from three to four feet under water."

Criticism of plans of Grainger and Miller for Kilmarnock Railway. 1836. Mitchell Library. 398109 .

"The (Tay) bridge was opened without any knowledge or observation on his (General Hutchinson of the Board of Trade) part of wind on the structure."

$$
\text { T.E.S.S. 1879/80. p.150. }
$$

\section{1.}

Engineering was one of the supplementary growth sectors singled out by Rostow as responding vigorously to the development of the railways. (1) However, engineering is a heterogenous industry and thus the impact of the railways must be analysed on a sectoral basis. In this section the influence of the railways on scottish civil engineering will be examined; in sections two and three mechanical engineering will be looked at; and finally the interrelationships between railway and other branches of engineering will be discussed.

1. Rostow, The Stages of Economic Growth. 1963. 55. 
Unfortunately yuantification cannot be satisfactorily applied to the civil engineering sector. The structure of the railway company accounts allows a monetary relationship be be established between railways and civil engineering only as a residual of capital expenditure after the costs of rolling stock, land and preliminary expenses have been deducted. This figure is so inflated by items not strictly of a civil engineering nature as to be of little, if any, value in the context of the inquiry. Any assessment of the effects that the railways had on civil engineering must therefore be confined to a qualitative consideration of some important issues - where did the engineers come from? Were any new engineering concepts devised as a result of railway developinent?

The majority of Scottish civil engineers employed on the early railways perhaps gained their engineering experience in road construction. William Paterson, engaged on the Slamannan in 1836 and later to build much of the Highland system with Joseph Mitchell, concurrently plied his original trade of road engineer. (1) Mitchell himself had been in charge of harbours and roads in the seven northern counties for several years before he turned to railway engineering. He too continued as surveyor of the Highland roads at the same time as pursuing his railway work. (2) His brother Alexander, employed by the Scottish Central and later the Dunblane, Doune and Callander, had superintended seven hundred miles of roads in Perthshire prior to these

1. Scotsman, 31 Nay, 1881.

2. Hercairney Papers. G.D.24, section 924, 2 March, 1844. S.R.0. 
appointments. (1) A third brother, Thomas, became resident engineer on the Slamannan line in 1837. (2) The engineering team responsible for laying out the greater proportion of scottish railway mileage before 1844, Thomas Grainger and John Miller of Glasgow, was initially concerned with road construction, and, in the absence of sufficient rallway work to keep them fully employed, continued for a while to survey roads. (3) Not all the early engineers were originally road makers e.g. Dunn of the Dundee and Newtyle was a colliery viewer and mineral surveyor. (4) However, although data on the origins of the early engineers is difficult to come by, it can, in the light of available information, be hazarded that the links between road and railway engineering were fairly strong.

Discussion so far has centred on Scottish engineers, but a substantial proportion of the civil engineers planning Scottish railways before 1850 were English, especially where major lines were concerned. One reason for this was the lead in technical knowledge gained by English engineers because of the earlier development of railways south of the border. George Stephenson was in high demand as he could give "the best possible information. (5) A second reason stems from the first. Frequently

1. Ibid.

2. Report of the Slamannan Railway, 9 February, 1837.

3. Prior to the railwa mania these two men were concerned with surveys of the Monkland and Kirkintilloch, Garnkirk and Glasgow, Ballochney, Paisley and Renfrew, Arbroath and Forfar, Dundee and Arbroath, Glasgow and Ayr, Edinburgh and Newhaven, and Edinourgh and Glasgow railways. Report on the Best Foad from the City of Glasgow to Ayrshire. 1829. Mitchell library.

4. Airlie Papers. G.D.16, section $38 / 77$, bundle 3, item 1. S.R.0. 5. Castlemilk Muniments. 14 October, 1825. N.L.S. 
"a neutral English engineer of eminence" was called in to arbitrate when disputes arose as to the best possible route. (1) However, undoubtedly the major reason was connected with the financing of the Scottish lines. George Stephenson was asked to advise on the Garnkirk and Glasgow "with the view of giving every confidence to the public," and this device of getting famous English engineers to associate their names with a Scottish project gained in popularity as lines became longer and needed more than local finance. (2) When funds had to be attracted from afar it proved useful to employ men who had already earned themselves reputations as successful railway engineers. It was maintained by the directors of the Scottish Central that "the shareholders at a distance would not have confidence unless the responsibility rested with a person known to them such as Mr. Locke." (3) These distant shareholders, especially the English, would have heard of Locke, Errington, Rastrick, Vignoles, Stephenson and Cubitt, whereas even Grainger and Miller had not yet made a name for themselves outside Scotland.

It must be emphasised that the English engineers were predominantly employed as consultants. On eleven of the twenty-two Scottish railways listed in the 1848 edition of Bradshaw the engineer-in-chief was an Englishman of repute, but on all of

1. Parliamentary Papers. 1837 IJ , p. 155-163. Greenock Telegraph, 28 March, 1898. Mitchell Library. 49419.

2. Castlemilk Wuniments, loc.cit.

3. Abercairney Papers. G.D.24, section 924, 7 June, 1844. S.R.0. Airlie Papers. G.D.16, section 38/82, 5 April, $1844 ; 9$ July, 1844 . S.R.0. 
them the resident engineer was a native scot. The use of the eminent consultant was not new. Thomas Telford had called in William Jessop to discuss the abortive Berwick to Glasgow project of 1811. (1) At times this practice was apt to cause trouble when questions were raised about the degree of responsibility held by the executive engineers. Joseph Mitchell and another engineer both resigned from the Scottish Central when Locke was brought in over their heads. (2)

As time passed the scottish engineers gained in experience and were able to stamp their mark on railway engineering as they had done in other branches of the industry. Thomas Bouch, of Tay Bridge noteriety, was first associated with the Bdinburgh, Perth and Dundee, and then went on to lay out, amongst others, the Peebles, St. Andrews, Leven and Crieff railways and was engaged on the Bdinburgh, Southside and Suburban at the time of his death. (3) The spectacular crossing of the Forth was partially, and the more successful Tay Bridge completely, the work of Scottish railway engineers, as were the two major railways built in scotland in the last decade of the century, the Glasgow Underground and the West Highland line. (4) However, despite the undoubted brilliance of the post-railway-mania scottish

1. 0.S. Nock, The Railway Engineers. 1955. p.39.

2. Abercairney Papers. G.J.24, section 924, 24 April, 1844. S.R.0. J. MitcheII, Reminiscences of My life in the Highlands. 1883. p. 154-157.

3. Railway Times, 12 October, 1878. BSS I/1, P.4. B.R.

4. Railway world, August, $1894, p .267$. The Bailie, I3 September, 1899. The design' for the Forth Bridge was by the English partnership of Fowler and Baker, but the construction was done by Arrol of Glasgow. (Engineering, 28 February, 1890). 
engineers, it can perhaps be suggested that the demise of the truly independently promoted company, and the eventual domination of the established companies in constructional work, gave greater scope for the employment of this talent than if newly promoted companies were constantly attempting to attract investors by virtue of the names associated with their projects.

The early flow of experience from road to railway engineering may have shaped the principles of the latter craft for the first lines were made as level as possible. Yet this was also conditioned by the state of mechanical engineering: not until engine efficiencies were improved could length and steepness be combined. Locke did change his mind about the difficulties of the Beattock summit and was justified in his retraction, but Nitchell's crossing of the Grampians had to await more powerful locomotives. (1)

Both the constructional techniques and materials of the road makers were initially adopted for railway bridges, but proved to be inadequate. (2) Incompetence may have accounted for one briage on the North British which "fell no less than three times before it was completed," but in fact nowhere more than in bridge

1. Stephenson Locomotive Society, The Caledonian Railway Centenary. 1947. p. 7 .

J. Simmons, The Railways of Britain. 1961. p.59.

2. R.C. Application of Iron to kailway structures. 1849 XXIX, p.xvi. Railway limes, 19 December, 1840. Wany of the early bridges were of timber, partly because of the lack of knowledge on iron structures, but perhaps also because of cheaper first cost. In 1880 there were still twenty-three such bridges remaining on the Northern division of the Caledonian system, but in general timber lost favour as a constructional material for major works soon after the post mania building was completed. (T.S.S.S. 1890/91. p.86). 
building was progress made through trial and error. (1) Cast iron in bridges was not new - Telford had employed in the early nineteenth century - but its use in railway bridges created new problems. (2) Little was known of the effects of variable loading on girder work and technical developments took the form of "a gradual strengthening of parts which had proved by accumulated experience to be too weak." (3) Unfortunately the rapid expansion of the railways gave little time for the assimilation of new ideas and in 1849 it was officially stated that "on the whole the art of railway bridge building cannot be said to be in that settled state which would enable an engineer to apply principles with confidence." There was, the statement continued, "a great want in uniformity of practice."

Once the post-mania construction had been completed, however, the time was available for the consolidation of knowledge and the evolution of general techniques. Cast iron cylinders were adopted for the under-structures of bridgs and viaducts when deep water had to be crossed, as a foundation for piers could be obtained in this way without resorting to the expensive, tedious and uncertain process of coffer dams. Another system that came into use for large bridge foundations was that of the compressed

1. Newcastle Journal, 24 October, 1844.

2. Simmons, op.cit., p.57.

3. P.S.A. Berridge, 'Girder Bridges on British Railways,' Railway Steel Topics, vol.3, no.2, 1955, p.5.

4. R.C. Application of Iron, op.cit., pp.xvi-xvii. Sinilarly, it could be said that there was a considerable difference of opinion between leading engineers of the day as to the laying out of lines. (S.C. Railway Acts Enactments. $1846 \mathrm{XIV}$, q.1250). 
air cylinder within which the pier could be constructed. (I) By 1869 a wide stretch of water had been crossed by the Solway viaduct and it had already been demonstrated that the motion of suspension bridges could be cured by stiffening. (2) The way was clear for the bridging of the great eastern estuaries. (3) Or was it? Tragically the night of 28 December, 1879 witnessed "one of the most appalling disasters that ever occurred." (4) Bouch's design for the high level Tay bridge had been passed by an independent examiner and whilst under construction had withstood gale force winds, but on that gale-swept night it collapsed with the loss of seventy-five lives. (5) Many reasons were put forward to explain the accident, including retribution for travelling on a Sunday, but two stand out, poor workmanshiv and bad design. It is the latter that concerns us here. The allowances for wind pressure were based on calculations made in 1759 which were not at all relevant to iron structures. Although gusts producing a pressure of 40 lbs. a square foot were not unknown, only 10 lbs pressure was allowed for on the grounds that gusts were only momentary. This was completely ignoring the fact that momentary high pressures could have ruinous effects. Whether the initial cause of the collapse

1. T.E.S.S. 1860/61. p.9.

I.E.S.S. 1877/78. pp.2-7.

2. Simons, op.cit., p.77. H.R.J., 26 September, 1857. Scottish Railway Gazette, 27 October, 1860.

3. Definite plans for the bridging of the Firths of Forth and Tay were afoot by 1864. (H.R.J., 5 November, 1864; 10 December, 1864 ).

4. Railway Times, 3 January, 1880.

5. H.K.J., 8 January, 1870; 10 February, 1877. 
was the throwing of the train against the bridge by the wind or the train on the bridge producing a wind resistant surface which was hit by a strong gust, the ignorance of what is now termed the theory of turning moments was bound to be a contributory factor. (1) The bridge was later reconstructed nat a lower level and with alterations and additional works for strengthening the structure thereof." (2)

However, faith in suspension bridges (especially those designed by Bouch) had been shaken and a decision was taken to cancel his contract for a Forth Bridge. (3) In fact such was the impact of the disaster on railway directors that proposals for tunnelling under the Forth were revived. (4) That the Forth should be crossed was deemed imperative and the Tay Bridge tragedy may thus have opened the way to a break-through in bridge building methods; for when built the Forth Bridge eschewed the traditional approach and was a calculated gamble in both constructional technique (being of the cantilever principle) and material (being almost entirely of steel). (5) This was an immense leap forward in bridge architecture as no other cantilever structure in the world had half the span of this bridge, two sections of which were 1,710 feet in length. (6)

1. See the long discussion in T.S.S.S. 1879/80 pp.129-237. Railway Times, $10 \mathrm{July}, 1880$. Simmons, op.cit., p.79.

2. Railway rimes, 26 June, 1880 .

3. Railway Times, 28 August, 1880.

4. Railway Times, 7 May, 1881 .

5. H.R.J., 21 January, 1882; 27 January, 1883. One lesson had been learned - the allowance for wind pressure was now 56 lbs a square foot. (H.R.J., 8 March, 1890).

6. H.R.J., 25 August, 1888 . Engineering, 28 February, 1890. 
Civil engineering techniques, as applied to railway inclines and bridges, were originally based on practices derived from road (and perhaps canal) construction. In tunnelling, however, there was little experience by which to be guided: constructing tunnels was "a novelty" in Scottish transport. (1) Yet little guidance was in fact needed as the Scottish railway system was notably devoid of tunnels - the whole Scottish section of the London, Nidland and Scottish railway in the twentieth century contained only fifteen and a half miles of tunnels - and nowhere in scotland was there a railway tunnel over two miles in length. (2) The reason for this was probably not a lack of knowledge - technology can be imported - but more likely a result of financial necessity. Railways were late in coming to the mountainous areas of the north because potential returns were not high enough to attract investors. By the time these lines were built, developments in mechanical engineering allowed inclines to be substituted for the more expensive tunnels. In fact it could be hazarded that the cost of tunnels was perhaps a factor reducing the potential rate of returns in the first instance. When the Glasgow underground came to be built there were some unique problems to be overcome, but the general principles had already been established elsewhere. (3)

1. R. Stevenson, Report on the Line of Canal Upon one Level Between the dities of udinburgh and Glasgow. 1817. p.I8.

2. J... Gardner, hailway Lnterprise. 1934. p.63. Simmons, op.eit., p.69.

3. Railway worla, August, 1894. pp.269-271. See also articles by G.G. Carey and R. Simpson in T.E.S.S. $1895 / 96$. 
$\mathbb{B}$ Scottish engineer did lay out the first line in Britain upon edge rails, but, after that, scotland had little to offer in the evolution of the permanent way, apart from a few experiments in the hardening of iron rails prior to the coming of the steel rail (1) There were few specifically Scottish developments in tunnelling. In the 1880 s a proposal for a subquacious tunnel to link Portpatrick with Donaghadee in Ireland was seriously considered, but this plan went the way of that for a channel tunnel and scotland's great contribution to civil engineering was restricted to the crossing of the Forth. (2)

\section{2 .}

The claim that early railway engineering "was a young man's game in which there were no precedents to follow" has more relevance where mechanical rather than civil engineering is concerned. (3) The specialised demand of the railways for rolling stock virtually created a new branch of engineering "drawing in some of the older firms and setting up some new ones." (4)

An estimate of the total rolling stock employed by the Scottish railway companies can be built up from figures given in the company accounts, scattered references in company histories

1. S.C. Railway Acts Enactments, $1846 \mathrm{XIV}, \mathrm{q} .993$.

T.S.S.S. 1858759 .

2. Rilway News, 4 September, 1886.

3. rock, op.cit., p.7.

4. 3.R. MitcheIi, The Coming of the Railway and United Kingdom Economic Growth,' Journal of Economic History, vol.XXIV, September, 1964, p.328. 
and specialist railway journals. Where no information was forthcoming, allowance was made by assuming that the total stock on all railways would bear the same ratio to train miles run (goods and passenger) as did the stock of companies for which data were available. The quantitative dominance of known companies renders error from this assumption slight. Renewals were taken as replacements to existing stock and do not include engines which underwent 'heavy' repairs, although "rebuilds," a fairly elastic term inferring the complete modernisation of an engine, have been counted. Conversions of wagons and carriages, of which there were relatively few, have been ignored. Totals of renewals for companies whose records were incomplete or unobtainable were estimated by assuming an average life of 25 years for locomotives and tenders and 30 years for carriages and wagons. If anything these assurations (based on details available in shareholders' inquiries, data as to dates of scrapping in the company histories and a comparison of scrapping figures with those of earlier additions to stock) err on the low side. However, the great majority of renewals are accurate figures obtained from the reports of the various locomotive superintendents. Quantification is not facilitated when one of the major companies, the North British, admits that "a considerable difference exists between actual and reported stocks," but such errors (when known) can be corrected and confidence can be placed 
in the estimates, shown in Table 4.1, after 1850. (1) The figures before this date for locomotives are fairly reliable, al though, because train mileage statistics are not available, no allowance could be made for the few missing minor companies. The main difficulty arises with the coaching and wagon stock as the companies did not generally publish figures before 1850 . Total stock in 1850 was estimated by deducting additions since that date from the total given in the Railway Returns of 1861 (the first year for which Board of Trade statistics are available) and assuming that there was a renewal of all scrapped vehicles. This figure was then distributed between the years 1840 to 1850 in the same proportion as was locomotive stock. At a later date there does not appear to be a relationship, either in aggregate or on a company basis, between the buying of locomotive and other stock, but this may not be so of the initial purchases before the railways began operations.

The problem of private wagons is practically impossible to solve. (2) Undoubtedly such wagons were part of railway demand for if traders had not provided them the railway companies would probably have had to; but unfortunately there is no means of estinating their numbers with any degree of accuracy. That they were considerable is not open to question; the Royal Comission

1. Report of the Committee of Investigation, 14 November, 1866 , p.9.

2. Aithough a principal coalowner put a locomotive and sixty wagons on to the Glasgow, Paisley and Greenock in 1842 (Railway Times, 9 July, 1842), private locomotives were generally confined to the sidings and yards of their owners. The real problem is that of private wagons not engines. 


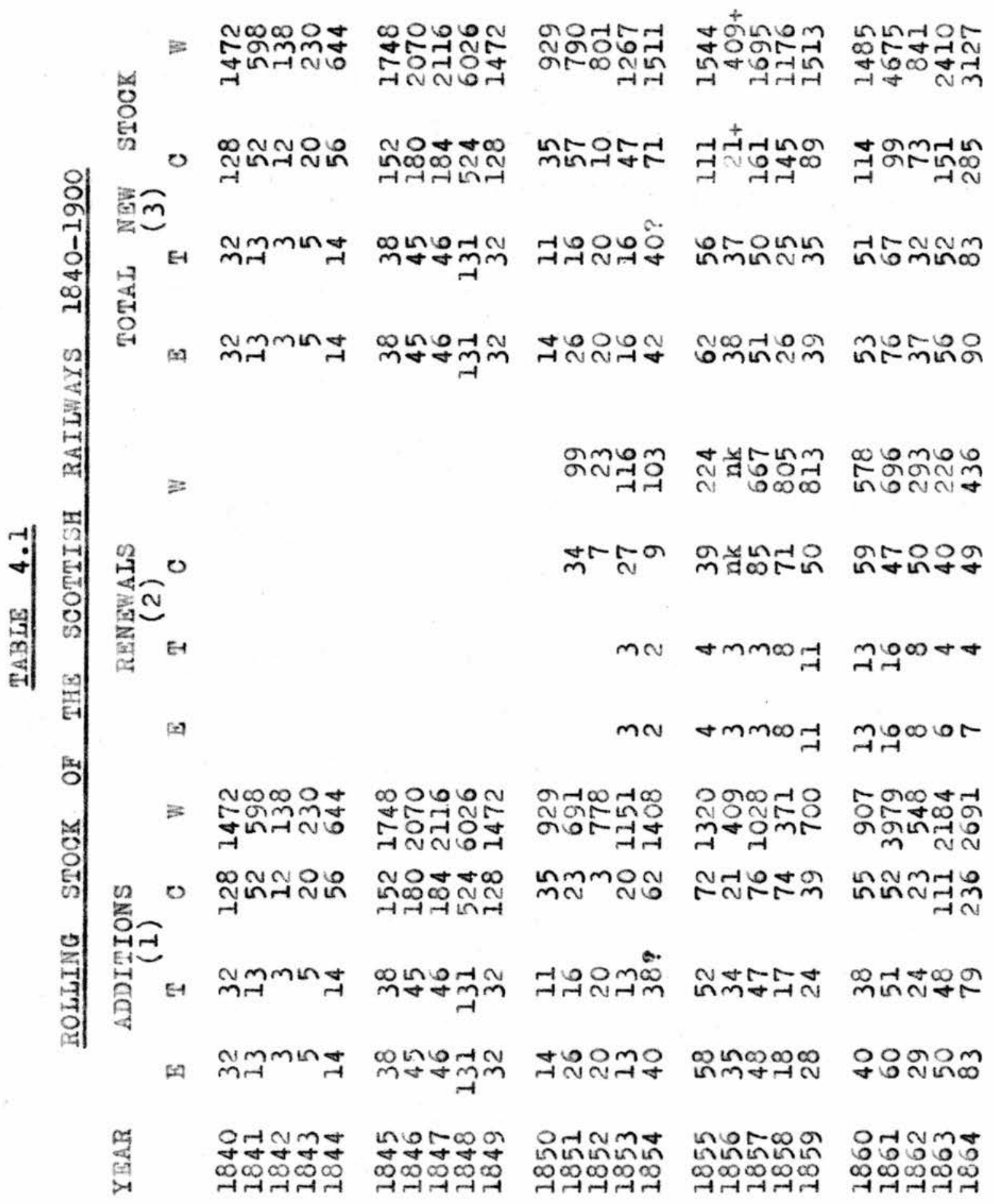




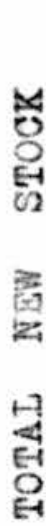

I

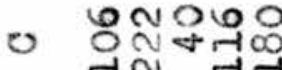

离

z

E) NH+ +4 in $m+\&$

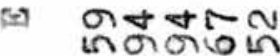
Norin $\infty m-1 \infty$ $m \otimes 0 \otimes \sigma$ in $+\infty \mathrm{mm}$ जा N minmeloot Nio

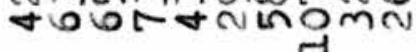

0 CNR O TN Gimo

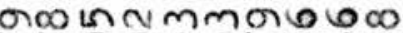

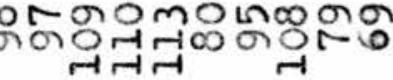

\बाँलि?

HLIN

mom-10 mNN เกษ $4 \infty 0$

Ln molo 600 Tाँ कार $\mathrm{rr}-\mathrm{mm}$

mmNn r

ot ininmin HMN N H HMr

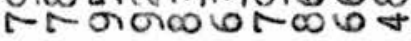

$\infty$ or $-\infty$

- Or noo -100 00 Oाnत का mmmm

Nion तomN $\forall \underset{\text { Gin }}{ }$ Tlo $+\mathrm{N}+\mathrm{ON} 0 \mathrm{NO} \mathrm{Cm}$ मानलम्नलमखN

In $-\infty \neq 0$ minm

mषONH ino in min

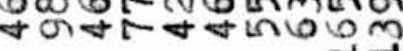
$-1-1-1-1$

$\operatorname{mom}$ 年

Nom

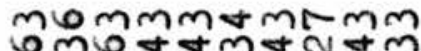
m $\rightarrow$ min

$\ln 20$

\&)

คin

$\infty$ or

* Oorrino

6. 0 m ल

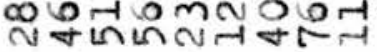

$-1 m+60$

Non

NTM N

in

or $\infty \mathrm{Ni}$

o tImLO N+MTN

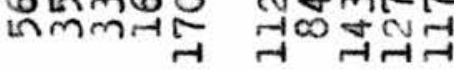

miñ

O NTCO

$\rightarrow \stackrel{+}{+} \omega N$

omodrthimin

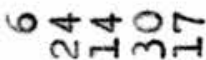

$+\pi+\infty 0$

0 or

$\operatorname{Ln} \rightarrow-10$

भOI

In

1000010 $\infty \infty \infty \infty \infty$

OHNmsing TNTHNTHT $\infty 000000000000$

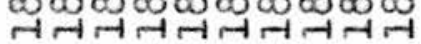

$\mathrm{OrNm}$ 0000000

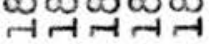
$\infty \infty \infty \infty \infty$
เก $0-\infty$ o $\infty 00000$ $\infty \infty \infty \infty \infty$ 

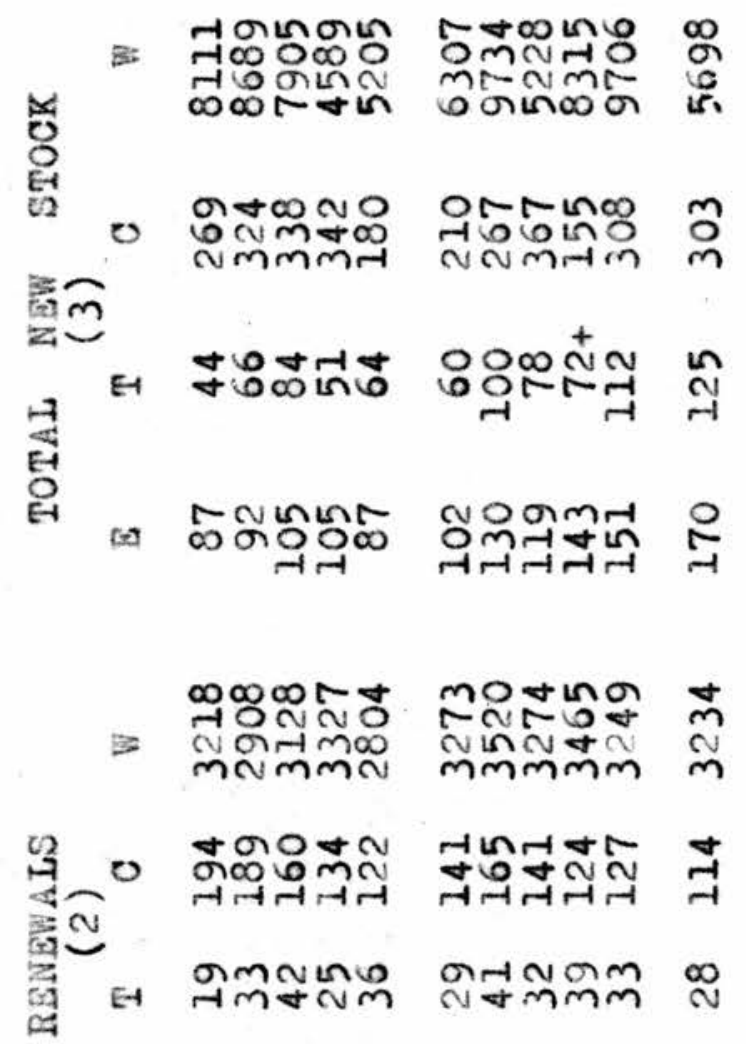

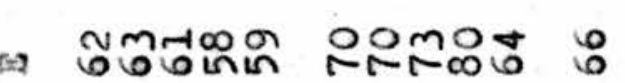
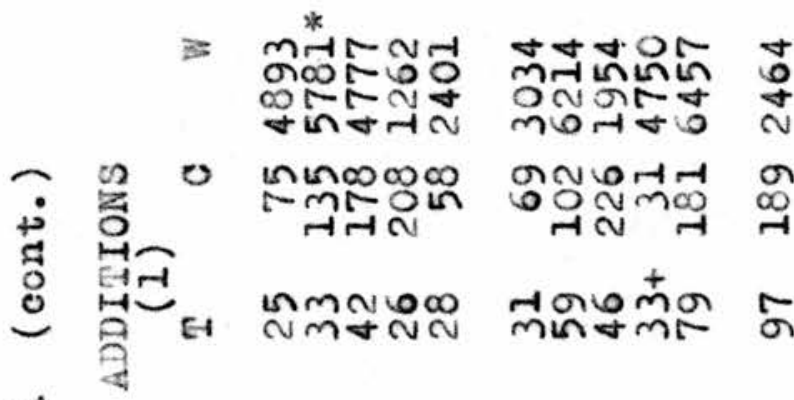

\section{म幺ष}

morto

int

OुO N

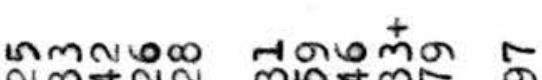

N

mintm

or

$\stackrel{4}{+}$

(2)

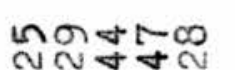

mog

ल्वे

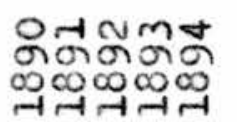

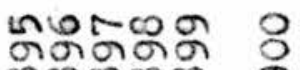

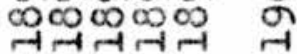

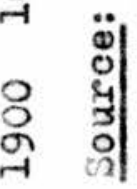

竎

$\stackrel{+}{\text { \& }}$

H

풘

.

is

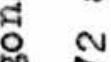

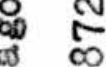

(3) $\infty$

झ

这

()

䩖索

के $\dot{0}$

द्व 0 हो

न1

द

तु

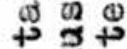

0 व

0 to

का

0 \&

क व

$0 .-1+5$

近

+क्त

ब) व

빔

๑ै व 0

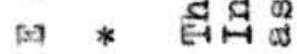

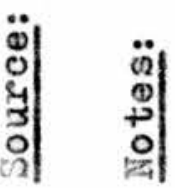


on Railways in 1867 reported that it was "a common case on many lines for traders to provide their own wagons" and in 1898 when the Caledonian owned 63,000 wagons it was reckoned that a further 33,000 traders' vehicles were in ase on that system. (1) In both the early 1870s and early 1890s the Galedonian bought large numbers of wagons from the traders in efforts to improve the efficiency of their service and so it is of little use to attempt to derive a trend from the figures of traders and company stock given in the shareholders' inquiry of $1867 / 68$. (2) In any event there is no justification for assuming that the traders would buy wagons in the same years as the railway companies. In fact it is arguable that they might take advantage of lower prices available when railway demand was not putting pressure on the capacity of wagon manufacturers. Complaints of colliery owners, the major owners of private vehicles, as to a deficiency of wagon supply by the railway companies suggest that the traders were unwilling to make purchases themselves at instances not of their own choosing. (3) Because of these difficulties no attempt has been made to estimate the volume of private stock and Table 4.1 refers to railway owned stock only.

One point that emerges is that by the 1870s renewals were dominating the additions to locomotive stock. The dominance of renewals, however, came a little later in the case of wagons and

1. R.C. Railways. 1867 XXXVIII, p.1xix. dininurgh Lvening Dispatch, 19 February, 1898.

2. RAC(S) $1 / 3-5$. passim. 3.R.

3. S.C.Coal. $1873 \mathrm{X}, \mathrm{q} .1769,1868-9,4799$. Scotsman, 24 March, 7 May, 11 october, 1873. 
carriages, presumably because of the longer life of these vehicles. A second major point is the growing absolute demand for rolling stock; the average number of locomotives purchased per annum in the 1850 s was 33 , and this rose in succeeding decades to 68 , 95, dropped to 82 in the 1880s, but increased to 112 in the last decade of the century. For carriages the respective decennial per annum averages were 81 (ignoring 1856), 139, 210, 246, and 276 and for wagons 1247 (ignoring 1856), 2322, 5413, 5908 and 7379 . The figures for the 1880s are perhaps explicable in terms of previous overexpansion.

It was not of course merely numbers that were important to the engineering industry. In Table 4.2 an attempt has been made to assess the monetary significance of the rolling stock purchases by reference to the company accounts. It is clear that, as the century progressed, replacement demand (generally revenue account expenditure was for replacements, repairs and renewals) came to dominate rolling stock expenditure and exercise a stabilising influence around a strong growth trend of total demand. The decennial per annum averages of total expenditure, with the percentage attributable to replacements in brackets, were, beginning in the 1840s, $2217,000(14 \%), £ 314,000(60 \%), £ 606,000(52 \%)$, $£ 1,002,000(60 \%), £ 942,000(67 \%)$ and $£ 1,512,000(71 \%)$. Unfortunately, it is impossible to break this down into component figures for locomotives, carriages and wagons. (1) However, Mitchell

1. In theory a breakdown could have been done by utilising the numerical estimates in conjunction with a price index derived from the company accounts, but in practice it proved impossible to obtain a satisfactory price index because of difficulties raised by hire purchase and building by the companies themselves. 
त्|

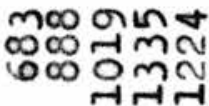

in $+\infty N$ in INT MN

- Tindm

$\infty 0$ mot

$\infty 00 \mathrm{Nm}$

$\infty$ ना 0 \%

inom\&0 $\infty m+\infty$ in $\infty \infty \infty$ or

in เก⿻

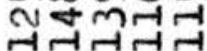

$\mathrm{H} \infty \mathrm{NO}$

in $\mathrm{m} N+$ in $\forall+0$ \%

$-1+6016$ $\rightarrow 0 \operatorname{tin} 0$

ôt In

क MNN

NOmot

rषinmm RNNHE मूO

NOHD\&

तथष

omolnt

Nज⿵

mowinm

+ 100

$\infty$ Hroun

और

(N)

Hन्मा लm

ODN NG

\section{OHNMA INGRCO} $\infty \infty 000$

$\infty \infty \operatorname{li}_{-1} \infty$ $\infty \infty \infty \infty \infty$

ONNM\& $\infty \infty \infty \infty$ $\infty \infty \infty \infty \infty$

1กต $\mathrm{N} \infty \mathrm{or}$ $\infty 00000$

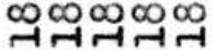

OnNm ตัตा์

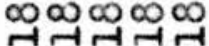

\section{下浪 0006 +}

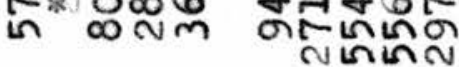

tinnmor ONMNN

$600 \mathrm{mc}$ G०त $\mathrm{N}$ -

$000 \mathrm{NH}$ กIIIN N N NO +mm \& in\&

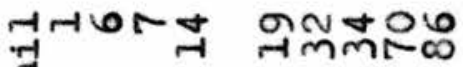

$\infty$ in न्नाम्न

NOm+o Nना-1m NNNN

06เกต +ion $N N N M$

IM int $\mathrm{C}$
DOSTN $\infty$ ON N
$+6 \mathrm{mom}$ NTH

ด NoOr HNMN

\section{0
01}

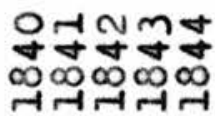

เกตร $\infty \infty \infty \infty \infty$

กำกตั $\infty \infty \infty \infty \infty$

inor-mo thin $\infty \infty, \infty, \infty$,

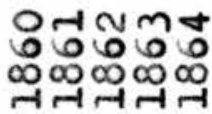



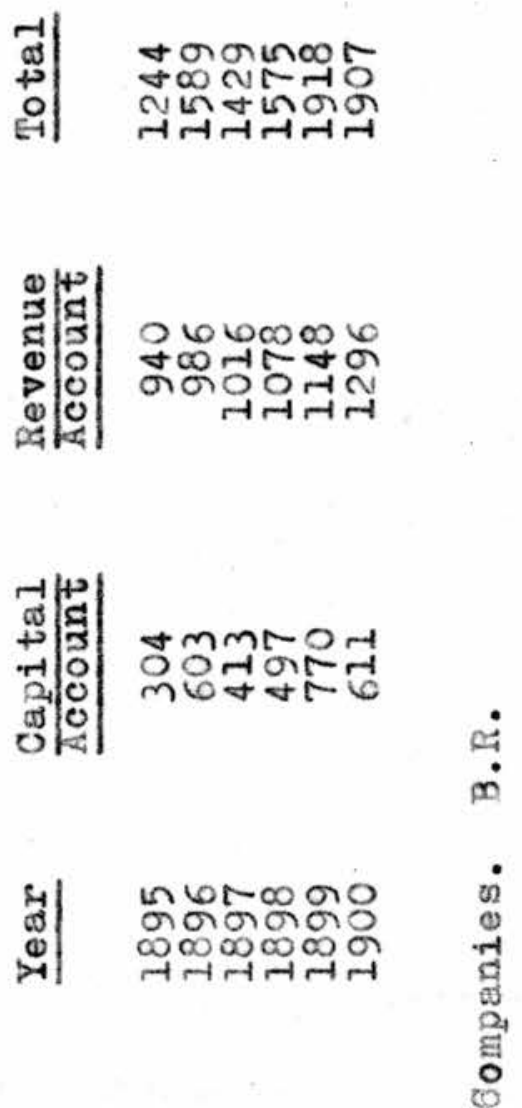

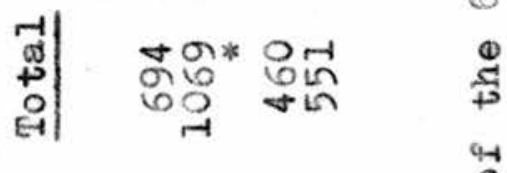
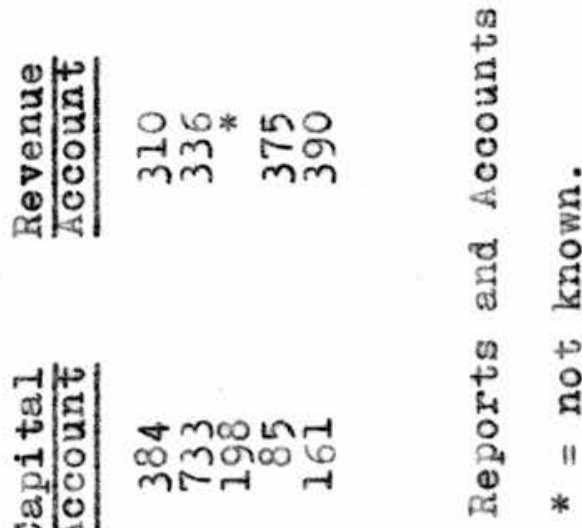

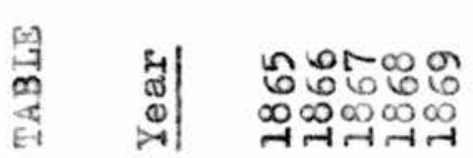

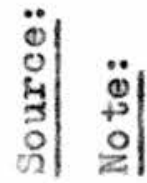


estimates that at least half of rolling stock expenditure went on products of the engineering industry, and on this basis perhaps three quarters of a million pounds per annum were entering this industry from scottish railways in the last decade of the century. (1)

Professor Checkland has pointed out that "as things stood in the (eighteen) thirties it was by no means obvious to promoters that the balance of advantage lay with the locomotive engine, as opposed to the stationary one, or even the horse." (2) This was as true in Scotland as elsewhere. Experinents were made with inclined planes, endless belts and even tarpaulins lashed to the end of carriages so as to take advantage of the wind. (3) However, despite later discussions on the merits of atmospheric railways, the playing of "See the Conquering Hero Comes" at the opening of the Dundee, and Arbroath in 1838 was perhaps indicative of the victory of the locomotive over alternative sources of power. (4) What must now be determined is who supplied the engines to the expanding Scottish railways.

The Garnikirk and Glasgow obtained two locomotives from Robert Stephenson and Co. of Newcastle in 1831. (5) This was only to be expected as English engineers had pioneered rolling stock design.

1. Mitchell, op.cit., p.327.

2. S.G. CheckIand, The Rise of Industrial Society in England $1815-1885,1966.13 .136$.

3. C. Landale, Report on the Dundee and Newtyle Railway. 1825. S.R.0. R. Pike, Railway Adventures and Anecdotes. 1887. p. 78 . Weekly NeW3, 3 November, 1898.

4. Airlie Papers. G.D.16, section 38/82, bundle 1, 19 Warch, 1844 . S.R.O. Railway Times, 13 october, 1838.

5. G. Buchanan, Account of the Glasgow and Garnkirk Railway. 1832. p.9. 
Scottish engineers, however, were not slow to follow. In the same year that Stephenson met this order another Lanarkshire line, the Monkland and Kirkintilloch, obtained "very high satisfaction" from two engines built by Murdoch and Aitken, a small Glasgow firm. (1) Dissatisfaction with the engines supplied from England, coupled with a conviction that they could do better, encouraged several of the ubiquitous Scottish general engineering firms to add yet another branch to their activities. (2) In the areas where railways developed so did the extension of existing firms into the locomotive trade. By 1838 Dundee could claim "a rising trade in locomotives" and in Glasgow over half a dozen firms were engaged in such work. (3) However, as can perhaps be deduced from Table 4.3 , as yet there was insufficient demand from the Scottish railways to encourage any firm to specialise completely in locomotive production.

When demand did increase in the 1840s it was English firms that obtained the bulk of the contracts, though, as is apparent from Table 4.3 , Scottish builders were by no means devoid of orders. The railway boom in England in the 1830 s had enabled specialist firms to be set up capable of attaining economies of scale. When orders were being placed for engines in batches of

1. Report, 1 February, 1832. Mitchell Library.

2. Trid. The locomotives supplied by Murdoch and Aitken were described as "the most efficient engine of the kind ever made" and were never out of operation through structural faults, unlike "the engines procured from England, by an adjoining railway company (which) have repeatedly been taken off the road, on account of needing repairs."

3. Dundee Courier, 9 octoher, 1838. Brief details of Scottish locomotive builders are given in appendix one to this chapter. 


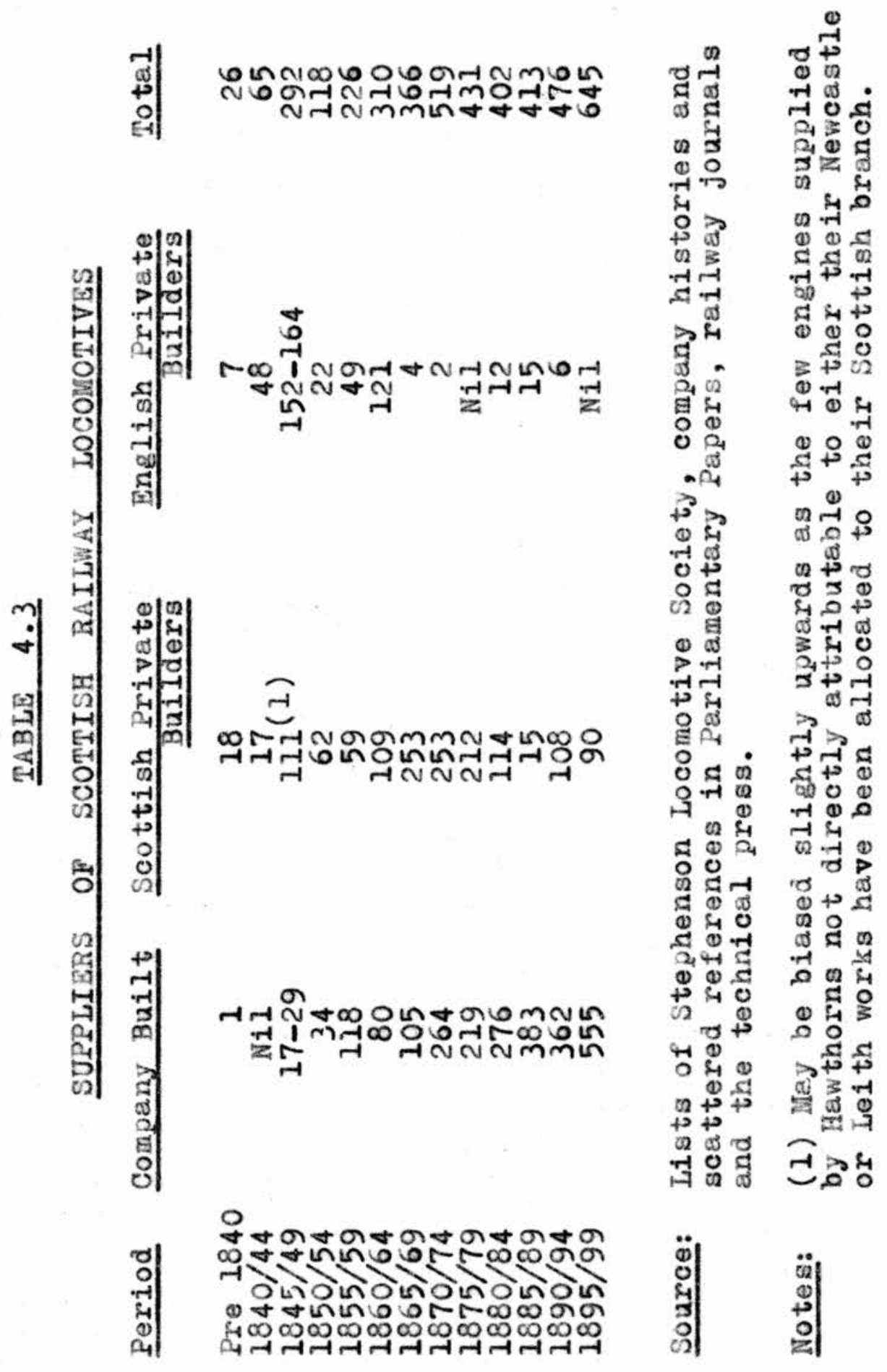


tens, twelves or more, the small firm had little chance in competition with the specialist who culd supply the full order in a shorter time. However, because of the huge post-mania demand for stock both in England and Scotland, the small firm managed to get work for small orders which the specialists, working at, or near, full capacity, were unable or unwilling to take. Though as demand fell off, following the completion of mania orders, the small firms went to the wall as far as locomotive production was concerned; especially as the railway companies themselves entered the ranks of specialist builders. (1)

Only two scottish firms seem to have continued to manufacture railway locomotives. One was Hawthorn and Company, originally the Scottish branch of a Newcastle firm, but an independent works from the early 1850s. The other was Neilson and Mitchell of Glasgow who decided to ease up on their marine and stationary engine work; though leeping it going for several jears, presumably to aid them financially in the early stages of the transformation to exclusive concentration on locomotive production. Scottish railway demand played an important role in allowing these two firms to become established: as far as can be ascertained between 1845 and 1859 approximately 55\% of Neilson's production and 45\% of Hawthorns went to indigenous railways. (2) Neilson's growth

1. J. Mayer, 'Bngineering and Shipbuilding Industries of Glasgow and the Clyde,' British Association. 1876. p.105.

2. Culoulated from Iists supplied by the Stephenson Locomotive Society. The percentage of Hawthorns' production is open to doubt because of the difficulty of distinguishing the scottish from the Newcastle supplies. However, any error acts to minimise the estimate. Much of the information about specific firms will not be footnoted here as its source can be found in appendix one. 
was, however, limited by the difficulty of obtaining competent men and perhaps also by the satisfaction of the companies with existing English suppliers. (1) Even in the early 1860s English private builders were supplying $40 \%$ of the Scottish railways' locomotives.

A second firm set up in Glasgow in 1861 when Dubs, a manager at what was now Neilson's Hyde Park Works, branched out on his own. His choice of Glasgow was probably dictated by contacts and the source of his financial support. This firm also relied substantially on orders from the scottish railways to help them gain a foothold in the locomotive market; in their first four years of production nearly 50\% of their output went to such lines. However, both Glasgow builders were moving into overseas markets and by 1867 it was being prophesied that Glasgow's engineers "bid faix to excel. as much in the construction of locomotives as they now undoubtedly do in shipbuilding." (2)

other Scottish engineering firms, notably those concerned with colliery work, did begin to manufacture locomotives, but they were not attempting to compete with the giants. Although the odd engine was supplied to the railway companies these smaller firms concentrated on the production of industrial locomotives, usually in one-off orders where few economies of scale were to be gained. There would have been no possibility of these companies offering a challenge to Neilson or Dubs without substantial financial backing in order to equip a works capable of rivalling those of

1. Mayer, op.cit.,p.105.

T.E.S.S. $1870 / 71$, p.126.

2. Railway News, 19 Notober, 1867. 
the heavily capitalised Glasgow plants. (1) Dubs himself had obtained such support from Glasgow businessmen, but this was before Neilson's had fully consolidated their position, and, of course, Dubs had a reputation for his work as a loconotive builder.

In 1886 it could justifiably be claimed that "the locomotive factories in the clyde valley ... (are) ... second to none in the world in importance;" two of the largest manufacturers in Britain were now situated in Glasgow along with the company works of the Caledonian and North British railways. (2) And in 1888 a third great locomotive firm set up in Glasgow. This was Sharp Stewart and Company of Manchester who had been involved in engine construction from the 1830s, but whose Atlas Works' lease had now expired. They moved into the available Clyde Locomotive Works of Neilson, who had left Neilson and Company to the care of James Reid after a dispute, but who had been unable to break into the trade on his own because of the satisfaction of the railways with their existing suppliers. (3)

Once the private Glasgow locomotive builders had broken into the English and, of more importance, the overseas markets, Scottish demand was no longer of much significance to them. In fact such work could not have served as a base on which to expand

1. The description of the two great Glasgow factories given in Engineering (18 0ctober; 22 November; 6 December, 1867) shows the impossibility of all but highly capitalised entrants into the trade successfully challenging their position.

2. Senttish News, 18 illay, 2886.

3. The Highland railway and the relatively minor Girvan and Portpatrick were the only Scottish companies to give him an order. 
for, as can be seen in Table 4.3, the railway companies continued to increase their own manufacturing capacity, using the private firms to hedge demand. The Scottish locomotive trade prospered on overseas demand. Between 1875 and 1888 over $70 \%$ of Dubs' and Nellson's output went abroad and from the arrival of Sharp Stewarts to the end of the century 65-70\% of the output of the three Glasgow firms was sent overseas. The respective figures for supplies to scottish railways were under $10 \%$ and under $7 \%$.

Under James Reid, Neilson's became the largest locomotive builders in Europe, but it was still deemed essential to enlarge if developing foreign competition was to be successfully met. To achieve the necessary economies of scale all three Glasgow firms amalgamated in 1903 to form the North British Locomotive Company which by 1907 employed 8,000 hands. Meanwhile their poor location, and perhaps also the success of their Glasgow rivals, had induced llawthorns' to lessen their emphasis on locomotive construction and concentrate instead on marine engineering. Generally the railways did not at first make their own locomotives. A desire to begin operations as soon as possible, coupled with capital expenditure restrictions, probably accounts for this. However, they had no intention of being "dependent on private establishments for ordinary engine repairs, which would have been attended with much inconvenience, as well as additional expense;" and it was an obvious logical and economic step to move from merely repairing their rolling stock to 
actually manufacturing it. (1) Producing for themselves would eliminate the builder's profit margin, but would not recessarily be cheaper unless economies of scale could be secured. (2) Although it is feasible that the backlog of orders and the rise in prices (of up to $30 \%$ ), because of pressure on private producers' capacity, at the time of the mania also encouraged the railway to produce their own engines, Table 4.3 suggests that this was not the case, and that it was not until the late 1850 s that company production reached substantial proportions. (3) Aa companies enlarged, a desire for greater uniformity, and hence interchangeable parts, also served to stimulate production in company workshops. (4) By the early 1870s 50\% of the demand of the Scottish railways was being met internally and the proportion rose to $85 \%$ by the end of the century.

The first engine to be built by a railway company in scotland was constructed at the Kipps works of the Monkland and Kirkintilloch in 1837. This was a solitary venture and it is argued that the cylinders were in fact purchased from a local engineering firm. (5) The Edinburgh and Glasgow, however, had at Cowlairs (Glasgow) one of the earliest permenent company manufacturing establishments in Britain. In 1841 , before the railway was in

1. EPD 1/1, 9 September, 1850. p.4. B.R.

2. It was later argued that privately produced locomotives were as cheap as those built in railway company workshops "when every proper charge is included by the latter." (T.E.S.S. 1869/70. p.160).

3. D. Lardner, Railway Economy. 1850. p.108. RAC(S) $1 / 35,22$ January, 1850. B.R. RAC(S) I/1A, 22 March, 1854. B.R.

4. S.B. Saul, 'The Engineering Industry' in D.H. Aldcroft, The Development of British Industry and Foreign Competition 18751914. 1968. p.196.

5. Report, 1 February, 1838. Witchell Library Journal of Stephenson Locomotive Society. 1837. p.205. 
operation, a decision was taken to build some of their own stock and locomotives were being produced by 1844. (1)

The Caledonian's first works were the Greenock shops of the Glasgow, Paisley and Greenock which they took over in 1847, but these were in a bad geographical position in relation to their system and in 1856 they moved to the St. Rollox site in Glasgow. (2) Some work continued to be done at Greenock and et Perth (the shops of the Scottish Central absorbed in 1865), but in 1882 their locomotive superintendent, Dugald Drummond, decided to concentrate construction work at St. Rollox, leaving the other works to continue as repair shops only. Accordingly, St. Rollox was remodelled and enlarged in 1884 to cover twelve acres and by the mid 1830 s was being acknowledged as one of the finest company works in Britain. (3)

The other dominant company in Scotland, the North British, was slower to venture into production. Notuntil 1852 could the locomotive superintendent report, even on the question of repairs, that "all work required is now done at St. Margarets (Edinburgh) instead of portions of it by other parties." (4) In fact these

1. Simmons, op.cit, p.225.

Professor Saul (op.cit., p.196) states that the North British were producing loconotives at Cowlairs in 1844 , but this works did not come into their possession until the 1860s. In fact, as is shown below, the North British were slow to take up locomotive manufacturing.

2. Stephenson Locomotive Society, The Caledonian Railway Centenary. 1847. p.18.

3. 0.S. Nock, The Caledonian Railway. 1962. p.87. H.R.J., 27 September, 1884 . tocomotive Engineering, voi.vIII, no.10, 1895.

4. RAC(S) I/1A, 10 September, 1852. B.R. 
shops never turned out more than six engines per annum, some of these from principal parts supplied by Hawthorrs, and in 1867 it was decided to inake this a maintenance department only, concentrating all new work at Cowlairs, recently acquired on taking over the Edinburgh and Glasgow. (1) Still before 1875 relatively few locomotives were produced here either. (2)

On the other hand the Glasgow, Paisley, Kilmarnock and Ayr were producing locomotives at their Cook street (Glasgow) works by 1848. In 1854 they moved to Kilmarnock because the company, now the Glaskow and South Western, had expanded and needed larger premises. Here they constructed all types of rolling stock until 1901 when new works were set up at Barassie to which carriage and wagon work were transferred. (3)

Further north the Great North of Scotland built some of their stock at Kittybrewster until transferring work to Inverurie at the turn of the century. These latter works had been built to increase capacity with a view to amalgamating with the Highland railway; there being difficulties to expansion at Kittybrewster. (4) The proposed amalgamation did not materialise, however, and the Highland continued to use their Loohgorm,

1. C.H. Ellis, The North British Railway. 1959. p.58. G. Dow, The First Railway Across the Border. 1940. p.26.

2. Mayer, op.cit., p.108.

3. Weekly News, 5 November, 1898. Stephenson Locomotive Society, The Glasgow and South Western Railway. 1950. p.45.

4. Weekly News, 5 November, 1898. London and North Bastern Railway, Inverness Locomotive, Carriage and Wagon Works. 1946. P.4. B.R. 
Needlefield and Inverness shops. (1)

The private locomotive builders did not take kindly to the railway companies constructing their own engines; a practice virtually confined to Britain. (2) James Reid violently attacked the policy of the railway companies, maintaining that they would obtain better workmanship and materials "by placing thenselves in the hands of manufacturers of established reputation." (3) This may or may not have been true. Without doubt an apprenticeship at Neilson's produced a competent and skilled worker, but the same probably held for the railway workshops. As for materials, many components both for private and company builders were supplied by the same firms, and there was no obvious reason why castings done internally should vary in quality between private and railway workshops. (4) where Neilson, Dubs and Sharp Stewart gained was in size and the economies of seale that could be realised from being large. Whereas the average jearly output of the Caledonian in the 1870 s was 11 engines, the North British 19 and the Glasgow and South Western 9, Dubs was producing 98 locomotives, Neilson 104, and Sharp Stewart, still

1. Stephenson Locomotive Society, The Highland Railway. 1955. p.60.

2. Saul, op.cit. p.195.

3. T.S.S.S., $1882 / 83$. pp. 21-23.

4. The locomotive superintendent of the North British believed "the establishment here is so complete and efficient as to render external aid in any department almost unnecessary; and I can consequently now supply all tyres, axles etc. required at a auch cheaper rate and probably of sounder workmenship and better material than they can be purchased at other manufactories."

( $\operatorname{RAC}(S) 1 / 1 \mathrm{~A}, 22$ February, 1853. B.R.) on this point see a.so T.....S. 1885/86, p.i21; Engineering, 15 August, 1879; The Album of Arts and Industries of Great Britian. 1887. p.321. 
at Ranchester, 89. (1) This must have led to savings in mass production utilising standard designs, bulk buying of materials, constant use of capacity and perhaps a reduction in fixed overhead per unit of output.

Reid also argued that the private manufacturer, in supplying all countries, obtained an interchange of ideas and knowledge of improvements far greater than that gained from the individual and isolated research of each company's locomotive superintendent "shut up very much in his own district." (2) A similar point had been advanced some years earlier by a more disinterested engineer - "... all the information the railway proprietor possesses regarding his motive power is that the engine employed on his own line is the one deemed by his own superintendent to be the best, and that the same engine is deemed by all other locomotive superintendents, or at all events by nine out of ten, as very inferior indeed." (3) However, the exchange of ideas was facilitated by the papers and discussions at the Institute of the Engineers and Shipbuilders of Scotland to which most of the railway engineers belonged. (4)

1. Calculated from lists supplied by the Stephenson Locomotive Society and data obtained from the railway company reports and accounts.

2. T.E.S.S. 1882/83. p.22.

3. $1857 / 58$. 2.130.

4. Patent restrictions might have hindered the spread of developments, but on one occasion, at least, they did not. When Patrick Stirling of the Glasgow and South Western devised a lubricating cap which extended the period during which oil could be delivered, so saving on wastage as well as on wear and tear, he announced that he would "be happy if anyone would make use of it." (T.E.S.S. 1861/62. p.166). 
Even if more orders had gone from the Scottish railways to private builders it would not necessarily have resulted in a better engine as most locomotive superintendents insisted on the use of their own designs. (1) The North British were perhaps unique in accepting, at least up to 1855 , the standerd designs of the makers. (2) This concept of individualism went so far as to william Stroudley even designing his own snowploughs for use on the Highland lines. (3) It could thus be argued that little in the way of economies of scale was lost through the railways building their own locomotives in wellequipped shops. There were potential economies to be gained but the locomotive superintendents refused to take them. (4)

Reid was also of the opinion that the ability of the private builders to keep abreast of the latest developments, coupled with the competition that existed between these producers, meant that "improvement has, for the most part, taken rise in the private manufactory." (5) This was sheer fallacy. Having their own way led the locomotive superintendents to several technical breakthroughs. A pressure guage invented by Allan of the Scottish Central was "pretty generally adopted" as was

1. S.3. Saul, The Market and the Development of the Mechanical Engineering Industries in Britain, 1860-1914." Economic History Review, vol. $\times x$, April, 1967, p.116.

2. EIlis, op.cit, p.53.

3. Engineering, i March, 1867.

4. Their attitude might have been responsible for the slow acceptance of the compound locomotive engine in Scotland. (T. S.S. 1905/0 0.264 ). Standardisation of materials on a national scale was not considered until 1902. (British Engineering Standards Specifications no.24).

5. T.3.S.S. 1882/83, p.22. 
the safety valve improved by the Caledonian's 0'Connor. (1) Innovation was encouraged by the makers of railway equipment who frequently endorsed the ideas of the superintendents in an endeavour to obtain contracts, e.g. Spencer and Co., manufacturers of rubber springs, patented a lubricator devised by Davy Jones of the Highland line and the self-lockine carriage doors make by P. \& W. Maclellan were the work of William Wheatley of the North British. (2)

These were minor, though important, improvements, but major technical developments were also made outwith the private builders' works. It was on the Scottish railways that the 4-4-0 locomotive was chiefly developed, but scotland's great contribution was to come in the $1890 \mathrm{~s}$ with the rapid improvement in the power of railway engines, perhaps encouraged by the "railway races" from London to the nortin of Scotland. (3) Between 1855 and 1890 the rated tractive effort of locomotives on scottish rallways approximately doublea, but in the next decade alone a similar absolute increase in power was recorded. Where the Boiler Demand Factor (a measure of the steaming capacity of locomotives) is used as the index of power the

1. T.E.S.S. 1800/01. p.9. ..5.5. 1869/70. p.188.

2. Scottish News, 18 Hay, 1880. Sngineering, 1 July, 1870. P.L. Payne, Rubber and Railways in the Nineteenth Century. 1901. p.139.

3. C.S. Lake, Railway Hagazine. 1925. vol.IVI, p.381. ..L. Ahrons, The British Steam Locomotive. 1927. p.195. Beonomist, 22 February, 1895. A. 3. Kecteod, The McIntosh Locomotives of the Caledonian Railway. 1948. p.5. simmons, op.cit., pp.115-117. 
following trend energes $-1856 / 00=250 ; \quad 1886 / 90=426$ and $1896 / 1900=525$, which again shows a remarkable deveiopment towards the end of the century. (1) These larger engines were eminently successful and impressed foreign observers to such an extent that several hundred were built under licence by the private manufacturers for export to the continent. (2)

One thing that Reid could perhaps be thankful for was that none of the Scottish companies attempted to produce stock for other railways, as did the London and North Western and the Great Eastern reilways in England. (3) The very few purchases of stock that took place between companies in Scotland were those of minor railways obtaining aecond hand equipment from the larger enterprises. (4) Why the scottish railway companies made no attempt to move into the realm of the private manufacturer is open to conjecture, but is perhaps explicable in terms of some combination of tine following factors: that by the tine the railway shops of the major companies had reached a size at which commercial production could have been undertaken there were few minor companies left to whom the loconotives could have been sold; that the major companies would not have dealt with each other because of the idiosyncracies of the locomotive superintendents;

1. Calculations made from specifications in the company histories published by the Stephenson Locomotive Society.

2. NacLeod, op.cit., p.5. Locomotive agazine, i899. p.41.

3. An injunction was obtained against this practice by the private builders in the late $1870 \mathrm{~s}$ on the grounds that it was not allowed for in the Aots of the railwaj companies. (Economist, 19 January, 1878).

4. See e.6. Journal of Stephenson Locomotive Society, June, 1937. p.153; June, 1936, pp.158-159; June, 1939, p.18i. H.R.J., is August, 1808 . 
and that the great Glasgow firms were emerging as specialist locomotive producers.

\section{3.}

The bulk of the literature dealing with railway rolling stock concentrates on locomotives to the detriment of carriages and wagons. Yet as a rough approximation it can be suggested that in the 1890 s between $60-70 \%$ of Scottish railway expenditure on rolling stock went on the provision of capacity rather than haulage power. (1) It is therefore of importance to look at this less glamourous section of mechanical engineering. Unfortunately information is difficult to come by and much of the following discussion is based on isolated rather than general material.

As with their first locomotives the Scottish railway companies initially obtained carriages and wagons from private builders, presumably because they felt themselves burdened with enough capital expenditure without adding the cost of the plant necessary for rolling stock production. Wuch of the pre-1850 coaching stock came from England. Carriages for the Edinburgh, Leith and Granton and the Edinburgh and Glasgow were supplied by

1. Conclusion based on the price index mentioned previously. Although little confidence was placed in the index as regards annual fluctuations, it was considered reasonable as an approximate indicator over a longer period of time. Saul, op.cit. (Aldcroft) p.205 makes the point that in 1913 British exports of railway carriages and wagons were well in excess of those of locomotives. 
Atkinson and Phillipson of Newcastle; those for the Edinburgh, Perth and Dundee were produced by William Bailey of Wolverhampton; Dunn and Son of Leicester provided the first class vehicles for the Glasgow, Paisley, Kilmarnock and Ayr; and the principul saloon carriages for the Caledonian came from Adums of Lonaon. (1) Experience, skill and capacity acquired in meeting the earlier English demands probably accounted for this trans-border flow of capital equipment. The Glasgow, Paisley, Kilmarnock and Ayr in fact decided to order puttern carriages of each type to be furnished by "one of the best London makers" which were "to serve as a model for others that may be ordered here." (2) This is not to say that scottish firms took no part in supplying their native railways. Such a view is especially invalid where third class carriages were concerned, for some of these were little more than open trucks and could not have required much, if any, experience of railway work. An Edinburgh firm, Russell and hacivee, provided carriages, including first class, to the North British and the Edinburgh and Northern. The lower class stock of the Glasgow, Paisley, Kilmarnock and Ayr came Irom Caird and Co. of Glasgow and from two Perth firms, Patrick Wallace and $\mathrm{M}$. Cuthoert. George Thompson of Stirling and William Kinross of the same city ulso furnished severul

1. Railway Times, 2 August, 1845; 5 September, 1840. H.R.J., 13 Jui, 1850. Stephenson Locomotive Society, The Highland Railway. 1955. p. 13 . NBK $1 / 2$ passim. B.R. 2. Railway Pimes, 8 September, 1838. 
Scottish companies. (1) All of these companies, except Caird, were makers of road carriages who merely adapted their techniques and knowledge to suit the requirements of the railways. (2)

Even less change would be necessary for the manufacture of wagons as collieries, iron works etc. had required them for some time. A few orders went south, as did a contract of the North British to Fox Henderson of Birmingham, but the bulk of orders appear to have been lodged with Scottish firms. However, as far as can be ascertained, there were no makers concentrating exclusively on the production of trucks before 1850 even with the combined demands of railways, mines and factories. (3)

As the railway came into operation and started to repair damaged stock it was, as in the case of locomotives, a logical step to begin to manufacture their own vehicles, firstly wagons and slightly later, (because of the greater degree of skill required?) carriages. The major companies were attempting this before 1850, and the difficulties of obtaining stock in the early 1850 s probably accelerated this tendency, as did a dissatisfaction with the woris of some of the private suppliers.

1. Scottish Railway Gazette, 28 February, 1840. Railway Times, 13 October, 1838; 5 September, 1840; 4 September, 1841. H.R.J., 13 Ju?.r. 1850.

2. For details of the firms see appendix two to this chapter.

3. Based on a survey of the railway company minute books. 
(1) However, as can be seen in Table 4.1, their demand for stock was too unstable for them to be economically self-sufficient and private firms still had to be resorted to.

Unfortunately many of the railway companies were in financial difficulties at this time and could not afford the high first cost of such purchases. This led to the development of "wagon companies" who built or bought wagons and then hired them out or sold them to the railways on deferred terms. (2) Such finance companies were slower to develop in Scotland than in England, but two were finally projected, both having close ties with the railway companies. The Glasgow Wagon Company included on its board directors of the Edinburgh and Glasgow, the Glasgow and South Western, the Forth and Clyde Junction, the Scottish Central and the Scottish North Eastern, whilst the Scottish Wagon Company was organised by officials of the North British Railway. (3) Little is known about the Glasgow company,

1. $N B R 1 / 5,1 / 6$, passim. B.R. H.R.J., 4 Se terober, 1847.

C. Hignet, The Glasgow and South Western Railway. 1965. Appendix.

As regards delays, the Stirling and Dunfermline line had contracted for an additional supply of wagons in 1853 "but as other companies have also been increasing their stock, and the manufacturers are in full employment, only a small portion has yet been delivered." (H.R.J., 16 April, 1853: 24 September, 1853). Because of pressure of business many manufacturers were turning ordens down. (GNS $1 / 1, p .472$. B.R.) The Great North of Scotland expressed dissatisfaction with some of the work received rrom Brown, Marshall and Co., especially as regards the quality of the material used, but added "nevertheless it is generally as good as is usually delivered to railway companies." (GNS 1/2, p.59. B.R.)

2. There is no eviaence of similar "carriage companies" being established.

3. Report of Committee of Investigation into Shareholders of the North British Railway, I4 November, $1806, p .39$. H.R.J., 16 JuIy, 1864; 28 January, 1865. 
but the Scottish Wagon Company originally operated on the principle of purchasing wagons and then selling them, though later they might have hired them out. Capital still flowed out of Scotland for the purchase of stock for though the first orders of this company included 300 wagons from Faulds of clasgow and Tod of Edinburgh, contracts were also made for 800 from the Beverley Company, 500 from the Metropolitan Company, 300 from Bray and Waddington and 300 from Laycocks of Newcastle. (1) Although buying on deferred terms meant that a $\$ 62$ wagon eventually cost $\& 75$ the prospect of spreading payments appealed to the railway companies and the wagon companies prospered. In 1874 the Scottish Wagon Company was the least successful in Britain, but still paid a dividend of $8 \%$. (3)

Scotland did not develop specialist private railway carriage builders and the railways came increasingly to make their own coaching stock. (4) Perhaps this was becuuse there was a rush into the trade at the time of the railway mania, but as demand fell off ( 1848 witnessed a greater effective demand than the years 1849 to 1855 addea together) prior to replacement requirements beginning, so the entrants went back to their original trade of building road carriuges. In December, 1853 no Scottish Iirm of any description tendered for a Great North of Scotland contract

1. Report of the Comittee of Investigution, op.cit., p.40.

2. Ioid., p.39.

3. H.R.J., 23 January, 1875.

4. The firm of Hurst Nelson did begin to produce carriages in the 1880 s, but tris does not appear to have been their major line of business. 
though nine English firms were in the field. (1) However, the fact that specialist firms were in operation in England at this time weakens the argument about Scottish builders. (2) The explanation of the different situations as regards private coach builders north and south of the border may lie in the fact that the English firms produced both carriages and wagons whereas the Scottish firms that disappeared made only carriages. The railway companies began to produce the bulk of their own coaching stock, but orders for special vehicles such as sleeping cars were still placed with private English firms, and the North British, for one, went outside their own works in the late 1860s - early 1870s when the replacement of worn out stock, inherited from the previous years' amalganations, overwhelmed their building capacity. (3)

Specialist wagon builders did, however, evolve within Scotland, probably because the volume and value of such business was much greater than that for carriages, even when railway company demand alone was considered. In addition there would be a demand from private traders and industrialists. Faulds was established quite early, but never achieved the eminence of two newer firms, R. \& Y. Pickering of Wishaw, who were constructing wagons from the 1860s, and Hurst, Nelson of Motherwell who began two decades later. P. \& W. Maclellan, the great structural engineers, also produced

1. GNS 1/1, p.472. B.R.

2. Sau1, op. cit., p.203.

3. $\operatorname{RAC}(S) I / 1 \mathrm{~A}$, passim. B.R. H.R.J., I March, 1873; 5 April, 1875. Stephenson Locomotive Society, The Highland Railway. 1855. p.29. I am grateful for information supplied by Mr. A. MacLean of the North British Railway Group. 
wagons, but many of their parts were supplied by Pickerings and their markets were predominantly abroad. (1) It is difficult to explain why the really successful firms were so long in being set up; perhaps it had something to do with limited demand in Scotland. Whatever the reason, in the years between the railway mania and the establishment of Pickerings, and even beyond that, specialist firms in England were able to seize a substantial proportion, though probably not the majority, of the Scottish market. By the end of the century, however, Scottish railway company wagons were either supplied by Pickerings or Hurst Nelson, or, more generally, were built in the rallway shops. (2)

The nineteenth century witnessed little advance in the design of non locomotive stock. In the late 1860s "the carriages, with the exception of being enlarged, are very nearly as they were when first introduced." (3) The same was true of wagons whose "most important improvement is their increased capacity." (4) Before the end of the century there were some minor breakthroughs in materials and constructional me thods, but these served primarily to accentuate the trend towards larger vehicles. Coaching stock at the time of the mania weighed between three and five tons depending on its class. By the late 1870 s even coaches holding only eighteen passengers reached nine tons and in the 1890 s corridor stock topped twenty four tons. Lengths correspondingly

1. See appendix two.

2. Glasgow Herald Trade Review for 1895.

CAL 1/42, 27 December, 1898. B.R. A. Lamont, How Scotland Lost Her hailways. 1945. pp.13-14.

3. T.E.S.S., $1866 / 67$, p.115.

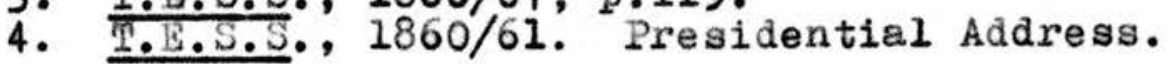


increased, rising from fifteen feet to being typically thirty reet, reaching fifty feet on the early corridor trains and attaining a peak of seventy feet on some of the Glasgow and South Western stock. (1) The tare weight of wagons rose from two to three tons in the 1840 s to nearly six tons by 1900. Aided by spring buffers replacing dumb buffers and better quality iron in wheels which allowed heavier loading, carrying capacity also rose. However, even in 1900 the standard on the North British (there is no reason to believe that this was atypical) was only eight tons, but the introduction of steel underframing in the 1890s increased this to ten tons by 1912 and twelve tons by 1918. (2) It was not just building materials and technical knowledge that limited the maximum size of wagons. The Caledonian experimented with thirty ton wagons in the 1850 s and fifty tonners in the 1890s, but these were not a success primarily because of the inter-relatedness of the railways and the economy mentioned in

1. Lardner, op. eit., p.105.

T.E.S.S., 188278 ; ;.10.

Stephenson Locomotive Society, The Glasgow and South Western Railway. p.44. Stephenson Locomotive Socie ty, The Highland Railway. p.5l. Simmons, op. cit., p.152.

Also information from inr. A. Mactean.

2. F. Wishaw, The Railways of Great Britain and Ireland. 1840. p.9. C.E.R. Sherrington, The conomics of Rail Transport in Great Britain. 1928. pp.198, 213, 217. Stephensan Locomotive Society, The Glasgow and South Western Railway. p.45. S. Stone, Railway Carriages and Wagons. 1903. p.39. . S.S., 1861/62. pp.27-33. PYB(S)I'1. B.R. I am also yrateful for information suppliea by Mr. J. Hay of the North British Railway Group. 
the previous chapter. (1) Existing capital works prevented the widespread introduction of large cupacity stock; tight curves and small wagon turntables of the railway companies contributed, out a more restrictive factor was the condition of the private facilities and the reluctance of their owners to incur the high first costs of rendering them capaole of taking lurger wagons. (2)

It was in the design of the many special vehicles that the locomotive superintendent allowed his initiative full rein. The Highland had double decker trucks for transporting sheep; the North British possessed floor-cloth vehicles especially for the Kirkcaldy linoleum trade; and Hianson of the Glasgow and South Western designea low-sided wagons for the Dunragid butter trafizc which doubled as corpse vans for many years. Whiskey, beer, live and dead meat, gunpowder, and a host of other products all required such special facilities. (3) In their carriage design the Scottish locomotive superintendents were more conservative. the corridor principle was introduced on the Anglo-Scottish service in 1893, together with dining cars, but was never widely adopted for internal traffic before the first world war. Steam heating generally awaited the twentieth century and stock lit by

1. Siramons, op. eft., p.157.

Locomotive hagazine. 1899, p.108.

2. See e.g. Sherrington, op. cit., p.213.

D.I. Burn, Economic History of Steelmaking. 1940. p.1.67.

3. Sherrington, op. cit., p.212.

Stephenson Locomotive Society, The Glasgow and South Western Railway, p.45.

Informetion from J. Hay. 
gas lamps were still being built by the North British and Highland companies in the first decade of this century. (1) The advantages of the bogie in allowing longer carriages to be operuted (and hence less frictional resistance in their axle vearings) and lower ones (hence less resistance to the wind) were known before 1870, but were not taken up by Scottish designers before 1880 and were not generally adopted before 1890. The main reason for the delay appears to have been the aifficulty of coupling up with existing stock. (2) Not until the improvements in locomotive performance forced the issue upon them did the superintendents attempt to surmount this obstacle of their own making. (3)

4 .

At the first annual festival of the iron trades of Glasgow held in 1865, Walter Neilson, the locomotive builder, proclaimed

1. Simmons, op. cit., p.152.

Sherrineton, op. cit., p.202.

Information from A. MacLean.

For a general survey of carriage design see C.H. Ellis, Nineteenth Century Railway Carriages. 1966.

2. T.5.S.S., 1866/67. p.119.

T.E.S.S., 1892/93. Presidential address.

3. Another branch of engineering that deserves mention in connection with the railways is that concerned with the telegraph. All lines benefittea from the telegrupin allowing them to utilise their time to greater advantage, but none so much as those railwas with substantial sections of single track. The Highland and Great worth of scotland accordingly adopted the telegraph block system much more rapidly than the other scottish companies. However, it would dppeas that no specilic developments in this field of engineering were associated with the Scottish railway system. (T.E.S.S., 1887/88, p.3; Railway limes, 7 June, 1850 ; Parliamentary Papers. 1873 LVII; C.E. Stretion, in the Electrical Engineer, 13 November, 1896). 
that "more steam engines and ships are now built in Glasgow and the neighbourhood than in any part of the world." (1) Perhaps he should have awarded the palm to the shipbuilders for another authority, writing about the same time, claimed "there is probably no branch of industry which has been more profitable in scotland during the last few years than iron shipbuilding." (2) Yet, according to Professor Campbell, the great era of shipbuilding was yet to come. Not until the industry consolidated on the Clyde in the l870s dia shipbuilding make its major contribution to Scottisn economic growth. From then until the first world war "shipbuilding was the chief growth point of the Scottish economy." (3)

How did railway engineering compare to shipbuilding and marine engineering as a component in the Scottish economy? Unfortunately, although it is possible to make estimates of their respective outputs, not until the twentieth century are figures obtainable for the "value added" which is the real measure of relutive performance. In 1907 the value added by Scottish marine engineering and shipbuilding totalled $25,836,000$ whilst that of the engineering depurtments of the railways was $21,629,000$ with another $\$ 457,000$ being contributed by the private wagon builaers, suppliers of wheels and axles etc. Figures for the private locomotive inanufacturers were not given "to avoid the

1. H.R.J., 11 March, 1865.

2. H.R.J., 2 April, 1864.

3. R.H. Campbell, 'Scottish Shipbuilding: Its Rise and Prozress,' scottish Geographical magazine, vol.8u, no.2, September, 1964 . pp.107-109. 
possible disclosure of particulars relating to certain firns." However, if the ratio of value added to the value of output was similar to that of wagon builders then c\&737,000 would be their contribution to the national product. The value added by Scottish railway engineering would therefore come to just under three million pounds. (1) This clearly fails to match the total from shipbuilding and marine engineering. Total value added is only part of the question about their relative economic contribution, but lack of data prevents an answer being found on the point of productivity. Value added per head came to $£ 82.8$ in railway engineering ( 280.1 if the locomotive estimates were omitted) but topped $\$ 90$ per worker in the shipyards; the average for Scottish industry as a whole was c£loo. (2) Yet do these figures mean anything? It was argued in the previous chapter that capital productivity and labour productivity were statistical phenomena alone, and that the only true measure of productivity was on an input/output basis where the inputs were a combination of both labour and capital. Unfortunately there is insufficient data on the capital intensity of scottish industries for any judgement on relative productivities to be made. Similarly a comparison with industries south of the border is meaningless without information on relative inputs. Shipbuilding and railway engineering were not independent

1. Based on the Census of Production for 1907. (1910 CIX). On the basis of value added in engineering as a whole the locomotive builders' contribution would have been $£ 534,000$.

2. A.W. Flux, ' Gleanings Irom the Census of Production,' Journal of the Royal Statistical Society, nay, 1913. 
of each other. The high pressure boiler devised by Trevithici for railway use was adopted for steamooats. In fact such vessels were plying on the Clyde before steam took to the rails in Scotland (ignoring the abortive attempt to use locomotives on the Kilmarnock and Troon). (1) Moreover, the development of railway competition "virtually forced the quick adoption of the iron screw steamer in the coastal transport of coal." (2) More specifically related to scotland was the construction of the first train ferry in the world, the "leviathian," in 1849. (3) Designed by Thomas Bouch for the Bdinburgh, Perth and Dundee railway and constructed by Ropert Napier of Glasgow, the vessel was used for the transport of goods across the rorth and later inaugurated the ferry service of the same company across the Tay. Considerable ingenuity was required in the design of loading arrangements - a task made difficult by the spring tidal differences of 24 feet. To solve this problem Bouch used a method where vehicles were run on and off the ferry by means of platforms on wheels which adjusted their position on a rap according to the state of the tide. (4) Throughout the century the railway com panies purchased vessels, some new, others second hand, in

1. W.S. Cormack, An Economic History of Shipbuilding and Harine Engineering. Th. D. klasgow. 1930. p.89.

2. J.R.1. Hughes and S. Reiter, The First 1,945 British Steamships," Journal of the American Statistical Association, 1958, p. 375 .

3. A canal boat carrying railway wagons had been introduced on the Monkland canal in 1835, but the Leviathian was a much more significant enterprise. (T. Grahame, Inland Communication and Transport. 1835, pp.58-59).

4. Ero 1/2, 22 March, 1850. B.R. Illustrated Iondon News, 10 February, 1850. Railway Magazine, June, 1904, p.530. 
pursuit of their policy of having a finger in every transport pie. (1) However, it is unlikely that their demands were of significance to the shipbuilding industry either qualitatively or quantitatively.

Another relationship with shipbuilding was the interchange of skills, both at executive und workshop level. (2) Such exchanges were not confined to these two industries. Wany engineers were equally at home working on railways, docks, drainage schenes, water works and numerous other enterprises. This is one aspect of what is termed "technological convergence" or "fallout." (3) Extremely difficult to quantify, this concept is concerned with the contribution of developments in one field to developments in other fields. Such links may be in the form of now methods of production which can be immediately applied elsewhere, often with little alterution or adjustment. Iess immediate in their application could be by-products or ideas thrown up in the process of research. A third important form of fallout is the subtle lorm of a technological transfer of know-how and a whole mass of advanced techniques which can substantially widen business horizons if assimilated into industrial thinking.

1. Duckworth und Langmuir, Hailway and Other Steamers. 1948. On the question of the relationship of the railways with other forms of transport see chapter ten.

2. That this occurred at manugement level is apparent from the obituaries of Scottish engineers given in the 5. E.S.S. That it took place at lower levels is surmised from the small differentials between wages in Glasgow shipyurds and locomotive shops. (See chupter seven, appendix one).

3. N. Rosenpers, Tecnnological Gnange in the ihachine Tool Industry 1840-i910,' Journal of Economic History, December, 1963. p. 423 . 
Specific problems raced by the railways did make some contribution to the pool of engineering knowledge which was drawn on by other branches of the industry. Many of the techniquea developed for the construction of the rorth Bridge were taken up for other feats of structural engineering. (1) Also generally adoptea in engineering circies was the bydraulic rivetting machine designed by william arrol to overcome difficulties faced in constructing the Broomielaw Bridge. (2) Arelatively minor technological development on the railwayg, the steam pressure gauge, paved the way for the establishment of a laboratory and engineering glassware industry in scotiand; John joncrieff learning his trade Irom Enoch Tomey who had set up a glass factory in Perth in 1850 principally to produce tubular glass for use in steam gauges. (3)

A major form of technological fallout is the spread of ideas to aid the understanding of engineering problems in a general way. In this category the Forth Bridge must surely stand as a monument to the triumph of theoretical application over the dominance of the practical man. This was the theme of william Anderson's lecture to the Institute of Civil Engineers in 1893. "Since 1848 the supremacy of theory over rule-of-the-thumb

1. See the series of articles by Andrew J. Biggart in the T.E.S.S. between $1884 / 85$ and $1889 / 90$. H. Dyer in A. Me Lean (ed.) Local Industries of Glasgow and the West of Scotland. 1901. pp.72-73.

2. T.S.S.S. 1946/47. p.34.

3. Information supplied by John Moncrieff Ltd., North British Glassworks, Pertin. 
has gradually, but surely asserted itself, witn the result that this country may cleim the honour of such a structure as the Forth Bridge, for the design and construction of which no tentative experiments were needed, though the form and mode of construction were very special, it not absolutely new; and the dimeasions, both in span and height, so gigentic that the authorg of the design could have derived but little aid Irom previous experience." (1)

Theory and the practising engineer had been slow to come to grips. In 1867 it was stated that in the United Kingdom there was "but one authorised and acknowledged high school of engineering science, and that is the Universit. of Glasgow." The following year witnessed the institution of the first engineering chair of the university or sdinburgh. However, it was admitted that the great continental engineering colleges were of a higher standard. (2) In any case lew of the leading Scottish engineers, railway or otherwise, had been to university; most of them graduated, as did the bulk of the engineers of lesser rank, from the shipjards; railway workshops or locomotive factories. They did, however, come into contact with the theorists through the auspices of the Institute of Engineers and Shipouilders of Scotland. The discussion that ensued frequently exhibited a clash between theory and practice; it often being argued that the theorists demanded too high a degree of accuracy. (3) Ihis attitude may have prevented the forth $3 r i d g e$ from having an instantaneous impact on railway engineering and even that which occurred may have been

1. H.R.J., 6 ifay, 1893 .

2. Engineering, 18 october, 1867 Information supplied by the Faculty of Engineering, the University or Eainburgh.

3. e.g. T.E.S.S. 1860/61; 1862/63; 1888/89. 


\section{THE UNIVERSITY of EDINBURGH}

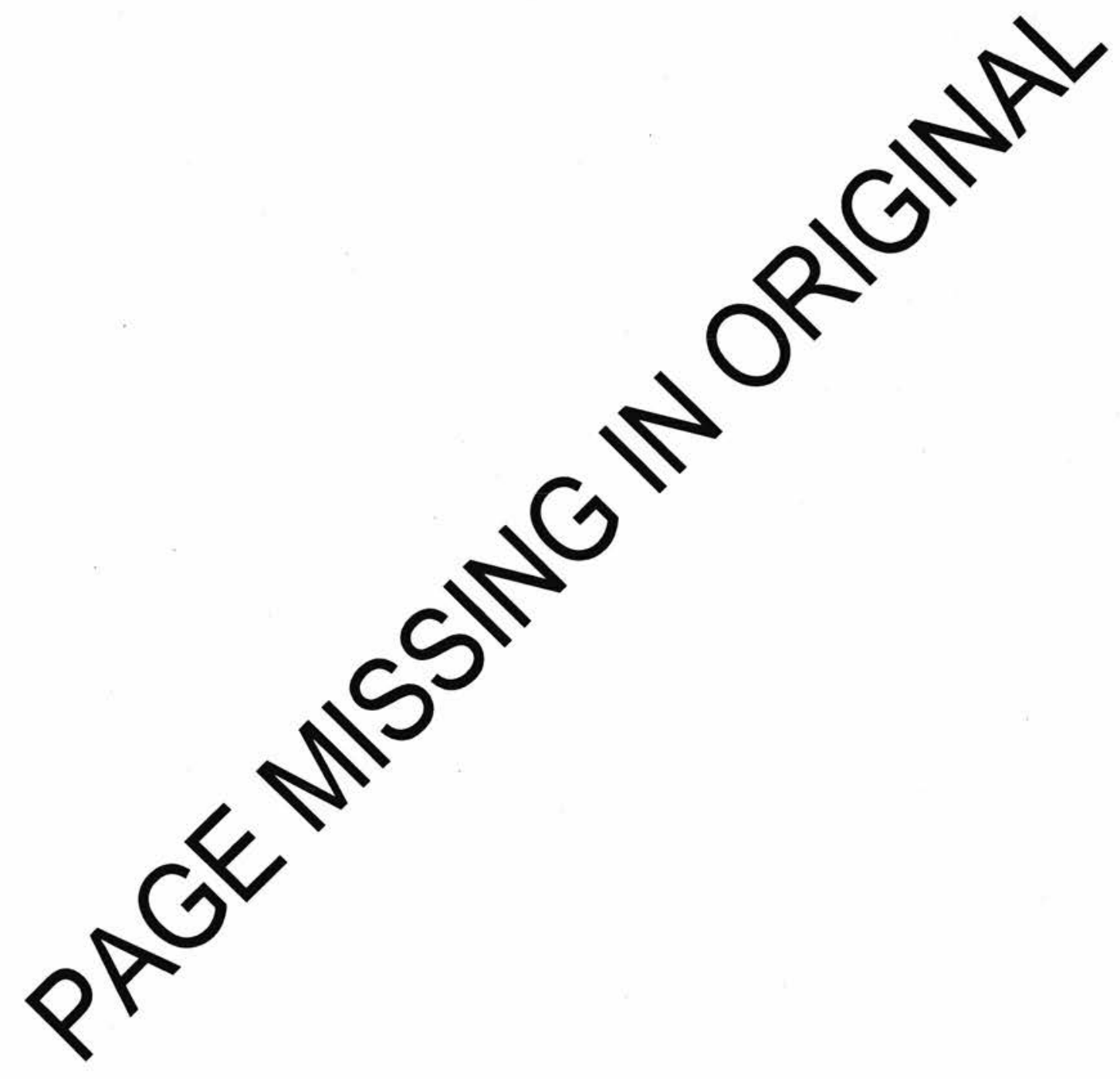


limited to the civil engineers. Even atter the bridging of the Forth it possibly remained true that many railway engineers still adopted the view expressed many years earlier by W. Johnstone of the Glasgow and South western - he "did not think that any engineer could confine himself to strict formulae in laying out railway lines in order to get across inaccessiole places. Hach engineer must fall upon plans of his own on the spot to get over the aifficulties met with." (1)

An important backward linkage of railway mechanical enzineering was the demand that it created for machine tools. (2) John Mayer, writing for the Brition Association in 1876, claimed that the Glasgow district "ocappiea a position of pre-eminance in this particular departinent of engineering construction." (3) The question to be asked is whether this had anything to do with the Scottish railways. If the records of the private locomotive builders are any guide the answer must be very little. Wost of Dubs' first equipment came from Whitworth's works and he continued to patronise this firm for several years, although over time other firms were used to a greater extent. Although Dubs' were producing machine tools for themselves from the beginning, not until the 1690s aid Scottish firms begin to supply their needs in significant quantities; and even then English firms supplied the bulk of them in value terms. Neilson's purchased tools from a

1. 2. S.S. 1800/61. p.37.

2. See Kosenberg, loc.cit., for a view on the importance of the machine tool industry.

3. Vayer, op.cit., p.87. 
variety of Iirms, but once again the great emphasis was on English suppliers. Between 1864 and 1873 Dubs obtained £31,106 of machine tools of which only 22,312 (7\%) came from Scotland, including those which they made for themselves. From 1874 to the end of the century Dubs and Neilson's between them purchased or made 2104,776 of tools, of which the Scottish proportion was 226,955 (26\%). (1) What Sharp Stewarts did is not known in detail, but they had always produced tools at Manchester and continued to do so after their move to Glasgow. (2)

The reason for resorting to England for this capital equipment (or producing it themselves) was primarily because of a lack of a machine tool industry within scotland capable of meeting their requirements. Mass production of locomotives in Scotland not only lagged behind that in Bngland but also behind the development of Scottish shipbuilding. Accordingly Scotland's machine tool industry grew on the basis of shipyard demand and it was to this that Hiayer was referring. Gearing production to the needs of the shipbuilders resulted in a different type of tool to that made in, for example, Manchester and Leeds. (3) The dominant position of the clyde in shipbuilding and the established position of English makers in the railway tool trade would not encourage

1. Calculated from data in Neilson and Co., 'Buildings and Fools,' Nos. 4 and 5; Dubs, 'Inventory of Great Fools; queens Park Works.' 1915.

2. Dyer, op. eit., p.49.

3. "Hoolmakersin scotland, who have principally to supply the extensive aemands of marine engineers and shipbuilders in their own lccality, are, by the nature of the heavy work for which theif mechines are intended, induced to look to great weights, massive framings and very large castings." (Engineering, 25 october, 1867). 
a move by the Scottish tool makers to supply the product needed by the locomotive bullders. When Dubs shopped around for his first tools there was no-one in scotland to challenge the reputation of Whitworth. Eventually, however, the monetary rewards from supplying the expanding requirements of both the railways and the private builders became sufficient to induce Scottish firms to begin to compete. When there was a general re-equipment in the 1890s Scottish firms obtained contracts, but by this time others too had entered the fleld. There were no longer one or two acknowledged specialista in the machine tool trade and supplies were now drawn from an international market of which Scotland was a facet.' Ability not patriotiam determined the allocation of orders.

\section{5.}

It can be suggested that the significant contributions by the Scottish railways to Scottish civil and mechanical engineering came in different periods. Only over time did Scottish civil engineers begin to lay out important lines free of English supervision, and not until the last decades of the century did any feat of Scottish railway engineering have an impact on the profession (save in the deleterious effect of the collapse of the Tay Bridge). The breakthrough that was achieved with the construction of the Forth Bridge had a world-wide influence, giving Scottish engineering a tremendous boost, and bringing Arrol a knighthood and contracts worth millions. 
On the other hand the great contribution of the railways to Scottish mechanical engineering came earlier; in the orders enabling a private locomotive building industry to become established. Over time domestic demand becane less importunt to these builders, but that is not to say thut the influence of the railways was no longer significant. They were still pumping money into the Scots economy - perhaps three quarters of a million pounds per ganum in the 1890s - via their own workshops, orders to the Scottish wagon builders, and, quantitatively less important, their demand for machine tools. 


\section{APPENDIX ONE}

\section{SCOTISH PRIVATE LOCOMOTIVE BUILDERS}

To avoia repetition relerences will be denoted by the following alphabetical symbols.

$A=M$ Smith, Journal of the Stephenson Locomotive Society, 1939.

$B=$ C.A. Uakley, 'The Mechanical Engineering Industry of Clydeside:

Its Origin and Development,' T.E.S.S., 1945/46.

$\mathrm{C}=$ The Locomotive, Railway Carriage and Wagon Review, April and Hay, 1927.

$D=J$. inayer, Engineering and Shipbuilding Industries of Glasgow and The Clyde,' British Association, 1876.

$\Xi=H$. Dyer, 'Local Inuustries of Glesgow and the West of Scotland,' British Association, 1901.

$F=$ Information supplied oy Mr. George Thompson of the univer.sity of Glasgow.

$G=J$. Knox, Airarie: An Historical Sketch. 1921.

$H=G \cdot D \cdot 58$, section $18 / 60$. S.K.0.

$I=$ Scottish News.

$J=W$. rindlay, History of Kilmarnock. 1909.

$K=$ Qlasgow as an Industrial Centre. 1936.

$I=$ S.E.G. Ly the, 'Shipouilding at Dundee down to $1914, '$ Scottish Journal of Political Economy, vol.9, 1962.

$M=$ Journal of Stephenson Locomotive Society.

$N=$ Engineering.

$0=\mathrm{J}$. Thomas, The Springburn Story. 1904 . 


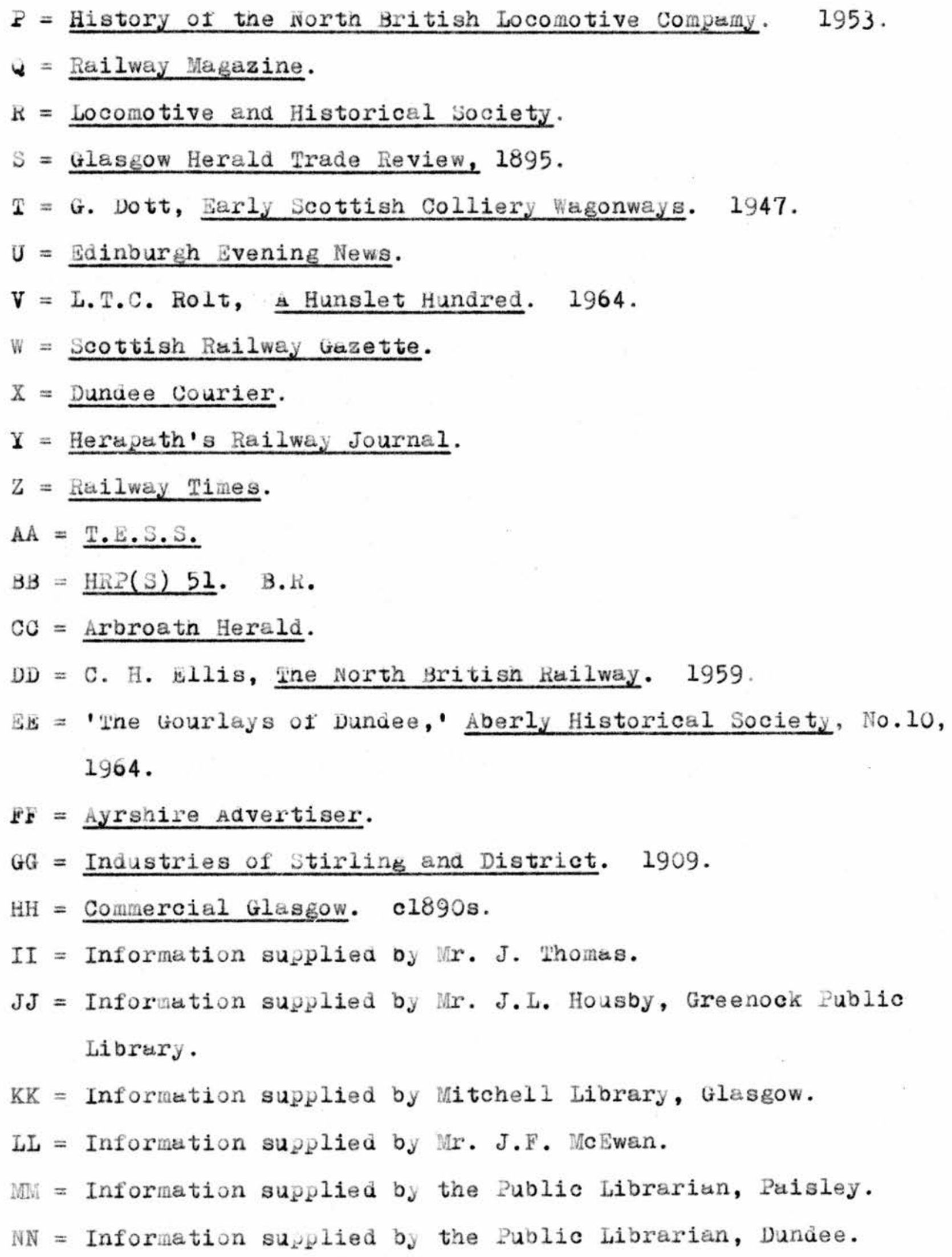


$00=$ Information supplied by the Public Librarian, Ayr. $P P=$ The Engineer.

AIRDRIE IKON COMPAiNy, AIRDRIE. Originally the Standard roundry the name of the Airdrie Iron Co. was adopted in 1868. They began to make locomotives the following year, the first order being for the Drumgray Coal Co. Altogether between 20 and 30 industrial engines were made, the last order being for Glasgow Corporation's Dawsholm Gas Works in 1900. The firm eventually closed down in 1913. (A-C-F-Gpp.87/88).

ANDHEWS, BARK AND COMPANY, KILMAKiNOOK. Formelly Allan, anarews and co. this firm specialised in tank locomotives for industrial concerns making at least three for the Carron Iron Company before 1885. (A-H, 31 December, 1885).

ARCHIBALD BAIRD AND COMPANY, PEACOCK CROSS, HAMILTON. AIthough this firm was listed in the Glasgow P.O. Directory as a locomotive builder it appears that they never actually made locomotives, but only dealt in them. At the Edinburgh International Exhibition of 1886 they showed various steel castings such as cranks and axle boxes and also tools used in mining, quarrying and railway work. (A-C-I, 11 May, 1886).

ANDREW BARCLAY, SONS AND COMPANY, CALEDONIA WORKS, KILMARNOCK. Established in 1840 to manufacture mining and general engineering equipment the firm soon progressed into the manufacture of locomotives and from 1860 were turning increasingly to this field. In 1892 the company became limited and the works were modernised, 
the locomotive department being "especially developed." By 1909 700 men were employed though not all in the making of locomotives for the firm was still producing mining machinery and pumping apparatus for both the home and export markets. At the time of ceasing such production in the 1960s they were the last builders remaining in Scotland and over 2,000 locomotives had been built, mostly industrial "pug" shunters. Most of their output in the nineteenth century was for the domestic market, but a good many were sent to South America, the West Indies, China and Egypt. One or two locomotives were supplied to the Edinourgh and Glasgow, the North British and the Caledonian, but in general the railway market was not their province. (A-C-E-J, pp.381-383-II).

BARCLAYS AND COMPANY, KILMARNOCK. This firm built at least one engine before being taken over by Andrew Barclay, Sons and Co. (A).

BARR, MORRISON AND COMPANY, KILMARNOCK. In 1885 Dick, Kerr and Co. took over this company which had produced several tank locomotives for industrial use. (A-C).

WILLIAM BEARDMORE AND COMPANY, DALMUIR. Built their first engine in 1919, but had given up this line of activity before the second world war. Their output went principally to India although a few orders went to home railways, noteably the London, Midland and Scottish and the London and North Eastern. (A)

BUTIERS BROTHERS, KINNING PARK, GLASGOW. First appear in the Glasgow P.O. Directory in 1867 and were described as "brokers for 
all classes of new and second hand machinery, cranes, hand and steam power crab winches, chains, engines and boilers; mortar mills; and also all kinds of new and second hand contractors' and builders' plant." Although at one time producing vertical boiler locomotives they made their name for the manufacture of cranes and derricks. (A-K, p.103).

CAIKD AND COMPAMY, GREENOCK. This firm began as a foundry in Cartsayke in l809, progressed to the making of machinery in 1826 and by 1844 had entered into shipbuilding. They built locomotives and carriages for the Glasgow, Paisley and Greenock, the Glasgow, Paisley, Kilmarnock and Ayr, und the Edinburgh and Glasgow railwas in the early 1840 s when they were employing over 800 men. Earlier they had supplied an engine to the Garnkirk and Glasgow line. They uppear to have given up this line of work by the 1850s. In 1916 they were taken over by Harland and wolff who closed the yard to concentrate their efforts in Belfast. ( $\mathrm{A}-\mathrm{C}-\mathrm{JJ})$.

J. C. CARMICHAEL, DUNDEE. The brothers Carmichuel set up us mill-wrights in Dundee in 1810 and became known for the excellence of their stationary engines for use in the flax industry. In 1821 they fitted up the first twin stean boat for the Tay ferry following with another two years later. The latter work introduced several important improvements which influenced work on other ferries. They were also early in the field of iron vessels, building at least three in 1838, although shipbuilding was later abandoned. Locomotive construction was added to their numerous 
activities in 1833 with the building of two engines for the Dundee and Newtyle railway at their Ward Foundry. Apparatus devised by the Carmichaels such as the fan blast used in the smelting of iron gives the impression of extremely competent seneral engineers capable of turning their hand to anything. The firm was carried on by their sons under the nume of James Carmichael and Co., becoming limited in 1894 though retaining a family directorship, eventually closing down in 1929. (A-C-I, pp.221/222-Mif, April, 1957, pp.105/106).

ALEXANDER CHAPLIN AND COMPANY, CRANETONHILL ENGINE WORKS, GOVAN. This firm built between 1867 and 1902 specialising in shunting engines with vertical boilers and cylinders, so of which were designed for the use of contractors. The firm began as Chaplin \& Dixon, engineers, in 1849, becoming Chaplin, Dixon and Robb, entineers, machinists, iron, house and roof engineers, in 1851, and finaily Alex. Chaplin and Co. in 1861. (A-C-N, 23 warch, $1860-K K)$.

CLYDE LOCONOTIVE COMPANY, SPRINGBURN, GLASGOW. Set up by Neilson after he left Neilson and Co. following a quarrel with James heid. This firm failed to prosper presumably because existing firms were satisfying their customers. Even their display at the Edinburgh International Exhibition in 1880 failed to bring them orders. In 1880 they did supply eight engines to the Highland line and two to the Girvan and Portpatrick the following year, but these were not enough to keep the firm in business and in 1888 the works were taken over by Sharp Stewart who transferred 
their locomotive production there from manchester. (A-C-I, 18 Hav, 1886-0, p.143-P).

DICK, KERR AND COMPANY, BRITANNIA WORKS, KILMARINOCK. In 1885 this company took over the firm of Barr and Morrison and were at that time chiefly engaged in the production of colliery, tramway and railway plant of all description. Much of their output went to the home market, but they also exported equipment to South Africa, India, America, Australia, Japun and China. By the early twentieth century they were recognised as engineers and contrectors for complete tramway and light railway equipment, supplying all the machinery and appliances necessary from their Ki.lmarnock works where 400 men were employed and from their Preston factory where the figure was 1,200. They had no dealings with the Scottish railway companies as they manufactured mainly industrial tank locomotives. In 1919 they became the Kilmarnock Engineering works. (A-E-J, P.383).

DICK AND STEVENSON, AIRDRIE BNGINE WORKS, AIRDRIE. Originating as Dick's Ioundry, the firm became Dick, Stevenson and Dick in 1862 with engineering added to their founding activities. Shortly afterwards the name Dick and Stevenson $\Lambda$ and the company be gan producing tank locomotives in 1864. Between then and 1890 when the firm went out of existence about fifty "pugs" were built, several going to Langloan Iron works and others to local collieries. Others were exported to Spain, Holland and even Singapore. $(A-C-F-G, p p .86 / 87)$. 
WILLIAM DIXON, CALDER AND GOVAN IRON WORKS. Produced locomotives for own use. (A)

D. DRUWMONO AND SON, GLASGOW RAILWAY BNGINESRING COMPANY, GOVAN. Founded by Dougald Drummond, the famous locomotive engineer of both the North British and Caledonian companies, this firm produced narrow gauge tank locomotives for gas works etc. and also manufactured wheels and axles for both home and export markets. $(A-C-\mathbb{E}-S, P .53)$.

DUBS AND COMPANY, GJASGOW LOCOMOTIVE WORKS. Henry Dubs, one time assistant at the works of Beyer Peacock and works manager of the famous Vulcan foundry in the 1840s, set up these works with the financial aid of several Glasgow businessmen when he left iveilsons in 1864 where he had been works manager. Generally known as the Queens Park Works these shops produced their first locomotives (for the Caledonian) in 1865 and made over 4,200 before the amalgamation of 1903. In 1879 they employed 1,240 men and by 1903 this had risen to 2,400. Incidently between 1886 and 1900 Dubs owned the Kingston Kailway Works in Canada. These had been sold to him by a man pressed for money and Dubs later sold them to a William Hartley. As far as can be ascertained there does not appear to have been a deliberate attempt at establishing an overseas plant. (A-B-C-D-R, vol.83, 1951, p.9N, 15 August, 1879-Q, January, 1951).

THOMAS EDINGTON AND SONS, PHOBNIX IRON WORKS, GLASGOW. Although building for the Glasgow, Paisley, Kilmarnock and Ayr in 1840 this firm appears to have then given up such work and 
concentrated on their foundry business. $(A-C)$

ROBERT FREW, TOWIEND, GLASGOW. Although claimed as locomotive builders by one authority no nineteenth century entry can be traced in the Glasgow P.O. Directory. In 1925 a firm of this name appears but is described as "iron und steel merchant."

FORREST AND BARR, GLASGOW. An entry in the Glasgow P.0. Directory of 1849 for William Forrest and Co., engineers and millwrights, changes to forregt and Barr in 1855, out reverts to William forrest and Co. in 1875. In 1884 the lirm was described as "engineers, crane manufacturers, sawill ironfounders." The last entry is in 1892. Built tank engines at some time. (A)

liBB, AND HOGG, VICTORIA BNGINE WORKS, AIRDRIE. Founded in 1866 this tirm moved to a Bellsayke site three years later, erecting the Victoria Engine works and becoming one of the largest Iirms in the district. To 1913 they built possibly 20 industrial locomotives, some from patterns acquired from thomas theculloch who closed down in 1890. (A-F-G, p.88).

GLENGARNOCK IRON WORKS, GLENGARNOCK. Built locomotives for their own use.

(A)

GOURLAY, MUDIE AND CORAPANY, DUNDEE FOUNDKY, DUNDEE. Began as general engineers, taking over the Dundee Foundry from James stirling and Co. in 1846 and building a few locomotives including an order for the Aberdeen railway. In 1853 the partnership was dissolved ana Gourlay was joined by his three brothers, the firm turning to shipbuilding but eventually going out of existence in 1908. (A-M, April, 1957, pp.105/106). 
GRANT, RITCHIE AND CORPANY, TOWNHOLME ENGINE WORKS, KILMARNOCK. Formerly Grant Brothers this firm produced tank locomotives, primarily for industrial purposes, but on one occasion in 1881 to the Fordell railway. (A-C-T, .7 ).

HAWIHORNS AND COMPANY, LEITH ENGINE WORKS, LEITH. These works were bought from James B. Maxton in 1846 by the locomotive builders, R. \& W. Hawthorn of Newcastle for erecting engines built by them for Scottigh railways in order to avoid sending complete engines by sea. After the Royal Border Bridge was opened in 1850 this was no longer necessary, but pe rhaps a more important reason for Hawthorns having doubts about the need for this plant was the decline in orders following the railway mania boom. With the threat of closure it would appear that several local land and marine engineering interests approached the Newcastle firm with the outcome that $R$. \& W. Hawthorm as such wi thdrew from the works, but formed a new company under the name of Hawthorns. Their share holding was around a third and the local interests took up the remainder. Several of the Scottish railway companies purchased stock from them, but engines were also supplied to India, Germany and, in the late $1860 \mathrm{~s}$, to South America, especially Chile. However, by the mid 1860s their colliery, land and marine work had increased to such proportions that they began to slide out of locomotive working. Their location difficulties in relation to railway transportation and the powerful competition from the Glasgow specialists would also make their railway work less attractive. In the early $1870 \mathrm{~s} \mathrm{R}$. \& W. Hawthorn sold out their holding in the company and locomotive production and repairs were gradually given up at Leith. By 1886 the firm was well 
known for their steam trawlers and carried on building small vessels until closure in 1928. (A-C-I, 10 fray, 1886-J, $31 \mathrm{July}$, 1957-LL).

GEORGE INGLIS AND COMPANY, ALBERT WORKS, AIRDRIE. In all this firm built seven locomotives, the first in 1900 and the last in 1925 which went to a cement works in Sheffield. (A-F)

JOHNSON AND RCNAB (later BARR AND BCNAB), PORT DUNDAS. As Johnson and McNab a locomotive was built for the Garnkirk and Glasgow in 1832, but it was as John Burr and Anurew McNab, ironfounders, engineers, sniths, millwrights and boilermakers that further locomotive production was done for the Ardrossan and Glasgow, Paisley and Greenock lines. (A-C-MMU)

KERR, STUART AND COMPANY. According to the Glasgow P.O. Directory this firm was founded as James Kerr and Co., "rolling stock and permanent way contractors" in Glasgow in 1881 and in 1883 was registered as Kerr, Stuart and Co., iron and steel merchants. In 1888 they were described as "engineers and contractors" and in 1891 (the last entry) as "engineers and railway plant merchants." In 1892 they deciaed to leave Glasgow and take over the California Works, stoke where they obtained orders for rolling stock through the influence of Glass Hooper, a leading financier of railway companies in India and South America. ( $\mathrm{V}, \mathrm{pp} .86 / 87$ )

KILMARNOCK ENGINBERING COMPANY. Built tank locomotives. See Dick, Kerr and co.

KINMOND, HUTTON AND STEEL, WALLACE POUNLEY, BLACKNESS, DUNDEE. This firm must have originated in the late 1830 s judging from 
contemporary statezents. They constructed the first locomotive for the Dundee and Arbroath in 1838, and later three others for the same company. Although not generally regarded as marine engineers there is evidence of their constructing ships boilers. Between 1850 and 1850 the firm is listed in the Dundee P.O. Directory as James Steel and Company, Lilybank Foundry. For many years James steel was the sole acting partner of Kinmond, fiutton and steel and in that capacity constructed several locomotives for use in the district and also a few for export, some of which went to the United States. In 1850 Herapaths reported that Messrs. Kinmond and Co. were selling by auction, machinery, engineers and machine makers tools, patterns and stock, locomotive engines and tenuers, railway carriage and wagon wheels. One can only presume that they had decided to leave Britain, and not the trade, for in 1853 the Kinmond Brothers of Dundee opened a locomotive works in montreal to manufacture engines for the projected Grand Trunk railway of Canada. Their tirst engine was only the second to be built in Canada, but despite a promising beginningthe firm went under in the 1857 depression. Back in Britain, by 1801 both the Lilybank and Wallace Foundries had passed into other hands. (A-C-R, 1930 vol.22, 1941, vol.50-W, 28 June, 1845-X, 9 0ctober, 1838-Y, 19 January, 1850-NN)

LENNOX, LANCE AND COMPANY, GLASgOW. It is argued by the writer in the Locomotive keview that this firm built tank locomotives for collieries and iron works. However, it would appear that they did not actually build locomotives, but deslt in these constructed by others. $(A-C)$ 
MARTYN BROTHERS, CHAPELSIDE WORKS, EIRDRIE. This Iirm took over Dick and Stevenson's patterns and drawings and between 1890 and 1900 built possibly six tank locomotives for colliery use. $(\mathrm{C}-\mathrm{F})$

THOMAS MCCULLOCH AND SONS, VULGAN FOJNDRY, KILRARNOCK. BUIIt tank locomotives, mostly narrow gauge, before closing down in 1890. See Gibb and Hogg. (C-F)

MCKENDRICK AND BALL, GLASGOin. ACcording to Smith this firm buift vertical boiler locomotives. John McKendrick first appears in the Glasgow P.O. Directory in 1861 when he is described as being "of A. Chaplin and Co." Henry william Balls connection with that Iirm dates from 1870. From 1877 to 1880 a London address is also given for McKendrick, Ball and Co. 1880 is the last entry for NicKendrick. H.W. Ball appears as "of A. Chaplin" until 1885.

JAMES RACFARLANE AND COMPANY, GREENOCK. This may not be the firm which Smith referred to as their entries in the local directory from 1886/87 to 1903/04 lists them as heating engineers, ironmongers, smiths and plumbers. (A-JJ)

MILLER AND COMPANY, VULCAN FOUNDRY, COATBRIDGE. Again it is probable that this firm never built but only repaired or dealt in locomotives. $(\mathrm{A}-\mathrm{C})$

MURRAY AND PATERSON, COATBANK ENGINE WORKS. Founded in 1868 for general engineering work this company also constructed and 
repaired tank locomotives for collieries and iron works. In 1899 the firm became limited and one year later moved to new works close to Whifflet Station on the Caledonian line. (B)

MURDOCH, AITKEN AND COMPANY, HILL STREET FOUNDRY, GLASGOW. Starting as millwrights and ironfounders in 1815 this firm progressed to making several marine engines in the 1820 s and in 1831 built the first railway locomotive to be constructed in Scotland for the Monkland and Kirkintilloch. They also constructed engines for the Garnkirk and Glaseow and the Paisley and Renfrew railways. The company did not grow greatly in size and remained \& sound general engineering business doing suffiiciently well to move to new and larger preaises in 1858. (A-B-C-D)

NEILSON AND COMPANY. In 1836 the firm was known as ditchell and Neilson of McAlpine Street, Glasgow, a year later it became Kerr, Mitchell and Neilson of Hyde Park Street, only becoming Neilson and Co. in 1845. In 1863 the firm moved to new works in Springburn naming them the Hyde Park Works and the company name was altered to Neilson, Reid and Co. in 1898, five years before tiney amel gamated with the two other great Glasgow locomotive ouilders to form the North British Locomotive Company. For the first year of its life the company made land and small marine engines including the stationary beam engines for use on the Cowlairs incline of the Edinburgh and klasgow in 1841. They then progressed into locomotive building constructing three small ones for the Garnkirk and Glasgow in 1843. Until the mid 1850 s they continued to manufacture all types of engines although concentrating more and 
more upon locomotive production and supplying wheels and axles to railway companies. After that time locomotives were the exclusive product. At first orders were mainly for the Scottish railways, but as contracts were gained to supply Bnglish and overseas companies the necessity of increased capacity enforced the move to Springburn. When Dubs left he was replaced as a manager-partner by Reid whose previous experience with sharp Stewart of Manchester brought the firm contracts and whose flair for designing "labour saving multiple tools" brought them the ability to compete successfully with anyone. By 1870 the works were employing 1,500 men and producing 130 locomotives per annum valued at $\$ 335,000$. In 1878 heid became the sole proprietor and he expanded the firm until it became the largest in Europe. Prior to the amalgamation the company employed 3,400 men and was producing over 200 engines each yesr. ( $A-B-D-0-P P, 1$ December, 2922; 17 May, 1901-Q, January, 1951, p.6-2, 23 October, 1841-P).

NORTH BRITISH LOCOMOTIVE COMPANY, GLASGOW. Founded by an amalgamation of Neilson, Reid and Co., Sharp Stewart and Co. and Dubs and Co. in 1903 to allow them to face up to foreign competition more effectively. The amalgamation permitted the concentration of processes, the forge, smithy and iron foundry work being done at Queens Park and the non-ferous castings, flanged plates and patterns at Springburn. (A-C-P).

J.M. ROWAN AND COMPANY, ATLAS WORKS, SPRINGBURN, GLASGOW. kowan was engaged in the locomotive trade as early as 1834 or 1835 and produced engines for the Wishaw and Coltness, the Glasgow, 
Paisley and Greenock and the ironkland and Kirkintilloch railways. He continued to prosecute the trade for several years but turned to producine industrial locomotives and locomotive parts. The last entry in the local directory is for 1871/72. Benjamin Connor, locomotive superintendent of the Caledonian, and Tait, who helped Neiilson organise their locomotive production, both worked in the Atlas works at one time. (A-D-AA, 1870/71, P.126-N, 25 May, 1866-KK).

SCOTP, SINCLAIR AND COMPANY, GREENOCK. This firm is listed in the local directory as early as 1832 though it may have existed eariler. Originaliy designated as engineers, iron and brass lounders, they soon en tered shipbuilding and later constructed locomotives and wacons for the Glasgow, Paisley and Greenock and the Caledonian railways, although this might have been influenced by Sinclair's nephew, Robert, being locomotive superintendent of both lines. (A-C-0, pp.81/82-BB, p.51).

\section{ALEXANDRR SHANKS AND COMPANY, DENS IRON WORKS, ARBROATH.}

Founded in 1840 this firm produced a heterogenous list of products including rollers, iron custin\&s, steam enfines of many kinds, pumps, crunes, excavating machinery and miscellaneous engineering goods. However, their speciality was lawnmowers in which they built up a large export business, opening a London office in 1870 to assist in this side of the gusiness. Fhe locomotives fhat they built were small and generally for use in dock and harbour work. In the late nineteenth century the firm came to specialise in malleable iron work including fittings for engines. (A-C-CC, 
19 February, 1891)

SHARP, HENDERSON AND CONPANY, AIRDRIE. Between 1870 and 1900 this company did a good deal of locomotive repair work, but never built engines. The belief that they did stems from a habit of putting their name plates on locomotives passing through their hands. $(A-F)$.

SHARP STEWART AND COMPANY, ATLAS WORKS, SPRINGBURN, GLASGOW. Founded in Manchester in 1826 or 1833 as Sharp, Roberts and Co. and became Sharp Brothers and Co. in 1844, Iinally taking the name of Sharp Stewart in 18.52. Originally producing cotton spinning machinery they were building locomotives by 1834 and were extremely successful in that trade moving in 1862 to new premises "to house the expanding company." When their Hanchester lease ran out they trangferred their ousiness to Glasgow taking over the works of the Clyae Locomotive Company in 1888. Before the great analgamation the firm had built over 5,000 locomotives. (A-C-Q, January, 1951-N, 14 December, 1894-P).

SHORT BROTHERS, GLASGOW. Although listed by Smith as locomotive builders, no trace can be found in the P.O.Directories. Their natne appears in the appendix of Scottisn locomotive builders in the Glasgow Iransport Museum's publication "Scottish Railway Locomotives," but the Museum could provide no further information. $(A-C)$.

SHOTTS IRON COMPANY, SHOTSS. Built locomotives for their own use. (A) 
SIMPSON AND COMPANY, DUNDEE. Nothing much is known of this firm who built for the Edinburgh and Glasgow, North British and Aderdeen railways. (A-M, August, 1948, p.201-DD, p.54).

STARK AND FULTON, NORTH STREET, ANDERSTON. This company supplied the Glassow, Paisley, Kilmarnock and Ayr in 1839, but seems to have concentrated on the making of sugar muchinery. $(A-B-C-D)$.

JALAES STIRLING AND COMPANY, HAST AND VICTORIA FOUNDRIEN, DUNDEE. The Dundee Foundry began iron founding in 1790 and was making steam engines and other machinery around 1820. James Stirling took charge in 1834 and in that year a locomotive was built for the bundee and Newtyle and later others for the Arbroath and rorfar. However, in the eariy 1840 s the foundry was taken over by Gourlays, becoming an ancilliary to their own shipyard. The works were a boon to the Scottish railways not only for the engines they produced but also for the men who learnt their skills there. Both Patrick and James stirling, both luter to achieve fame as locomotive engineers, served their apprenticeships in this, their uncle's works, and others to work in the foundry included Archibald Sturrock, another famous locomotive superintendent, and James Gow who became resident engineer on the Arbroath and Forfar. (A-C-W, 7 October, 1846-I-EE-NN).

ST. ROLLOX FOJNDRY COMPANY, GLASGOW. In 1835 this firm tried their hand at locomotive work and constructed the "Frew" for the Garnkirk and Glasgow. (A-C-O, p.32). 
J. \& R. TAYLOR, SMITH STREIS, AYR. This company produced at least one engine for the Dalmellington Iron Company. The business may have been carried on at the Kyle Foundry, Townhead which passed into the hands of J.M. Rodger in the $1880 \mathrm{~s}$. (A-00). T.M. TEMNANT AND COAPANY, NEWINGMON WORKS, EDINBURGH. Built vertical boiler engines. Appears in the Edinburgh P.O. Directory from $1854 / 55$ to $1871 / 72$. After $1862 / 63$ adaress is Bowershall, Leith. $(\mathrm{A}-\mathrm{C})$.

J. \& T. YOUNG, VULCAN FOUNDRY, NEWTON GREEN, AYR. This firm made ship's auxiliaries, colliery and agricultural machinery. They made the first locomotive in Ayr in 1863 for the Ayr colliery Control o1 the firm passed to A. de J. Hunter in 1890. (FF, 9 Warch, 1863-00). 


\section{APPENDIX TWO}

\section{SCOTLISH PRIVAIE CARRIAGE AND WAGON BUILDERS}

ReIerences are as for appendix one.

CAIRD hID CONBANY, GREENOCK. See appendix one.

M. CUTHBERT, PEKTH. A coachbuilder who did some railway work for, among others, the Edinburgh, Perth and Dundee. He is not listed in the local directories after 1852/53. ( 2,13 October, 1838-EPD 1/3, p.107. B.R.).

R. FAULDS, PARLIAMENTARY ROAD, GLASGOW, This firm was providing wagons for Scottish railways by 1850 at the latest and attained a prominent position for a number of yeurs prodicing over a thousand wagons per annum in the period $1874 / 75 / 76$, the last years for which figures are available. Besides wagons they also manufactured large quantities of contractors' plant such as turntables. (D-GNS $1 / 2$, p.504. B.R.).

HURST NELSON AND COMPANY, HOTHERWELL. Producers ot railway curriages, wagons, tramway cars, light railway rolling stock, wheels, axles, forgings, smith work and iron and brass castings. (s. p.53-s).

WILLIAIM KINROSS AND SONS, STIRLING CARRIAGE WORKS. Established by William Croall and Henry Kinross in 1802, but Croall later lett to found his own business in Edinburgh. Entered the railway trade Irom their normal road carriage business at the time of the railway mania and obtained considerable orders from the Scottish 
Central. However, they appear to have soon abandoned railway work. (GG, p.39/40).

P. ¿ H. MACLENMAN, CLUTHA WORKS, GLASGOW. Founded in 1811 this great engineering firm was producing virtually everything incidental to the manufacture of iron for engineering or industrial purposes by the 1890s. One of their many products was railway wagons for which the market appears to have been primarily overseas and by the turn of the century some 3,000 wagons per annum were being made. (D-S-HH, p.224).

K. $¥$. PICKERING AND COMPAKX, WISHAW. Beginning US Pickering and Son in the mid 1860 s this firm wes producing 340 wagons a month by 1870 as well as menufacturing wheels, axles, wrought and cast iron mountings una doing some general engineering work. Their works were entirely rebuilt in the late 1890 , s time when they were employing 500-600 men and producing 3,000 wegons per annum as well as 4,000 sets of wheels and quantities of miscellaneous colliery and railway plant and stores. In addition they did much repair work and had branch works all over Scotlend for this purpose; the principal ones being at Hirdrie and thornton, rife. (D-E).

A. PORTEOUS, MUSSELBURGH. Although supplying The North British witn pallast wagons in the 1840 s the only person of this description in the Edinouren P.O. Directory was a "smith and bell-hanger." (NBR 1/3, p.250). 
RUSSELI AND NCNEE, PRINCES STREET, EDIMBURGh. hlex RusseIl was listed in the local directory as a coachouilder of princes Street between 1807 and 1837 and James Nolfee as a coachbuilder of George street (and later kose street) between 1830 and 1837. The firm of Russell, licNee and Company, coach and harness makers were listed between 1838 and 1851, and Mcivee, James and Co. from 1851 to 1880. Kailway work appears to have been undertaken only at the time of the railway mania.

SCOT2, SINCLAIR AND COMPANY, GRSENOCK. See appendix one.

GBORGE THOMPSON, STIRLING. Established before 1809 this firm was listed as Thompson and Buchanan in 1833 when the partnership broke up and Buchanan returned to his klasgow enterprise. originally producing dog carts, wagonettes and carriages, railway work was unaertaken at the time of the mania, but appears to have been given up in favour of high class carriage work, and later motor cars. (GG, pp.29/32 - WIC 4/4, p.3. B.R.).

JALES TOD AND SON, LEITH WALK, EDINBURGH. Bstablished in 1810 and were involved in sinith and engineering work until being taked over in 1876 or 1877 oy Oliver and Arrol, Leith Walk Iron works. The first entry showing that they were wagon builders was in $1863 / 64$. They also manufactured springs and advertised themselves as machine makers.

P. WALLACE, PERSH. Originally coachbuilders this firm undertook railway work for the Scottion Central but disappear from the local directory after 1854/55. (SCR 1/l. B.R.) 


\section{CHAPTER FIVE}

\section{RAILWAYS AND THE IRON AND STEEL INDUSTRIES}

"How men can believe that anyone can, six or eight years beforehand, tell when a rail will wear out, and a sleeper will rot, and still more wonderful how many of them exactly, out of thousands, shall fail in that year, ... is to us not surprising, but astonion ing."

$$
\text { H.R.J., } 6 \text { Hareh, } 1852 .
$$

"It is impossible to estimate the life of rails."

$$
\text { Sconomist, } 15 \text { March, } 1873 .
$$

"... the impossibility of predicting the life of a rail, which in my opinion cannot be ascertained until it is actually removed from the line."

I.I. Bell, Memoranda as to the Wear of Rails. 1900. p. 76 .

\section{1.}

The iron and, towards the end of the century, the steel industry occupied key positions in a scottion economy based on heavy industry because they possessed important backward linkages with coal-mining and forward linkages with engineering and shipbuilding. Moreover, they were significant heavy industries in their own right, for in $184826 \%$ of British pig iron was made in Scotland and, between 1881 and 1889, Scotland was the leading regional producer of oven-hearth steel. (1) Thus to establish

1. A.D. Gayer, . Rostow, and A.J.S. Scwertz. The Growth and Fluctuations in the British Economy 1790-1850. 1953. p.323. .A. Sinclair, The Growth of the British Steel Industry in the Late Nineteenth Century,' Scottish Journal of Political Economy, vol.6, 1959. p.37. 
the part played by the railways in the transformation of the Scottish economy it is essential to examine their impact upon the development of the iron and steel industries by considering the railways' demand for ferrous products, their service as a means of transport and their influence on determining the location of the industries.

2.

The significance of Scottish railway demand to the indigenous iron industry can be determined only by knowing the size of that demand in relation to the output of the industry. However, even the producers of Scottish iron had no idea of the composition of their market. The President of the West of Scotland Iron and Steel Institute in the early 1890s did not feel capable of giving a reliable computation of demand' outside shipbuilding. (1) Yet, although aggregate data is not readily available, a model can be constructed which utilises scattered information to produce an estimate of the railways' demand for iron used, both in laying out the permanent way and in building rolling stock. (2)

1. Journal of the west of Scotland Iron and Steel Institute, 189273, p.6. (Afterwards J.W.S.).

2. Some railway company accounts occasionally list the quantities of rails purchased in certain years, but these are too infrequent to render their use worthwhile and they also suffer from the handicap of being records of orders not deliveries. It must be pointed out that the model is concerned with quantities and not velues as speculation in Scottish pig-iron mekes it impossible to deter ine the price received by the producer. For details of this spe culation see R.H. Campell, 'Fluctuations in Stocks: a Nineteenth Century Case Study,' Oxford Economic Papers, 1957. 
The statements cited in the heading to this chapter show the difficulties that contemporaries had in determining the volume of iron that a railway was liable to consume in the form of rails alone. Even with the benefit of hindsight the model cannot hope to be accurate, but it can give some idea of the order of magnitude of the demand.

A problem to be faced in the calculation of $r$ ilway demand for permanent way material is that official statistics of Scottish railway mileage did not begin until the late 1840 s and did not distinguish between track and route mileage before 1860. Moreover, the accuracy of these figures is distorted by lags in the flow of information between the companies and the Board of Trade. To overcome these handicaps various sources were used, primarily Bradshaw and corrected versions of H.G. Lewin's 'Early British Railways' and The Railway Mania and its Aftermath,' to produce an estimate of railway mileage which differs from the official version in chronology, but which shows negligible total error. (1) In estimating track mileage it is difficult to allow for the doubling of a line originalIy single as this is not recorded in either the official or secondary statistics. However, only $3 \frac{1}{2}$ miles are unaccounted for up to 1860 and this was distributed proportionately amongst known construction. From 1860 the official data is reliable if corrected for obvious errors and allowances made for rounding. Lines of more than double track were not listed separately for Scotland before 1893, but at this date such track accounted for less than $0.4 \%$ of total nileage.

1. This can be seen in appendix one, columns one and two. 
If the railway companies had bought materials in advance and stocked them, then for the purposes of the model the mileage figures would have to be backdated, but there is no evidence of this being done on a substantial scale. Contracts were often made in advance to secure advantage of low prices, but generally the rails were to be delivered at a future date when needed. (I) Any error emanating from this assumption would not be perpetuated in the renewals estimate since rails cannot begin to wear out until the railway is brought into operation.

Sidings are not adequately recorded until the turn of the century when the following ratios between track mileage in operation and sidings mileage are obtained; 1904 1.00: 0.39, 1905 1.00: 0.41, 1906 1.00: 0.43, (2) In 1867 a ratio of 1.00: 0.27 was to be found on the Caledonian system and, for the purposes of the model, this was deemed to hold for Scottish railways as a whole. (3) Since railwy construction went on in the more isolated

1. e.g. North British, RAC(S) 1/1A, 24 March, 1859, B.R. Slamannan, Hitchell Library, Glasgow 53154-7, 8 February, 1838. North British, H.K.J., 30 Narch, 1872.

2. Calculated from the Railway Returns of the Board of Trade. Figures exist for earlier years, but are marred by the absence of returns from the major Scottish companies.

3. Calculated from a comprehensive report made to the Caledonian Shareholders' Inquiry of $1867 / 8$ by John Hawksworth, engineer of the company. $\operatorname{RAC}(\mathrm{S}) 1 / 3, \mathrm{~B} . \mathrm{R}$. (afterwards Hawksworth). It is apparent that no universal relationship holds between track mileage and the mileage of sidings, points and crossings. Sidings are much more intensive in the industrial regions e.g. one mile of the Caledonian's Dalmarnock branch had 5 miles 579 yds of sidings as contrasted with the 3 miles 510 yds existing on the forty-three niles of track between Dundee and Perth. The Peebles, an agricultural line, pos essed 2.41 miles of sidings to its 18.72 miles of track. Hawksworth, loc.cit., Railway Times, 21 March, 1857. 
regions throughout the remaining years of the century and there was a general, but not explosive, expansion in industrialisation elsewhere there is no strong objection to the assumption of a linear trend in the sidings ratio between 1867 and 1904. Prior to 1867 the ratio of $1.00,0.27$ was assumed to hold in the absence of any evidence to the contrary. Any error will be a once and for all effect as sidings renewals tended to be made from old materials. In addition, the fact that sidings were generally less than onefifth of total demand before 1855, and that this proportion declined thereafter with the rising importance of track renewals, will diminish the importance of any error.

The early lines laid relatively light rails, but the increases in both the weight and speed of the traffic rendered necessary a corresponding increase in the weight of the permanent way. In 1830 the Garnkirk and Glasgow had used $28 \mathrm{lb}$ rails (36 $\mathrm{lbs}$ in some places), but had been relaid with heavier material within seven years. In 1837 both the Arbroath and Forfar and the Dundee and Arbroath opted for a $48 \mathrm{lb}$ rail and by 1840 a 75 lb rail was the choice of both the Edinburgh and Glasgow and the Glasgow, Paisley and Greenock. (1) Development was less rapid in the next sixty years, but by the end of the century 90 lb rails were standard on many lines. Chairs and fishplates also increased in weight, but it should be noted that there was no weight relationship between

1. Report of Garnkirk and Glasgow, 1 March, 1837. S.C. Railways. 1939K. p.129. Parliamentary Papers (Accident Reports). 1859 XXVII. p.42. Railway Times, 29 December, 1838. 
the constituent parts of the permanent way, although heavier chairs came into use with the adoption of the steel rail. Average weights given in appendix one (columns seven and eight) were calculated for most years using data extracted from company histories, official accident reports, directors' reports to shareholders and company minute books. For jears where no information was available weights were obtained by assuming a linear trend between calculated points. This assumption is justified on the grounds that there was unlikely to be a sudden and universal decision to adopt a heavier rail for all new lines; a linear trend represents the gradual replacement of lighter rails by heavier ones.

Developments in the permanent way such as the use of the fishplate and the increase in the length of rails were taken to follow the pattern of introduction as on the Caledonian. Support for this can be found in the accident and directors' reports.

The major problem in constructing the model is that of estimating renewals. In the early days rails became obsolescent rather than worn out. (1) Estimates of how long the permanent way would last were wildy optimistic. Miller, the engineer of the North British, claimed that 'a period of twenty-five years may be safely assumed as an average over the North British lines' for rails and, although some chairs were occasionally broken, he thought 'they

1. Replacing too light track with heavier materials occurred in the early 1850 s on the Dundee, Perth \& Aberdeen Junction (Railway Times, 20 September, 1851), the Manklands (H.R.J., 30 October, 1852) and on the Dundee \& Arbroath (H.R.J., 8 January, 1853). 
would last for more than double the period of the rails.' (1) However, by the 1880s an iron rail was expected to last but ten years on main lines and most sections were relaid within nine to twelve years. (2) Really the duration of rails ought not be be expressed in terms of years as 'the life of rails was entirely a question of tonnage, and of speed and of frequency of trains.' (3) Unfortunately information as to traffic density is available only on a company basis and then only in terms of train miles run, with no mention of ton mileage. (4) However, this data can be used to produce an index of traffic density based on train miles run per mile of track. For scotland this index rose from 4.65 in 1861 to 9.88 by the end of the century. The reduction in average rail age from 15 to 19 years in 1867 (calculated from Hawksworth's data covering 46\% of Scottish railway mileage) to 9 to 12 years in 1886 (given by Sir Lowthian Bell in his study of the British iron trade) was attributed primarily to this increasing wear and tear. (5) These estimated average ages were taken as correct in the sense that a rail laid between 15 and 19 years before 1867 could be expected to be due for renewal in the year of Hawksworth's report.

1. Report of the Committee of Inquiry into the North British Railway, $\operatorname{RAC}(3) 1 / 1 \mathrm{~A}, 26 \mathrm{July}, 1849, \mathrm{p} .4$. B.R. D. Lardner in his Railway bconomy, 1850, p.51 expected at least a twenty year life for rails.

2. I.L. Bell, The Iron Trade of the United Kingdom, 1886, p.34.

3. Railway News, 23 May, 1876 .

4. It was in a regression of average length of life of rails on ton riles per mile of road that $R$.W. Fogel found statistical significance. Railroaus and American Economic Growth, 1964, p.172.

5. The index of traffic density automatically allows for longterm trends in weights of trains and rails etc. when used in conjunction with the evidence on ages of rails. 
Estimates of the potential length of life of rails put down in other years were then obtained by assuming that the trend towards a shorter life bore a direct relationship to the trend of the traffic density index. Allowance was made for the varying intensity of traffic within Scotland at any particular point of time by assuming that renewals of all rails laid in the same year would be distributed normally around the estimated average length of life of those rails. (I) Data in Hawksworth's detailed tables, whilst not exhibiting a completely normal distribution, suggests that such an assumption is not without justification. It would be too long a process to work out renewals for individual companies and so an aggregate renewals table was constructed on the assumption that these rails would be of the same weight as those on new lines each year. This leads to some underestimation of demand in the early 1850s when relevations of excessive capital expenditure led to construction on what was termed the 'cheap principle,' involving few heavy works and the use of lighter operating equipment which included the permanent way. However, the error would be at most $2 \%$ of total permanent way demand and this only in certain years. The increases in the weight and speed of traffic so shortened the life of wrought iron rails that alternative materials were sought. As early as 1853 the Edinburgh and Glasgow laid some of M. Stirling's hardened iron-top rails in Falkirk tunnel and by the late 1850s these patented, hardened rails were employed on the

1. Fogel, op.cit., pp.171-172 used a log normal distribution, but found that a normal distribution affected the results by only c.1\%. The evidence available for scotlend suggests that a normal distribution was more au ropriate. 
heavily used parts of the North British. (1) As the quality of iron rails deteriorated (2) the Glasgow and South Western also recognised the 'importance of considering whether a more lasting description of rail, made so by Messrs. Dodds and Sons Patent Process, or otherwise, should not, for the future be used.' (3) Despite their apparent success they were not widely adopted, not so much because of cost, but more because it was discovered that the hardening sometimes made the rails brittle. (4) Early attempts to radically increase the length of active life by the use of double-headed rails which could be turned failed, because the surface of the lower head became indented through long contact with the cast iron chairs. (5) Steel was the key to longer life, either to edge iron rails as done by the Glasgow Iron Company, (6) or, more generally, in the form of a complete rail. Being harder, such rails were less liable to be crushed, and, being stronger,

1. $\mathrm{RAC}(S) 1 / 73$ and I/1A. B.R. Maurice Stirling's rails were 5eing experimentally manufactured at Dundyvan in 1849. Railway Chronicle, 22 September, 1849. kailway Times, 3 May, 1851.

2. K.c. kaIlways, 1867 XXXVIII, q. 17039 Professor Kankine's presidential address, T.E.S.S. 1858/9. The Glasgow \& South Western complained of The inferior quality of the rails manufactured now, compared with those furnished at the construction of the railway.' H.R.J., 16 March, 1861. Inferior quality as well as the increasing intensity of traffic may well have been the reason that made 'very few makers ... disposed to give even a seven year guarantoe for iron rails.' H.R.J., 26 April, 1866.

3. H.R.J., 16 Narch, 1861.

4. Parliamentary Papers (Accident Reports) 1872 LII, p.39. The cost of the process to the North British was about \&l a ton including the erection of special furnaces and the purchase of the patent. $\operatorname{RAC}(\mathrm{N}) 1 / 1 \mathrm{~A}, 26$ September, 1860 and 22 March, 1861. B.R.

5. K.IN. Salkade, Permanent Way Textbook, 1934, p.134.

6. Engineering, 13 August, 1869 . 
they were less liable to fracture, both of which meant greater durability.

The switch to the use of steel rails did not follow automatically, or rapidly, from the granting of Bessemer's patent. The English witnesses to the Royal Commission of 1867 explained their reluctance to adopt the steel rail as being a product of its high price and an unsureness as to the degree of its durability. (2) There is no reason to believe that the Scottish companies would be any more progressive in their adoption. Experiments on the wearing qualities of steel ralls and switches were begun in 1861 by James Deas of the North British who found them 'giving great satisfaction' on severely worked sections. (3) However, elsewhere there were complaints of breakages, though this was explained as being because the steel was too hard or, what is more likely, the maker has been sailing too close to the wind in his attempt to use Scotch or other common iron along with haematite.' (4) The majority of companies experimented with the new

1. Tests showed that steel could withstand two and a quarter times the strain taken by iron of similar section. I. L. Bell, Memoranda as to the Wear of Rails, 1896, p.58. However, the strength of steeI in fact led to a lessening of the anticipated life of steel ralls by allowing heavier axle loads.

2. R.c. Raijways, 1867 op.cit., q.16220, 17407 and 17838.

3. RAC(S) I/1A, January, 1862. B.R. Engineering, 5 April, 1867.

4. Engineering, 29 June, 1866. Though it is now recognised that steel rails are more liable to suddenly fail transversely 'metal fatigue: - than wrought iron ones. However, they are free from the longitudinal splitting which iron rails are apt to suffer. J.D. Dearden, 'The Centenary of the Steel Rail,' Railway Steel Topics, vol.4, no.1, 1957, pp.2l-3. See also J.E. Stead, Mcro-lechanical Examination of Old Steel Bails and Tyres," J.K.S. 1896/7, p..25-36. 
rails, but as late as October, 1871 the Great North of Scotland had not used thell at all. (1) Even with their greater durability proved (this was not acknowledged by the Caledonian until 1873) the high price of steel rails relative to that of iron delayed their general substitution. With the narrowing of the price differential the steel rail was widely adopted and by 1879 most companies were, like the North British, "laying down almost nothing but steel rails." (2) Price would, however, deterinine only the material for renewals and not their timing as the necessity for safety would allow little margin for postponement. (3) A second factor conditioning the choice of metal was the bottleneck in

1. H.R.J., 14 October, 1871.

2. KAC(S) $1 / 2$, February, 1879. B.R. In 1864 the price of iron rails was $\& 7$ a ton and that of Bessemer steel rails \&17.10s a ton. In the next six jears steel rails fell in price to a ton whilst iron ones remained around $\$ 7$. In the next few years prices of both rose, but in the four years from 1873 the price of steel rails relative to that of iron fell some $50 \%$ K. Warren, 'The Sheffield Rail Trade, 1861-1930.' Institute of British Geographers, vol.34, 1964, p.139. J.C. CErr and W. TapIin, h History of the British Steel Industry, 1962, p.29.

3. The cost of permanent way material could possibly influence a decision as to new construction e.g. the Edinburgh \& Glasgow delayed making contracts for rails as they anticipated a price fall (Railway Times, 7 March, 1840), but since rails are one of the last items necessary there is sufficient scope for altering dates of rail purchases wi thout retarding actual construction. Frequently rails were ordered when prices were low c.lthough not needed there and then e.g. North British (H.R.J., 30 March, 1872), Border Union (RAC(S) i/lA, 24 Varch, 1857), Highland (H.R.J., I Hay, 1880). Treat North of Scotiand (H.R.J., 15 September, 1883). The reason was not simply to cut costs, but also to make a profit on their eventual sale as scrap. Safety factors prevent the postponement of relaying, but low prices may well advance it. However, it has been pointed out that price fluctuations do not normally affect replacements of rils. W. Hoffman, British Industry 1700-1950. 1965, p.246. 
production of steel rails. With the increased desire to use such rails after 1870 the manufacturers became overwhelmed with orders - "the difficulty now appears to be not to pay for steel rails but to get them," (1) - and the pressure would not be eased until production capacity expanded. For the purposes of the model the rate of supersession of steel over iron shown in Table 5.1 has been taken from the records of the Glasgow and South Western and from information given by Lowthian Bell on the Bnglish North Eastern.

As with the first iron rails the early advocates of steel overestimated its potential useful life. One witness to the 1867 Commission thought forty years not improbable. (2) Again, as with iron, the increasing intensity of traffic rendered such calculations invalid. Bell's reports on the North Eastern in 1896 and 1900 show an average age in the region of fifteen to seventeen years. (3) In the mid 1920s the average length of life was given as twenty-one and a half years, but the increase may be due simply to the realisation that rails had previously been taken up too

soon. (4) Another contributory reason was that steel rails were made softer when it was appreciated that hard rails were apt to wear more. (5) A similar procedure to that used in calculating

1. H.R.J., 18 March, 1871.

2. K.C. Ráilways, 1867 op.cit., q.17404-5.

3. I.L. BeII, Memoranda as to the Wear of Rails, 1896, p.27. I.L. Bell, Memoranda as to the Wear of Rails, $1900,8.76$.

4. W.V. Wood \& Sir Josiah Stamp, Railways, 1928, p.48. Bell in his preface to the Memoranda of Ig00 wrote of 'the impossibility of predicting the life of a rail, which in my opinion cannot be ascertainad until it is actually removed from the line.'

5. Parliamentary Papers, 1900 LXXVI (part one), Cd. 174, p.108. H.J. SkeIton, Deonomies of Iron and Steel, 1894, p.241. 


\section{TABLE 5.1}

STEEL RAILS AS A\% OF RAILS LAID

Year North Eastern Glasgow \& $\underset{(1)}{(2)}$ South Western Model

$\begin{array}{rrrr}1870 & 6.21 & ? & 5 \\ 1871 & 7.90 & 9.69 & 10 \\ 1872 & 13.35 & 17.20 & 15 \\ 1873 & 10.59 & 15.46 & 15 \\ 1874 & 26.44 & 24.66 & 25 \\ 1875 & 35.02 & 62.71 & 60 \\ 1876 & 33.89 & 58.39 & 80 \\ 1877 & 59.80 & 77.03 & 80 \\ 1878 & 98.89 & 79.94 & 100 \\ 1879 & 98.69 & ? & \end{array}$

Notes: (1) Calculated from I.I. Bell, Memorandum as to the Wear of Rails, 1896, p.29.

(2) Calculated from data in company records. RAC(S) $1 / 11-12$. B.R. 
the renewals of iron ralls was adopted for steel.

In general, line renewals were made with new rails and although some branches were relaid with old rails, as was the Wilsontown branch of the Edinburgh and Glasgow in 1857, such work was not significant. (1) Repairs made with old materials were a more frequent occurrence, but again were not of statistical importance. Sidings renewals, however, were generally effected with old rails and chairs. (2) There would be plenty of these available as usually whole stretches of line would be relaid at a time, not all of which would be equally worn.

Finally it should be noted that, although chairs and spikes might be expected to have longer lives than the rails which come into contact with the trafic, it was the general practice that - whenever renewals are made, the old road is wholly replaced by new rails, chairs, sleepers and fastenings.' (3)

The resulte found in Appendix 1 and column 9 and summarised in Table 5.2 wust be checked against data not used in the construction of the model to test their statistical validity. The aggregate figures cannot be tested as there are no independent estimates available, but some indication as to the validity of treids and fluctuations can perhaps be obtained from isolated information given by individual companies in their annus reports, and from data contained in old materials books. Such information as exists

1. $\operatorname{RAC}(\mathrm{S}) \mathrm{I} / 73$, 3.R. See also H.R.J., 26 Warch, 1864.

2. Hawksworth, op. cit., p.19. Bell, Memoranda, $1896, p .31$. Bell, Tron Irade, 1886, p.41.

3. Hawksworth, op. cit., p.i9. 
is insufficient to 'prove' that the results are correct but gives no indication that they are wildly inaccurate. The nodel was applied to the Glasgow and South western ralway and the estimated renewals checked against figures for actual renewals given by the company engineer in his half yearly reports. (1) Error was commonly less than $\pm 10 \%$ which does not suggest that a model aggregating all Scottish railways would be highly unrealistic. Confirmation that Caledouian was not atypical in having the greater part of its renewals concentrated 15 to 19 years after being laid was sought in the records of the sales of old North British permanent way material. (2) These showed a peak slightly later than might have been expected, but as this company was following a penny-pinching policy in the early $1860 \mathrm{~s}$ in an effort to maintain dividends it can be hazarded that they might delay renewals to the maximum that safety would allow. (3) However, before discussing the significance of the results it is necessary to compute an estimate of the iron used for other railway purposes. Early railway bridges were mainly of timber or stone, partly because of fears about the safety of iron castings when subject to tensile forces when employed in railway under-bridging. (4) Iron came more into use towards the end of the century and steel made a

1. $\operatorname{RAC}(S) 1 / 11-12$. B.R.

2. NBR 4/46-7. Sales and Receipts of Old Materials. B.R.

3. See the keport of the Comittee of Inquiry into the North British Railway 1866. $\operatorname{RAC}(S) 1 / 18$. B.R.

4. R.C. The Application of Iron to Railway structures, 1849 XXIX, P.XVii. J. Nitchell, Paper to the British Association on the Highland Railway, quoted in ungineering, 13 September, 1867, pp.205-7. ......., 1890/1, p.I41. 
spectacular debut in the bridging of the Firth of Forth, but the quantities used were probably small. However, figures exist for the metal content of the Tay and Forth Bridges and these have been taken into account. Stations were built primarily of wood or stone (and later brick) and their demand for iron must have been relatively slight.

Rolling stock demand for iron can only be estimated if the totals of rolling stock are known. The assumptions pertaining to the computation of these totals can be found in the previous cheter (section two) and the totals in Table 4.1 of that chapter. In estimating the amounts of iron used in the construction of that rolling stock more assumptions have to be made, but again it is emphasised that all that is being sought is some idea of the order of magnitude of the demand without any claims being made as to its exactitude. Locomotives were taken to consist solely of iron and steel, as were tenders, their weights being calculated from references in company and accident reports, but primarily from the works of the Stephenson Locomotive Society. This assumption will inflate the final estimate of demand, but, if Fogel's work is any guide, at most by $10 \%$ in relation to locomotive demand, which is less than $5 \%$ of total railway demand for iron. In the second half of the century their weights doubled, that of locomotives rising from below twenty-three tons to around forty-five tons, and that of tenders incressing to well over thirty tons from fifteen tons. Wastage in their construction may have been high, but the employment

(1) See appendix two. 
of Bell's figures in calculating pig iron equivalent thakes some allowance for wastage. It is also probable that much of the metal was capable of re-use. All carriages were taken as standard second class and all non-coaching stock as the standard mineral wagon then in operation. As mineral wagons dominated the numbers of stock, error emanating from this assumption will not be significant. The amount of metal used in these vehicles in the late nineteenth century was computed primarily from data in the design book of Messrs. R. \& Y. Piokering, carriage and wagon builders of Wishaw who supplied much Scottish rolling stock. (1) For earlier dates the ratio between metal and tare welght in the later vehicles was assumed to hold. The weight of metal in carriages trebled to about six tons between 1850 and 1900 as the companies increased the passenger capacity of their vehicles, but there was scarcely any increase in the metal content of mineral wagons as those of eight tons capacity soon became standard.

Total demand for rolling stock iron expressed in terms of pigiron equivalent is summarised in Table 5.2 together with perment way demand. There is a rising trend from an avarage annual demand of under 6,000 tons in the 1850 s to nearly 33,000 by the last decade of the century. It must be borne in mind that substantial error may have arisen from the ignoring of traders' wagons. If these were of the same magnitude and dimensions as those of the railway companies a further six thousand tons of iron might have gone for

1. The records of this company are kept in the Scottish Business Records Archives, Adain Smith Building, University of Glasgow. 
railway purposes in some years during the last quarter of the nineteenth century. (1) However, total railway demand for pig iron is dominated by permanent way requirements which rose from averaging 25,000 tons each year to over 90,000 in the same period.

\section{4 .}

These estimates of potential railway consumption of the products of the Scottish iron industry were probably nowhere near achieved for much of the permanent way material was purchased in England and Wales. In 1827 the Ballochney obtained patent malleable iron rails from the Bedlington Iron Company of Northumberland and they re-ordered from the same firm when relaying with heavier rails ten years later. (2) The preference of the early Scottish railways for English rails is understandable since the Scottish iron industry was relatively undeveloped, lacking both the experience and expertise in rail making which the English compenies had acquired by virtue of the earlier railway development south of the border. Scotland's ironmasters made attempts to enter what was at times a highly lucrative market, but the tendency to purchase outside Scotland remained as strong as ever. The Aberdeen company bought rails for the whole of its line from Messrs. Scholefield of Rotherham and the New British Iron Company

1. Although at first there was a wide diversity in practice, by the 1880s private wagons were generally conforming to railway company standards and specifications. J. Reid, T.E.C.S., $1882 / 3, \mathrm{p} .11$, and the Minutes of the Fifeshire Main Collieries, GD $58 / 25 \% 1, \mathrm{p} .225$.

2. Mitchell Library 53154-7, Ballochney, 28 May, 1827; 7 February, I837. 
gained the Caledonian contract. The Great North of Scotland obtained its rails from Bolkcow and Valghan of lild lesborough and the same firm was chosen by the dinburgh, Perth and Dundee, who also had dealings with Morrissey, Jansen and Company of Newcastle and the short-lived East of Scotland Malleable Iron Company. (1) It was not only this Scottish company that tried to break into the rail market. Two other specialist firms, The West of Scotland and the Ayrshire Malleable Iron Companies, also tried and failed. (2) At least one established ironmaster also made the attempt. John Wilson of Dundyvan shared the first contracts of the North British with Cargill, Morrissey and Company of Newcastle and Sir John Guest of Dowlais, but many of his rails proved defective and in April, 1849 he was paid 22,000 for the cancellation of a contract for one thousand tons of rails. (3) As the railways stretched to the north of Scotland and the era of the iron rail drew to a close it was still English firms that supplied Scotland with rails. (4) The extent of non-scottish supplies of rails can perhaps be judged from an inquiry into rails broken by a faulty engine on the Caledonian between November, 1871 and March, 1872. Of 81 rails examined the suppliers were as follows:

26 Darlington Iron Company

1. Scottish Railway Gazette, 30 August, 1845. GINS I/I, P.4T and BPD I/3, pp.10,288, 295, 476. B.R. MS. 6355. pp.38-9. N.L. .

2. R.H. Campeli, 'Sarly Ralleable Iron Production in Scotland,' Business History, vol.4, no.1, 1961, pp.23-33.

3. MBK 1/4, I9 Ipril, 1849, 3.R. Wilson also gained a contract from the Glasgow, Dumfries a Carlisle, but 'as an inducement for forgoing cert in clains of damages which he had preferred against the individual directors of the time.' H.R.J., 13 April, 1850 .

4. e.g. for the Sutherland. Engineering, 6 Narch, 1868. 


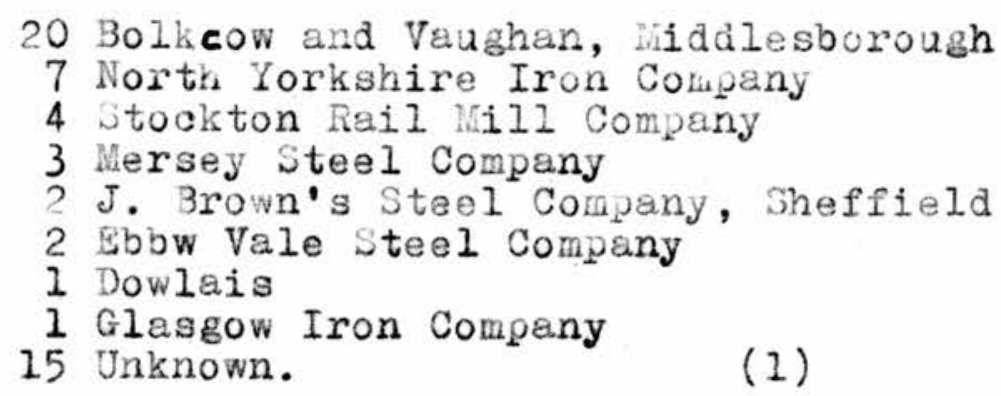

A combination of factors explains the failure of the Scots to obtain a share in the market for rails. The introduction of puddling was delayed until about 1836 as Scotland had no reserves of skilled labour and snglish and Welsh workmen had to be brought in to instruct the scots in the art. (2) Even then the finished product was not of a high enough standard to seriously challenge that of the established manufacturers south of the border. The main reason for this was the $1 \%$ phosphorus content of ordinary Scotch pig which increased the fluidity of the metal, thus improving it for foundry purposes, but raising a problem for the malleable iron producers, akin to that later to face the Bessemer steel manufacturers in Scotland, in that the metal produced was too brittle. This would not have been a great handicap if the Scots had been willing to rix with other brands, for it was well known that mixing produced better iron and such a procedure was adopted, for example, in South Wales. (3) However, in the early days at

1. Purliamentary Papers (Accident Reports), 1872 LII, p.39.

2. Colliery Guardian, 4 April, 1868.

J.H. CI pham, An conomic History of Modern Britain: The Larly Railway Age, I930, P.426.

i. Miller, The kise and Progress of Coatbriage, 1864, p.171. I am gratefuI to Wr. Kenneth warren for this reference and

\section{for p. $303(1)$.}

3. Railway Mazine and the Annals of Science, vol.3, 1838, pp.401-2. R.C. Application of Iron, op. cit., 9.519, 1389 and $p .265$. 
least, the Scottish ironmasters would not follow such a practice. (1) Bost of them did not even attempt to produce malleable iron, being satisfied with the substantial profits being made from the sales of their pig iron. Serious efforts to breach the walls of the rail market came when the pig iron sector was relatively depressed, and a desire grew to augment declining profits by the making of malleable iron which was in demand. In the late forties three companies were set up specifically to enter this trade, but unfortunately the application of the decision to invest coincided with high costs of construction, thus sadding the emergent companies with high capital expenditure, whilst production did not start until prices for rails were on a downward trend. All three companies failed and with their failure ended the large scale attempts of the scots to emulate the malleable iron producers of England and Wales. (2) The superior skills of the latter allowed

1. One exception was the Blaikie Brothers of Aberdeen who used three-quarters best hot-blast Scotch pig-iron with one quarter Welsh pig. Ibid., p.412.

2. R.H. Campbell, Early Malleable Iron Production in Scotland, op. cit.

The decision to invest in malleable iron plant was taken when the prices of all iron were high, but the pig iron trade, although still profitable in the $1840 \mathrm{~s}$, was relatively depressed compared with the extremely profitable 1830s. One reason being that in Lanarkshire the better fields were being worked out and higher royalties were being demanded for the remainder; thus resulting in increased costs. Many ironmasters were aware that their pig was being taken over the border, made into malleable iron and shipped back, and hoped that the development of malleable iron production in scotland would enable them to keep some of the profits of that branch of the industry at home. See R.H. Campbell, The Growth and Fluctuations of the Scottish Pig Iron Trade 1828-73, Ph.D. Aberdeen, 1956, pp.177-37, 209; Ayrshire Advertiser, 14 January, 1847; cottish Railway Gazette, 3 January, 1846. 
them to take advantage of cheapening transport costs which, although enabling the export trade of Scotch pig to develop, also meant that welsh rail makers could employ such iron, delivering it back in a finished form in Glasgow at prices which the Scots could not hope to compete with. (1)

In the late 1860s the Scots did begin to mix their local iron with Cleveland iron in order to meet competition from that district in the production of plate for shipbuilding. Over 70,000 tons was imported from Cleveland in 1867, but malleable iron production remained comparatively small, accounting for 142,000 tons of a total Scottish iron make of some 1,031,000 tons in that year. (2)

The change to steel rails made little difference to the nationality of the supplier. Sheffield had the first two regular makers of such rails, the trade being latched on to their existing quality work in railway iron. In the 1860 s half the Bessemer rails made in Britain originated in Sheffield. The Welsh manufacturers lagged a little in switching to the new product and had to overcome a declining reputation as makers of iron rails, whilst the other areas to achieve fame in the steel rail trade had still to establish

1. W. Truran, The Iron Trade of Great Britain, 1855, p.169.

2. D. Bremner, The Industries of Scotland, 1869, pp.33-5. The Conomist, 14 March, 1868 , remarked that the "comparatively nigh price of Scotch apears to be favouring the introduction of the cheap North of England brands into the Scotch foundries and malleable iron works." See also Monthly Circular of William Connal, pig-iron storekeeper of GIasgow, ror December 1859 \& I874 kept in Ditchell Library. The famous Scottish forges of Purkhead and Lancefield founded their reputation in skill rather than the cheapness of their products. R.H. Campell, Ph.D. op. cit., p.137. 
a name for quality work. (1) To 1865 only one Scottish company, that of Rowan of Glasgow, had entered the steel rail business and the pressure of other orders, coupled with a lack of demand, led to a suspension of their Bessemer rail work, which although later revived found only limited success. (2) The next serious attempt came when the Steel Company of Scotland was formed in 1871 as the first large new company set up especially to utilise the Siemens' process, erecting open-hearth furnaces at their Hallside works for this purpose in 1873. The original intention was to specialise in the manufacture of steel rails, but the general expansion in rail making capacity operated against profitable production and the company adopted a policy of diversification, successfully producing steel for constructional work and shipbuilding. (3) of eight Scottish firms possessing Siemens' plant in 1884 only the Steel Company of Scotland and David Colville and Sons of the Dalzell Vorks, Motherwell manufactured rails and the last named firm did not feature rails in the advertisement of their products.(4)

1. K. Warren, op. cit., p.131.

2. Ibid., p.135. F.Kohn, Iron and Steel Manufacture, 1869, p.84. I.F. Gibson, The Establishment of the scottish Steel Industry, Scottish Journal of Political Economy, vol.5, 1958, pp.24-5.

3. Carr \& Iaplin, op. cit., p.35, Gibson, op. cit., pp.28-9. The directors" report for october, 1879 speaks of a "growing demand in this direction (ship and bridge building)" and that for August, 1880 states thet production was "chiefly steel for ship and boiler purposes." The report for October, 1881 suggests that by then major fluctuations in sales were produced by shipbuilding and constructional demand, with rails playing only a minor role. See also a list of the products of the company in the Scottish News, 11 May, 1886.

4. H. Griffiths, Iron and Steel Manufacturers of Great Britain, 1884, pp.66-71, 140. A point of interest here is that letters between Dubs, the famous locomotive builder, and Anderson, the Secretary of the Call nder \& Oban, suggest that Dubs might have been considering entering the rail trade, but probably the explanation is that he was acting on behalf of the Steel Company of Scotland, of which he was a director, but wis.using his works address. COB $8 / 14$ letters for May, 1875, B.R. 
It must have been difficult for the Steel Company of Scotland to make headway in the steel rail market in view of the general expansion of capscity and the reputation of established suppliers. The North British gave its contracts in 1893/4 to the Moss Bay Company of Workington and to Cammell and Company of Sheffield; ten thousand tons being purchased from Cammells after the steel Company of scotland had been refused a further contract. The newer railways would not even give the scottish firm a trial. The Edinburgh Suburban and Southside obtained its rails from the Moss Bay Company and the Glasgow Central Underground opted for Cammell and Company.

Several factors account for the failure of the Scottish ironmasters to grasp what was a second chance to break into the rail trade. One was obviously that their first failure meant that they had few links with the market. A second factor operating in the short run was that the late 1870 s were generally a period of low prices which strengthened the reluctance of the ironmasters to venture from a still fairly stable position into a new enterprise. This reluctance to change was a product of the structure of an industry concerned primarily with the making and marketing of pig iron. There was no strong incentive for them to take up the manufacture of steel; the persons who had to find new markets for their product or, alternatively, adopt the new steel-making processes were the manufacturers of malleable iron, who were a

1. NBR 1/40, 22 June, 21 December, 1893, 26 April, 17 August, 1894. 35S I/I, p.34. B.R. Railway World, vol.3, August, 1894, 
minority of the Scottish ironmasters. Not until the early $1880 \mathrm{~s}$ was there anything that could be termed a Scottish steel industry and this came as the growing demand for shipbuilding caused, firstly, the makers of malleable iron and, secondly, a few, but only a few, of the iron smelters to change to the manufacture of steel. (1) Development, however, was rapid and by the 1880 s Scotland was the leading open-hearth steel producing region in Britain. (2)

There was also a strong technical obstacle to change in that the phosphorus content of Scottish ore (hence pig) rendered it unsuitable for both the Bessemer and Siemens' processes until the development of the Gilchrist-Thomas technique. Early attempts by Thomas Jackson and William Dixon, the latter under the personal supervision of Henry Bessemer, had proved fallures because of this. Rowan, who succeeded, had used Cumberland pig. (3) The Steel Company of Scotland, in making an attenpt at the large scale production of steel, was hoping to utilise 'Blue Billy,' the residue after the copper and silver have been extracted from iron pyrites, win was at that time becoming the raw material of the Scottish

I. R.H. Campbell, Scotland Since 1707, 1965, pp.232-4. H.R.J., 27 January, 1883 commented on the "limited area of steel manufacture in Scotland." The change of the malleable iron-makers would be necessitated by their main market, the shipyards, adopting steel as a constructional material. The relatively late development of the malleable sector of the iron industry in scotland had coincided with the rise of iron shipbuilding on the Clyde, which in the 1860s and 1870 s absorbed between 65 and $70 \%$ of total Scottish malleable production. Gibson, op. cit., p.33, Sinclair, op. cit., p.35.

2. Gibson, op. cit., p.29. SincIair, op. cit., p.37.

3. Carr \& Tapiin, op. cit., p.28, campeII, Scotland Since 1707, op. cit., p.232. 
sulphuric acid industry. Although the costs proved to be too high, it was this hope that 'Blue Billy' would solve the problem of suitable ore supplies that encouraged the attempt to make steel where the established iron masters stood aloof. As local Scottish ore reserves were worked out Scottish smelting plants became increasingly dependent on imported ores, with which they produced supplies of pig suitable for the manufacture of acid steel, thus easing the transition to the steel age. (1)

Permanent way iron in the form of chairs and spikes did come from scottish iron companies. The early minute books of the North British list contracts with George Mushett of Dalkeith, W. Scott of Inverleithing, a Mr. Whitelaw of Aberdeen and Tod and Sons of Edinburgh. The only order outside Scotland was for 2,800 tons of chairs from Fox Henderson of Birmingham. (2) These forms of railway iron were products of the foundry for which Scottish pig was eminently suited. With the change to steel, however, some orders began to be placed with English manufacturers.

The Phoenix Foundry, Glasgow obtained the exclusive right of manufacture in Scotland of Griffin's patent iron sleepers. However, there is no evidence of their use on Scottish railways and presumably, as with the iron sleepers produced by the Anderston

1. Campbe11, Scotland Since 1707, op. cit., pp.233-4. Gibson, op. cit., p.32.

2. NBR ITI-6 passim. B.R.

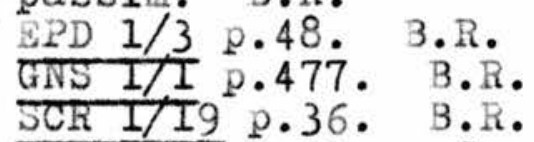

(Ed. \& N) SCottish Railway Gazette, 28 February, 1846. (Aberdeen) H.K.J., 19 Jotober, 1850. 
Foundry and Messrs. P. \& W. MeLellan, their market lay abroad.

Little metal was used in the early railway bridges and in any case Scottish hot blast iron was regarded as inferior for the purposes of large castings by many engineers. (2) At a later date iron and steel came more into use, but at first external suppliers were still resorted to. The cast iron columns for the first Tay Bridge did come from the Falkirk iron works, but most of the girder work originated in Cardiff. However, its successor was built with the products of the Dalmarnock Iron Works and the Steel Company of Scotland, and the latter firm, with Colvilles, also secured part of the contract for the construction of the Forth Bridge, although 12,000 of the 55,000 tons were to come from the Landore Works, Swansea. (3)

When railways went underground Scotland once again did not supply all her own railway metal. Although the steel for the Glasgow Central came from the Steel Company of Scotland and the Glasgow Iron and Steel Company, Wishaw, the contract for the iron work and girders had to be shared by David Colville and Sons with Goodwin, Jardine and Company and Dorman, Long and Company both of Middlesborough, the latter company with Morr Iron and Steel Company of stockton on Tees providing the plates. (4)

The majority, but not all, rolling stock iron probably

1. J. Mayer, Engineering and Shipbuilding Industries of Glasgow and the Clyde, 1876, . 103 .

2. K.C. The Application of Iron, op. cit., q. 230 - "the custom in scotland has been to care nothing about the quality," p. 381, "not adapted for making bridges or heavy machinery." 3. H.R.J., 26 october, 1872. Engineering, 28 February, 1890. 4. Rallway World, vol. 3, August, 1894, p.270. 
originated in scotland. It would be expected that the locomotives, carriages and wagons purchased in England, (of which there were quite a number before the railways set up their own workshops and the Scottish private manufacturers became established) (1) would utilise English materials especially when even a Scot declared that Scottish iron was 'quite unfit for wheel-making.' (2) In addition, throughout the century large quantities of best quality Yorkshire iron were used everywhere in the manufacture of crank and other axles, often being preferred to steel. (3) on the other hand Krupps of Germany had introduced steel tyres to Scotland via the Great North of Scotland about 1860, and by 1863 Rowan and Company of Glasgow were producing Bessemer steel tyres, axles and forgings of the highest quality. (4) At first a lack of demand restricted their output of steel to forty tons a month, but in 1871 the firm was fully engaged on general steel forgings and production of high class steel tyres for railway use. The latter link with railways was consolidated in 1872 when the firm undertook limited liability and one of the new directors was a representative of Neilson and Company, the locomotive builders. (5) The Steel Company of Scotland also manufactured rolling stock components, but the

1. Up to 1849 English builders supplied at least 207 of the 383 locomotives known to be in use on Scottish railways.

2. W. Neilson, T..S.S., 1857/58, p.120.

3. H. Skelton, op. cit., p.69. Moores MonthI Magazine, May, 1896, p.39. Dubs \& Co., Urders outward. Scottish Business Records Archives.

4. E.L. Ahrons, the British Steam Locomotive, 19?7, pp.163-65. Stephenson Locomotive Society, The Grest North of Scotland Railway, $1954, \rho .303$. Kohn, o. cit., p.84.

5. Carr e tapIin, op. cit., p.28. Gibson, op. cit., p. 5 . 
Scottish companies by no means monopolised their native railways' contracts. At the end of the century the Caledonian was splitting its orders for engine tyres equally between H. Bessemer and Company and the Steel Company of Scotland, the latter also sharing the wagon tyre contract with an English firm. In addition wagon drawbars were supplied by Cammell and Company of Sheffield. (1) The private rolling stock manufacturers also sub-contracted outside Scotland. In the 1890s Dubs obtained crucible cast steel from Cammells, some cast steel tyres from Krupps and frequently other locomotive fittings such as bearing springs, and copper pipes and tubes from knglish firms. The chief manufacturer of wagons in Scotland, R. \& Y. Pickering and Company, purchased wagon brasses and rolled knee bars from the Sandwell Iron and Axle Company, Smethwick and nuts and bolts from another smethwick firm, the Patent Rivet Company. However, the bulk of their metal requirements were met within Scotland. Steel plates for Dubs came from the Steel Company of Scotland, Neilson and Haxwell and P. \&W. Molellan, the latter firm also supplying many of the tyres and axles. Alexander Rowan provided the spark arresters and J. Wilson and Son the wrought iron pipes and furnace lubricators. For Pickerings wagon castings came from Pott, Cassels and Williamson, engineers of Motherwell, and the Ardeer Foundry, Stevenson. Wilson Baird of Glasgow supplied bar iron, knee bars, steel tyres and axles and 'Siemen-Martin' steel plates, while wrought iron buffer forgings were made by Miller, Russell and Company, Overton

1. CAL 1/40 14 December, 1897. B.R. 
Forge Ltd., Wishaw. (1)

By the end of the century many Scottish engineering firms were making their own castings, mainly from Scots metal, but in the late 1860s it was "contrary to the usual practice of mechanical engineering works in Scotland to make their castings on the spot," although the demand was still for Scottish metal from "the numerous and well-fitted foundries in the neighbourhood." (1)

As is shown in Table 5.2, the demand of Scottish railways for iron in the nineteenth century exhibited an upward trend, rising from c.44,000 tons in the $1840 \mathrm{~s}$ to c.124,000 tons in the $1890 \mathrm{~s}$ and totalling c.31,000, 74,000, 111,000 and 107,000 tons in the intervening decades. The downward movements in the $1850 \mathrm{~s}$ and $1880 \mathrm{~s}$ are explicable in terms of low replacement demand; inthe first case because the impact of the previous building was not jet making itself felt, and, secondly, because the use of the steel rail cut replacement demand for a while. Many problems have emerged in the computation of these figures, but have been overcome, some more convincingly than others, by the use of assumptions based on the evidence available. However, in attempting to determine the importance of this demand to Scotland a further difficulty arises in the nature of the statistics of Scottish iron production.

The early 'Vineral Statistics' tend to reiterate the errors of the secondary sources on which their Scottish figures are based. However, a reliable set of statistics can be produced from the

1. Dubs and Company, Orders Outwards,

R. \& Y. Pickering, Contract Book No.1, Scottish Business Records Archives. 


\section{TABLE 5.2}

\section{RAILWAY DEMAND FOR IRON}

Period Demand for per- Demand for roll- Total Production of manent way iron ing stock iron demand Scottish pig

$\begin{array}{rrrrr}1840 / 49 & 38.8 & 5.5 & 44.3 & 454 \\ 1850 / 59 & 25.3 & 5.5 & 30.8 & 815 \\ 1860 / 69 & 62.3 & 11.6 & 73.9 & 1083 \\ 1870 / 79 & 86.3 & 24.2 & 110.5 & 1022 \\ 1880 / 89 & 80.4 & 26.3 & 106.7 & 1034 \\ 1890 / 99 & 91.4 & 32.8 & 124.2 & 935\end{array}$

Notes: All measured in 1000 tons of pig iron per annum. For sources and fuller details see appendices one to three. 
records of William Connal and Company, storekeepers of pig iron in Glasgow. They are especially useful in that they register not only production, but also sales of the iron, which is valuable information as stock movements were often in the order of $\pm 10 \%$ of total sales. (I)

Annual production of pig iron averaged 450,000 tons in the 1840 s and maintained a high rate of growth throughout the next decade before attaining a peak of $1,083,000$ tons per annum in the 1860s. There followed a period of stagnation and eventual decline, but, as pig iron manufacture fell away, that of steel began to increase, rising from 50,000 tons in 1879 to 245,000 by 1886 . Information as to the production of malleable iron, from which rails were made, is not available in a comprehensive series for Scotland, although it is clear that this sector of the iron industry did not achieve a position of any significance until the late 1850s at the earliest. Between 1864 and 1880 malleable iron production averaged 200,000 tons per annum. Its rate of decline in the face of the overwhelming superiority of steel was much slower than in England, but this was a sign of conservatism, not of strength, as technical progress within the industry was non-existent. (2) Another point to be noted is that not all new rails need be

1. R.H. Campbell, 'Statistics of the Scottish Pig Iron Trade 1830-65,' J.W.S., vol.64, 1956/7. Monthly Circulars of William Connal and Co. - Nitchell Library.

2. Carr \& Taplin, op. cit., p.108. Gibson, op. cit., p.37. T.J. Byres, Thitrepreneurship in the Scottish heavy industries, 1870-1900,' in P.L. Payne (ed.), Studies in Scottish Business History. 1967, p. 256. 
a new demand upon the iron industry or even upon the rallnaking section of that industry. The committee inquiring into the affairs of the North British in 1849 were informed "that when the rails are so far bruised and injured as to be unfit for service, they can be rerolled, and the deficiency in quantity supplied at about 22 10s per ton, so that replacing the rails will not be so serious an expense as many persons may suppose." Moreover, as the company's engineer pointed out, they "will not be greatly diminished in weight." (1) How much iron rails lost in weight through abraison in use and waste in rerolling is difficult to say, but for steel the comparable figures were up to $20 \%$ in use and $7 \frac{1}{2} \%$ in remanufacture. (2) However, it is doubtful if much rerolling went on because of the costs involved in shipping the rails to English and Welsh railmakers, especially when a local market existed for scrap. (3) The Glasgow and South Western had not

1. Committee of Inquiry into the North British Railway, 1849, 2. I. L. Biti, The Iron Trade of the United Kingdom, op cit., pp.37, 41 .

3. The companies did not reroll their own rails. In fact the London and North Western was unique amongst British railways because of its policy of rolling its own rails. C.E.R. Sherrington, The Economics of Rail Transport in Great Britain, $1928, p .83$. It 15 also rair to argue that not enough renewais were needed to stimulate the rise of a rerolling trade within Scotland, especially in view of the fact that the malleable iron industry, possessor of potential rerolling equipment, was virtually non-existent in Scotlend until (say) 1860 and thus could not take up rerolling as a profitable sideline. Thus the bulk of rerolling, if it was to be done on a substantial scale, would have to be done by specialist railmakers south of the border. 
formed any decided opinion as to the cost/durability ratio of the rerolled rails it was using in 1858, but the resident engineer thought it might "be for the interest of the Company to convert all their old rails, by rerolling, into new ones, if this can be effected at moderate cost." The absence of further statements suggests that costs were too high, if it is remembered that the North British sold most, if not all, of its old rails as scrap and would be unlikely to miss the opportunity of rerolling if it were at all profitable. (1)

What then can be said about the role played by her railways in the development of Scotland's iron and steel industries? If all the iron used by the rallways had originated as Scottich pig, only on rare occasions before 1875 would it have accounted for 10\% of total scottish sales or production of pig-iron. The average potential level of consumption between 1840 and 1870 was below $7 \%$ as is shown in Table 5.2. Following the fall in demand after the completion of the post mania construction the proportion was less than 5\%, but it began to increase during the 1860 s as further building and the replacement of worn out equipment took 1. $\operatorname{RAC(S)1/11}, 20$ August, 1858. $\mathrm{NBR} 4 / 46,4 / 47$, Sales and The railways seem to have missed few opportunities to sell old materials. The Caledonian was a relatively prosperous company in 1897, but still sold, amongst other items, coach trimmers' rags, old axle grease, old tickets and waste cinders. The proceeds from these sales were not inconsiderable; in two months in 1895 the North British obtained £7,588. CAL 1/41, 14 December, 1897, NBR 1/40, 20 July, 1895. 
place. However, most rails, (totalling perhaps half of the permanent way demand by weight), were supplied by English manufacturers. Even allowing for English use of $50 \%$ scotch pig in their rail manufacture this further reduces the importance of the railway demand. (1) On these assumptions, and if all rolling stock iron was Scottish, it is arguable that without that demand Scottigh pig-iron production would have achieved over $95 \%$ of the growth that it did attain between $1840 / 44$ and $1865 / 69$.

It is more difficult to ascertain quantitatively the part of the railways in the expension of the malleable iron and cast iron sectors of the industry. No Scottish ironmaster managed to successfully break into the market for rails, and those firms founded deliberately to exploit the railway demand for wrought iron falled to prosper. The rise of the Scottish malleable iron industry owed little to the railways. No production figures are available for cast iron, but if all Scottish pig domestically consumed - some 173,000 tons per annum in the 1840 s and 283,000 tons in the following decade - is taken as being in the making of cast iron then the railways required at the most between $7 \%$ and 10\%. The lower figure is counting non-rail permanent way demand only, and the higher total includes rolling stock demand. For the 1860 s computation is made more difficult because of the growth of the malleable iron sector which consumed a proportion of the pig iron. If Bremner's figure of 142,000 tons in 1867 is typical of malleable iron production of the decade then, by a similar

1. No English witness to the Royal Comission on the Application of Iron to Railway structures quoted a ratio above this. 
calculation to that above, between $10 \%$ and $15 \%$ of cast iron production went to meet railway requirements. (1)

Two factors were operating on the demand side to make the railway's needs of more importance to the Scottich iron and steel industry in the last quarter of the nineteenth century. Firstly, equipment was getting heavier. Between 1860 and 1900 the average weight of rails rose $26 \%$, of chairs $75 \%$, and of locomotives $58 \%$. (2) Secondly, renewals began to exercise a strong influence upon demand, as is indicated in appendix oine. Not only does renewal demand exhibit less fluctuation from year to year than new mileage demand, it also, except in years of unusul constructional activity, dominates absolutely total demand for permanent way iron. In only 7 years in the last quarter of the century did new track opened exceed $25 \%$ of total track renewed.

The proportion of total pig iron production potentially absorbed by the railways rose from about $10 \%$ to $15 \%$ by the end of the century with occasional fluctuations as high as 20\%. Again much permanent way material came from south of the border but less Scottish metal would be used in its preparation than previously. (3) For the purposes of the model the increase in rail production within Scotland was considered as being cancelled out by this diminished use of Scottish pig in Bngland. On the same assumptions as before, a rate of growth in the order of $90 \%$ of that actually achieved by the pig iron industry between $1870 / 74$ and 1895/99 could have been

1. Bremner, op. cit., p.33.

2. See Appendix one columns seven and eight, and Appendix two, column one.

3. See below p.335. 
expected if there had been no railway demand. However, allowance must be made for the increased use of English pig by the Scottish steel-makers. Imports, primarily from Cleveland rose from 72,000 tons in 1867 to average 300,000 tons per annum during the period 1875/80 and over 425,000 tons between 1895 and 1890. (1) If railway steel produced in Scotland contained as much English pig as did Scottish steel in general, then the absence of railway demand would have cut the rate of growth by about only $5 \%$. In fact, as pig iron production remained stagnant at slightly over 1,020,000 tons per annum during the 1870s and $1880 \mathrm{~s}$ before declining to 935,000 tons in the following decade, it can be argued that railway demand, via the other sectors of the iron industry, had an important part in maintaining the level of output and the use of existing capacity as the demand for coastwise and foreign shipments fell away. It also ought to be noted that, although the Scottish steel industry was reliant on the shipyards, the major steel producer was originally set up to tap the railway demand for rails, albeit not just Scottish railways. The Steel Company of Scotland might have developed anyhow when the Clyde shipbuilders turned to steel, but the existence of the Company may have encouraged that switch by having the material on hand; moreover who is to say what lessons may have been learned from ten years

1. See Appendix three, column ten. 
experience. (I)

It has been suggested that in the aggregate the Scottish iron and steel industries did not need indigenous railway markets to ensure growth, although one section of that industry, the pig iron trade, may have been grateful for their stabilising influence towards the close of the century. Individual firms may have been more dependent for their fortunes upon railway demand, but this is unlikely in view of the tremendous influence which external markets exerted on the industry as a whole. The evidence that exists suggests that the engineering firms who supplied the home railways with equipment generally diversified their output to various markets at home and abroad, thus reducing the significance of Scottish railway demand for iron through this channel. (2)

6 .

At times the railways in Scotland may have been more a backward linkage of the Scottish iron industry than the reverse. Rolling stock scrap was estimated by multiplying the various

1. It is difficult to substantiate the hypothesis that the steel Company of scotland encouraged the switch to steel by shipbuilders, but they did make great play in their advertising with the success of a ship, the Rotomahana, built of steel manufactured at their Blochairn works, which was involved in an accident from which an iron hulled vessel would have sunk. (W. Denny, 'On Steel in the shipbuilding Yard, Mransactions of the Institute of Naval Architects, vol.XXI, 1880; J. Pollack, Dictionary of the CIyde. I888; I am grateful to Dr. P.L. Payne of the University of Glasgow for this information).

2. There is no doubt that some foundries benefitted enormously from the railways as a whole as they produced nothing but railway equipment. 
quantities of scrapped vehicles by the average weight of each category an average life ago. These average lives were the same as those used in calculating renewals. Few vehicles were scrapped before 1860. After that date totals for scrapped vehicles were obtained by a comparison of total existing stock (as given in the Railway Returns) with the figures for renewals and additions to stock as estimated from the railway company records. From 1870 these are reliable, but for the previous decade it is probably best to assume that the number of scrapped stock was the same as the stock renewed. Expressed in terms of pig iron equivalent scrapped rolling stock produced about 2,000 tons of material each year in the 1860s. As the railway network expanded heavier vehicles and a great volume of scrapping increased this to around 15,000 tons by the late 1890s. (1)

As for the permanent way, rerolling of rails does not appear to have been the prevalent practice. Most companies followed the policy of the Caledonian whose old materials were "ei ther sold or applied to incidental repairs on portions of the line which do not require to be renewed, or in the construction of additional sidings and branches." (2) How much was sold and how much relaid is difficult to determine. In the absence of information for any Scottish Company it must be accepted that the figure for those reemployed lies somewhere between one-third and two-thirds. The former was the estimate of the storekeeper of the North Eastern

1. See Appendix four.

2. Hawksworth, 오. cit., p.19. 
regarding rails taken from main lines and branches, and the latter estimate is of rails taken from main lines only which were found to "have a further useful life in sidings and branches, where traffic is light." (1) Ultimately all rails would become scrap, but the time lag might be extensive. As late as 1923, seventy years after the opening of the line, some of the original Great North of Scotland rails were to be found scattered in odd sidings. (2)

Some old rails were sold to other companies; the Fordell purchased second hand rails from the North British as did the Selkirk and Peebles. The major buyers of scrap iron were, however, the engineers and ironmasters. As early as 1836 the Ballochney sold six and a half tons of old rails to the Dundyvan Iron Company. (3)

With the change to steel problems were raised. Questions about the utility of used steel rails featured predominantly in the discussion of a paper on The haintenance and Renewal of Permanent Way' given to the Institute of Civil Engineers in 1866. Wrought iron rails could be cut up, piled, forged or rolled down into something useful, but was this as true of the more durable and practically unbreakable steel ones? In fact C.W. Siemens' recently introduced open hearth furnace meant that they could be reworked. Not only were they "capable of ready conversion," but

1. I.L. Bell, Memoranda, 1896, op. cit., p.31. wood \& Stamp, op. cit., p.48.

2. Stephenson Locomotive Society, Great North of Scotland, op. cit., p.303.

3. G. Dott, Early Scottish Colliery Wagonways, 1947, p.7. Mitcheli Library, 53154-7, Ballochney, 2 February, 1836. 
they were "worth nearly or quite as much, ton for ton, and irrespective of the extent to which they may have been worn, as Bessemer ingots themselves." (1) Furthermore, Scotland had little integration between her iron and steel making which meant that the steel producers lacked supplies of molten iron. This handicap was overcome by their expert use of large quantities of steel scrap obtained mainly from the shipyards, but presumably also from the railways. (2)

However, the chief customer for railway scrap, if the sales of the North British are at all typical, was the engineering industry. Nost of the old materials were purchased by Scottish companies although occasionally, as in 1879, London firms would tender successfully for large amounts. It was not just the larger companies that bought the scrap, for frequently small firms, who were willing to pick up odd amounts at points over the system, would obtain contracts. The bulk of the scrap metal, however, would be taken by one or two of the large engineering firms and this became increasingly true as steel, which needed special facilities for reconversion, increased its proportion of total railway scrap metal towards the end of the century. In the case of the North British, Messrs. P. \& W. McLellan, who possessed such facilities, dominated the sales by the early 1890s, taking $49 \%$ in 1892 and $66 \%$ in 1896. (3).

1. Proceedings. I.C.E., 20 Warch, 1866. ingineer, 20 Apri, 1866.

2. K. Warren, 'Locational Problems of the Scottish Iron and Steel Industry since 1760,' Scottish Geographical Magazine, April, $1965, \mathrm{p} .26$.

3. NBR $4 / 46,4 / 47$, Sales and Receipts of Old Materials. B.R. 
The difficulties alluded to make it impossible to estimate accurately how much scrap was coming onto the market, but with a few assumptions, it is possible to hazard a guess. If half the rails lifted from main lines and sidings were iminediately sold for scrap and the rest had a further active life of (say) ten years, then towards the end of the century perhaps 70,000 tons of used railway material was being sold each year. (1) This was equal to $6 \%$ of total pig iron production and over $80 \%$ of railway demand for scottish pig. In the aggregate the railways were almost meeting their own requirements, though of course purchasers of the old materials and suppliers of the new were generally not one and the same.

\section{7.}

Did the railways then aid the iron industry in its capacity as a transport agency? The advent of the railways in Britain could have had disastrous results for the scottish iron industry. Prior to their coming the high cost of carriage and the remoteness of Scottish industrial location protected the relatively inefficient industry, but, as the efficiency of bulk transport improved, a decline in its fortunes might have occurred due to English and Welsh competition, had not the application of the hot blast cut

1. See Appendix four. 
production costs so drastically. (1)

It is arguable, however, that it was shipping and not the railways that carried the Anglo-Scottish trade of the iron industry. Ironically, in the immediate post-mania construction boom the absence of through railway communication enforced the use of coastal shipping to deliver rails from south of the border. The Perthshire Advertiser commented on the fact that "since Saturday no fewer than three vessels have arrived at Perth, loaded with rails, from wales for the Scottish Central Railway." (2) Even when a railway link had been established contracts frequently specified delivery at various ports along the line. (3) Presumably cheaper shipping rates held sway as they did regarding the shipment of Scottish pig iron to England. (4) A further factor making for the employment of sea rather than rail transport would be the links already established with the shippers. In the decade

1. J. Butt has argued that, in the pre-railway age, inadequate communications were an obstacle to the resource-orientated Scottish iron industry, but J.R. Hume pointed out that Wales and West Cumberland were relatively much worse placed. In addition he suggests that of the pre-railway iron works only Muirkirk and Wilsontown were really isolated. ['The Scottish Iron and Steel Industry Before the Hot Blast, 'J.W.S., vol.73, no.6, 1965/65]. But until inland trensport costs were drastically reduced any local markets would be protected monopolies. here poor communications would hinder the development of the Scottish industry would be in the question of obtaining markets external to Scotland.

2. quoted in H.R.J., 15 November, 1845.

3. E.g. The portpatrick contract with Bailey Brothers and Co. of Liverpool. H.R.J., 16 April, 1859.

4. In 1883 the rate Ior Scottish ig by sea from Ardrossan to Runcorn was $3 \mathrm{~s}$ a ton. (Minutes of Svidence for Manchester Ship Canal Bill - quoted in K. Warren, 'Rail Trade, op. cit., p.155). Railway charges on the Caledonian for such merchandise were from $5 \mathrm{~d}$ a ton for one mile, $3 \mathrm{~s} 8 \frac{1}{2} \mathrm{~d}$ for twenty-five-miles, $5 \mathrm{~s} 3 \frac{1}{\mathrm{~d}} \mathrm{~d}$ for fifty miles and $7 \mathrm{~s} 4 \mathrm{~d}$ for one hundred miles. (HR?(S) 5I, p.274, B.R.). 
from 1836 the Scottish iron industry was commercially dependent on the English and overseas markets and on the easy access to tide water which helped cheapen supply costs. Clapham estimated that not less than three-quarters of the Scottish make was shipped down the Clyde in 1846. (1) In the mid century two leading Scottish foundries, the Carron Company and the Albion Works of Andrew McLaren at Alloa shipped goods direct from their works to London wharves. (2) The railways' share of Scottish pig taken to England remained meagre, accounting for only 36,000 tons in the years $1888 /$ 90 compared with the 561,000 tons sent by sea. (3) It was the facility for shipment that undoubtedly helped maintain Scots pig iron exports in the face of growing English competition, for both the Forth and Clyde "may be reached at a cost of about one-tenth of the railway carriage payable on English pig irons made in the Midlands, before the latter can reach equally good shipping ports." (4)

Was it therefore as regards the internal traffic that the Scottish railways made their contribution? Even within Scotland the railways do not appear to have monopolised the iron traffic. Lack of data makes it impossible to express this statement adequately in quantitative terms. Generally the official traffic returns

1. Clapham, op. cit., .426 . The figures in Appendix three suggest that two-thirds would be more appropriate.

2. R.H. Campbell, Carron eompany, 1961, p.213, Carron Company Records GD 58/18/78. Crrcular to Shipping Agents (undated) S.R.O. S. Griffiths, Guide to the Iron Trade of Great Britain, 1873, p.168.

3. Calculated from figures in an unnamed newspeper cutting found in the volumes of Connal's Monthly Circulars.

4. Skelton, op. cit., p.29. 
failed to distinguish iron ore from other minerals, and this is especially true of the two major companies serving the iron producing districts. Thus the role of the rilways has to be assessed on the basis of qualitative statements rather than on statistical evidence. The Monkland and the Forth and Clyde canals in the west of Scotland preceded the development of the trade in 'hot blast' iron and greatly assisted in its growth, though the coming of the railways allowed even more territory to be opened up, e.g. the Wishaw and Coltness line made possible the use of a large field of ironstone found in the coal measures some time previously, but which had been before the construction of the railway "an object scarcely worthy of attention." (1) Further south, the Dalmellington iron company was not unduly hampered by the delayed construction of railway links forcing them to cart all their pig iron sever miles to Ayr. It was making a profit from 1853 and producing 27,000 tons when a railway connection eventually came four years later. (2) Yet they did take legal action to enforce the G.S.W. to extend their line beyond Ayr. (3) In 1846 most of the iron manufactured in the Airdrie district went out by canal in both directions and elsewhere the famous ironmaster dynasty, the Bairds, had a canal running through the centre of their works on which "a great proportion of the manufactured iron is sent out."

1. R.H. Campbell (Ph.D.) op. cit., p.3, 210.

2. D.L. Smith, The DalmelIington Iron Company, 1967, pp.19-27.

3. H.R.J., 27 March, I85?.

4. S.C. Railway and Canal Amalgamations, 1846 XIII, 9.915. Bremner, op. cit., p.37. 
However, gradually the railways began to secure the traffic. Despite the existence of an east-west canal system, plenty of pig iron and coal was being transported by rail from the West of Scotland to Leith Docks in 1867, and, when haematite ore began to be brought into Scotland from north west England, the Solway railway viaduct was built with the specific intention of obtaining this trade. (1) Yet it was not until the last decades of the century that the railways really began to tap the iron traffic of the canals. One reason for this delay was that the canals in the industrial areas were rallway owned and the companies saw no sense in siphoning off the traffic until the customers demanded railway accommodation. (2) Moreover the railways had few outstanding advantages over canals. Their speed is not so essential in the shor t-distance haulage of bulk goods unless the transport mode is stretched to full capacity. Regularity of service was assured as on the Forth-Clyde canal system stoppages through bad weather were rare and holdups for repairs averaged less than a day and a half a year. (3) Where the railways scored was that the use of canals involved cartage costs and trans-shipment expenses between the works and the canals, a factor of increasing importance as the location of sectors of the industry shifted, e.g. the malleable iron industry

1. R.C. Railways, 1867 , op. cit., q. 9468 .

2. K.C. CanaIs and Waterways, I907 XXXII, Appendix 39, especially 0.146. The relationship between the railways and other modes of transport is discussed in chapter ten.

3. Ibid. Appendix $39, p .140$. The stopping of the canal linking GIasgow to Greenock in 1801 by frost caused the manager of the Muirkirk Iron Company to favourably view a scheme for a railway between those towns which he considered might "help off the pigs well." 'Early Scottish Railways' The Three Banks Review No.74, June, 1967, p.30. Further discussion of the relative merits of railways and other modes of transport will be found in chapters eight and ten. 
moved away from the canals and out of the Coatbridge area.

It might be argued that, on the basis of financial evidence, the Scottish ironmasters showed little interest in obtaining railway facilities before 1850. The Houldsworths were willing to invest $\alpha 31,000$ in an attempt to obtain a railway connection from Ayr to their Dalmellington Iron Works, but generally Scottish ironmasters participated only to a limited extent in railway investment in the first half of the century. John Houldsworth, John Wilson of Dundyvan and the Baird dynasty subscribed 289,000 , $£ 63,000$ and $£ 30,000$ respectively in 1846 (actual investment was well below these figures - perhaps less than $50 \% 1$, but the vast majority of ironmasters seem to have preferred a less active role in railway promotion. (2) However, this cannot really be attributed to a lack of interest for at a later date ironmasters were often prominent on the boards of railway companies. The probable reason for their lack of financial support is that the rapid expansion of capacity in the scottish iron industry required most of their available funds. (3) It may be significant that William Baird, later to become chairman of the company, did not join the Caledonian board until 1852. (4)

The performance of the railways was by no means satisfactory to the ironmasters. Complaints that rates were too high were

1. R.C. Canals and Waterways, 1907, op. cit., appendix 39, p.146. K. Warren, 'Locational Problems' op. cit., p.23.

2. D.L. Smith, op. cit., p.273 Parliamentary Papers, 1846, XXXVIII.

3. See chapter one, pp.12-13; 17-18.

4. Bradshaw, 1852, p.241, RAC(S) I/3, March, 1853. B.R. 
frequent, expecially when the Scottish producers were feeling the pinch of English competition. The President of the west of Scotland Iron and Steel Institute maintained that English west coast makers could deliver into the lower reaches of the clyde by water at the same cost as railways took local iron there, and that English east coast producers could deliver by sea to Aberdeen and Dundee at less than the railways charged from Lanarkshire. This, he argued, was not in the interests of the railway companies as they would eventually lose business and so they should reduce rates to allow the Scottish industry to become competitive. (1) No mention was made of whether the railways could afford to do this as a short run gamble on a long term success. In fact the railways had served the industry well in the depression of the late seventies giving the ironmasters a drawback of $15 \%$ from their ordinary charges. (2)

The efficiency of railway service was hampered by the use of too small wagons. The Caledonian had experimented with a fifty ton vehicle for use in the iron trade, but little came of it and responsibility for this lay primarily with the ironmasters whose existing equipment provided a serious obstacle to any changes on the part of the railway companies. (3) Even at the beginning of the twentieth century it could be claimed that "there is not, at present time, a single shipping port, iron and steel work, or gaswork, or any work in Scotland, capable of dealing with a wagon of

1. J.W.S., 1897, p.10.

2. Scotsman, 31 March, 1880.

3. Engineering, 12 February, 1892. tocomotive Magazine, 1899, p.108. 
a carrying capacity of 30 or even 20 tons ..." (1) Furthermore, the firms frequently possessed inadequate tracks for marshalling trucks quickly which did not facilitate railway efficiency, nor did the use of railway wagons as a storage points. Privately owned wagons also prevented the railways from making the best use of existing capacity. (2)

It was also claimed that not all areas were adequately served. Bremner maintained that Nessrs. Rigby and Beardmore would have obtained a greater share of government contracts for armour plating had their Parkhead forge been nearer to a railway. (3) Again there is no mention of whether it would have been in the railway companies' interests to spend money in accommodating the firm. If the railway connection was to have such beneficial results then there is no reason why the firm should not have paid for its construction. Overall it is fair to conclude that unsatisfactory railway service was not solely the fault of the providers of that service.

The railways also had a role in determining the location of the iron and steel industries, but once again their importance did not achieve its greatest significance until the steel age. The high input to output ratio of the early iron industry led to a choice of an interior location for smelting, in preference to a coastal site, and primarily these works were situated on the

1. G. Paish, "The British Railway Position," 1902, p.117, quoted in D. Aldcroft, The Entrepreneur and the British Economy 1870-1914,' Economic History Review, 1964, p.129.

2. D.L. Burn, Bconomic History of Steel-Making, 1940, p.167.

3. D. Bremner, op. cit., p.55. 
Monkland canal or its cuts. The coming of the railway accentuated the choice of an interior site by further opening up large fields of raw materials. Such was the importance of the supplies of coal available from the deep seams in the central part of the Lanarkshire coalfield that the pig iron industry remained in the Coatbridge area, in preference to the coast (and shipping ports to its major markets), even when ores were having to be brought to the district after local resources became exhausted. (1) Railways (existing and potential) were probably the determining factor in the location of the Ayrshire industry, which developed in the 1840 s as Lanarkshire entrepreneurs feared the exhaustion of blackband deposits. (2)

The first malleable iron works also chose sites around the Monkland canal, but in 1840 the Mossend works were erected alongside the Wishaw and Coltness railway, and the ill-fated West of Scotland Malleable Iron Company picked the same railway a few years later. Later the malleable iron industry tended to shift away from the Coatbridge area, and Notherwell and Wishaw became centres of the industry, especially after 1870. Lack of space around Coatbridge may have been one cause of the shift, but railway connections from these new centres to their markets must have helped determine the new locations. (3)

Coalfield location was of less importance to the steel

1. Third Statistical Account of Scotland, Lanark, 1960, p.30. K. Warren, Locational Problems, op. cit., p.?l.

2. Ibid. Scottish Railway Gazette, 28 June, 1845. D.L. Smith, op. cit., p.19. GIasgow Courier, 18 June, 184 ?.

3. Third Statistical hecount, Lanark, op. cit., p.30. K. Warren, 'Locational Problems,' op. cit., p.23. 
industry as fuel comprised a smaller proportion of the cost of manufacture than in pig iron. (1) Here the railways played a decisive part. One necessity of the site chosen by the steel Company of Scotland was that it should have "good railway connections with coal and iron districts," and the decision must have been influenced by the Caledonian's willingness to conclude a favourable traffic agreement. (2) Canals were no longer considered as locational determinants and all new steel works relied on the railways as transport agencies e.g. Hallside (1871), Wishaw (1885), Dalzell (1881), Clydebridge (1888) and Hemington (1890) were all along the Caledonian line from Glasgow to Wishaw. (3)

It is clear that the Scottish rallways were of much more importance to the native iron and steel industry in providing transport facilities than in consuming the products of the industry. However, it is not apparent that they played a significant role before 1850 - the 'take off' years of the iron industry. Coastal shipping took most of the Anglo-Scottish traffic and not until the last thirty years of the century did railways come to supersede canals in the domestic ferreous trade. As a determinant of the location of the industry the railways were of significance at an earlier date, but did not attain their greatest

1. In the early 1890 s one ton of pig iron would require 1.54 tons of coul in its making but only 1.25 tons in its conversion to steel. Calculated from quantities given in J.W.S., 1892/3, p.3.

2. Nteel Company of Scotland letterbooks - quoted in Gibson, op. cit., p.27. Chi IfI i tem 983 , B.R.

3. Third Statistical Accounts, Lanark, op. cit., p.30. 
importance until the steel age.

\section{8 .}

Finally, as the role cannot be assigned to the rallways it may be of interest to examine the factors promoting the expansion of the Scottish iron industry. It is clear that transport services in the 'take off' years were primarily provided by canals and coastal shipping, but these were in existence before that period and probably acted more as permissive factors in aiding and allowing the expansion than actually stimulating it. The growth of the industry stemmed directly from the introduction of the hot blast in the late 1820 s which had a two fold effect in allowing the inferior coke of Scotland to be replaced by uncoked coal and also in enabling the high temperatures, necessary for the reduction of the blackband ironstone, to be attained economically. The ready availability of minerals, the cheap labour supply, and small mineral royalties all combined to boost the Scottish pig iron industry forward on the basis of low cost production. Although some engineers held that hot blast iron was insufficiently strong, especially for large castings, and some speclfications, including Government ordnance, excluded its use, the comparative cost advantage secured by the Scottish industry allowed markets to be generally easily obtained, with the result that Scotland's share of total British pig iron production rose from $5 \%$ in 1825 to $17 \%$ in 1840 and $26 \%$ in 1848. The high profitability of the industry encouraged the native ironmasters to maintain a high rate of investment, despite the 
gradual decline into depression, because of the lingering optimistic expectations engendered by the boom of 1836 and the technological developments within the industry. (1) This continued investment meant that when British demand for railway iron surged upwards the Scottish industry possessed the capacity necessary to absorb it. The railway mania "gave a great stimulus to the iron trade" and nowhere more than in Scotland, where pig iron production rapidly increased in order to meet the requirements of the railmakers in England and wales who supplied the growing mania demand for rails in England, Wales and Scotland. (2) Although demand for Scottish made rails was slight, the production of pig to be made into rails in England (and increasingly abroad) was an important factor in the expansion of the Scottish iron industry in the thirty years preceding the formation of the Stecl Company of Scotland. (3)

The viability of the pig ixon industry was in fact dependent

1. Campbell, Scotland Since 1707, op. cit. pp.117-123. Gayer, Rostow, and Sowartz, op. cit., had been lost in the process of conversion. At the Clyde Iron Works one ton of cast iron had required:

in 1829 using coke and cold air in 1830 using coke and heated air in 1833 using coal and heated air

$\begin{array}{cccl}\text { tons } & \text { cwt } & \text { qtrs } & \\ 8 & 1 & 1 & \text { of coal } \\ 5 & 3 & 1 & \text { of coal } \\ 2 & 5 & 1 & \text { of coal. }\end{array}$

This had "a great effect on the increase of the manufacture in Scotland," but in England and Wales the reduction in costs was not so great as less coal had been needed originally. Scrivenor, History of the Iron Trade. 1854. pp.259-261).

2. crivenor, op. cit., p.286.

3. Fogel, op. cit., Pp.i93-195; P. Temin, Iron and Steel in Nineteenth Century America. 1964, p.21; T. Brassey, Work and wages, I872, p.191. 
on sales to external markets. Between 1846 and $187029 \%$ of production was exported directly to foreign countries and $32 \%$ sent to England and Wales. (1) Henry Bessemer's presidential address to the Iron and Steel institute contained the significant remark that "wherever civilisation had advanced Scotch pig had found its way." (2) The development of the cleveland iron industry with its cheaper product, together with the discoveries of iron fields in Lincolnshire and Northamptonshire, depreciated the general selling position of Scotch pig iron in English markets. However, the qualities of the Scottish metal, especially the mixing abilities of No.I pig, and the facilities for shipment helped maintain scotland's foreign markets. (3)

Yet consumption within scotiand must have made an important contribution as it averaged about two-fifths of total sales of Scottish pig. Undoubtedly some of this also went abroad in the form of finished products. By the mid 1860s shipbuilding was a major consumer of Scottish pig, taking around 15\% of annual production, although the development of cheaper iron production in England
north east $\bigwedge$ coincident with the rise of iron shipbuilding on the Clyde prevented the Scottish ironmasters from monopolising this market. The revival of pig iron production in 1879 was attributed

1. Calculated from appendix three, columns five, seven and eight.

2. Transactions of the Iron and Steel Institute, 1872, p.5.

3. Scotland achieved the cheapest production in Britain in 1855 at which point her reserves of blackband ironstone had dwinded. Carr \& Maplin, op. cit., p.81. S. Griffiths, op. cit., pp. 27-8. 
directly to steamship contracts made with the Clyde jards.

It is also clear that the malleable iron industry owed its existence to shipyard demand. Shipbuilding also contributed a great deal to the growth and prosperity of the Scottish steel industry. In fact as one steelmaker recalled in 1911 it was fair to conclude "that when the clyde is busy trade generally, and especially the iron and steel trade ..... is also busy. That has been I believe, the universal experience of the past." (2) overall, it is fair to say that there was an independence in the development of the Scottish pig iron trade, though not of the malleable iron and steel industries, and the development of her heavy industries. Even the most important home consumer, the Clyde shipyards, gained their reputation first as engineers only progressing to shipbuilding at a later stage and, as mentioned, even then the reliance on the Scottish iron industry was not complete, although growth might have been slower wi thout the readily available local supplies. The iron trade of Scotland was predominantly a pig iron producing trade not dependent for its prosperity on the furtiner manufacture of iron within Scotland or on the heavy industries of Scotland in general. However, with the rise of the Scottish steel industry based upon open hearth production for the shipyards Scotland began to consume more of her domestically produced pig, the proportion growing from $23 \%$ in

1. Connal's Circular for December, 1879, p.4. For an estimate of shipyard demand for iron, see appendix three, column four.

2. Quoted in Byres, op. cit., p.251. 
$1882 / 3$ to $50 \%$ in the early 1890 s and $59 \%$ in 1902

$$
9 .
$$

Both as carriers of raw materials and finished products and as determinants of the location of the iron and steel industry, railways, functioning as transport agencies, became more important in the last three decades of the century, though they had previously aided the siting of the iron industry by allowing the exploitation of local mineral deposits. When consumption of the products of the industry are also considered - the support to the stagnating pig-iron sector, the establishment of a rail making compeny which diversified into other products, and the prestige which the steel industry as a whole must have received from the construction of the Forth Bridge - the indications are more than ever that the Scottish railways only became of significance to the industry as it shifted from its traditional form of a pig iron trade to one of steel production.

1. Skel ton, op. cit., p.28. Warren, 'Locational Problems,' op. cit., $\frac{1}{\text { p. } 25 .}$ The estimates in appendix three do not agreeprecisely, but the same trend is apparent. 


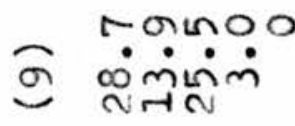

$\widehat{\infty}$

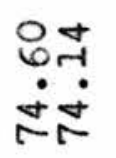

Nํㅇำ

r. m

mंत्रिं

TNRT

RTNOE

notn $6 \infty$

$-i \dot{0} \cdot$

사용

- $100 \mathrm{~m}$ Inก⿻ Tovio

NNMNrt मीनात्न -iिisim NHN $\because \prod_{-1}^{m}{ }_{\pi-1}^{\infty}$

NT 6 -10 N N IntO

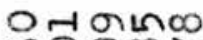
MO GDE ㄴ, 000 in HOT

$\rightarrow \infty \mathrm{mm}$

in NMn

सान्नलि

$\rightarrow m \infty 0 m$

Nintor $\infty \pi n$

\& NমINOO

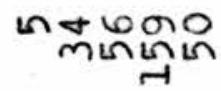
$\underset{\forall}{\forall m+\infty}$

Omf

$r-1600 \mathrm{~N}$

m oñन्त O. त्र $\mathrm{N}$ -

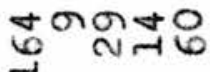

nino

חino

तथ

เnต $\mathrm{H} N \mathrm{~N}-1$

-

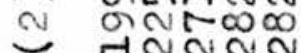

NTINON

Nimbin

H

HT

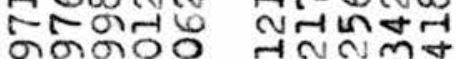

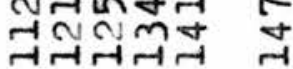

-1

$\mathfrak{n}$

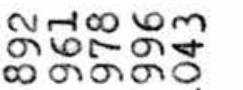

th L 0 mo TัO तnलm

$\underset{4}{\infty}$

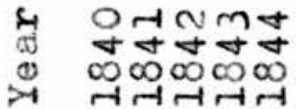

I 6 - $\infty$ வேையே

ON Nm+ ๓๐ 000

in 6 - 0 or แกเก็นก $\infty \infty \infty \infty \infty$

OnNm\& $\infty \infty \infty \infty$ त्न-1त्न- 
क

NMbOr ம்ச்சம் वारूम

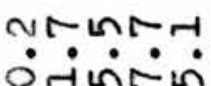

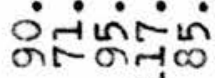
न्म

- काषण

$\infty$ : .

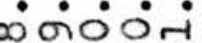
NNmmm

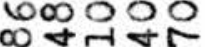
- . . . iिmंm mलmm

Omtand - $\bullet \cdot$. षा mmmmm

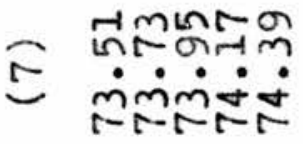

MmNMN 6T$\dot{0} \dot{0} \dot{0}$

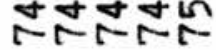

mitor ㄸำกㄴ? เท่เกต่ tritric

รตัตเกo 0 I0 -க்க் TNT r m**** - $\bullet \cdot \bullet$ HNNTE mmo वंஸ் ஸัเ
(6) TाNmW

- NNNDN

coin 00 manma
$0 \pi+\infty 66$ $\forall m<10 m$
$800 \mathrm{~m}$ m Onलmल
Im$0000 \mathrm{mco}$ ن $\dot{0} \dot{0}$ $\infty \infty \infty \infty$

Mn 6 Non - • minmm?

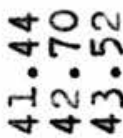

HNm 든 نان 00000

$4+0.010$ जा कीन

$66-1$ - $\infty \mathrm{m}$ जत्न

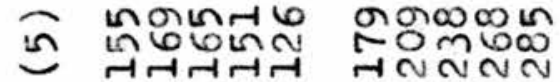

+hrmo mommin

g) MON

mot $\infty$ in $06 \div N$ 때페

$N-\infty$ minco H-1 In Nin MNONON

$\infty$ or
\& ming
MNNMN

N

m mint<smiles>CCC[13C](=O)CC</smiles>

营

照

ก 6 - 0 or 66666

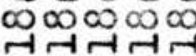

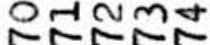
$\infty 0000$ $\infty \infty_{n \rightarrow-1,-1}$ mon ingin on m जी $\infty+\pi \infty$ ㄴำ $\forall$ N $\lim _{1 \rightarrow 1}^{-1}$ in $\infty \infty \infty \infty \infty$
-1Nㅓ $\infty \infty \infty \infty$

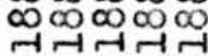

in 6 - $\infty$ or $\infty \infty \infty \infty$ $\infty \infty \infty, \infty$
$\mathrm{OHN}$ बाना $\infty \infty \infty$ 


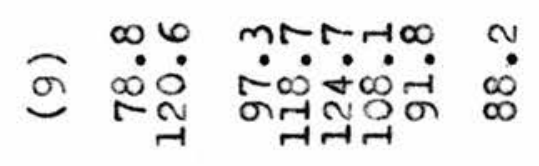

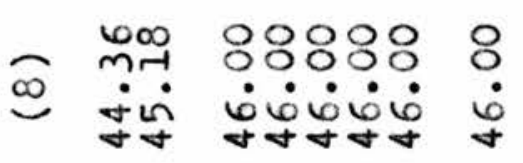

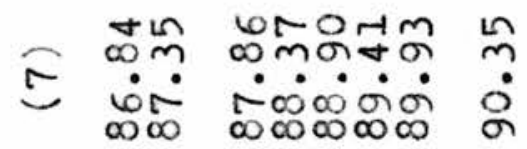

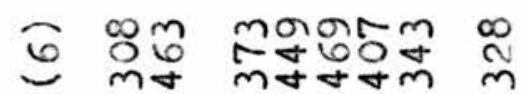

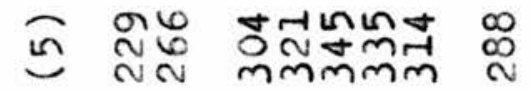

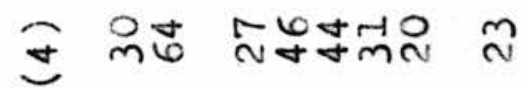

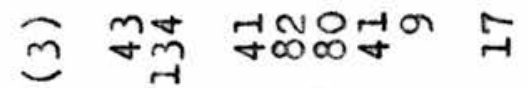

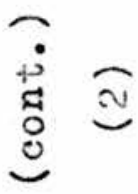

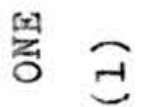

量

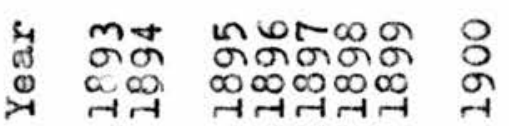

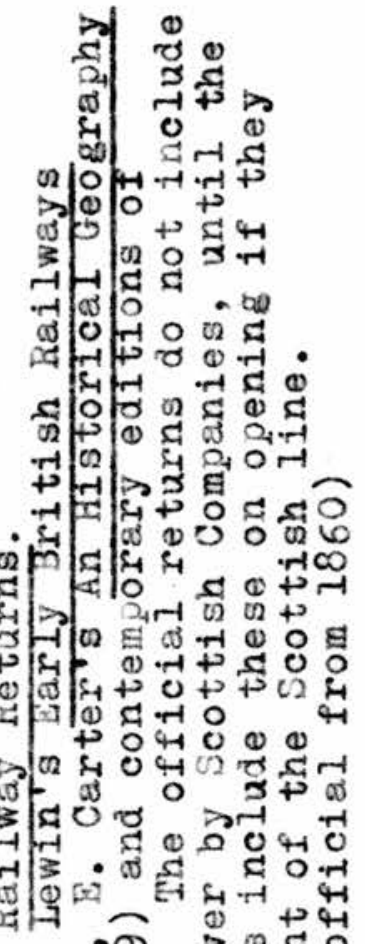

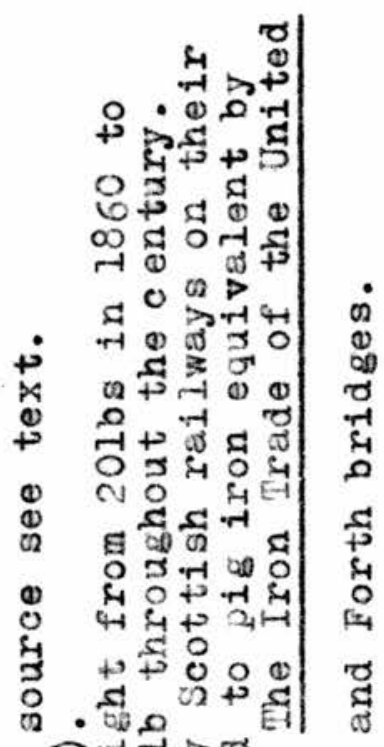

i.t-

परित्र०० \&

क्ष 3 (1)

पद द्व क्ष -1

बनेत्र

थै

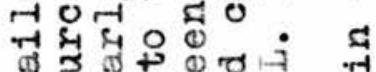

4 0 क

ตี.

- mन-1

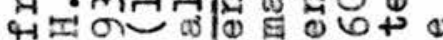

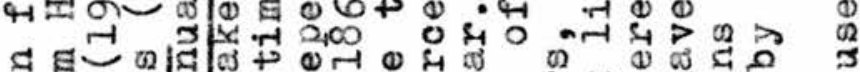

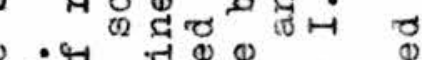
1)

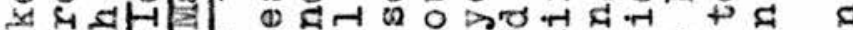
ॠथ

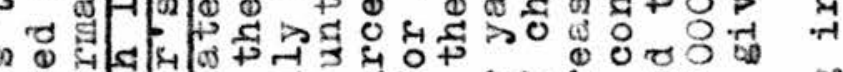

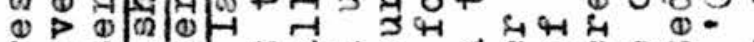

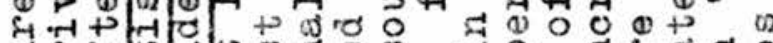
की द्व 4 स

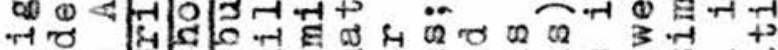
4 की

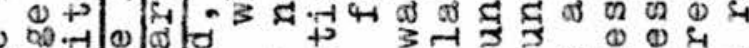
(0)

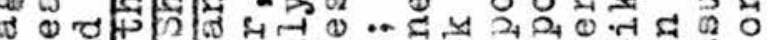

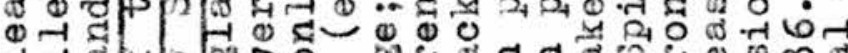
r w w 更 (1)

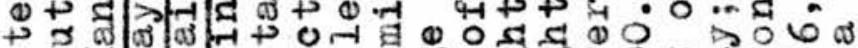

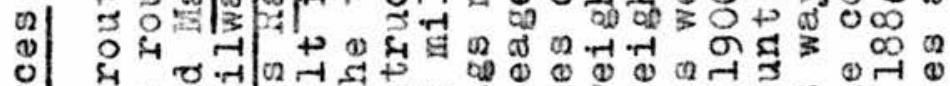

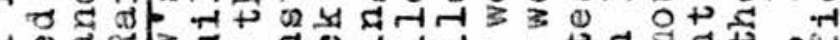
거

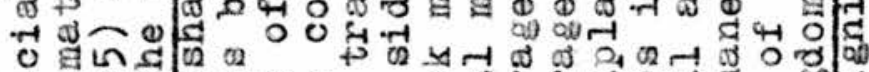

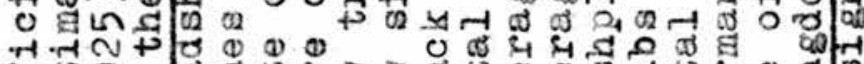

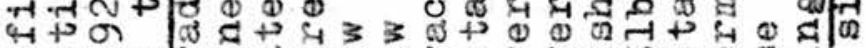

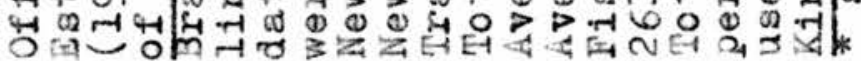

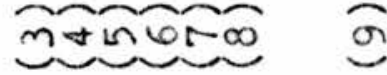


APPENDIX TWO

SCOTTISH RAILWAYS: DEMAND FOR ROLLING STOCK IRON 1840-1900

Year

1840

1841

1842

1843

1844

$1845 \quad 21.0$

1846

1847

1848

1849

$1850 \quad 22.6$

$1851 \quad 23.1$

$\begin{array}{ll}1852 & 20.7\end{array}$

$\begin{array}{ll}1853 & 20.7\end{array}$

185423.4

$1855 \quad 24.7$

$1856 \quad 24.0$

$\begin{array}{ll}1857 & 23.8\end{array}$

$1858 \quad 26.4$

185929.2

$1860 \quad 29.1$

186126.3

$1862 \quad 28.3$

$1863 \quad 30.0$

186430.1

1865

1866

1867

1868

1869

$1870 \quad 31.8$

$1871 \quad 30.4$

$1872 \quad 32.6$

$1873 \quad 33.1$

$1874 \quad 35.7$

$\begin{array}{ll}1875 & 34.4 \\ 1876 & 35.1 \\ 1877 & 36.2 \\ 1878 & 36.4 \\ 1879 & 41.2\end{array}$
(2)

9.8
10.4
11.0
11.7
13.1

13.5

13.5

13.7

13.9

14.1

14.6

14.7

13.3

13.3

15.0

15.4

15.3

15.3

17.6

15.2

16.9

17.9

17.0

21.1

22.5

20.9

22.0

21.6

21.5

21.2

20.4

18.8

21.5

25.3

24.5

25.4

24.8

26.1

27.2
(3)

1.00
1.25
1.50
1.75
2.00

2.01

2.02

2.03

2.03

2.04

2.04

2.05

2.09

2.13

2.17

2.21

2.25

2.30

2.35

2.40

2.45

2.50

2.55

2.61

2.67

2.74

2.80

2.86

2.92

2.98

3.04

3.10

3.16

3.22

3.28

3.35

3.41

3.48

3.54

3.61
(4)

(5)

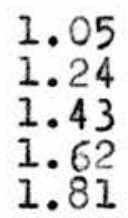

3.0

1. 3

0.3

0.6

2.00

2.08

2.16

2.25

2.33

6.4

7.5

7.6

21.8

5.3

2.41
2.48
2.55
2.55
2.55

3.6

3.7

3.4

7.0

2.56

2.56

2.56

2.57

2.57

8.2

3.2

8.3

5.6

7.2

2.57

2.58

2.58

2.58

2.59

8.1

19.2

4.9

11.6

16.6

2.59
2.59

2.60

2.60

2.60

10.9

8.8

9.4

12.3

2.61

2.61

2.61

2.62

2.62

20.1

27.1

28.4

31.2

21.5

2.62

2.63

15.1

25.9

42.3

2.63

17.1

2.64

14.2 
APPENDIX TWO (cont.)

$\begin{array}{llllll}\text { Year } & (1) & (2) & (3) & (4) & (5) \\ 1880 & 47.8 & 27.0 & 3.68 & 2.64 & 24.5 \\ 1881 & 35.4 & 27.6 & 3.75 & 2.64 & 27.7 \\ 1882 & 41.0 & 27.7 & 3.82 & 2.64 & 20.8 \\ 1883 & 39.7 & 27.7 & 3.80 & 2.64 & 27.0 \\ 1884 & 40.6 & 28.3 & 3.97 & 2.65 & 20.7 \\ 1885 & 40.1 & 28.9 & 4.06 & 2.65 & 24.7 \\ 1886 & 41.7 & 30.8 & 4.15 & 2.65 & 22.4 \\ 1887 & 40.4 & 28.7 & 4.24 & 2.65 & 21.9 \\ 1888 & 40.9 & 28.9 & 4.33 & 2.65 & 34.7 \\ 1889 & 40.1 & 28.1 & 4.41 & 2.65 & 35.4 \\ 1890 & 40.6 & 33.8 & 4.50 & 2.65 & 10.8 \\ 1891 & 42.1 & 32.0 & 4.65 & 2.65 & 38.4 \\ 1892 & 41.8 & 31.8 & 4.80 & 2.65 & 37.2 \\ 1893 & 46.8 & 33.0 & 4.95 & 2.65 & 25.7 \\ 1894 & 49.4 & 36.9 & 5.10 & 2.65 & 26.7 \\ 1895 & 45.2 & 33.5 & 5.25 & 2.65 & 30.7 \\ 1896 & 45.3 & 35.9 & 5.40 & 2.65 & 44.9 \\ 1897 & 43.9 & 32.8 & 5.55 & 2.65 & 27.2 \\ 1898 & 43.8 & 33.5 & 5.70 & 2.65 & 39.6 \\ 1899 & 44.7 & 34.1 & 5.85 & 2.65 & 47.7 \\ 1900 & 46.2 & 33.8 & 6.00 & 2.65 & 36.2\end{array}$

Notes and Sources

(1)(2) Average weight of (1) locomotives (2) tenders expressed in tons. Calculated from data in the histories of the Scottish railway companies published by the Stephenson Locomotive Society - the Caledonian 1947, the Klasgow and South Western I950, the Great North of Scotiand 1954 and the Highland 1957. No differentiation was made between tank and tender locomotives as this is cancelled out by a similar non-differentiation in the physical quantities table in appendix two. To 1852 a constant proportionality was assumed between the weights of engines and tenders. The weights of tenders may be exaggerated by some of them being in 'working order,' but the error resulting from this is insignificant.

(3) (4) Amo int of fron in (3) carriages and (4) wagons expressed in tons of pig-iron equivalent. Estimated from references in the company histories; the record books of $\mathrm{R}$. \& Y. Pickering, wagon builders of Wishaw (kept in the Scottish Business Records Archives, University of Glasgow), Royal Commission on Coal supplies, 1904 XXIII, p.282; F. W ishaw, the Kailways OF Great Britain and Ireland, 1840, passim; D. Lardrer, Railway Economy, 1850, p.105; C.E.R. Sherrington, The 
Economics of Rail Mransport in Great Britain, 1928, pp.198, 213, 2IT; Lransactions of the tngineers and Shipbuilders of Scotland, $1860 / 1$ presidential address, 1866/7, p.II5, I882/3, p.IO, and from information supplied by Messrs. J. Hay and A. Maclean of the North British Railway Group. Linear trends were taken to hold between known points and until the introduction of steel underframes in the 1890 s a constant proportion was assumed between the tare weight of a vehicle and the amount of metal used in its construction (with allowances for the use of bogies and experiments in wheel arrangements).

(5) Total estimated demand for rolling stock iron expressed in terms of 1000 tons of pig-iron equivalent. Calculated by multiplying the total additions to rolling stock shown in appendix two by the appropriate average weights. 
9

of

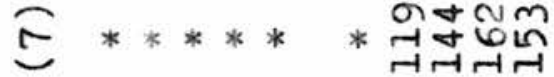

.

O

(1) 애요

in dinñd

$\ln 000 \mathrm{O}$ ํㅏㄴำ

mino MTRNOR

00000

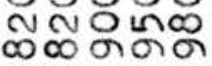

in $m+\infty 8$ กี

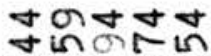
NNNํำ

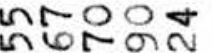
ํํำ

ow

c $6+m$ เ बूष्थल

$\infty \infty O N N$ Nㅣำ

No กm

g이요유

O

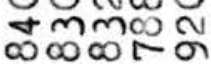

이이잉

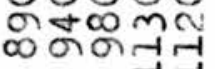

ㄴ rim int

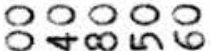

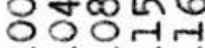
नत्मत्

하 त्रा

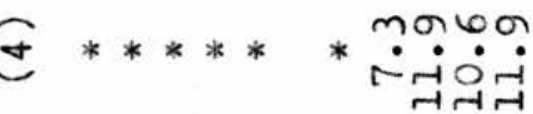

․ำ? ष6त्र तก กี่

\&

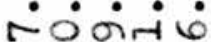
mon? o 6 ingm नiñ $\rightarrow \operatorname{crc}$ กำ $\dot{0+}$ $\rightarrow$ 岱 $\infty \sim 66 m$ TNobn tinbmo تंنिimi m mininmm -1 $+\infty 6 \infty$ in •. बंब $\rightarrow \infty$

बrmmo $m$ min் $\dot{m} \dot{0}$ onorm - -10 mเn $m \forall N \&$

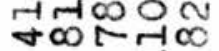
ம் $\forall$ नत्त

Nom Ommlon trintoom lot $+\infty 0$ ح

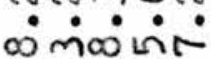
भกต์ mintir $\infty \dot{\pi} \dot{-i} \dot{-1}$ i் ranoo o. 00 inin

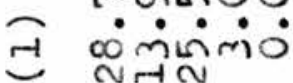
ம்சن்சن mb6

ง Unก⿻ ம்iri-i

ก-10 บ

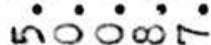
N寸Nm

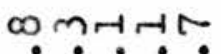
mं̃min murav

$+2$ ติก

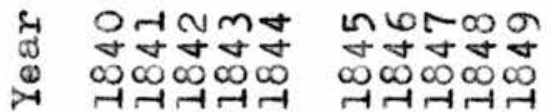

OnNmt เกเป็นกเก $\infty \infty_{-1}^{\infty} \infty \mathbb{N}_{-1}^{\infty}$

in 6 r $\infty$ or เกเกเกเกเก $\infty \infty \infty \infty \infty$ $\rightarrow+\rightarrow+i-1$,

OnNm+ 66666

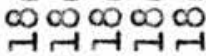

in 6

66 $\infty \infty$ 


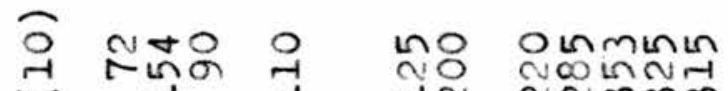

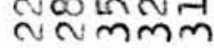

InOLNO mNषme mamषm
กのष

$60 \mathrm{mNO}$

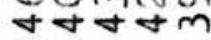

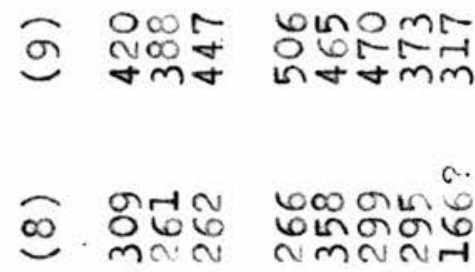

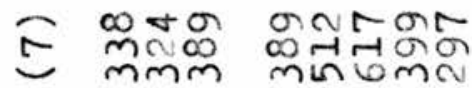

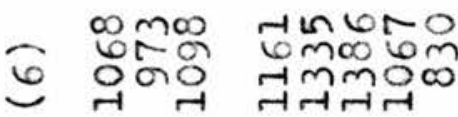

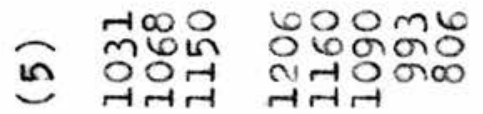

OMNNN เก त-

100006 नुषात्

นกเกOก INTMmo नात्नत्न

96690 ष्तNत्त तन्मतन
Gmbor onition

늠 int a onco mmin\&

rmi

\&昆

NOD -100 - $100 \mathrm{OH}$

두음 HTH

$\forall 6 \sim \infty \infty$ OMmNT orion

N+NMN mEन

\& मुंक्म

rmoro - $\cdot$. กำ ơ mint

๓NO mLn

. क जा जा तTH N

HrGष्म - córí mo $1 \infty$ Nmm\&

HNU⿺𠃊 نंல் कान्तम

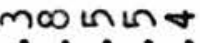
$-10000$ MNO

Nor

$\infty \leftarrow 0 N N$

m نேं ता $100 \mathrm{rr}$

n $6000 \mathrm{~m}$ ம்டர் onmo

or -ن்ن் -10\%

NAMnO نं : कानान

HTOLM ن $\infty \infty$ का -1 -

Horm N نํํㄴㅁ NTDON 눙ㅇ

T IT -. $+\mathrm{N}+1+\mathrm{N}$ NN Mm

$\infty$ \&NT ن் NNNNO نे मथष्तन

CLIT

०ं

HoOno

نं்imi बNTH

rmoLn HiNíri GTAT

$\infty$ mos வெं்ن் $6+\cos$
वर्तिक

$\infty \infty+4$ เกตร

$-\infty$ or 666 $\infty \infty \infty$

- $90 m$ m TrNT $\infty \infty \infty \infty \infty$

10 6 rod on THTR 000000000 तान्मतन्न
OHNmt $\infty \infty \infty \infty \infty$ $\infty 00000$ in 6 $\infty \infty \infty \infty 00$ $\infty \infty \infty \infty \infty$
Ondm\& ननना $\infty \infty \infty \infty$ 
ฮํำ

क

$\widetilde{\infty}$

$\widetilde{N}$

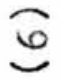

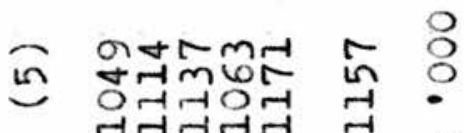

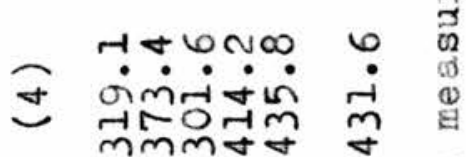

obar? $\div$ है

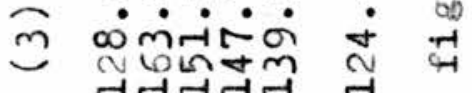

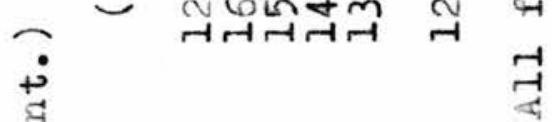

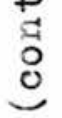

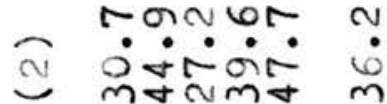

(19

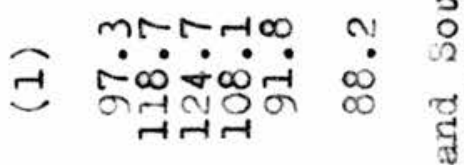

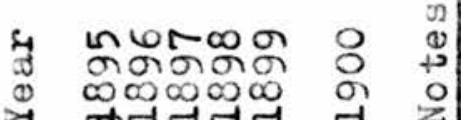

$\dot{8}: \dot{0}$

नृष्ठ

का ली 0 म

$\rightarrow+1$

ज्ञात

जx

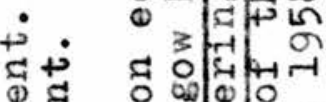

\&

त्र के

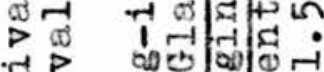

(⿻)

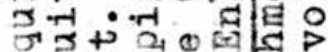

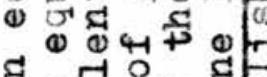

I.

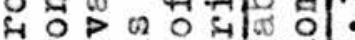

$r$ \&

1 . 34.420200

की

(2) म

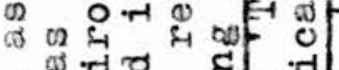

ช

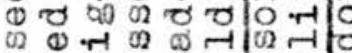

of on ये \& y

Q क क o तु

यद कर $x$ का भास

$\times \mu_{1} 00.7$.

(1) xण

द का वृ

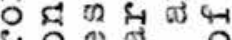

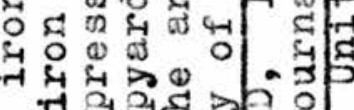

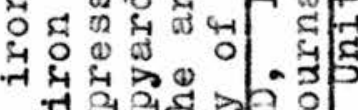

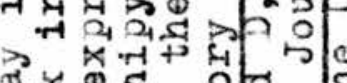

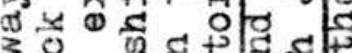

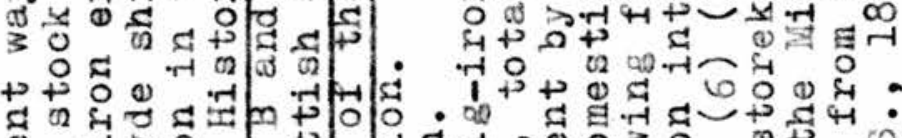

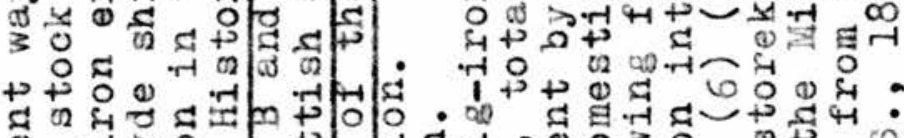

(1)

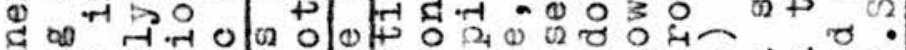

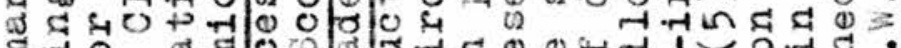

घ्र 0 क

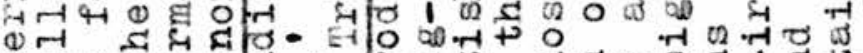

बन द्व

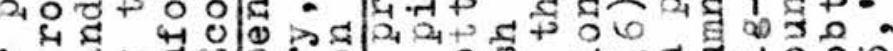

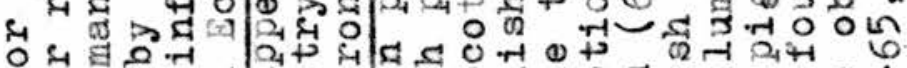

फ०

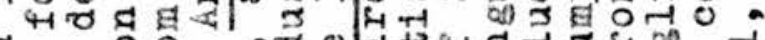

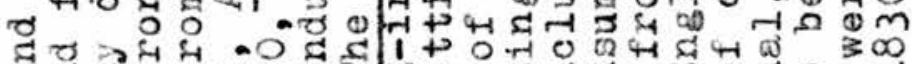

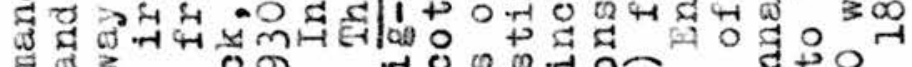

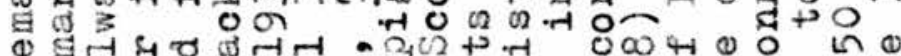

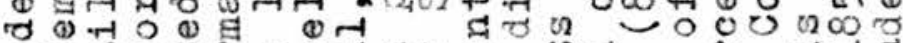
त्व

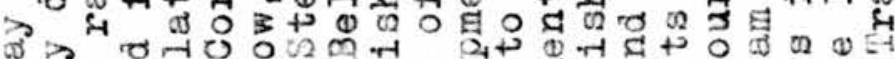

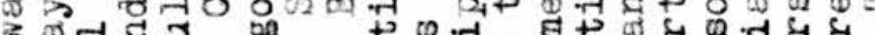

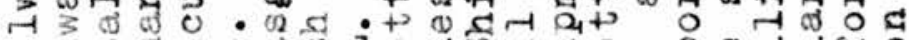

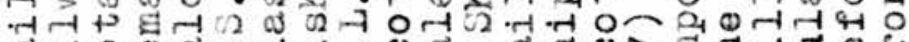

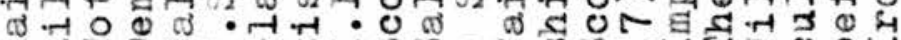
य कैस

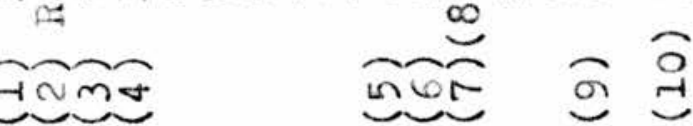


APPENDIX FOUR

SCOTTISH RAILWAYS: SCRAP IRON

Year

(1)

(2)

(3)

1840

1841

1843

1844

1845

1846

1847

1848

1849

E

C

W

1850

1851

1852

1854

1855

1856

1857

1858

1859

1860

1861

1862

1863

1864

1865

1866

1867

1868

1869

1870

1871

1872

1873

1874

1875

1876

1877

1878

1879

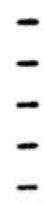

0.1

5.9

7.0

2.8

3

34

$2 \cdot 9$
$3 \cdot 2$
$4 \cdot 8$

$4 \cdot 9$

6.7

7.5
9.0

10.1

12.5

15.4

17.2

18.0

24.3

26.1

29.8

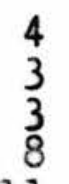

11

7
27
9

99
23
116
103

0.4

0.1

0.4

0.3

32.6

35.6

34.2

30.7

25.3

13
16
8
6
7

39

nk

85

71

224

$\mathrm{nk}$

667

805

813

0.9

0.1

2.0

2.5

2.6

$59 \quad 578$

$47 \quad 696$

$50 \quad 293$

$\begin{array}{lll}6 & 40 & 226\end{array}$

2.7

3.0

1.2

1.0

1.5

10

30

211

29

41

41

14594

0.9

0.8

2.5

4.3

5.2

35.3

41.2

48.3

55.1

68

41

41

1158

$102 \quad 1062$

6.6

$11 \quad 1305$

$82 \quad 1549$

37

55

60.5

60

1711

63

$37 \quad 1690$

6.8

8.7

7.8

7.9

69.6

64.8

75.8

80.7

73.5

42

55

53

50

49

$\begin{array}{rr}22 & 1678 \\ 41 & 1883 \\ 69 & 3339 \\ 134 & 1567 \\ 145 & 2358\end{array}$

7.3
8.4

12.7

7.5

7.8 
APPENDIX FOUR (cont.)

Year

1880

1881

1882

1883

1884

1885

1886

1887

1888

1889

1890

1891

1892

1893

1894

1895

1896

1897

1898

1899

1900
(1)

E

58

71.4

67.5

63.6

59.3

54.3

47.4

37.9

33.6

29.1

28.9

31.0

38.5

48.3

53.8

60.7

69.0

74.4

80.1

78.1

73.5

67.5
70

41

52

80

76

74

59

58

64

65

66

59

59

70

70

73

65

66
(2)

W

$\begin{array}{llr}135 & 3101 & 9.9 \\ 164 & 3494 & 12.9 \\ 123 & 2211 & 13.8 \\ 172 & 3966 & 16.1 \\ 192 & 3977 & 17.6\end{array}$

122

4448

4199

3913

3974

3222

18.6

17.9

15.8

16.3

13.9

3218

2932

3174

2646

13.6

13.1

14.3

66

99

2887

11.6

13.0

90
213
89
83
99

105
3278
3535
3275
3523
3301

$14 \cdot 3$
15.8
14.6
15.9
14.8

3241

14.2

Notes and Sources:

(1) Amount of rails taken from main lines and branches expressed in 1000 tons of pig-iron equivalent. Estimated by multiplying renewals mileage by the average weight of rails laid $x$

(2) years before where $x$ is the typical age of rails taken up. Number of engines, carriages and wagons scrapped each year. To 1869 these are totals of renewals, but thereafter are totals of vehicles actually scrapped. For method of calculation see text.

(3) Rolling stock scrap expressed in 1000 tons of pig-iron equivalent. For method of calculation see text, but note that the number of tenders scrapped is taken to be equal to the number of renewals throughout. 


CHAPTER SIX
RAILWAYS AND COAL-MINING

"More coal fields have been discovered upon the sides of that portion of railway already executed, than were known to exist at the institution of the Company." Report of the Wishaw and Coltness Railway, 30 June,

"Coals are now conveyed along one of the Lanarkshire Railways, a distance of 10 miles, at a lower rate than is paid for carting them from the lonkland Canal Basin to the Broomielaw, a distance of little more than one mile."

Glasgow Railway and Tunnel.. 1829. p.4. (Mitchell Library).

How much coal was carried on the Scottish railways might seem a relatively straightforward question, but it is one that proves incapable of a straightforward answer. Two major factors account for this. The first is that no statistics of ton-mileage are available, and so figures for tons carried, with no mention of distance travelled, have to be used. One difficulty stemming from this lies in the danger of double counting, especially prior to the emergence of the big five companies when the same coal might have passed through the hands of more than one company. The gradual absorption of the smaller lines might therefore have exerted a downward bias on the total of tons carried. The second important factor acting to prevent the production of satisfactory coal transportation statistics is that most companies (all after 1868) failed to distinguish coal from other minerals in their traffic returns. 
Table 6.1 sumarises what can be said about the development of the coal traffic on each of the major systems; allocating to each system, from their date of opening, companies later absorbed into that system. It is quite clear that the volume of minerals carried rose substantially, even allowing for the inadequacies of tons, as opposed to ton-miles, as a measure of the traffic. It is perhaps reasonable to assume that the coal traffic also increased. However, the absence of figures relating to coal only renders it impossible to say whether the increase in coal traffic matched up to the increase in coal mined. Receipts for the transportation of coal and other minerals also exhibit an upward trend, but they cannot be used as an index of coal traffic since rates of carriage not only varied over time and between companies, but also according to the distance travelled.

There is little doubt of the importance of minerals receipts to the railway companies. In 1856 the railways obtained slightly more than $\$ 500,000$ from the carriage of minerals and by 1899 this had risen to nearly $£ 3,000,000$, some $48 \%$ of goods receipts and $27 \%$ of all receipts. What now needs to be asked is whether the importance of the coal industry to the railway companies was reciprocated.

$$
2 .
$$

At the beginning of the nineteenth century scottish coal-mining was carried on in the same areas, and perhaps in the same manner, as it had been for the preceding two centuries. Coal mines pocked the shores of the Forth and were also scattered within Ayrshire 


\section{TABLE 6.1}

COAL TRAFFIC AND RECEIPTS ON THE MAJOR RAILWAY SYSTEMS

Company Year 1000 tons

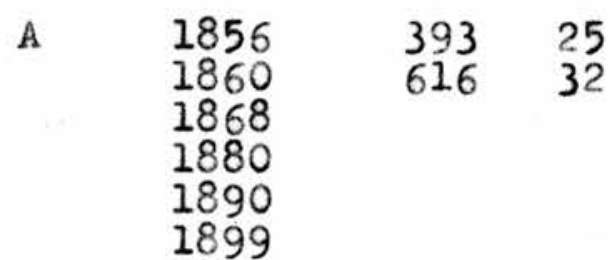

B $\quad 1856 \quad 493 \quad 48$

$1860 \quad 1440 \quad 89$

1870

1880

1890

1899

C $\quad 1856$

1860

1870

1880

1890

1899

D $\quad 1856$

1860

1867

1871

1880

1890

1899

1860
1867
1880
1890
1899

$\begin{array}{rr}28 & 4 \\ 71 & 9 \\ 110 & 14\end{array}$

$\begin{array}{lr}17 & 2 \\ 56 & 13\end{array}$
(2)

(3)

.000 tons ఓ.000

$\begin{array}{rr}105 & 7 \\ 164 & 12\end{array}$

3061

4397

6425

10762

12676

21445

238
328
524
835
904
1240

$82 \quad 10$

$716 \quad 42$

1504

3436

5268
8207

11280

$17565^{*}$

1481

2372

3177

3789

4233

6402

140

236

383

640

851

$1245 *$

184

215

276

323

132

195

254

277

273

396

* includes half the traffic on the City of Glasgow Union - traffic on this line had been

1871

1895

99
133
143
310

19
28

24

46 
Key to Companies:
(A) Caledonian
B) North British
C) Glasgow and South Western
D) Great North of Scotland
E) Highland.

Source: Railway Returns. 
and around Glasgow and Edinburgh. At this time the difficulties of distribution perhaps outweighed the problem of mining coal; the inadequacies of the existing transportation preventing the inland extension of domestic markets and hindering the exploitation of the vast Lanarkshire coalfield. Cartage costs were, so prohibitive that many areas simply had to do without coal. Others found that the area from which they drew coal was limited e. g. at the beginning of the nineteenth century no coal came to Edinburgh from pits over seven miles away, and in Glasgow the limit was apparently two miles nearer. (1) Cartage costs were high partly because of the time involved, but perhaps more because of the limited quantities that could be carried. At most the early carters could take around 24 cwt. each journey, but frequently much less was taken. In the Lothians the amount tended to average 12 to $15 \mathrm{cwt}$. and, for some reason, only half this in the Alloa district. (2) However, from the end of the third decade of the century the Scottish coal industry began to expand at a more rapid rate than hitherto. Two factors were at work. Firstly, the application of the hot blast accelerated the development of the iron industry, a major coal consumer, and, secondly, improvements

1. R. Bald, View of the Coal rrade of Scotland. 1808. pp.29; 39. In the $18 \overline{40 s}$ the Hawick district was supplied from the laidlothian field, coal "being carried in carts, a distance of 20, 30 or even 40 miles, and ... sold at enormously high prices." But, as the supporters of a proposed railway pointed out "this of course limits their consumption both for household and manufacturing purposes." (NBR 1/2. p.171. B.R.). The shorter maximum haulage distances into Edinburgh and Glasgow may have been conditioned by the availability of sea cosl. On the general difficulties of obtaining coal in districts away from the coal producing areas see the surveys carried out by the Board of Agriculture between 1793 and 1816 .

2. A.S. Cunningham, Mining in Mid and East Lothian. 1925. p.52 J. I. Carvel, One Hundred Years in Coal. 1944. p.25. 
took place in the field of transport. (1) It is the latter which concerns us here.

Transport innovation had not been absent before this period of expansion. The old Statistical Account records a 'composite' railway at Alloa in 1785 and even earlier, in the 1720s, a line had been constructed to link the Tranent mines with Port Seton harbour. These were not isolated instances; one researcher has located seventeen such colliery wagonways constructed in Scotland before 1820. (2) The railways were not the sole transport agency aiding the Scottish coal industry. Mineral deposits in Lanarkshire were opened up by the Monkland Canal, which in 1793, only three years after it began operations, had four new collieries along its banks. (3) Later the opening of the Union Canal in 1822 enabled the coalmasters of Lanarkshire to obtain an extensive share of the coal trade of Edinburgh, presumably because the catchment area of the metropolis was limited to a seven mile radius if cart transport alone was to be employed. (4)

1. A.J. Youngson-Brown, The Scots Coal Industry 1854-1886. D. Litt., Aberdeen. 1952. pp.3-6. It should be pointed out that, although the hot blast cut coal consumption per unit of iron produced, the price elasticity of demand for the cheapened product was such as to increase the total consumption of coal by the iron industry.

2. Old Statistical Account, vol.VIII. p.614. G. Dott, Early Scottish Colliery Wagonways. 1947.

3. Youngson-Brown, op. cit., p.5.

4. Cunningham, loc. Cit. The Edinburgh authorities had warmly welcomed this project "as a measure for giving facility and cheapness to the carriage to the City of the Western coals." (Memorial to the Lord Provost and Magistrates of Edinburgh respecting the projected Railweys. c.1830. p.7. G.D.26 section 15/94. S.R.O.). 
Despite these improvements it was the development of the railway proper (as opposed to wagonways) in the third and fourth decades of the nineteenth century that really stimulated the expansion of the coal industry from the supply side. The Honkland and Kirkintilloch originated in a plan of 1823 to challenge the Monkland Canal Company, whose monopoly of the carrying trade from the Monkland coalfield was giving rise to complaints of excessive charges. The railway was designed to link the collieries directly to the Forth and Clyde Canal, albeit by a more circuitous route than the Monkland Canal, but with much lower tonnage charges. This line was so successful that it was soon doubled in order to accommodate the traffic. (1) Yet it was not this success that stimulated the promotion of the Ballochney and Garnkirk and Glasgow railways as is frequently thought, for both were planned before the Monkland and Kirkintilloch began operations. The Ballochney was to connect the mineral district of New Monkland with the Monkland and Kirkintilloch railway and proved a tremendous triumph - "new coalworks are establishing on that railway every year." The tonnage carried on the Ballochney rose from just over 18,000 in 1828 to 127,590 by 1833. (2) With the planning of the Garnkirk and Glasgow by the "principal coal consumers in Glasgow, with the mineral proprietors both of West and East Nonkland" came a change in the policy of the railway promoters.

1. G. Buchanan, Account of the Glasgow and Garnkirk Railway etc. $1832, \mathrm{p} .4$. Report, 3 February, 1830. G.D.16 section 38/78. S.R.0.

2. Buchanan, op. cit., pp.6-7. iltcheII Library. S.C. Railway acts snactments. 1846 XIV. 
Previously the lines in this district had been built to facilitate the transportation of coal from the collieries to the canals, but this railway challenged the canals by providing a direct route from the coalfield to the city of Glasgow. This line was also a great success; several mines were opened along its path and coal carried into Glasgow along the railway reached 143,520 tons by 1835. (1) Yet another line to help develop the Lanarkshire coalfield was the Wishaw and Coltness. Its promoters claimed "there is not a district in Scotland, to which extensive coal consumers can look with such certainty for an abundant, cheap and (we may add) perpetual supply of that indispensible fossil as that which it is the object of this railway to intersect." (2) A. reading of the early reports of the company offers much justification for their eulogies. (3)

In the east, some of the colliery owners of the East Lothian and Midothian fields constructed a horse railway from Dalkeith to St. Leonards (Edinburgh) and eventually extended it to Leith docks. (4) However, in the Fife coalfield the railway idea met with less success. Plans for a line to connect Balbirnie Colliery with the port of Newburgh were first put forward in 1825 , but did not bear fruit until the late 1840s. (5)

1. Buchanan, op. cit., pp.7; 10. Railway Times, II ilay, 1839.

2. WIC $4 / 3.1828$. pp.3-4. B.R.

3. Acollection of these will be found in the Hitchell tibrary.

4. Cunningham, op. cit., p.112.

5. T. Grainger, Doservations on the Edinburgh, Dundee and Northern Railway. 1841. 
To 1833 all but one of the railways constructed in scotland was built primarily to aid coal mining. The exception was the Dundee and Newtyle, presumably becausenthe relative absence of coal deposits north of the Tay, but this line still acted as a carrier of coal by distributing that brought by sea to Dundee. Even the great interurban line linking Edinburgh and Glasgow was conceived partially as an agency to the coal industry. First proposed as the Edinburgh, Leith and Glasgow in 1830, it was prophesied that it would become "the means of supplying the metropolis with coal from the inexhaustible supplies of Lanarkshire." (2)

In the late 1830 s when inter-urban lines were all the rage, railways designed principally to facilitate the transportation of coal maintained their popularity. The slamannan, an eastward extension of the Ballochney, proved of importance to the coal consumers of both Edinburgh and Glasgow. A little later the Wilsontown and Coltness was constructed to "open up a most valuable tract of mineral country." (3)

With the railway mania of the mid 1840 s, railways of all kinds were projected including many concerned with coal supplies. The Bdinburgh and Hawick was seen as "the nearest route by which an abundant supply of coals, an article of which the south-eastern counties stand most in need, can be obtained." Sven where coal

1. ..C. Railway Acts Enactments, op. cit., appendix 2. Airlie Papers. G.D.16, section 38782 , item 41 . p.8. S.R.0.

2. Edinburgh Observer, 24 Decerner, 1830. Trospectus. 1830. p.6. Mitchell Library.

3. Railway IInes, 4 July, 1840. GIasgow Courier, 18 June, 1842. 
was not the primary consideration it frequently featured as a secondary argument as with the promoters of the Edinburgh and Northern. (1)

It was at the time of the railway mania that lines designed to carry supplies of coal long distances, rather than simply open up land locked coalfields, came into prominence. The Edinburgh and Hawick has already been mentioned: another was the Great North of scotland which aimed at halving the price of cosi in the interior of north-eastern scotland, then supplied at high cost by carts driven long distances inland from the sea ports. (2) Still it is estimated that in $185281 \%$ of railway mileage lay in the coalfields area - defined as the region bounded by straight lines between Tryport, Greenock, Girvan and Gifford. (3) After mid century the emphasis, as far as lines concerned with coal are concerned, turned away from exploiting mineral deposits lying sterile because of inaccessibility, and towards a general expansion of the railway network to allow cheap coal to be made available to persons living in or out of the Midland belt, where most of the earlier railway development had occurred. By 1870 the proportion of line lying within the coalfields area had dropped to $34 \%$, though this cannot be attributed solely to the changing policy as regards coal lines. (4) The railways were thus helping create a national market for coal which was to be of importance to the coal industry

1. Scottish Railway Gazette, 7 June, 1845; 21 June, 1845.

2. GINS I/3. p.9. 3.K.

3. roungson-Brown, op. cit., p.43.

4. Ibid. 
as the demand from the ironmasters within the industrial belt fell away.

This is not to say that lines designed to open up coalfields were no longer constructed. On the contrary, construction of this type continued throughout the century. In the late $1850 \mathrm{~s}$, for example, the North British proposed to link Hawick with Carlisle and in doing so exploit the Plashetts coal and mineral fields. (1) In the 1870 s the desire to build exploitive coal lines remained strong. The Glasgow and South Western pushed forward plans for its Ayr and Mauchline and other branches in that area as they "would have the effect of opening up a large district of country full of minerals." (2) In the east, the Edinburgh and Roslin was seen as "a means of opening up the Gilmerton, Loanhead and Dryden coal and ironfields." (3) Later in the decade, as the Monkland field approached exhaustion, the North British found the Bothwell seams and the Glasgow, Bothwell, Hamilton and Coatbridge was constructed under their asgis to exploit this field. (4)

Over the last quarter of the century the building of lines to exploit coal deposits may have slowed as new fields for development became scarcer, but it never ceased. However, the emphasis now was on lines giving better outlets to markets. In the late 1880s the Glasgow and South Western was constructing branches to link several mines more directly to the ports so as "to afford facilities

1. $\operatorname{RAC}(S) 1 / 1 \mathrm{~A}, 8$ August, 1857. B.R.

2. H.K.J., 24 September, 1870 .

3. H.K.J., 26 November, 1870.

4. Kailway News, 5 September, 1874; 25 March, 1876. H.R.J., 8 March, 1879. 
for getting larger quantities of coal to the markets than there were at present." (1) One of the chief purposes of the Lanark and Dumbartonshire, built in the early 1890s, was to assist the Lenarkshire coal proprietors to find new markets. (2) Another line of immense service to the Lanarkshire coalmasters was that opened by the Caledonian from Hamilton Hill to Queen's Dock in Glasgow to enable coal to be sent directly to the quayside; in addition this line, in service by 1894, tapped seven new coal depots en route. (3) The Caledonian also planned a railway from their Iine at Spierstack to join that at Muirkirk, and thus put the Lanarkshire coalfield in more direct connection with the ports on the Ayrshire coast. (4)

To about 1850 it can be said that the main concern of the railways built as regards the coalfields was to open them up. Afterwards, greater, though not exclusive, emphasis was laid on the developing of markets, either externally by making more direct routes to the ports, or internally by promoting the universal provision of cheap coal.

\section{3.}

There is no doubt that the railways played a most important role in opening up the coalfields. Frequently the proposal to build a line would stimulate a search for mineral deposits and useable seams were often discovered. This was especially true

1. H.R.J., 23 February, 1889.

2. H.K.J., 9 October, 1896.

3. H.K.J., 30 November, 1894 .

4. H.K.J., 10 January, 1896. 
of the early Lanarkshire railways; their reports record the opening up of several new collieries along the routes survejed and even more coming into operation when the lines were opened. (1) The impact of the coming of the railways to Ayrshire has been adequately dealt with elsewhere, but perhaps an example can be given. (2) The proposal for the Ayrshire and Galloway (its construction had to wait several years) led immediately to two proprietors discovering "extensive fields of blackband on the line of railway." (3) As regards these two great coal regions one can only agree with Professor Hemilton's view that "Lanarkshire and Ayrshire had to await until the coming of the railways until they could take full advantage of the rich stores with which they were endowed by nature." (4)

The discovery of new coal deposits was not limited to the early days of railway development, but it is more likely that new seams would be developed rather than discovered by the railways after the late 1860s when the geological survey of Scotland began. (5) A final point to be made in this context is that on at least one occasion a railway company loaned money to be expended on boring for coal. This was done by the North Bxitish for soundings in the Canobie district and proved to be a highly successful business venture. (6)

1. See the collection of reports in the Mitchell Library.

2. J.H.G. Lebon, 'The Development of the Ayrshire Coal-Field,' cottish Geographical Magazine, vol.49, May, 1933.

3. Scottish Railway Gazette, I3 December, 1845 .

4. H. Hamilton, he Industrial Revolution in Scotland. 1932, p.251.

5. New pits continued to be estabished on the systems, e. g. the Glasgow and South Westem reported a "number of new collieries being put down" in the early $1860 \mathrm{~s}$, (H.R.J., 16 March, 1861) and the building of the North Monkland in an old coalfield area in the 1880s had a similar result. (H.R.J., 7 April, 1882).

6. RAC(S) 1/1A, 27 September, 186i; 26 september, 1862. B.R. 
The plans of the railway companies to develop the mineral resources of Scotland did not always come up to expectations in the short run. Only a portion of the Dunfermline line was constructed, "the remainder being deferred until coal pits were sunk." (1) The Edinburgh, Perth and Dundee also ran into this problem of colliery development lagging behind railway construction. (2) However, these particular shortfalls can perhaps be explained as reactions of the post mania depression. The main problems faced in developing the Scottish coal traffic were those found by the Aberdeen company in 1853; on the one hand a scarcity of wagons, and on the other a scarcity of coal at the existing pits. (3) These factors are discussed below in section four. The location of coal mining is partially fixed by natural factors, but less so the location of industry or population. Railway communication, in assisting the choice of sites or settlements of the latter, might have acted towards favouring the expansion of one coalfield to the detriment of another. An example of this was whereas Lanarkshire manufactories consumed a substantial proportion of the dross from the mines of the area, in Ayrshire there was no such industrial demand. (4) Bven in the early 1870 s many pits in the vicinity of towns and villages in Ayrshire were dependent on local sale. Where population was distant, however, local markets might not exist, as at New Cumnock where a good seam was left untouched as "there is no market for

1. Scottish Railway Gazette, 27 March, 1847.

2. RAC(S) 1/37, 9 September, 1850; 22 March, 1851. B.R.

3. H.K.J., 29 October, 1853.

4. K.C. Coal. 1871 XVIII. Committee C. p.116. 
the house coal in the district." (I)

The coming of a railway could have a tremendous impact on an existing colliery. John Horne records that the output of the pits around Kirkintilloch "speedily increased" when a railway was constructed to link them with the North British at Townend. (2) However, not all mines received such a boost. Many of the early collieries were inefficiently located, partly because of poor geological knowledge, and when railway development passed them by, they failed to expand as rapidly (if at all) as those mines with railway connections.

A survey of the Scottish coalfields at the turn of the century emphasises how important it was for a colliery to possess links with a rallway. (3) Considering the Ayrshire field alone several examples are forthcoming. The Geological Survey had indicated that a coal measure existed around Guelt, but no properly directed effort had been made to exploit it since it lay isolated at an elevation of four hundred feet above the railway. The only portion of the Muirkirk field which had not been thoroughly developed was a strip about two miles long, lying to the west of Muirkirk, and separated from the Glasgow and South Western line by the river Ayr. The 1870s had witnessed the working of splint and gas coal at Dalgain, but only to a linited extent; partly because there was no railway communication and all the coal had to be carried about four miles to Mauchline. Of course it was not always the lack of a railway that hindered development. Geological

1. Ibid., p.361. K.C. Coal Supplies. 1904 XXIII. q.8742.

2. J. Horne, History of Kirkintilloch. 1910. p.180.

3. R. Dron, The Coalfielas of ScotIand. 1902. 
faults along the Kingcase dyke affected one area, and intrusive indigenous rocks, together with blown sand, hampered mining attempts along the coast between Irvine and Saltcoats. Yet generally it could be asserted that the absence of a railway was either the primary or at least the secondary reason for the failure to develop. (1)

The railway companies were not passive acceptors of their coal traffic and frequently attempted to stimulate the production of coal within their systems. One of the earliest instences of this was the decision of the Edinburgh and Dalkeith to allow a 25\% discount on all coal shipped at Fisherrow in an effort to encourage further exportation. (2) The same company attempted to promote all the year round mining (and hence continuity of wagon use) by allowing coal proprietors four months credit on coal sent to their St. Leonards depot during the summer and autumn months. (3) Later examples of drawbacks and discounts to increase trace and promote production are easy enough to find. The sdinourgh, Perth and Dundee cut by fourpence a ton the cost of carrying coal to Dundee for shipping in order to encourage traffic at that port, whilst the North British, by similarly offering reduced rates, hoped to expand the coal trade of Leith. (4)

In addition, most of the railway companies began to act as

1. Ibid., pp.33-40; 65 .

2. EDR $1 / 1.2 .68 .1832$. B.R.

4. IVIdi/3. p.i28. NBR 1/5. p.111. B.R. Some discounts were given more to ensure that the railway company concerned obtained the carriage contract than to stimulate the production of coal. See for example NBR 1/5, 19 February, 1852. B.R. 
agents for the coalmasters, though the station clerks were usually required to accept orders for every coalmaster and forbidden to act solely on behalf of a particular merchant or colliery. One company, at least, went further than merely accepting orders. It was written of the Aberdeen railway that "it appears that this company not only sells the best Scotch coal by the ton to households, but also for the convenience of the poor, they sell it by retail at wholesale prices in quantities of 28 lbs weight and upwards." (2) Most of the railway companies set themselves up as watchdogs in the public interest and advised the public to purchase coal from the railway depots where its quality and quantity would be guaranteed. (3) of course the railways were not disinterested parties, for the more they could get the coal merchants to use the depots, the more rent they would obtain and the more coal would probably be carried by rail. How successful this policy was is difficult to determine as there are no figures available as to the quantity of coal passing through the railway depots. Perhaps one pointer is that in $1839 / 40$ there were 79 coal merchants in sdinburgh and Leith of whom 10 used the railway depots; twenty years later the total had risen to 99 and 20 of these rented railway premises.(4)

1. e.g. NBR $1 / 5$. p.411. B.R.

2. H.R.J., 20 Vctober, 1855.

3. The Edinburgh and Dalkeith maintained that fraud was impossible when coal was purchased from a railway depot - "it is especially to be remembered, that the Railwäy Company and their officers have no cominon interest with the coal owners, or the dealers in any article carried on the railway: they only furnish the means of transport, and it is their interest to see justice done to tha public, in which the officers exercise the function of a tulce, in virtue of powers conferred by the Railway Act." (EDR 1/1. p.130). The North British advertised "the only caIs brought to dinburgh by railway direct from the pits. They are therefore guaranteed to be free from mixture with other inferior coal." (Edinburgh and Leith P.0. Directory. LIV). 4. dinburgh and Leith P.0. Directory. 1839/40. p.225; 1859/6' $.366-367$. 
Not all the efforts of the railways to stimulate the coal trade were successful. In August, 1884, the Glasgow and South Western made an important concession to the iron and coal traders by placing the four main Ayrshire ports - Ayr, Irvine, Troon and Ardrossan - on an equal footing as regards the total cost of carriage from any point. The idea being that vessels trading in Lanarkshire minerals could save time and expense by calling at ports lower down the coast. Whatever its rationale, the scheme was an abyssmal failure as the traffic proved to be "very limited in quantity and unremunerative to carry." (I)

Furthermore not all the attempts of the companies to increase their coal trade worked to the advantage of the scottish industry. In 1849, for example, the North British set up an Edinburgh depot specifically to deal with deliveries of English coal. In fact the London Comittee of the shareholders of this railway had, as an avowed objective, the aim "to promote the trade of English coals to Edinburgh." (2) At the end of the century the railways were acting as distributive agents in the north east for coal delivered by sea to Aberdeen, but only about a seventh of this was from Scottish mines. (3)

Another aspect of the railways' exertions to stimulate their coal carrying business which would meet a mixed reception from the coalmasters was their undoubted success in smashing regional monopolies and intensifying competition. wite obviously the entrenched interests did not welcome a reduction in their monopolistic

1. H.R.J., 16 August, 1884; 21 March, 1885.

2. Keport of the Committee of Inquiry. 1849. p.5. B.R. 3. 5.C. Railway Rates and Charges. 189? XV. 9.5222. 
positions. A memorial to the magistrates of Edinburgh suggested thit the coal proprietors of Stirlingshire and Linlithgow were opposed to the building of an Edinburgh to Glasgow railway, as they wanted to limit competition in their commodity. (I) Later the promoters of the Edinburgh and Northern alleged that the coalmasters, who already possessed a good market, were quite prepared to let "the whole of the Fifeshire trade ... be dragged about in carts for ever." (2)

There is little debate as to the fact that, with the coming of the railways, regional markets were no longer protected by distance. In the 1860 s the Caledonian broke the monopoly position of the Fife and Lothian coalmasters in the east coast ports by taking Wishaw coal directly to Granton and Leith. Wishaw coal was also carried to the north via Perth when the Fife miners deliberately restricted their output. (3) In the next decade Fife coal prices were lowered, and even depressed at times, as the Caledonian offered reduced rates to collieries on their system who competed with the Fife colmasters in the Forth shipping trade. At an earlier date the coal traffic from Midothian to Peebles had been lessened when the Caledonian constructed a branch from Symington to Peebles which allowed western coal to giin a hold in that market. (5) Further north, and later in the century, the building of the Highland system resulted in Scottish coal being

1. G.D. 26, section 15/94. S.R.O.

2. Jotish hailway Gazette, 21 June, 1845.

3. H.M.J., IO Decem5er, 1864 .

4. Scotsman, 12 August, 1878.

5. M... 15 April, 1865. 
brought in by rail to replace that previously supplied from Newcastle by sea. (1) Yet, despite this evidence of broken monopolies, one important point must be born in mind; coal sold not only by its price, but also by its reputation. Perhaps two-way traffic along any railway was almost as common (though not in volume terms) as uni-directional flows. (2).

\section{4 .}

With one or two qualifications a superficial case has been advanced that the railways contributed a good deal to the development of Scottish coal mining, but before any definite conclusions are drawn some of the issues must be examined in detall.

The coalmasters frequently accused the railways of exploiting the consumer by charging excessive rates for the carriage of coal. It was claimed, for example, that although the North British cut the cost of Lothians coal at Hawick from $31 / 8 \mathrm{~d}$ a ton to $18 / 6 \mathrm{~d}$, the cost might have been reduced still further to $11 / 6 \mathrm{~d}$ had there been effective competition. (3) The calculations are open to debate, but the general point is valid.

There is also no question that in times of difficulties the railways were not averse to increasing their charges. The North British demanded an addition $2 \mathrm{~d}$ a ton, irrespective of distance, in 1875 because of advances in wages and the price of materials (including coal). However, they promised to reduce the rates when

1. H.R.J., 7 May, 1892 .

2. See the advertisements in the P.O. Directories.

3. H.R.J., 17 April, 1858. 
costs were correspondingly reduced. (1) The circumstances of this increase may have been akin to a dispute between the Edinburgh, Perth and Dundee and their local coalmasters in 1850. The coalmasters had increased the price of their coal thus raising the operating costs of the railway, who retaliated by putting up thei $r$ charges. The dispute became fierce and eventually the railway threatened to withdraw the temporary reduction it was giving on coals taken to Dundee via Perth and the coalmasterg backed down. (2) In another dispute about the same time, however, it was the railway company that gave in. The trouble in this instance was the rent charged by the railway for the use of its coal depots. The Blairgowrie colliery proprietors refused to pay what they considered were exorbitant charges; in return the railway announced that the wagons owned by the colliery would not be allowed on the railway. The outcome was that the railway management retracted and agreed to check with the other railway companies as to what they charged. (3)

A major row between the collieries and the railways erupted in the early 1890 s when new rates legislation came into force. The coal traders were virtually as one in complaining that they were paying higher charges as the result of legislation designed to protect them. The figures in Table 6.2 suggest that their protest was not unjustified; receipts per ton carried rising on all the major railways. Yet, the increases proved only temporary, and in 1895 the majority of coal traders were probably paying less than

1. H.R.J., 8 February, 1875

2. EPD 1/3. pp.46-68. B.R.

3. Ibia. 


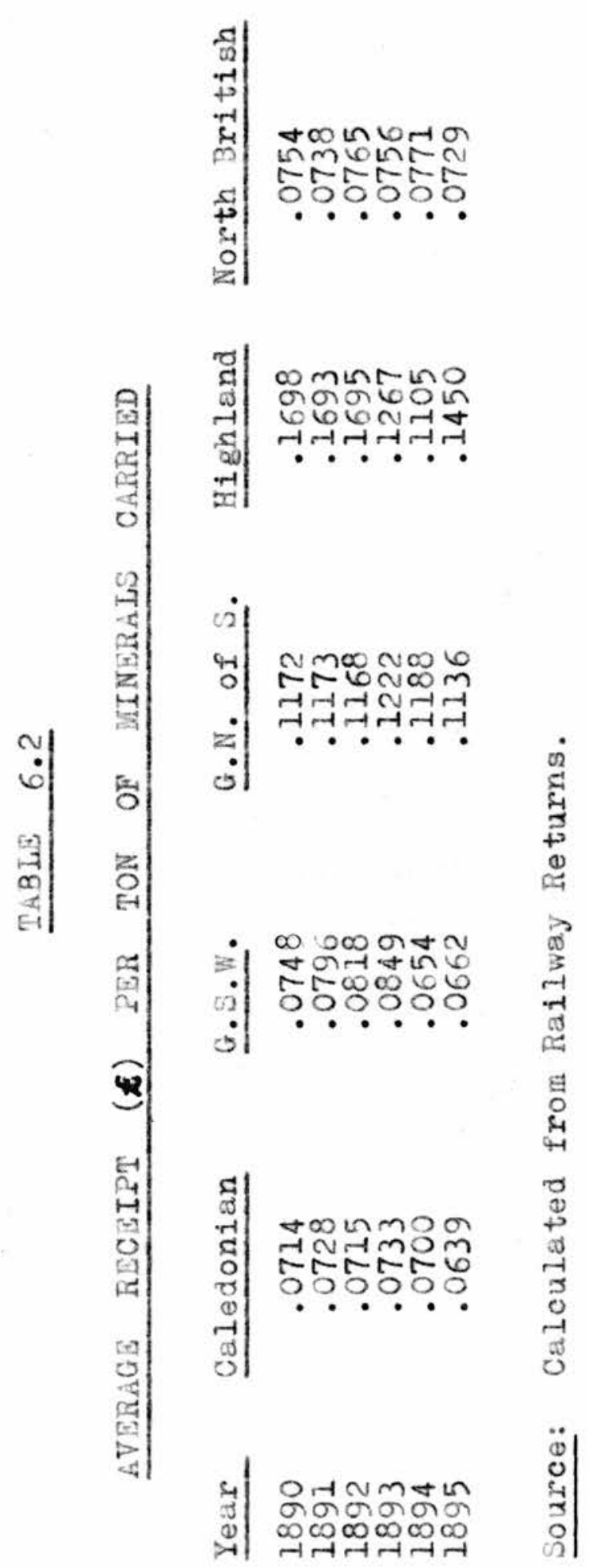


in 1890.

Railway rates exhibited downward flexibility at other times as well. In the late 1870s, when iron and coalmasters were obtaining relatively low prices for their products, the railways directors were not at all reluctant to reduce carriage rates in order to ease their position. Some (perhaps those who were in the trades themselves) even felt it was their duty; a "very material concession" was thus given to enable the coal traders to carry on their operations. (1) The approaches of the coalmasters etc. were not always, or even predominantly, productive of a reduction in freight rates, but it is fair to say that the railway companies rarely rejected the overtures out of hand. For example, when the coal exporters and mine owners of the West of Scotland asked the Caledonian for a reduction in the carriage rates to Leith and Granton, the railway compeny turned them down, but only after careful consideration of the matter, and they did offer to increase the facilities for shipping at Grangemouth. (2)

Not all railway rates were flexible, but those "agreements extending over many years, for the conveyance of minerals at low rates" did not necessarily work against the coalmasters, even in periods of falling prices. These agreements were often signed for periods up to twenty years in order to secure a guaranteed traffic to the railway company. Whether they did help the railway in the long run is open to doubt. One shareholder of the Glasgow and South Western felt that these long standing agreements meant that

1. H.R.J., 20 September, 1879.

RaIway Times, 18 May, 1878.

2. H.R.J., 20 March, 1896. 
as costs rose the mineral traffic of the company was run at a "decided loss," and another shareholder estimated that in two decades such legacies from the past had cost the railway $£ 106,000$. (1)

The railways did not bear the sole responsibility for the level of their charges. On the Great North of Scotland for instance the coal traffic was spasmodic and often in small quantities - three-quarters of a ton was a common load - and thus could not hope to obtain the rates that would have been given to dense, bulk traffic. (2) A second point revolves around the question of fixed overheads. The average length of haul of mineral traffic in Scotland was less than in England which, ceteris paribus, increases unit overheads per ton mile relative to south of the border. (3) What must be emphasised, however, is that even if the railways were exploiting a monopoly position, and this was not always possible because of inter-company rivalry, they had drastically reduced the overall cost of coal transportation within Scotland. Prior to the coming of the railways it was a frequent cry by the coalmasters that they were being priced out of markets because of "the heavy land carriage we have to bear." (4) Railway charges were generally less than a third of road haulage costs which must have benefitted the traffic in a comodity such as coal with a low value/bulk ratio. (5) wo examples may give some indication of the impact of the railway. The opening of the Arbroath and

1. H.K.J., 22 November, 1873; 22 March, 1879; 22 March, 1890.

2. S.C.Railway Rates and Charges, op. cit., q.5474.

3. E.k.J., 22 Harch, 1879.

4. PYB(S) $1 / 2$, p.160. B.R.

5. The question of the savings brought about by reduced transport costs is discussed in chapter eight. 
Forfar cut the price of coal in Forfar by over twenty per cent. (1) Later the Gallander and Oban reduced the cost of coal to the inhabitants of Lochearnhead from $18 / 20$ shillings to 13 shillings a ton. (2)

The question of whether the railways could have done more to aid the development of the Scottish corl industry does not revolve solely around rates and the opening up of new fields. One factor of paramount importance was the efficiency of the service provided by the railway companies. A noted phenomenon of the Scottish coal industry in the later decades of the century was the relative absence of stocks. (3) This was partly because the miners were opposed to stock-piling, believing that in times of high demand their existence would put a ceiling on wages. (4) It was also partly because the coalowners felt that stocks cost money (in that losses occurred through deterioration) and served only to keep the men employed in times of depression. (5) But a third very important reason was the belief that "when the demand came the railway company would not be able to take away the increased quantity. (6) Although this was specifically the claim of the Inspector of Mines for the Eastern District of Scotland, it was an allegation perennially echoed round all the Scottish coalfields. In 1850 the Edinburgh, Perth and Dundee ran into a storm of criticism on

1. Railway limes, 16 February, 1837.

2. Scotsman, 26 April, 1870.

3. The were of course not non-existent. See g.C. Coal $1873 \mathrm{x}$. q.1740; 1922 .

4. Ibid., q.6596.

5. Ibid., q.6680.

6. Ibid., q.1877. 
this account. Sir William Dunbar, owner of the Wellwood Colliery, complained of "the want of wagons for the conveyance of his coal." Another complainant was the Lochgelly Coal Company who felt that the shortage of wagons would necessitate "ceasing to work one or more of the pits." Mr. Watt of the Dysart Colliery was also complaining of a shortage and the Earl of Rosslyn was taking legal advice about the railway's liability for the deficient supply of vehicles. (1) The Edinburgh, Perth and Dundee was not alone in its plight for the early 1850 s also witnessed similar complaints about the North British, Monkland and Aberdeen lines to name but three. (2)

Nor were the complaints peculiar to one period of time. In 1861 the price of coal in Glasgow rose primarily because of "the deficient carrying power of the railways" which had been "notoriously and utterly inadequate for years past." (3) And also it would seem for years to come, for in the next decade the Lanarkshire coalmasters maintained that the "only hindrance to the full development of the trade is the want of means of transit;" and in the decade after that they complained that ships were being held up "in consequence of the limited supply brought to the loading cranes by the railway company." (4) However, it was really in the 1870s, and more especially in the boom of 1873, that complaints intensified. The columns of the scotsman throughout that

1. EPD 1/3, pp.377-391. B.R.

2. NBRI/6, p.305. B.R. REILway Times, 27 December, 1851.

H.K.J., 29 Votober, 1853.

3. Colliery Guardian, 5 June, 1861.

4. Scotsman, I9 December, 1870. Iron and Coal Trades Review, 10 September, 1886. 
year testify to the inadequacies of wagon supplies; in March, "a want of railway wagons,"in May, "a great hardship was occasioned by the want of trucks," and in october, some mines were working only three days a week "owing to the scarcity of wagons." (1) Witnesses to the Select Committee of that year also emphasised this problem, but did point out that the problem was less serious in Ayrshire. (2)

It should be obvious that this deficiency of carrying power was of the utmost importance to the coal industry in that it limited its potential expansion. Yet it ought to be asked whether all, or even most, of the blame attaches to the railway companies. One solution to the problem lay in the hands, or rather the pockets, of the coal-owners themselves. Originally the North British, like several other companies, decided to supply wagons for the coal traffic themselves, but by the early 1850s (probably because of the complaints) they proposed that the coalowners should provide wagons, and that allowances in respect of charges should be made for their use. (3) This policy became widespread and raises the question of whether some blame for the shortages can be apportioned to the coulmasters. Why did they not purchase enough wagons of their own to prevent transport bottlenecks occurring at times of high demand? In fact it is fair to say that they did buy a substantial number of wagons, e.g. in 1898 about a third of

1. Scotsman, 24 March; 17 May; 11 October, 1873.

2. 5.C. Coal. 1873 X. q.1769; 1869; 4799; 4803 .

3. NBR I/3, 5 May, 1847. B.R. NBK $1 / 6$. p.139. B.R. .C. Reilway Acts Enactments. 1846 XIV. Appendix 2 shows that of eight scottish companies that responded two used their own wagons exclusively, but the others allowed privately owned wagons to be used for the coal traffic. 
the mineral vehicles in use on the Caledonian system were traders' wagons. (1) Whether they should, or could, have bought more is debatable, but in at least one period of time, the 1870s, they had invested heavily in new plant which simultaneously increased production, but prevented them having free capital to purchase the wagons in which to take it away. (2) Many collieries preferred to possess their own rolling stock in order to ensure a regular supply of wagons, but it is apparent that in times of high demand both their own and the railways' supply proved deficient. (3) Few complaints were heard at times of normal demand; the problem was that neither the coalowners nor the railway companies thought it an economic proposition to invest in wagons which served only to meet fluctuations in demand and spent a good proportion of their economic life standing idle.

It could be suggested that the railways were best suited to solving the problem of wagon supply as their vehicles, unlike privately owned rolling stock, would not be designated to any particular colliery, and as such there would be less idle time involved. How much of an attempt did the railway companies make to anticipate normal increases in demand? In the early post-mania years the North British, for one, adopted a wait and see policy.

1. Edinburgh Evening Dispatch, 19 February, 1898.

2. T.J. Byres, Entrepreuneurship in the Scottish Heavy Industries, 1870-1900' in P.L. Payne (ed.), Studies in Scottish Business History. 1967. To buy a wagon is a capital cost which might involve an immediate outlay considered too high when there was a chance of having it supplied by the railway companies as a revenue cost.

3. R.C. Coal Supplies. 1904 XXIII. q.11987-11989. 
" but if the mineral trade turns out such as it is likely to, an increase of mineral wagons will be necessary, but to what extent it is not easy to say until the trade is more fully developed." (I)

Some indication of the later policy of the railway companies can perhaps be obtained from the ratio of wagons available (derived from Table 4.1 and appendix four of chapter five)to coal output. Between 1860 and 1900 there were 24 years in which Scottish coal production showed an increase over the previous highest output, and in only six of these cases did the wagon/output ratio rise above its value at the previous coal production peak which does suggest that wagons were being acquired prior to absolute necessity. Several assumptions are, however, implicit in this suggestion, viz, that rolling stock did not become used more or less intensively (haulage distances may have varied because of differential rates of expansion in the various coalfields), that the percentage of the wagon stock available to the coal industry remained constant; that annual correllations are meaningful (increases in wagon supply and coal output may have been concentrated in different periods within a year). Bearing in mind all these difficulties it can (very) tentatively be hazarded that generally the rallways were purchasing wagons in anticipation of normal increaseg in demand rather than to ease pressure on existing stock. This is less true of the mid 1860s and late 1870s, but seems to hold thereafter; there is no doubt that the increased expansion of Scottish coal production from 22.5 million tons in that year to 33.1 million tons by 1900. This is not to infer that shortages were non-existent.

1. Committee of Investigation, 20 June, 1849. Appendix S. B.R. 
It must not be thought that the coalmasters were completely devoid of blame for the shortage of wagons. Their unwillingness to purchase more stock than they did is excusable, but not so the inefficiency with which they utilised the existing wagons, especially those belonging to the ralway companies. Vehicles were frequently used as temporary storage points and thus rendered unavilable for railway service. The companies did attempt to enforce demeurrage payments in the early 1870s, but their efforts had made little impression by the time of the great scarcity of 1873. Generally the companies were reluctant to demand such payments for fear of losing the traffic, though towards the end of the century, when the intense inter-company rivalry had to some extent died down, agreement was reached between the major companies as to a collective policy of enforcing payments. (1)

It could be argued that the very existence of private wagons aggravated the situation. Providing their own vehicles helped solve the problems of an individual colliery, but eased the overall situation much less, since wagons allocated to the exclusive use of one coal company not only add to the difficulties of marshalling, but are apt to produce a situation where idle wagons and shortages of carrying capacity exist side by side on the same system. The problem may have worsened as the century progressed "The system worked tolerably well so long as the trade was in the hands of a comparatively small number of iron and coalmasters, each of whose traffic was sufficient for full train loads; but as the traders increased and with

1. S.C. Coal, op. cit., q.4799; 1871. k.c. Coal' supplies, op. cit., q.15,382. Economist, 5 December, 1903. 
them the number of (private) wagons, the sidings and depots became so overcrowded with wagons requiring continual shunting and marshalling - those of each individual owner, however few, having to be separated from the others, and forwarded, loaded or unloaded, from and to different pits - that it was only with difficulty the traffic could be kept moving." (1)

The desire of the component units within the Scottish coal industry to compete more successfully by ensuring themselves of a wagon supply in fact tended to produce a situation where the industry as a whole failed to obtain the potential efficiencies that the railways were capable of achieving. Against this it has to be considered whether the railways would have been able to buy enough wagons to provide a more efficient service than was given; fear of a wagon shortage was what had encouraged private ownership to develop originally.

More efficient service could also have been provided if the railways had employed wagons of larger carrying capacity. The existence of privately owned stock was one factor that operated against their introduction. Most collieries had their yards and equipment organised and sized so as to be suitable for their own wagons, though generally these would be of the same dimensions as standard railway vehicles. In 1920 only four companies out of thirty nine in Lanarkshire that responded to a Ministry of Transport Inquiry could deal with wagons of twenty ton capacity. In Fife the figure was none out of five and in the Lothians none out

1. R.C(s) 1/4, March, 1871. B.R. It is apparent from reading the working timetables of the companies that railway enployees were not always scrupulous in utilising private wagons, but the companies did insist that particular colliery's wagons should not be taken elsewhere. 
of six. (1) The railways could not introduce the larger wagons unless the coalmasters were willing to reorganise and re-equip their surface facilities. The cost of this would have been large and the benefits might $\hat{\Lambda h}^{\text {th }}$ ve been apparent in the short run; nor might they accrue solely to the coalmasters. This might be explanation enough for the reluctance of the coalnasters to alter their facilities, but it has also been argued that the Scottish coalmasters had a "mixed" entrepreneurial record and were not always progressive in their investment attitudes. (2) If this is true then their reluctance to spend in this instance becomes even more explicable.

The overall position as regards wagon supply seems to be that both the railways and the coalmasters bear a share of the responsibility for the recurrent shortages, though the complaints do seem to ease off in the last decades of the century when the railway companies invested heavily in new stock. As for the inability to introduce larger capacity vehicles which would have eased the problem, the primary obstacle appears to have been the unwillingness of the coalmasters and other industrialists to pay for the facilities to accommodate them.

Greater efficiency in coal transportation would have raised the ceiling to coal production and possibly have encouraged greater expansion of the coal industry. However, not all the gap between actual and potential output can be attributed to transport inefficiencies. The attitude of the miners also produced an upward

(1) C.B.7, section 4/26. Dimensions of Wagons. S.R.0. (2) Byres, op.cit., pp.224-225. 
inelasticity to coal supply in so far as they exhibited a pronounced preference for lelgure as wage rose. (1) It is difficult to assess the relative importance of miners' work patterns and inadequate railway service in limiting expansion. Perhaps it is wisest to wre with Youngson-Brown "that in some districts and at some times capacity was the limiting factor, in other districts and at other times employment.* (2)

5.

So far it has been the supply side of the coal industry that has been emphasised but the factors operating on the demand side must also be examined. The first question to be considered is the importance of the railways as consumers of coal, and then how important other consumers were.

The main difficulty in assegsing the importance of Scottish rallway consumption in the pre-mania period is that most of the available contemporary data refers only to Inglish practice. It is known that in 1839 each trip on the Arbroath and Forpar required 1176 lbs of coal, which, if referring to a return journey, would give a consumption figure of c.39 lbs per train-mile run which is not significantly different from performances south of the border. (3)

What is apparent from the Inglish evidence is that there was an important breakthrough in fuel consumption in the early 1840s. (4) Yet it is difficult to make any estimates of early Scottiah

1. S.C. Coal, o․ cit., q.1955-56; 4816; 6680.

2. Youngs on-Brown, $\frac{\text { Op }}{9}$ cit. $\mathrm{pp} .53-54$.

3. Railway Times, 29 June, 1839 . J. Weale, Locomotive Engines. 1850. p.27-40.

4. We Ahrons, The British Steam Locomotive. 1927. E.L.Ahrons, op. cit., p.65. 
consumption from these Snglish figures as variations in performances between companies render it impossible to produce reliable averages. Furthermore, pounds consumed per mile mean little unless there is adequate information as to the weight of the trains or the speed at which they were travelling. Again many estimates are merely of consumption in running and make no allowance for coal used in raising steam. Partly because of the paucity of Scottish data on locomotive performance and partly because of the absence of adequats mining statistics, no attempt has been made to estimate Scottish railway coal consumption before 1854. However, it can be hazarded that unless Scottish coal production underwent a remarkable upward surge in the decade preceding the beginning of reliable mining statistics, then, in the light of the later consumption estimates, Scottish railways demand could have been of little significance to the coal industry.

The consumption figures that have come to light are shown in the appendix to this chapter and clearly demonstrate the diversity of performance between the companies. Taking the worst practice, that of the North British, then by the use of the statistics for train-miles run (differentiating between passenger and goods), and by allowing $25 \%$ for coal used in purposes other than the hauling of trains, a figure of 169,000 tons is obtained for the maximum potential consumption of coal by the Scottish railways in 1854 . (1)

1. $20 \%$ was allowed for coal used by engines running light or shunting. This figure was based on evidence in an engine mileage book of the Great North of Scotland covering the years 1894-1906. (Property of North British Railway Group). 5\% was allowed for coal used in workshops and stations. This was calculated from figures given by the Caledonian in the early 1870s. (H.R.J., 4 October, 1873). Obviously neither estimate may hold for other periods of time, but in the absence of evidence to the contrary they are the best means of making the estimates of coal consumption more realistic. 
This is approximately $2.3 \%$ of Scottish coal production in that year.

In the late 1850s the Board of Trade published some statistics of coal consumption by Scottish railway companies which again revealed the wide diversity of practice. (1) At one end of the scale was the Caledonian which consumed 50.20 lbs per mile run and, at the other, the Inverury and old Meldrum which used only 14.53 Ibs per mile. The average consumption figure for Scottish railways was given as 39.62 lbs per mile, which, if the missing companies were not atypical, would give a total consumption of about 212,000 tons, again allowing for non-running coal demand. This represents some $2.6 \%$ of weottish coal production which further emphasises that railway demand was not a factor making for accelerated expansion of the coal industry.

In fact the consumption of Scottish coel by the Scottish railways probably never reached even these meagre proportions as before c.1860 coke not coal was the chief locomotive fuel and certain types of Scottish coal, primarily that mined in Fife and the Lothians, were unsuitable for coking purposes. (2) This led to the eastern railway companies ei ther obtaining coke, or coal suitable for coking, from England. The karley Hill Coking Company of Newcastle supplied many of the Scottish lines in the late $1840 \mathrm{~s}$ and 1850s. (3)

1. Parliamentary Papers. $1857 / 58$. LI. p.96.

2. H.K.J., 2 December, 1854 .

3. H.K.J., 8 April, 1854 . NBRI/3, 15 May, 1847. B.R. ENDI/3. passim. B.R. It should be noted that one of the early railway companies in the west, the Glasgow, Paisley, Kilmarnock and Ayr, at first imported coke from liverpool, though they soon abandoned the practice. (Railway Times, 6 March, 1841). This may have had something to dowith the undeveloped state of the Ayrshire coalfield at the time. 
Two of the early eastern railways did purchase their coke within Scotland. The Arbroath and Forfar bought their supply from a Mr. Gow who owned coke ovens in Arbroath, and the Dundee and Newtyle obtained their fuel from Carmichaels' Foundry in Dundee. However, both the suppliers made the coke from an equal mixture of Garisfield and Prudhoe Main (Newcastle) coal. (1) Later, when the Scottish Central set up sixteen coke ovens of its own, it remained true that much of "the coal used in the manufacture of the coke is brought from the north of England." (2) Other companies also manufactured their own coke, though the Edinburgh and Glasgow abandoned this practice in 1849 and the Edinburgh, Perth and Dundee still had to make outside contracts because of the limited capacity of its works. (3) The use of coke can be said to have been on the way out by the late 1850s, although even in 1866 the North British was utilising coke to such an extent as to arouse

1. F. Wishaw, The Railways of Great Britain and Ireland. 1840. pp. 6; 83.

2. Railway times, 18 January, 1851.

3. Glasgow Chronicle, 25 August, 1841. RAC(S) $1 / 23,2$ Harch, 1849. B.R. BIDI/3, I5 March, 1848. B.R. 
comment. (1) The main reason for this company's diverse practice was the unsuitability for locomotive fuel of the coal to be found in their southern sector. (2)

Did the railways become of more importance to the indigenous coal industry when coke consumption faded away? Using the same assumptions on non-haulage use as before, and information on the performance of the Caledonian in 1873, an estimate of 790,900 tons is obtained as potential railway consumption. (3) This accounts for approximately $4.7 \%$ of the output of the Scottish coal industry which would seem to suggest that railway demand increased in significance. However, the Caledonian may not have been representative of all scottish railways. If the consumption on the Caledonian had been taken as typical in the late 1850 s then the

1. Coke and coal cost the North British an average of 214,350 per annum in the $1850 \mathrm{~s}$ but generally the cost of fuel was considered to be so cheap as to deter research into the locomotive engine with the view of rendering it more efficient as regards fuel consumption. (KACS S I/IA; K.H. Johnston, British Railways and Their Recovery. 1949. p.142). It was the problem of substituting coal for coke rather than questions of fuel economy that concerned railway engineers in the 1840s and 1850s. The main obstacle to the employment of coal was the smoke that it produced, which was anything but agreeable, especially to the passengers in open carriages. Various methods were tried to overcome this problem, most of them centred around improving the firebox, but the solution in fact was much simpler, for eventually it was realised that all that was needed was so me arrangement to admit a supply of air above the burning coal to give more complete combustion. Except for this the coal burning locomotives had "boilers and fireboxes almost exactly similar to those adopted when coke was used." (T.E.S.S. 1858/59. p.2 and article by Patrick Stirling; Wishaw, op. cit., p.112; J. Thomas, The Springburn Story. 3964. p.94. Engineering, 2 February, 1866).

2. North British Railway Inquiry, 16 November, 1866. pp.109-110. B.in.

3. $\overline{\text { H.R.J., }} 4$ October, 1873. 
proportion of Scottish mining output absorbed by the railweys would have been $3.1 \%$ and not $2.6 \%$. This still suggests a rise in the significance of railway demand.

If the 1873 consumption rate is taken to hold for the rest of the century, then in 1880 the Scottish railways consumed 868,400 tons ( $4.7 \%$ of total output), in $18901,166,900$ tons $(4.8 \%$ ) and in $19001,519,300$ tons $(4.6 \%)$. Again the question arises as to whether the Caledonian was typical, but a more important problem is whether the consumption rate in 1873 would still hold in 1900. In view of the attitude of the engineers to fuel economy the rate is unlikely to have gone down, especially when it is born in mind that heavier locomotives were being introduced.

However, when indirect demand is taken into consideration the significance of railway demand in the later nineteenth century does not exhibit the relative stability that estimates of direct demand would suggest. (1) Even though the railways were consuming more iron (and steel) than in the mid century, and Scotland had begun to manufacture her own rails, the rise in total demand in the last two decades of the century failed to match up to the rapid increase in the output of the Scottish coal industry (as can be seen in Table 6.3). There can be no doubt that railway demand provided an important outlet for scottish coal, but nevertheless they cannot

1. This was partly because fuel economies within the iron industry cut the amount of coal needed to produce one ton of pig iron from 3.25 tons in the 1850 s to 3 tons by the 1860 s and this fell to 2.5 tons by 1881 . (Youngson-Brown, op. cit., p.35). In the early 1890 s it had been reduced even further to 1.75 tons. (Calculated from data in T...S. 1892/93). 
have stimulated the rapid growth of that industry as they were consuming a relatively smaller proportion of the total output than they took in earlier periods.

\section{TABLE 6.3}

SCOTIISH RAILWAY DEMAND FOR COAL

\begin{tabular}{|c|c|c|c|c|c|}
\hline Year & $\frac{\text { Direct }}{\text { Demand }}$ & $\frac{\text { Indirect }}{\text { Demand }}$ & $\frac{\text { Total }}{\text { Demand }}$ & $\frac{\text { Scottish Coal }}{\frac{\text { Production }}{\text { million tons }}}$ & \% Take \\
\hline $\begin{array}{l}1854 \\
1857 \\
1873 \\
1880 \\
1890 \\
1900\end{array}$ & $\begin{array}{r}169 \\
212 \\
791 \\
868 \\
1167 \\
1519\end{array}$ & $\begin{array}{r}572 \\
595 \\
2159 \\
1775 \\
777 \\
1405\end{array}$ & $\begin{array}{r}741 \\
807 \\
2905 \\
2643 \\
1944 \\
2924\end{array}$ & $\begin{array}{r}7.4 \\
8.2 \\
16.9 \\
18.3 \\
24.3 \\
33.1\end{array}$ & $\begin{array}{r}10.0 \\
9.9 \\
17.5 \\
14.4 \\
8.0 \\
8.9\end{array}$ \\
\hline
\end{tabular}

Source: See text.

3.R. Mitchell and P. Deene, British Historical Statistics. 1962. p.115-116.

What sectors of the market were expanding rapidjy and pulling the mining industry into a period of sustained growth? (1) It most certainly was not the native iron industry which absorbed a declining proportion of coal output, partly because it failed to sustain its own rate of growth, and partly because the techniques of fuel economy within the industry improved. In $185432.3 \%$ of the total Scottish output was required for pig iron production, but

1. It can be suggested that it was the demand side that was the key force for there is no evidence of any breakthrough on the supply side. Machine cutting was slow to be introduced and although some railways were constructed to aid mineral development in certain areas, the fact that all the coal producing regions of scotland shared in the expansion of output suggests that dem nd factors were generally operative. (A.K. Cairncross, The scottish sconomy. 1954. p.110; Byres, op. cit., p.254). 
this fell to $23.5 \%$ in 1870 , $14.3 \%$ in 1880 and $8.9 \%$ in 1886 . (1) In absolute terms the amount taken by the pig iron producers never rose above the level of 1870. (2) The decline was not made up by the steel industry, who, despite their expansion, took only $2.4 \%$ in 1885 and $4.5 \%$ by the end of the century. (3)

Youngson-Brown assigns a dynamic role to exports in the period 1859/60 to $3.884 / 85$, during which the amount shipped abroad increased ninefold in absolute terms, and rose from $4.7 \%$ to $14.2 \%$ as a proportion of total Scottish coal output. (4) This dynamism continued into the period of rapid mining expansion. In 18904.3 million tons were exported (a rise of 2.4 million tons within a decade) and by the end of the century the figure reached 7.4 millions. In terms of a percentage of total scottish coal output the respective figures are $17.6 \%$ and $22.4 \%$. (5)

This sharp rise in exports does not, however, explain all the expansion in coal production. Some 19 million tons in 1900 (an increase of 4 million tons from 1890) must have been consumed by United Kingdom manufacturers, other than the Scottish ferrous interests, or in the domestic hearth. Why this should have increased is not important here, but it can perhaps be argued that, without the expangion of the railway system in the previous decades,

1. Youngson-Brown, op. cit., p.36.

2. A. Slavin, Earnings and Productivity in the Scottish Coalmining Industry During the Nineteenth Century' in P.L. Payne, op. cit., p. 237 .

3. Calculated from data in I.F. Gibson, 'The Establishment of the Scottish Steel Industry,' Scottish Journal of Political Economy, vol.5. 1958; and 18. .... 189?/93.

4. Youngson-Brown, op. Cit., p.260.

5. Calculated from SIavin, op. cit. 
this coal could not have reached its markets, or that the market might not have existed because of excessive transport costs in a railway-less economy. Moreover, the existence of railway connections may well have stimulated the development of industry and hence industrial demand for coal. Unfortunately it is impossible to assess the importance of this quantitatively and it must remain a matter for conjecture.

\section{6.}

The early stages of Scottish railway development were marked by an interdependence of railway and colliery; in fact the majority of the early lines were constructed to carry coal. The railways did not merely provide a better means of transport to existing pits; frequently they opened up mineral fields and many new pits were sunk simply because the proposal for a rallway encouraged a geological survey of the projected route. This form of aid to the coal industry continued throughout the century, but from about 1850 the help increasing became of another form, viz., making cheap coal generally available throughout the country. The extensive building of lines in the second half of the rineteenth century greatly facilitated and cheapened the transport of coal, which together with other factors stimulated the growth of industry which, in its turn, generated a still greater demand for coal. The railways themselves were not unimportant consumers of coal when indirect demand is taken into consideration. This was especially true of the 1870 s when fuel economies within the iron 
industry had not reached the levels of the 1890s.

Yet it can be argued that the railways could have done more. Complaints by the coalmasters of a lack of wagons to take away their coal became part of industrial folklore. The inability of the transport system to handle the ever mounting volume of business was of paramount importance to the coal industry, although, as suggested, it was not entirely the fault of the railway companies. The seriousness of this deficiency in the carrying capacity of the railways is scarcely open to question. In limiting the expansion of a potential leading sector it would also serve to produce a shortfall in Scottish economic growth. However, heavy investment by the railways in wagon stock in the 1890 s eased this hindrance to expansion and on the basis of growing export and home demand the Scottish coal industry rapialy expanded. 


\section{APPENDIX ONE}

CONNUMPTION OF COAL ON SCOTTISH RILWYS: SOME SVIDENCE.

(1) Aberdeen

\begin{tabular}{|c|c|c|}
\hline Year & & consumption \\
\hline $\begin{array}{l}1849 \text { to } \\
1859 \text { to } \\
1850 \text { to } \\
1850 \text { to }\end{array}$ & $\begin{array}{l}\text { Jly } \\
\text { Dec } \\
\text { Jly } \\
\text { Dec }\end{array}$ & $\begin{array}{l}1586 \text { tons } \\
1259 \text { " } \\
1726 " ~ \\
1961 " ~\end{array}$ \\
\hline
\end{tabular}

Source: $\underline{\operatorname{RAC}(S) 1 / 36}$ B.R.

(2)

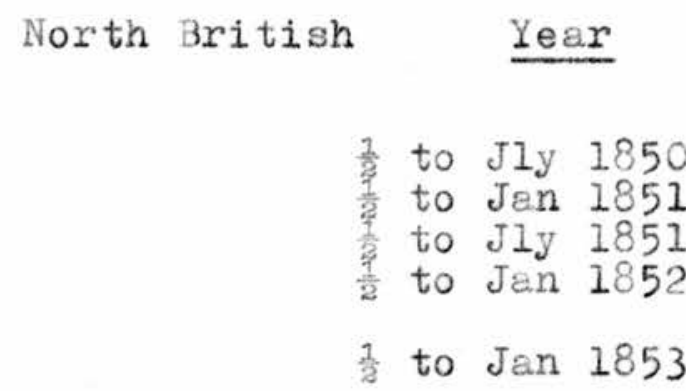

Source: $\operatorname{RAC}(S) I / 1 A$. B.R.

(3) Sdinburgh, Perth Year

\section{and Dundee}

\begin{tabular}{cl} 
consutal & lbs permile (coke) \\
\hline 10,641 tons & 40.5 \\
$10,664 "$ " & 38.75 \\
9,947 " & 35.5 \\
9,473 " & 32.0 \\
$10,689 "$ & 33.5
\end{tabular}

lbs per mile

42.4 (coke)

32.0 (coke)

28.0 (coal \& coke)

23.0 (coal \& coke)
$185 ?$

1855

1856

1857

1858

$1859 *$

$1860^{*}$

$1861 *$ los per mile (coke and coal)
goods

15.88

34.67

12.23

14.77

12.36

24.69

22.44

22.88

11.16

29.58

27.25

27.94
25.29
58.85

51.32

57.24

* It would seem that these figures are for consumption of coal and coke measured in terms of coal equivalent.

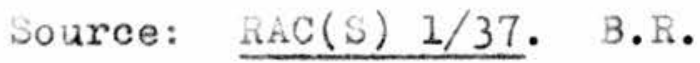


(4) Scottish Central

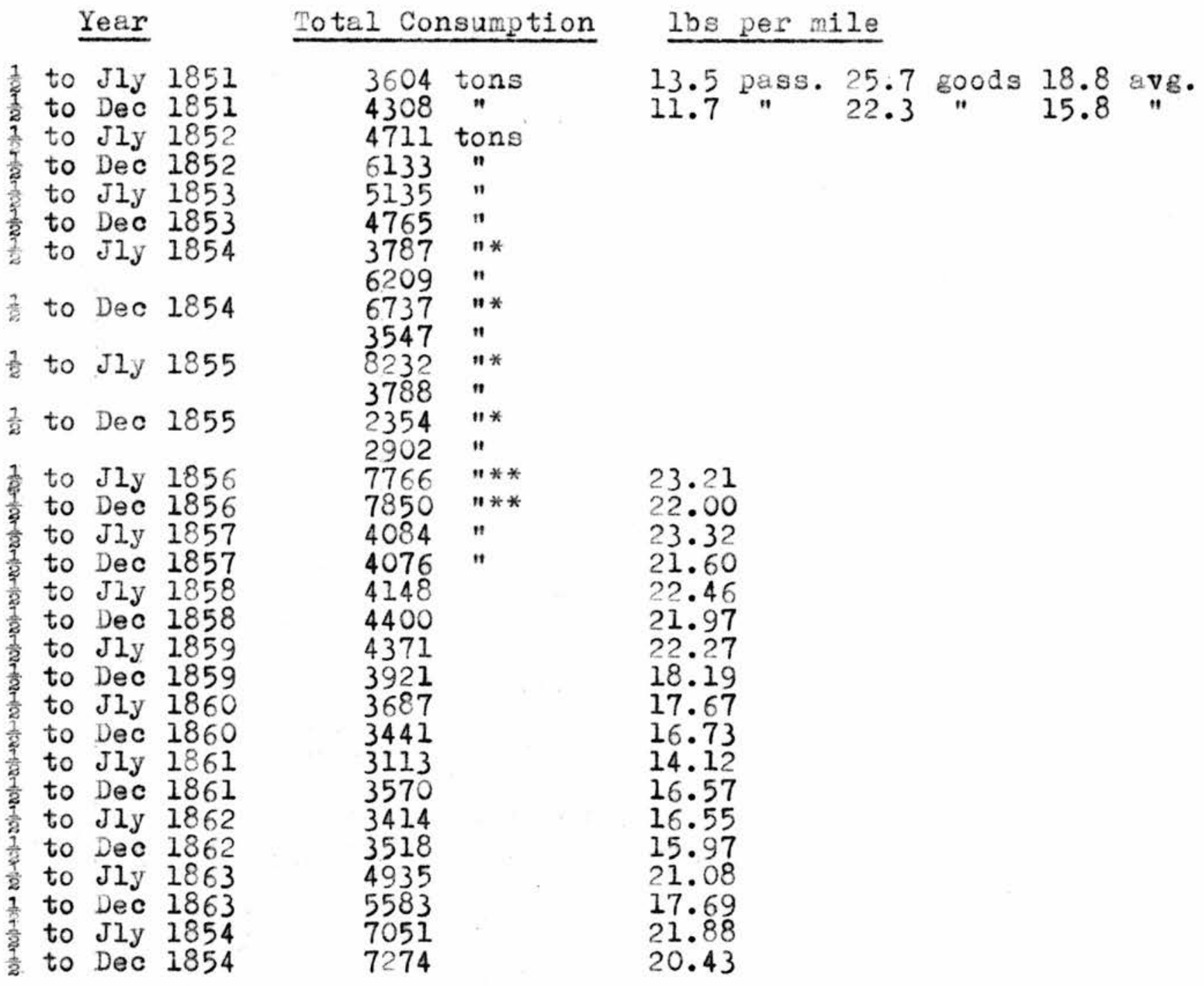

* first figure refers to coke, second to coal

* includes Edinburgh, Perth and Dundee After 1855 figures are of coal and coke expressed in terms of coal equivalent.

Source: $\operatorname{RAC}(S) 1 / 34$. B.R. 


\section{CHAPTER SEVEN}

\section{ASPECTS OF RAILWAY EMPLOYNENT}

"... the kind of employment offered by the Lines Open was very different from that which was afforded by the Lines Constructing."

Tooke and Newmarch, History of Prices. 1857. vol.5, p.234.

"Railway porters are ready with the utmost civility and promptitude to take charge of the baggage of each passenger, and carry it to the vehicle by which he is about to depart. The rules of the companies exclude the payments of gratuities for these services; nevertheless, it is most just to say nothing can exceed the civility and obliging conduct of all the inferior agents so employed."

$$
\text { D. Lardner, Railway Economy. 1850. p.133. }
$$

"The Scotch fought with the Irish and the Irish attacked the Scotch; while the rural peace-officiers, utterly inadequate to suppress the tumult, stood calmly by and waited the result."

J. Francis, A History of the English Railway, $\begin{aligned} & 1851 \\ & \text { vol.2. } \\ & .73 .\end{aligned}$

\section{1.}

Although railways were a growth point of the Scottish economy throughout the nineteenth century, they employed eight thousand fewer workers in 1901 than in 1847. The reason for this, as can be seen in Table 7.1, is that the decline in demand from constructional activity outweighed the increase in operating staff. This reduction in the total work force reflected the railway mania, or, more precisely, its aftermath. In the four years from 1847, as the post-mania building was completed, the number of constructional workers declined from a peak of over fifty-two thousand to a mere 
TABLE 7.1

EMPLOYMENT ON SCOTTISH RAILWAYS 1847-1901

\begin{tabular}{|c|c|c|c|}
\hline$\underline{Y E A R}$ & OPERAPING STAFF & CONSTRUCTION & TOTAL \\
\hline $\begin{array}{l}1847 \\
1848 \\
1849 \\
1850 \\
1851 \\
1852 \\
1853 \\
1854 \\
1855 \\
1856 \\
1857 \\
1858 \\
1859 \\
1860\end{array}$ & $\begin{array}{r}5,018 \\
7,481 \\
8,520 \\
8,516 \\
8,107 \\
8,271 \\
8,979 \\
10,002 \\
11,403 \\
11,635 \\
11,575 \\
12,647 \\
13,278 \\
14,481\end{array}$ & $\begin{array}{r}52,795 \\
25,503 \\
17,792 \\
7,979 \\
695 \\
128 \\
3,114 \\
5,685 \\
5,985 \\
5,300 \\
8,597 \\
6,333 \\
8,567 \\
9,499\end{array}$ & $\begin{array}{r}57,813 \\
34,084 \\
26,312 \\
16,495 \\
8,802 \\
8,399 \\
12,093 \\
15,687 \\
17,388 \\
16,935 \\
20,172 \\
18,980 \\
21,845 \\
23,980\end{array}$ \\
\hline 1861 & $15,042^{3}$ & 4 & \\
\hline 1871 & $18,338^{3}$ & & \\
\hline 1881 & 22,623 & 3,129 & 25,752 \\
\hline 1884 & $38,408^{2}$ & & \\
\hline 1891 & 36,317 & & \\
\hline 1901 & 42,815 & 5,589 & 48,404 \\
\hline Source: & $\begin{array}{l}1847-60 \frac{\text { Railway }}{1884} \\
1861-1901 \frac{\text { Kallway }}{\text { Census }}\end{array}$ & $\begin{array}{l}\text { Returns } \\
\text { Returns } 1884 \text { IXX } \\
\text { of scotland. }\end{array}$ & \\
\hline
\end{tabular}

Notes:

(1) Unfortunately the official railway returns of numbers supply a continuous series of data only from 1847 to 1860 , and one isolated return in 1884. Recourse must be had to the occupational tables in the population censuses to supplement the official figures, but here difficulty arises in the form of inconsistent occupational definitions over time, and the nondifferentiation of constructional and operating workers.

(2) The 1884 figure includes miscellaneous employees in hotels, canals, telegraphs, steamboats, docks and piers, which, if deducted, give a total of 36,794 persons involved in pure railway employment.

(3) Employment on the railways in 1861 and 1871 came to 21,949 and 30,138 persons respectively, but these totals included 
6,907 and 11,800 "carriers on railways" which were deducted. The total for 1861 also included 237 navvies, but since substantial mileage was opened in that and the following year these navvies were taken to be members of the operating staff, and the total employment figure deemed to refer to that staff.

(4) It is not possible to make estimates of the numbers employed in construction because over the century railway building became less labour intensive. This is deduced from scattered references to the number of workers on particular works and tests made to correllate the above data with mileage opened. The reasons for less labour per mile are likely to be the use of better explosives, the introduction of the mechanical shovels and perhaps a different type of construction work. 
six hundred and ninety-five persons. However, from 1852 railway employment rose steadily, accelerating in the last two decades of the century to create approximately twelve hundred extra jobs each year. Whether, as one economic historian has suggested, this helped to absorb the labour released from the declining agricultural, cotton, and flax sectors is debatable, especially since the majority of railwaymen were, in a sense, skilled workers, as can be seen in Table 7.2 . (1) Again railway employees had to be fairly literate because of the necessity of reading weekly notices and making out reports. Although it has been argued that the working man was not as illiterate as has often been supposed, literacy and other required skills would tend to reduce the numbers that could have worked on the railways had there been vacancies. (2) Nevertheless, it may be that the labour was not displaced from the declining industries, but existed at the margin of entry, and could therefore have more easily undertaken a railway career; though the different geographical distribution and sex structure of the employment offered by the expanding railways and the decaying industries would mitigate against this. (3) What is probable is that at the end of the century more jous were filled by local scots than at the height of the railway mania constructional boom because of the 1tinerant nature of railway navies,

1. A.J. Youngson-Brown, The Scots Coal Industry 1854-1886. D. Litt., Aberdeen. 1952. pp. 21-22.

2. R.K. Webb, The British Working Class Reader 1790-1848. 1955.

3. In 1861 agriculture, cotton and flax employed nearly 210,000 women; by the end of the century this had been reduced to just over 70,000. Those released could not possibly have been absorbed into railway employment as only 222 females were working for the Scottish railway companies in 1901. 


\section{TABLE $\quad 7.2$}

STRUCTURE OF SCOTTISH RAILWAY BMPLOYMENT IN 1860

OCCUPATION

Secretary or Manager

Treasurer

Engineer

Superintendent

Storekeeper

Accountant

Inspectors and Timekeepers

Stationmasters

Ticket Collectors

Draughtsmen

Clerks

Foremen

Engine drivers

Assistant engine drivers

Guards

Artificers

Switchmen

Gatekeepers

Police

Porters

Platelayers

Jabourers

viscellaneous

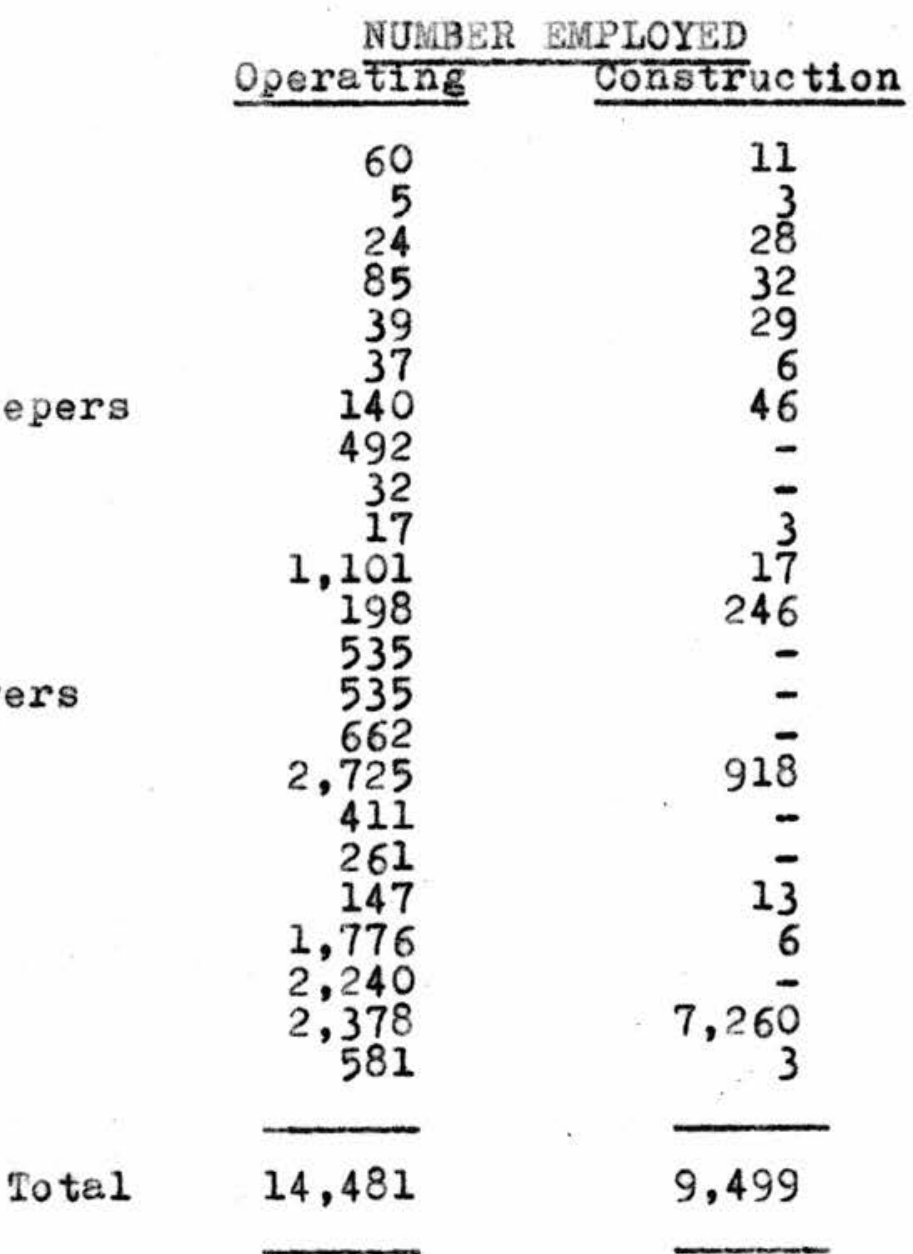

NUMBER EMPLOYED Operating Construction

101

198

535

535

411

261

1,776

, 240

, 378

581

7,260

9,499

Source: Railway Returns 1860 LXI 
created by the regional, national, and international fluctuations in raliway construction.

Yet, even in 1901, when the Scottish railway network was nearly at its peak, only $3.17 \%$ of the "employable male work force" worked on the railways. (I) In countiea with fewer high wage industries railway employment (if it existed to any extent) would appear relatively attractive and its regional importance perhaps exceed its national significance as it did in Perthshire (5.09\%), Fifeshire $(4.57 \%)$ and Dumfries-shire (4.48\%), but even here the railways did not approach the pressure put on the resources of the labour market by other industrial sectors or agriculture. (2) Despite this, railways were, in the early twenthieth century, important employment sectors in the major railway termini and distribution centres; operating staff ranking as the eighth leading male occupational group in Edinburgh, Leith and Dundee; sixth in Aberdeen, Greenock, Paisley and Kilmarnock; fifth in Glasgow and second in Perth. (3)

Rallway construction following the mania offered temporary employment to the local populace en route, but, al though some agricultural labourers took the opportunity to earn $3 / 6 \mathrm{~d}$ a day

1. This is defined as the total male population over the ate of twelve less those unemployed who were under fourteen or over sixty. (Calculations from data in 1901 Census).

2. Some of this employment would be the result of railway demands for materials and equipment, the extent of which can be judged from the previous chapters.

3. Parliamentary Papers. 1908 CVII. pp.507-552. 
instead of their normal $1 / 7 \mathrm{~d}$ to $2 / 3 \mathrm{~d}$, the builders of the Scottish rail railway system at this time wereAprimarily local men.. (1) The main force of the navvies and labourers comprised Irish and Highlanders, with the Fnglish making more contribution to the masons, joiners, engineers and contractors. (2)

The Highlanders predominated in Perthshire, although the majority of them were not permanent railway navvies, but labourers, who had taken the opportunity offered by railway employment in these years; some, like thirty men from the Isle of Harris who went to the Scottish Central, having had appointments arranged by their proprietors. (3) Further south there were more Irish workers, drawn from the casual labour in the inaustrial areas, from those who crossed the Irish sea deliberately to seek railway employment, but not from the annual migratory flock of Irish harvesters, who appear to have resisted the temptation to make money in railway building. (4) Irishmen had been significant in Scottion railway construction prior to the mania, comprising three-quarters of the labour force on the Glasgow and Ayr line in the late $1830 \mathrm{~s}$ as well as a substantial proportion on the Ddinburgh and Glasgow, and were to remain a chief so urce of

1. S.C. Railway Labourers. 1846 XIII. q.1422-23; 1532-1535. H.L. Bowley, Wages in the United Kingdom in the Nineteenth Century. 1900. p.5T.

2. J.S. Hand ley, The Irish in Scotland. 1943.0 .61$. S.C. Railway Labourers, op. C1t., q.73; 458.

3. 1019., 9.T3; 167. Handley, op. cit., p.61. Scottish Kailway Gazette, 12 December, 1846.

4. S.C. Railway Labourers, op. cit., q.460-461. Handley, op. cit., p.62. 
constructional labour throughout the century. (1) Presumably, not having roots in Scotland they showed less disinclination to move around in search of employment than native Scots. Where the operating staff originated is difficult to say, though, if England's experience is any guide, it can be conjectured that the railway police, originally employed to keep the navvies in order, became the first signalmen, presumably because they were deemed responsible, and that porters and guards came from coaching firms superseded by the railways. (2) Few Scots could have obtained railway experience prior to the 1840 s owing to the lack of early lines in Scotland and the difficulties of labour mobility in the first half of the nineteenth century which hindered their gaining employment on English lines. (3) However, to some extent engineers, artificers, labourers and clerks probably found their existing skills adequate.

The major bottleneck on the operating side seems to have been at the higher levels of employment. Experienced managers and competent locomotive superintendents were scarce throughout the century and competition for their services was keen. (4) The Caledonian offered to double the salary of Andrew Dougall, Secretary

1. Rallway Times, 11 August, 1838 . Glasegow Constitutional, 4 July, 1840. Parliamentary Papers. 1860 XXXIII, evidence of James Cowan, raI way contractor. (Witness 498 ). J.E. Handley, The Irish in Modern Scotland. 1947. p.125. Journal of the Stephenson Locomotive Society, October, 1966. p.301.

2. J.K. WhItoread, The kallway Pollceman. I96I. pp.17; 43.

3. The Caledonian is reputed to have sent its original employees to the Lancaster and Carlisle line to learn railway duty. (Dundee Advertiser, 9 September, 1897).

4. Unless an alternative source has been given, biographical material has been obtained from the company histories published by the Stephenson Locomotive Society. 
and General Manager of the Highland, but he remained in his position when his employers guaranteed him $£ 1,000$ per annum and promised that this would be increased if the company became more prosperous. Others were less loyal. The Highland itself tempted Stroudley from the Edinburgh and Glasgow, only to lose him to the London, Brighton and South Coast five years later. In 1912 they lost another locomotive superintendent when Peter Drummond, who had joined them from being Assistant Works Manager of the North British, went to the Glasgow and South Western. The Glasgow and South Western had also gained their previous locomotive superintendent, Jaxes Manson, from another Scottish railway, the Great North of Scotland, but he had originally trained at their Kilmarnock works. In turn the Glasgow and South Western had lost three of its best locomotive superintendents; Patrick Stirling to the Grest Northern; his brother James to the South Rastern, and Hugh Smellie to the Caledonian. The latter company also captured the renowned Dougald Drummond from the North British in 1882, but had earlier lost Sinclair to the Bastern Counties. Managers too found it profitable to change companias. William Grafton, Assistant Superintendent on the Caledonian, was appointed manager of the Peebles line, and Mr. Young of the Caledonian and Dumbarton moved to the Forth and clyde Junction. (1)

Many experienced men came from the established English companies. H. B. Mitchell, the first General Superintendent of the Caledonian's Edinburgh terminus had transferred from the Great western. (2)

1. H.R.J., 1 Way, 1858; 9 April, 1864.

2. H.K.J., 15 January, 1848 . 
Later, Smithell, of the Lancashire and Yorkshire, moved to Scotland to manage the Caledonian. (1) The Lancashire and Yorkshire also supplied the North British with a General Manager, Rowbotham, in 1852, and, fifteen years later, the North British once again turned to Sngland, this time to obtain S.L. Manson of the Great Northern. (2) Another twenty-four years and they attracted the famed Connacher from the Cambrian, although he had earlier worked on the Scottish Central. (3) The North Sastern supplied managers to the Great North of Scotland in 1880 (William Moffat) and to the Highland in 1898 (Thomas Wilson). Both these latter companies had obtained locomotive superintendents from south of the border; William Barclay of the Highland gained most of his experience on the Great Bastern, whilst Kinnear Clark moved to the Great North of Scotland from London, and James Johnson from the Widland Works at Derby. (4) Stroudley of the Highland and the Edinburgh and Glasgow had previously worked on the Great Western and the Great Northern. Another locomotive engineer to move north was Thomas Wheatley, who come to the North British from the Iondon and North Western. (5)

This transference of key personnel was not one way traffic for others gained experience on Scottish linea before seeking their fortunes over the border. The Stirling Brothers and Sinclair have already been mentioned but they were not alone in their

1. H.R.J., 19 October, 1867.

2. H.k.J., 14 August, 1852; 29 April, 1867.

3. H.K.J., 15 August, 1891.

4. H.K.J., 27 September, 1890.

5. H.K.J., 12 January, 1867. 
travels. S.W. Johnson, locomotive superintendent of the North British, switched to the Great Bastern; Hugh Smellie went to the Maryport and Carlisle before returning to the Glasgow and South Western; and the Great Northern took Robertson away from his position as superintendent of the Highland line. (1)

The pattern that emerges is of a continual flow of top personnel using each job as a stepping stone to greater heights, be it at the same level of hierarchy on a more important railway or to a higher position on a line of equal or less significance. (2) This is not to say that internal promotion to the top positions was negligible. In 1840 Feter Robertson became locomotive of the Glasgow, Paisley, Kilmarnock and Ayr from being foreman in the Ayr running sheds. James Stirling had been employed for most of his career by the Glasgow and South Western, becoming works manager at Kilmarnock before being appointed locomotive superintendent in 1866. David Jones reached the position of locomotive superintendent of the Highland in 1870 after entering the service of one of its constituent companies, the Inverness and Nairn, fifteen years previously. John Folds Ruthven was promoted to a similar rank on the Great North of scotland on the merits of keeping the stock in repair, whilst foreman of the workshops. One

1. Engineering, 14 December, 1866.

2. The career of Peter Drummond perhaps epitomises this. He served an apprenticeship with Forrest and Moor of Glasgow, and later became a member of the locomotive staff of the London, Brighton and South Coast. In 1875 he joined the Cowlairs Works of the North British under his more famous brother Dougald, moving with him to the Caledonian in 1882 and eventually becoming Assistant Works Manager. From this position he was appointed to be Locomotive waperintendent of the Highlend in 1896 , remaining there for sixteen years before finally occupying a similar post on the more important Glasgow and South Vestern. 
of the most famous of Scottish locomotive engineers, Alexander McIntosh of the Caledonian, was appointed to that position from being Chief Inspector of the running department. Managers too were internally recruited. John Walker, Secretary of the North British became the company's manager after the resignation of Mason. (1) On the Caledonian James Thompson rose from Goods Menager to General Manager when Smithell retired, whilst Brunton served the Glasgow and South Western for forty years before attaining a similar position. (2) McLaren, one time General Superintendent of the Caledonion, had risan from the "lowest ranks," and when Connacher left the North British in 1899, the directors took a decision not to go outside the company in the appointment of his successor. (3)

In fact it can be suggested that over the century the pattern of top personnel movement was changea by the growth of the railway industry, the amalgamation of lines, and the passage of time which meant that the companies could produce enough experienced men to fill key positions from their own employees. This is born out by a 'Who's Who' in the Railway Year Book for 1901. Of twelve top railway officers, representing all the major Scottish lines except the Highland, only one had not had long service with the company he now helped to run. (4)

1. Railway News, 29 Aieugt, 1874.

2. H.K.J., 4 kebruary, 1882.

3. B.K.J., 23 July, 1892; 29 September, 1899.

4. KaIIway Year Book for 1901. pp.221-224. 


\begin{tabular}{lcc}
\multicolumn{4}{c}{ TABLE 7.3} & \\
ACCIDENTS TO RAILWAYHBN IN & SCOTLAND & 1890-19 \\
\hline & & \\
Year & Killed & Injured \\
\hline 1890 & 92 & 313 \\
1891 & 97 & 322 \\
1892 & 89 & 274 \\
1893 & 78 & 314 \\
1894 & 77 & 256 \\
1895 & 79 & 433 \\
1896 & 92 & 402 \\
1897 & 83 & 457 \\
1898 & 107 & 500 \\
1899 & 109 & 444 \\
1900 & 117 &
\end{tabular}

Source: Railway Returns on Accidents.

Note: Injured was defined as being unable to work for five hours on any of the three days following the accident. 
In considering the conditions of labour, constructional workers must again be differentiated from the operating staff. The sad conditions of the railway navvies stimulated a Parliamentary inquiry which revealed the enormity of the misery they suffered and the iniquities under which they laboured. (1) The dangers of the job (perhaps even greater in Scotland where no inquest was held) were accepted, but the system of monthly payment and the prevalence of truck and tomm-shops produced bad feeling between the men and their employers. (2) Exploitation of masons on the North British in the late 1840 s by shopowners charging high credit rates reduced their monthly cash wage to ten shillings whereas four shillings a day had been earned. (3) The industrial structure in which a contractor selected subcontractors, who appointed gangers, who, in turn, hired men was productive of another evil, the danger of never being paid at all. (4) Denands for the responsibility for payment to lie with the main contractor were irequent, as employment by an irresponsible, inadequate, or simply untrustworthy subcontractor might mean working for nothing. (5) In addition there was little chance of subsidiary employment for members of a navvy entourage in the isolated regions where building of ten took place. One final point about navvy incomes is that in

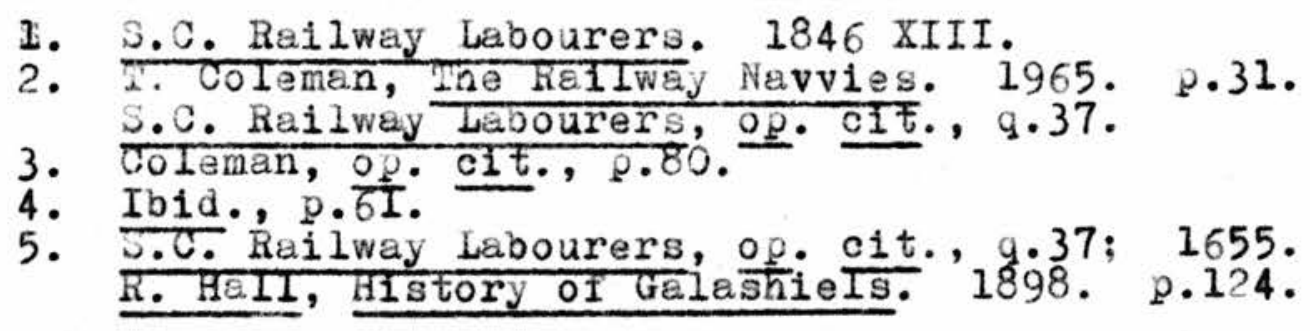


order to maintain them the navvy would have to adopt an itinerant life since constructional employment in any region was essentially temporary.

Tales of navvy violence, immorality and terrorism are legendary. Carlyle declared that he had not, in his travels, "seen anything uglier than that disorganised mass of labourers, sunk threefold deaper in brutality by the threefold wages they are getting" and Francis maintained that navvies "were in a state of utter barbarism." (1) The mixing of nationalities was a frequent cause of trouble and the subcontractors took pains to avoid the employment of multiracial wherever possible. (2) The English fought the Irish in the belief thet the latter accepted work at lower wages, but religion and racial prejudice rather than economics was at the root of the warfare between the Catholic Irish and the Presbyterian Scots. (3) At Gorebridge nationalism resulted in the murder of a scots policemen who had arrested Irish navvies for theft; even more brutal was the killing of an English ganger by Irish labourers he had dismissed. (4) The military were often called out to quell disturbances, as at Calder, or Stonehaven, where labourers had made "an indiscriminate attack on the inhabitants." (5) On the Edinburgh and Glasgow fifteen hundred Irish and even more Scots were prevented from battling by the presence of the army, as were navvies at Lauder,

1. woted in Railway agazine, June, 1907. Francis, op. cit., p.T0.

2. Ibid., p.73. J.C. Railway Labourers, op. cit., q.1417; 1421. Handley (I943), op. cit. , p. 69.

3. .C. Railwa Iabourers, op. cit., q.1420.

4. Coleman, op. cit., p.87. Handley (1943), op. cit., pp. 72-74.

5. Economist, 15 January, 1848 . sottish Guardian, 11 Jandary, 1848. 
where severe rioting had ensued when credit was refused them following the bankruptcy of their contractor. (1)

It could be that brutal conditions brutalised the men. Scotland had experienced the problams of organising, housing, feeding and employing a mass of navies before, when the Caledonian Canal was being built, but the sheer volume of construction taking place in the post-mania period intensified all these problems to a degree beyond the capabilities of many subcontractors. Atrocious living conditions worsened the moral and physical health of the navvy community, as can be seen in the high mortality rate produced by the cramped and crowded dwellings which they occupied during the cholera epidemic of 1847. (2) Some companies tried to prevent conditions becoming intolerable but little was achieved; the Caledonian opened a night school for their navvies, but only about one hundred men were enrozled of the ten thousand at work. (3) The overall picture is a black one, especially when contrasted with the conditions of the operating staff.

It is true that higher wages could be obtained in building lines, but most railway employees obtained remuneration on a par with workers in other occupations, especially when it is considered that uniforms were supplied free and bonuses could be earned for accident-free work and for "saving coal and oil." (4) One pass per

1. Scotsman, 30 June, 1841 .

HaII, op. cit., p.125.

2. H.R.J.T24 July, 1847 .

3. Scotfish Railway Gazette, 12 December, 1846.

4. A. Brend, Index of hnes, Connections, Amalgamstions, etc., ChronologicaIly Arranged. 1902. B.R. R.C. Labour. 18g2 XXIVI. p.18. The alm of accident bonuses was not to increase the take-home pay of the workers, but to reduce the anount of compensation that had to be paid by the companies. (Railwey News, 15 September, 1877). On the question of wases see the appendix to this chapter. 
annum was granted to the railwayman and his immediate family though he could obtain as many privilege tickets at reduced rates as his weges would allow hin to purchase. (1) In addition pensions were quickly introduced and such a scheme was in operation on the Glasgow, 2aisley and Greenock as early as 1841. (2)

Discipline was strict and perhaps understandably so, for the negligent railway worker is a dangerous one. Full time attention to the job was deemed essential and this probably accounts for the sacking, by the North British, of a guard who was also a publican, and for the hostility shown by the same company, forty years later, to a Cooperative Society of Railway Workers in Springburn. (3) Yet the loss of his job also faced the porter who dared to accept a tip, and in fact anyone was lisble to "immediate dismisas without cause assigned." (4) Still employment was probably more secure than in constructional work which was subject to far greater fluctuations in demand. "Unpleasant consequences" were the lot of those guilty of insubordination, but fines and suspensions could be levied for a variety of offences as can be seen in the 3 taff Record Books. (5) Professor Simmons has alluded to the similarities between an army and a railway company in matters of loyalty, discipline and corporate feeling, and it is perhaps not so strange to find the Caledonian insisting on "military neatness" from its

1. Appendix to Working Timetables. B.R.

2. Railway Tines, 3 ApriI, I84I.

3. The guard protested that it was his wife that actually ran the business, but he was still asked to resign. (NBR 1/6, p.205.B.R.) J. Thomas, The Springburn Story. 1965. pp.124-125.

4. Rules and Regulations of tre Forth British Railway. 1866. rule 14.

5. Ms. 6354,27 February, 1847. N.L.S. 
employees. (I)

Harsh discipline and arbitrary dismissal, however, were not the prerogative of the railway companies in the nineteenth century. What irked the railway employee were the long hours he was called on to work, frequently without overtime being paid. (2) His was a dangerous enough job without fatigue adding to the risks he already underwent. (3) Rach year one in twelve shunters and one in fifteen guards could expect to be injured whilst involved in shunting operations, and in 1901 over 217,000 (about $0.6 \%$ of the wage bil1) was paid out by the Scottish companies under the Vorkman's Compensation Act. (4) In the id twentieth century there is a tendency for the railwayman to work long hours as this is the only wa. to increase his take home pay, but in the nineteenth century long, and sometimes excessive, hours were an enderic feature of his job. (5) The question of long hourg, Hore than anything else, was the cogent factor in the emergence of national, militant unionism amongst Scottish railwajmen. (6)

Wany workmen were provided with houses, but the motive was not entirely altruistic. It ensured that the men, usually of the

1. J. Simmons, The Railways of Britain. 1962. p.181. Caledonian Rilway hules. 1848. p.75.

2. 5.C. KaIIWEy Servents (Hours of Labour). 1890/91 XVI. The conplaint of long hours was more aplicable to footplate men, guards, shunters and sienalmen than platelayers or workshop men ( 9.775$)$, nor were conditiong 2.5 bad on the northern lines $(q .547)$.

H.I.J., 13 January, 1899. Angineer, 30 January, 1890.

3. Jee Table 7.3. P.S. Bagwell, the Reilwaymen. 1963. p.95 says the job was approximately twice as dangerous as mining.

4. Railway Servants (Hours of Labour). 1898 LXXXII. Mailway Re turns 1901.

5. 3.C. Koberts, Tages on the Railways. Political quarterly, vol.28, 1955. p.123.

6. See below, section five. 
skilled grades, were there when needed, and were kept "under the eye of the manager," and, needless to say, wages were correspondingly reduced to pay a rent fixed at a level "so that the capital affords a fair return." (1) Again the establishment of a superannuation fund to which the rallway companies contributed equally with their salaried servants was not a mere welfare scheme. On one railway, at least, payments to the fund of $2 \frac{1}{2} \%$ of the monthly salary were made a condition of employment, and anyone quitting his post forfeited his chance of a retirement pension, which rose from $25 \%$ of annual salary after ten years continuous service to $67 \%$ after forty-five years. (2)

More clearly a welfare scheme was the encouragement which the companies gave to their workers to invest money in the railway through the medium of a Railway Savings Bank, which paid a higher rate of interest than available in other savings institutions. Deposits is that organised by the North British rose from 29,828 in 1879 to 2411,320 in 1900 and the number of accounts from 249 to 900, and in the Caledonian's bank deposits increased in value from $\$ 24,000$ in 1875 to $\$ 370,000$ in 1892 and the number of depositors from 450 to 3,400 . (3)

4 .

The welfare schemes and fringe benefits offered by the

1. H.R.J., 21 March, 2857.

2. H.K.J., 21 September, 1872 . H.K.J., 2 october, 1880.

3. RAC(S) $5 / 106$ p.i80. B.R. NBR 4/228. B.R. Elasgow Herald, 21 January, 1893. 
companies served a dual purpose; firstly, of promoting company loyalty by trained servants, and, secondly, of attracting men into the industry. The same function was served by increasing wages with years of service and by a substantial degree of internal promotion for the non-executive grades. The Staff Record Books of both the North British and the Caledonian show a strong tendency for long service and internal advancerent through seniority, although frequently promotion, especially for clerks and stationmasters, was gained only by a move to another station or depot within the system. The Caledonian policy was to select "those officers whose conduct is exemplary ... for promotion as opportunities occur;" and verification of the implementation of such a policy by other companies was given by the Chairan of the Highlend, who declared that "men who had been long in the service naturally rose to higher positions, and it was not a policy of the directors to discharge such men to take on new ones." (1)

Despite these policies the rallways still occasionally suffered from labour shortages. Fierce competition for men during the post-mania constructional boom resulted in high wages being paid in an attempt to cut laoour mobility. In the space of three years wages of navvies on the Scottish Midlund Junction rose from

1. Oaledonian Railway Rules. 1848. p.77. Railway News, 5 Miay. 1877. Redundancy was not a serious problem in this expanding industry. That which occurred was generally the result of amalgamations, but was not substantial since the absorbed lines still had to be worked. Those that suffered would be, e.g., the men not re-employed when the Caledonian, which had taken over the Scottish Central, decided to have all major workshop work done in its own shops in Glasgow, and only repairs at Perth. (H.R.J., 30 September, 1865). 
nine shillings a week to twice that amount. (1) The Edinburgh, Perth and Dundee complained of losing employees to contractors, and construction on the proposed Hawick, Selkirk and Jedburgh branches of the North British was delayed because of the inability to obtain a labour force. (2) Problems of labour shortages and consequent high wage demands also arose during the later building boom in the 1860s. (3) Operating staff were less subject to upward fluctuations in demand, but here too the supply occasionally proved inadequate. In the late 1870s the Caledonian thought that its men were not pulling their weight, attributing this to the ease with which jobs (and presumably comparable wages) could be obtained elsewhere; the same company also found great difficulty in attracting goods and passerger porters at the end of the century. (4)

Yet generally, judging from the Staff Record Books, labour turnover was low and labour shortages infrequent. Over time the supply of potential railway workers may have tended to outpace the demand for their services. The Highland certainly found such a situation in the early 1870s, though this might have been due to a lack of well paid alternative en ployment, and, at the time of the labour troubles in the $1890 \mathrm{~s}$, the North British thought it "well to remind the staff that the company have always on the list of applicants for employment a number of eligible men, which numbers

1. Weekly, News, 5 November, 1898.

2. EID $1 / 3 \cdot \mathrm{P} \cdot 25$. B.R. NBR I/2, 27 August, 1846; 28 September, 1847. B.R.

3. H.R.J., 9 June, 1866.

4. KaIIway News, 23 March, 1878. 1.R.J., 21 July, 1891. 
have increased since the sick, accident and superannuation funds have become generally known and appreciated." (1) It is doubtful if many railwaymen found themselves in complete agreement with Hodgson, General Manager of the North British, who believed that "every man feels like myself that, when promoting the company's interests, he is doing that duty which he is called upon to do in this world," but it could be argued that the low rete of turnover points to the success of the various welfare policies in creating company loyalty. These were, however, reinforced on occasions by agreements between the scottich companies that no company should induce another's servants to lecve by offering higher wages, and that a servant must have his employer's permission to transfer to another company. (2)

\section{5.}

The shortage of experienced railwaymen (as opposed to potential workers) made company loyalty a virtue which was rewarded accordingly, but should the employees prove ungrateful strong counter measures were usually evoked. The North British drivers' first strike for example was defeated by the use of blackleg labour from the engineering shops, and although the accidents and delays caused by the use of these inexperienced men produced a great deal

1. H.R.J., 4 May, 1872. Circular of 15 November, 1890.

2. From his speech at the North British Railwey Employees' Soiree, Oetober, 1965. wuoted in J. Thomas, op. cit., pp.101-102. H.R.J., 15 January, 1848. 
of inconvenience, the company gersevered in its decision, with the result that eventually the original drivers gave up hope of re-emuloyment and emigrated to the united States with the aid of funds provided by drivers on other lines. (1) This determination on the part of the companies to tolerate no usurption of their power by their workers, together with the fact that, even with a demand for their services expanding faster than the total labour force, Scottish railwaymen were ill placed in the labour market (not only was supply tending to outrun demand, but their jobs were watched by envious eyes, eager to take over the instant the companies opted to forgo quality standards at times of industrial disputes) may explain, in part, why strikes were infrequent, and workers' successes even rarer, and perhaps also the relative absence of unionism on Scottish railways. (2)

Numerically, unionists formed only a small percentage of the railway jabour force; in 1901 only 3,599 scots were members of the Amalgamated Society of Railway Servants. (3) Even this was a result of an expansion in the late 1890s for in 1892, admittedly a jear after an unsuccessful major strike, there were but 1,500 trade unionists on all of scotland's railways. (4) Measured quantitatively or qualitatively railway unionism in Scotland was never strong. It can be hazarded that in the light of reasonable industrial conditions, especially the enjoyment of security of

1. H.R.J., March-June, 1850.

2. The extent to which the companies took this concept of power can perhaps be judged from the North British who deliberately required weekend work from men who had expressed an interest in starting Sunday first aid classes. (Thomas, op. cit., p..119-120).

3. G.W. Alcock, Pifty Years of Railway Trade Unioñism. 1922. p.560

4. G.D.H. Cole \& K.P. Arnot, Irade Jnionism on the kailways. 1917. p.16. 
employment, combinations only arose at flash points, when discontent was strong enough to overcome the obstacles to organisation. The most important of these was the attitude of the companies, who regarded trade untonism with abhorrence throughout the century. In 1850 the North British resolved "to take the necessary means to resist the combination that has been forned among the men." Blackleg labour and prosecutions of men for leaving the service of the company without due leave or warning were amongst the weapons used. (1) Their attitude did not soften with time; they would have been in full accord with a circular sent out by James Thompson, General Maniger of the Caledonian -

"I cannot ignore the fact that agitation exists in a number of railway centres, and I desire to ask every member of the staff to corisider well the advantages he at present possesses, before he, under the term 'cessation of labour' or suchlike, decides to act as certsin advisers prompt, because disguise it as they may, the advice is to give up and resign your situations on this railway." (2)

Geographicsl and arade aivisions contributed to the slow development of national unionism but this too was partially conditioned by the attitudes of the companies. The employers refused to consider union officials as any thing but "meddlesome outsiders" and, in forcing the men to approach only their respective departmental heads with their complaints, they disrupted solidarity amongst the various occupational groups. (3)

In these circumstances local craft or grade combinations were more likely to emerge than a national 'all grades' railway union.

1. NBR 1/4, 19 Varch, 1850. B.R.

2. 5.C. Railway Servants (Hours of Labour), op. cit., q.8640..

3. T.. King ford, Labour keldions on the Kailways, 1835-1875,' Journal of Transport History, vol.1, No.?, November, 1953. 
Even these were regarded with hostility by the companies: to such an extent that, though fiercely competitive at times, they did not refrain from ad hoc combinations amongst themselves to defeat militant combinations of their workers. The North British contacted other companies immediately their engine drivers had resolved to strike; dismissed representatives of railwaymen found that other companies rarely entertained their aplications for employment; and men were even sent by the scottish companies to help break strikes on English lines. (1)

Unionism on a national basis did not arrive until 1872 when the Scottish Society of Rajlway Servants was formed. National in name and nationalistic in nature it opposed all attempts of the English-based Amalgamated society of Railway Servants to extend into Scotland. (2) The latter union did manage to establish a branch in Eainburgh by 1876, but the numerical strength of the English union in scotland remained small, partially because of the lower contributions asked for by the scottish society. (3) Prior to 1872 there appears to heve been little industrial militancy on the scottish railways, only one strike having taken place; this was on the North British where the drivers made an unsuccessful attent to prevent their daily wge being reduced from

1. NBR I/5, 22 March, 1850. B.R. R.C. Labour, op. cit., p.18. BagweIr, op. cit. 34 . Times, 15 Tugüst, 1887.

In I890s a nutual aid agreement was signed by several English and Scottish companies. (C L I/41, ite 134 . 175. 604. B.R.)

2. Alcock, op. oit., p.?08. W. Harwi ck, Gononic Developments in Victorian Scotlarid. 1936. p.197.

3. Bagwell, op. cit., .148. 
5s to $4 \mathrm{~s}$ when they were working in the sheds. (I) However, as can be seen in Table 7.4 , industrial relations were less peaceful from the date of the founding of the scottish railwaymen's union. let there was no national strike until 1890.

This strike was the culmination of many years' grievances over long hours and stemmed directly from inadequate and efficient management. The companies could not cope with the roblems raised by rapid growth which meant that their men had to work excessive hours. This was nothing new, but is glleged to have intensified in 1890, especially as regards the North British who had failed to plan for the increase in traffic consequent upon the opening of the Forth Bridge. (2) In Narch, 1890 one North British driver averaced seventeen hours a day, and another, in five consecutive days, worked $21 \frac{1}{2}, 21 \frac{1}{2}, 19,19$ and 24 hours. (3) These are extreme examples, but it is fair to sey that systematic overtime was prevelent. Long hours may have been tolerated if they had been conpensated for by increased wages, but the day wage was based on the trip system with nothing extre being paid for overtime rendered necessary by delays en route etc. One driver was paid for his sixty hour week when in fact he had worked 91 hours. (4)

A campaign was launched by the railwaymen in hugust, 1890 to put an end to these iniquities: demands being made for a general ten hour day with overtime to be paid after that. Although the

I. H.R.J., 6 April, 1850.

2. Water a director of the North British admitted that "they had not made adecuate provision for the sudden expansion of traffic." (S.C. Railway Servants (Hours of Labour), op. cit., q.9114-9115).

3. J. Mavor, the ncottigh kai way Jtrike. 1891. p.27.

4. Engineer, 30 January, 1890 . 


\section{TABLE 7.4}

STRIKES ON SCOTTISH RAILWAYS

$\underline{D A C}$

(1) Apri1, 1850

(2) 1872

(3) 1873

(4) May, 1878

(5) Ootober, 1878

(6) January, 1883

(7) 1890

(8) March, 1890

(9) December, 1890 to January, 1891
COMPANY

Horth British

?

Caledonian

Caledonian

Caledonian

Caledonian

North British

?

North 3ritish

North British

Caiedonian

Glasgow and

South vestem

\section{ISSUE}

Reduction of engine drivers' pay when working in sheds. One week strike by 1,300 railwaymen in Glasgow. Firemen and brakesinen to obtain a rise of $2 /-$ a week. 2,000 men siruck over a wage reduction of $5 \%$. vorkshop trouble over increase in hours from 51 to 54 without increased pay.

Strike throughout the Caledonian

syster in a vain attempt to obtai a nine hour day and paid overtime Ailso agitation on the North British.

Strike at Aberdeen over hours, but involved only 16 people. 394 men in perminent way dept. in a dispute over wages - won a shiling a week rise. Major strike over hours.

Source:

(I) H.R.J., 6 April, 1850.

(2) Johnson, History of the Working Classes in Scotland. 1929. p.358.

(3) Ibid., p.359.

(4) KaIlway News, 7 May, 1878.

(5) Kailway Iimes, 5 october, 1878.

(6) H.K.J., 20 January, 1883; 27 January, 1883. J. Mavor, The Scottish Railway Strike. 1891.

(7) R.c. Labour. I89? XXXVI. p.55.

(8) TुId.

(9) Mavor, loc.eit. 
men were not unanimous in advocatine strike action, they were stimulated into it by the traditional attitude of the companies in refusing to recognise an 'all-grades' representative. (1) The strike predominantly afiected the North Bitish and the Caledonian and, to a lesser extent, the Glasgow and South Western with the two less intensively worked northern lines not being involved. At its height over seven thousand men were out, but the rigours of a joottish winter and the use of blackleg labour (some from Ireland, but most from England) soon put an end to it. (2)

The strike cost the companies about two hunared thousand pounds in respect of lost traffic, and further experses would include the payment and housing of blacklegs and repairs to stock damaged by unskilled labour. (3) The Scottish economy suffered even more. The Singer Sewing Wachine factory had to close since it relied on the railways to bring in its 5,000 wor'sers. (4) For a month "next to no trade" had taken place and expensive carriers had to be resorted to by, amongst others, the manufacturers of Galashiels in order to send goods into England. (5) Scarcities and increased distribution costs also pushed up prices, that of coal in Glasgow doubling. (6)

1. Bagwell, op. cit., pp.14?-143.

E.R.J., 2J Decernoer, 1890.

A blow by blow account of the strike can be found in Mavor.

2. Glasgow Herald, 24 December, 1890.

Kailway Review, 16 January, 1891.

ALCoCk, OP. CIt. , p.246.

3. Mevor, op. ciE., p.24.

4. Ibia.

5. 1100, 8 January, 1891.

Minutes of Galashiels Manufacturers' Corporation, Michaelmas, 1891.

6. BagweII, op. cit., p.I44. 
Yet the men gained little from the strike, apart from the non-strikers who obtained a bonus of a week's wages and, in many cases, promotion. The union was not recosnised, and many strikers, as in previous strikes, were unable to obtain reinstatement. (1) Henry Tait, the Secretary of the Scottish Society of Railway wervants, believed that something was achieved in that there has been "a disposition to shorten the hours by the companies." (2) he strike did force the issue of long hours into the open and resulted in a 1893 Act giving the 3oard of rade permissive powers to investigate complaints of excessive working. However, the extent of the complaints do not suggest that the position improved; the powers of the Board of Trade proved inadequate and led the editor of the Railway Review to declare in 1907 that "in our opinion the Act of 1893 has had a fair trial and hes proved a fuilure." (3)

one result of the strike was to oring the scottish railwaymen within the fold of the Aalgamated Societ, of Railway Servants. The drain of funds auring the strike, and possibly the fact that assistance had been freely given by the English society, convinced the scota that absorption was inevitable. In 1892 the Scottish Society was swallowed up, and although a ninority retained an indepenaert scottioh kiliwaymen's Union, it lasted only antil July, 1895, when it was disaolved because of debts and its members accepted into the English General Railwajworkers Union. (4)

1. H.R.J., 27 Januar, 1888; June (passim), 1850; 31 January, I891.

2. S.C. Railway Jervants (Hours of Labour), op. cit., q.1013.

3. Rallway keview, I5 Iebruery, 1907.

4. Marwiok, op. cit., p.197. 


\section{APDNIIX \\ WAGES ON SCOTTISH RAILWAYS}

Comparioon of railway wages with those in other industries is rendered difficult (if not impossible) by several factors, not least the absence of data. The celebrated wages statistician, A. L. Bowley, believed that the construction of a vages index for reilwaymen would be "unlikely." (1) How richt he was. Facts are herd to come by; ustole information even nore so, e. staff records appear to exist for engine drivers, firemen or guards. Tuble 7.5 is bssed on a few scattered sources and no claims are made as to its conrehensiveness; any conclusions drawn are at best tentative.

Definitional problems within the ralwey industry are slight sinee the function of guards, signalmen, engine drivers, porters and firemen changed littie over the century. However, with interindustrial compansons difficulties do aribe. With what nonrailway occupation does one compre the job of a signalman or platelayer? How doss one ellow for changing definitions of occupations as, for example, in the shipyards, where the change from wood to iron and steel, and from seil to steam must have revolutionised the concepts of 'shipwright' or 'shipbutider'?

A strict comparison of the wage rates in Table 7.5 with those for other ochpations, shown in Grble 7.6, is invelid because hours of labour varied between industries, as did fringe benefits. 2. 1906. Bowley, Journel of the Royal Statistical Society, vol. 69, 
Railwaymen received free uniforms, cheap travel and perhaps a company holise over and above their weekly wage. (1) If monetary earnings did not reflect true earnings, it is equally true that weekly wage rates need not necessarily corresuond; yet this was more likely in non-rallway occupations whele overtime was zore commonly paid. Finally the regularity of railway employment must be considered in any comparisons rade with occuparions liable to experience slump and underenloyment.

Bearing all this in mind, only aitile can be ssid ubout wages on scottigh railway. The top men received rewards commensurate with their responsibilities, and these were incressed as the problems and responsibilities of runing en expending company multiplied. In 1849 the vecretary and General hanager of the Caledontan earned $k l, 800$ per anaum, but by 1908 the jobs hid been dichotomised and carried recunerations of di, 400 tnd 22,00 respectively. During the same period the Goodu Hanager's sulary rose from $\$ 250$ to $\mathrm{LI}, 000$, the Engineer's from $\mathcal{L} 800$ to $\mathrm{Cl}, 600$ and the Locomotive Supexintendent's from 6500 to 21,750 . (2) The earnings of some superior officers were made dependent on the dividend paid by the compeny, but this ides seems to heve been later dropped, except for those "who have so ne influence more or less in increasing the traftic and promoting economy." (3)

1. Today it is considered that these perks do not close the wages gap between railway and other industries; whether they were more iraportant in the nineteenth century is open to conjecture. B.C. Roberts, 'Wages on the Railways,' Political Luarterly, vol. 28,1955 . p. 123.

2. RAC $(S) 1 / 3$. B. CAL $4 / 1$. B.R.

3. H.R.J. 8 June, 1850 (Edinburgh, Perth and Dundee); 25 Septemoer, 1852 (Caledonian); 26 March, 1853 (Glasgow and South Western); 4 April, 1868. 
Over tine the wages of the lower echelons were fairly stabla. Scales of pay were in vogue in which wgges were an increasing function of years of service, and thus regular bargaining for rises was rendered less necessary. Fluctuations were infrequent, but not unknown. In 1872 the three najor noottish companies a.11 put wages up, only to lower them again five years later. (1) It has already been shown that returns to railway labour rose during the later nineteenth century, the average annual wage rising from $£ 58.9$ in 1872 to $\$ 68.9$ by 1901. (2) The evidence in Table 7.5 would suggest that seniority accounted for a substantial proportion of this; the wage/length of service scale extending upwards for most railway occupations. In adition minimum wages also appear to have risen. From the data in Pable 7.6 it would not seem that the railwayman was losing ground to his contemporaries in other occupations.

Workers in the railway workshops were in a diflerent position, sometimes stronger, sometices weaker, from the operative staff, for alternative employment was available elsewhere without an occupational switch, ox, in many cases, a geographical one being necessary. This was especially true of the Caledonian and North British shops which shared the Springburn district of Glasgow with three private locomotive firms and the shipyards of Glasgow were also within easy reach.

1. H.R.J., 23 Harch; 30 March; 3 August, 1872. see $\overline{1}$ so the petition from porters and firemen at Burntisland to the North British in 1872. (NBR 4/223. B.R.) Railway News, 5 ifay, 1877.

2. See chapter three, p. 179. 


\section{TABLE $7.5(\mathrm{a})$}

WAGES ON SCOTTISH RAILW AYS

$1849 \quad 1850 \quad 1852^{(4)} 1856^{(5)} 1867^{(6)}{\underline{1 a t e} \cdot 609^{(7)}}^{(4)}$

Engine drivers $30 /-(9)$ average

Firemen

$20 /-(3)^{33 /-t 034 /-}$ $27 /-\operatorname{ton} 2 /-$
$20 /-$

Guards

$$
\begin{gathered}
\text { average } 20 /-t \varphi_{3} \text { ) average } \\
22 /-(8) 24 /-
\end{gathered}
$$

Porters

18/-to30/$15 /-t_{0} 18 /-$ $20 /-$ to $27 /-$

Labourers 17/-to19/-

Signalmen $13 /-$ to 14/-

Shunters

Platelayers

Sources: (1) MC(A) I/3, Caledonisn 1849; calculated by dividing the wages bills by the number of employees. B.R.

(2) Ibid. Caledonien 1850.

(3) NBK I/4, IIth February, 1850. B.R.

(4) Mats) 1/9, Glasgow snd South western 185?, calculated as for (1) and (2). B.R.

(5) George Grahan to the Caleanian directors, 25th April, 1856. Miss.6356, N.I.S.

(6) D. Bremner, "he Industries of cotisnd," 1867. PP. $103-104$.

(7) NB 15/1, Lainburgh ittion taff Recoras. 3. . .

(8) KaImgy Times, 9th March, 1844: Glasgow, Paisley, KilmurnodK aind hyr.

(9) H.K.J., 6th April, 1850; North British.

Notes: Vages probably correspond to take home pay. 
TABLE $7.5(\mathrm{~b})$

\section{WAGES ON SCOTISH RAILWAYS}

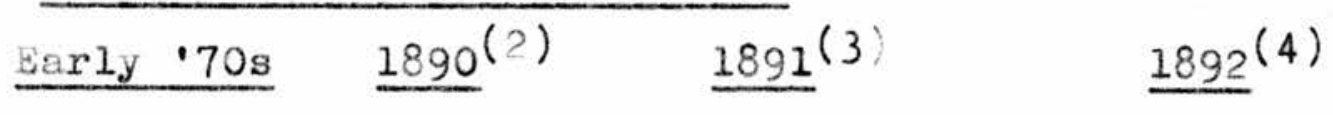

ingine drivers

Firemen

Guards

Porters

Labourers

Signalmen

Shunters

Platelayers

$$
27 /-\min . \quad \begin{aligned}
& 25 /- \text { to } 30 /--650 \\
& 30 /- \text { to } 35 /--445 \\
& 35 /- \text { to } 40 /--862 \\
& \text { over } 40 /--175
\end{aligned}
$$

$27 /-$ to $42 /-(\mathrm{Ab} \cdot)$

$30 /-$ to $42 /-($ NB. $)$

$19 /-$ to $4 /-(\mathrm{Ab}$.
$18 /-\mathrm{to}_{2} 4 /-(\mathrm{NB}$.

$22 /-$ to

$15 /-t 020 /--37$

$20 /-t_{0} 25 /--902$

$25 /$-to $30 /--1278$

$30 /-$ to $35 /--2$

$35 /-t o 40 /--6$

over $40 /-\quad-14$

$15 /-t_{0} 20 /--1874$

$20 /-$ to $25 /--84$

$25 /-$ to $30 /--15$

$16 /-\operatorname{to} 18 /-(\mathrm{Ab}$.
$17 /-\operatorname{to} 23 /-(\mathrm{NB}$.

$10 /-$ to $15 /--45$

$15 /$-to20/- $-458 \quad 17 /$-to $20 /-$ (NB.)

$20 /-$ to $25 /--84$

$25 /-$ to $30 /--1$

$23 /-$ to $30 /-(\mathrm{Ab}$.
$21 /-$ to $30 /-(\mathrm{NB}$.

$15 /-t 020 /--665$

$20 /-$ to $25 /-1713$

$25 /-$ to $30 /-45$

$30 /-$ to $35 /-6$

$20 /-t_{0} 24 /-(\mathrm{Ab}$.

$1899^{(5)} 24 /-$ to $35 /-$

$$
\begin{array}{ll}
20 / \text {-to } & 15 /-t_{0} 20 /-53 \\
35 /- & 20 /-t_{0} 25 /-117 \\
& 25 /-t_{0} 30 /-224 \\
& 30 /-t_{0} 35 /-51
\end{array}
$$

$10 /-\operatorname{tol} 5 /-5$

$15 /-t_{0} ? 0 \%-5483$

$20 /-t_{0} 25 /-984$

$25 /-$ to $30 \%-34$

$30 /-$ to $35 /-4$

$$
\begin{aligned}
& 20 /-t_{0} 28 /- \\
& 1899(4) 21 / \text {-to } \\
& 30 /-
\end{aligned}
$$

$16 /-t_{0} 18 /-(\mathrm{Ab}$.

Source: (1) NBR 15/1, Edinburgh Station Staff Books. B.R.

(2) S.C. Railwey Servants (Hours of Labour) 1890-91 XVI.

(3) Abstract of Labour Statistics IgOI LXIII p.153. Number indicates totel of men on the three major companies in each wage range.

(4) R.C. Leibour 1892 AXXVI 9.18 (Aberdeen); p. 4 (North उritish).

(5) H.R.J., i6th June, 1899.

(6) H.K.J., 8th september, 1899. 
TABLE $\quad 7.6$

WAGES IN SELECTED SCOTMISH INDUSTRIES

\begin{tabular}{|c|c|c|c|c|c|c|}
\hline & 1851 & \multicolumn{2}{|c|}{1860} & $1867-70$ & $1880-81$ & $1890-92$ \\
\hline $\begin{array}{l}\text { Agricultural } \\
\text { Labourers } \\
\text { (per day) }\end{array}$ & & $2 / 3$ & & $2 / 5 d$ & $2 / 10 d$ & $3 /-$ \\
\hline $\begin{array}{l}\text { Shipwright } \\
\text { (per week) }\end{array}$ & $\begin{array}{l}21 /- \text { to } \\
25 / 6 d\end{array}$ & $24 / 5$ & & $\begin{array}{c}27 /- \text { to } \\
30 /-\end{array}$ & $\begin{array}{l}29 / 3 \text { d to } \\
31 / 6 d\end{array}$ & c $36 /-$ \\
\hline $\begin{array}{l}\text { Lanarkshire } \\
\text { Niners }\end{array}$ & $1841-50$ & $1851-6$ & $1861-70$ & $1871-80$ & $1881-90$ & $1891-96$ \\
\hline (per day) & $3 /-$ & $3 / 8 d$ & $3 / 9 d$ & $\begin{array}{l}6 / 10 d \text { to } \\
4 / 4 d\end{array}$ & $\begin{array}{c}4 / 6 \mathrm{~d} \text { to } \\
4 / 9 \mathrm{~d}\end{array}$ & $5 / 8 d$ \\
\hline $\begin{array}{l}\text { Masons } \\
\text { uilding (3) }\end{array}$ & $20 /-$ & 25 & & $28 / 8 d$ & $25 / 6 d$ & $31 / 10 d$ \\
\hline $\begin{array}{l}\text { (per week) } \\
\text { Carpenters }\end{array}$ & $21 /-$ & 24 & & $29 / 6 d$ & $27 / 7 d$ & $34 /-$ \\
\hline $\begin{array}{l}\text { Printers }(4) \\
\text { (per week) }\end{array}$ & 1852 & 1860 & 1868 & $1881-82$ & $1891-92$ & \\
\hline in Glasgow & $25 /-$ & $25 /-$ & $27 / 6 d$ & $32 / 6 \mathrm{~d}$ & $34 /-$ & \\
\hline in Edinburgh & h $25 /-$ & $25 /-$ & $27 / 6 d$ & $\begin{array}{l}30 /- \text { to } \\
32 / 6 \mathrm{~d}\end{array}$ & $32 / 6 d$ & \\
\hline dex of Wag & s of & 1850 & 1860 & 1868 & 1879 & 1891 \\
\hline $\begin{array}{l}\text { Ballantyn } \\
\text { ctories, Gr }\end{array}$ & $\begin{array}{l}\text { 's } \\
\text { lashie }\end{array}$ & 100 & 169 & 172 & 172 & 207 \\
\hline
\end{tabular}

Source: (1) A.I. Bowley, Wages in the United Kingdom in the Nineteenth Century, $1900, p .57$; refers to the south of scotland.

(2) ibid., p.107.

(3) iहाव., pp.89-90 summer weekly wages.

(4) ibid., p.75.

(5) ibid., p.104.

(6) Information supplies by Mr. C. Gulvin of the Portsmouth College of Technology.

Numerous faults exist in the above data which are listed in the original text. The prime objection is that they relate to special districts. 
In England, wages in the railway workshops tended to coincide with those in the engineering industry, sharing the latter's general fluctuations. (1) There is no reason to suspect any different of Scotland, especially because of the strong concentration noted above. Bowley found that in Glasgow the rallway companies had frequently made changes with the general changes of the local engineering industries, but there is not enough evidence to show whether this had invariably been the case. (2) However, the fact that, even in the north, mechanics on the Great North of Scotland, unlike the operatives, had a Saturday half holiday points to industrial competition for skilled technicians making its presence felt. (3) Table 7.7 , although highly inadequate in coverage, also lends support to the idea of inter-industrial unification of wage rates, presumably because of a near perfect labour market for technicians and mechanies.

Workshop men were paid fortnightly, even those employed on piece work, for a fifty-four hour week (in contrast to the seventytwo hours of engine drivers, firemen and guards). Sunday work was paid at double time (time and a half for engine drivers etc.), though they in fact did little of such work, and overtime at time and a half (time and a fifth for engine drivers etc. when paid). (4)

Philip Bagwell, in his history of the National Union of Rail-

1. Bowley, op. cit., p.708.

2. Ibid.

3. GINS $\mathrm{i} / 2, \mathrm{p} .222$ B.R.

4. M.C.Labour. i892 XXXVI. pp.92-94. 
TABLE 7.7

GLASGOW ENGINEERING WAGES 1870-71

Locomotive works Marine Engineering

Pattern-makers

Fitters

Finishers

Turners

Smiths

Strikers

Labourers

Boiler-makers

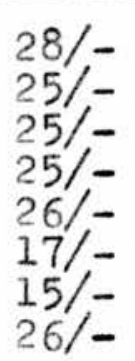

$26 / 6 \mathrm{a}$

$24 / 3 d$

$24 / 3 d$

$25 /-$

$27 /-$

$16 /-$

$14 / 3 \alpha$

$26 / 9 d$

Source: A.L. Bowley, Journal of the Royal Statistical Society, $1905, p .572$. 
waymen, claimed that "throughout the entire period before the first world war, railwaymen in Scotland worked longer hours for less pay than their brethern south of the border." (1) This has to be modified slightly in that a small minority of English companies had a worse record of overworking their men, but, in general, wages were lower in Scotland. (2) However, in the light of twentieth century experience, this, presumably, was not the prerogative of the railways. (3)

1. P.S. Bagwell, The Railwaymen. 1963. p.139.

2. S.C. Railway Servants (Hours of Labour). 1890/91 XVI. Labour Statistics. 1901 LXIII. pp.152-153. H.R.J., 26 August, 1898. Engineering, 8 october, 1869. See also a series of articles in the Railway News (November, 1874 - January, 1875) which discussed rates of pay on English railways in general terms.

3. It is known that in the nineteenth century shipbuilders on the Clyde received less than those similarly employed on the Thames. W.S. Cormack, An Economic History of Shipbuilding and Marine Engineering. Th.D. Glasgow. 1930. p.259. 
CHAPTER EIGHT

\section{THE TRANSPORTATION OF FREIGHT}

"Facility of transport has rendered it highly profitable to convey coals, cattle, minerals, fish, dairy and garden produce, slate, timber, granite, and a thousand and one other commodities, over long distances, to points of consumption previously as inaccessible as the tropics."

Tooke and Newmarch, History of Prices. 1857. vol.5, p.359.

"In considering the improvement of goods traffic, it is very difficult to institute any comparison with the past, because the introduction of the railway system has entirely altered all the conditions of that traffic, and has enabled industry and trade to spring up which, without railways, could have had no existence."

R.C. Railways. 1867 XXXVIII. p.Ixv.

\section{1.}

Perhaps the most important八to be assessed about the coming of the railways is the extent to which transport costs were reduced. Were savings merely marginal, serving only to encourage the trader to transfer his existing traffic to the new mode of transport, or was the reduction substantial enough to stimulate the further growth of the Scottish economy? This is not an easy question to answer, as readers of Fogel and Fishlow will be well aware, and the inadequacies of the data relating to scotland render the problem even more difficult. In this section an attempt will be made to measure the direct financial savings attributable to the lowering of carriage costs by the railways; in section two the other advantages often ascribed to railways will be examined in order to ascertain whether emphasis should be placed on the less direct 
savings; and finally an assessment will be made of the quality of the service offered by the railways.

The method adopted in estimating the savings in transport costs brought about by tine railways was to attempt to ascertain how much it would have cost to transport the goods carried by the railways in a particular year between the same points had the railways not existed. This involves two extreme assumptions both of which operate to give an upward bias to the railways' savings. Firstly, that in the absence of the railway no new types of transportation would have developed, and, secondly, that commercial and industrial location would not have differed substantially from that existing in the year for which the estimates are being made. To measure direct economic savings along the lines suggested above requires two basic sets of data. Firstly, an analysis of the goods that were carried by rail, including details of the types of goods and the distances travelled, and, secondly, the comparative costs of different methods of transport. Unfortunately when the available evidence is surveyed inadequacies abound.

The Board of Trade's annual "Railway Returns" show how much traffic (divided into coal and minerals, general merchandise and livestock) each company carried and what the receipts were from each class of traffic. However, no indication is given as to the distance travelled. Why the government did not want such a detail is perhaps explicable as a belief that they had gone far enough, in terms of controls, in an age still permeated with an atmosphere of laissez-faire. In the early days too the companies themselves might not feel the need for detailed statistics as many undertaking 
were small enough for the management to believe that they knew what was going on. In addition, and probably more relevant, they had little idea of what information they ought to be producing. When a specific problem cropped up then data would be sought, but there was no policy of generally collecting statistics which might prove useful. (1) Later on the traffic books of the various companies yield much information as to the volume of traffic loaded and unloaded at each station, but once again nothing is said about the distance travelled. It might have been possible to use this station data to compute a 'best fit' of traffic flows, but the records are by no means complete which renders such a sophisticated model impracticable. (2)

Fortunately, several Railway Clearing House documents have been discovered which throw light upon some traffic flows. (3) The first of these deals with traffic between twenty two places or areas in Scotland and seventeen places or areas in England in the eighteenth months to 31 January, 1868. However, not all the transborder traffic is given in'such detail as the Caledonian

1. When a North British shareholder wanted a geographical breakdown of his company's traffic and costs he was told that the "results could be of no prectical value." (RAC(S) $1 / 1 \mathrm{~A}, 29$ September, 1870. B.R.). For general criticisms of railway statistics see articles by J. Denvers and W. Acworth in the Journal of the Royal Statistical Society for 1888 and 1902 .

2. As the Hritish hali modernisation plan proceds more records are coming to light and such a project might well prove feasible in a few years time. An even more sophisticated model could be based on the centre of gravity of population method, but there is no evidence that flows of goods and minerals would be in proportion to populations of areas. (See W. Isard, Methods of Regional Analysis: an Introduction to Regional Science. 1960).

3. NBR 4/236; NBR 4/237; EGR 4/7; EGR 4/8. B.R. 
company refused to supply information in respect of certain flows, though an estimate of the total receipts of this nonspecified traffic is avallable. (1) The second document shows details of traffic carried on the North British railway system between points and railways south of the Forth and points and railways north of that estuary for the 12 months ending 31 January, 1868. The other documents concern traffic using the Edinburgh and Glasgow railway in 1863 and 1864. That all the documents covered periods in the 1860 s eased problems of extrapolation and 1867 was taken as the year for which calculations of direct savings would be made. (2) When allowance is made for the periods covered something like $13 \%$ of the total goods and mineral traffic on scottish rallways in volume terms and $33 \%$ in terms of receipts is accounted for by these flows. (3)

A brief digression from the main theme of this chapter to

1. It is estimated that the unspecified receipts of the Caledonian came to $£ 188,815$ and that a further $£ 82,085$ was the North British's due for carrying Caledonian traffic. NBR 4/236, p.107. B.R.

2. Adjustments were made on the assumption that the Edinburgh and Glasgow railway's traffic grew between 1863 and 1867 as it did between 1863 and 1864. For the transborder traffic a simple two-thirds can be taken for, although this assumes that traffic in the first six months of the year is roughly equal to that in the second half, the half yearly railway returns prior to 1860 suggest that this is plausible; in the five years $1855 / 59$ the second half year figures averaged only $3 \%$ more than the first half. Of course the transborder traffic may not have exhibited the same periodicity as Scottish internal traffic, but there is no way of demonstrating this.

3. No assessment can be made as to the livestock flows, for 1867 was an atypical year following the cattle plague. Unfortunately too the transborder traffic does not distinguish between goods and minerals. 
comment on the transborder traffic can perhaps be justified here. Published quantification of such flows in the mid nineteenth century appear to have been limited to one estimate of through traffic to England being a quarter of Scottish traffic. (1) Table 8.1 summarises the Anglo-Scottish traffic for the eighteen months to February 1868 and lends support to Professor Campbell's assertion that "the (railway) link provided with England in the later 1840 s was the greatest step towards economic integration since 1707." (2) Compared to the estimates of transborder traffic before the railways were built a startling increase is recorded. (3) Assuming that the non-categorised Caledonian traffic was distributed in the same proportion between goods and passengers as the known traffic, then the number of passengers crossing the border increased by over $300 \%$ in twenty-seven years. The increase in tonnage carried cannot be calculated, but if the passenger trend is any guide it cannot be insignificant.

Were these flows, however, of any importance to the scottish economy? It is impossible to put a value on the transfers for although railway rates did take some cognisance of the market value of the goods carried, there was no strict relationship, and, in any case, the statistics do not allow even the distinguishing of goods from minerals let alone the different types of goods. (4) Although it is possible to assert that the flow of goods out of

1. D.G. Campbe11, Railway Amalgamations. 1870. p.10.

2. R.H. Campbell, ScotIand Since ITOT. 1965.9 .96$.

3. Report of a Treasury Committee on Railway Communication between London, Dublin, Edinburgh and Glasgow. $1841 \mathrm{XXV}$.

4. G. Findlay, The Working and Management of an English Railroad. 1891. 
Scotland was greater than the flow inwards in volume terms, this may not, therefore, necessarily accord in value terms. (1) As a percentage of the volume of traffic on Scottish railways the transborder traffic ie not all that outstanding, being $1.4 \%$ for passengers and $4.2 \%$ for goods and minerals. Of more importance for the railway, however, the transborder flows were much more significant as percentages of total traffic receipts being $13 \%$ for passengers and $19 \%$ for goods and minerals.

\section{TABLE 8.1}

ANGLO-SCOTWISH TRAFFIC (for the eighteen months to 31 January, 1868:

via via $*$ via via via via Berwick Carlisle* Carlisle* Hexham Morpeth Sprouston

$\begin{array}{lrrrrrr}\begin{array}{l}\text { Passengers } \\ \text { (numbers) }\end{array} & 161,598 & 197,934 & 22,451 & 62,569 & 268 & \text { nil } \\ \begin{array}{l}\text { Parcels } \\ \text { (numbers) }\end{array} & 135,151 & 263,969 & 47,155 & 17,466 & 103 & \text { nil } \\ \begin{array}{l}\text { Goods and } \\ \text { Minerals(tons) }\end{array} & 217,779 & 511,236 & 173,466 & 60,828 & 2,045 & 8,285 \\ \begin{array}{l}\text { Livestock } \\ \text { (trucks) }\end{array} & 4,457 & 7,728 & 2,100 & 2,873 & 1,076 & 596\end{array}$

$$
\text { TOTAL }
$$

Passengers

444,820

Parcels

463,844

Goods and

Minerals

973,639

Livestock

18,830

1. Calculations based on tables in NBR 4/236 suggest that, as regards the volume of passengers and parcels, the balance was slightly in favour of flows into scotland, but that for goods and minerals the balance was strongly in the other direction. One difficulty was to decide what traffic was "up" or "down", railway parlance not being the same in scotland as in England. 
Source: NBR 4/236. B.R. Table L. pp.124/125.

Note: The Caledonian did not supply certain figures - see the footnote on page

* Caledonian station

幕 North British station.

It is not possible to say that had the transborder lines never been constructed the Scottish economy would not have been drastically affected, for we have no knowledge of the relative values of internal and external trade, or of the extent to which the internal was conditioned by the external. The Anglo-Scottish lines can probably best be seen as part of the system of trunk lines "so necessary for the exploitation of foreign demand on which the country's industrial expansion was increasingly dependent." (1)

$* * * * * * * * * *$

Having derived certain traffic flows the problem then arises of how to deal with the rest of the traffic. It is of little validity to invoke proportionality since the traffic flows cover freight that would most likely use water transport as an alternative in the absence of the railways, whereas the residue, being generally traffic within a company system, would exhibit a higher tendency to utilise road transport in such a situation. The solution adopted was to deduct the flow data from the aggregate returns of each company (as given in the Railway Returns) and then by dividing the remaining total receipts by the total tonnage obtain an indication of average receipt per ton carried, which by reference

1. R.H. Campbell, op. cit., p.94. 
to railway rate books will give some indication of the average distance travelled.

Several further problems immediately raise their heads. Firstly, different goods travelled at different rates which would tend to overstate the actual distance travelled if a "cheap rate" good was considered to be the typical product carried. This difficulty can be eased, though by no means solved, by assuming that the residual traffic on each system was divided between general merchandise and minerals in the same proportion as was total traffic on each system, thereby allowing two estimates of distance travelled to be obtained, one for general merchandise and one for minerals. (I) In each case the lowest normal class rate was taken. This should produce little error in the case of minerals, but there will be a greater degree of error as regards general merchandise.

This leads on to the question of how useful the railway rates are in obtaining these estimates of distances travelled. One thing that is clear is that the rates authorised as maximums by Parliament bore little relationship with reality and that it is essential to use the actual rate books of the companies. These are not easily available because of the tendency to destroy old books when new rates came into force, but enough data to justify an attempt at estimating savings can be obtained from lists retained in the Historical Records of the British Rail Board and

1. The proportions of total tonnage taken as general merchandise and the proportions of total goods traffic receipts (excluding livestock) accruing from such traffic were: Caledonian (20.5\% - £55.7\%); G.S.W. (14.5\%-£42.9\%); G.N.S. $(58.6 \%-£ 75.2 \%)$; Highland $(60.9 \%-£ 76.4 \%)$; and North British $(24.9 \%-£ 57.7 \%)$ 
from isolated references. (1) As to these book rates, Bagehot may have been exaggerating when he spoke of railway rates being fixed "in a sort of twilight ... in an atmosphere of probabilities and of doubt where nothing is very clear, where there are some chances for many events," but it is true that the rates do not appear to have been scientifically determined. (2) One trouble is that Cardwel1's Act of 1854 allowed companies to differentiate between areas in fixing their rates, and thus actual or potential competition could well result in spatially diverse rates within the same system. However, differences between systems seem to have much greater than within systems and the use of averages within a company's catchment area should not result in substantial error. (3) A second difficulty comes from the structure of railway rates which taper with distance travelled. Unfortunately, the decline in marginal receipts is not directly proportional to the distance, but exists in a form which means that the average distance, if calculated in the manner outlined above, would understate the true average distance. However, the choice of class rates will work

1. GNS 1/2, p.83; $\operatorname{HRP}(S)$ 51, pp.240 and 274; Caledonian rates from Ballieston Station (unclassified document); NBR 4/232; NBR 4/233; EGR 4/7; EGR 4/8; EGR 4/9; Edinburgh, Perth and Dundee rates (unclassified document). The se documents do not merely deal with the companies under whom they were catalogued.

2. Quoted in W.M. Acworth, The Elements of Railway Economics. 1905. p.73.

3. In 1878, for example, it was stated that rates on the North British for distances between 5 and 40 miles averaged $1.45 \mathrm{~d}$ a tonmile, on the Caledonian 1.93d, and on the Glasgow and South Western 1.10d. (Rajlway Times, 18 Nay, 1878). That competition influenced rates was made clear by the manager of the North British who explained, when London sugar refiners complained of the favourable rates given to the refiners at Greenock, that this was because "Greenock is of course available for water communication to every point, or almost every point." (S.C. Railway Rates and Fares. 1882 XIII. q.577). 
towards cancelling out the potential error from this source.

Yet another complication arises from the general practice of allowing a reduction in rates if the trader provided his own wagons; usually the amount was a farthing a mile up to sixteen miles and an eighth of a penny a mile thereafter. (I) This will be reflected in receipts, but to what extent is unknown. A useful indicator would be the number of private wagons in existence, but the only definite statistics to hand refer to only one railway, the Caledonian, and to only one year, 1898, both of which may be atypical. In addition there is no knowing the relative intensities of use to which privately owned and railway owned wagons were subjected. However, if it is assumed that all stock would do the same volame of work and that the Caledonian ratio of approximately 2:1 in favour of its own stock was typical, a further modification can be made to the model in respect of the average distances travelled. (2)

The most important problem as regards railway charges is that the companies made many long term (often over twenty years) agreements with traders at below book rates. This price discrimination

1. See $\operatorname{HRP}(S)$ 51. p.240; NBR 3/10; CAL 3/10. B.R.

2. Edinburgh Evening Dispatch, I9 February, 1898. Two references for the Iate IIIOs suggest that the Caledonian ratio may be too high. In 1918 it was stated that in the United Kingdom as a whole there were 750,000 railway owned wagons and 650,000 privately owned ones. (S.C. Transport. 1918 IV, q.806). By 1919 privately owned ones were in the majority. (wuoted in D.H. Aldcroft, The Efficiency and interprise of British Railways 1870-1914,' Explorations in entrepreneurial History, 1968, $\mathrm{p}$. 170). However, both or tre e rigures may have been influenced by the first world war, and as Scotland differed from elsewhere in other railway matters why not in this? 
developed for several reasons: the trader alght be willing to accept responsibility for loss or delay; he might be obtaining discount for regular bulk consi gnments, or for providing his own sidings, both of which cut the costs of the railway companies; it might be that without the reduction traffic would be lost to cheaper and perhaps more direct forms of transport; such rates could also result from attempts to attract traffic which otherwise may not have existed at all; finally, in a few cases, a cut rate agreement was the price of Parliamentary support. (1)

By the end of the century the numbers of such arrangements ran into millions, and, writing in the 1920s, Wood and Stamp reckoned that $75 \%$ of traffic went at these so-called "exceptional rates." (2) It has been suggested that these special rates gained in importance towards the end of the century when the book rates became less flexible following the Railway and Canal Traffic Act of 1894. (3) However, the evidence to support this point is not strong and in 1882 the maneger of the North British had claimed that a "large proportion" of the mineral traffic in Scotland was carried according to rate agreements with the traders. (4) Even in 1893 , before the rate structures became rigid, the Chairman of the Glasgow and South Western remarked that "the bulk of our traffic, passing both locally and through, is carried at exceptional rates."(5

1. R.C. Railways. 1867 XXXVIII, p.xlvii. The S.C. General Revision of Railway Rates and Charges. $19 ? 0$ XXIV, p.13, was of the opinion that many industries had in fact been built up on the existence of these special rates.

2. W.V. Wood and J. Stanp, Railways. 1928, p.196.

3. D.H. Alderoft, the Ecli pse of British Coastal Shipping, 19131921,' Journal of Transport History, vol.6, no.2, 1963, pp.27-28.

4. S.C. Railway Rates and Fares, 1882 XIII, q.536.

5. H.H.J., I8 Herch, 1893 . 
For the purposes of the model three-quarters of the traffic will be presumed to have been conveyed at reduced rates.

Another problem arises from the fact that railway rates were not static over time. Drawbacks were given to the sugar traders and ironmasters when their respective trades were depressed, but whether this was first recorded in the receipts and then given back is not clear, though it is suspected that this was not the case. (1) Although general alterations in recorded rates occurred from time to time, especially in the early days when companies were proceading on a trial and error besis, the overall picture is one of long periods of unchanged book rates e.g. the Caledonian had identical mineral rates in 1853 and 1861. (2) This arouses suspicion that exceptional rates were in operation and that book rates were retained unrevised, either because of administrative difficulties or so that 'stupendous reductions' could be offered. What has to be determined is how far below book rates were these special chiarges. In extrene cases exceptional rates could be over forty per cent below, but a study of the agreement books of the two major Scottish companies suggests that on average the reduction was in the region of $18 \%$ to $30 \%$, depending on the distance involved. (3) For the purposes of the model $25 \%$ was taken, although to do this is to try and formalise something which grew up "in an accidental

1. W.M. Acworth, The Railways of Scotland. 1890, pp.100-101. Scotsman, 13 warch, 1880 .

2. HTRP(S) 51, pp.240 and 274 . B.R. C.J. Campoel1, British Kailways in Boom and Depression. 1932. p.18; J. Stamp, The iffect or Irade FIuctuations on pofits, Journal of the hojal statistical cociety, vol.131, 1918.

3. NBK 3/10; NBR 3/20; CNL 3/3; CAL 3/10. B.R. 
manner without system of principle." (I)

On the basis of the preceding discussion it is possible to obtain some idea of the average distance travelled by the residual traffic within each company's system. These are shown in Table 8.2 together with the effects that the ase of the assumptions have on the resulta. The estimates may appear low, but it must be remembered that they refer to an aggregate from which most of the longer distance traffic had been deducted. It can be seen that the assumption about exceptional rates has more influence on the results than that about traders' wagons; in fact it was found that a ratio of $1: \perp$ as regards railway and private vehicles would have made no significant difference to the cesuits. These two major assumptions are perhaps less valid when applied to the Highland and Great North of scotland compenies who had fewer dealings with e.g. coal and ironmasters than did the more southern lines. However, the influence of the assumptions, as applied to these two companies, on the final estimate of financial savings will be slight because of the much ereater volume of traffic carried on the other railways.

Two major problems appear when the rates of alternative forms of transport are considered. Firstly, the scarcity of date and, seconily, the question of whether pre-railwey data or that pertaining to the competitive era should be utilised.

On the first point the available information is shown in apvendix one; though not comprehensive it is much better than that

1. S.C. General Revision Railway Rates and Charges, op. cit., p.13. 


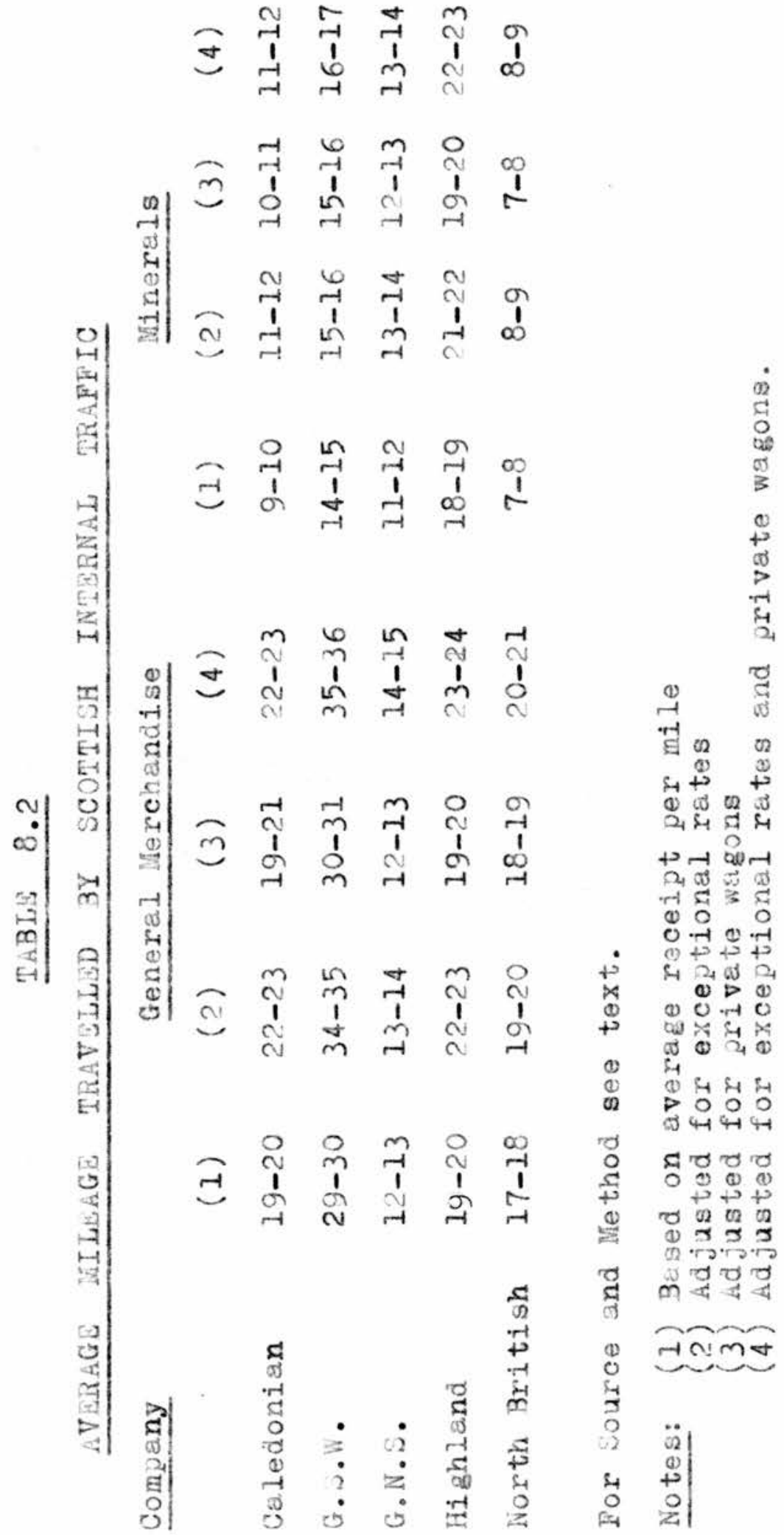


used by either Fogel or Fishlow. (1) Seversi comments are still called for. Gererally the data either indicates charges between two points, or just a general rate is given with no evidence as to whether or not the rates taper with distance. Yet the data supplied by the seottion Central railway would suggest, at least as regards land transport, that unit costs did decline with the distance travelied. Thus not allowing for this, as must be done because of the paucity of the data on this point, will bias the results in favour of railway savings. The rates cited in the appendix may of course be atypical either because of the time of the jear concerned or because of the biased nature of the source. This latter objection applies to the major source of non-railway rates, the evidence cited by the railway companies in their petitions to parliament. However, the opponents of the railway were allowed to challenge the authority of the railways' figures so they are probably genuine.

As regaras the second point it is essential that the prerailway rates be taken as the advent of the railways forced their competitors to reduce their rates and this saving must surely be

1. On the inadequacies of the data in these two American studies aee P.D. HeCielland, 'Railroads, Anerican Growth, and the New Economic History,' Journal of Economic History, Narch, 1968, pp.105-109. 
attributed to the railwajs. (1) To utilise the rates actually existing when the railways were in operation was the great mistake of Fogel which practically gucranteed him obtaining a small social saving. However, it must be asked whether the retes of the pre-railway era should be price adjusted if the are to be used for 1867 traffic flows. Theoretically the answer is jes but in practice it is impossible to do it. Economies of scale nay well have been secured had the volume of traffic on the roads, canals and seas been substantially increased for this would reduce unit overhead costs, unless these nodes of transport had been previously utilised at full capacity. In the absence of competition, however, is there any reason why these reductions should have

1. That railway competition caused a reduction in the rates charged by olner transport media is easy to substantiate. The charge for transporting heavy merchandise between Edinburgh and Glasgow before the railway was built was at least $18 \mathrm{~s}$ a ton, but this was slashed to a mere 2s ( $c f .2 s / 4 d$ by rail) when competition became intense. This, however, led to both parties finding their dividends reduced and their plant becoming inefficient, and eventually agreement was reached on the canal charging $8 \mathbf{s}$ which was still well below the previous monopoly rate. (S.C. Railway and Canal. Amalgamations. 1846 XIII, q.776-777 and 816; PYB(S) I/8, PN.84I; 857. B.T.T. An earlier example is that of the Honktand Canal Company reducing its charges to meet railway competition and to such an extent as to deprive the railway of a considerable proportion of its revanue. ?Rejort of Monkland and Kirkintilloch Railway, 1 February, 1832). Coastal shipping a.so reduced its rates e.8. the freight rate for cattle from Aberdeen to London was between 3 ? $\mathbf{s}$ and $42 \mathrm{~s}$ in 1836 - seasonal variations - but this hea been cut to between $15 \mathrm{~s}$ and $20 \mathrm{~s}$ by 1861 , mainly because of railway competition. (Information supplied by Mr. Clive Lee, Universit. of Aberdeen). As regards road transport a useful piece of evidence that competition reduced rates can be seen in the data given by the railway companies in support of their parliamentary aplications in 1845. (PYB(S) i/4. B.R.). Hoot companies suggested that cart transport cost between $4 d$ and $9 d$ a ton-mile, but the gdinburgh and Dalkeith, which unlike the others had been in existence for over a decade, pointed out that carters in competition with it were charging only $2 d$ to $4 d$ a ton-mile; and this railway was not even powered by locomotives. 
been passed on to the consumer? Technological breakthroughs (even external to scotland) right also have reduced costs, but again the question is whether these gains would have been swallowed up by increased profit mergins. It can be suggested that at least part of the benefits woula heve been passed on to the consumer simply because the transport market situation was one of monopolistic competition rather than complete monopoly. Still it is not possible to determine what rates would have been on nonrailway transpost in 1867 had the railways never existed, and the simplest solution is to assume that an average of the rates in the two decades prior to the railway mania, excluding areas already feeling railway competition, would be the relevant charges. The data in appendix one would suggest the following ton-mile rates as operative - the first refers to minerals, the second to general merchandise - carts $5.21 d, 9.00$; canals $3.86 \mathrm{~d} ; 6.42 d$; east coast sea route $1.47 \mathrm{~d}, 3.16 \mathrm{~d}$; west coast sea route $0.66 \mathrm{~d}, 2.50 \mathrm{~d}$. Obviously these rates are a key variable in the calculation of relative costs and further evidence way significantly alter any results. (1)

1. For coastal vessels steamer rates were taken as even in the late $1830 \mathrm{~s}$ it was stated that stearers were "preferred generally" to sailing vessels. (PYB(S) 1/7, p.39. B.R.). Why the west const prices should differ so much from the east coast is difficult to determine; the obvious answer is that only one example has been found for the west coast which may have been atypical. Yet surely it is more realistic to utilise known data than assume that east coast route charges would be representative of west coast ones. The figures for rates utilised in the model are medions of those in the appendix; this prevents an abnormal figure distorting the average. 
In estimating the distances that would have been travelled by alternative forms of transport several points have to be considered. Firstly, road distances between two points are rarely the same as rail distances; a sample of one hundred routes, both long and short distances, suggests a ratio of road to reil in the order of $0.87: 1.00$. (1) However, the building of the lay and Forth bridges later in the century would shift the ratio more in favour of the railways. Secondly, the amount of wagon haulage necessary for the goods to reach the railway or shipping point. Most collieries and factories possessed railway sidings und, if the attitude of the famous Scottish railway engineer John Viller was at all typical, farmers also would be able to reach the railway fairly easily. (2) To determine how far is, however, difficult; Fogel's method was to take one-third of the farthest distance of any point in a county from a railroad or waterpoint as the average distance within that county to such points. (3) This method yielded reasonable results where agricultural comodities were concerned, but is it valid to adopt such an approach in the case of coal and other minerals? The solution adopted, if it can be called a solution, was to assume that mineral traffic would need

1. Rail distances were taken from tables issued by the Railway Clearing House and road distances from contemporary Post office Directories.

2. "In constructing lines just now through agrioultural districts, I an putting sidings, or stations, at alnost every public road, so as to be accessible to farmers in their own farms, diminishing in the amount of curtage." (S.C. Railway Acts Enactments. $1846 \mathrm{XIV}, \mathrm{q} .1009$ ).

3. Fogel, op. cit., pp.66-68. 
no certage to a ruilway, but thet general merchandise would be carted one-third of the farthest distance of any point within the area served by each reilway system (as it existed in 1867) to a railway station. (I) A similar set of assumptions was made as regerds getting to the final destination from the rajlway on the grounds that a substantial proportion of mineral traffic would go straight to factory or port without any intermediary wagon transport. To some extent errors enanating from this assumption as applied to minerals and general merchandise respectively will cancel out. It would obviously have been better to use regions rather than railway systems, but as trafilc figures are available only on a company basis there is no option. Fortunately, the companies served well defined sress, although some error is inevitable where the railway s served the same district. In addition the area to the north of the Highland railway was not included and a slight error must have cesilted from this. In establishing the distance to a watempint a sinilar procedure was followed, although in this case all freight was deened to have been carted, not just general mefchandise, on the grounds that few mines possessed canals or were on the coast. (2) (An estimate of the effect of this assumption will be found below). The total distances travelled by wagon which have been derived by this aethod must then be adjustea from air line to road mileages; a sample of one hundred contemporary routes suggests a conversion factor of 1.416 .

1. Based on maps at the British Rail Board's Historical Archives the following air-line distances were obtained: Caledonian 4.02 miles; Glasgow and South Western 4.37; Great North of Scotland 4.57; Highland 4.55 and North British 3.03 .

2. The following air line distances were obtained: Caledonian 13.07 miles; Glasgow and South western 9.27; Great North of Scotland 14.67; Highland 14.51; and North British 12.93. 
On the basis of the preceding discussion an attenpt can ce nade to estinate the direct financial savings made by the railw ys in the transportation of freight. The results, sumarised in Table 8.3, suggest a figure between $£ 3,150,000$ and $23,520,000$. Several coments, however, must be macie as regaras the results in general and those of each sector. First of all the trarsborder estinates made no attenpt to assess savings made south of the border; this involves difficulties where the sea routes are concerned as the exact point at which the borale was crossed, especially on the west coast. The decision to take a horizontal line from the border points on the raspective coasts through the shipping routes concerned mej produce some error. No allowance was made in section two for the possible use of canals other than the Forth and Slyde, workland and Gainbargh Union, dud in section three for any canals at all. It would not have paid the vast majority of the traffic in section three to attempt to ulilise the existing water transport, but undoubtedly there would be some use though to what extent is difficult to say. It can be hazarded that the small priváte canals would not come into significant use because of their short leneth which woula render it uneconomicul to incur the costo of additional loading ond unloding. However, had, for exalule, the mineral projucers providea themselves with canal conneations some 150,000 miles of wagon haulage would have been saved, which would, assuming canal charges as on the rujor canals, have resulted in a saving of around 2850,000 . No attempt was made to assess the general signilicance of loading costs, insurance, wastage, damage, port and shore duties etc. because of a lack of 


\section{TABLE 8.3}

SAVINGS ON RAILWAY FREIGHT TRANSPORTATION IN 1867.

\begin{tabular}{|c|c|c|c|c|c|c|c|c|}
\hline Traffic & (a) & $\begin{array}{l}n s \\
00 \\
\text { (b) }\end{array}$ & $\begin{array}{l}\text { With or } \\
\text { without } \\
\text { railways }\end{array}$ & $\begin{array}{l}\text { Form of } \\
\text { transport }\end{array}$ & & $\begin{array}{l}\text { Mile } \\
\text { (a) }\end{array}$ & (b) & $\begin{array}{r}\text { Cost } \\
2 \cdot 000\end{array}$ \\
\hline \multirow[t]{2}{*}{ (A) } & 155 & 494 & Without & $\begin{array}{l}\text { Canal } \\
\text { East Coast } \\
\text { West Coast } \\
\text { Cart* }\end{array}$ & $\begin{array}{l}\text { Sea } \\
\text { Sea }\end{array}$ & $\begin{array}{l}3556 \\
6355 \\
17671 \\
2914\end{array}$ & $\begin{array}{r}11,260 \\
20,125 \\
55,597 \\
9,226\end{array}$ & $\begin{array}{r}276 \\
207 \\
338 \\
310 \\
1131\end{array}$ \\
\hline & & & With & $\begin{array}{l}\text { Rail } \\
\text { Cart** }\end{array}$ & & 809 & & \\
\hline
\end{tabular}

(B) 91290 without

B) 91290 without

$\begin{array}{lrr}\text { Canal } & 3200 & 10042 \\ \text { East Coast Sea } & 2407 & 7553 \\ \text { West Coast Sea } & 4231 & 13276 \\ \text { Cart* } & 2531 & 8790 \\ \text { Cart*** } & 491 & 1044\end{array}$

Estimated Saving $£ 768,000$

With Rail

Cart**

1042

247

78

81

286

$\frac{41}{733}$

307

$\frac{40}{347}$

Estimated Saving $£ 386,000$

(c) 366111648 Without Cart*** $\begin{array}{lll}\text { (c) } 71850 & 123941 & 5385 \\ \text { (d) } 75066 & 135222 & 5751\end{array}$ With Rail Cart**

$\begin{array}{rl}39640 & 1898 \\ 33875\end{array}$

Estimated Saving (c) $\$ 2,000,006$

Notes: (A) Transborder (excluding unknown Caledonian)

(B) Internal Scottish trafic (from Clearing House data)

(C) Residual Traffic (from Railway Returns)

(a) General Vierchandise

(b) Minerals

(c) Lowest Range of Table 8.?

(d) Upper Range of Table 8.2

* To ana from a water point (only to in (A)]

* To and from a railway station [only to in $(A)$ ]

*** Unbroken journey. 
information; all these would, if Fogel's study is any guide, probably increase railway savings. One final, but important, point about the alternative form of transport in the absence of the railways is that in some cases, where cart transport alone would be utilised, the total distance travelled could, using the cost data as a parameter, be reduced by up to $c 50 \%$, assuming that a road was available. This extreme would apply to only a small fraction of the total traffic, but demonstrates that there is an upward savings bias in assurning that traffic would, in the absence of a railway, follow a roughly similar route by road.

It is clear from Table 8.3 that the railways made some savings by being more direct than water transport, but without doubt their greatest contribution was in reducing the volume of relatively expensive wagon and cart haulage. In addition to these savings there would be those from traffic still going by canal and steamer, but at rates reduced by the competition of the railways; inadequate data, however, makes it impossible to estimate such savings. To say that the railways saved over three million pounds in the transportation of freight is in itself meaningless; the figure must be put into statistical perspective. This will be done in the concluding chapter of the thesis, along with the savings from passenger travel estimated in chapter nine.

One of the original assumptions making for an overestimation in savings was that in the absence of the railways no new forms of transport would have developed i.e. that the economic evolution of the steam locomotive did not stop the search for better transport media or even divert it along different lines. This opens up a 
credibility gap of some magnitude which cannot, in the current state of knowledge, be closed. What can be discussed is whether the existing modes of trensport could have handled the volume of traffic actually flowing in 1867 , but once again inadequate data hinders a satisfactory treatment.

The military and parliamentary roads existing in seotland in the immediate pre-railway era may well have been an improvement on what had gone before but they were still far from satisfactory. George Stephenson quoted one traveller's opinion that the reason for the roadmaker's name being inscribed on milestones en route was so that the weary voyager would know who to curse. (2) Admittedly Stephenson was not an unbiased witness, and a similar comment could perhaps be made on J.L. MacAdam who in 1811 criticised Scottish turnpikes as being "worse than those in England although materials are more abundant, of better quality, and labour at least as cheap." (3) However, other travellers, both Scottish and English, also testified to the inadequacies of Scottish roads.(4)

i. J.R. Stephen, The History of Roads in the Highlands of Scotland in the Eighteenth and Nineteenth Centuries. Ph. D. Aberdeen. 1936.

2. T.H.S., vol.6. 1824. P.2.

3. Quoted in H. Hamilton, An Economic History of Scotland in the Eighteenth Century. 1963. p.227.

4. e.g. P. Graham, Agricultural Survey of Stirlingshire. 1812. One traveller, writing with the superiority of the Englishman abroad, found the road between Glasgow and Paisley more like a ploughed field than a turnpike and had stuck so often on another road that only thirty two miles were travelled in one whole day. On being told that the Kerriemuir to Forfar road was the worst in Scotland, he declined to venture upon it - "as I knew what the best was, I had no mind to try the worst." (P. Barber, "Journal of a Traveller in Scotland 1795-96.' Scottish Historical Review, vol.36, 1957). 
On the other hand the poet, Robert Southey, seemed to indicate the the main roads outside of Perthshire were reasoneble. It is also true that, whatever the deficiencies of the roads, substantial reductions in travelling times had been made e.g. in 1678 a return journey between Edinburgh and Glasgow took six days but had been cut to less then twenty hours by the $1830 \mathrm{~s}$. (2) In addition, a Select Committee's comment in the exrly twentieth century that roads in the Highlands were "feirly suitable for the light traffic of the district, of ten consisting of crofters' carts carrying not more than 10 cwt." suggests that the traffic determined the state of the roads rather than the reverse. (3) This would then infer that unless the growth of traffic was solely due to the coming of the railways some new road building would have taken place to meet the needs of the increased traffic. What the costs of this would be is undeterminable. The average cost of the parliamentary roads in the Highlands built in the late eighteenth and early nineteenth century was less than $\$ 400$ a mile which compares extremely favourably with the c\&15,000 a wile of the railways built between 1840 and 1865 even ellowing for price changes. (4) However, Highland roads were far from typical, as the above quotation has indicated, and who is to say what effect the pressure on resources would have had if an intensive road building programe had been undertaken in scotland.

1. R. Southey, Journal of a Tour in Scotland in 1819. 1999. p.26.

2. D. Lardner, Railway Economy. $1850 . \mathrm{p} .32$. PYB(s) $1 / 7$, p.29. B.R.

3. S.C. Rural Transport (vootland) 1919XXX, paragraph 7 .

4. Road costs calculated from J.S. Stephen, loo.eit.; rail costs from data in chapter three. 
Notonly the costs of the roads would have to be considered for additional horses and carts would have to be purchased in order to move the traffic. To estimate the costs of this would involve a host of assumptions as to the capacity of carts, the working life of both carts and horses, the intensity to which they were utilised and, most important, that the prices of each would not have been affected by the pressure of demand which is extremely unlikely.

A substantial volume of traffic would have gone by coastal shipping had there been no railways. However, once again the inadequacies of data prevent an estimate of the money that would have to be laid out to allow such a development to take place. No figures exist for the capacity at which these vessels were operating prior to the railways so this would have to be assumed as would average sailing speed and time spent loading and unloading. Once the volume of additional tonnage required could be established then perhaps total capital expenditure could be estimated by using the average costs of tonnage launched on the clyde.

Whether the canals could have been improved or extended is a difficult question to answer. It is of little validity to say that the canals would not have done anything in the absence of railways as they did little in the face of railway competition. Admittedly aquaducts, buildings at the water's edge and other physical handicaps prevented the deepening and widening of the existing canals, but the major reason for the apparent resignation to their fate when the railways appeared is that the investing 
public lost interest in the canals once the railways came on the scene. (1) Is Jackman rightly pointed out, "in the fascination that the railways exercised from the outset, the possibility of materially and effectively improving the waterways was lost sight of." (2)

However, it can be argued that even if the total capital costs of providing sufficient roads, harbours, canals, carts, ships, canal boats, and the equipment necessary to produce them were substantially less than those involved in creating the railway network in existence in 1867, the money might not have been forthcoming. The railways seized the public's mind to an unprecedented degree and in fact revolutionised the capital market by their impact. (3) Is it likely that forms of transport in existence for many years before the coming of the railway age could suddenly have gripped the imagination of the populace to a similar extent? Perhaps the development of the steamship might have forced the money market to adjust, but still this form of transport would have left a great deal of the country's traffic unaffected.

Finally it should also be considered whether the saving as defined in the model is in fact a true saving. We are not

1. R.C. Canals and Waterways. 1907 XXXIII, Appendix 39, p.141; q.3167-68, 29728.

2. Jackman, The Development of Transportation in Modern England, 1962. p.659. The attitude of contemporaries is well stated by $F$. Wishaw, The Railways of Great Britain and Ireland. 1840. p.vi. ". canal and turnpike roads have, as it were, had their dey, and must yield the palm to that greatest achievement of modern times, the iron railway."

3. B.R. Mitchell in fact maintains that the railways had their greatest influence in the financial field. "The Coming of the Railway and United Kingdom Economic Growth, 'Journal of Economic History, 1964. p.333. 
concerned with McClelland's valid point that the true saving to the community is the saving in real resources as measured by the differences in marginal costs of alternative forms of transport, but with the question of whether the volume of traffic going by rail in 1867 would have utilised the alternative forms of transportation at the rates they would have been charging. (1) To assume that it would is to assume that the demand for transport services is completely price inelastic which is scarcely credible. If it were true then the railway managers were not behaving rationally in charging less than the maximum allowed by Parliament in areas where competition was negligible. Accepting that some degree of elasticity existed, then, in the absence of the railways, Scottish industry and agriculture would not have produced as much as they were producing in 1867. However, to say how much traffic was actually created by the railways is, fin the light of available data, an impossible task; for example it is not known how much traffic was travelling by non-railway means either before the coming of the railways or at any time afterwards; nor is there any information as to the form of the elasticity function. In a short term analysis generated traffic can reasonably be ascertained, but over time, as in this instance, exogenous influences on growth intervene, making it impossible to quantify the role of railways in creating traffic. (2) All that can be said is that the estimated savings include some unknown percentage of developmental traffic and is not

1. Mclelland, op. cit., p.11l.

2. N.R. Gillesphy, The Tay Road Bridge: A Case Study in CostBenefit Anal sis,' Scottish Journal of Political Economy, vol. XV, no.2, June, 1968 . 
merely concerned with exploitative traffic.

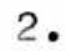

Relative charges were not the sole determining factor in the competition for custom between the rallways and other forms of transport. A Select Committee in 1920 pointed out that, ceteris paribus, a marginal difference in price would cause a switch from one mode of transport to another, but the real world is rarely that of the economic theorist and the potential user would also consider the relative costs incurred through speed, convenience and regularity. (1)

It might prove useful to see what contemporary advocates of railways had to say on these points and attempt to assess the validity of their claims. Charles MacLaren, one-time editor of the scotsman, was a driving force in getting railways accepted in Scotland, and his views can perhaps be taken as representative of the early railway enthusiasts. In a series of newspaper articles, later published as a pamphlet, he made the following assertions as to the superiority of the railways over other forms of transport: (a) to travel at over $4 \mathrm{~m} \cdot \mathrm{p} \cdot \mathrm{h}$. on a canal was impracticable and destructive; (b) railways could be built at one-third the cost of a canal which meant that money would be easier to raise and any failure would be less ruinous; (c) uphill travel was quicker by railway, and even if stationary engines had to be used they would be cheaper than canal locks; (d) railways did not need a

1. S.C. General Revision of Railway Rates and Charges. 1920 XXIV. p.7. 
supply of water and therefore would be less affected by frost or drought; (e) railways interfered leas with property; (f) "railways have this grand advantage, that they may either be usefully combined with the ordinary roads of a country, or be substituted for them, and expanded into a general system of internal communication;" (g) farmers would not cart to canals "with the trouble of attending shipping and unshipping;" and (h) commodities would not be "detailed weeks on the way by wind and tide." (I)

Points (b) and (e) are related more to the feasibility of constructing a railway than to the relative advantages of this form of transport to the user, except in so far as construction costs might be reflected in pricing policy. Suffice it to say here that cheapness of construction was not a predominant characteristic of many Scottish lines, and that a significant number of Scottish landowners did not share Mactarens views on railways and the amenity of their estates. (2)

There is no denying that the railways were the fastest means of transport existing in the nineteenth century, as is stated in points (a) and (c), but it can reasonably be asked if speed is of all that importance. The coming of the railway reduced the time of a journey between Bdinburgh and Glasgow by about six hours (some $80 \%$ ) but does this mean anything economically? (3) Being able to move quickly from one point to another is perhaps of most utility to the passenger (this will be discussed in the following chapter),

1. C. Maclaren, Railways Compared with Canals and Common Roads, 1825. $\mathrm{pp} .82-89$.

2. See chapter three, sections one and four.

3. R.C. Canals and Waterways. 1907 XXXIII. Appendix 39, p.143. 
and agricultural producer (see chapter 11) but, according to Tooke and Newmarch, speed also had relevance to freight transport in that the faster goods can be brought onto the market then the less stocks need to be held by the final seller. (1) However, this merely shifts the responsibility for holding stocks further back along the distribution chain towards the original producer; there may of course be economies of scale to be secured in doing this. Only if industrial production can respond readily to the stimulus of demand can transport improvements reduce total stockholdings (excluding goods in transit). From a subjective point of view it would seem more logical to talk of significant reductions in holdings (including goods in transit) when the time factor is being cut from weeks to days rather than from a day to a matter of hours. Despite this, an attempt, albeit an approximate one, was made to estimate the savings in goods in trangit brought about by faster transport. That transit time was cut some $80 \%$ does not infer a proportionate reduction in the volume of goods in the transport pipeline; this would be the case only if the roads and canals were being utilised at full capacity, and it would be ridiculous to suggest that this had been the situation. Yet it may well be, that to carry the volume of goods taken by rail in 1867, road and canal resources would have been nearly fully utilised, and the estirate of savings will be based on this

1. Tooke and Newmarch, op. cit., p.374. 
hypothesis. (1) Several other assumptions are also necessary,

viz. (i) that transportation time was cut by $80 \%$; (ii) that the average speed of a freight train in 1867 was $15 \mathrm{m.p.h.;} \mathrm{(iii)}$

that the average haul of a goods train was 25 miles. (2) On these assumptions the average volume of goods in transit at any point of time was 33,000 tons, an estimated reduction of 235,000 tons had the railways not been available. Unfortunately, it is impossible to place a value on this saving; if all railway freight was coal then some $£ 60,000$ would have been saved but of course much of the tonnage was of more valuable commodities than coal. (3) If all mineral traffic was valued as coal then the value of non-mineral traffic would have to approach $\$ 2.10$ s a ton for the reduction of goods in transit to contribute $\$ 170,000$ (equal to about $10 \%$ of the investment in Scottish railways at that time). How feasible this was is not known.

1. The calculations of $\mathrm{S}$. Lebergott (Journal of sconomic History, Decerber, 1966, vol.XXVI, no.1) showing that railways in the United states could provide at least three times as much freight service as canals for an equivalent resource cost seem to ignore the point that neither medium was working flat out. The luggage boats on the Edinburgh and Glasgow canal route were only carrying $25 \%$ of their potential maximum load, but what is important is whether the roads and canals could have handled the traffic that the railways did without being choked up i.e. would the utilisation of these media approach full capacity? This cannot in the light of current knowledge be answered.

2. $\mathrm{PYB}(\mathrm{S}) 1 / 7$. B.R. Railway Returns.

3. Calculated from 3.R. Mitchell and P. Deane, Abstract of British Historical Statistics. 1962. p.115.

Although average bulk/value ratiog could be ascertained for commodities known to have been carried in reasonable quantities the extent of "unknown" traffic renders this meaningless in the context of total savings. A few tons of extremely high valued merchandise could seriously inflate the average value of total freight traffic. 
Speed is important to the businessman in the sense of quickening postal deliveries; here of course the extra speed of the passenger train is used to advantage. There were some complaints of delay, e.g. when the railways decided in 1853 to reduce their speed in winter, so as to reduce the risk of accident, the Glasgow merchants dealing with Lancashire threatened to send their goods by stearer unless their normal postal service was ensured, but generally the railway service seems to have been satisfactory. The railways most certainly speeded up the delivery of business letters, but businessmen do not seem to have taken up the parcel post as much as was expected, though the general public more than made up for this. (2) The importance of the mail to commerce and industry must, however, remein one of the unquantifiables of economic history.

A substantial proportion of Scottish railway traffic was in coal and minerals to which speed would be of far less importance than to perishable goods. What was needed as regards these bulk commodities (and gll goods in continuous use) was regularity of service i.e. a guarantee that distribution and deliveries would proceed according to plan. In a physically linited area such as Scotland regularity of service might well be a more important factor than speed in determining the level of stocks held. Henry Brown, a woollen manufacturer of Galashiels, writing in 1829, advised the laying in of coal stocks for the winter, partly because the city

1. H.R.J., 17 December, 1853. S.C. The Conveyance of Mails by Railway. 1854.XI.q.322-387. S.C. Railway Rates and Charges. $1892 \mathrm{XV}$. pp.603-605.

2. T.E.S.S. 1883/84. p.8. 
carters had less need to venture awa. from the metropolis in winter and accordingly charged higher rates, and partly because a combination of bad weather and worse roads made transport difficult, and hence expensive, at that time of the year. (1)

What we have to establish is whether or not the railways provided a nore reliable service than other forms of transport. Racteren in points (d) and ( $h$ ) makes the argument advanced by most railway promoters; that the railways were less interferred with by the vagaries of the climate than were their rival modes of transport. Such hypotheses can be partially checked by reference to the press but little statistical evidence appears to exist.

The canals appear to have suffered at times from the Scottish winters. In 1801 the Muirkirk Iron Company reported that severe frost meant that "communication by water is in a ereat measure stopt."(2) In the same decade, but further north, the Aberdeen canal does not appear to have operated at all in winter, though this was in its early years and may have had so mething to do with restricted demand. (3) That stoppges occurred on the canals because of adverse weather conditions is also suggested by the advertisements for coal which appeared on the opening of the Edinburgh and Glasgow railway and pointed out that coal would now be guaranteed iresh from the pits "every day winter and summer." (4)

1. H. Brown's Diary. 1828/29. pp.109-110. (I am grateful to Lifr. C. Gulvin for this reference).

2. Three Banks Review, June, 1967, p.30.

3. Aberdeen Journal, 20 September, 1809.

4. E.A. Pratt, Scottish Canals and Waterways. 1922. p.167. See also H. Hamilton, The Economic Evolution of Scotland. 1933. p.21, for similar claims about the lionkland railway system. 
Two decades later the Forth and Clyde Navigation opened a branch railway "to enable the canal company to keep a grip of their traffic when the canal is blocked with ice;" but there was an alternative motive, namely "to enable them in fostering trade into Grangemouth." (I) At the beginning of the twentieth century, however, the Caledonian railway manager stated that the aanals under his charge were stopped very infrequently by frost and that this had not occurred in the ten years preceding the Royal Commission to which he was giving evidence. (2) Fortunately some quantitative analysis can be done from data pertaining to the tolls given to the Corporation of Edinburgh by users of the Union Canal. (3) These were based on the tonnage passing through the canel and some indication of the impact of winter can thus be assessed from the quarterly figures. Adequate information can be obtained for seventeen winters although a continuous time series is not available. There was usually a drop in receipts in the winter months, but generally this was a fall of less than $10 \%$ from the average of the rest of the year. On five occssions, however, it was between $20 \%$ and $25 \%$, and in two instances over $50 \%$. Some of the reduction may be attributed to a general decline in business activity during the winter months; some was also due to abnormal trade at other times of the year pushing up the average; but there is little doubt that the closing of the canal must have played a part in at least two,

1. R.C. Canals and Waterways, op. cit., Appendix 39, p.141. H.R.J., 21 March, 1871; 22 March, 1879.

2. R.C. Canals and Waterways, op. cit., q.31202-31209.

3. I are grateful to the Corporation of Edinburgh for permission to consult their archives. 
if not seven, winters of the seventeen examined. It could be suggested that the non-winter figures mignt be affected by stoppages through drought and llood, but the only evidence that has come to light on this point is a statement by a railway supporter that the Momkland Canal was occasionally affected by a water shortage. (I)

Were other modes of non-railway transport affected by the weather to the same extent as were the canals? No quantifiable evidence has been found on this point and subjective judgements have to be made. Canal boats were unlikely to suffer, as might coastal shipping, the frustration of becalment or the rages of severe storms. (2) Yet, if a value judgement is allowed to creep in, the personal observations of the writer do not suggest a lack of wind is characteristic of the Scottish climate, nor would this matter so much as steam ships came more into operation. It might also be tempting to suggest that scotland was peculiarly subject to bad weather around her coasts; the Tay did freeze up every winter, but the very fact that coastal shipping remained viable would seem to demonstrate that adverse climatic conditions were of little count. (3) Koads no doubt felt the effects of snowdrifts, frost and floods, but their hardening in sumer might well have made them reasonable thoroughfares. (4) Overall it is impossible

1. G. Buchanan, Ihe Glasgow and Garnkirk Railway. 1832. p.4.

2. One witness to a Parliamentary Comittee commented on the difficulties of shipping the 29 miles between Dundee and Perth "It depends on the weather and the winds, I have seen them some times from 5 days to 14 days." (PYB(S) 1/2. p.157. B.R.).

3. PYB(S) 1/2. p.162. B.R.

4. One important issue which is open to conjecture is whether trouble would arise less or more frequently within the industrial belt. 
to say whether the canals suffered more than other non-railway forms of transport, but in the absence of evidence to the contrary it can be hazarded that at least they did not have it easier. If ell non-railway transportation was equally affected by the climate then, using the parameters of the previous calculation, an estimate of the effect on stock holding can be made. Again several other assumptions are needed; that railways were unaffected by the weather and that altholgh stocks might well be held in anticipation of winter transport difficulties their level would be geared to what happened regularly and not to abnormal closures. Taking $20 \%$ as the stocks held extra to those in transit the railways saved some 48,000 tons, but no value can be put to this. It should, however, be noted that this is less than $25 \%$ of the savings achieved through faster transport. An additional point on the question of canal closures is that the non-closure of the Forth and Clyde Navigation in the twentieth century was partially attributable to the employment of a horse drawn ice-breaker, and it can be conjectured that if canals had been working to a high degree of capacity, as they might havo in the absence of the railways, then a continuous flow of traffic could well have performed the same function.

So far only one side of the coin has been examined. In fact the above calculations have assumed thet the railways were not subject to helts through climatic conditions. Clearly this is not true. On several occasions heav rain washed away embankments and led to a suspension of traffic. (1) Presumably too, though I 1. e.g. Railway News, 25 August, 1877. Newcastle Journal, 24 October, 1844. 
have found no mention of it, rails buckled just as much during exceptionally hot weather in the nineteenth century as in the twentieth. However, the major form of climatic interference with rail travel was that of snow drifts. In the late $1860 \mathrm{~s}$ communication between Ballater and Aberdeen was checked for nearly a week. (1) In April, 1875 the Highland railway spend \&3,000 in clearing lines, re-erecting the telegraph and feeding the beseiged residents of Dalwhinnie. (2) Professor O'Dell wrote of one famous incident in 1879 when it could be announced by officials in Inverness on the Monday night that the where-abouts of the $3.10 \mathrm{p} . \mathrm{m}$. Sunday Mail was "an absolute mystery." (3) Events such as these, and the destruction of part of the Solway Viaduct in 1881 by ice floes, are perhaps isolated occurrences, but it can be emphatically stated that in most parts of the winter some part of the Highland system would be immobilised by snow. (4)

It is arguable that the same climatic conditions that stopped the railways would equally have stopped other forms of transport. On several occasions of extreme wintery conditions the railway journals made great play of the fact that the railways got through when all else failed. (5) of course if the other modes of transport weren't working it was of little utility for the railways to

1. H.a.J., 9 February, 1867.

2. Railway News, 1 Nay, 1875.

3. A. O'Dell, Railways and Geography. 1956. pp.57-59.

4. J.h.F. Gardner, Railway Unterprise. 1934. p.26. O'Dell, op. cit., p.130.

5. e.g. Railwa Tines, is February, 1839. Scottish Railway Gazette, 29 December, 1860. 
keep going, as in 1879, when the High Jand found that as the carts could not reach the stations there was little traffic for their trains to take. (1)

It is also arguable that when the rallway service was interrupted it was unlikely to be in districts where traffic was heavy, and thus the loss to the econorny, though not to the individual shipper, would be minimal. Again the railways would no doubt have scored easily over canals and roads in the northern regions, but the contribution of these areas to the Scottish economy was not important enough to warrant the "axiom of indispensability" to the economy of railways.

One final point on the question of regularity is that in theory the railways might score over the canals in the matter of closure due to repairs, for the railway can keep traffic flowing by single line working or rerouting, whereas the canals, in Scotland at least where there was no network of waterweys, could not do either. However, in practice the canals do not appear to have been unduly hampered in their operations by stoppages for repairs. In the fifteen years to July, 1907 the Forth and Clyde canal was stopped nineteen times, usually for thirty six hours (longest was three days twanty hours) and the Monkland was stopped only twice though one of these was for twelve days five hours. (2) These statistics do not appear to give the railways an overwhelming competitive advantage though it can be argued that had the canals had to deal with a greatly expanded volume of traffic then repairs might have

1. H....., 3 tias, 1879.

2. R.C. Canals and Waterways, op. cit., Appendix 39, p.140. 
been needed more frequently.

Allied to the question of regularity is that of convenience. Points $(f)$ and $(g)$ of Mactaren refer to some aspects of this, but several more can be mentioned. Many cosstal routes were sailed only once or twice a week. Admittedly this was a consequence of inadequate demand, but it did mean that a long delay was inourred if a load missed the boat. (1) Moreover at times of high demand a load might well arrive at the docks in time but be refused because of a shortage of stowage space. The canals often proved incapable of adaption to new conditions e. and aquaducts which prevented the more modern and larger vessels from using the canals and involved the coastal steamers in additional loading and unloading. (?) of most importance as regards convenience was the greater flexibility of the railway over water, though not road, transport. A railway line could easily be laid into a factory yard to run to whece it was immediately required and thus save the costs of double loading and unloading which a combination of canal and cart would require. (3) One final point

1. $\mathrm{PYB}(\mathrm{S}) \mathrm{I} / 7, \mathrm{p}, 51$. 3.R.

2. R.C. Canals and Waterways, op. cit., q.29728; 31136-31137; Appendix 39, p.141.

Much loading and inloading was necessary in the pre-railway era, e.g. goods sent by sea from Perth to Edinburgh went first to Dundee where they were put on lighters and towed by small steam boats "which is of course attended with considerable delay and expense." ( $Y$ Y $(S)$ 1/2, evidence of Vlarshell. B.R.). However, this specific case seens less a case of inadequate facilities and more a case of inadequate denand rendering it uneconomical for a ship to take goods directly from Gdinburgh to Perth.

3. R.G. Cangls and liaterways, op. cit., q.31305; 31120. The importance with which the avoidance of such double loading Was viewed can be seen from a decision of the awners of the Netherdale Mill to construct over half a mile of track at their own expense to make sure of a railway link. (Border Advertiser, 8 April, 1874. 
about convenience is that it was not until the railway network really developed that convenience could be said to approach anything near optimum, e.g. until the waverly route to sngland was opened goods fror the Hawick area had to go to Dngland via Eainburgh which gave rise to many complaints of delay. (1) By the end of the century, however, the reilways had brought all scotland into the realms of a twenty-four hour service from Bdinburgh or Glasgow whereas in 1861 only a third of the Soottish population could have been so served had reliance had to be placed on cenal and rosd trensport. (2)

\section{3 .}

Maximum gain to the economy can come only if maximum efficiency is attained and, although second-best theory might suggest that if the rest of the economy is out of phase it is no good one sector being optimally utilised, it is useful to attempt to assess how well the Scottish railways served their clients. Two English statisticians claimed that "when we get across the border we leave behind us English notions of railway discipline, and come upon a very sorry state of things as regards punctuality and intelligent organisation." (3) However, doubt has already been cast on their judgement in Table 3.7 which suggests that the Scottish companies had lower operating costs per unit of revenue and per train mile

I. H.R.J., 18 May, 1867 .

Letter Book of H. Ballantyne, 22 August, 1855. (I am grateful

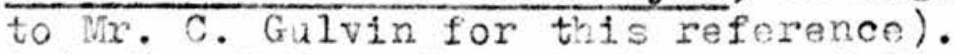

2. Calculated from data in Census of Scotland.

3. E. Foxwell and T.C. Farrer, Express Trains English and Foreign. $1889, \mathrm{p} .58$. 
run than the rest of Britain.

This does not of course answer the question of how efficient Scottish railway service was. Ideally we should have to produce models showing the potential maximum efficiency that could be achieved in various aspects of railway work and then calculate the short-fall. on this optimum. The state of quantifiable knowledge, however, renders such an approach impossible and all that can be done is to ascertain what types of complaints were made about railway service and then attempt to assess their general validity in a qualitative form, bearing in mind that complaint was possibly an endemic feature of traders' relationships with any transport medium. How many traders were like James Johnston of Elgin who continually complained about the railways overcharging and delivering late, but still remained a $r$ gular user of the railway, and in fact sought discount on this ground? (1)

The question of rates was usually to the forefront in any trader-railway confrontation, but, although protests about high charges are easy to find, only very rarely is there evidence of a corapany charging over the legal maximum and this was generally confined to agricultural commodities. (2) Therefore, unless Parliament was sanctioning unduly high rates the railway companies, operating in a free enterprise economy, can scarcely be classed as extortioners. In any case the attitude of the traders towards

1. General Book, passim but especially 15 November, 1855; 25 April, 1856. (I am grateful to Mr. C. Gulvin for this reference).

2. See chapter eleven, section seven. When rates over book value were charged this was frequently explainea as being for "carted and delivered" and not nerely station to station. 
demeurrage, small consignents eto. nust in itself huve been exerting upwrd pressure on costi and hence on chargos. It could perhaps be argued thet the general price fall in the late nineteenth century made the leas flexible railway rates tore of a burden, but it is significant that an analysis of the repliee from the Scottish Chambers of Comerce to the Royal Comisston on the Depression of Prade and Industry did not rention the cost of carriege as an sggraveting factor. (I) In fact, at times of distress, rebates appear to have been sivon to certain industrialists and businessmen, but it should be noted that such drawbucks do not necessarily benefit the economy and may, if not given universally, merely beafit one producer at the expense of another. (2) Railway rates may in fact have been nowe flexible than might apgear on the surfece; exceptional rather than book rates being altered. (3)

The greatest dispute over rates came in the early $1890 \mathrm{~s}$ when revised rates as demanded by a Porliamentary Act came into force. Following the recomendation of a Select Comrittee the hailway and Canal Traffic Act of 1888 required the railway companies to submit for parliamentary ap roval a revised classification and schedules of maximum rates. After protracted bargajning these came into operation on the first day of 1893. Many companies, however, hed

1. Parliamentary Papers. 1886 XXIII, vol.2, p.128.

2. See p. 442 .

See also S.C. Railway Rates and Fares. 1882 XIII, Q.538.

3. W. Ashworth, An conomic History ol ingland 1870-1939. 1960. p.124, suggests that book rates were inflexible as their comlexity rendered any revision a riajor economic and adninistrative operation. This would be less true where individual exceptional rates were concerned. 
not comprehensively reorganised their rate structure and, to protect themselves while things were sorted out, made their old maximum authorised rates the current book rates. The Economist suggested that the railways might be perfectly honest in stating that they did not intend to raise rates, but the majority of traders do not seem to have shared that journel's confidence and condemned the new rates. (1) However, the North British chairman, for one, rackoned that his company had in fact reduced a large proportion of its rates "many of then to a considerable extent" and only increased rates either to remove snomalies or to end complaints of undue preference to certain traders in certain areas. He maintained that "in the case of the Scotch companies particularly" ruch of the apprehension was due to rate books being open to public inspection without "gufficient time for revision being granted by Parliament," and added that "the officers of the company are deily meeting traders ... whose rates had not been adjusted, and the directors are confident that in a very shor time, all just grounds for dissatisfaction will be removed." (2) Toble 8.4 showing the average revenue per mile travelled suggests that his prediction was not justified either for the Morth British or the other Scottish companies. (3)

Two other points can be made about railway charges. Firstly, despite the occasional complaint of monopoly exploitation it should be remembered thet the railways did offer lower transport

1. Economist, 24 Octooer, 1891.

2. $\mathrm{RAC}(\mathrm{S}) 1 / 2,11$ warch, 1893. 3.R.

3. This was not the case where mineral traffic was concerned (p.370) The explanction probably has something to do with the greater volume of exceptional rate agreenents made in this sector of railway traffic. 


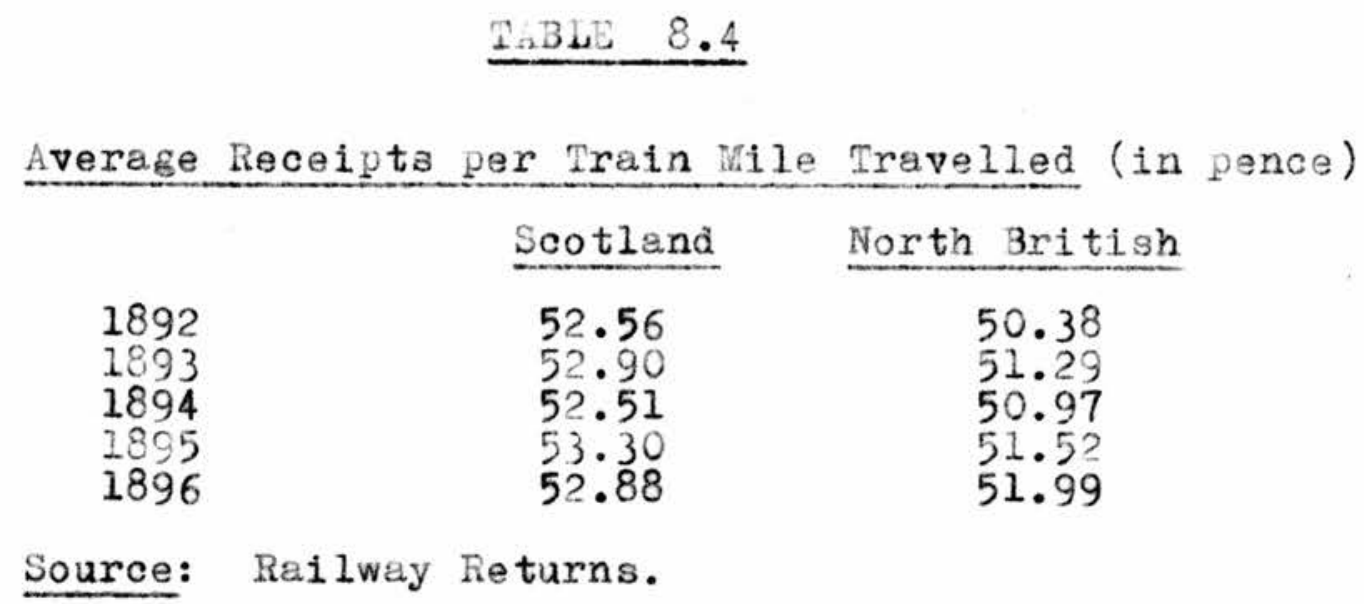

rates than existed before their construction. (1) Furthermore they did not always, or perhaps even mainly, charge the raximum permitted by Parliament e.g. they were entitled to charge special rates for small quantities "but as a matter of fact did not do it." (2) However, had they allowed others to be carriers on the line as was often the original intention then competition may have reduced charges even more. Secondly, payment did not have to be made immediately. Outstanding traffic accounts of the Caledonian in the 1870s usually totalled around $\$ 100,000$ at the end of each month which the chairman thought "compared favourably with other companies." (3) This credit allowance must have reduced the

1. Competitive rates cuuld themselves be matters for complaint: on the Edinburgh to Glasgow route severe competition between canal and railway had reduced revenue to uneconomic levels, but when a more realistic charge was brought into operation the consumers, having experienced very low charges, were up in arma. As one canal manager pointed out "if the railway and the canal had arranged together three years ago, the public would have been satisfied, I think, with $15 \mathrm{~s}$ a ton, and now they are not satisfied with $8 \mathrm{~s}$, bectuse they have been accustomed to $2 \mathrm{~s}$. (s.c. Railway and Canal Analgamations. 1846 XIII. 2nd Report. $q .816)$.

2. Parliementar fapers. $1892 \mathrm{XV} .9 .3689$.

3. H.R.J., 22 March, 1879. 
demands on the workine capital of traders end industrielists thus facilitating the accumulation of fixed capital for economic development.

The proviaton of facilities once the railwas were in operation has been discusged more fully in the context of the coal industry and the productivity of railway capital, but a lew points can be raised of reiterated here. (1) Complaints of a whortege of wagons seem enderic and at one stage the Scottish iron treders considered taking the Caledonian before the Railway comissioners or the question of tradiag facilities. (2) However, to some exteat, the maldistrioution of wagons was due to the trader beconing "gcoustomed to look upon the railway wagon as his warenouse." (3) Yet the ruilwe compunies were not free from olane for it was their reluctance to enforce deneurrage paythents, through a fear of losing trade, that encouraged the trabers to retain wadons for temporary storage purposea, or to loca whilst awaiting orders or the arrival of vessels at porti. (4) Not until the early twentiethcentury did the jeottish companied get together to solve the problem by declarind an intention to demand payents. (5) Although the traders dia benefit throduh obtuining cheap storkge thej faj well have lost

1. See chapter six, section four and chapter three, section four.

2. Geononist, 26 Novenber, 1891.

3. C.M.K. Sherrington, The Econowics of Rail Transport in Great 3ritain. 1928. vol.2, ..TO.

4. Economist, 5 December, 1903.

5. IJId. Detheurrage, si a theofetical econowic deterrent, was used on the arbroath and Forfar from its beginning (Byelaw 5); on other lines (e.8. in 3 k 1/3, 25 Jeniary, 1848) it was broaght in when it was found that too many wagons were standing idle at tire discretion of the traders. 
out overall through this action precipitating a generial shortage of wagonis.

Another source of inefficiency was the absence of eas, connections betwean the rallway tesmini in Glastow and this, like the failure to insist on demeurrage payments, ecn probebly be attributed to the intense rivalry between the railwy companies. (1) Further instences where competition dia not guarantee banefit to the consumer cen be cited. A Board of Trade inspotor attributed the employment of inferior rolling stock on the North British to competition with the Crledonisn which allowed less money for repair and renewels. (2) Theoretically the adoption of a standard guese should have eased transport difficulties, but their unwillingness to contribute to the prosperity of other compenies caused the Great North of Cootland to refuse to be party to any through agreemente for coal from Lanark, Fife or the Lothians until 1886. (3)

A1. this is not to sey that competition did not produce any beneficial results. Ahen the North British gejned access to the Dundee area, traditionally the home of the Galedonian, it was extued that "while the service of the trains has becone better and more exp ditious, the rates have been in some instmess lowered by a thira." (4) If the railway companies had gone in for cutthroat competition the consumer would gain through lower charges. (5)

1. 1....., 1862/63. p.17.

2. Prliamentary 2avers. 1870 IIX. .5 .

3. Parliamentary papers. 189 ? XV. q.5257.

4. D.G. Caipbell, Railway Amalgamations. 1873. p.6.

5. The Comittee of Inquiry into the affeirs of the North British, op. cit., p.lol gave examples of reductions of nearly $50 \%$ given under compe titive duress. 
This was presumably why, when the Caledonian and the North British agreed to divide the receipts of previously competitive traffic, the Glasgow Chamber of Commerce was up in arms at this being "inimical to public and comercial interests and progress." (1) On the other hand, as the Glasgow Herald pointed out, the public surely derived an "enormous advantage" from the making of return, season and traders' ticket 3 available by the trains and routes of either company between all connecting points on the companies' systems. (2) Rate competition could also disrupt commercial and industrial planning. Might not a higher but stable rate be more beneficial in this context than a fluctuating one? Some of the rates offered were so low as to be inevitably unsustainable e.g. at one time the third class fare between Edinburgh and Glasgow was as low as sixpence for the forty four mile journey. (3) It could also be argued that the higher charges would allow more money to be spent on the provision of greater and better facilities. (4) Unproductive competition need not necessarily be in terms of the charge to the consumer. In September, 1871 it was rep or ted that along the routes to the north from Edinburgh and Glasgow "the competition between the companies is confined to facilities and accommodation and does not extend to rates and fares." (5) over the following decadss of the century such competition was perhaps more typical than price wars, but the running of duplicate services, competitive trains often starting at the same time, was surely not

1. H.R.P.(S) 5I. B.R.

2. Glasgow Herald, 21 January, 1993.

3. 1.I.J., 22 September, 1855.

4. Economist, 31 Octover, 1891.

5. $\mathrm{RAC(S)1/2}, 28$ September, 1871. B.R. 
really serving the public and must have involved the railway companies in pecuniary sacrifice. (1)

It has just been sugrested that competition does not inevitably produce benefits elther to the economy as a whole or to the recipients of the favours offered. However, it is not possible to assert that amalganation and the reduction of competition would necessarily be better. The Select Committee on Railway and Canal Amalganetions in 1846 thought that if a railway got the carrying trade of a district into their own hands "the benefits arising from it, if conducted within proper limits and under juicious regulations are indisputable," but a later Committee found it difficult to sey whether or not greater facilities were produced by amalgamation. (2) One danger would be the possibility of the exploitation of an imperfect market, but of more relevance to Scotland would be the detrimental effects on plenning of the instebility of many agreements made between the rallway companies as to charging equal rates, trovelling at equal speeds, sharing receipts and facilitating through traffic. Space does not permit a full catalogue of the agreements between Scottish railway compantes, a discussion of which probably ranks more in the realms of afplomatic rather then economic history. Suffice it to say that agreements, disagreements, and realignment of allies went on virtually unabated throughout the century and that, apart from amalgamations, few agreements remained permanent. At the end of the century all five major companies wero negotiating for closer

1. Beonomist, 5 December, 1903.

2. Parliamentary Papers. 1846 XIII. lst Report. Parliamentary Papers. 1872 XIII. p.xxv. 
working agreements, but, as the Economist stated, "there is such a traditional jealousy smong the Scotch rajlway companies, thet we will not take for ercnted that the desiderated, and at present projected, benefits will actually be secured by cooperation."

All in all the evidence is inconclusive. Over time the emergence of the larger companies may have produced economies of scale, but these need not have been passed on th the consumer. Ail that can be hazarded is that the Scottion railways perhaps gave their clientele a more efficient service than those south of the border despite the utterations of Foxwell and Farrer to the contrary. Ashworth also makes a valid point when he stateg "whatever the defects of the railways, they were providing in the early years of the twentioth century a range of service sdapted to the needs of a far areater variety of persons and activities than forty years earlier." (2)

1. Lconorist, 5 December, 1903.

2. Ashworth, op. eit., p.126. 


\section{APPENDIX ONE}

COSTS OF NON-RAILWAY FREIGHT TRANSPORT

\section{Year Between \\ (1) CART TRANSPORT}

1810 In the borders

1828 Area of proposed Wishaw and Coltness railway

1829 K1lmarnock Glasgow

1831 Edinburgh -

1837 Edinburgh Glasgow

Glasgow Kirkcaldy

Glasgow - Dundee

Edinburgh - Ayr

Ayr - Glasgow

1838 Galashiels Edinburgh a minimum of $8 \mathrm{~d}$ a ton mile on a turnpike

$8 d$ a mile on turnpike

30 s ton

Cost

Source
John Rennie,' Report on a Proposed Railway from Kelso to Berwick,' p.10

Report of Grainger and Miller, $p .9$ WIC 4/3, B.R.

Report of Grainger and Miller on'Best Rosd from the city of Glasgow to Ayrshire,' P.15.

40 s a ton

Report on Edinburgh, Leith and Glasgow Railway, p.I

$30 s-48 s$ ton PYB(S) $1 / 7$. B.R.

$35 s-40 s$ ton

23 ton

$£ 4-£ 5 / 6 / 8 \mathrm{~d}$ ton

35 s ton

3/- return per cwt. very charge on some goods)

Minute Book of Galashiels' Manufacturers' Corporation, p.60

1840 Edinburgh - Leslie

20s ton

PYB(S) $1 / 2$

B.R.

Cupar Auchtermuchty

Newburgh - Perth 30s ton

Newburgh - Dundee \&2 ton

Kirkcaldy - Leslie $6 / 8 \mathrm{~d}$ ton

Kirkcaldy - Newburgh los ton 
Year

Between

Cost

Source

1840

Lochgelly pits to a distance of 23 miles

1845 Area of proposed Aberdeen railway

6d-9d ton mile PYB (S) $1 / 2$. B.R.

Area of proposed Caledonian railway

$5 d-6 d$ ton mile

Area of proposed Clydesdale Junction railway

Dundee - Perth

$8 s-13 s$ ton

Area of proposed Edinburgh and Northern Railway

Area of proposed Glasgow, Barrhead

4d-9d ton mile

and Neilston railway

Area of proposed

Cumnock branch of

Glasgow, Paisley,

Kilmarnock and Ayr

Area of proposed Scottish Central railway

$6 d$ - is ton mile

8d-10d ton mile

4d ton mile

Area of proposed Scottish Midland Junction railway

2/6d for 4 miles

$3 / 6$ d for 8 miles

$5 /$ - for 12 miles

$8 / 9$ d for 26 miles

$7 d$ ton mile
PYB(S) 1/4. B.R. 
Year Between Sost Source

(3) JOURNEYS INVOLVING SEA TRANSPORT

1837 Glasgow - London $\begin{aligned} & 4 \mathrm{~s} \text { cwt including whar- } \\ & \text { fage and delivery }\end{aligned}$

Edinburgh - London 40 s ton by steamer

Port Dundas - avg. 13s excluding

Dundee canal tolls

Port Dundas - $\quad 8 / 8 \mathrm{~d}$ ton of pig iron

Dundee

Port Dundas - $\quad 7 / 3 \mathrm{~d}$ ton of pig iron

Newcastle

Port Dundas - Hull 10/- ton of pig iron

Glasgow - Dundee 20 s ton excl. shore duties

Leith - Greenock 15s ton

1838 Aberdeen - Lonảon packages 1/6d-2/6d barrel Based on records bulk

of Aberdeen

Steam Navigation

cotton yarn 1/6d barrel Co. Data supbulk plied by Mr. Clive preserved provisions $3 /$ - ersity of barrel bulk Aberdeen

cast iron under ton $12 /-$ 1-2 tons $15 /-$.

1840 Leith - Dundee 7s-15s ton incl. shore PYB(s) 1/2. B.R. duties

Leith - Perth 9s-20s ton incl. shore duties

1845

$$
\begin{aligned}
& \begin{array}{l}
\text { Aberdeen - } \\
\text { Arbroath Dundee }
\end{array} \\
& \begin{array}{l}
\text { Glasgow - Liver- } \\
\text { pool }
\end{array} \\
& \text { Dundee - Perth ton } \\
& \text { Ds-8s ton by steamer }
\end{aligned}
$$

From the limited information that has come to light shore duties in Scotland appear to be in the region of $6 \mathrm{~d}$ to $9 \mathrm{~d}$ ton, but these may have generally been included in the cost of carriage. (PYB(S) 1/2 p.165 and PYB(S) 1/7, p.48). 


\title{
CHAPTER NINE
}

\section{THE TRANSPORTATION OF PASSENGERS}

\begin{abstract}
"Railroad travelling is a delightful improvement of human life. Man is becoming a bird, he can fly longer and quicker than a Solan goose. The early Scotsman scratches himself in the morning mists of the north and has his porridge in Piccadilly before the setting sun. Everything is near, everything is immediate - time, distance and delay are abolished."
\end{abstract}

Sidney Smith. Quoted in M. Robbins, The Railway Age. 1965. p.43.

\section{1.}

The first Scottish railways were built primarily for facilitating the transportation of coal and only gradually did thoughts turn to considering the potentialities of passenger traffic. Passengers had been carried on the Kilmarnock and Troon shortly after its opening and had also been transported on other coal lines, but not until the Dundee and Newtyle was projected in the late 1820s did the idea catch on of constructing a railway specifically with the intention of obtaining a proportion of its revenue from the carriage of persons. (1) Even before this scheme was completed, visions widened in the form of a proposal to link Edinburgh and Glasgow; again with an eye to the prospective rewards to be obtained from the conveyance of passengers. (2) Despite this, until the

1. A.C. O'Dell, Railways and Geography. 1956. p.49. Airlie Papers, G.D.16, section 38/77. bundle 3, item 1. S.R.0.

2. Prospectus, 28 December, 1831. George Stephenson believed that this railway ought to concentrate on passenger transport - "The expedious, safe and cheap conveyance of passengers being as I conceive the object which in all undertakings of this description, should be specifically aimed at." (Report. p.7. I am grateful to Mr. John Hume of the University of Strathclyde for this reference. 
mid 1830s mineral lines dominated proposals for railway construction. Capital, it would seem, was reluctant to come forward for enterprises associated with passenger travel; the eleven miles of the Dundee and Newtyle took five years to construct because of financial difficulties and the Edinburgh, Leith and Glasgow project was never started. (1)

From 1836, however, proposals for passenger lines were both more numerous and more successful in attracting finance. Perhaps this was due to the phenomenal success of the Liverpool and Manchester railway, but, whatever the reason, by 1842 Scotland possessed three major inter-urban lines linking Glasgow, Paisley, Kilmarnock, Ayr, and Edinburgh, as well as several lesser lines around Dundee, all of which catered extensively for passenger travel. In 1850 Scottish railways carried nearly nine million passengers earning 2600,000 in the process, and such traffic continued to develop until at the end of the century over one hundred and twenty two million persons were being conveyed and nearly four million pounds being earned, as can be seen in Table 9.1

$$
\text { TABLE } 9.1
$$

THE DEVELOPMENT OF PASSENGER TRAFFIC IN SCOTLAND

\begin{tabular}{|c|c|}
\hline Year & Number of Passengers \\
\hline
\end{tabular}

1850

1860

1870

1880

1890

1900

\section{Source: Railway Returns}

$\begin{array}{rr}8,844 & 600 \\ 16,493 & 1,002 \\ 27,047 & 1,553 \\ 45,597 & 2,206 \\ 75,216 & 2,834 \\ 122,201 & 3,827\end{array}$

1. Airlie Papers, op. cit., bundle 1, items 8-16; 32-40. S.R.0. 
It will be shown that, as regards the carriage of bulk commodities, the victory of the railway over other modes of transport was neither immediate nor complete. (1) This was not the case where the carriage of persons was concerned, for by 1844 it was being stated that the "railway companies may be taken, for all practical purposes, to possess a complete monopoly as far as regards the conveyance of passengers." (2) A twofold reason for this sweeping (though slightly exaggerated) success was suggested by a contemporary eulogist - "It is to be presumed that no-one will now dispute the utility of railways, or the vast superiority, in nearly all respects, of this new mode of travelling over the old, and especially in respect to those two most important considerations, the saving of time and money." (3)

As in the case of goods traffic the railways broke down monopolies, but they themselves did not offer uniform rates, following the tenet that "in fixing fares you must have great reference to the district" (and presumably the potential competition). However, if cost alone was the determining factor, the compulsory "Parliamentary train" carrying passengers at a maximum fare of a

1. See chapter ten.

2. S.C. Railways. 1844 XI. Appendix 2.

3. Bradshaw's Guide to Railway Shareholders. 1849. p.20.

4. S.C. Railway Acts Enactments. 1846 XIV. q.1149. According to one President of the Board of Trade - "the charges made by railway companies have been regulated not with respect to the maximum of toll or charge in the Railway Companies' Acts, but with respect to other modes of conveyance with which the railway companies come into competition." (Clerk of Penicuik, G.D. 18, section 3723. item I. S.R.O.). 
penny a mile would weigh heavily in favour of the railways, at least where road transport was concerned.

Jackman suggests that one factor helping the railways to undercut the stagecoaches was the differential passenger duties paid by the two modes of transport. (1) That on coaches was one farthing per mile on each passenger seat whether occupied or not, whereas the railways paid only a halfpenny a mile for every four actual passengers. In addition the coaches also bore the burden of tolls, licence duty, taxes on coachmen and guards, and an assessed tax on draught horses. However, the railways could argue that they were subject to parish rates. (2) How these balanced out is impossible to determine, and all that can be said is that on the one directly comparable tax the railways had a significant advantage. The passenger duty would accentuate the difficulties of the stagecoaches once they began to feel railway competition as they might be paying a proportionately heavier duty on a declining number of passengers.

This advantage did not hold against water transport, and in fact both coastal shipping and canal boats were able to undercut their railway rivals. The coming of the Glasgow, Paisley and Greenock railway forced its river and canal competitors to "greatly reduce" their fares, but it is significant that they were able to offer lower tariffs than the railway. (3) And in later years,

1. W.T. Jackman, The Development of Transportation in Modern England. 1962. pp.620-621.

2. See chapter eleven, section seven.

3. Railway Times, 12 July, 1841; 11 September, 1849. For other examples see H.R.J., 2 May, 1846; 30 May, 1846; Scottish Railway Gazette, 27 January, 1849; Railway Times, 29 March, 1851. 
when a shareholder of the Glasgow and South Western objected to the cheapness of passenger fares on certain routes, it was explained that the steamboats running in competition inexorably determined their level. (1)

However, competitive fares were not everything as a letter to the Railway Iimes pointed out - "the Scots are no doubt strict economists, but they understand the economy of time as well as that of money." (2) There is no question that the railways were the fastest means of passenger transport. Even in the early $1840 \mathrm{~s}$ passenger trains were frequently averaging over twenty miles an hour; well above what rival media could offer. (3) A not unbiased witness to the Select Committee on Railways in 1839 remarked in reference to the Garnkirk and Glasgow railway that "the canal opposition ... does not appear to be of much force, as the canal boats take three hours to perform the distance of eleven miles, which the railway coaches will do in less than thirty minutes: the gain of time may therefore be fairly estimated as an inducement to passengers more than equivalent to the difference of fares." (4) Corroborative evidence of the existence of such a preference for more expensive but faster travel can be seen in Table 9.2.

Speed may also have had favourable psychological attractions. Rany passengers probably echoed the thoughts of Sydney Smith "Railroad travelling is a delightful improvement of human life.

1. H.R.J., 22 March, 1884 .

2. Railway Times, 29 October, 1842.

3. Railway Times, 19 June, 1841.

4. S.C. Railways. 1839 X. q.3572. 


\section{TABLE 9.2}

\begin{tabular}{|c|c|c|c|c|}
\hline Route & Transport & $\begin{array}{r}\text { Number of } \\
\text { Passengers } \\
\end{array}$ & Fare & Time \\
\hline Glasgow-Paisley & $\begin{array}{c}\text { Canal } \\
\text { Railway }\end{array}$ & $\begin{array}{l}185,000 \\
423,000\end{array}$ & $\begin{array}{l}4 \frac{1}{2} d \\
8 d a\end{array}$ & $\begin{array}{l}60 \text { mins. } \\
15 \text { mins. }\end{array}$ \\
\hline Glasgow-Greenock & $\begin{array}{c}\text { Canal } \\
\text { Railway }\end{array}$ & $\begin{array}{l}312,000 \\
611,000\end{array}$ & $\begin{array}{l}8 d \\
1 /-\end{array}$ & $\begin{array}{r}150 \text { mins. } \\
60 \text { mins. }\end{array}$ \\
\hline
\end{tabular}

Source: S.C. Railways 1844 XI. q.5365-6366.

Man is becoming a bird, he can fly longer and quicker than a Solan goose ... Everything is near, everything is immediate - time, distance and delay are abolished." (1) Other travellers were perhaps less impressed by dynamics, preferring instead to be charmed by the "appearance of grandeur and ostentation." (2)

Jackman suggests that a further incentive offered by the railways was that of increased comfort. (3) This may not have been immediately apparent, especially in Scotland where railway passengers generally opted for cheaper travel and less comfort, even amongst "the higher classes of society. (4) The extent that this reached on some lines can be seen in Table 9.3. The management of the Garnkirk and Glasgow claimed that "Scotch folks generally are frugal to a fault" and pointed out that people would not ride in their new "handsome and well-appointed carriages." (5) Yet the decision of many passengers to travel third class or lower was

1. Robbins, op. cit., p.43.

2. Jackman, op. cit., p.658.

3. Ibid. p. 605.

4. Kailway Times, 29 August, 1840.

5. F. Wishaw, The Railways of Great Britain and Ireland. 1840. p.109. 
partly attributable to the Scottish companies offering extremely low rates for these classes, an extreme example being one farthing a mile on the Glasgow, Paisley and Greenock. (1) That third class carriages were not conducive to comfort is readily confirmed by contemporaries and it could not have helped matters when, for example on the Ayrshire line, "a calf was taken up at Dalry, its legs tied, and the animal thrown in among the feet of the passengers." (2) Yet it must be remembered what the alternative forms of transport offered. To travel inside a stagecoach could up the fare by over 50\% and to have a sabin on the Glasgow to liverpool steamer cost one pound as compared to five shillings travelling steerage. ( 3 )

\begin{tabular}{lcccc}
\multicolumn{2}{c}{ TABLE 9.3} \\
PASSENGERS & TRAVELLING IN & EACH CLASS (\%) \\
\hline Railway & First & Second & $\frac{\text { Third and Fourth }}{2}$ \\
\hline ee and Arbroath & 4 & & 16 & 80 \\
gow and Ayr & 8 & 34 & 58 \\
gow and Greenock & 9 & 27 & 54
\end{tabular}

Source: S.C. Railways. 1844 XI - Fifth Report, Appendix 2, p.12.

1. S.C. Railway Acts Enactments, op. c1t., q.1109-1lll. It was also pointed out that the fares on Scottish lines were lower than on English railways and had been from the first.

2. Quotation from Scottish Reformers' Gazette in Railway Times, 29 August, 1840. The earliest third class carriageswere uncovered and in the 1840 s many of them were without windows or lights of any kind. (Sherrington, op. cit., p.193). See also Wishaw, op. cit., pp.111-112.

3. PYB(S) 1/4. passim. B.R. The Witness, 7 October, 1840. See also Appendix One. 


\section{3.}

Although Scottish railway companies relied more on their goods and mineral traffic than did the railways elsewhere in Britain, the revenue from passengers still made a substantial contribution to the companies' balance sheets. Both these points can be seen in Table 9.4. The question to be asked is whether the benefits to the economy were commensurate with the returns obtained by the railway companies. In this section an attempt will be made to measure the financial savings of cheaper and faster transport and in the following section less quantifiable effects of railway passenger travel will be discussed.

$$
\text { TABLE } 9.4
$$

PROPORTION OF REVENUE FROM PASSENGER AND GOODS TRAFFIC

$\underline{\text { Region }}$

England \& Wales Ireland

Scotland

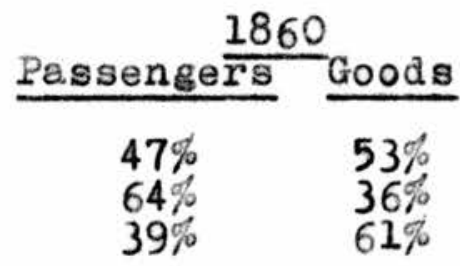

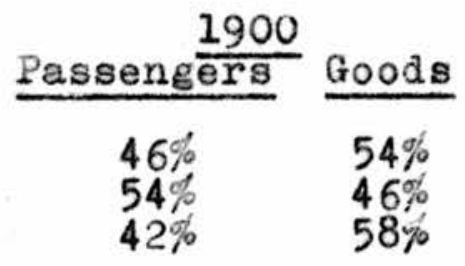

Source: Railway Returns.

To ascertain how much the railways saved in direct financial costs it is necessary to know the average rates charged by nonrailway transport prior to the coming of the railway. From the information that has been discovered (see Appendix One) it is suggested that the following "average" per mile would not be atypical: canal boats $0.96 \mathrm{~d}, 1.42 \mathrm{~d}$; stage coaches 2.20d, 3.50d; 
west coast sea-going vessels $0.25 \mathrm{~d}, 1.00 \mathrm{~d}$; and east coast vessels $0.81 d ; 1.35 d$. (1) As with freight, there is the question of the normality of the west coast figure, but since, in the case of freight, the use of this rather than the east coast figure would have altered the total direct savings by only $8 \%$ the west coast figure was again taken for the purposes of calculations. It was also assumed that the proportion of first class to other passengers was the same on the transborder flows as in other traffic ( $12 \frac{1}{2} \%$ ) and that first class rail pessengers would pay the higher of the two averages for each type of non-rail transport when travelling by on such media. (2) The typical railway passenger fare was cl.30d a mile and so it can be seen that the railways had no strong price advantage over water transport, but a substantial one where road

1. These averages are median figures derived from the information given in appendix one. The highest figure given refers to the best aervice offered; the lower to the standard service. only one observation was available for the west coast route which might bias the estimates, but it was for the main service and might thus be typical.

2. The proportion of first class passengers for each company was Caledonian 11.7\%; G.S.W. 9.8\%; G.N.S. 12.6\%; Highland 14.3\% and North British $14.1 \%$. 
travel was concerned. (1)

In estimating the direct financial savings of railway passenger transport the technique adopted was the same as that employed in calculating the savings in freight transportation, though on this occasion there are no problems of private wagons or exceptional rates to complicate the issue. The major assumption in this instance was that first class passengers would travel by stage to their embarkation point whilst other passengers would walk.

The results obtained are summarised in Table 9.5. It is noticeable that the direct savings made in the carriage of passengers is substantially less than in the transport of freight. Differences in the volume of each type of traffic partly account for this, but the two major reasons appear to be, firstly, the assumption made above about walking which reduces the potential volume of road transport which the railways could have cut, and,

1. Between 1840 and 1866 each railway company was compelled to supply details of its average fare per mile, but the method of compilation was such as to provide a theoretical rather than a true average. The instructions given by the Board of Trade were to "divide the total obtained by adding together the fares charged from either terminus of the line to every single station on the line (including branches) by the total obtained by adding together the distance (in miles) of such terminus from each station." This obviously ignores any weighting which the flows of passengers and their distribution between classes would necessitate if a true average fare was to be obtained. A more realiatic average can be obtained for the years when statistics of passenger miles travelled were kept by dividing this total into the total of receipts for passenger traffic. This average allows for different classes, season tickets, party discounts, parliamentary fares, cheap day returns etc. Unfortunately, for scotland the passenger mileage figures are comir eh ensive only between 1856 and 1859; however for these jears the average fare per mile came to $1.28 \mathrm{~d}, 1.32 \mathrm{~d}, 1.30 \mathrm{~d}$ and 1.28 , a remarkable degree of stability. It is interesting to note how much cheaper it was to travel alive than dead for the usual rate for a cor-

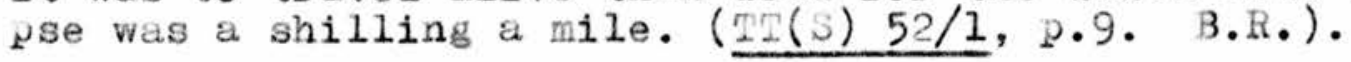




\section{TABLE 9.5}

SAVINGS ON RAILWY PASSBNGER THAVEL IN 1867

\begin{tabular}{|c|c|c|c|c|c|c|}
\hline Iraffic & Passengers & $\begin{array}{l}\text { With or } \\
\text { without } \\
\text { railways }\end{array}$ & $\begin{array}{l}\text { Form of } \\
\text { transport }\end{array}$ & $\begin{array}{l}\text { Mi } \\
\text { (a) }\end{array}$ & $\begin{array}{l}\text { eage } \\
000 \\
(b)\end{array}$ & $\begin{array}{l}\text { Cost } \\
2.000\end{array}$ \\
\hline \multirow[t]{4}{*}{ (A) } & \multirow[t]{4}{*}{297} & \multirow[t]{3}{*}{ Without } & \multirow{3}{*}{$\begin{array}{l}\text { Canal } \\
\text { East Coast } \\
\text { Sea } \\
\text { West Coast } \\
\text { Sea } \\
\text { Coach* }\end{array}$} & 866 & 6061 & 29 \\
\hline & & & & 3947 & 27632 & 115 \\
\hline & & & & $\begin{array}{l}4458 \\
1053\end{array}$ & 31205 & \\
\hline & & With & $\begin{array}{l}\text { Rail } \\
\text { Coach** }\end{array}$ & 286 & & \\
\hline
\end{tabular}

(B)

603

Without

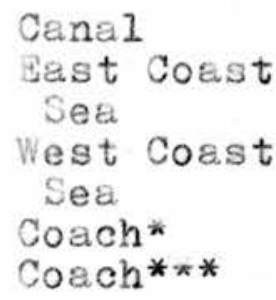

$1517 \quad 10619$

52

$204314301 \quad 60$

$2584 \quad 18088 \quad 30$

$2446 \quad 35$

$330 \quad 2312$

$\frac{26}{203}$

With Rail

Coach**

813

$\frac{12}{229}$

Estimated saving-£2 $\overline{6,000}$

(c) 21,280

Without Coach***

$27241 \quad 173044$

1984

With

Rail

Coach** 19944

1105

$\frac{290}{1395}$

Estimated saving $£ 589,000$

Notes: (A) Transborder (excluding unknown Caledonian)

(B) Internal Scottish traffic (from Clearing House Data)

(C) Residual Scottish traffic (from Railway Returns)

(a) lst class passengers

(b) Non lat class passengers

* To and from a water point [only to in $(A)$ ]

* To and from a railway station [only to in $(A)$ ]

*** Unbroken journey. 
secondly, the greater differentials between the respective road and rail charges in the case of goods. It is to be noted that in one class of passenger traffic the railways were actually more expensive than other forms of transport, even at their pre-railway prices. This and the low direct savings on the transborder traffic would suggest that the saving of money by the saving of time may have been the key factor in the victory of the railway, especially where long distance travel was concerned.

The direct savings continued to be made for the rest of the century. New reductions were bound to come as the railway network extended into regions and districts previously reliant on coach and cart. However, a rough index of fare changes on railway routes in existence in 1855 also shows further reductions as the century progressed. In fact the figures in Table 9.6 imply that direct fi nancial savings to passengers increased by about 10\% during the last thirty years of the century without taking into account the increase in the number of passengers, a proportion of which must have been a response to lower fares.

That there was a price elastic demand for passenger transport can be demonstrated from the Garnkirk and Glasgow losing customers as it progressively raised its fares, as is shown in Table 9.7. However, the general argument is that the railways demonstrated the existence of price elasticity of demand by lowering the cost of travel. Examples of rapia development in passenger travel following the coming of a railway were cited by the famous Scottish railway engineer, Grainger. These strongly support the hypothesis of the railways' low rates not merely attracting passengers from 


\section{TABLE 9.6}

\section{INDEX OF THE COST OF PASSENGER TRAVEL$$
1855=100
$$

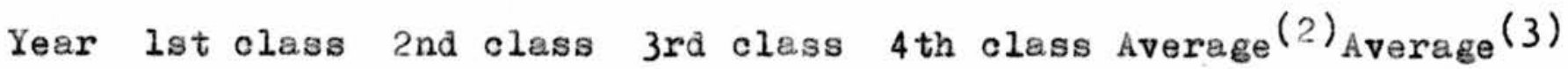

$\begin{array}{rrrrrrr}1855 & 100 & 100 & 100 & 100 & 100 & 100 \\ 1870 & 97 & 93 & 100 & 100 & 99 & 98 \\ 1880 & 96 & 92 & 99 & 99 & 99 & 97 \\ 1890 & 95 & 91 & 97 & \text { n.a. } & 97 & 96 \\ 1900 & 91 & \text { n.a. } & 91 & \text { n.a. } & 91 & 91\end{array}$

Source: Railway Timetables - B.R.

Notes: (1) Based on a sample of fifty routes both long and short distance. One trouble is that second class was abolished generally in Scotland in 1893 and had been abandoned by several companies before then. There had also been a mingling of third and fourth classes and the constitution of each was open to wide interpretation between the companies.

(2) Weighted by the number of passengers in each class on Scottish railways as a whole.

(3) Weighted by passenger receipts in each class on Scottish railways as a whole.

\section{TABLS 9.7}

PASSENGERS ON THE GARNKIRK AND GLASGOW RAILWAY

\section{Year}

To April 1836

To April 1837

To April 1838

To April 1839
Fare

$6 \mathrm{~d}$

$8 d$

$8 d$

$10 \mathrm{~d}$

\section{Number of Passengers}

12,733

9,594

9,798

6,989

Source: S.C. Railways 1839 X. q.3455. 
other forms of transport, but strikingly tapping latent demand. (1) Accepting Grainger's dictum that for Scotland "a low rate of charge is quite essential to the very existence of a passenger traffic" it can be argued that without the advent of the railway age the mobility of persons would have been seriously handicapped by high costs. (2)

The saving of time must also have contributed to increased mobility; the coming of the transborder railway for example reduced the time of a journey between Edinburgh and London from

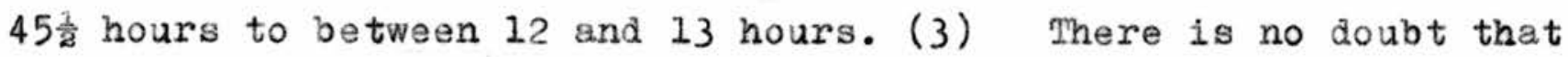
as the century progressed the railway traveller in scotland could reach his destination quicker and more conveniently. This is clear from Table 9.8 which shows the development in this respect of services between the major Scottish towns and cities. The main reasons for this were technical developments in mechanical and civil engineering which rendered faster speeds feasible, and amalgamations within and extengions of the railway network which allowed greater through travel. (4) In addition, towards the end of the century the bridging of the Tay and Forth estuaries drastically

1. S.C. Railways, op. cit., q.3454.

2. Ibid.

See also S.C. Railway Acts Bnactments, op. cit., q.1223-1226.

3. A.C. O'Dell, 'A Geographical Examination of the Development of the Scottigh Railways,' Scottish Geographical Magazine, vol.55, 1939, p.147.

4. The convenience of through journeys can be illustrated by the fact that prior to the Edinburgh and Glasgow railway it was planned to carry passenger: from Glasgow to gdinburgh via a combination of rail and canal transpor $t$ which, including stoppages, would take almost four hours. The building of the through line cut the time to about one hour and a half. (HRP(S) 1, (15) and official timetables. B.R.). 
TABLE 9.8

INDEX OF SPEED AND CONVENIENCE $(1855=100)$

\begin{tabular}{|c|c|c|c|c|}
\hline Year & Mode of Transport & $\underline{A}$ & $\underline{B}$ & $\underline{\mathrm{C}}$ \\
\hline $\begin{array}{l}1840 \\
1855 \\
1860 \\
1865 \\
1870 \\
1875 \\
1880 \\
1885 \\
1890 \\
1895 \\
1900\end{array}$ & $\begin{array}{l}\text { coach } \\
\text { railway } \\
" \text { " } \\
" \text { " } \\
" 1 \\
" \\
"\end{array}$ & $\begin{array}{r}45.4 \\
100.0 \\
101.7 \\
118.1 \\
118.9 \\
120.6 \\
127.1 \\
129.4 \\
146.6 \\
162.1 \\
172.1\end{array}$ & $\begin{array}{r}n \cdot a . \\
100.0 \\
99.8 \\
115.7 \\
120.2 \\
118.1 \\
124.8 \\
129.3 \\
148.6 \\
163.5 \\
176.1\end{array}$ & $\begin{array}{l}58,76^{*} \\
100.0 \\
100.0 \\
123.5 \\
147.1 \\
158.8 \\
170.6 \\
182.3 \\
200.0 \\
217.6 \\
247.0\end{array}$ \\
\hline
\end{tabular}

Source: Official timetables for railways and Post Office directories for coaches.

Key: $\quad A=$ speed of fastest service including delays while changing trains

$B=$ average speed of five fastest services

$\mathrm{C}=$ number of services available on weekdays.

Notes: * counting the royal mail

This is an unweighted index of services between Aberdeen, Ayr, Berwick, Carlisle, Dundee, Edinburgh, Glasgow, Perth and Stirling. It may thus be unduly influenced by the crossing of the Firths of Tay and Forth in the last two decades of the century. It has to be unweighted as detailed trafic flows on inter-urban routes are not available.

cut the times of journeys north. There was also the intense rivalry of the railway companies which ensured that any innovation leading to faster travel would be agopted. If was this spirit of competition that stimulated the famous "railway races" of $1888 / 1895$ between the east and west coast transborder routes. These racss, however, proved to be more allied to the prestige of the companies than to the convenience of the passengers - who wants to arrive in Aberdeen at 4.32 in the morning? - and were eventually abandoned by 
mutual agreement. (1) Inter-company rivelry may also account for the increase in the number of trains available, which allowed stoping services to be operated without detriment to express services. To assess the monetary significance of the faster travel brought about by the rallways it is first of all necessary to estimate how many hours were saved. This has to be done for 1867 so as to fit in with previous calculations, but unfortunately the last year for which passenger mileage figures are available is 1859. However, if a constant proportionality is assumed between passenger receipts and passenger mileage then approximately 267.5 million miles were covered by railway passengers in 1867 . (2) Assuming that the average speed of a stagecoach was between 7 and 10 miles per hour and that of a passenger train 25 to 30 milles per hour, then if all railway passengers in 1867 had had to travel by coach a total saving of between 16.05 million and 29.30 million hours was made. (3) However, this should be reduced by $13 \%$ because of the greater directness of road transport. Great difficulties arise when a value has to be placed on the time saved as several studies of modern transport developments have

1. Glasgow Weekly Mail, 24 August, 1895. A.C. O'Dell, op. cit., (1956). p.179.

2. The stability of this relationship in the years 1856/59 has already been noted.

3. The average for coaches was based on estimates given to the Parliamentary Committees on Railway Bills (PYB(S) $1 / 1-1 / 7$. B.R.) and the average for trains from two random samples of 1867 timetables. It is, of course, being assumed that in the absence of railways no breakthroughs would have been $m_{\varepsilon}$ de as regards other transport media that would have significantly increased their speed. 
demonstrated. (1) Without a breakdown of passengers into occupational groups and without knowing the reasons for their travellinf (business, pleasure, etc.) it is not possible to accurately assess the value of each hour saved. Dr. Lardner did suggest that "travellers in general belong to the superior and more intelligent classes" whose "time is proportionally more valuable," but unfortunately his was a qualitative not a quantitative approach. (2) However, if speed was the sole determinant of the choice of those using the railways shown in lable 9.2 then these people placed an average value of between $2.67 \mathrm{~d}$ and $4.67 \mathrm{~d}$ an hour on time. (3) For the purposes of the calculations an average value of $3.67 \mathrm{~d}$ an hour was taken, but to assume this is to implicitly take that sixty savings of one minute equals twelve savings of five minutes equals one saving of an hour, which is denied even by the example from which the average was derived. The complexities of consumer surplus are such as to render it impossible to deviate from the assumption if any estimates are to be made. A further difficulty stems from the fact that the valuation was

1. See R. Millar and D. Sawers, The Technical Development of Modern Aviation. 1968; C.D. Foster and M.E. Beesley, Estimating the Social Benefit of Constructing an Underground Railway in Iondon,' Journal of the Royal Statistical Society, vol.126, part 1, 1963; 1. B. Besley, The Value of Time Spent in Travelling: Some New Evidence,' Economica, vol.XXXII, no.126, May, 1965; N.R. Gillhespy, - The Tay Road Bridge: A Case Study in Cost-Benefit Analysis,' Scottish Journal of Political Economy, vol.XV, no.2, June, 1968. 2. D. Lardner, Railway Leonomy. 1850. p.13.

3. This is perhaps not too unreaiistic as average wage data (see the appendix to chapter eicht) coupled with Beesley's (op. cit.) calculations of leisure time being valued at one-third of working time suggest a general valuation of working class time at $2.4 \mathrm{~d}$. 
obtained from 1844 data and this should be price adjusted if it is to be used for 1867; but with what? Average wage data would suggest an increase of perhaps $25 \%$ but not all travellers were workers. In the face of this impasse it is more convenient, if less valid, to ignore indice problems and use the 1844 data uncorrected.

Applying the value of $3.67 \mathrm{~d}$ an hour to estimates of total time saved suggests that somewhere between $£ 213,000$ and $£ 390,000$ was saved by the railways speeding up transport. The total in fact may be higher because a proportion of the persons traveling by train in 1867 might have considered walking as the alternative form of transport. No attempt was made to differentiate between generated and other traffic, because of the difficulties alluded to in the previous chapter, but it should be noted that the two types of traffic would not gain equally from the faster journeys made feasible by the railways. (1) Coupled with the direct financial savings from cheaper and nore flexible transport the railways probably saved passengers in 1867 somewhere in the region of $£ 785,000$ to $£ 963,000$. The significance of this, together with the savings from freight transpoct will be discussed in chapter twelve. In addition travellers must have benefited from the development of competition in facilities in the later nineteenth century •

No calculations of savings from accidents have been attempted, partly because no figures exist for non-railway accidents and 
partly because of the difficulties associated in placing a value on human life and limbs. The official accident reports of the railway department of the Board of Trade, however, do not suggest that the railways were a particularly accident-free mode of travel. Finally, in the case of freight there was an extra saving in the form of traffic on road, sea and canal travelling at reduced rates, but this is less important as regards passengers because of the domination of the railway in this sphere of transport.

\section{4 .}

The development of pleasure traffic was a socio-economic phenomenon, but predominantly it was a response to a low price stimulus. Such traffic went at cheap rates partly because it was not subject to passenger duty, but mainly because the railway companies aimed only at covering operating expenses and making some contribution to overhead costs. (1) This type of traffic developed quickly for by the early 1840s the Glasgow and Greenock line was "regularly crowded with sea-bathing folk" and other lines were giving special facilities for parties of e.g. Oddfellows and teetotallers. (2) Even earlier the Kilmarnock and Iroon had

1. NBR 1/5, p.130. B.R.

Railway Times, 7 June, 1851. RAC(S) I/IA, 20 March, 1851. 3.R. For the same reason discount ves offered on femily tickets or bloc bookings, but to guard against abuse such applications were entertained only from "respectable" householders. (TI(s) $52 / 1, p .22$, B.R.).

2. Railway Times, 31 July, 1841. Glasgow Constitutional, 13 July, 1842. 
enabled the latter resort to become "a fashionable sea-bathing town." (1) By 1850 the North British, for one, was involved in Thomas Cook's pleasure trips and such tours into scotland were well established by the early 1860s. (2) Tourism and the sporting traffic was undoubtedly stimulated by the railways, and they in turn obtained ample reward for their expenditure on advertising, on hotels and on special services. In fact the directors of the Highland maintained that tourism was "the great prop of our line" and the other major northern line also set great store by such traffic. (3) Overall it is reasonable to argue that the social and economic effects of tourist and excursion traffic were beneficial to Scotland though it must be born in mind that such traffic may have forced the railway companies to invest in rolling stock which may not have been economically utilised.

Another effect of railway passenger travel was the creation of dormitory areas, e.g. Newport and Tayport when linked to Dundee by the Tay bridge, and residential suburbs such as Lenzie. (4) The development of such areas was often the deliberate policy of the railway companies who offered cut-rate fares to persons (and often to their families as well) who constructed houses along the line but away from the main centres of population. (5) Their 1dea in doing this was to obtain the income not only from the passengers

1. A traveller of 1829 quoted in O'Dell, op. cit. (1956) p.149.

2. NTSR $1 / 5$ passim. B.R. HRP(S) $51 . p .244$. B.R. H.K.J., I8 June, 1859.

3. H.R.J., 7 May, 1881; 10 October, 1881.

4. ODDell, op. cit., p.140.

5. e.s. apecial fares would be offered to children travelling to school (NBR $1 / 3$, p.160. B.R.) and $65 \%$ could be saved on a twelve month ticket (NBR 1/5, 18 April, 1850) B.R. 
but also from transporting the goods which the new urbac dwellers would require. Cheap fares by themselves may not have been enough to stimulate building, but the railways were also able to offer "convenience, regularity and speed."

It was hoped in some quarters that the construction of lines in the Highlands would create enough employment to put an end to emigration. (2) Others thought the railways would offer a different solution by encouraging "people to settle on the land, and by bringing them within easy reach of populous centres remove one of the chief reasons for quitting remote districts." (3) However, despite evidence of some residential building they were forced to acknowledge that "the building of none of the railways that penetrate the Hichlands has been attended to by an increase of population en route." (4) Whilst bearing in mind that correllations between two sets of statistics prove nothing because other factors might be at work, it is 1lluminating to see what happened to the northern population when the railways arrived. Table 9.9 shows the alterations in the total population of three northern counties and of Scotland as a whole over the nineteenth century. It might, judging from the evidence in the table, be suggested that the coming of the railways in facilitating movement, and perhaps making the Highlander more aware of the outside world, accelerated the

1. S.C. Rural Transport (Scotland) 1919xxx, paragraph 77 .

2. The views of one Highland M.5. on the anticipated benefits of the Dingwall and Skye line can be seen in H.R.J., 30 July, 1864.

3. S.C. Rural Transport (Scotland), op. cit., paragraph 77.

4. Ibid., paragraph 46 . 


\section{TABLE 9.9}

ABSOLUTE CHANGES IN TOTAL POPULATION 1801-1901 $(\cdot 000)$

\begin{tabular}{|c|c|c|c|c|}
\hline Period & Caithness & Sutherland & Ross and Cromarty & Scotland \\
\hline $\begin{array}{l}1801 / 11 \\
1811 / 21 \\
1821 / 31 \\
1831 / 41 \\
1841 / 51 \\
1851 / 61 \\
1861 / 71 \\
1871 / 81 \\
1881 / 91 \\
1891 / 1901\end{array}$ & $\begin{array}{l}+0.8 \\
+5.8 \\
+5.3 \\
+1.8 \\
+2.4 \\
+2.4 \\
-1.1^{*} \\
-1.1 * \\
-1.7^{*} \\
-3.3^{*}\end{array}$ & $\begin{array}{l}+0.5 \\
+0.2 \\
+1.7 \\
-0.7 \\
+1.0 \\
-0.5 \\
-0.9^{*} \\
-0.9^{*} \\
-1.5 * \\
-0.5 *\end{array}$ & $\begin{array}{l}+4.6 \\
+7.9 \\
+6.0 \\
+3.8 \\
+4.0 \\
-1.3^{-1} \\
-0.4^{*} \\
-2.4^{*} \\
-0.7^{*} \\
-2.3^{*}\end{array}$ & $\begin{array}{l}+197.4 \\
+285.7 \\
+272.8 \\
+254.8 \\
+267.4 \\
+173.5 \\
+272.8 \\
+399.5 \\
+280.0 \\
+446.5\end{array}$ \\
\hline
\end{tabular}

Source: Census of Scotland.

Note: Railway existing in the county is signified by *

migration from the more distant areas. Whether on balance the gain to the areas to which they moved outweighed the loss to the Highlands is a matter for conjecture.

As regards shorter distence mobility there is much in Lardner's comment that "when cheapness can be sufficiently combined with speed, considerable advantage is gained by the operative classes." (I) The Parliamentary trains and the running of third class carriages did offer cheapness, but, as a Board of Irade of ficial pointed out in 1872, "this traffic is carried on at present under great disadvantages; of inconvenient hours, of slow travelling etc." (2)

1. Lardner, o. cit., p.13.

2. S.C. Railway Companies Amalgamations. 1872 XIII. Appendix $N$, p.825. One example is the decision of the North British to attach third class carriages to only one train in the morning and one in the afternoon on their through routes. (NBR 1/4, April, 1848. B.R.). 
For pleasure purposes this may not have been too deleterious, but it could have had adverse economic effects. Not until 1883 were compulsory Workmen's Trains with special cheap fares inaugurated. The result of this in London was a mass migration of the working classes to the suburbs and this nay also have been true of Glasgow. (1) By 1899 over eleven million Scottish workers per annum were using these special trains in addition to those obtaining reduced fares on other trains. (2)

One final economic effect of rail passenger transport which does not lend itseif to easy quantitative analysis is that of traders' tickets. Special tickets at reduced rates were frequently issued to traders using the line for business purposes. On the North British a treder giving the company 21,500 worth of business could obtain unlimited first class travel over two hundred and fifty miles of track for $\$ 38 / 12 /$ - per annum with proportionate reductions for smaller distances and different classes; representatives could obtain up to twenty per cent discount on tickets. Although existing to a limited extent in England these special tickets appear to have been universal in Scotland. (3) Such privileges may well have discriminated in favour of big business, but arguing the pros and cons of large scale organisation is beyond the scope of this thesis.

1. H.J. Dyos, 'Railways and Housing in Victorian Iondon,' Journal of Transport History, vol.2, no.2, 1955. p.91. However, it should be noted that of 160,000 trade union members in South London who were questioned in 1897, well over three-quarters used no public transport for journeys too and from work. (M. Robbins in The Journal of Transport History, vol.2, no.3, May, 1962, p.194).

2. Parliamentary Papers. 1900 LXXVI (Part one). p.338.

3. S.C. Railway Rates and Fares. 1882 XIII. q.541. 


\section{APPENDIX ONE}

\section{Cost of Non-Railway Passenger Transport}

Year

Between

Cost

Source

(1) $\mathrm{COACH}$ IRAVEL

1830 London - Edinburgh

$26 / 15 /-$ $23 / 10 /-$

C.G. Harper, 'The Great North Road,' 1901, 0.55 .

1830 Edinburgh - Glasgow

1837 Lanark - Glasgow

1837 Palkirk - Edinourgh

Glasgow - Stirling

Ayr - Edinburgh

Glasgow - Edinburgh

1838 General

1840 Edinourgh - Ayr

Edinburgh - Kilmarnock

1840 Edinburgh - Dundee

Cupar - Edinburgh

1845 Area of proposed Aberdeen railway

Area of proposed Caledonian railway
$11 /-$

Report to Subscribers of the Edinburgh, LeIth and G1asgow Reilway,

4/6d Joshua Richardson, General Report on the Newcastle, Sdinjurgh and Glasgow Railway, p.29.

$6 /-\quad$ PYB(S) $1 / 7 . \quad B . R$.

$9 /-$

EI $/ 2 /-$

$13 /-6 \mathrm{~d}$

4.5d per mile R.C. Railways, 1867

2.5d per mile XXXVIII, p.Iiii.

$18 /-$

The Witness, 7 October, 1840

$16 /-$

$10 \%-$

$16 /-$

$12 /-$

$\operatorname{PYB}(\mathrm{S}) 1 / 2 . \quad B . R$.

$8 /-$

average

3.5d per mile PYB(S) 1/4. B.R.

2.0d per mile

3.Od per mile 
Year Between

1845 Area of proposed

Clydesdale Junction

Railway

Dundee - Perth

Edinburgh - Hawick

Area of proposed

Barrhead and Neilston

railway

(2) CANAL BOALS

pre Aberdeen Canal

1830

Aberdeen - Inverurie

pre- Paisley canal

railway

1837 Glasgow - Edinburgh

Glasgow - Stirling

Glasgow - Falkirk

1839/ Edinburgh - Glasgow 40

2.0d per mile for short distances

$$
2 /-
$$

3. Od per mile

$$
\begin{aligned}
& 6 / 5- \\
& 4 /- \\
& 2 /- \\
& 3 /- \\
& 2 /-
\end{aligned}
$$

$6 / 6 \mathrm{~d}$

$4 / 6 \mathrm{~d}$
Source

PYB(S) 1/4. B.R.
Jean Lindsay in the Journal of Mransport History, vol. VI, no.3, p.156.

Stephenson Jocomotive Society, 'The Glasgow and South Western Railway.' 1950. p.7. PYB(S) $1 / 7$. B.R.

\section{(3) COASTAL SHIPPING}

Average
$1836 /$ Aberdeen - London
44

1841 Glasgow - Liverpool
$\{3 / 4 / 3 d$

$£ 2 / 2 / 4 d$

$£ 1$
Calculated from information supplied by ins. Clive lee of the University of Abardeen.

L. Hill to Chas. Stewart, 27 January, 1841. 


$$
\text { - } 508-
$$

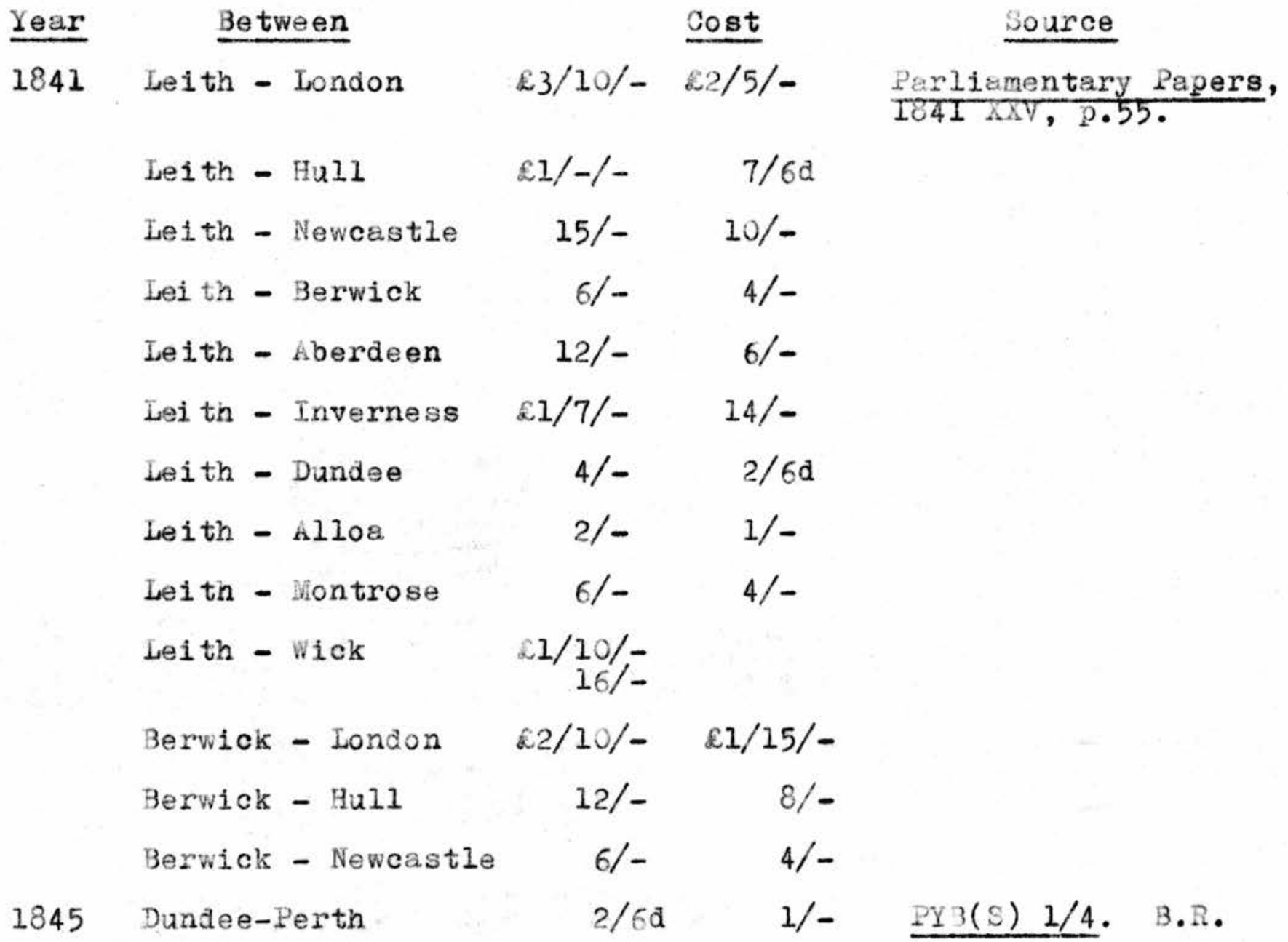


CHAPTER TEN

\section{RAILWAYS AND OTHER TRANSPORT MEDIA}

"Within the first twenty years of the railway era, this young giant had overshadowed all other systems of carrying, some of which had taken centuries for development."

W.T. Jackman, The Development of Transportation in Modern England. 1962 edition. p.665.

"An account of inland transport in the late nineteenth century and of the changes that were taking place in it must ... be centred on the history of the railways, with other modes of transport viewed principally in relation to the railways."

W. Ashworth, An Economic History of England 1870-1939.

\section{1.}

In the previous two chapters reference has been made to the various advantages that railways held, or were supposed to hold, over other forms of transport. Here the effects of these advantages in aggregate on the non-railway forms of transport will be examined. In this section the impact of the railways on roads and road-users will be assessed; in section two their effect on the Scottish canals; and finally the results they had on shipping, both coastal and ferry.

To evaluate the impact of the coming of the railway on the fortunes of turnpike trusts, the revenues of trusts known to be in competition with railways were contrasted with the revenues of all Scottish trusts and also with random samples of trusts that may or may not have been challenged by the formation of railways. 
The results, shown in Table 10.1, make it clear that the construction of a competitive railway bode financial evil for a turnpike; trusts competing with railways experienced a fall in income more than twice as great as Scottish turnpikes as a whole in the period $1834 / 35$ to $1848 / 49$, and, as railways consolidated their networks and built up their traffic, competing turnpikes continued to suffer a greater decline in revenue than turnpikes in general. It should be pointed out, as did the Select Committee on Turnpike Trusts in 1839, that it was not only the railways that were having a depressing influence on the trusts; coastal and river steamers were taking traffic away and perhaps some fixed rates bore too heavily in periods of low prices, but the fact remains that when a railway did compete against a turnpike there was no doubting the victor. (1) Writing in 1841, one observer commented, "Her turnpike roads, once the boast of Renfrewshire, are about to be eclipsed by railways." (2)

The traffic estimates submitted in the Parliamentary petitions of the railway companies suggest that they were quite confident of attracting most of the traffic travelling on roads par allel to the line. It would also seem that the turnpike trustees were well aware that the railways were dangerous rivals for many of the railways were not only forced to buy off their opposition but were, in

1. S.C. Turnpike Trusts. 1836 XIX. Railway Times, 8 August, 1840.

2. Third Statistical Account of Renfrew. 1962. p.62. 


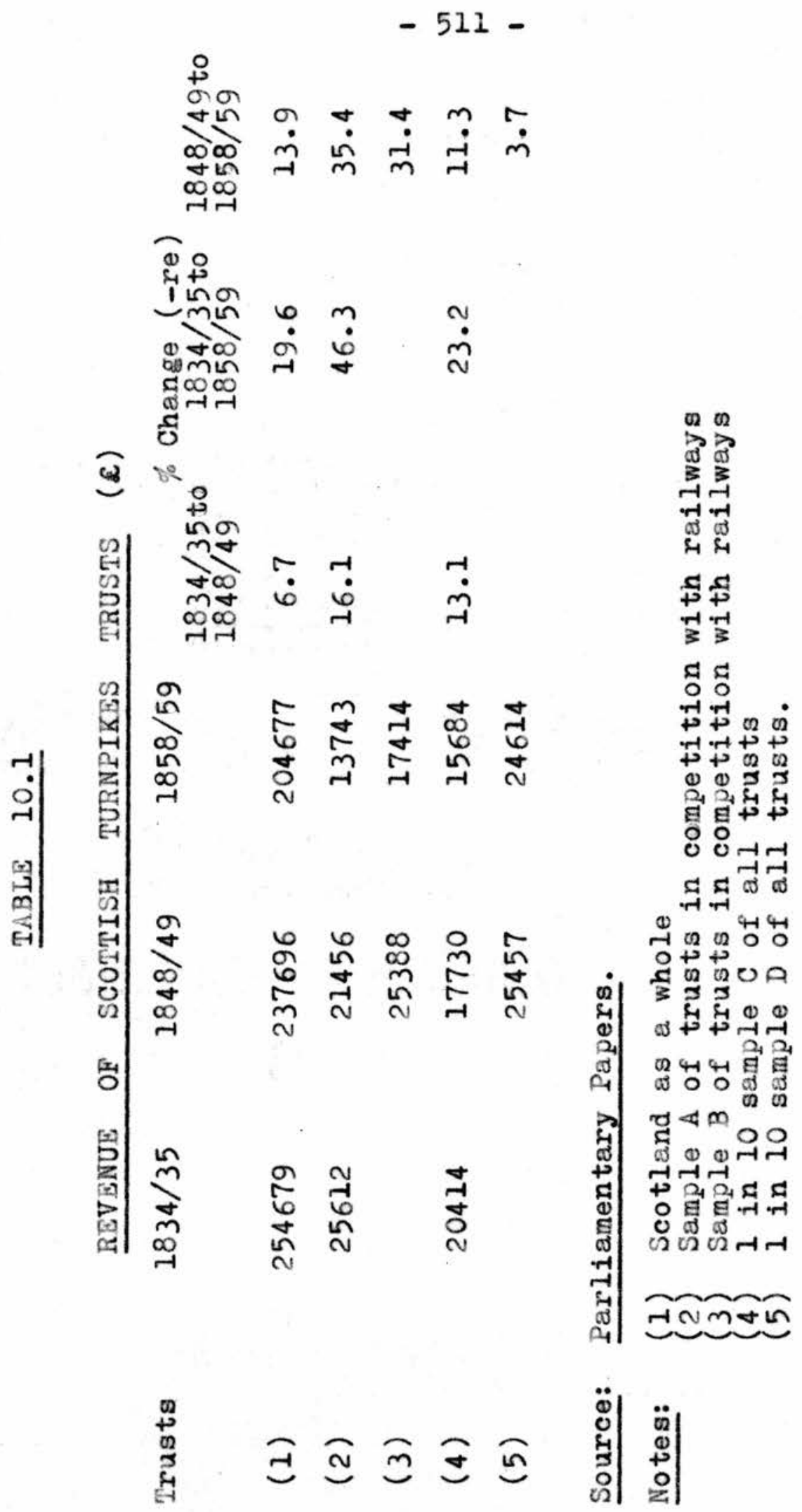


te majority of cases prior to the railway mania, also expected io undertake responsibility for relieving the trustees of a portion of the debt for which the trustees were liable. (1) This was not customary in England but lasted in Scotland until the mid 1840s when, after an attempt to introduce a clause into all Scottish rallway bills making for full compensation for turnpike traffic losses, it was decided by the House of Commons that no claims for contingent losses could be sustained by either the subscribers or creditors of the road trusts. It was argued in some quarters that the social benefits of turnpike roads entitled the subscribers to protection from something which they could not have en visaged happening at the time of making their subscription, but against this it was pointed out that the social benefits of the railways just as much entitled their subscribers to protection from being saddled with the debts of the road trustees. (2)

Not all turnpikes were damaged by the advent of the railway in their locality. The Select Committee cited above had no doubt in declaring that "it appears that nearly all roads or highways leading to stations, or termini, of steam communication have increased in their traffic." (3) There is no reason to assume that this conclusion was invalid for scotland, especially when there is evidence that a turnpike built to link the Arbroath and Forfar line with Brechin enjoyed a considerable volume of traffic. (4)

1. G.D. 135, box 82, bundle marked Edinburgh and Dalkei th Railway, S.R.0; RAC(S) I/1A, 31 July, 1844. B.R.; G.D. 206, section

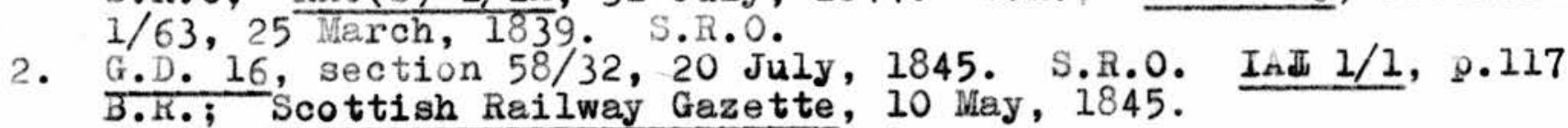

3. S.C. Turnpike Irusts, op. cit, p.iv.

4. Railway Times, $9 \mathrm{July}, 1842$. 
However, whether the conclusions of 1839 would hold in 1858 when branch lines had weakened the utility of turnpikes as feeders is debateable. Turnpike revenues as a whole were on the decline and it may well be that carrying traffic to a railway station merely retarded the fall for individual roads.

As for the users of the roads, it is quite clear that the railways soon replaced the horse or the horse and gig as the mode of transport for commercial travellers, although contemporary statements rather than statistics have to be relied upon in maintaining this. (I) However, as regards carriers and carters some quantifiable information is obtainable from the Edinburgh and Leith Post Office Directories. In $1838 / 9$ the number of journeys made by carriers each week from the metropolis to other towns and cities in Scotland, as well as to several important north of Ingland cities, was 660. This involves some double counting as a carter might visit more than one town on a trip, but even allowing for this a fall in the number to 231 within twenty years is significant evidence that the railways had a detrimental effect on the long distance carrier, especially when it is born in mind that the railway network was by no means complete at this date. On the other hand the substantial evidence of contracts made by the railway companies with local carriers coupled with the development of the parcel post suggests a different story where intra-community cartage is concerned. (2) C. Robb and Company, for example, who had previously

1. J. Mitchell, Reminiscences of My Life in the Highlands, 1883. vol.2, p.76.

2. T.E.S.S., $1883 / 84$. p.8. Scottish Railway Gazette, 13 November, 1847. 
acted as general carriers between Glasgow and Kilmernock, found it more profitable to become carters for the railway companies in Glasgow and other large towns. (1) Some of the rallway companies did their own carting e.g. the Edinburgh and Glasgow to 1847 and then Glasgow and South Western from 1861, others, such as the North British until 1879, preferred to employ recognised carters under contract, but which ever method was adopted it became the custom to cart free. This had not always been the case and presumably arose out of the intense rivalry that characterised the nineteenth century Scottish railway relationships. Support for this view comes from the chairman of the North British who told the shareholders in 1875 that "so long as it is the custom to cart free, the North British must do what its neighbours do." (2)

Carriers were of course concerned with goods, passengers were the province of the stage coaches in the pre railway era. The greater speed of the railway should in itself have attracted many of the old

1. The Bailie, 22 April, 1896.

2. Scottish Railway Gazette, 13 November, 1847. H.R.J., 14 September, 1861 . Railway Times, 5 October, 1875. Interesting light on why the North British entered the carting trade is shed by a Memorandum of 25 February, 1924.

(H.R.P.(S) 12 B.R.). It had been their general policy to employ two sets of carters in Glasgow and Edinburgh so that competition would keep each set efficient. However, in 1879 when the sole surviving propriet or of one firm, J. \& B. Cameron, died without heirs, the North British purchased the firm so as to prevent the Caledonian interests taking it over. They had, however, to run it as a private concern since they had no statutory powers to become carters themselves. In retaining the name of the previous owner they had the secondary consideration of preventing a nephew of the late $\mathrm{Mr}$. Cameron using it to obtain the goodwill that the reputation of his uncle had produced. 
coach passengers to the new form of travelling and this appears to have been the general case with most competitive coaches disappearing virtually overnight (or in the case of coaches carrying mails at the end of their contract). (1) Such was the overwhelming competitive advantage of the railway that when, in spite of available railway accommodation, the Glasgow to Stirling coach was found to be in high demand, the Railway Chronicle was led to remark that there must be something very wrong with the management of the railway company. (2) It ought to be pointed out that several of the early railways did not put coach companies out of business simply because before the railways came into operation there was insufficient demand to maintain a coach service and that to a great extent the railways created their own traffic. (3) However, this is not the full story for several coach proprietors realised that they could survive as viable enterprises until the railway network of Scotland was fully mapped out. This could be done by running coaches in connection with rallway services, which in view of the great increase in passenger traffic developed by the railways, might well have proved profitalo. Against this is the fact that when the Caledonian at empted to do it they found their

1. Railway Times, 12 Morch, 1842 . H.R.J., $14 \mathrm{JIy}_{1} 1855$.

2. Rallway Chronicle, 14 September, 1850.

3. S.C. Railways. 1839 X. q.3455. 
expenses outweighing their receipts, though this may have paid indirectly by attracting passengers to the railway. (I) Running a more flexible service was also a way of surviving e.g. the Idinburgh to Glasgow coaches, outpaced by the railway, switched to a longer route and tapped areas previously left unserved. (2) In addition a few coaches were able to take advantage of the unintegrated state of the Scottish railway companies and exploit through routes which defective or non-existent inter-company arrangements left for them. (3) Presumably these opportunities declined as amalgamations and working agreements increased.

Finally it might be noted that the suburban services of the railways which replaced local coach services in the 1870s were themselves the victims of the march of progress towards the end of the century when municipal and private tram companies, exhibiting far more geographical flexibility than the railways, began to compete for the intraurban passenger traffic. (4)

\section{2 .}

In 1898 canals belonging to railway companies in Scotland made an average profit of $\$ 281$ per mile compared with the $\$ 23$ a mile of railway

1. Scottish Railway Gazette, 20 June, 1846. Edinburgh Evening Courant, 8 January, 1849. Dunfermline Monthly Advertiger, 14 April, 1843.

EPD 1/3. pp.219, 369, 395. B.R.

CAL 4/7I. B.R.

2. Railway Times, 31 August, 1844 .

3. H.R.J., 26 March, 1859.

4. Glasgow Evening News, I November, 1895. H.R.J., 21 August, 1896; 11 September, 1896. 
owned canals in Ingland and Wales. On the other hand, independent canals in Scotland earned a profit of only \&l9 a mile contrasted with the $£ 259$ a mile of their southern counterparts. (1) $\mathrm{T}_{\mathrm{h}}$ is diversity might simply be a matter of unfair comparison, Scotland having only 153 miles of the 3320 miles existing in all three countries, but, as will be seen below, other factors were also operative.

At the end of the nineteenth century Scotland possessed only five canals of any significance, three of which were in the hands of the railway companies. Both the independent canals, the Crinan, built to save vessels a 70 mile voyage round the peninsula of Kintyre on their way to the clyde from the north west of that river, and the Caledonian, projected chiefly with a view to facilitating trade between the Baltic and the west coast of Scotland, had to resort to the public purge for completion of their construction. (2) Their economic existence proved as difficult as their birth for what little potential traffic there might have been was firstly deterred by the rates charged, and later by the failure of the operators to adapt to the needs of improved and larger capacity vessels. (3) From the first scarcely economically viable, and later cormercially obsolete, these two canals remained relatively devoid of traffic which might have gone by rail, and thus avoided railway competition or take-over. (4)

The other three major canals in existence at the end of the century,

1. Parliamentary Papers. 1900 LXXV. p.5.

2. J. Priestley, Historical Account of the Navigable Rivers, Canals, and Railways of Great Britain. 1831. p.172. G.R. Porter, The Progress of the Nation. 1847. vol.2, p.36.

3. E.A. Pratt, scottish Canals and Waterways. 1922. pp.22-32; 50-6

4. R.C. Canals and Waterways. 1907 XXIII. p.439. 
the Monkland, the Forth and Clyde, and the Edinburgh and Glasgow Union, formed a useful coast to coast route in the important industrial belt of the Central Lowlands: These were in the hands of the railway companies, but they were not taken over in order to be exploited as a uniform system, for rival railways controlled the canals involved.

The Monkland Canal in the Lanarkshire coalfields possessed a monopoly of the coal trade from that area into Glasgow which it appears to have exploited to such an extent as to have stimulated proposals in the 1820s for railways designed to break the stranglehold. (I) However, the canal proprietors fought back, firstly by opposing the building of the lines, and, when this failed, by cutting rates, increasing facilities and building short feeder railways, this tine meeting with more success. In 1846 this canal was transferred to the Forth and Clyde Navigation which, as the two were practically one system, seemed a logical step especially in view of the increasing railway competition following the railway mania. (2)

The Forth and Clyde Navigation, linking Grangemouth on the east coast with Bowling on the Clyde, appears to have been a highly successful venture though once again complaints about exploitation of its monopoly position were voiced. An aditional stimulus to traffic was given in 1822 by the opening of the Union canal which linked the Forth and Clyde

1. G. Buchanan, An Account of the Glasgow and Garnkirk Railway. 1832 . p.4.

2. WIC $4 / 3$, I May, 1827. B.R. Pratt, op cit. pp.149-151. Railway Times, il May, 1839 . 
Navigation to the city of Idinburgh. However, twenty years later, the construction of the Edinburgh and Glasgow rallway took away praotically all the passenger traffic and led to a rate war for the goods traffic in which both sides lost heavily. At one stage amalgamation of all the eanal concerns with this railway was contemplated, but the opposition of the Inglish shareholderg in the railway compeny to the amount of compensation demanded by the canala, and the opposition of many trading interests to the take over as such, eventually produced a situation where the Union canal was absorbed and an agreement was reached with the Forth and Clyde navigation as to fixing rates and apportioning traffic. (I)

Not until two decadeg later was the question of take over again mooted and this time the raliway concerned was the Caledonian. The reason for this move was that the Caledonian was seeking an east coast port which it could develop and presumably take traffic away from the North British who already had such an outlet at Leith. Grangemouth geemed the obvious choice, but the Caledonien found that it was unable to obtain control of the port without also taking over the Forth and Clyde Navigation. However, several factors were also working to encourage the Caledonian to do this. Plrgtly, the canal to some extent offered a challenge to the Edinburgh and Glaggow railway who

1. Pratt, op. cit., p.123. H, R.J., S September, 1846; 9 November, 1852 . S.C. Railway and Canal Amalgamations. 1846 XIII. 9.232, 752-927. Scottigh Reilway Gazette, 25 i vvember, 1848. 
had previously been involved in a joint purse agreement with the Caledonian before opting out and amalgamating with the Caledonian's major rival the North British. Secondly, although the Caledonian. and the Navigation company had come to an arrangement in 1857 "with the view of preventing injurous competition," in 1865 the latter organisation was proposing the construction of two new canals which would be in competition with branches of the Caledonian. Finally, the canal was a going concern and the railway directors believed it would pay for itself in the future.

Their expectations were fulfilled in the sense that the canal was not an unprofitable burden, but whether money spent on the canal would have been more profitably employed elsewhere is open to question, in view of the fact that the acquisition of the canal by the railway coincided with an accelerated decline in the canal receipts. (2) However, this does not appear to have been the result of deliberate policy by the railway company, for the Caledonian had every incentive to promote traffic development on the Monkland canal which was in a coalfield dominated by the North British and, as stated, the Forth and Clyde also challenged this rival railway. The decline in traffic was only to be expected as local collieries were becoming exhausted, branch lines of rival rallway companies were tapping traffic (this of course may have intensified once the canals fell into railway hands), and

1. $\mathrm{PYB}(\mathrm{S}) 1 / 162 . \mathrm{pp} .5 ; 9$. Pratt, op. cit., p.127. H.R.J., I2 September, 1857; 30 December, 1865; 27 April, 1867. FCN $4 / i$. B.R.

2. Pratt, o․ cit., p.127. 
Caledonian branches built in retaliation had the same result as far as the canal was concerned. Moreover customers were exhibiting a preference for the Plexibility of the railway. (1) There is no evidence that the railwey allowed the canals to stagnate; in fact everything points to a greater degree of efficient maintenance. (2) However, the only type of traffic to increase in the period 1868-1908 was part of the through traffic, principally pig-iron and timber carried between Grangemouth and Glasgow. (3)

The other canal, the Edinburgh and Glasgow Union, not only provided the metropolis with weitern coal via the Forth and Clyde Navigation but rivalled the Idinburgh to Glasgow coaches for passenger traffic. (4) With the opening of the railway linking these two cities however, came a decline from which the canal never recovered. Both the Forth and Clyde and this canal had strongly opposed the building of the rallway and had in fact forced the railway to adopt a steep incline tunnel at the Glasgow end, on the grounds that a high level station might interfere with future plans for a ship canal. (5) Opposition was still strong when the railway came into operation and a period of intense competition ensued in which for example passenger fares fell. by a third and some goods rates by seven-ejghths. (6) It has been estimated that, from the time of the opening of the railway

1. Ibid., pp.128-132.

R.C. Canals and Waterways, op. cit., appendix 39.

2. Ibid.

3. Pratt, op. cit., p.132.

4. Ibid., po.163-165. Railway Tines, 18 May, 1839.

5. Reilway Times, 4 August, 1838 .

6. S.C. Railway and Canal Amalgamations, op. cit., p.776-777. 
to the absorption of the canal by the railwey in 1849, the canal's revenues just covared maintenance costs and interest owing on debts. As far as can be ascertained the railway decided to take over the canal simply to end the ruinous competition with no strong views as to developing the traffic. However, according to dues paid to the City of Idinburgh the traffic was fairly well maintained until the latter decades of the century when it fell away, despite the canal having been kept in good condition and the railway company making several attempts to stimulate custom by of fering special low rates. Using the canal involved too much loading and unloading which increased labour costs and the risk of damage as compared to the use of the railway and so inevitably the traders came to prefer railway service.

The point remains that, despite their gradual decline in profitability, the railway owned canals in Scotland did well as compared with most canals in the United Kingdom. This was not simply a case of the Scottish railways taking over the more successful canals and leaving the less profitable ones alone, for scotland had possessed more than the five canals recorded in 1900 and the railways had played a role in the disappearance of several of them. (2)

In 1807 a canal was begun which was to link Glasgow with Paisley

1. City of dinburgh Archives, Canals, miss., bundle 6 . Pratt, op. cit., pp.167-169. Parliamentary Papers. 1900IXXI. p.79

R.C. Canals and Waterways, op. cit., q.31305.

2. Apart from the canals which gained Acts unpublished work deposited in the National Library of Scotland (consultable by permission of $\mathrm{Mr}$. J. Howdle) shows over twenty small private canals also constructed in Scotland. These were of short length and there is no evidence of the public being allowed to use them. 
and Ardrossan, but the difficulties of raising noney resulted in the canal stretching only as far as Johnstone. The idea was taken up again in the late 1820 s but this time the connecting link between Aròrossęn and Johnstone was to be a railway. This too proved unattractive to lnvegtors and reached only as far as Kilwinning. Unfortunately, the construction had been gtarted at the Ardrossan end which left a situation where the scheme had produced a canal at one end, a railway at the other, and nothing in between to link the two. The inconvenience of having the disunited canal and railway under the same management led in 1840 to a separation of controlling powers. This did not make the canal any more profitable, especially as railway competition intensified; the competing railway did make an agreement as to the division of traffic but this was ruled illegal by the law Officers of Scotland, and the railway directors also realised that they could do better without the arrangement. (2) In 1869 the Glasgow and South Western railway took over the canal, now heavily in debt, to prevent the canal falling into Caledonian hands, and were put under an obligation to keep the canal in good order. (2) Although this was done, the canal facilities were not in demand and the railway decided to use the land occupied by the canal to more economic purpose and obtained permission to use the canal bed for a railway, the "Paisley

1. Pratt, op. cit., pp.275-277. Railway imes, 20 January, 1846; 20 June, 1847. Scottish Railway Gazette, 10 January, 1846.

2. $\overline{P Y B(S) ~ I / 39.0 .67 . \mathrm{B} . \mathrm{R}}$. Earlier complaints by the canal manager suggest that the railway had attempted to smash the canal by rate warfare. (GPA 4/1. B.R.) 
Canal line," which linked up with the rest of their system. (1) Another canal that came into railway hands and was evantually closed was the $\frac{3}{4}$ mile long Forth and Cart, which, by acting as a link, gave continuous navigation from the Forth and Clyde to the town of Paisley. This was logically taken over by the Forth and Clyde Navigation and thus later came to be a possession of the Caledonian railway company. Unfortunately for the canal the opening in 1882 of the Glasgow, Yoker and Clydebank railway under the auspices of the North British deprived it of nearly all of its traffic. It struggled on until 1893 when it was decided to close down and lay part of the Lanarkshire and Dumbarton railway along the canal bed. (2)

A third waterway to form the base for a railway line was the Inverurie to Aberdeen canal. This was not a financially successful canal and when the projected Great North of Scotland railway offered the proprietors $£ 36,000$ for it under the threat of otherwise running a reilwey line parallel to the canal the offer was taken up. The railway compeny bought the canal as they believed it would save on land costs if their line was laid along the canal bed. They also felt that their line might not have been sanctioned had not the purchase been proposed, and of courge filling in the canal removed potential competition. In fact the contractors were in such a hurry to

1. Pratt, op cit., p.277.

H.R.J., 24 June, 1882.

2. Pratt, np. cit., pp.125-126.

H.R.J., 3 November, 1855.

K.C.Canals and Waterways, op. cit., p.146. 
construct the railway that they drained the canal before it was cleer of vessels. (I)

It may be that the existence of the railways prevented the fruition of plang for a Forth and Clyde ship canal. Yet the threat of potential railway competition did not deter the promoters of the Manchester ship canal. The answer probably lies in the recommendation of a Royal Commission on Imperial Defence for the interested parties to see whether funds would be forthcoming and then aporoach the government for assistance. This was a similar attitude to that taken over the Argyll ship canal half a century earlier with the same result that no canal was constructed (2) Whether the railways had any effect on the supply of investible funds is open to conjecture.

'Chroughout the nineteenth century coastal shipping remained a formidable competitor of the railways. Access to the sea is difficult to restrict which would tend to keep coastal shipping itself highly competitive. In addition there is no need to lay down permanent track, though this might be offset by other capital costs. The greatest advantage, however, that coastal shipping possessed over the railweys wes thet the latter had to act as common carriers whereas the

1. J. Iindsay in Journal of Transport Historyy, vol.vi, no.3. pp.161-163. Aberdeen Journal, 2 September, 1845. Railway Chronicle, 8 December, 1849. H.K.J., 3 December, 1853. GNS I I. P.457. B.R.

2. Pratt, op. cit., p.207. PRO(S) $27 i / 1$. p.290. Argyll Canal. B.R. 
shipping interests could pick and choose their trafic. (1) To some extent their success in competing lay in offering cheap passenger fares on the longer passenger journeys, but primarily it was in goods traffic that coestal shipping challenged the railways. Not until the last decade of the century did rallways, by use of exceptional rates, begin to seriously undermine the major traffic of the coasters. (2)

That coastal shipping more than held its own (except in perishables and cattle) is clear from statements made by the railway companies and contemporary observers. The Caledonian found in 1850 that "the competition by sea has made it necessary to carry at less remunerative rates than might otherwise be charged." (3) About the same time, but on the other coast, the North British was finding that earlier prophecies that "the steamers might pay to the north of Edinburgh, but to the south their attraction could never compete with the rail" had been too optimistic. (4) Later in 1875 the North British gaid that it was "quite clear" that in certain classes of goods they could not compete with the steamers. (5) Further north the Highland acted cautiously about any rate increase because of the active competition of sailing vessels. (6) Numerous other examples

1. S.C. Railway Companies Powers. $1864 \mathrm{XI}$, evidence of J. Brown. B.C. Railway Company Amalgamationg. 1872 XIII. p.xix.

2. D.H. Alderoft, The Eclipse of British Coastal Shipping, 19131921, Journal of Transport History. vol.6, no.2. 1963.

3. Railway Chronicle, 28 September, 1850.

4. $\mathrm{MBR}$ 1/4, $21 \mathrm{Merch}, 1850 . \mathrm{B} . \mathrm{R}$. Railway rimes, 2 September, 1843.

5. Railway News, 5 April, 1875.

6. H.R.J., 3 May, 1873. 
could be given, all of which would show that the railways were well aware of the realities of competition from the slower but cheaper coagting vegsels. (1) Other factors besides cheapnegs also encouraged the use of shipping in preference to the railways. It was argued that in Aberdeen the steamers were more convenient as the railway station was too far out of town. (2) It was also maintained that several of the east coast^companies were too concerned with taking traffic to the south via the west coast route, presumably because of agreements made with the Caledonian; this, it was said, gave the east coast steamers an advantage. (3) In addition, to send goods by rail down the east coast involved making arrangements with the North British and, at the time of writing (1853), this company was far from being an 1deal commercial partner. Strangely enough when an Anglo-Scottish traffic agreement was organised involving major companies on both sides of the border, rates tended to rise and trade was diverted from the railways to the ateamers. (4) Free access to the sea meant that individual industrial companies could, if they wanted, own their own vessels. One notable example of this was the famous Carron iron company who set up their own line of coasting serew steamers to London, not only for their own purposes, but also for the use of the public's goods which proved to be quite

1. e.g. H.R.J., 5 November, 1859. Bradshews Gulde to Railway Shareholders. 1853. pp.2; 189.

2. H.R.J., I Nay, 1852 .

3. H.R.J., 20 August, 1853.

4. H.K.J., 20 September, 1857. 
profitable at times. (I)

Being well aware of the competitive prowess of the coastal steamers, the railway companies made several attempts to come to terms with them. The first attempts were more in the nature of employing the steamers to fill in routes where the railway did not operate. The Glasgow, Paisley, Kilmarnock and Ayr assisted a company setting up a service between Liverpool and Ardrossan in 1840 and, although this agreement broke down, fresh arrangements seemed to hold at least until the west coast railway route was operative.

(2) Later arrangements, or attempted arrangements, were of two typeg. Firstly, a railway company that was challenged directly by coastal shipping would often try to get agreement on the rates to be charged so as to avoid excessive competition. Secondly, some railway companies would make arrangements to convey traffic to the boats sailing in competition with rival railway companies. (3) However, these agreements did not seem to prove very successful or permanent. The first type broke down presumably because the shipping proprietors felt little need for such agreements, except in the ngrthern counties where there is evidence that the coming of the railway eroded the

1. H.R.J., 21 February, 1852 .

Carron Company. G.D. 58, sections 18/58; 18/78. S.R.0.

2. Railway IImes, 29 August, 1840; 3 September, 1842; 20 January, 1844.

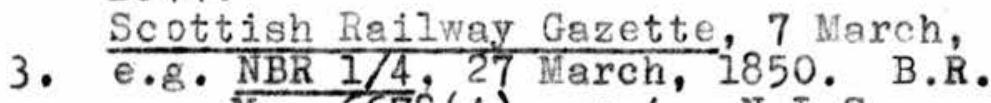
NS. $6678(4)$. p.4. N.I.S. H.R.J., 28 September, $186 i$. 
prosperity of the coastal trade. (1) The second kind would decline as the smaller rallway companies were absorbed into larger concerns and also as through arrangements became more common. Some of the railway companies in fact took the step of entering into the shipping trade, but this was mainly concerned with river traffic which will

be discussed below. The North British attempted to organise steamers from Silloth to Carlisle, the Portpatrick railway became involved in the Irish sea ferrieg and, in the north, the Highland railway purchased steamers to establish a service between the Western Isles, Orkney and the mainland. (2) It might be noted that in the latter case the service was taken over within five years by MacBrayne of Glasgow; to the railway's satisfaction who said they had always opined that their function was to manage railways "and leave the steamers to others," but that they could not get anyone interested enough to start the service in the first place. (3)

The river steamers, especially those on the Clyde, also proved formidable competitors to the railways, whose solution was to attempt to make agreements and eventually to go into the steamer business themselves. Many of the early agreements were to employ steam boats to run in conjunction with rallway services i.e. because the railways

1. J. Lees, A History of the County of Invernegs. 1898 . p.347. H.R.J., 28 September, 1861.

2. H.R.J., 2 April, 1864; 7 February, 1863. RAC (S) I/1A, 8 August, 1857. B.R. Railway News, 21 october, 1876.

3. H.K.J., $8 \mathrm{May}, 1880$. It should be noted that a Post office contract secured in 1877 guaranteed the operators of this service againgt 1098. (H.R.J., 5 May, 1877). 
were unable to travel the whole distance from Glaggow to various ports served by steamers, they hoped that the superior speed of the railways for part of the journey coupled with a steamboat for the rest would enable them to compete successfully against steamers going the full distance. These agreements never seemed to last; the probable reason for this being that it was financially less rewarding for the steamers to travel (say) half the distance and hand over its passengers to the railway than to take them the full journey, especially whem, without their cooperation, the rallways could not guarantee passengers the full trip.

The answer, as far as the railway companies were concerned, was to obtain vesgels and run steamer services themselves. The first to attempt this seems to have been the Glasgow, Paisley and Greenock in the mid $1840 \mathrm{~s}$, but they ran into tremendous opposition from the existing steamboat owners, as did all the later attempts by other railway companies. Time and time again when the railways attempted to obtain powers to run steamers they were defeated in Parliament.

It was argued by the steambot owners that the railways, in having limited liability, possessed an advantage over the steamboat companies which would allow them to amass capital, compete on unequal terms and, in driving out the independent gteamers, obtain a monopoly

1. Railway Times, 29 December, 1838; $10 \mathrm{July,} 1841$; 14 January, $1843 ; 16$ March, 1844.

Greenock Advertiser, 7 January, 1843.

2. H.K.J., 14 September, 1844; 20 March, 1845; 9 June, 1855. 
of the river traffic. Furthermore, it was contended that the railways could make up on their railway charges what they might lose in undercutting the independent boats on the river. However, in 1864 a Select Committee on Ra1lway Companies' Powers decided that there waw nothing illegitimate about using larger capital resources and that if the railways did obtain a monopoly of the river trade then legislation on maximum fares and obligations to carry could prevent its abuse. Moreover, they said that it was spurious to argue that the railways could make up their losses elsewhere as competition between rallways themselves was not negligible. They thus came to the conclusion that they were "unable to see why companies owning railways should not own steamers also, if it be expedient for the development of their traffic, why to the business of carrying by land, they should not add that of carrying by sea." (I)

The decision then rested with the railway shareholders but in several cases there was no new deciston to make. The recommendations of the 1864 Comittee had merely given de jure recognition to a de facto situation, for, when parliamentary permission to own steamers had been refused, on several occasions directors of the railway agreed to run boats in their name providing that the railway shareholders would guarantee them against loss. (2) The shareholders were not usually unwilling to give permission. Trouble only arose

\section{Parliamentary Papers. $1864 \mathrm{xI}$. pp.i1i-1v. For Scottish evidence see pp.26; $40 ; 91$.}

2. Ibia. p.115. North British Investigation, 15 November, 1866. p.10. 
when the steamers were put into operation and the sharebolders began to suspect that losses were being incurred which undermined railway dividends. How valid their protests were is difficult to ascertain as the rallways did not publish separate accounts for their ancilliary concerns, but the very fact that they did not, coupled w1th the evasive replieg often given by directors to shareholders' questions, points to some justification for the complaints. The Committee of Investigation into the affairs of the North British railway in 1866 adinitted that the Steam Packet Company with which the railway was associated had been "an unfortunate and unremunerative undertaking." However, they did add that "whether it may not have Indirectly have benefitted the railway (they) have not had the means of ascertaining." (I) This is the key point - did the traffic that the steamers brought to the railways more than compensate for the Iosses on the traffic that the steamers themselves carried? If the railway director were rational businessmen (though in view of some of their other decisions on capital expenditure this is debatable) then some light on this point might be shed from the histories of the various railway steamer enterpriges. If they were allowed to survive then possibly they were making a contribution to the overall profits of the railway company.

The North British Steam Packet Company had as mentioned been set up as a nominally independent concern. This had come about when

1. Ibid. p.10. 
the railway company had leased the Port Carlisle railway, the Silloth railway and Silloth harbour in 1861 , and had, at the seme time, purchased the vessels of the Silloth Bay Navigation Company in order to make use of what they had earlier termed "the great facilities for the shipment of coals, minerals and passengers to Ireland and the west ports of England." However, the following year John Burns, a steamboat owner, obtained an interdict against the railway company and the 1863 Parliament gave permission for railway steamers to ply only between Belfast and Silloth. This led to several of the directors making the offer to run a packet company on the guarantee that personal losses would be made up from the railway funds. The packet company continued to operate throughout the century as a private coneern before being officially acquired by the railway in 1902 and wes not wound up until after the first world war. (I) A few flgures anc calculations available for the early twentieth century do suggest that the steamers were in fact a viable concern in their own right. (2) The North British also had a share with the Caledonian and the Lanarkshire and Dumbarton railways in the Ioch Lomond steamers and also took over the Galloway Steam Packet Company which was hitting the railway with its Forth of Firth pleasure cruises. (3)

1. $\operatorname{MRP}(\Sigma) 35 . \mathrm{B} \cdot \mathrm{R}$. RAC(S) 171A, 8 August, 1857. B.R. C.H. Flis, The North British Railway. 1959. pp.216-217.

2. $\operatorname{HRP}(s) 35.3 .6 .3 . \overline{1}$.

3. $\operatorname{MRP}(S) 34, B . R$. HRP (S) 21 . B.R. Edinburgh Evening Diapatch, $28 \mathrm{July,} 1933$. 
The Caledonian railway, having absorbed the Glasgow, Paisley and Greenock which had previously tried to break into the steamer business, also made an attempt in 1852, but failed because of the competition of the existing vessels. Their failure in fact led to an agreement with the existing steamoat owners which lasted some fifteen years. It was not until the late 1880 s that the Caledonian, after several parliamentary defeatg (the recomendations of the 2864 Committee had not automatically or universally become lew), decided to adopt the expedient of an "independent" Caledonian Steam Packet Company. This attempt to break into the river trade seems to have come off. It was perhaps because of the racing prowess of Captain Williams on, the Caledonian's man in charge, but more likely it was because economio conditions were propitious i.e. a larger population in the areas gerved who were perhaps now more travel minded and also the fact that tourism was on the increase. (1)

The intense rivalry of the railway companies was inherited by these offshoots of theirs, and became extremely severe in the 1890s, especlally on the clyde, leading to an arrangement in 1895 to stop unnecessary competition. (2) The general impression that is gained from the railway companies' activities is that they felt the need to operate steamer services and that these services proved of economio advantage to the companieg indirectly if not directzy.

1. W.C. Galbraith, The Caledonian Steam Packet Company Itd. 1949. pp. $1-7$.

2. Ibid. pp.13; 22-24; 27. HiRPS $16 . \mathrm{pp} .1-2$. 
There was less opposition from the steamboat owners to the railways running ferries, partly because as early as 1848 Parliament had laid down the general principle that a sea passage of the nature of a ferry was more convenient to passengers if in the hands of the connecting rallways. (1) From then on there was explicit recognition of "the great facilities given to the public by placing ell the links of through communications in the same hands." (2) The reservations of the steamer proprietors were confined to comments such as that made by a witness to the 1864 Committee, "from the experience which I have had in Committees, the definition of ferry obtains a very wide range." (3) In general they had little objection to the railways running genuine ferry services and those across the Tay and Forth were in operation as soon as the adjoining rallways were opened.

An Act of 1842 authoriged the Duke of Buccleuch and John Gladstone to establish a ferry between Granton and Burntisland. Two years later a railway branch to the pier at Granton kas approved and in 1847 the rallway company, now the Edinburgh, Leith and Granton, purchased the ferries and the piers. (4) The Queensferry passage w as not operated by the railways until a little later. In 1863 the North Britioh was authorised to construct certain works in conjunction with a ferry and if they had not done this within two years

2: S:C: Railway Companieg' Powers, op. cit.,p.115.

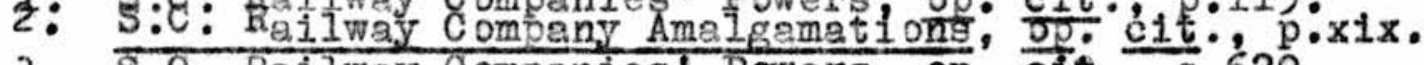
3. S.C. Railway Companies' Powers, op. olt. , q.629. 4. HRP $(S)$ 26. pp.1-3. B.R. 
the option was to pass to the Edinburgh and Glaggow. As events proved, the Fdinburgh and Glosgow was swallowed up by the larger company and it was not until 1867 that the North British began to work the ferry. This was continued until the opening of the Forth Bridge in 1890 when agreement was reached with Nessrs. Arthur of South Queensferry to work it on behalf of the rallway compsny for \&100 per annum. (I) Further north, the Edinburgh and Northern were authorised to purchase the right of ferry between Ferryport and Broughty in 1846. By 1888, after the opening of the more stable Tay Bridge, receipts from the ferry totalled $2177: 10: 6 \mathrm{~d}$ whilst operating costs came to about $£ 700$. A five year agreement was therefore made with David Wilson and Son to work the ferry for ¿550 a jear in an effort to restrict losses. In 1892 the North British, who had become the controlling railway in the early 1860s, sought powers to abolish and discontinue the ferry, but had to drop the idea because of strong opposition. Fventually in January, 1894 Messrs. Wils on and Son sald they would work both ferries for \&375 per annum. (2)

$$
4 .
$$

When considering the economic relationghip of the railways and other forms of transport three major points emerge. Firstly, that

1. $\operatorname{HRP}(\mathrm{S})$ 39a. B.R.

2. $\mathrm{HRT}(\mathrm{S}) 47 . \mathrm{B} . \mathrm{R}$. 
neither road nor canal transport could hope to survive railway competition. Turnpike trustees were aware of this from the start, but many canal proprietors, on the other hand, envisaged using railways as feeders to their waterways. (1) However, even before Scotland had thirty miles of proper railways it was clear that only the canal owners envisaged the new mode of transport as existing solely to act as their servants; ag early as the late 1820s the construction of the Garnkirk and Glasgow marked the first direct challenge of an independent railway to a canal. It is fair to say that, had they wanted, the railweys could have put any canal out of business because of their abillty to offiget on other routes losses Incurred by undercutting canal rates and charges. The aggregate English experience of rallway owned canals, as shown in their revenue statisties in 1900, could well have been repeated in Scotland had not several of them provided an important through route withinan industrial region. Even this might not have saved them had not the ownership been divided between two rival rallway companieg each of which found the other's lines competing againgt their stretch of canal; this gave them an incentive to encourage the canal traffic rather than merely maintain the canal as the take-over agreement usually stipulated. When other canals attracted the interest of the railway companies they seem to have invariably ended by being drained and a railway being run along the canal bed. Over time even the canals nourished

1. Railway Chronicle, 13 October, 1849. J. Rennie, Additional Report for Promoting a Canal between Edinburgh and GIasgow, 27 July, 1801. 
by the railway companies found that competition from other raflways, the preferences of traders, and changes in the location of industry produced Inevitable decline.

However, the advent of the railway did not bring universal economic disaster to all other forms of transport. This was partly because the railways were not in competition with certain of the cansls or lateral turnpikes; it was partly because the railways were unable to crush the opposition when they tried to, as in the case of coastal shipping; and it was partly because some of the crushed opposition changed its function and reappeared as economically viable, often working in conjunction with the rallways as was the case with the carters who switched from inter to intre-town certage.

Finally, it should be noted that the railways did not confine their transport activities to their own lines and, at various times, were operating or were involved in almost every other form of transportation. It would not appear, however, that they were following a policy of establishing a co-ordinated transport system, but were instead taking up the other transport activities either out of rivalry to another railway or because they sensed profit, either direct or indirect. Their approach was the same as with their hotels which although they might not be directly profitable "in many Instances" acted as "valuable feeders of passenger ... traffic." (I)

1. E.R.J., 20 October, 1888 . 


\section{CHAPTER ELEVEN}

RAILWAYS AND AGRICULTURE (1)

"... while in the country railway steam engines on the atmospheric plan are not only to perform all the work of the lines, but are to employ their surplus power in impregnating the earth with carbonic acid and other gases, so that vegetation may be forced forward despite all the present ordinary vicissitudes of the weather, and can be made to grow at railway speed."

Editor of the Bankers' Magazine. Quoted in J. Francis, A History of The Inglish Railway. 1851. vol.2, p.143.

\section{1.}

The greatest advantage that the railways possessed over other forms of transport in the nineteenth century was undoubtedly their speed. Since, in the field of goods transport, speed has most relevance where the freight is perishable, it could be that the rallways had most to offer the Scottish economy in the agricultural and fishery sectors.

Even before steam had taken to the rails, one Scot envisaged the great potentialities that railroad transport could bring to agriculture. Writing at the end of the eighteenth century Dr. James Anderson declared that the lowering of the cost of carriage would, by widening the extent of the market and facilitating the use of fertilisers, "give such encouragement to agriculture as no other measure that can be contrived could ever effect. (2) About twenty

1. Agriculture here is very loosely defined to include fruit growing, forestry, and fishing.

2. J. Anderson, 'On Cast Iron Railways,' in Recreations in Agriculture. 1799. pp.209, 213-214. 
years later plans for a Berwick railway inspired a local post to pen the following lines

".. Yes, revels shall now happily sooth her (Scotland's) wail. Even in poor coal-less, lime-less, Tividale. Then agriculture shall wi' commerce smile .." (I)

By the 1840s their ideas and aspirations were being reiterated by Scottish witnesses to a Select Committee, but this time with evidence to support their hypotheses. Reductions in costs and increases in land values were cited by the famous railway engineer, John Miller, and, perhaps of more significance, by the agricultural expert, James Smith of Deanston. Their evidence and information supplied by other witnesses convinced the committee that "it is impossible, therefore, to overestimate the importance of this new instrument placed at the command of the agriculturalist." (2)

It is, however, also impossible to give much numerical significance to the influence of the railways on Scottish agriculture, but certain structural changes can possibly be attributed to the development of the railway network. In this chapter a generally nonquantitative assessment is made of the railways' impact on certain sectors of agriculture, forestry and fishing, but a statistical analysis is included in the case of their effect on corn prices and land values. Although of undoubted interest, it was decided that a study of the food supply of an individual town, such as those made

1. Quoted in W.A. Johnman, 'The Canals, Tramroads and Rallways of Roxburghshire,' Transactions of the Hawick Archeological Society, 1919 , p.19

2. S.C. Railway Acts Enactments. 1846 XIV, p.viii; q.1008-1014, $3152-3252$. 
of Manchester and Sheffield, was beyond the scope of this thesis.

$$
2 .
$$

Table Il.I illustrates the expansion of animal husbandry in Scotland during the second half of the nineteenth century. Undoubtedly this was primarily determined by changing tastes and increasing importation of corn, but the rallways must have had an important conditioning influence in facilitating the development of the cattle fattening trade, in easing the transportation of sheep, and in being essential to the establishment of the long-distance milk trade.

\section{$\underline{\text { TABLE } 11.1}$}

\section{SCOTTISH LIVESTOCK STATISTICS $(1000)$}

$\underline{\text { Year }}$

\begin{tabular}{cccccc} 
& Cattle & & & \multicolumn{2}{c}{ Sheep } \\
\cline { 5 - 6 } in milk & others & calves & breeding & feeding & lambs \\
298 & 469 & 207 & 2708 & 1139 & 1848 \\
434 & 529 & 235 & 2978 & 1635 & 2702
\end{tabular}

Source: Tr.H.S. 1855/57, p.207. Parliamentary Paperg, 1902. Cmd. 1121, p.2.

William M'Combie, cattle dealer and M.P. for Aberdeenshire, in his evidence to a Select Committes in the early 1870s, reckoned that the Scottish cattle trade had changed completely since he entered

1. W.E. Bear, 'The Food Supply of Manchester,' Journal of the Royal Agricultural Society, 1897. J. Blackman, 'the Food Supply of an Industrial Town,' Business History, vol.5, nol, 1963. 
the business in the 1820s. When he began all Scottish cattle for the Inglish market were sold lean to English graziers, there being no point in fattening them in Scotland if they had to walk south. However, the advent of the steamship, and later of the railway, made it profitable to fatten beasts in Scotland so that the trade was revolutionised, it "no longer (being) the raw material that left for the south, but the finished article of commerce." (1) The railways also played a part in facilitating the use of fertilisers which led to a greater cultivation of turnips on which the cattle were winter fed. (2)

As indicated, the steamship struck the first blow against the transborder droving trade. By 1840, twelve years after the first boatload left Aberdeen, over eight thousand head were being dispatched, and this figure was doubled within the next decade. (3) The decline of transborder droving was accentuated by the coming of the railways, but the internal droving trade retained its viability until late in the century when the railway had spread through the cattle breeding areas. Haldane believes that the opening of the Callander and Oban line in 1880 marked the acceleration of the decline of internal droving, which can be said to have finished by 1901 (the jear of the last

1. S.C. Noxious Businesses. $1873 \mathrm{x}, \mathrm{q} .3001$. Quotation from A. Harvey to the British Association in 1859.

2. J.A. Symon, Scottish Farming Past and Present. 1959. p.183. It would appear that the lower districts of Aberdeenshire and Banffshire were eminently suited for growing good turnips and grass. (J. Black, On the Agriculture of Aberdeen and Banff Shires,' Tr.H.S., 1870. p.9).

3. J.H. Smith, 'The Cattle Trade of Aberdeenshire in the Nineteenth Century,' Agricultural History Review, vol.3, no.2, 1955, p.114. 
Falkirk tryst). (1) Although droving was no more directly expensive than rail transportation, it is not surprising that it did not survive competition from the railwoys as cattle lost weight in walking (a sixty mile drive could lower the value of a bullock 5\%), the journey was slow (stops for feeding and the danger of overheating and fatigue limited the speed to twelve miles a day) and occasionally troublesome (cattle might have to be shod). (2).

In 1848 , the year the railway reached Aberdeen, twelve thousand head of cattle were sent by rail to London, Edinburgh and Glasgow. Within twenty years the figure was forty-four thousand. (3) However, it should not be assumed that the railways gained an immediate and sweeping victory over the steamships. The winter of $1852 / 53$ witnessed six thousand head being dispatched from Aberdeen by rail, but also four thousand head going from the same city by sea to Iond on and Newcastle, avoiding the railways altogether. (4) The figures in Table 11.2 show that even by the mid 1860 s the steamers had by no means been eclipsed, about a third of the Aberdeen cattle sent to Lond on still going by sea. A similar ratio was estimated as operative in 1870. (5)

1. R.R.B. Haldane, The Drove Roads of Scotland. 1952. pp.220-221. From the district between Tyndrum and Callander about $70-80,000$ cattle and 100,000 sheep were brought down annually by the drove roads prior to the coming of the railway. (Scotsman, 26 April, 1870)

2. S.C. Railway Acts Enactments. 1846 XIV, T.B. Franklin, A History of Scottish Farming. 1952. p.131. T. MacLelland, 'On the Agriculture of the Stewartry of Kirkcudbright and Wigtownshire,' Tr.H.S., 1875, p.72.

G. Menzies, 'Report on the Transit of Stock,' Pr.H.S., 1869, pp. 463-464. Roxburghshire farmers preferred to send cattle to Newcastle by rail via Idinburgh than drive them over the border. (H.R.J.. 17 April,1858).

3. Smith, op. cit., p.115.

4. H.R.J., 20 August, 1853.

5. Black, o․ cit., p.11. 
The prolonged battle between the steamships and the railways might appear surprising in view of the advantages which the railway could offer the cattle dealer. Firstly, it was much safer. M'Combie had never lost a beast in transit by rail, but could not say the same of the sea journey. (1) However, this was sornewhat

\section{TABLE 11.2}

\section{ABERDEEN TO LONDON CATTLE TRADE}

$\begin{array}{lrr}\text { Year } & \text { By Rail } & \text { By Sea } \\ 1859 & 13,130 & 7,282 \\ 1860 & 13,993 & 3,782 \\ 1861 & 8,852 & 8,324 \\ 1862 & 6,281 & 4,518 \\ 1863 & 9,623 & 4,163 \\ 1864 & 7,624 & 3,551 \\ 1865 & 9,031 & 4,558\end{array}$

Source: W. M'Combie, The Cattle Trade. 1866. p.80.

mitigated by the owners of the Aberdeen steamers raising an insurance fund for the protection of cattle shippers in the late 1850s. (2) Of course this may have affected the cost of shipping unless the steambot owners were reducing their profit margins in an effort to withstand railway competition. MPCombie did acknowledge that "the cattle go well by sea when the weather is moderate, but in rough weather they are safer by rail." (3) This seems to have been the general opinion, for Messrs. Swan and Son of Edinburgh who handled

1. S.C. Noxious Businesses. $1873 \mathrm{x}, \mathrm{q} .3002$.

2. W. M'Combie, Cattle and Cattle Breeders. 1869. p.70.

3. Ibid., p.71. 
95\% of the stock imported into Scotland used the steamboats when the weather was favourable. (1) Yet others must have taken the riak for M'Combie also asserted that "a year seldom passed without the shippers having heavy losses." (2)

Allied to the question of safety was the condition of the beasts after their fourney. Lardner thought that the cattle arriving in Iondon by sea were in an unnatural state seeming "stupified and ... suffering from fatigue." (3) That cattle were knocked about at sea was also the opinion of a Kincardineshire cattle farmer seeking the establishment of a railway from that counts to the south. (4) As regards rail transport the owners of the first batch of cattle sent by rail from Carlisle to Norwich "were highly satisfled with the order in which the cattle had arrived." (5) On the other hand, one agriculturalist maintained that both in the case of sea and rail transport the animals were liable to exposure and to being shaken and knocked about. (6) Whether "the rapidity of the journey," which astonished the aforementioned dealers sending cattle to Norwich, meant there was less injury in the cage of the railway is open to conjecture.

The steamships, however, had one important advantage; they offered cheaper rates. Originally the steamers used to charge $£ 3$ a head for taking cattle from Aberdeen to London but this was reduced to $\mathrm{kl} / \mathrm{ls}$ by 1865 . (7) This was not due solely to railway competition as the

1. S.C. Railways. 1881 XIV, q.6022.

2. MCombie, Dp. cit., p.70.

3. D. Iardner, Railway Economy. 1850. p.9.

4. $\mathrm{PYB}(\mathrm{S}) \mathrm{I} / 3$, v01.2, p.I6. B.R.

5. Dumfries Herald, 26 March, 1847.

6. Menzies, op. cit., pp.470, 478 .

7. Smith, on. cit., p.115. 
price had been reduced to $£ 1 / 12 \mathrm{~s}-£ 2 / 2 \mathrm{~s}$ (seasonal variations) in the mid $1830 \mathrm{~s}$ and to $21 / 2 / 6 \mathrm{~d}-£ 1 / 7 / 6 \mathrm{~d}$ by 1843 before the railway competition began. (I) The comparative railway rate in 1865 was 21/5g. (2) What seems to have happened is that sea carriage from Banff, Fraserburgh, and Peterhead was given up and shipments of Cattle concentrated at Aberdeen, perhaps in order to obtain economies of scale. (3) In addition it should be noted that the Great North of Scotland railway company thought it more in their interest to advise "the cattle dealers and others in the north" that they "would find it of great advantage to come to Aberdeen." (4) Promoting the development of this port was seen as giving them greater profits than would encouraging through rail traffic to the south.

It should be pointed out that some areas did not have the option of choosing their form of transport. The railway stretched up the east coast in a series of fits and starts not reaching Thurso unt1l 1874. Yet this did not mean a monopoly for the steamship since this mode of communication was also absent. The Sutherland Farmers' Club, for example, was well aware of the disadvantages of the long, arduous overland drive to the south, but were unable to persuade any steamship company to establish a service because of the seasonal nature of the traffic and the absence of a return cargo. (5)

1. Information supplied by Mr.Clive Lee of the University of Aberdeen.

2. Smith, 1oc. c1t.

3. Black, op. cit., p.11.

4. H.R.J., $\frac{6}{6}$ December, 1851.

5. P.T. Wheeler, 'The Development of Shipping Services to the East Coast of Sutherland,' Journal of Transport History, vol.6, no.2. 1963, pp.113-114. 
Emphasis so far has been placed on the Aberdeen-London cattle trade and the increased supplementation of rearing by feeding that occurred in Aberdeenshire. However, several other structural changes also took place. Cattle continued to be reared in the remoter areas, especially in the northern counties, to be taken out of the Highlands for fattening, but as the rallways moved further north feeding developed, although only to a limited extent because of natural resources. (1) A growing number of store cattle were imported from Ireland for fattening in Scotland (and hence qualification as "prime Scots"?). (2) Some of these were transported along the Caledonian canal, but the majority seem to have been in the hands of the railway companies. The North British constructed a new loading bank at Silloth in 1864 "to meet the requirements of the increasing cattle traffic from Ireland" and the Caledonian built a line to have direct access with the Glasgow cattle market in an attempt to increase their share of the trade. However, the bulk of the Irish cattle coming into Scotland appear to have travelled on the Glasgow and South Western. (3) The railways also changed the practices of cattle farmers in Berwickshire. In the first half

1. Black, op. olt, p.12.

J. MacDonald, On the Agriculture of the Counties of Ross and Cr omarty,' Tr.H.S., 1877 , p.96. R.C. AgriculturaI Interests. 1881 XVI, p.531.

2. Smith, op. cit., p.117. J. Giliespie, The Cattle Industry in Scotland,' Tr.H.S., 1895. p. 235 .

J. Dickson, (On the Agriculture of Perthshire,' Tr.H.S., 1868. p. 172 .

J. Milne. 'On the Agriculture of Aberdeen and Banff Shires,' Tr.H.S. 1871, p.392.

3. S.C.Noxious Businesses. $1873 \mathrm{X}, \mathrm{q} .3014$. RAC(S) I/1A, February, 1864. B.R. H.R.J., T Hay, 1881 . 
of the century almost every farmer bred and reared a large proportion of the cattle fed on his farm, but by the end of the century less than $1 \%$ did so. Instead it was found more profitable to take advantage of the facilities offered by the railways to bring in cattle from over the border and from Ireland. (1) Absence of good communications had hindered the development of the cattle industry in Dumfriesshire and Galloway, no livestock being sent by sea because of the slownegs of the sailing vessels. The first stimulus to cattle feeding in these regions was given by the steamship and an even greater one by the rallway. although this was much later coming to Wigtown than to Dumfries. In the yesr to July, 1873 over 14,500 cattle were sent out of Galloway alone by rail and sea, excluding Irish cattle landing at Stranraer and being forwarded by rail.

The steamship may have been the original stimulus to the livestock fattening trade of Scotland, but the dead meat trade was und oubtedly the child of the railways. It was impossible to carry killed meat any distance by sea except in salted form, and only small quantities left Scotland for the South even in this form. (3) A breakthrough came with the linking of Aberdeen and Lond on by rail which allowed a substantial trade - an average of 8,000 tons per annum in the 1860 s - in beef carcasses to be set up between these

1. J. Wilson, 'Half a Century as a Border Farmer,' Tr.H.S., 1902, p.44. R.C. Agricultural Interests. $1881 \mathrm{XVI}, \mathrm{q} .40397$.

2. J.Gillespie, 'On the Agriculture of Dumfriesshire,' Tr.H.S., 1869, pp.277-278. MacLelland, op. cit., pp.17, 38-41. H.R.J., 9 September, 1848 .

3. Smith, op. cit., p.ils. S.C. Railway Acts Inactments. $1846 \mathrm{xIV} . \quad \mathrm{q} .3252$. 
two cities. A further stimulus came with the extension of the railways through the Highlands; by the early 1880 s $11 \%$ of Iond on's imports of dead meat came from Aberdeen and a further $15 \%$ from elsewhere in Scotland. (I) That the steamers hardly participated in this traffic is apparent from Table 11.3 .

\section{$\underline{T A B L E} 11.3$}

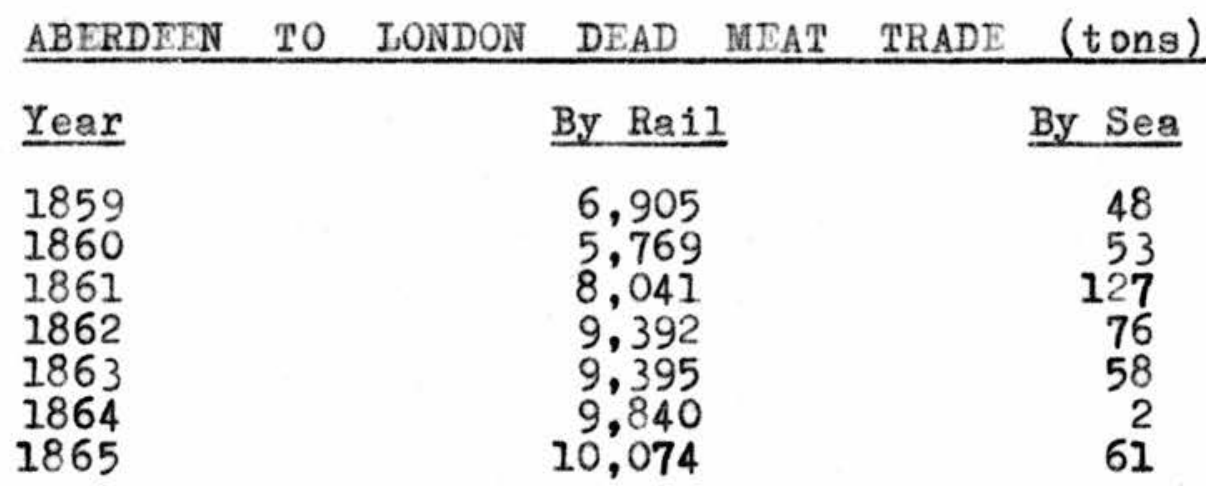

Scurce: W. M'Combie, Cattle and Cattle Breeders. 1869. p.80.

That dead meat could be transported over long distances by rail probably accounts for the growth of the butchering and related trades in Aberdeen, the number of fleshers in the city rising from approximately 40 in 1840 to 100 by 1880. Iven by 1870 it could be asserted that the butchers were also the principal cattle dealers in Aberdeenshire, some of them feeding their own cattle so as to ensure regular meat supply. Of courge other factors, such as the expansion of local population, would also be relevant, but it is significant that 
at the opening of a new slaughter house in 1909, Bailie Wilkie pointed out the great extent of slaughtering for meat destined for southern markets and added that Aberdeen was "peculiar" in this respect. (1)

Many of the previous remarks on the transit of cattle are equally applicable to the carriage of sheep, but a few additional points can be made. Before the coming of the railways sheep were frequently walked from Sutherland to Yorkshire, and walks of a hundred miles or more to and from the wintering grounds were not uncommon. One man and a dog could control (say) 200 sheep which kept the direct costs of such droves down to between $2 d$ and $4 \mathrm{~d} a$ head for 24 miles and $5 d$ to $8 d$ for 45 miles, in contrast to the railway charge of $4.80 \mathrm{~d}$ to $5.89 \mathrm{~d}$ per truck (beasts) mile in 1282. (2) However, since the railways became established in the trade the indirect costs must have weighed heavily in their favour. In a plea for a railway to link Tain and Stirling in 1845 it was remarked that "even before the sheep of Sutherland and Caithness can reach Tain at present, they are lamed, and of course wretched, while they lose condition every day. and hour from that spot, and yet their journey to Iancashire is hardly more than begun." (3) On the other hand it still had to be admitted that a rail journey knocked the sheep about a little. (4)

1. Information supplied by M.K. Milne, Aberdeen Public Librarian.

2. Menzies, op. cit., pp.464-465. $\operatorname{PYB}(\mathrm{S}) \mathrm{i} / \mathrm{T}$. $\frac{\mathrm{C}}{\mathrm{B} . \mathrm{R}}$. S.C. Railway Rates and Fares. 1882 XIII, appendix 3, p.34. 3. Scottish Railway Gazette, 12 July, 1845.

4. H.R.J., 30 JuIy, 1864 . 
As with cattle the development of the steamship encouraged the switch to feeding from merely breeding as happened in Dumfiesshire. (1) In some areas, however, e.g. Nairn and Elgin, the swing was away from sheep to cattle, and although counties such as Sutherland and Caithness could be termed "sheep counties" the emphasis here was on breeding and rearing not on feeding. (2) Although the wintering of sheep in the eastern and southern counties was traditional it was greatly facilitated and expanded by the railways. (3) A dead meat trade to Inglish markets, chiefly London, also developed w1th the advent of the railway. (4)

Pigs are notoriously bad travellers and were generally carted inistead of walked to market. The rallways were, therefore, perhaps able to make a greater direct saving on the transportation of these animals, although the speed of the railways may have been detrimental to their condition, pigs being highly susceptible to cold. (5) Nevertheless the railways seem to have obtained a share of this trade, over 16,000 per annum being carried by the Highland and Great North of Scotland companies in the early $1860 \mathrm{~s}$, and further south the railways helped Dumfiesghire farmers find a market for fresh

1. Gillespie, op. cit., 1869, p.278.

2. A. MacDonald, On the Agriculture of the Counties of Elgin and Nairn,' Tr.H.S., 1884 , p.119. J. MacDonald, 'On the Agriculture of the County of Caithness,' Tr.H.S., 1875, p.252.

J. MacDonald, 'On the Agriculture of the County of Sutherland,' Tr.H.S., 1880, p.76.

3. J. MacDonald, op. cit. (Sutherland), p.77.

W.M. Acworth, The Rai.lways of Scotland. 1890. p.158.

R.C. Agricultural Interests. 1881 XVI. q.43464.

4. Ibid., q.37531-37532.

5. Tenzies, op. cit., pp. 465, 483. 
pork and live pigs in the mining and manufacturing towns of the north of England. (I)

\section{TABLE 11.4}

LIVESTOCK TRAFFIC ON SCOTYISH RAILWAYS

\begin{tabular}{|c|c|c|c|c|}
\hline Year & Cattle & Sheep & Pigg & Receipts \\
\hline $\begin{array}{l}1856 \\
1.860 \\
1865 \\
1876 \\
1886 \\
1896\end{array}$ & $\begin{array}{c}300,600 \\
353,552 \\
488,762 \\
\text { n.a. } \\
\text { n.a. } \\
\text { n.a. }\end{array}$ & $\begin{array}{r}980,748 \\
1,068,502 \\
1,819,125 \\
\text { n.a. } \\
\text { n.a. } \\
\text { n.a. }\end{array}$ & $\begin{array}{r}48,923 \\
72,227 \\
88,388 \\
\text { n.a. } \\
\text { n.a. } \\
\text { n.a. }\end{array}$ & $\begin{array}{c}\text { n.2. } \\
\text { n.a. } \\
92,476 \\
173,038 \\
195,164 \\
222.715\end{array}$ \\
\hline
\end{tabular}

Source: Railway Returns.

Note: $\quad$ n.a. = not available.

Some indication of the volume of livestock carried by Scottish railways is given in Table 11.4 , but unfortunately several factors operate to prevent any estimate being made of the savings obtained from this trade. Firstly, the only avallable statistics of traffic flows fail to distinguish between the various kinds of animals and are in any case heavily affected by the cattle plague of the mid 1860s. Secondly, although data exist on the direct costs of transporting cattle by road, sea and rail, the same is not true of the indirect costs. Scattered information exists on the losses in weight and value of beasts driven to markets, but how many died or were injured on board ship is unknown, and, as for rallways, a con-

1. Calculated from the Railway Returns. Gillespie, op. cit., 1869, p.314. 
temporary statement still holds - "so far as we are aware there are no statistics in existence showing the loss of weight which stock suffer during a railway journey or the colds, inflammation, and other ills engendered by its privations." (1) A further difficulty would be what concept of value to use, for the urban price and product differed markedly from those received and dispatched by the farmer. Finally, one important contribution made by the railway, that of allowing the trader to respond quickly to market forces, is incapable of being measured.

Milk, being a highly perishable commodity, might have been expected to increase sharply in production with the coming of the railway as a distributive mechanism, but this does not appegr to have been the case, partly because the jolting of the early, unspecialised railway vans was apt to curdle the milk, but more because until the 1860s urban dairies, possessing their own livestock, were adequate to meet the needs of the populace. (2) Even in 1877 half of Edinburgh's milk was internally produced. (3) In addition it was feasible to cart milk (say) ten miles into town should the demand outpace immediate supplies. Dumbartonshire farmers carted all their milk into Glasgow and other towns and villages as late as the mid 1880s. (4) Dairy farmers away from concentrations of population

1. Nenzies, op. cit., p.480.

2. C.S. Orwin \& E.H. Whetham, History of British Agriculture 18461914. 1964. p.19.

3. T. Farrell, 'On the Agriculture of the Counties of Edinburgh and Iinlithgow,' Tr.H.S., 1877, p. 35 .

4. Ibid, , p.5i.

J.M 'Neilage, 'The Agriculture of the County of Dumbarton,' Tr.H.S., 1886, pp.14-15. 
concentrated on making cheese and butter and practically ignored commercial milk production.

However, during the last three decades of the nineteenth century the situation changed. Writing in 1888 one authority claimed that sweet milk dairying at a distance from a large town could be dated as beginning within the previour fifteen to twenty years and, more especially, to the late 1870s. (2) In 1883 the Caledonian carried 71,000 gallons of milk into Aberdeen, by 1900 this had risen to 265,000. Moreover, the catchment area was growing, the average length of journey to Glasgow rising from forty-two to forty-seven miles within the same period. (3) Distance became of little object, partly because the charge made by the railways remained constant after twenty-five miles. Milk was carried, for example, from Lockerbee to Dundee and from Linlithgow to Newcastle. (4)

Several factors brought about the acceleration in the railway milk trade. Changes in the sanitary laws acted against having large livestock dairies in the hearts of towns and cities; keeping cattle in towns never really picked up after the cattle plague of the 1860s. (5) Milk consumption per head rose steadily during the last quarter of the nineteenth century, presumably because of the increase in real wages. (6) The increasing foreign competition in

1. Maclelland, op. cit., p.52.

2. J. Spier, 'Dairying in Scotland,' Tr.H.S., 1888, p.318.

3. Calculated from CAL $4 / 86,4 / 92,4 / 100 . \bar{B} \cdot$.

4. A. Hutcheson, 'The Past and Future of Scottish Agriculture,' Tr.H.S., 1899, p.127.

Farre11, op. cit., p.36.

5. Hutcheson, loc.cit. Farrell, op. cit., pp.35-36.

6. R.H. Rew Journal of the Royal Statistical Society, vol.55, 1892, p.266. 
the cheese trade may have persuaded many farmers in the south and west to take advantage of the facilities offered by the railway companies and turn to the less competitive milk trade, though others stuck to cheese-making in the summer when milk was plentiful and cheap; Stirlingshire farmers could obtain lld a gallon in January but only 6d gallon in May, June and July. (1)

Changes were also made in the structure of the milk trade. Uniess farmers lived near to towns they no longer retailed milk themselves in the streets, but sold their milk wholesale to the city dairies, often on yearly contracts. (2) The development of the milk trade made it essential for there to be an all year round supply of milk. This involved a regular succession of calvings and necessitated the introduction of artificial feeding stuffs because turnips tainted the milk. (3) A by product of this development was increasing quantities of butter milk which were sold on the streets of Glasgow, used to feed pigs and supplied to bakeries. (4)

Neither the dairy farmer nor the cattle traders and farmers were

1. Hutcheson, 1oc.cit.

Spier, op. cit. pp.319-320.

Gillespie, op. cit., p.3Il.

W.H. Ralst on, 'The Agriculture of Wigtownshire,' Tr.H.S., 1885, p.122.

J. Tait, 'The Agriculture of the County of Stirling,' Tr.H.S., 1884 , pp.164-165.

2. MPNeilage, op. cit., pp.14-15, 19, 25, 35, 46. Spier, op. cit. p. 317.

3. Ibid., p.312. Orwin \& Whetham, op. cit., p.149.

J. Tait, 'The Agriculture of Lanarkshire,' Tr.H.S., 1885, p.39.

4. Ibid., p.62.

McLeliand, op. cit., p.52.

Ralston, op. cit., p.125. 
fully satisfied with the service offered by the railway companies. In 1898 "the larger towns, villages and watering places along the eastern seaboard are anything but well supplied with milk," but this was primarily the fault of the farmers for not cultivating the trade. (1) However, that the southern portion of the Rhinns district and part of Ayrshire were still confined to cheese making even after the first world war can be attributed to a deficiency in ra1lway communication. (2)

The milk traders did not complain about the speed of the trains, but this cannot be said for the butchers, probably because the latter's perishable products had to travel greater distances. In warm weather whole truckloads of meat were apt to be lokt, though the gradual introduction of the refrigerated van would ease this problem. (3) Complaints of inadequate speed were not confined to dead meat in the summer months. The railway companies professed to bring Aberdeen cattle to Iond on within 36 hours, but $\mathbb{M}^{\prime}$ Combie reckoned 40 to 42 hours not uncommon and had known of 44 hours on occasions. This might involve being late for the market, but, of more importance, the condition of the livestock deteriorated as they generally went without food and water during the journal. The reason for this was the impracticality and delay of unloading and reloading cattle en route. (4) One solution devised was that of

1. Spier, op. cit., p.342.

2. S.C. Rural Transport (Scotland). 1919 XXX, para.17.

3. S.C. Noxious Businesses. $1873 \mathrm{X}, \mathrm{q} .3016$.

4. Ibid., q.3056, 4048 . 
Mr. W. Reid of Granton who was awarded a silver medal by the Highland Society in 1865 for designing an "improved" cattle truck embodying water troughs, but within four years its use was abandoned because the troughs inevitably filled with dust or became blocked up. (1) Another solution was advocated by John Swan, the cattle trader, who proposed watering stations with mobile troughs that could be brought alongside the cattle trucks. Whether anything became of this idea is not known. By 1881 the time had been reduced to 33 hours so perhaps such innovations were becoming less necessary. (2)

Earlier it was stated that $M \cdot C$ ombie had not lost any cattle in rail transit, but other traders did experience losges. However, M'Combie laid the blame at their own door not the railways'. The reason for the deaths was, in his opinion, the walking of the beasts perhaps ten miles to a railhead when for the past six months or so they might never have set foot outside their stalls. (3) Again when the railways began to charge by the truck rather than per head, deaths occurred because the traders, in a false effort to economise, often overcrowded the wggons. (4)

The rates charged by the railway companies were themselves subject to criticism. Cumberland and Westmoreland farmers protested that railway rates, particularly those of the Caledonian, prevent ed

1. H.R.J., 28 January, 1865. Engineering, 12 November, 1869.

2. S.C. Railwayg. 1881 XIV, appendix 73 .

3. McCombie, op. cit., p.72.

4. Menzies, op. cit., p.478. 
the Inglish graziers making greater use of the Scottish cattle markets. In reply the Caledonian traffic manager implied that his hands were tied by agreements made with the North British, which might suggest an acknowledgement that the rates were too high. Complaints were also made about the lower rates given to foreign cattle, particularly American and Canadian, in preference to domegtically reared beasts. The answer given to this charge by the railways was that they would not get the foreign cattle at all if higher rates were asked as they would simply remain on board ship and be taken south for fattening.

\section{3.}

Iittle can be said in quantitative terms about the influence of the railways on Scottish grain production. It is known that grain was an important element of the traffic on the Scottish Central railway and that, at one time, "the grain trade was more than a third of the whole traffic between Edinburgh and Glasgow," but unfortunately no general documentation of grain traffic flows exists. (2)

All that is feasibly susceptible to measurement is the effect that the railways had on grain prices, and this is fraught with

1. S.C. Railways. 1881 XIV, q.5981-6069, appendix 19.

2. H.R.J., 26 March, 1859. Scottish Rallway Gazette, 19 May, 1860. 
difficulties. The main point of trouble is the concept of price to be used. Unless one has the time and patience to work out average yearly prices for each grain market in Scotland reliance has to be placed on the annual county fiars prices. In theory these were supposed to cover all the main types of victuals, but only those grown and marketed within a county. Rosalind Mitchison has pointed out the extent of their unreliability in the seventeenth and eighteenth centuries and it is arguable that this worsened in the nineteenth century. (1) One writer in the early 1850s proclaimed that "... the modes of striking the Fiars in several counties of Scotland are different, inconsistent, and contradictory, and that the manner of conducting this great process is generally loose, inefficient, and incorrect." (2) There are several potential sources of error in their format. Firstly, it may have proved easier for a farmer to market his grain away from the county town, possibly in another county altogether e.g. 40,000 tons of grain per annum were passing along the Forth and Clyde canal in the early 1830s. (3) Some counties allowed corn sold outside the county to be counted for fiars purposes, in some cases deducting transport costs, in others no such deduction being made. Secondly, in most counties

1. R. Mitchison, The Movements of Scottish Gorn Prices in the Seventeenth and Eighteenth Centuries,' Economic History Review, sec ond series, vol.xviii, no.2, August, 1965.

2. G. Paterson, Historical Account of the Flars in Scotland. 1852.p.4. See also the criticisms in Corn Averages (Scotland) 1834 XIIX, pp. $1-6$

3. Edinburgh, Leith and Glasgow Railway, 28 December, 1831. Mitchell Iibrary. 
a half to two-thirds of the crop was unsold at the time the fiars were struck and thus that price may not be truly representative. Thirdly, the method of compilation might change over time thus making temporal comparisons difficult. Finally, some of the earlier fiars orices are for an assortment of local and national weights and, although care was taken, there is an element of inaccuracy in converting them into the standard weights in operation during the later period. Despite these potential pitfalls the use of fiars can perhaps be justified by an official statement in the early twentieth century - "Whatever may be the admitted imperfections of Fiars Prices, they, at any rate, form a continuous and systematic official chronicle of values superior in many respects to any other series of agricultural prices."

Bearing these points in mind, an examination can be made of the impact of the establishment of the railway network on Scottish grain prices. Edith Whetham, in her study of Scottish farming prices, suggested that, as the century progressed, the development of a railway system would tend to lessen price differentials between regions. (2) Presumably this would occur by allowing distant farmers to benefit from increasing urban demand and also by facilitating the movement of grain from low to high price areas. In an attempt to ascertain whether there was any equalising tendency five

1. Agricultural Prices (Scotlend). 1902 XXI. p.ix.

2. .H. Whetham, Prices and Production in Scottish Farming 1850-1870. Scottish Journal of Political Economy, vol.9, no.3, $1962, \mathrm{p} .236$. 
regions of three counties each were arbitrarily designated Northern (Aberdeen, Banff and Elgin), Eastern (Roxburgh, Berwick and Haddington), Western (Ayr, Dumfries and Lanark), Central (Edinburgh, Perth and Stirling) and Highland (Sutherland, Ross and Calthness) - and an analysis made of intra and inter-regional price differentials over time. However, because of the inherent inadequacies of the source material the analysis was very simple, no reliability being placed in the results of sophisticated statistical techniques.

The results of the analysis can be seen in Tables 11.5 and 11.6. When intra-regional prices are considered there is a fairly convincing trend towards an equalising of prices over the century In the ease of wheat, a less convincing one in the case of barley, and no consistency at all where oats were concerned. This has possibly something to do with the fact that oats and barley found more local uses than did wheat and entered less into commercial transations. When inter-regional price variations were considered, between $1828 / 32$ and $1854 / 56$ the percentage of prices narrowing was 40 for wheat, 30 for oats and 50 for barley. Between 1828/32 and 1890/94 the corresponding percentages were 50, 20 and 30, hardly suggestive of a narrowing of differentials, especially in view of prices being generally higher in the earlier period. It can only be hazarded that transportation costs were not reduced significantly enough relative to prices to warrant vast inter-regional grain flows over any distance. Intra-regional flows would involve a smaller 


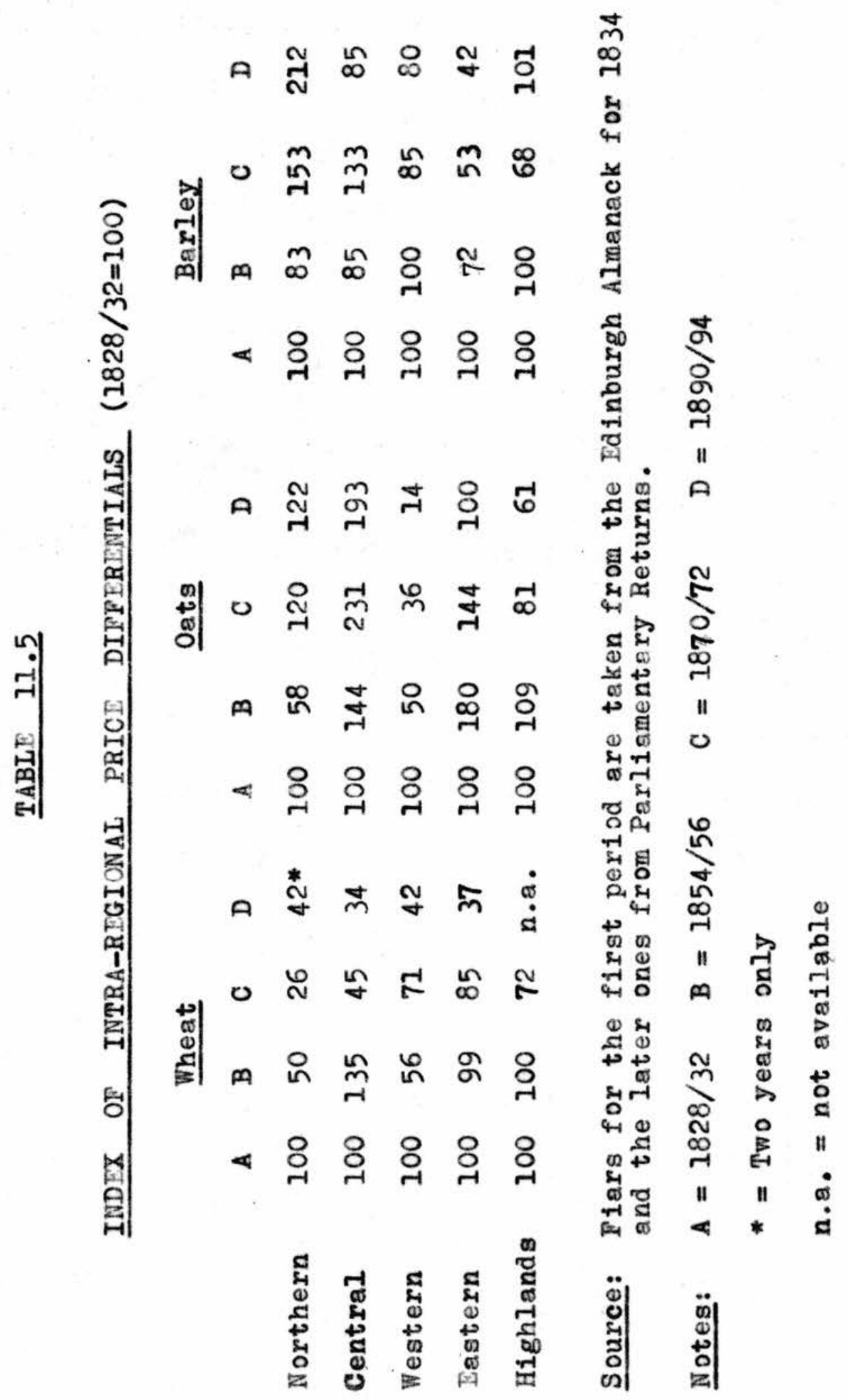




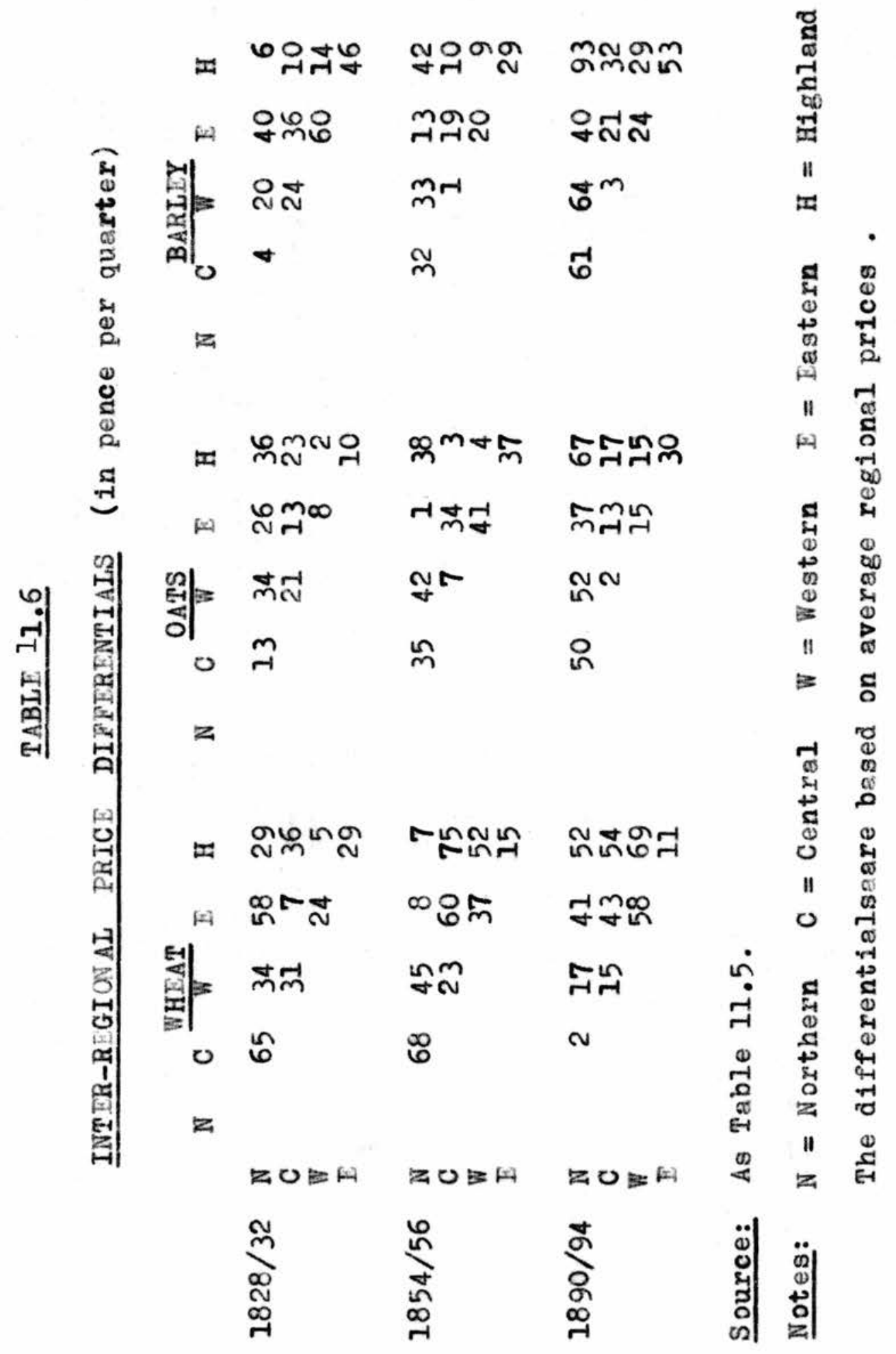


percentage of transport costs in the final prices and would therefore be more likely to be affected by the coming of the railways.

\section{4 .}

Potatoes were first sent from Perth up to London in the late 1820 s and by 1840 such a trade was well established, not only from Perth, but also from Fife, Forfar and the Iothians. (1) A substantial internal trade had also developed with the counties of Ayr, Lanark and Renfrew supplying Glasgow, and the Lothians furnishing the needs of Edinburgh. (2) The railways built at this time served to accentuate these developments, but the later expansion of the Scottish railway network both reinforced existing trends and brought about structural changes in the trade. Areas where previously potatoes had been fed to pigs, because prohibitive transport costs priced them out of distant markets, now entered upon comercial cultivation of the crop. (3) The old main markets of London, Edinburgh and Glasgow remained important, but Nanchester and Newcastle increased in significance and the transborder potato traffic reached substantial proportions. (4)

1. J. Dickson, 'On the Agriculture of Perthshire,' Tr.H.S., 1865, p.176.

R. Salaman, The H1story and Social Influence of the Potato. 1949, p.401.

Franklin, op. cit., p.153.

2. Franklin, Ioc. cit.,

3. Gillespie, op. cit., p.315.

4. S.C. Railway Rates and Fares. 1882 XIII, $q .559$.

R.C. Agricultural Interestg. 1881 XIV, q.36595. C.J.B. MacDonald, 'Potato Growing in the Lothians,' Tr.H.S. 1895, p. 308 . Scotsman, 31 March, 1880. 
In the west the late 1850s witnessed a significant development when Ayrshire farmers, after giving up large scale production followIng the blight of 1845 , began to cultivate early potatoes for which the county's sheltered beach lands, high rainfall, humid atmosphere and high winds were eminently suitable. (1) Whether this development had anything to do with the rallways is debatable, but their existence was undoubtedly taken advantage of as a distributive mechanism; the dealers purchasing the standing orop and the farmers' responsibility ending with delivery to the nearest rallway station.

(2) This practice of growing early potatoes spread to other counties, but in one area, Dumbartonshire, the reverse happened with emphasis being concentrated on the late varieties and the production of the early kind practically abandoned, and although potatoes became "the keynote of Dumbartonshire arable farming" from the 1860s, their sale was restricted to the shire and surrounding districts. (3) Specialisation could still maintain local monopolies despite transport improvements.

It has been argued that, notwithstanding the aubstantial railway potato traffic, it could have been developed even more by the building of more lines in Wigtownshire and Ayrshire where soil and climate were favourable for the cultivation of early potatoes, but where inadequate transport facilities deprived the farmer of

1. Franklin, op. cit., p.154.

2. Salaman, op. cit., p.404.

3. Salaman, op. cit., p.405. M'Neilage, op. cit., pp.13, 53. 
markets. (1) This is true, but it should not be allowed to detract from the important, if not essential, distributive role played by the rallways in the Scottish potato trade.

\section{5.}

In the early nineteenth century fruit growing flourished in the Clyde Valley, but its prosperity declined when steamships from Ingland and Ireland broke the local monopoly and forced prices down. (2) This competition was presumably reinforced by the development of the railways, at least where England was the rival concerned. Apple growing, however, remained very prosperous until imports from Canada and the United States became heavy. (3) Not until the last quarter of the century did the railways serve to positively assist the Scottish fruit industry, and this came with the development of strawberry cultivation in Scotland. This took place around Perth and in the district between Blairgowrie and Coupar Angus, but the main centre appears to have been Clydesdale. (4) The railway was probably not essential to this development a.though its speed must surely have helped the fruit retain its Preshness right to the market. It should also be noted that

1. S.C. Rural Tranaport (Scotland). $1919 \mathrm{XXX}$, para.112.

2. Symon, op. cit., p.416.

3. J. Bair, the Cultivation and Marketing of Strawberries in Clydesdale,' Tr.H.S. . 1892, p.136.

4. Symon, on. cit., p.417. Bair, op. cit., pp.145-146. R.C. Agricultural Interest. $1881 \mathrm{XIV}, \mathrm{q} .546$. 
although many early strawberries were sent to Glasgow for domestic consumption and much of the later crop went to England for preserving, both of which would utilise rail transport, this would not be the case where the fruit was used in R. \& W. Scott's preserve works at Carluke, right in the middle of the strawberry belt.

As with other aspects of Scottigh agriculture and horticulture the Committee on Scottish Rural Transport claimed that the railways could have done much more, though the situation in this case was not just the usual complaint of inadequate transport facilities cutting market opportunities, but also that the absence of lines on which pickers could be conveyed into the region hindered the development of a bush and soft fruits industry in the suitable sheltered valley near Fintry in Stirlingshire. (2) In reply to this it could be argued that the fruit traffic would be seasonal and that unless other traffic was to be expected then it might not have aeemed a profitable proposition to the railway companies.

\section{6.}

The coming of the railway had one definite effect on Scottish agriculture in that, by reducing transport costs, it tended to smash local monopolies and produce a reorientation of markets, with those on a railway generally gaining at the expense of the ones that

1. Bair, op. cit., pp.150-153.

2. S.C. Rural Transport (Scotland). 1919 XXX, para.214. 
were not.

Regular auction marts for livestock alongside or near to railway stations took over from the periodic fairs along the old droving routes. In the Iothians old established local fairs, such as at Gifford, became neglected in favour of cattle fairs at Iinton and weekly Iivestock auctions at Haddington, both of which were well served by rall communication. (1) Elsewhere the traditional cattle fairs at Warthill, Rayne, Lumsden, Ackley and Amulree gave way to weekly or monthly auction sales at the stations of Inverurie, Insch, Huntley, Turiff and Maud. (2) It was not just in livestock farming thet the railways produced changes in the location of markets; when the railway came to Duns a grain market was established with times of sales arranged to fit in with the trains from Edinburgh. (3) Although it cannot be completely attributed to the development of the Scottish railway system, it is perhaps significant that of 43 important Scottish fairs and markets listed in the Edinburgh and Leith Post Office Directory in 1840, only 11 remained large enough to warrant a mention in 1880. However, being on a railway did not guarantee that a market could be established, as can be seen from the experience of Dunblane. In the early 1870s an attempt was made to develop cattle, sheep and grain markets at

1. R.S. Skirving, 'On the Agriculture of East Iothian,' Tr.H.S., $1873, \mathrm{p} .43$.

2. Orwin \& Whetham, op. cit., p.98. Black, op. cit., pp.10-1I.

3. Edinburgh Evening Courant, 20 October, 1849. 
the local station, but they were not a success and what trade they had bullt up was eventually absorbed into that of larger centres. (1)

The fortunes of Dunblane may be related to another facet of the railways' influence on the structure of markets, that of producing greater centralisation by facilitating the transport of crops, stocks and persons to distribution centres. Despite Haddingt on being on the railway itself, the greater concentration of railways on Edinburgh enabled the metropolis to take over Haddington's distinction of being the largest corn market in Scotland; the easy access to Edinburgh making the farmers of Fife less dependent on the locel fairs. Adequate rail comnunication with Edinburgh may also account for the poor attendance at the weekly grain markets held in Galashiels and Selkirk.

\section{7.}

Several complaints about the service offered to farmers by the railways have already been cited. In this section an attempt will be made to assess the validity of the most general complaints. Farmers may or may not be conservative, but by the early 1860 s most of them "were now quite alive to the economy of railway transit." (3)

1. A.M. Barty, The H1story of Dunblane. 1944. p.273.

2. Skirving, op. cit., p.39.

J. MacDonald, 'On the Agriculture of the County of Fife,' ir.H.S., 1876, p.6.

A. MacDonald, 'The Agriculture of the County of Selkirk,' Tr.H.S., p.119.

3. Chairman of the Peebles railway, quoted in H.R.J., 9 April, 1864. 
However, as the rigours of the 'agricultural depregsion' impinged upon them, their thoughts turned towards the necessity of achieving further economies, for as the prices of agricultural commodities fell, so a railway charge based on weight and not on value would eat away at profit marging.

In his evidence to the Royal Commission on Agricultural Interests an influential Aberdeenshire farmer, J.W. Barclay, M.P., voiced the opinion that "there is no doubt that farmers in this country suffer considerably from the excessive, and in many ways illegal rates" charged by the railway companies. (I) However, the great majority of witnesses do not appear to have supported his assertion and the general conclusion of the Commissioners, as regards Scotland, was that only exceptionally were there cases for redress, and these were virtually confined to inland areas where the railways had no competition to fear. (2) Certainly anomalies existed, e.g. on the North British grain travelled the 43 miles between Edinburgh and Alloe for 1.39 a ton-mile, while the 52 miles to Kelso cost $2.01 d$ a ton-mile, but anomalies and varying rates are surely only to be expected in a free enterprise railway system. (3). Certainly some rates appeared high, but only one case of overcharging was legally substantiated, that of the charges made by the Great North of

1. R.C. Agricultural Interests. 1881 XVI, q.43198.

2. Ibid., pp.532, 537-539, 544, 549-550, 567-568.

3. S.C. Railway Rates and Fares. 1882 XIII, appendix 3. The reports to the Royal Commission on Agriculture in 1895 cited instances of farmers, during the slack period of the year, carting six to eight miles past their local station to dispatch goods from another station further away from their destination. It was reckoned that a rate differential of $10-20 \%$ existed where the railways were immune from competition. (1895 XVII, pp.17, 30, 36 and 43). 
Scotland railway to the Aberdeen Commercial Company, and part of the trouble here came because the rates for fertilisers were fixed by parliament in the days when dung meant manure not guano. (I) What annoyed many farmers were the differential rates offered to home and foreign agricultural produce, but the basic reason for this was that the forelgn supplies were available in bulk and were accordingly rewarded for allowing the railways to secure economies of scale. (2)

As it became apparent that agricultural prices were not going to increase of their own accord the unification of protest, absent in 1881, began to appear, especially after the general revision of railway rates in the early 1890s which, according to the Highland and Agricultural Society, led to a "large and serious increase in rates for the carriage of produce." (3) Excessive rates were specifically alleged in the cases of quantities of less than two tons, especially if travelling short distances. The rates offered were as low as those generally offered in Ingland, but some lines south of the border were experimenting with special rates for small quantities of agricultural product. Although it was not apparent

1. S.C. Railways. 1881 XIV, q.631-643, 648-650, see also appendix 16 . H.R.J., 2 April, 1881.

2. R.C.Agricultural Interests. 1881 XVI, q.36022, 36308, 36389$36393,43198, p .568$. R.H. Rew, 'Farmers and Railway Rates,' Journal of the Royal Agricultural Society, vol.6, 1895.

3. Tr.H.S., 1898, p.515. 
that the railways stood to gain by encouraging small scale farmers who could not provide enough freight to fill a wagon, when it was brought to the attention of the railway companies that a potential traffic in eggs, butter, fruit, vegetables and poultry was being lost because of prohibitive transport costs they agreed to try out special rates, and this seems to have worked to the satisfaction of both parties. (I)

It can also be suggested that in some cases the farmers had only their fatalistic apathy to blame. This can be illustrated from the cross examination of one witness to the Royal Commission on Agricultural Interests in 1881, James Dalziel of Dumfies.

Do you know the mileage? - No. Then you have not looked into the case very critically, have you? - No.

If the farmers complain, why do they not look into the question very critically? - The Railway companies just do as they like with us, they make their own charges and never mind us when we complain.

So that you leave yourselves at their mercy? - We have to do it. Is it becruse you do not know how to proceed? - I do not think 1t is that, but we think we should get redress.

Haye there been any representations made to the railway companies? - No - none that I know of. (2)

The Select Committee enquiring into the adequacies of communications in rural Scotland after the first world war were of the opinion that for the failure of some areas "to attain the degree of improve-

1. Tr.H.S., 1898, PR. 503, 508,515 .

H.R.J., 3 April, 1896; 20'March, 1896; 18 June, 1897;

27 August, 1897.

R.C. Agriculture, 1895 XVII, p. 30 .

2. R.C.Agricultural Interests. 1881 XVI, q.37987-37992. 
ment of which they are capable deficient transport must in part be blamed." They went on to attack the railway companies for generally failing to build ahead of demand - "to teat the expediency of constructing a new line solely by the amount of viable traffic, or even by the amount of traffic reasonably to be anticipated within a few years, is we think, to miss something of the value of a development policy." (I) This is perfectly true, but can private enterprise be expected to see its short term profits cut In the hope of something to come an unstated number of years in the future? It has been suggested earlier that shareholders were not always content to remain sleeping partners when their dividends were being threatened. (2) Moreover, it was suggested in chapter nine that the coming of the railway to remote districts tended to accelerate depopulation, so the hope of future profits held out by the Committee may not have been realistic.

Pinally, the railways could argue that whatever their deficiencies as transport media they more than compensated the farmers by subsidising their rates for most of the nineteenth century. The Glasgow and South Wewtern, for example, could point out that in four agricultural parishes they owned $0.29 \%, 0.37 \%, 0.33 \%$ and $0.35 \%$ of the land, but paid $16.46 \%, 19.41 \%, 20.10 \%$ and $26.35 \%$ of the total assessment, and in one outstanding case they paid $37.0 \%$ when possessIng only $0.19 \%$ of the land and the parish did not even have a station. (3) The assessment of the Crieff and Methven railway

1. S.C. Rural Transport (Scotland). $1919 \mathrm{XXX}$, para.16.

2. See chapter three, pp.149-150.

3. H.R.J., 20 March, 1896. 
rose from about $£ 500$ to just short of $£ 5,000$ simply because it became part of the Caledonian system and was assessed on the same terms as the min line. (I) In Lanarkshire the attitude of the local authorities forced the railways to go to the courts for their own protection. (2)

However, by the end of the century the protests of the railway companies had ended and it was the turn of the local authorities to complain that the rates paid by the railways were too low and were inequitable towards heritorg. So alarmed were the authorities that they held a conference on the subject in Edinburgh in January, 1903. (3) Their anxiety is easily understood for in 1901/2 the Highland railway was not worth a farthing to the authorities of the country traversed except in respect of stations, and it was forecast that if the current rates of depreciation continued even the formidable Caledonian would disappear from the valuation roles of Ianarkshire

1. Abercairney Paperg. G.D.24, section 926, 2 November, 1870. S.R.0.

2. R̃ilway News, 2 October, 1875.

3. W.A. Dykes, The Valuation of Railways in Scotland for Rating Purposes. $1 \overline{903 .}$ 
within twelve years. (I)

8.

A correspondent to the Berwick Warder in 1846 remarked

"scarcely any class begins to feel the benefit of railways more

than fishermen do." Almost fifty years later the economist, W.M. Acworth, claimed that "... It is to the railway rates that the fishing industry (of Scotland) owes it that it exists at all." (2)

In fact throughout the century the coming of a railway was envisaged

as a panacea to all the fisherman's troubles. The view of the

Banffshire Journal was not atypical -

"The first great revolution or change favourable, in a decided degree, to the growth and support of the fisheries in general along our coast, must be patiently waited for till the opening

1. Glasgow Herald, 27 December, 1902.

The railways in scotland were valued not by the municipal or imperial assessors but by a Rallway Assessor whose sole occupation this was. The statutes only partially outlined the methodology of his assessment which was supposed to be based on a rent at which it might reasonably be expected to have been let from year to year. However, as railways were never let, a complex method of assessment evolved in which so many deductions were allowed from gross revenue that often less than a third remained as rateable value. The technique which emerged by 1900 was to deduct from gross revenue (i) working charges including half the expense of maintaining the pormanent way (ii) $10 \%$ for interest and depreciation on the value of stores in hand (iii) $5 \%$ for interest on the estimated sum of floating capital required for carrying on the business (iv) $18 \%$ on the value of plant employed in working other lines (v) $25 \%$ upon the reputed value of rolling stock, machinery, tools, and furniture, in respect of tenants' profits and other allowances (vi) an abatement in respect of earnings accruing to each company for traffic carried in plant belonging to traders. The anomalies of the system meant that if a railway re-equipped itself with improved or more valuable machinery it could conceivably pay lower rates in contrast to ordinary heritors who paid increased rates when they improved their property.

2. Quoted in Scottish Railway Gazette, 12 December, 1846. Acworth, op. cit., p.128. 
of the Great North of Scotland Railway ... This power has already begun to operate at Scarborough, and along the whole of the Yorkshire coast. Fish of every kind, in fine fresh condition, penetrate daily into the densest masses of our manufacturing population. We anticipate that within four years, or perhaps less, those dwelling on the shores of the Moray Firth will be partakers in this heart-cheering occupation. We anticipate that we shall become the providers... to the southern towns of the line, Aberdeen, Dundee, Edinburgh, York, Birmingham, and, lastly, the great swallower-up of all and everything, Lond on itself: (I)

As railways were proposed and projected further north such eulogies were repeated time and again. The supporters of the Dingwall and Skye in 1864 pointed out "that our seas teem with fish at the present moment ... but the difficulty is to procure barrels, and selt and markets - wants which might all be supplied by a line of railway." (2) And towards the end of the century the Treasury made a financial contribution to the Mallaig extension of the West Highland railway "with a view to the development of fishing and crofting industries in the western districts and the Hebrides." (3)

Did the railways deserve the attention lavished on them? Obviously their speed vastly extended the potential markers of the Scottish fishing ports and perhaps also facilitated specialiss:ion and economies of scale by allowing activities to be concentrated on selected ports. (4) There is no doubt that when the railway opened

1. Quoted in H.R.J., 10 April, 1847.

2. H.R.J., 30 July, 1864 .

3. Quoted in The Story of the West Highland Railway. B.R.

4. The railways carried fish from 139 Scottish ports in 1900 , but nearly $80 \%$ was despetched from only eight of them, and Aberdeen itself accounted for about $40 \%$. (Returns Relating to the See Fisheries of the United Kingdom. 1901 LXX, pp.44-45). 
up new sources of demand it was readily taken advantage of e.g. in the first year that the Highland railway reached Kyle of Lochalsh 4,540 tons of fish ( $=c .5 \%$ of total Scottish rail shipments) were taken away. However, it should be noted that this was to the detriment of Strome Ferry where fish carried away by rail fell from 5,338 tons in 1895 to a mere 52 tons by the end of the century. It should also be noted that, although one writer attributes the outstanding success of Aberdeen's white fish industry to the linking of that city by rail to southern markets, the real reason probably lies in other factors such as the introduction of steam trawlers or changes in demand patterns. (2) Railways were really only a permissive factor for although the city had been on the railway network from the mid century, almost $90 \%$ of the nineteenth century increase in the dispatch of fish from Aberdeen came in the last five years of the century. (3) A third point to be made is that the total volume of fish landed in Scotland in the yearg 1898-1900 was 853,000 tons, of which the railways carried approximately 320,000 tons i.e. only $38 \%$. (4)

Despite these qualifications contemporaries had little hesitation in attributing the rise of the Scottish fishing industry to the advent of the railways. The Fishing Gazette wrote of the

1. Ibid.

2. J.R. Coull, 'The Historical Geography of Aberdeen,' Scottish Geographical Magazine, vol.79, no.2, September, 1963, p.91.

3. Parliamentary Papers. 1901 IXx, p.44.

4. Ibid. 
impetus given to Scottish sprat fishing by the extension of the railway system in the north of Scotland and the editor of Herapeth's emphasised the role of the railways in developing the fresh fish traffic between Scotland and Iondon. (1) However, it should be Etressed that the great expansion of the fish traffic on the Scottish railways came in the late nineteenth century. In 1881 49,000 tons were carried, but by 1900 the figure had more than doubled to 115,104 and, as suggested above, this was probably due to factors outside the control of the railway companies.

This is not to say that the railways did nothing to assiat in the expansion for they cooperated with the Fish League in experiments using refrigerated wagons, $\mathrm{e} i \mathrm{x}$ of which were in operation between the Scottish ports and Iond on in 1884. (3) Another way in which the railways definitely assisted the fishing industry was by offerIng special rates, at something like two-thirds of the normal rate, to fish workers to get to the ports during the geason, and also to the fisherwomen travelling from e.g. Newhaven to the border towns. (4)

Coincldent with the rapid development of the trade came the growth of complaints about the service offered by the rallway companies. This appears to have been mainly connected with the

1. H.R.J., 24 December, 1870; 8 Apr11, 1871.

2. Rallway News, 3 July, 1886. Parliamentary Papers. 1901 LXX, p.45.

3. H,R.J., 30 October, 1880 . T.E.S.S. $1883 / 4$, p.6.

4. TT(S) $52 / 27$. B.R. H.R.J., 2 April, 1859. 
depression of prices rather than any inability on the part of the railways to handle the increased traffic.

The question of rates was usually to the fore. In the early 1880 a complaints were mede by some traders that high rates for fish were discouraging potential traffic. It was argued that since the 1860s, especially following the amalgamations, the rates for fish had risen so much that they accounted for something 11 ke $44 \%$ of the sale price of Montrose fish in Billingsgate. (I) Protests were also made that special fish trains were unavailable and that if the fish consequently went by passenger train an extra pound per ton was charged (Montrose to Billingsgate). (2) There was some justification in these complaints but there was also a case for the rallway companies. The North British openly admitted to exploiting a monopoly position by charging a substantially higher rate from Montrose to Glasgow than from Montrose to Birmingham "it is a fair rate to Glasgow, because we have command of the market in Glasgow, but if we were to take the same rate per mile to Birmingham we should lose the trade." (3) However, the Scottish companies appear to have advocated a lower through rate to the Fnglish markets for e.g. Shetland fish, but were opposed by the English parties to the through agreements. (4) The companies also

1. S.C. Railways, 1881 XIV, appendix 42, q.1152, $1198-1200$. S.C. Railway Rates and Fares. 1882 XIII, $q .578$.

2. S.C. Reilways. 1881 XIV,

3. S.C. Railmay Rates and Fares. 1882 XIII, q.594.

4. S.C. Railweys. I8EI XIV, appendix 42. 
argued that $28 \%$ was a more normal proportion of transport costs to selling price, and suggested that if the fishermen were suffering, it had more to do with the cuts taken by the Iondon fish traders and fish curers than with rallway rates. (I) There does seem to have been an absence of fish specials, but this was later defended by the Board of Trade on the grounds that quite often special trains had been sent to a port on receipt of a telegram, only for it to be found that there was no load to iake, either because the fish were landed too late to catch the market or because a glut of fish already in the market rendered it unprofitable to send additional catches. (2)

In January, 1886 the merchants and fishermen of Wick and Puteney-town memorialised the railway companies for "an immediate concesgion of the present high and almost prohibitory railway rates on f1sh Irrom Scotland to England." In return they promised that herrings usually sent salted to the Baltic would instead be sent fresh by ra1l to English markets. (3) Nothing appears to have come of this proposal, but, in the case of a complaint about inadequate provision of railways to the fishing ports of the woray Firth, the companies took positive steps to remedy the deficiency by constructing new lines from Portsoy to Elgin and from Keith to Buckie. (4) In fact the number of ports served by the Scottish railways rose from 124 in 1886 to 139 in 1900. (5)

1. S.C. Rallway Rates and Fares. 1882 XIII, appendix 32.

2. H.R.J., 8 November, 1890.

3. Railway News, 27 March, 1886.

4. Railway News, 11 May, 1886.

5. Rallway News, 3 July, 1886. Parliamentary Papers, 1901 IXX, pp.44-45. 
It can be argued that the railways played an important permissive role in the development of the Scottish fishing industry, but whether this was of equal importance to the Scottish economy as a whole is less obvious. It is here that a distinction has to be made between local and general economic analysis. A few train loads of fish each day may not have meant much to the nat1onal product or even to the individual railway companies, but to the fishing ports of Scotland and the 29,600 people employed in the f1shing industry in 1901 they meant the difference between economic Iffe and death.

\section{9.}

It might be expected that the railways, with their demands for timber for fences, sleepers and rolling atock, would have been important customers of the Scottish forestry industry, but this is not born out by the evidence. Until the mid 1840s not enough mileage was constructed to have any significant influence on the demard for timber, and, in any case, many of the early railway engineerg preferred to use stone blocks as sleepers. (1) Even when it was found that stone could not withstand the strain of increasing traffic, the railway companies failed to put pressure on the Scottish forests, as it was discovered that Baltic timber lasted longer than Scots fir. (2) The general adoption of creosoting alsolengthened the I. H.R.J., 30 oct ober, 1852; 10 September, 1853. 2. Report of the Committee of Inquiry to Shareholders of the North British Rallway. 26 July, 1849. p.4. B.R. 
life of timber used as sleepers and thus reduced total potential demand. In the immediate post-mania period there was an important demand for timber to be used in bridges and stations, but this tended to be a once and for all demand, later construction and renewals utilising bricks, stone, and metal. (1) Over the century the railways made use of timber, but either they imported much of it, or their total demand was slight, for in the 1890s it was argued that housebuilding and shipbuilding took the bulk of Scottish timber domestically consumed. (2)

Where trensportation of timber was concerned, however, the railways made a great contribution. Before the North British built lines to Hawick, Jedburgh and Kelso the only derand for timber was local because of the prohibitive transport costs, but after their construction timber was easily carried into the Lothians and elsewhere, and "now (1872) when an important wood sale takes place, wood merchants come from Edinburgh, Newcastle, Carlisle etc." (3) Further north Speyside timber was, before the coming of the railway, floated down river, but this was apt to be stopped by drought and in times of flood losses could be severe. The opening of the rallway provided a safer and more regular form of communication between the forests and the ports. (4) One authority went so far as to claim

1. Engineering, 16 April, 1869.

2. Glasgow Herald Trade Review 1895, p.54.

3. C.Y.Michie, 'On the Prices of Forest Produce,' Tr.H.S., 1872, p.222.

4. Ibid., p.216. 
In the early 1870s that "almost the only circumstance that has enhanced the value of wood within the past ten or fifteen years is the reduction of the rate of transport derived by railway communication." (1)

10.

It was suggested in chapter three, section four that the land costs of the railways were not the "blackmails of the forties" that they have often been alleged to be. Yet it remains true that the railway companies believed that they paid excessive prices for their land. What probably annoyed the companies was that their other maxim as regards land was that the coming of a railway virtually automatically increased the value of the estates through which it passed. The Arbroath and Forfar railway in fact had to pay one-third more than it had anticipated for land, simply because the prospect of it being built increased land valuations. (2) It was claimed that the North British "will ... in no long time, double the value of almost every acre of land which the line touches" and the directors of the Great North of Scotland issued a circular to landowners asking them not to be avaricious in their demands since the value of their land would most likely be enhanced. (3) An advocate of the Deeside line wrote to the local landed proprietors

1. Ibid., p.225.

2. S.C. Railways. $1939 \mathrm{x}, \mathrm{q} .3435-3436$.

3. Scottish Railway Gazette, 20 June, 1846. GNS I/1, p.203. B.R. 
about "the effect which such a railway must have in lessening the cost of improvements on land and of buildings, and consequently, in raising the rental and value of your property." (1) The general attitude of the railway companies is epitomised by the Caledonian chairman, who in speaking of the support that the Wemyss Bay line had received from the property owners en route, remarked "which properties, as a matter of course, would thereby be greatly enhanced in value." (2)

That the rallways had a beneficial effect on land values was not merely the opinion expressed by rallway promoters in their efforts to raise capital and cut land costs. The agriculturalist, James Smith of Deanston, maintained that "there are few districts in which railway communication could be introduced, where the value of the country through which the railway passed would not be raised to an extent equal to the whole cost of the railway." (3) Twenty years later the Economist justified the construction of directly unremunerative branch lines on the grounds that they had substantial external economies, especially the raising of land values. (4) The Times thought "it would be impossible to find a single acre not worth more today than before the introduction of the railways." (5)

1. G.D.105, section 733. S.R.O.

2. H.R.J., 8 April, 1871.

3. S.C. Railway Acts Enactments. $1846 \mathrm{XIV}, \mathrm{q} .3172$.

4. Economist, 19 May, 1866 .

5. Times, 8 February, 1876. 
In this section an attempt will be made to assess the validity of these claims. The starting point is a statement of George Buchanan in 1832 that in consequence of the opening of the Ballochney line "property has risen in value all over the neighbourhood, mineral property to an enormous extent, and even land very considerably."

In this statement he spotlighted the important dichotomy between mineral and site values. It might well be expected that those lines designed to develop the mineral resources along their routes would raise their estate values, but this magic rags to riches argument is not so obvious in the case of agricultural holdings or country estates. It is perhaps significant that the only proprietor who objected to the Wishaw and Coltness line pleaded "no minerals," and thus no compensating benefit to the destruction of the amentity of his estate. (2) The aforementioned claim of James Smith was based on the increased facilities for the distribution of agricultural inputs and products afforded by the rallways. Against this it can be pointed out that the extension of the market area for distant farms would act to the disadvantage of those with a previous monopoly. Moreover, the rallways in aiding the mobility of labour might well have encouraged migration from the land thus forcing a rise in agricultural wages perhaps to the detriment of the return on agricultural capital. (3) Finally, it can be suggested that the

I G. Buchanan, Account of Glasg ow and Garnkirk Railway. 1832. p.6.

2. Letter to the Subscribers of the Wishaw and Coltness Railway, 20 June, 1832 . Mitchell Library.

3. The railways also encouraged migration to other agricultural areas where higher wages were available. (Dickson, op. cit., p.174). 
continued hostility, throughout the century, towards the rallways by many owners of country estates supports the hypothesis that the railways did adversely affect their amenity. Yet, on the other hand the Duke of Atholl, ardent for so long in opposition to the railways and demanding heavy compensation from the Highland, finally used the existence of this line as an inducement to the roup of his Glen Edendon estate. (1)

In an attempt to weigh the pros and cons resort was had to the valuation rolls of Scotland retained in the Scott1sh Record Office. Under the Lands Valuation (Scotland) Act annual valuation rolls were complled from 1855 by the county surveyors for rating purposes; the assessment being based on what the surveyor thought the rent would be if the land was placed on the open market. It is thus a notional value, but presumably a realistic one related to market prices of land in the vicinity, especially as it could be appealed against. Since the rolls did not begin until after rallways had been constructed in most, if not all, industrial areas, it would be difficult to distinguish the effect that a new railway had on land values from the long term trend of previous construction, and the effect of either from that caused by industrial growth which could have been induced or aut onomous. For this reason six predominately agricultural counties were studied. A further advantage of using these counties is that as well as having comparatively late railway development,

1. G.D. 237, section 169, 23 December, 1874 . 
they also had relatively little which facilitated the task of tracing its effects.

Taking the counties as a whole, the evidence in Table 11.7 suggests that land values generally increased more, in absolute terms, in the quinquenium following the opening of a railway than in the preceding five years. However, these results may have been influenced by general long term trends in the valuations and, if any conclusions are to be made, the analysis must be taken further. Accordingly the counties were broken down into parishes with and with out railways, and the short sun trends in their respective land valuations calculated. These are shown in Table 11.8. The overall influence of long term trends renders it impossible to compare time periods for the same parish or county, and, because of this and the fact that different time periods were taken for each county (because of the chronology of rallway development) it is also invalid to compare parishes in different counties. All that can be compared is the performances of parighes within the same county and within the same time period.

There are several potential error factors in the investigation. Firstly, the fact that parts of a non-railway parish may well have been nearer to a line than sections of the parish through which the railway passed. Sir Rowland Hill reckoned that the railways had a positive effect on land four miles to either side of the line; it has to be presumed that the size of the Scottish parishes kept the major portion of the benefits on average within the railway 


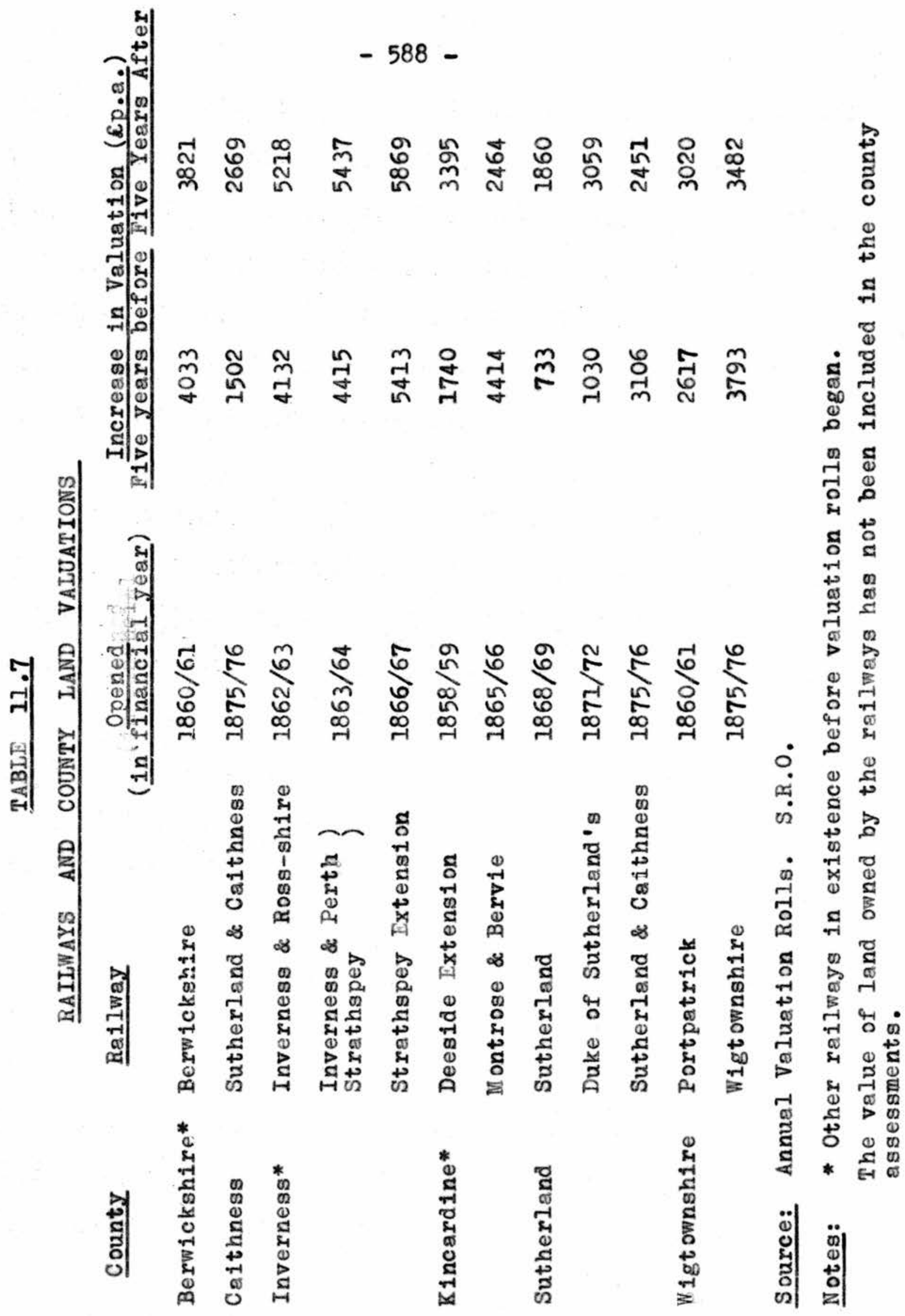




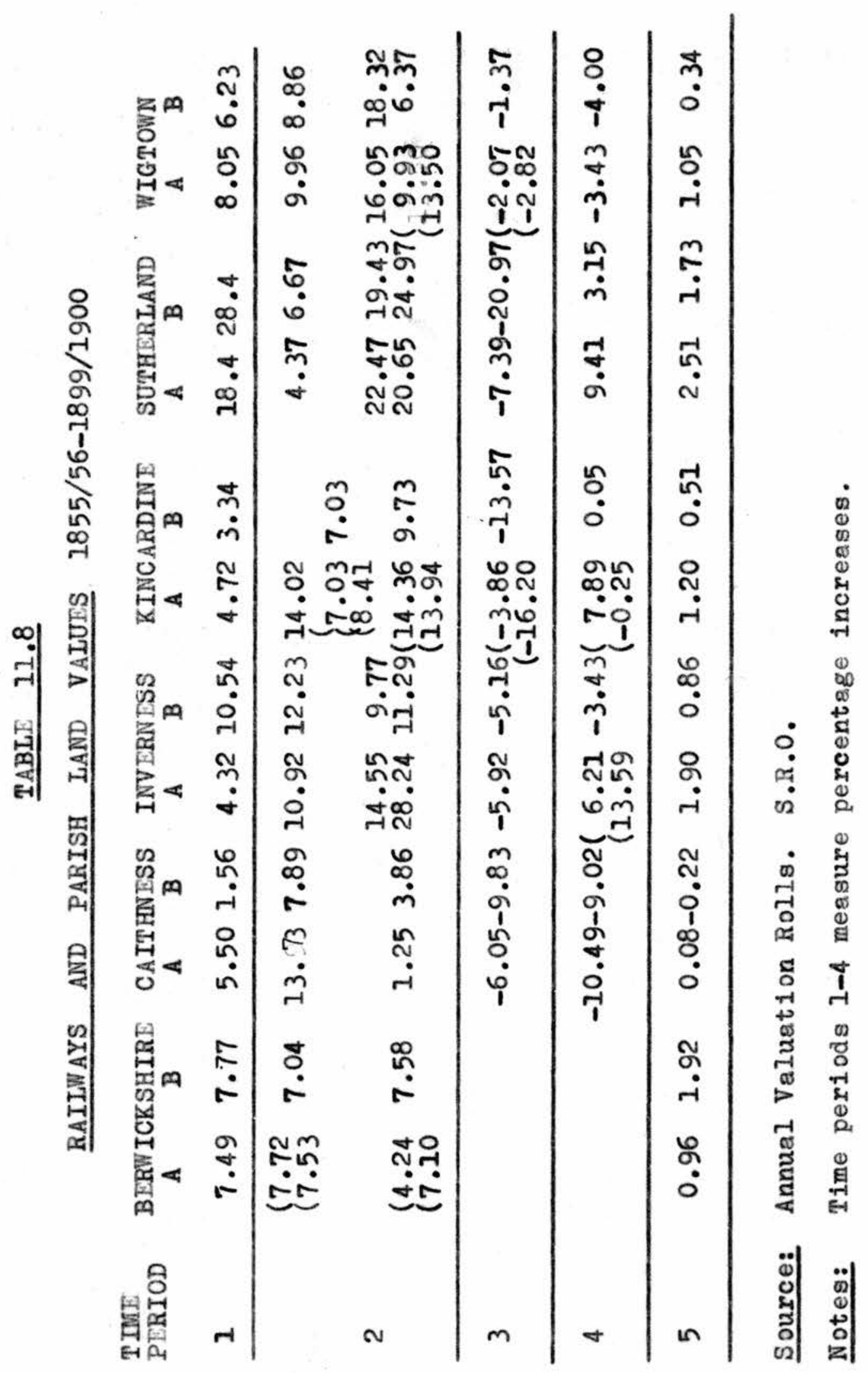


TABLI 11.8 (cont.)

Notes: Time periods (I) The period before most parishes had railways - In the case of Berwickshire, Kincardine and Inverness a few parishes did possess a line.

(2) A period of a general rise in land values - as this is over 20 years in length several smaller time periods are utilised.

(3) A period of a general cecline in land values.

(4) The last decade of the century in which conflicting trends were in operation.

Time period (5) shows annual rates of growth in values. Those for Berwickshire cover the period $1855 / 56-1871 / 72$ only and that for Caithness $1870 / 71-1899 / 1900$.

$A=$ Parishes with railways. $B=$ Parishes $w i t h o u t$ railways.

In (1) "with" refers to parishes alraady possessing railways or to obtain them in the early years of the next period.

Brackets are used in other time periods to distinguish parishes obtaining railways at different states, the newcomers being recorded second.

parishes. (1) The rearrangement of parishes over time also causes some difficulties and, in the case of Berwickshire, renders analysis impossible after 1870. A third problem arises through several of the parishes possessing more than one rallway. The effects of this within a time period are shown in Table 11.8 by the use of brackets linking the rallway parishes, the newer ones being shown last. The efficiency of the assessors must also be questioned. It can perhaps be supposed that their efficiency would increase

1. R.C. Railways. 1867 XXXVIII, p.exix. 
over time as the part-time assessors, subject to the influence of private clients, gave way to full time professionals. However, new appointments and the possibility of the delegation of responsibility might affect the validity of comparisons between parishes. Finally, it should be noted that land values increased for other reasons than the opening up of new markets by the railways. Throughout the nineteenth century the transactions of the Highland and Agricultural Society are filled with reports of land reclamations and improvements. Some of this, but not all, would be induced by the coming of a railway.

Bearing all this in mind what can be said about the railways and land values? It is apparent from time period five of Table 11.8 that the parishes possessing railways generally fared better than those without them. The county of Berwick is the one exception to this rule and this may partially be explained by the analysis for this area covering only sixteen years and not including the period of general decline in land values (time period three) when the railway parishes on average, allowing for statistical error, suffered less than elsewhere. Of course it is necessary to assess whether the railway parishes would have done better anyway, even if they had not had railways. Reference to section one of the table shows that prior to the coming of the railway in Inverness and Sutherland the increase in land values of the parishes never to have railways was much greater than that of parishes later to have 
railways. In Caithness, Kincardine and Wigtown the railway parisher fared best from the first, but the comparative rates of growth between the two types of parish widened in Kincardine and Wigtown, although it narrowed slightly in Caithness. However, the pre-railway period is in most instances only a few years which may be insufficient for the purposes of comparisons.

Overall it can be suggested that the construction of the railways had a long term beneficlal effect on the land values of parishes through which they passed, though whether the lesser performance of the non-railway parishes can be attributed solely to an absence of a line is open to conjecture. However, it is not apparent that the coming of the railway had an immediate effect; its benefits were perhaps more to aid gradual development than to suddenly increase values. This is only to be expected as agricultural change does not occur overnight, conservatism, commitment and natural factors all working to slow the pace of innovation. In addition the development of tourism and induced investment in the form of residential building could both be expected to take time. 


\section{CHAPTER TWELVE}

CONCLUSIONS

"New sources of wealth and of Industry will be developed; and a new impulse given to the prosperity of Scotland." Railway Times, 4 August, 1838.

"It is certain that the whole economy of production and distribution ig undergoing a change as complete and lasting as that which Printing accomplished for learning, or the discovery of Steam for machinery."

Tooke and Newmarch, A Hiatory of Erices. 1857, vol.5, p. 351 .

During the nineteenth century the fortunes of the Scottish economy became increasingly dependent upon the activities of the heavy industries which by 1900 employed 15\% of the total Scottish labour force. (1) The primary aim of this thesis hes been to assess the role played by the indigenous railways in the development of these heavy industries, both as consumers of industrial products and as distributive mechanisms. It is, however, scarcely desirable, and at times hardly practical, to study such a relationship in isolation from the rest of the economy. Accordingly an examination was also made of aspects such as the source and productivity of railway capital; the structural chenges in the agricultural sector brought about by the railway; the railways as employers; and the impact of rallway operation on other forms of transport. Comments on the validity of the techniques and date utilised and on the results obtained will be found

1. T.J. Byres in P.I. Payne, Studies in Scottish Business H1story. 1967. p.250. 
in the preceding text; what follows is an attempt to generalise on the basis of those results.

An examination of the backward linkages of Scottish railways with the engineering, coal, and iron and steel industries suggests that in Scotland rallways were not generally a force making for the expangion of the heavy industries by virtue of a demand for their output. Furthermore it can be suggegted that any demand influences on particular indugtries of the coming of the railways to Scotland were not instantaneous and only became of significance over time; if at all. In the case of iron and steel, railway demand increased in importance after (say) 1870 but was still only a very minor (c.5\%) of total output; the main reasons for this being, firstly, the Inability of the scottish ironmasters to break into the rail trade because of a lack of skilled labour, but, of more importance, an unwillingness to mix their iron with that from other sources in order to overcome problems raised by the phosphoric content of Scottish ores; and, secondly, the belated and relatively unsuccessiul attempt to enter the steel rail trede because of overcaution, the unsuitability of the pig iron and a lack of contacts. Less quantifiable in their influence, but also indicating a greater contribution by the railways in the later decades of the century, were the founding of the steel Company of Scotland in the hope of entering the rail trade and the use of steel in the bridging of the Forth estuary. In mechanical engineering the coming of the railways created a new sector, but the bulk of locomotive orders before (say) 1850 were contracted in England, though 
the following twenty years witnesged the establishment of a locomotive building industry in Scotland based on indigenous demand. Over the last three decades of the century, however, the private manufacturers became predominantly concerned with external demand, and, although the railway company works expanded their output, their total capacity was only in the order of $15 \%$ of that of the private producers. A gcottish non-locomotive rolling stock industry did not develop until the later nineteenth century, early reliance being again placed on English suppliers though not to the same extent as with locomotives. It was also not until the later nineteenth century that the Scottish machine tool industry began to have many dealings with the railway companies. The influence of the railways on civil engineering is difficult to guage, but the major contribution may well have come with the building of the Forth Bridge which introduced new principles and demonstrated that theory could be successfully applied to practical problems. Finally, in the case of coal, the direct demand of the Scottish rallways was of little significance to the industry throughout the nineteenth century, though its importance did increase after technological improvements in locomotive design made it easier to utilise Scotilsh coal. When indirect demand is taken into account, however, the rallways do appear to he been important consumers, especially sound 1870, but total consumption was only slightly higher at the end of the century than in 1873 and, because of the rapid expansion of coal output in the 1890s on 
the basis of non-railway demand, the percentage going to railways was less in 1900 than in the 1850 s.

The railways did, however, make a substantial contribution to the development of the Scottish coal industry in their primary role as transport agencies. AII but one of the Scottish rajiways built before 1835 had the objective of opening up coal deposits and although lines constructed specifically for this purpose then declined as a proportion of total construction, they remained significant; in addition the vast majority of lines were concerned to some degree in the carriage of coal. It can be suggested that over the century the role of the railways in opening up markets perhaps began to have greater influence on the Scottish coal industry than did their role in bringing new seams into operation. Capacity problems did appear in the form of wagon shortages and wagon size but neither was absolutely the fault of the rallway companies who seem to have purchased stock in anticipation of demand. It is arguable that any immediate impact that the rallways had on the heavy industries came in fact from the supply of transport. Admittedly, especially in the case of the iron industry, much traffic continued to go by water, but the railways had forced such competitors to drastically reduce freight rates almost overnight. Finally it can be suggested that the railways became an important locational determinant as the iron industry moved into the age of steel.

It has been shown that in the first half of the nineteenth century a substantial proportion of the rallways' capital equipment was 
supplied from south of the border. It can be further suggested that the capital spending of Scottish railway companies was, to some extent, a transfer payment between Englishmen. The first Scottiah lines were generally locally financed by persons interested both in direct and indirect returns, but from the mid 1830 s rallway capital became blind and English money began to flow north in search of high dividends. Up to c.1850 it can be suggested that the relatively scarce Scottish capital was subjected to demand pressures from many sources as a take-off, based on the hot blast, progressed into sustained economic growth. Railways were but one of the competitors for funds and English investors to some degree filled an investment gap left by industrialists, who preferred to allocate their monetary resources to their own enterprises rather than to the creation of social overhead capital. The degree of dependence on Inglish finance probably declined over the rest of the century as funds became available from the profits of sustained growth, and also as lines began to be built in areas less obviously directly profitable to the railway investor. Yet the continued dominance in total construction of companies heavily weighted with English finance would suggest that English capital still performed a useful, if no longer essential, function throughout the second half of the century. Prior to 1850 the Scottioh railways were partially dependent on external supplies of finance, capital equipment and, to a lesser extent, coal. In adition the constructional labour force, though not the operating one, also recruited in a British, as opposed to a Scottish, market; 
English craftsmen, but more especially Irish navvies, performing a large proportion of the constructional work.

Over the nineteenth c ntury somewhere in the order of $\$ 200$ millions of capital was expended by Scottish rallway companies; this spending being regulated by the availability of funds and influenced by the expandionist policy pursued by most boards of directors. That ortioum use was not made of these capital resources is easy to determine; excessive costs being incurred in the purchase of land, buying off opposition, and in parliamentary and preliminary expenses. It is less easy to determine the productiveness of railway capital. Indices based on monetary returns and train-miles run would suggest that the rate of growth of physical productivity was merely slowing down in the late nineteenth century whereas monetary proauctivity never again attained the level it reached c.1870. There were several contributory factors: inter-company rivalry leading to the provision of excess facilities; a wide range of services, and a fragmented traffic pattern; the problem of interrelatedness whioh produeed bottleneok in wagon oupply and ospecity; a rise in the proportion of minerals in total traffic which were relatively less profitable to carry; the building of some branch lines and also main line construction in the north of Scotland because of low traffic density, and some suburben lines because of high land costs; and perhaps also low returns on ancilliary investment.

Productivity as customarily measured 1s, however, a poor concept to apply to service industries when attempting to assess their role 
in stimulating growth. Railways aided the economy, as well as the individual shippers, by drastically reducing transportation costs, primarily by smashing existing monopolies who were exploiting their position, but also by reducing the recuired volume of relatively expensive road transport. It has been suggested that in 1867 savings in the order of $\$ 3,925,000$ to $\$ 4,483,000$ were made for the Scottish economy by rallways in the carriage of isoods and passengers. (1) The significance of these figures can only be assessed by a comparison with some other magnitude. Unfortunately no national income figures exist for Scotland at this time and some other control must be sought; in any event national product itself may be inflated by the economic influence of the railways. Perhaps the best solution is to express the savings as a rate of return on the capital invested in the railways. Taking a fifty year depreciation period such savings raise the rate of return (net profits plus social savings) on Scottish railway capital in the late 1860 s to over $18 \%$ (over $30 \%$ if a twenty-five year depreciation period) which compares favourably with $41.5 \%$ on the Union Pacific Railway in the United States in the 1870 s and $25.4 \%$ on the Tay Road bridge in modern

1. These figures do not include any estimate of the savings made through greater speed and conven_ence in freight transport because of the difficultieg in valuing good traffic. If all freight had been coal then about $\$ 75,000$ would have been saved. 
Scotland. (1) It can also be expected that the savings would rise more than proportionately with the spread of the railways to the isolated regions, but moreso, because of the volume of traffic involved, with the bridging of the great eastern estuaries. However, it must be born in mind that two assumptions made for the purposes of estimating the savings (that, in the absence of railways, no other transportation breakthrough would have occurred and that the distribution of population and industry would have been unchanged) give a strong upward bias to the results. Still it would seem reasonable to assume that the social savings of the Scottish railways outweighed their direct profitability; and that, when both are considered, the contribution of the rajlways to the Scottish economy was certainly far from insignificant.

Another important point about the savings is the question of how they were being made. Were the railways lowering the cost curve of transportation, thus benefitting the economy by fewex resources being used by the more efficient transportation device, or was the consumer gaining because of insfficient pricing on the part of the railway companies, i.e. was marginal cost above marginal revenue? The latter case must have applied on occasions where

1. R.W. Fogel, the Union Pacific Rejlrosd. 1960. pp.97; 101. N.R. Giliesphy, The Tay Road Bric,e. Ścottish Journal of Political Economy, vol.XV, 1968, p.181. These measures, however, are not directly comparable since different techniques were utilised and different types of saving measured; Fogel, for example, considered the question of land values which was not taken in this instance. 
rallways were in competition witis other forms of transport; the railways making up for a loss on this traffic by charging higher rates elsewhere. This mignt produce an inefficient allocation of resources but this can only be determined by investigating what the consumer of railway services did with the resources that the railways enabled him to $\varepsilon$ ve, and, in the state of current knowledge, this is impossible to determine. It is even too difficult to discover whether the resourees saved by the consumers were greater or smaller than those taken by the railways in excess of efficient allocation.

It was not merely in price competition that the railways overcame their competitors. The greater speed of the locomotive proved psychologically (and economically) attractive to passengers and was indispensible to the carriage of perishable commodities; proving especially beneficial to the fishing industry, and also to agriculture, where the development of the rallway re-structured this sector of the economy by making possible the establishment of long distance milk and dead neat trades, as well as accontuating the growth of a cattle-fattening industry.

Overall two major hypotheses can be advanced. Firstly, that the role of the railways in the transformation of the Scottish economy lay primarily in the gupply of transport rather than in their demand for industrial products. Even where transport was concerned it can be suggested that the use of the railway may have lagged, but consumer preference for other modes of transport must 
have been significantly influenced by the reduction in their charges forced by railway competition. Where railways were utilised it is arguable whether or not they were equal to the task thrown upon them - shortage of transport capacity may have slowed the expansion of the heavy industries - but the savings made in transport costs by the coming of the rallway must have made a substantial contribution to economic development.

The second hypothesis is that Scotland could not have built her own rallway system unless she had been prepared to wait for her economy to reach such a stage of development as to be able to supply her own finance and capital equipment. Whether this would ever have been reached without the rallways is open to conjecture, but if an even longer lag behind English railway development than did occur was to be avoided, foreign aid in the form of men, money and materials was an essential precondition of railway construction and operation in Scotland.

Finally, it must be emphasised that to hold the railways responsible for growth or structural change is not the same as saying that without the railweys this would not have occurred. This thesis is concerned with whether the Scottish railways were a force making for Scottish economic change and not with what might have happened in the absence of railway development. Technological breakthroughs may well have taken place in other forms of transportation, but not necessarily so - bottlenecks have persisted for considerable periods 
of time despite pressing requirements - and even if such developments had occurred they would still have had to catch the eye of the investing public, something which the railways were able to do to an unprecedented extent. 


\section{BIBLIOGRAPHY}

\section{Primary Sources}

(a) Historical Records of the British Rail Board, Edinburgh.

A comprehensive collection of data pertaining to Scottish railways, including minute books; published reports and accounts; unpublished accountancy records; debenture, mortgage and loan books; shareholders' registers and transfer books; traffic records, rate books and timetables; legal records and parliamentary papers; letter books; rolling stock registers and diagrams; maps, plans and surveys; sales ledgers; staff records; and scrapbooks of cuttings. In addition there is a library of railway journals and books dating back to the early railway age. These have now been placed in the Scottish Record Office.

(b) Scottish Record Office, Fdinburgh.

An index of matters relevant to railways to be found in the family and business muniments is available. The main manuscript sources used were:

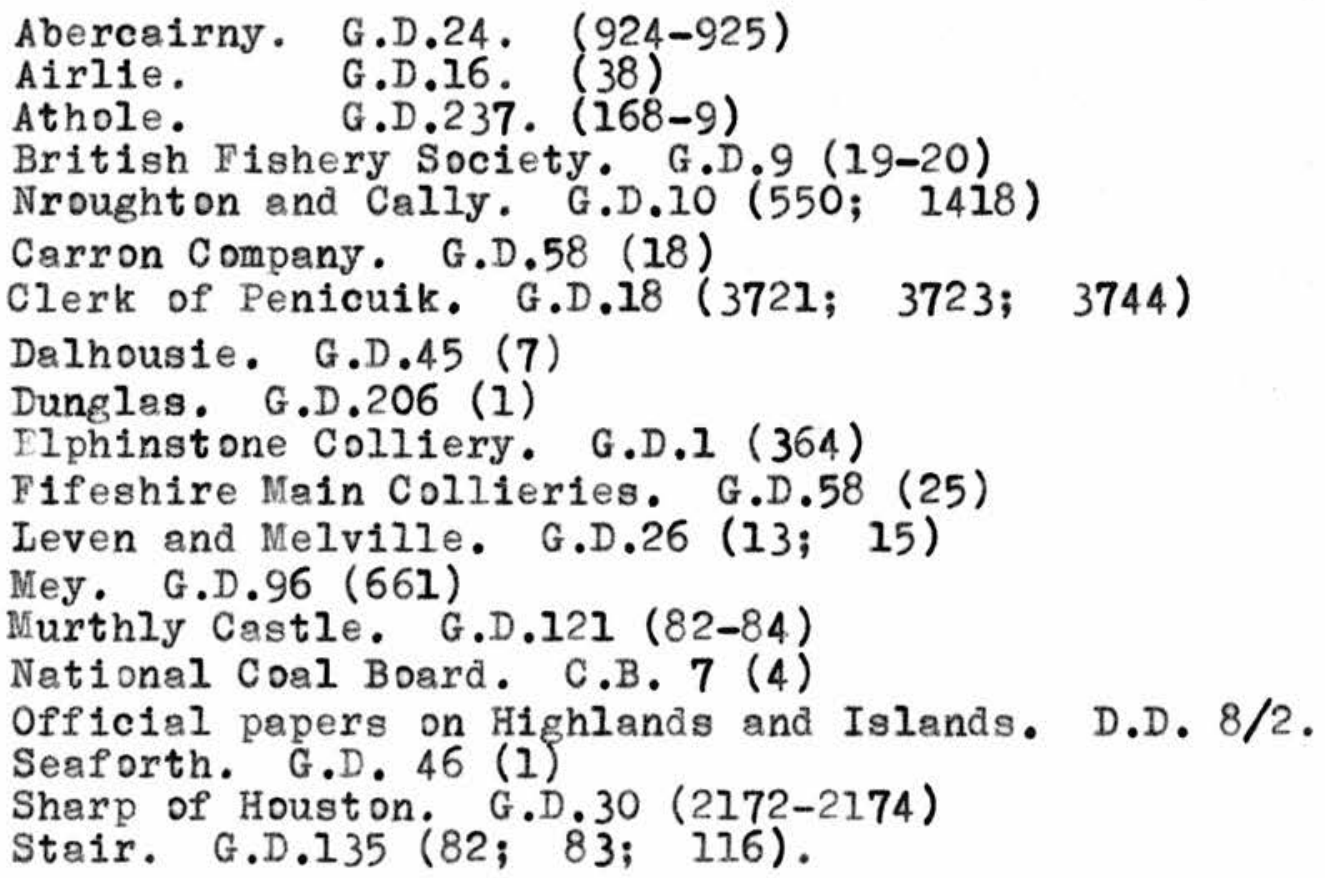

The valuation rolls of Scotland were also consulted. 
(c) National Library of Scotland, Edinburgh.

An index of matters relating to railways in their manuscript collection is available. The main sources used were:

Brown. 2841 (1840/41).
Brown (Peter) 3263 (1862).
Caled onian Railway. 6678.
Castlemilk 5327.
Douglas $8084^{\circ}$
Lothian 5801.
Melville $642(99)$.
Pitfirrane 6412.
Railways 6354-56.

(d) Mitchell Library, Glasg ow.

Reports and accounts of early Lanarishire railways.

Records of William Connal, pig iron storekeeper of Glasgow.

(e) Scottish Business Records, University of Glasgow.

Steel Company of Scotland.

R. + Y. Pickering, wag on-builders.

Dubs, loc omotive manufacturer.

Neils on, loc omotive manufacturer.

(f) North British Railway Group, Edinburgh.

Collection of accounts, timetables, and general rallway

literature; made available by courtesy of Mr. A. MacLean.

(g) Business Records of Scottish Woollen Industry.

Sales Ledger of $\mathrm{H}$. Ballantyne.

Minute Book of Galashiels Manufacturers' Corporation.

Diary of $\mathrm{H}$. Brown.

General book of Johnst on of Elgin.

These documents were made available to me by Mr. C. Gulvin, now of the Portsmouth College of Technology. 
(h) Minute Books of Scottish Banks.

Made available to me by Professor S.G. Checkland, University of Glasg ow after permission was granted by the directors of the banks.

(1) City of Edinburgh Archives.

Canal data.

Newspapers and Periodicals

(a) Contemporary:

Bradshaw's Railway Shareholders' Manual.

Economist.

Edinburgh Evening Courant.

Edinburgh Magazine.

Engineering.

Engineer.

Glasg ow Herald.

Herapath's Railway Journal.

Journal of the West of Scotland Iron and Steel Institute.

Loc omotive Engineering.

Locomotive Magazine.

Moores' Monthly Magazine.

Post Office Directories.

Railway Chronicle.

Railway Magazine and the Annals of Science.

Railway News.

Railway Times.

Railway World.

Railway Year Book.

Scots Magazine.

Scotsman.

Scottish Railway Gazette.

Transactions of the Engineers and Shipbuilders of Scotland.

Transactions of the Highland and Agricultural Society.

In addition local newspapers and commercial journals were frequently consulted on specific points; references to these will be found in the footnotes. 
(b) Modern.

Great North Review.

Journal of the Stephenson Loc omotive Society.

Locomotive, Ra1lway Carriage and Wagon Review.

Magazine of the North British Railway Group.

Railway Magazine.

Railway Steel Topics.

Scottish Railways.

\section{Parliamentary Papers}

\section{Royal Commissions.}

Application of Iron to Railway Structures. 1849 XXIX. Railways. 1867 XXXVIII. Coal. 1871 XVIII.

Agricultural Interests. 1881 XVI.

Depression of Trade and Industry. 1886 XXIII.

Labour. 1892 XXXVI.

Agriculture. 1895 XVII.

Coal Supplies. 1904 XXIII.

Canals and Waterways. 1907 XXXIII.

\section{Select Committees}

Turnpike Trusts. 1836 XIX.

Railways. $1839 \mathrm{x}$.

Poor Law (Scotland). $1844 \mathrm{X}$.

Railways. 1844 XI.

Compensation for Land. $1845 \mathrm{X}$.

Railway and Canal Amalgamations. 1846 XIII.

Management of Railroads. 1846 XIII.

Railway Labourers. 1846 XIII.

Railway Acts Enactments. 1846 XIV.

Commercial Distress. 1847/48 VIII.

Conveyance of Mails by Railwoy. 1854 XI.

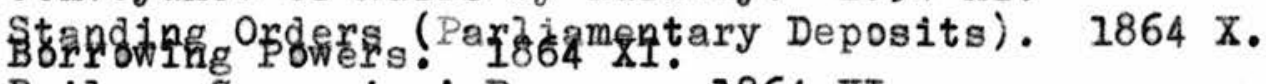

Railway Companies' Powers. 1864 XI.

Railway Companies' Amalgamations. 1872 XIII.

Coal. $1873 \mathrm{X}$.

Noxious Businesses. $1873 \mathrm{X}$. 
Select Committees (cont.)

Railways. $1881 \mathrm{XIV}$.

Railway Rates and Fares. 1882 XIII.

Ra1lway Servants (Hours of Labour). 1890/91 XVI.

Ra1lway Rates and Charges. 1892 XV.

Transport. $1918 \mathrm{IV}$.

Rural Transport (Scotland). 1919 XXX.

General Revision of Rallway Rates and Charges. XXIV.

\section{Other Papers.}

Railway Returns including accident reports (annual).

Census of Population (decennial).

Census of Froduction (published 1910-1912/13).

Corn Averages (Scotland). 1834 XIIX.

Subscription Contracts. 1837 XIVIII.

Railway Communication between London, Edinburgh, Glasgow and Dublin. $1841 \mathrm{XXV}$.

Subscription Contracts. 1846 XXXVIII.

Parliamentary Loans. $1846 \mathrm{XXV}$.

Brick Production. $1846 \mathrm{XXV}$.

Preliminaty Expenses, 1859 XXIII.

Shareholding. 1886 LVII.

Tiailway Servants (Hours of Labour). 1898 LXXXII.

Steel Rails. 1900 LXXVI.

Sea Fishery Returns. 1901 LXX.

Shareholding. $1902 \mathrm{XC}$.

Cost of Iiving of the Working Classes. 1908 CVII.

\section{These}

R.H. Campbell, The Growth and Fluctuations of the Scottish Pig Iron Trade 1828-73. Ph.D. Aberdeen. 1956.

W.S. Cormack, An Economic History of Shipbuilding and Marine Engineering. Ph.D. Glasgow. 1930.

J.S. Stephen, The History of Roads in the Highlands of Scotland in the Eighteenth and Nineteenth Centuries. Ph.D. Aberdeen. 1936.

A.J. Youngson Brown, The Scots Coal Industry 1854-1886. D. Litt. Aberdeen. 1952. 
Articles

W.M. Acworth, 'Iight Rallways,' Journal of the Royal Agricultural Society. vol.6, 1895.

D.H. Aldcroft, 'The clipse of British Coastal Shipping, 1913-21,' Journal of Transport History, vol.VI, no.2, 1963.

D.H. Aldcroft, 'The Entrepreneur and the British Economy 1870-1914,' Economic History Review, vol.XVII, 1964.

D.H. Aldcroft, 'The Efficiency and Enterprise of British Railways, 1870-1914,' Explorations in Entroprenourial History, vol.5, no.2, 1968 .

C.M. Allan, 'The Genesis of British Urban Redevelopment with special reference to Glasgow,' Economic History Review, vol.XVIII, no.3, 1965.

W. Ashworth, 'Changes in the Industrial Structure: 1870-1914,' Yorkshire Bulletin, vol.17, no.1, 1965.

W. Ashworth, 'The Late Victorian Economy,' Economica, vol.XXXIII, 1966.

J.D. Bailey, 'Australian Borrowing in Scotland in the Nineteenth Century,' Economic History Review, vol.XII, no.2, 1959.

P. Barber, 'Journal of a Traveller in Scotland 1795-96;' Scottish Historical Review, vol.36, 1957.

W. Bear , 'The Food Supply of Manchester,' Journal of the Royal Agricultural Society, vol.8, 1897.

M.E. Beesley, 'The Value of Time Spent in Travelling: Some New Evidence,' Economica, vol.XXXII, no.126, 1965.

J. Blackman, 'The Food Supply of an Industrial Town,' Business History, v01.5, no.1, 1963.

A.I.Bowley, 'A series of Articles on Wages in Journal of the Royal Statistical Society between 1899 and 1906.

S.A. Broadbridge, 'The Early Capital Market: The Lancashire and Yorkshire Railway,' Economic History Review, vol.VIII, no.2, 1955.

T.J. Byres, 'Entrepreneurship in The Scottish Heavy Industries 18701900' in P.I. Payne (ed.) Studies in Scott1sh Business History, 1967. 
J.B. Caird, 'The Making of the Scottish Rural Lendscape,' Scottish Geographical Magazine, vol.80, no.2, 1964 .

R.H. Campbell, 'Investment in the Scottish Pig Iron Trade, 1830-43,' Scottish Journal of Political Economy, vol.1, no.3, 1954.

R.H. Campbell, 'Itatistics of the Scottish Pig Iron Trade 1830-65,' Journal of the West of Scotland Iron and Steel Institute, v01.64, 1956/57.

R.H. Campbell, 'Fluctuations in. Stocks: A Nineteenth Century Case Study,' Oxford Economic Papers, vol.IX, 1957.

R.H. Campbell, 'Early Malleable Ir on Production in Scotland,' Business History, vol.4, no.1, 1961.

R.H. Campbell, 'Scottish Shipbuilding: Its Rise and Progress,' Scottish Geographical Magazine, vol.80, no.2, 1964.

A.D. Chandler, 'The Railroads: Pioneers in Modern Corporate Management,' Business History Review, vol.39, 1965.

S.G. Checkland, "The British Industrial City as History: The Glasgow Case,' Unban Studies, vol.1, no.1, 1964.

P.H, Cootner, 'The Role of Railroads in United Stateg Economic Growth,' Journal of Foonomic History, vol.23, no.3, 1963

J.R. Coull, 'The Historical Geography of Aberdeen, ' Scottish Geographical Magazine, vol.79, no.2, 1963.

J.H. Dunning, 'United States Subsidiaries in Britain and Their U.K. Competitors,' Business Ratios, vol.I, no.l, 1966.

H.J. Dyos, 'Railways and Housing in Victorian London,' Journal of Transport His tor.y, vol.2, no.2, 1955.

C.H. Feinstein, 'Income and Investment in the United Kingdom, 1856$1914 . '$ Economic Journal, vol.7i, 1961.

A.W. Flux, 'Gleanings from the Census of Production,' Journal of the Royal Statistical Society, Miay, 1913.

C.D. Foster \& M.E. Beesley, 'Estimating the Social Benefit of Constructing an Underground Hailway in London,' Journal of the Royal Statistical Society, v01.126, part 1, 1963.

I.F. Gibson, 'The Establishment of the Scottish Steel Industry,' Scottish Journal of Political Economy, vol.5, 1958. 
N.R. Gillesphy, 'The Tay Road Bridge,' Scottish Journal of Political Economy, vol.XV, no.2, 1968.

H. Hamilton, 'Economic Growth in Scotland 1720-1770,' Scottish Journal of Political Economy, vol.6, 1959.

J.R.I. Hughes and S. Reiter, 'The First 1,945 British Steamships,' Journal of the American Statistical Association, vol,53, 1958.

W. Isard, 'Transport Development and Building Cycies,' Quarterly Journal of Tconornics, vol.57, 1942/43.

W.A.P. Johnman, 'The Canals, Tramoads, and Railweys of Roxburghshire,' Transactions of the Hawick Archarological Society. 1919.

J.R. Kellett, 'Urban Transport History from Legal Records,' Journal of Transport History, vol.VI, no.4, 1963.

J.R. Kellett, 'Glasgow's Rallways, 1830-80: A Study in Natural Growth,' Economic History Review, vol.XVII, no.2, 1964.

A.G. Kenwood, 'Railway Investment in Britain, 1825-75,' Economica, vol.XXXII, no.127, 1965.

W.G. Kerr, 'Scotland and the Texas Mortgage Business,' Iconomic Hist ory Review, vol.XVI, no.1, 1963.

P.W. Kingsford, 'Labour Relations on the Railways, 1835-1875,' Journal of Transport History, vol.1, no.2, 1953.

S. Lebergott, 'United States Transport Advance and Externalities,' Journal of Economic History, vol.XXVI, no.4, 1966.

J.H.G. Lebon, 'The Development of the Ayrshire Coal-Field,' Scottish Geographical Magazine, vol.49, 1933.

J. Lee, 'The Construction Costs of Irish Railways 1830-53,' Business History, vol.9, no.2, 1967.

J. Lindsay, 'The Aberdeenshire Canal, 1805-54,' Journal of Transport History, vol.6, no.3, 1963.

S.E.G. Iythe, 'Shipbuilding at Dundee Down to 1914,' Scottish Journal OF Political Economy, vol.9, 1962.

P.I. McClelland, 'Railroads, American Growth, and the New Fconomic History,' Journal of Economic History, vol.XXVIII, no.l, 1968. 
D.S. MacMillan, 'The Scottish Australian Company 1840-50,' Scottish History Review, 1960.

D.S. MacMillan, 'Scottish Enterprise in Australia 1798-1879' in P.I. Payne, op. cit.

K. Maiwald, 'An Index of Bujlding Costs in the United Kingdom, 1845-1938,' Iconomic History Review, vol.VII, no.2, 1954.

Z. Maiwald, 'The Construction Costs and the Value of the British Merchant Fleet, 1850-1938,' Scottish Journal of Political Economy, vol.3, 1956.

B.R. Mitchell, 'The Coming of the Railway and United Kingdom Economic Growth,' Journal of Economic Hittory, vol.XXIV, no.3, 1964.

R. Mitchison, 'The Movements of Scottish Corn Prices in the Seventeenth and Eighteenth Centuries,' Economic History Review, vol.XVIII, no.2, 1965.

E.V. Morgan, 'Ra1lway Investment, Bank of England Policy and Interest Rates, 1844-48,' Economic History, vol.IV, no.15, 1940.

A.C. O'Dell, 'A Geographical Examination of the Development of Scottish Railways,' Scottish Geographical Nagazine, vol.55, 1939.

S. Pollard, 'Capital Accounting in The Industrial Revolution,' Yorkshire Bulletin, yol.15, no.2, 1963.

H. Pollins, 'The Finances of the Iiverpool and Manchester Railway,' Econoric History Review, vol.V, 1952.

H. Pollins, 'A Note on Railway Construction Costs,' Economica, vol.XIX, no.70, 1952.

H. Pollins, 'whe Marketing of Railway Shares in the First Half of the Nineteenth Century,' Economic History Review, vol.VII, 1954.

H. Polling, 'Aspects of Rallway Accounting before 1868' in A.C. Littlet on and B.J. Yansey, Studies in the History of Accounting. 1956.

H. Polling, 'Railway Contractors and the Finance of Railway Development in Britain,' Journal of Transport History, vol.3, nos.1 \& 2 , 1957.

R.H. Rew, 'Farmers and Railway Rates,' Journal of the Royal Agricultural Society, vol.6, 1895. 
M. Robbins, 'What Kind of Railway History Do We Want?' Journal of Transport History, vo1.3, no.3, 1957.

B.C. Roberts, 'Wages on the Railways,' Political Quarterly, vol.28, 1955.

N. Rosenberg, 'Technological Change in The fiachine Tool Industry 1840-1910,' Journal of Economic History, vol.23, no.3, 1963.

S.B. Saul, 'The American Impact Upon British Industry,' Business History, vol.111, no.1, 1961.

S.B. Saul, 'The Market and the Development of the Mechanical Engineering Industries in Britain, 1860-1914,' Economic History Review, vol.XX, no.1, 1967.

S.B. Saul, 'The Engineering Industry' in D.H. Aldcroft (ed.) The Development of British Industry and Foreign Competition 18751914. 1968.

H.A. Shannon, 'Bricks: A Trade Index, 1785-1849,' Economica, 1934.

H.A. Shannon, 'The Coming of General Limited Liability' in E.M. CarusWilson, Essays in Economic History, 1954, vol.1.

J. Simmons, 'The Scottish Records of the British Transport Commission,' Journal of Transport History, vol.3, no.3, 1957.

W.A. Sinclair, 'The Growth of the British Steel Industry in the late Nineteenth Century,' Scottish Journal of Political Economy, vol.6, 1959.

A. Slavin, 'Earnings and Eroductivity in the Scottish Coal-Mining Industry during the Nineteenth Century' in P.I. Payne, op. cit.

J.H. Smith, 'The Cattle Trade of Aberdeenshire in the Nineteenth Century,' Agricultural History Review, vol.3, no.2, 1955.

J. Stamp, 'The Iffect of Trade Fluctuations on Profits,' Journal of the Royal Statistical Society, vol.131, 1918.

A.J. Taylor, 'Labour Productivity and Technological Innovation in the British Coal Industry, 1850-1914,' Economic History Review, vol.XIV, no.I, 1961 .

R.E. Tyson, 'Scottish Investment in American Railways: The Case of the City of Glasgow Bank, 1856-81,' in P.I. Payne, op. cit.

C.H. WaIker, 'Unincorporated Investment Trusts in the Nineteenth Century,' Iconomic History, vol.IV, no.15, 1940. 
J.T. Ward, 'Scottish Landowners and the Railways: A Preliminary Note,' Scottish Railways, vol.2, 1967.

C.N. Ward-Perkins, 'The Commercial Crisis of 1847,' Oxford Economic Papers, v01.II, 1950.

K. Warren, 'The Sheffield Rail Trade, 1861-1930,' Institute of British Geographiers, vol.34, 1964.

K. Warren, 'Locational Froblems of the Scottish Iron and Steel Industry since 1760,' Scottish Geographical Magazine, vol.81, nos.1 and 2, 1965.

P.T. Wheeler, 'The Development of Shipping Services to the East Coast of Sutherland,' Journal of Transport History, vol.6, no.2, 1963.

E.H. Whetham, 'Prices and Production in Scottish Farming 1850-70,' Scottish Journal of Political Economy, vol.9, 1962.

E.H. Whetham, 'Ilvestock Prices in Britain 1851-93,' Agricultural History Review, vol.II, 1963.

- 'Early Scottish Railways,' Three Banks Review, no.74, 1967.

\section{$\underline{\text { Books }}$}

Unless otherwise stated the place of publication is Iondon; an asterisk denotes that the publisher was not known.

W.M. Acworth, The Railways of Scotlend. 1880.

W.M. Acworth. The Ilements of Railway teonomics. Oeford. 1905.

E.I. Ahrons, The British Stesm Locomotive. 1927.

G.W. Alcock, Fifty Years of Failway Trade Unionism, 1922.

J. Anderson, Recreations in Agriculture. 1789-1800.

J.I. Anderson, the Story of the Commercial Bank of Scotiand. Edinburgh. 1910.

W. Ashworth, An Economic History of England 1870-1939. 1960. 
P. Bagwell, The Railwaymen. 1963.

R. Bald, View of the Coal Trade of Scotland. Edinburgh. 1808.

Sir M. Barclay-Harvey, A History of the Great North of Scotland Reilway. 2nd Edition 1949 .

A.M. Barty, The Bistory of Dunblane, Stirling. 1944.

I.I. Bell, The Iron Trade of the United Kingdom. 1886.

I.I. Bell, Memorandum as/to the wear of rails. (N.E.R.) 1896.

I.I. Bel.J, Memorandum as the wear of rails, No.2. Leeds. 1900.

G. Blake, Glasgow Ilectric. 1960.

M.R. Bonavie, The Economics of Transport. C.U.P. 1955.

A.I. Bowley, Wages in the United Kingd om in the Nineteentra Century. C.U.P. 1.900 .

A. Brand, Index of Iines, Connections, Amalgamations etc. Fdinburgh. 1902.

T. Brassey, Work and Wages. 1872.

D. Bremner, The Industries of Scotland. Edinburgh. 1869.

British Railways Board, The Reshaping of British Railways. 1963.

G. Buchanan, Account of GJasgow and Garnkirk Rajiway and other railways in Lanarkshire. Tdinburgh. 1832 .

D.L. Burn, Economic History of Stee]-Making. C.U.P. 1940.

A.E. Cairncross, Home and Foreign Investment 1870-1913. C.U.P. 1948.

A.K. Cairncross (Editor), The Scottish Economy. Glasgow. 1954.

C.D. Campbeil, British Railways in Boom and Depression. 1932.

D. Campbel], Reminiscences and Reflections of an Octogenarian Highlander. Inverness. 1910.

D.G. Campbell, Railway Amalgamations. Glasgow. 1873.

R.H. Campbell, Carron Company. Edinburgh. 1961. 
R.H. Campbell, Scotland since 1707. Oxford. 1965.

E.H. Carr. What is Hiatory? Penguin. 1965.

J.C.Carr \& W. Taplin, A History of the British Steel Industry. Oxford. 1962.

E.F. Carter, An Historical Geography of the Railways of the British Isles. 1959.

J.I. Carvel, One Hundred Years in Coel. Edinburgh. 1944.

Central Statistical Office, National Income and Expenditure. 1964.

W. Chambers, About Railways. Edinburgh. 1865.

E.D. Chattaway, Railways - Their Capital and Dividends. 1855.

S. . Checkland, The Rise of Industrial Society in England 1815-1865. 1966.

J.H. Clapham, An Economic Hist ory of Modern Britain, Vol. II the early Railway Age. C.U.P. 1930.

T.C. Cochran, Railroad Leaders, 1845-70: The Business Mind in Action. Harvara U.P. 1953.

R.I. Cohen, The Hist ory of Milk Prices. Oxford. 1936.

2. Colburn, Loc motive Engineering. 1871.

G.D.H. Cole \& R.P. Arnot, Trade Unionism on the Railways. 1917.

T. Coleman, The Rallway Navvieg. 1965.

A.K. Conrad and J.R. Meyer, Studies in Econometric History. 1965.

A.S. Cunningham, Mining in Mid and East Lothian. Edinburgh. 1925.

St. John V. Day in British Association Some of the Leading Industries of Glasgow and the Clyde Valley. Glasgow. 1876.

P. Deane \& W.A. Cole, Britigh Economic Growth, 1688-1959. C.U.P. 1964 .

P. Deane, The First Industrial Revolution. C.U.P. 1965.

P. Donaldson, Guide to the British Economy. Penguin. 1966.

G. Dott, Early Scottish Colliery Wagonways. 1947.

G. Dow, The First Rallway Across the Border. I.N.E.R. 1946. 
R.W. Dron, The Coalfields of Scotland. 1902.

Duckworth \& Langmuir, Railway and other Steamers. Glasgow. 1948.

H. Dyer, in A. McLean (ed.) Iocal Industries of Glasgow. British Association 1901.

W.A. Dykes, The Valuation of Railways in Scotland for Rating Purposes. Glasgow. 1903.

C.H. Ellis, The North British Ra1lway. 1959 edition.

0.H. Ellis, British Railway History. 1960 Idition.

C.H. ElIis, Nineteenth Century Railway Carriages. 1966.

D.M. Evans, The Commercial Crisis. 1849.

G. Findlay, The Working and Manegement of an Engligh Railroad. 1891 .

W. Findlay, History of Kilmarnock. Kilmarnock. 1909.

A. Fishlow, American Rallroads and the Transformation of the Ante Bellum Economy. Harvard. 1965.

R.W. Fogel, The Union Pacific Railroad. Balt imore. 1960.

R.W. Fogel, Railroads and American Economic Growth. Baltimore. 1964.

E. Foxwell \& T.C. Farrer, Expresg Trains English and Foreign. 1889.

$\mathrm{J}$. Francis, A History of the English Railway. 1851.

T.B. Franklin, A. History of Scottish Farming. Edinburgh. 1952.

W.C. Galbraith, the Caledonian Steam Packet Co. Itd. Glasgow. 1949.

if.I. Galloway, Annals of Coal Mining and the Coal Irade. 1898.

J.W.F. Gardner, Railway Enterprise. 1934.

A.D. Gayer, W.W. Rostow, A.J. Scwartz, The Growth and Fluctuations in the British Economy 1790-1850. Oxford. 1953.

W.A. Gillies, In Famed Breadalbane. Perth. 1938.

W.T. Gordon, Our Home Rajlways. 1910.

T. Grahame, Inland Communication and Transport. Glasgow. 1835. 
T. Grainger, Observations on the Idinburgh, Dundee and Northern Railway. Edinburgh. 1841.

I.F. Grant, The Economic History of Scotland. 1934.

M.D. Greville \& J. Spence, A Handbook to Closed Passenger Lines of Scotland. Ra1lway and Canal Historical Society. 1963.

H.W. Griffiths, Iron and Steel Manufacturers of Great Britain. 1884 .

S. Griffiths, Guide to the Iron Trade of Great Britain. 1873.

H.J. Habakkuk, American and British Technology in the Nineteenth Century. C.U.P. 1962.

A.R.B. Haldane, The Drove Roads of Scotland. Edinburgh. 1952.

A.R.B. Haldane, New Ways through the Glens. Edinburgh. 1962.

Haley (edit.), A Survey of Contemporary Economics. American Economic Association 1952.

R. Hall, History of Galashiels. Edinburgh. 1898.

H. Hamilton, The Industrial Revolution in Scotland. 0xford. 1932.

H. Hamilt on, The Economic Evolution of Scotland. Historical Association. 1933.

H. Hamilton, Economic History of Scotland in the Eighteenth Century. Oxford, 1963.

J.E. Handley, The Irish In Scotland. Cork U.P. 1943.

J.E. Handley, The Irish in Modern Scotland. Cork U.P. 1947.

C.G. Harper, The Great North Road. 1901.

C. Highet, The Glasg ow and South Western Railway. Edinburgh. 1965.

A.0. Hirschman, The Strategy of Economic Development. Yale U.P. 1958.

E.J. Hobsbawm, Industry and Empire. 1968.

W. Hoffman, British Industry 1700-1950. Oxford. 1965. 
J. Horne (edit.), The History of Kirkintilloch. Kirkintilloch. 1910.

D.I.G. Hunter, Edinburgh's Transport. Edinburgh. 1964.

W.T. Jackman, The Development of Transportation in Modern England. 1962.

I.H. Jenks, The Migration of British Capital to 1875. New York. 1927. w. Jevons, The Coal Question. 1866.

T. Johnson, History of the Working Classes in Scotland. Glasgow. 1929

K.H. Johnston, British Railways and Economic Recovery. 1949.

A. Keith, The North of Scotland Bank 1836-1936. Aberdeen. 1936. A.W. Kerr, History of Banking in Scotland. 1926.

J.M. Keynes, General Theory of Employment, Interest and Money. 1936.

F. Kohn, Iron and Steel Manufacture. 1869.

R.W. Kidner, Light Railway Handbook. Edinburgh. 1950.

G. Kinnear, Banks and Exchange Companies. Glasgow. 1847.

J. Knox, Airdrie, An Historical Sketch. Airdrie. 1921.

A. Lamont, How Scotland Lost her Ra1lways. Scottish Nationalist Party. 1945.

C. Landale, Report on the Dundee and Newtyle Railway.* 1825.

D. Lardner, Railway Economy. 1850.

H.G. Lewin, Early British Railways. 1925.

H.G. Lewin, The Railway Mania and its Aftermath. 1936.

J. Parry Lewis, Building Cycles and Britain's Growth. 1965.

F.E. Lister, The Car Builders' Dictionary 1909. Chicago. 1909.

Lond on and North Eastern Railway, Inverness Locomotive, Carriage and Wagon Works. 1946.

W. MacAdam, The Birth, Growth and Eclipse of the Glasgow and SouthWestern Railway. Glasg ow. 1924. 
J.M. McBain, Arbroath, Past and Present. Arbroath. 1887.

W. M'Combie, Cattle and Cattle Breeders. Edinburgh. 1869.

W. M'Ilwraith, The Glasgow and South Western Railway. Glasgow. 1880.

J. Mackinnon, The Social and Industrial History of Scotland. 1921.

C. Maclaren, Railways compared with Canals and Common Roads. 1825.

A.B. Macleod, The McIntosh Locomotives of the Caledonian Railway. 1948.

D.S. Macmillan, The Debtor's War. Melbourne. 1960.

W.H. Marwick, Economic Developments in Victorian Scotland. 1936.

W.H. Marwick, Scotland in Modern Times, 1964.

R.C.O. Matthews, A Study in Trade Cycle History. C.U.P. 1954 .

J. Mayer, Engineering and Shipbuilding Industries of Glasgow and the Clyde. British Association, Glasgow. 1876.

J. Mavor, The Scottish Railway Strike. Glasgow. 1891.

R.K. Middlemas, The Master-Builders. 1963.

A. Miller, The Rise and Progress of Coatbridge. Glasgow. 1864.

B.R. Mitchell \& $P$. Deane, Abstract of British Historical Statistics. C.U.P. 1962 .

J. Mitchell, Reminiscences of my Iife in the Highlands. 1883.

E.V. Morgan and W.A. Thomas, The Stock Exchange. 1962.

N. Munro, The History of the Royal Bank of Scotland. Edinburgh. 1928.

C.H. Newt on, Railway Accounts. 1930.

O.S. Nock, The Railway Engineers. 1955.

0.S. Nock, Scottish Railways. Edinburgh. 1961.

0.S. Nock, The Caledonian Rallway. 1962.

O.S. Nock, The Highland Railway. 1965.

North British Locomotive Co., History of the N.B.L. Co. Glasgow. 1953. 
R.R. Notman, A Letter to the Landed Proprietors of Deeside." 1850. A.C. O'Dell, Railways and Geography. 1956.

C.S. Orwin \& E.H. Whetham, History of British Agriculture 18461914. 1964 .

G. Paish, The Britigh Railway Position. 1902 .

G. Paterson, Historical Account of the Fiars in Scotland. Edinburgh. 1852.

P.I. Payne, Rubber and Railways in the Nineteenth Century. Iiverpool University Press. 1961.

P.I. Payne, Studies in Scottish Business History. 1967.

R. Pike, Railway Adventures and Anecdotes. 1887.

G,R. Porter, The Progress of the Nation. 1847.

E.A. Pratt, Scottish Canals and Waterways. 1922.

J. Priestly, Historical Account of the Navigable Rivers, Canals and Railways of Great Britain. 1831.

G.S. Pryde, Scotland from 2603 to the Present Day. Edinburgh. 1962. R.S. Rait, The History of the Union Bank of Scotland. Glasgow. 1930. M.C. Reed, Railways in the Victorian Economy. Newt on Abbot. 1969. J. Reid, Manual of Scottish Stocks. Edinburgh. 1841. J.M. Reid, Glasgow. 1956.

J.M. Reid, The History of the Clydesdale Bank. 1958.

J. Rennie, Additional Report for Promoting a Canal between Edinburgh and Glasgow.* 1801.

J. Rennie, Report on a Proposed Railway from Kelso to Berwick. Edinburgh. 1810.

J. Richardson, General Report on Newcastle, Edinburgh and Glasgow Railway.* 1837 .

M. Robbins, The Railway Age. Penguin, 1965. 
D. Robertson, The Princes Street Proprietors. Edinburgh. 1935. I.T.C. Rolt, A Hunslet Hundred. 1964 .

W.W. Rost ow, British Economy of the Nineteenth Century. Oxford. 1948 .

W.W. Rostow, The Steges of Economic Growth. C.U.P. 1963 edition.

W. Rost ow (Editor), the Economics of Take-off into Sustained Growth. 1965.

R. Salaman, The History and Social Influence of the Potato. C.U.P. 1949.

K.N. Salkade, Permanent Way Text Book. Bombay, 1934.

W.E.G. Salter and W.B. Reddaway, Productivity and Technical Change. C.U.P. 1966.

C.I. Savage, An Economic History of Transport. 1959.

H. Scrivenor, History of the Iron Trade. 1854.

C.E.R. Sherringt on, The Economics of Rail Transport in Great Britain. 1928.

J. Simmons, The Railways of Britain. 1961.

H.J. Skelton, Economics of Iron and Steel. 1895 or 1894.

A.E. Smith, George Smith's Money - A Scottish Investor in Americe. 1966.

D.I. Smith, The Dalmellingt on Iron Company. Newt on Abbot. 1967.

R. Southey, Journal of a Tour in Scotland in 1819. 1929.

Stephenson Iocomotive Society, The Caled onian Ra1lway Centenary. 1947.

Stephenson Locomotive Society, The Glasgow and South Western. 1950.

Stephenson Locomotive Society, The Great North of Scotland Railway. 1954 .

Stephens on Locomotive Society, The Highland Railway. 1957.

R. Stevenson, Report on the Iine of Canal Upon One Level Between the Cities of Edinburgh and Glasgow. 1817.

S. Stone, Railway Carriages and Waggons. 1903. 
J.A. Symon, Scottish Farming Past and Present. Edinburgh. 1959. P. Temin, Iron and Steel in Nineteenth Century America. M.I.T. 1964 . J. Thomas, The Springburn Story. Newt on Abbot. 1964. J. Thomas, The Callander and Oban Rallway. Newt on Abbot. 1966. J. Thomas, The West Highland Ra1lway. Newt on Abbot. 1967. Tooke and Newmarch, Higtory of Prices. 1857. W. Truran, The Iron Trade of Great Britain. 1855. A.S. Turberville, A History of Welbeck Abbey and its Ownerg. 1939. J. Weale, Locomotive Inglnes. 1850. R.K. Webb, The British Working Class Reader 1790-1848. 1955. J.R. Whitbread, The Railway Policeman. 1961. A. Williams, Iife in a Railway Factory. 1915. F. Wishaw, The Railways of Great Britain and Ireland. 1840. W.V. Wood and Sir Josiah Stamp, Railways. 1928.

W. Woodruff, The Rise of the British Rubber Industry during the Nineteenth Century. Iiverpool U.P. 1956.

- Commercial Glasgow. c.1890.

- Glasgow as an Industrial Centre. 1909.

- Industries of Stirling and District. 1909.

Reference was also made to volumes in:

0ld Statistical Account of Scotland New Statistical Account of Scotland Third Statistical Account of Scotland. 